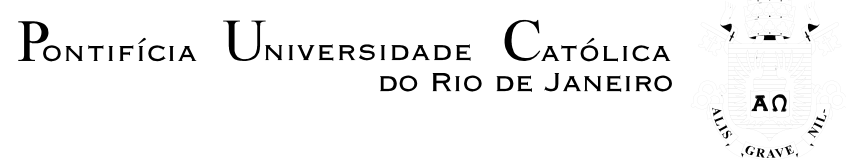

Maria Izabel de Carvalho

\title{
Entre a Rocinha no Brasil e Siloé na Colômbia, quais são as similaridades? Estudo comparativo do processo de destinação dos resíduos sólidos gerados nos dois lócus e suas formas de tratamento
}

Tese de Doutorado

Tese apresentada como requisito parcial para obtenção do grau de Doutor pelo Programa de Pós-graduação em Serviço Social do Departamento de Serviço Social da PUC-Rio.

Orientador: Prof. ${ }^{a}$ Valéria Pereira Bastos Coorientador: Prof. Ricardo Rodriguez Quintero 


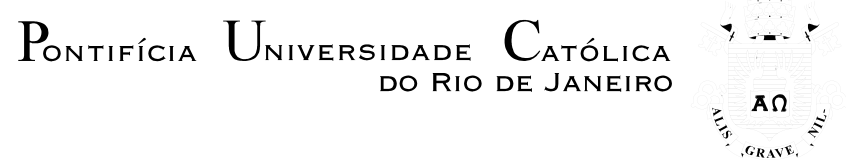

Maria Izabel de Carvalho

\section{Entre a Rocinha no Brasil e Siloé na Colômbia, quais são as similaridades? Estudo comparativo do processo de destinação dos resíduos sólidos gerados nos dois lócus e suas formas de tratamento}

Tese apresentada como requisito parcial para obtenção do grau de Doutor pelo Programa de Pós-graduação em Serviço Social da PUC-Rio. Aprovada pela Comissão Examinadora abaixo.

Prof. a Valéria Pereira Bastos

Orientador

Departamento de Serviço Social - PUC-Rio

Prof. Ricardo Rodriguez Quintero Coorientador Pontificia Universidad Javeriana Cali, Colombia

Prof. Rafael Soares Gonçalves Departamento de Serviço Social - PUC-Rio

Prof ${ }^{\mathrm{a}}$ Tania Horsth Noronha Jardim Departamento de Serviço Social - PUC-Rio

Prof. - Maria Auxiliadora Vargas Universidade Salgado de Oliveira (Juiz de Fora/MG)

Prof. Fábio Fonseca Figueiredo UFRN

Rio de Janeiro, 28 de maio de 2021. 
Todos os direitos reservados. É proibida a reprodução total ou parcial do trabalho sem autorização da universidade, da autora e do orientador.

\section{Maria Izabel de Carvalho}

Graduou-se em Serviço Social na PUC-Rio (Pontifícia Universidade Católica do Rio de Janeiro) em 2010. Cursou MBA em Gerenciamento de Projetos na UCP (Universidade Católica de Petrópolis) entre 2012/2013. Cursou Mestrado em Serviço Social, na linha de pesquisa "Questões socioambientais, urbanas e formas de resistência social" na PUCRio (Pontifícia Universidade Católica do Rio de Janeiro) entre 2014/2016.

Ficha Catalográfica

Carvalho, Maria Izabel de

Entre a Rocinha no Brasil e Siloé na Colômbia, quais são as similaridades? Estudo comparativo do processo de destinação dos resíduos sólidos gerados nos dois lócus e suas formas de tratamento / Maria Izabel de Carvalho; orientadora: Valéria Pereira Bastos; coorientador: Ricardo Rodriguez Quintero. 2021

$321 \mathrm{f}$. : il. color. ; $30 \mathrm{~cm}$

Tese (doutorado)-Pontifícia Universidade Católica do Rio de Janeiro, Departamento de Serviço Social, 2021.

Inclui bibliografia.

1. Serviço Social - Teses. 2. Resíduos sólidos. 3. Rocinha. 4. Siloé. 5. Brasil. 6. Colômbia. I. Bastos, Valéria Pereira. II. Rodriguez Quintero, Ricardo. III. Pontifícia Universidade Católica do Rio de Janeiro. Departamento de Serviço Social. IV. Título. 
Dedico à minha família, em especial a minha mãe Cícera e ao meu pai Francisco, pelos quais tenho muito amor; e às pessoas que generosamente concederam os seus depoimentos, tornando essa pesquisa possível. 


\section{Agradecimentos}

Agradeço a Deus em primeiro lugar, por me guiar sempre, pela força e sabedoria para ultrapassar todos os obstáculos que surgiram durante essa jornada.

A toda minha família, em especial aos meus queridos pais Cícera e Francisco, os quais amo incondicionalmente e que me apoiam em todos os momentos da minha vida; aos meus irmãos Helton e André e aos meus sobrinhos por fazerem parte da minha vida, por compreenderem às minhas ausências, mesmo em momentos importantes da nossa vida familiar e pelo amor de todos vocês.

À minha família de coração, que a vida foi agregando ao meu convívio ao longo dos anos.

A todos (as) que fazem parte do meu ciclo de amizade, em especial os (as) mais próximos (as), que acompanharam de perto todo esse período.

À minha queridíssima orientadora Valéria, pela generosidade, compreensão, paciência, confiança, incentivo, troca, por todos os ensinamentos e pelo importantíssimo papel desempenhado durante toda essa jornada, contribuindo para que eu realizasse o intercâmbio na Colômbia, bem como o cumprimento dos demais processos relacionados ao doutorado, ao longo desses quatro anos. Você é especial para mim.

Ao professor Rafael Soares Gonçalves, por todos os ensinamentos e pelo importante papel que teve na minha vida acadêmica ao longo de todo o doutorado. A todos os (as) professores (as) do doutorado pelos ensinamentos e contribuição ao longo de todo esse período.

À PUC-Rio, pela oportunidade de retornar a casa que eu tanto prezo, para mais uma etapa de aprimoramento acadêmico. Essa instituição simboliza muito na minha vida. Como costumo dizer, "sou filha da PUC" com muito orgulho e por ela tenho uma imensa gratidão. 
À Pontificia Universidad Javeriana Cali - Colombia, por me receber de braços abertos para a realização do intercâmbio e por todo o apoio que recebi das equipes dessa instituição.

Ao meu querido coorientador Ricardo, que me recebeu em Cali e que fez tudo o que estava ao seu alcance para tornar minha experiência, nesse território, a melhor possível.

A todas as pessoas e instituições, tanto da Rocinha quanto de Siloé, que generosamente concederam os seus depoimentos, tornando essa pesquisa possível. Aos nossos irmãos colombianos que foram tão generosos comigo durante todo o período do intercâmbio, com muitos dos quais hoje tenho uma amizade que prezo. A todas as instituições que direta ou indiretamente colaboraram para que eu chegasse até aqui.

A todos (as) aqueles (as) que direta ou indiretamente contribuíram para que eu chegasse até aqui, a minha eterna gratidão.

O presente trabalho foi realizado com apoio da Coordenação de Aperfeiçoamento de Pessoal de Nível Superior - Brasil (CAPES) - Código de Financiamento 001. 


\section{Resumo}

Carvalho, Maria Izabel de; Bastos, Valéria Pereira (Orientador); Quintero, Ricardo Rodriguez (Coorientador). Entre a Rocinha no Brasil e Siloé na Colômbia, quais são as similaridades? Estudo comparativo do processo de destinação de resíduos sólidos gerados nos dois lócus e suas formas de tratamento. Rio de Janeiro, 2021. 321p. Tese de Doutorado Departamento de Serviço Social, Pontifícia Universidade Católica do Rio de Janeiro.

A presente tese tem por finalidade apresentar um estudo comparado entre a favela da Rocinha - Rio de Janeiro no Brasil e Siloé (Comuna 20) em Cali na Colômbia. A proposta foi analisar o processo de destinação dos resíduos sólidos urbanos gerados nos dois locais e suas formas de tratamento, considerando a realidade e a cultura local, mas buscando dá relevância às diferenças e similitudes de cada lócus. O percurso metodológico que ancorou o estudo apoiou-se na pesquisa de cunho documental e bibliográfico, o que nos permitiu ampliar o conhecimento sobre a legislação, assim como em diversas normativas, artigos acadêmicos entre outros documentos, objetivando compreender como a gestão dos resíduos é regulada nos dois países. Já a pesquisa de campo, foi ancorada na estrutura metodológica de cunho qualitativo, efetivada por meio da observação direta nos campos de estudo, o que nos proporcionou tanto o alcance das informações não explicitas nas falas das entrevistas, como nos garantiu vivenciar as duas realidades, conhecendo os hábitos, costumes e diferenças culturais, políticas e sociais de cada grupo envolvido na pesquisa. E as entrevistas foram do tipo semiestruturadas, efetivadas nas duas localidades, o que nos proporcionou realizar a escuta de diversos sujeitos envolvidos no processo de tratamento, gestão e destinação dos resíduos nas duas áreas, a saber: representantes das empresas de limpeza urbana, representantes de estabelecimentos comerciais, moradores, organizações de catadores/recicladores de materiais recicláveis e reutilizáveis, e catadores/recicladores, objetivando compreender qual é a visão de cada agente em relação à geração e destinação adequada dos resíduos sólidos urbanos em suas 
localidades. A sistematização dos dados, aliados as informações coletadas em conversas e provenientes da vivência nos locais, nos permitiu concluirmos que a política de resíduos, tanto brasileira como colombiana, trouxe melhorias socioambientais para as localidades, contudo, ainda há muito que ser realizado na perspectiva da promoção de forma igualitária da prestação de serviços na área socioambiental, principalmente, na questão da geração, tratamento e destinação adequada dos resíduos. Acreditamos que a tese poderá também subsidiar novos estudos tanto no Brasil como na Colômbia a respeito da temática.

\section{Palavras-chave}

Resíduos sólidos; política pública de resíduos sólidos; Rocinha; Siloé; Brasil; Colômbia; América Latina; favela; bairro popular. 


\section{Abstract}

Carvalho, Maria Izabel de; Bastos, Valéria Pereira (Advisor); Quintero, Ricardo Rodriguez (Co-advisor). Between Rocinha in Brazil and Siloé in Colombia, what are the similarities? Comparative study of the solid waste disposal process generated in the two locus and its forms of treatment. Rio de Janeiro, 2021. 321p. Tese de Doutorado - Departamento de Serviço Social, Pontifícia Universidade Católica do Rio de Janeiro.

The purpose of this thesis is to present a comparative study between the favela of Rocinha - Rio de Janeiro in Brazil and Siloé (Comuna 20) in Cali, Colombia. The proposal was to analyze the process of destination of the urban solid waste generated in the two places and their forms of treatment, considering the local reality and culture, but seeking to give relevance to the differences and similarities of each locus. The methodological path that anchored the study was supported by documentary and bibliographic research, which allowed us to expand knowledge about the legislation, as well as in several regulations, academic articles and other documents, aiming to understand how waste management is regulated in both countries. The field research, on the other hand, was anchored in the qualitative methodological structure, carried out through direct observation in the fields of study, which provided us with both the reach of the non-explicit information in the interview statements, and guaranteed us to experience both realities, the habits, customs and cultural, political and social differences of each group involved in the research. And the interviews were of the semi-structured type, carried out in both locations, which allowed us to listen to several subjects involved in the process of treatment, management and disposal of waste in both areas, namely: representatives of urban cleaning companies, representatives of commercial establishments, residents, organizations of collectors / recyclers of recyclable and reusable materials, and collectors / recyclers, aiming to understand what is the vision of each agent in relation to the generation and proper disposal of solid urban waste in their localities. The systematization of the data, combined with the information collected in 
conversations and from the experience in the places, allowed us to conclude that the waste policy, both Brazilian and Colombian, brought socio-environmental improvements to the localities, however, there is still much to be done in the perspective equal promotion of the provision of services in the socioenvironmental area, mainly in the issue of generation, treatment and proper disposal of waste. We believe that the thesis may also support new studies both in Brazil and in Colombia on the subject.

\section{Keywords}

Solid waste; public policy on solid waste; Rocinha; Siloe; Brazil; Colombia; Latin America, slum; popular neighborhood. 


\section{Resumen}

Carvalho, Maria Izabel de; Bastos, Valéria Pereira (Tutor); Quintero, Ricardo Rodríguez (Co-asesor). Entre Rocinha en Brasil y Siloé en Colombia, ¿cuáles son las similitudes? Estudio comparativo del proceso de destino de los residuos sólidos generados en los dos locus y sus formas de tratamiento. Río de Janeiro, 2021. 321p. Tese de Doutorado Departamento de Serviço Social, Pontifícia Universidade Católica do Rio de Janeiro.

El propósito de esta tesis es presentar un estudio comparativo entre la favela de Rocinha - Río de Janeiro en Brasil y Siloé (Comuna 20) en Cali, Colombia. La propuesta fue analizar el proceso de destino de los residuos sólidos urbanos generados en los dos lugares y sus formas de tratamiento, considerando la realidad y la cultura local, pero buscando dar relevancia a las diferencias y similitudes de cada locus. El camino metodológico que ancló el estudio se basó en la investigación documental y bibliográfica, lo que permitió incrementar el conocimiento sobre la legislación, así como en diversas normativas, artículos académicos y otros documentos, con el objetivo de comprender cómo se regula la gestión de residuos en ambos países. La investigación de campo, por su parte, se ancló en la estructura metodológica cualitativa, realizada a través de la observación directa en las zonas de estudio, lo que nos brindó tanto el alcance de la información no explícita en los enunciados de la entrevista, como la garantía de experimentar ambas realidades, conociendo los hábitos, costumbres y diferencias culturales, políticas y sociales de cada grupo involucrado en la investigación. Las entrevistas fueron semiestructuradas, y realizadas en ambos lugares, lo que nos permitió escuchar a los diversos sujetos involucrados en el proceso de tratamiento, gestión y disposición de residuos en ambas áreas, a saber: representantes de empresas de limpieza urbana, representantes de establecimientos comerciales, vecinos, organizaciones de recolectores de materiales reciclables y reutilizables, y catadores/recicladores, con el objetivo de comprender cuál es la visión de cada agente en relación a la generación y disposición adecuada de residuos sólidos 
urbanos en sus localidades. La sistematización de los datos, combinada con la información recolectada en conversaciones y de la experiencia directa en los lugares, permitió concluir que la política de residuos, tanto brasileña como colombiana, trajo mejoras socioambientales a las localidades, sin embargo, aún queda mucho por realizar en la perspectiva de promoción equitativa de la prestación de servicios en el ámbito socioambiental, principalmente en el tema de generación, tratamiento y disposición adecuada de residuos. Creemos que la tesis también puede apoyar nuevos estudios tanto en Brasil como en Colombia sobre el tema.

\section{Palabras clave}

Residuo sólido; política pública de residuos sólidos; Rocinha; Siloe; Brasil; Colombia; América Latina, tugurios; barrio popular. 


\section{SUMÁRIO}

1. Introdução

24

2. Contextualizando a favela/bairro popular na América

45 Latina: entre a Rocinha no Brasil e Siloé na Colômbia

45

2.1. Cidades latino-americanas no século XXI: uma breve contextualização

2.2. As agências multilaterais e o desenvolvimento latino-

53 americano

2.3. O desenvolvimento e os impactos no processo de urbanização das áreas populares das cidades latinoamericanas: Rio de Janeiro e Cali

2.3.1. Rio de Janeiro: o processo de urbanização e as favelas

2.3.2. Cali: o processo de urbanização e os bairros populares

68

2.4. Dois mundos distintos e uma realidade comparável: a 74 favela oficializada Rocinha e a comuna reconhecida como Siloé

3. Panorama da política pública de resíduos sólidos na América Latina com foco no Brasil e Colômbia

3.1. A atual conjuntura dos resíduos sólidos na América Latina

3.1.1 O panorama da gestão dos resíduos sólidos no contexto brasileiro e colombiano

3.2. A política nacional de resíduos sólidos no Brasil e na Colômbia

3.2.1 Um olhar sobre os avanços e retrocessos da política nacional de resíduos sólidos brasileira e colombiana 
4. Rocinha e Siloé: apresentação e análise dos 145 resultados a partir da fala dos sujeitos

4.1. A visão dos moradores sobre a forma de destinação dos resíduos sólidos a partir de cada lócus pesquisado

148

4.2. A visão das empresas de limpeza urbana em relação

165 ao trabalho prestado

4.3. As organizações de catadores/recicladores e o olhar sobre o trabalho executado

189

4.4. Catadores/recicladores: o labor e a realidade vivenciada 204 no dia a dia

4.5. O comércio: geração e destinação de resíduos sólidos

213

5. Considerações Finais

221

6. Referências Bibliográficas

232

7. Apêndices 244

7.1. Apêndice 1- Formulário: moradores da Rocinha 244

7.2. Apêndice 2 - Guia de conversación con pobladores de Siloé

247

7.3. Apêndice 3 - Formulário: empresa de limpeza urbana - 250 Rocinha

7.4. Apêndice 4 - Guia de indagación sobre la empresa de limpieza urbana - Siloé

7.5. Apêndice 5 - Roteiro: organização de catadores - 262 Rocinha

7.6. Apêndice 6 - Guia de conversación con organización de recicladores - Siloé

7.7. Apêndice 7 - Roteiro: catadores da Rocinha 
7.8. Apêndice 8 - Guia de conversación con recicladores de 270 Siloé

7.9. Apêndice 9 - Roteiro: estabelecimentos comerciais - 272 Rocinha

7.10. Apêndice 10 - Guia de conversación con el 274 establecimiento comercial - Siloé

7.11. Apêndice 11 - Termo de consentimento livre e 276 esclarecido - Rocinha

7.12. Apêndice 12 - Consentimiento informado - Siloé 278

7.13. Apêndice 13 - Documento fotográfico da Rocinha 280

7.14. Apêndice 14 - Documento fotográfico de Siloé 297 


\section{Lista de Figuras}

Figura 1 - Taxa de urbanização na América Latina e no 50 Caribe: 1950

Figura 2 - Taxa de urbanização na América Latina e no

51 Caribe: 2010

Figura 3 - Existência de Bancos Multilaterais e sua distribuição

55 por área geográfica de atuação

Figura 4 - Taxa de escolaridade segundo o nível educativo no município de Cali - 2013 a 2019

Figura 5 - Localização da cidade do Rio de Janeiro 63

Figura 6 - Localização de Cali 69

Figura 7 - Bairros irregulares em Cali - 1950 a 1979

Figura 8 - Vista panorâmica da Rocinha 74

Figura 9 - Vista panorâmica de Siloé $\quad 75$

Figura 10 - Bicas coletivas de água na Rocinha 77

Figura 11 - Mapa da densidade habitacional em Cali em $2020 \quad 88$

Figura 12 - Quadro ilustrativo referente à densidade 88 habitacional em Cali em 2015

Figura 13 - Percentual de domicílios segundo o destino do lixo 103

Figura 14 - Gráfico da geração total de RSU - 2017/2018 104

Figura 15 - Gráfico da coleta de RSU - 2017/2018 105

Figura 16 Quantidade de RSU coletada nas regiões e no 105 Brasil - 2017/2018

Figura 17 - Participação das regiões no total de RSU coletado 106 (em percentual) - 2017/2018

Figura 18 - Índice de cobertura da coleta RSU (em percentual) 106 $-2017 / 2018$

Figura 19 - Disposição final de RSU no Brasil por tipo de 107 destinação (t/dia) - 2017/2018

Figura 20 - Disposição final dos RSU coletados no Brasil (t/ano) 108 - 2017/2018

Figura 21 - Quadro indicando o total de municípios, por tipo de 108 disposição final adotada - 2017/2018 
Figura 22 - Quantidade de municípios com ou sem iniciativas de coleta seletiva - 2017/2018

Figura 23 - Distribuição dos municípios com ou sem iniciativas 109 de coleta seletiva (\%)

Figura 24 - Recursos aplicados na coleta de RSU - 2017/2018 110

Figura 25 - Recursos aplicados nos demais serviços de limpeza 110 urbana - 2017/2018

Figura 26 - Municípios atendidos e média de toneladas/dia, segundo o tipo de destinação final - 2018

Figura 27 - Distribuição do sistema de destinação final

Figura 28 - Assuntos constantes na PNRS - Brasil 122

Figura 29 - Hierarquia do manejo de resíduos sólidos no Brasil 125

Figura 30 - Fluxo simplificado de resíduos nos sistemas de 127 logística reversa

Figura 31 - Hierarquia da gestão de resíduos sólidos na

132 Colômbia

Figura 32 - Financiamento estimado da PNGIRS-Colômbia

Figura 33 - Disposição final de RSU no Brasil, por tipo de destinação (t/ano)

Figura 34 - Estimativa da evolução da disposição inadequada no Brasil

Figura 35 - Toneladas aproveitadas por ano - segundo informações passadas a SUI - Colômbia

Figura 36 - Total de organizações de recicladores que reportam informação da atividade de aproveitamento às instituições oficiais - 2016 a 2018

Figura 37 - Fatura de serviços públicos: usuário de Belisário Caicedo (estrato 3)

Figura 38 - Fatura de serviços públicos: usuário de El Cortijo (estrato 1)

Figura 39 - Biciclo - equipamento utilizado na atividade de varrição em Siloé

Figura Documento fotográfico da Rocinha

Figura Documento fotográfico de Siloé 


\section{Lista de quadros}

Quadro 1 - Dados do Rio de Janeiro $\quad 60$

Quadro 2 - Dados de Cali 61

Quadro 3 - $\quad$ Cali população e mudanças físicas décadas 1970- 72 1990

Quadro 4 - Acontecimentos na limpeza urbana de Bogotá 113

Quadro 5 - Processos que culminaram na PNRS 121

Quadro 6 - Definição de alguns conceitos segundo a PNRS 123

Quadro 7 - Evolução da base legal da gestão de RS na 128 Colômbia de 1979 a 2016

Quadro 8 - Definição da PNGIRS - Colômbia 129

Quadro 9 - Definição de alguns conceitos segundo a PNGIRS 130

Quadro 10 - Panorama dos RS no Brasil - comparação entre 135 2010 e 2019

Quadro 11 - Evolução dos sistemas de logística reversa comparação: 2010 e 2019

Quadro 12 - Celebração de Acordos Setoriais e outros 139 instrumentos

Quadro 13 - Formas de disposição final dos RS na Colômbia 2016 e 2018

Quadro 14 - Tabela de siglas de identificação dos sujeitos da pesquisa

Quadro 15 - Perfil dos moradores entrevistados

Quadro 16 - Fala dos moradores sobre a problemática dos resíduos sólidos no seu local de moradia

Quadro 17 - Fala dos moradores sobre a destinação dos resíduos sólidos

153

Quadro 18 - O que pensam os moradores sobre a destinação inadequada dos resíduos sólidos

Quadro 19 - Opinião dos moradores sobre os serviços prestados pela empresa de limpeza urbana

Quadro 20 - Outros serviços que poderiam ser prestados pela empresa de limpeza urbana

Quadro 21 - Opinião dos entrevistados sobre as ações de 
educação ambiental - se é importante ou não para

o contexto dos resíduos sólidos

Quadro 22 - Dados dos representantes das empresas de

165

limpeza urbana entrevistados

Quadro 23 - Tipos de serviços prestados pelas empresas de

170 limpeza urbana na Rocinha e em Siloé

Quadro 24 - Fala dos entrevistados sobre a prestação de serviços de limpeza urbana nas áreas de difícil acesso

Quadro 25 - Equipamentos utilizados pelas empresas para a coleta e varrição

Quadro 26 - Canal de comunicação entre as empresas de limpeza urbana e os usuários

175

184

Quadro 27 - Visão do representante da COMLURB e Ciudad 186 Limpia sobre a população

Quadro 28 - Perfil dos representantes das organizações de catadores

189

Quadro 29 - Total de catadores/recicladores associados às organizações de catadores/recicladores e divisão por gênero

Quadro 30 - Bens materiais que compõem o patrimônio das organizações de catadores/recicladores

Quadro 31 - Perfil dos catadores/recicladores entrevistados

205

Quadro 32 - Fala dos catadores/recicladores sobre o rompimento de sacolas na Rocinha e em Siloé

Quadro 33 - Principais problemas enfrentados pelos catadores/recicladores na Rocinha e em Siloé

Quadro 34 - Perfil dos comércios 213

Quadro 35 - Definição de pequenos e grandes geradores de 214 resíduos sólidos no Rio de Janeiro e em Cali

Quadro 36 - Fala de representantes comerciais sobre a problemática dos resíduos sólidos na Rocinha e em Siloé 


\section{Lista de gráficos}

Gráfico 1- Vezes por semana que os moradores da

Rocinha e de Siloé descartam os resíduos sólidos, segundo os entrevistados

Gráfico 2- Já teve ou conhece alguém que tenha tido problema relacionado ao descarte inadequado de resíduos sólidos - Rocinha e Siloé

Gráfico 3- Contraiu ou conhece alguém que tenha contraído doenças relacionadas aos resíduos sólidos - Rocinha e Siloé

Gráfico 4- Participação em atividades voltadas para a educação ambiental, onde tenha sido abordada a temática dos resíduos sólidos - Rocinha e Siloé 


\section{Lista de siglas e abreviaturas}

CFI Corporação Financeira Internacional.

Miga Agência Multilateral de Garantia de Investimentos

GEF Global Environment Facility.

BEI Banco Europeu de Investimentos

NIB Banco Nórdico de Investimento

FOE Fundo para Operações Especiais.

CII Corporação Interamericana de Investimento

Fumin Fundo Multilateral de Investimentos

BERD Banco Europeu para Reconstrução e Desenvolvimento

AfDB African Development Bank

Bladex Banco Latinoamericano de Comércio Exterior

BDAN Banco de Desarrollo de América del Norte

Badea Arab Bank for Economic Development in Africa

ISDB Islamic Development Bank

IDA Associação Internacional para o Desenvolvimento

Fida Fundo Internacional de Desenvolvimento Agrícola

FAsD Fundo Asiático de Desenvolvimento

ADB Asian Decelopment Bank

ADF African Development Fund

CAF Corporação Andina de Fomento

BCIE Banco Centro Americano de Integração Econômica

Fonplata Fundo Financeiro para o Desenvolvimento da Bacia do Prata

ICIIEC Corporação Islâmica de Garantia para o Investimento e Crédito a Exportações

ICDPS Corporação Islâmica para o Desenvolvimento do Setor Privado

FEMIP Facilidade para a Parceria e Investimentos na Região EuroMediterrânea

MEDIT.B Banco do Mediterrâneo ANK 
EADB Banco de Desenvolvimento do Leste da África

BOAD Banco de Desenvolvimento do Oeste da África 
"Algo só é impossível até que alguém duvide e acabe provando o contrário." (Albert Einstein) 


\section{1 \\ INTRODUÇÃO}

A problemática de destinação inadequada dos resíduos sólidos urbanos assola quase todo o mundo, porém, assim como muitas outras questões, ela é sentida, sobretudo, pelas pessoas que têm menor poder aquisitivo. Sendo esse grupo, mais exposto às injustiças socioambientais, em função das consequências decorrentes dos efeitos produzidos no ambiente.

Com o passar dos anos o consumo só aumentou e, consequentemente, a geração de resíduos sólidos também, porém o tratamento devido desses resíduos não acompanhou o ritmo desse crescimento, o que vem acarretando sérios danos ao meio ambiente, assim como também à população que reside nas chamadas zonas de sacrifício, como a Rocinha no Rio de Janeiro/Brasil e Siloé em Cali/Colômbia, campos de pesquisa deste estudo, que se constituiu por meio da metodologia de estudo comparado, cujo objetivo foi analisar o processo de destinação dos resíduos sólidos gerados nos dois lócus e suas formas de tratamento, considerando suas similaridades e diferenças.

A nossa escolha por esses dois campos se deu, em primeiro lugar, pela semelhança geográfica e pelas características urbanísticas similares existentes entre ambos os territórios; e em segundo lugar, pela viabilidade de efetivação da pesquisa, por haver um contato na Pontifícia Universidad Javeriana de Cali na Colômbia, por intermédio do professor/doutor Ricardo Rodriguez Quintero, que se dispôs a contribuir, enquanto coorientador, para a efetivação da pesquisa em Siloé na Colômbia.

A Rocinha, um dos nossos campos de pesquisa, está situada na Zona Sul do Rio de Janeiro no Brasil, entre os bairros de São Conrado e da Gávea, duas regiões nobres da cidade. Geograficamente falando, é um vale e parte considerável da população reside nas áreas altas da favela. Seu surgimento consta da década de 1930, porém somente na década de 1990 é reconhecida oficialmente como bairro, todavia não dispõe até hoje, dos mesmos serviços com os quais conta um bairro dito formal. 
Já nosso segundo campo de pesquisa, a Comuna $20^{1}$, está localizado na ladeira Sul Ocidental de Cali na Colômbia. O primeiro bairro dessa comuna é Siloé, que foi oficialmente reconhecido em 1964. Essa é uma região, assim como a Rocinha, predominantemente montanhosa e conta com uma pequena área na parte plana. Quanto a sua origem, há divergências em relação ao início de sua ocupação. Há relatos que apontam que essa área começou a ser povoada no início dos anos 1930, porém existem indícios de que a parte baixa da ladeira já era habitada desde 1927.

Chamamos a atenção para o fato de que a Comuna 20 de Cali na Colômbia é reconhecida popularmente por seus habitantes, pelos caleños e colombianos em geral, como Siloé. Quando se fala em Comuna 20, geralmente os colombianos não identificam a que território a pessoa está se referindo, no entanto, quando se diz Siloé, imediatamente os moradores de outros territórios sabem que parte da cidade está sendo mencionada, portanto, neste estudo, quando falarmos de Siloé, estamos nos referindo a Comuna 20 de Cali, como um todo.

Salientamos que o nosso interesse por este estudo, antecede ao período que cursamos o mestrado e se deu a partir da nossa observação, por meio das experiências vividas a respeito da presença do acúmulo desordenado de resíduos sólidos em determinadas áreas da favela da Rocinha, sobretudo no sub-bairro conhecido como Valão, em função de atuarmos profissionalmente entre os anos de 2009 e 2011, no trabalho de atendimento às famílias direta ou indiretamente impactadas pelas obras do Programa de Aceleração do Crescimento (PAC) $)^{2}$ na Rocinha.

Nesse período, por termos acesso, em função das obras, a uma área geográfica da Rocinha até então não visitada por nós anteriormente, foi possível observar uma grande quantidade de resíduos descartados de forma indevida, tanto nos becos quanto dentro dos talvegues ${ }^{3}$ existentes nessas localidades, com destaque para a área do Valão. Durante uma de nossas visitas de campo, presenciamos uma moradora que, de sua janela, lançou uma fralda descartável dentro do talvegue. A partir daí, começamos a nos questionar quanto ao processo de geração, destinação e tratamento dos resíduos sólidos nas áreas

\footnotetext{
${ }^{1}$ Comuna é um termo usado na Colômbia para se referir a uma unidade administrativa, na qual a área urbana de uma cidade média ou principal do país, que agrupa bairros ou setores específicos, é subdividida. A maioria das capitais dos departamentos é dividida em comunas.

2 Programa do Governo Federal brasileiro, criado em 2007, com foco no planejamento e execução de obras de infraestrutura social, urbana, logística e energética do país.

${ }^{3}$ Parte mais baixa de um vale por onde corre a água da chuva e das nascentes ou o canal mais fundo de um rio.
} 
populares. Portanto, esse foi o pontapé inicial, culminando na pesquisa de mestrado, que tratou dessa temática na favela da Rocinha, sendo posteriormente ampliada na pesquisa de doutorado, visto que nos propomos a aprofundar a discussão expandindo-a por meio de uma análise comparativa entre a Rocinha no Brasil e Siloé na Colômbia, por considerarmos existirem semelhanças, embora sejam respeitadas as singularidades existentes em ambas as localidades.

No que diz respeito ao estudo comparado, Sartori et al. (1999) afirma que não é possível comparar nem duas coisas totalmente iguais, como também não, duas coisas completamente distintas. Por esse motivo, acreditamos que a escolha dos lócus desta pesquisa, se justifica, pois se encaixa perfeitamente nessa classificação, uma vez que cada um tem a sua particularidade, porém se assemelham em outros pontos, como, na questão geográfica, nas características urbanísticas, na forma de tratar as expressões da questão socioambiental, como as relativas ao trato com os resíduos sólidos, entre outros.

Além da motivação já citada, tal estímulo também ganhou relevância pelo fato de ter sido moradora da Rocinha até o início do terceiro ano do doutorado (2019), local que mesmo após o processo de mudança, continuo frequentando assiduamente. Portanto, essa questão se constitui como uma possibilidade de contribuir para a mitigação dos problemas socioambientais existentes na favela, na perspectiva da busca por melhor qualidade de vida ambiental para a população local, assim como também, para o segundo campo desta pesquisa Siloé.

No concernente ao caminho percorrido no transcurso do doutorado, esse foi um caminhar longo e com a presença de obstáculos, alguns menores e outros maiores, desde o início até a finalização deste estudo. Desde o princípio, sempre existiu a vontade de realizar um intercâmbio mais duradouro, para que, além de apreender da melhor forma possível a realidade de um dos campos (Siloé), até então pouco conhecido por nós, houvesse a construção de uma relação mínima de confiança com os sujeitos locais e, também, devido à questão idiomática, que necessitava ser aprimorada, uma vez que desde o princípio, objetivávamos que as entrevistas fossem aplicadas por nós mesmos, por entendermos que para além do que é verbalizado, existem outros elementos que surgem no ato de uma entrevista, por exemplo, as expressões corporais, que são de suma importância para o entendimento da questão; e foi assim que conforme programado, se deu o processo. 
Foram dez meses de imersão nesse território, realizando observação de campo, contato constante com os sujeitos e lideranças locais, participação em reuniões do Comité de Planeación, uso do diário de campo e a realização de entrevistas, que aconteceram entre agosto e o início de outubro de 2019, o que nos propiciou conhecimento mais aprofundado sobre esse campo, dando-nos maior propriedade para discorrer sobre ele. As entrevistas presenciais foram de suma importância, contudo, visando um alcance mais abrangente sobre o objeto do estudo, enviamos também esse mesmo formulário, na versão on-line da plataforma do Google, para alguns moradores, e obtivemos alguns retornos; e o último nos foi enviado em novembro deste mesmo ano.

Inicialmente não foi uma tarefa fácil, tendo em vista 0 fator desconhecimento, pois apesar de ser uma área popular similar à que residimos durante muitos anos e a muitas onde já trabalhamos, não tínhamos conhecimento das especificidades locais, sobretudo no que concerne a questão da violência. Era um país, uma cidade e um bairro popular novo, a ser desbravado dia a dia, para que tirássemos nossas próprias conclusões enquanto pesquisadores, a partir dos métodos adotados. Na primeira tentativa, não foi possível acessar nem mesmo a rua principal, pois muitas pessoas vendo que não éramos locais, pelo sotaque e pouco domínio do idioma, diziam para não adentrar, pois segundo elas, era uma área muito perigosa. Isso foi ouvido inúmeras vezes, tanto de quem era morador quanto de pessoas que dali não era. Um dos relatos mais assustadores foi o que dizia que certo dia um casal que não morava ali, havia desaparecido ao visitar a parte alta.

O fato de termos residido e trabalhado em áreas periféricas no Brasil, foi primordial para não nos amedrontarmos diante de tantos relatos assustadores, mesmo estando em outro país, pois sabemos que esses espaços são sempre vistos como império da violência, como se todos os que ali residissem fossem bandido-criminosos. Discurso que é incorporado e reproduzido constantemente, até mesmo por quem ali habita. Com isso não queremos dizer que não exista violência, porém sabemos que não se dá como está no imaginário popular e nos canais midiáticos.

Salientamos que nesse território, foi de grande importância a colaboração dos funcionários da empresa de limpeza urbana local, que, sobretudo inicialmente, nos apresentou a algumas lideranças, nos proporcionou visitas ao território e o acompanhamento de atividades.

A opção por morar no campo de pesquisa durante o intercâmbio, também foi primordial, pois além de facilitar a circulação e a observação constante, aos 
poucos confirmamos o já imaginado, isto é, seria possível transitar sem a companhia de terceiros, pois o fato de ficar dependente de alguém nos limitaria, uma vez que não é sempre que as pessoas têm disponibilidade para tal, e ademais, seria também uma observação não guiada, ou seja, sem ruas ou becos previamente pensados por quem nos guiasse.

Por alguns meses, nos limitamos a observar com frequência a parte plana, avançado com cautela, até chegar ao topo de Siloé, sem que fosse necessária a companhia de um sujeito local.

Na Rocinha, por ser um território onde já residimos e que continuamos a frequentar, o processo de observação se deu durante todo o andamento da pesquisa, com exceção do período do intercâmbio.

Nesse campo, em consequência do cenário instaurado devido à pandemia causada pelo COVID-194, alguns dos processos da pesquisa tiveram que ser adaptados, com o intuito de manter os prazos estipulados para a finalização do curso.

As entrevistas se dariam na segunda quinzena de março, justamente quando se instaurou oficialmente no Brasil, a pandemia. Tivemos, portanto, que adiar as entrevistas, na esperança de que tudo fosse se normalizar dentro de um período não muito longo, o que não aconteceu. Então, lançamos mão da aplicação de formulários on-line (Google Forms - que já conhecíamos por termos utilizado a ferramenta anteriormente, de forma complementar em Siloé, conforme citado acima), no primeiro semestre de 2020, para dois grupos que se fez possível: com os moradores e com a única organização de catadores existente no território.

Com os demais grupos, os catadores, representantes comerciais e a companhia de limpeza urbana, não logramos fazer uso desse instrumento. Os dois primeiros, sobretudo, porque não conseguiríamos chegar a eles dessa forma; e o último, por uma questão de preferência do representante da instituição, que por meio de contato telefônico prévio, relatou preferir que fosse presencial. Adiamos o máximo possível a aplicação das entrevistas presenciais, visando preservar a saúde de todos os envolvidos, porém não havendo mais como esperar, tendo em vista o prazo final do curso, realizamos as entrevistas

\footnotetext{
${ }^{4}$ A COVID-19 é uma doença infecciosa causada pelo novo coronavírus (SARS-CoV-2), sendo o primeiro caso reportado em dezembro de 2019 na cidade de Wuhan, na China. Tornou-se uma pandemia mundial, ceifando milhões de vidas. Até o momento, morreram em decorrência da doença, em termos mundiais 3.373.504 pessoas (15/05/ 2021 às 09h) e no Brasil 432.785 pessoas (14/05/2021), segundo dados do site: https://www.worldometers.info/coronavirus/ e https://g1.globo.com/jornal-nacional/noticia/2021/05/14/brasil-registra-2189-mortes-por-covid-em24-horas.ghtml, consecutivamente.
} 
faltantes no mês de outubro de 2020, respeitando todas as recomendações das autoridades sanitárias.

No tocante às principais categorias que fundamentaram o estudo nesses campos, temos: favela, bairro popular, território, política pública de resíduos sólidos (PNRS/Brasil e PNGIRS/Colômbia), a própria definição do termo resíduo sólido e, por fim, a discussão a respeito da questão socioambiental.

Quanto à categoria favela, trazemos a visão de Silva (2009) que aponta que esse espaço é historicamente representado no imaginário da grande maioria, como o lugar da ausência, sendo "definida pelo que não seria ou pelo que não teria. Nesse caso, é apreendido, em geral, como um espaço destituído de infraestrutura urbana - água, luz, esgoto, coleta de lixo" (SILVA, 2009, p. 16). Lícia do Padro Valladares (2005) aponta que:

A imagem matriz da favela já estava, portanto, construída e dada a partir do olhar arguto e curioso do jornalista/observador. "Um outro mundo", muito mais próximo da roça, do sertão, "longe da cidade", onde só se poderia chegar através da "ponte" construída pelo repórter ou cronista, levando o leitor até o alto do morro que ele, membro da classe média ou elite, não ousava subir (Valladares, 2005, p. 36).

Ainda a esse respeito, Alba Zaluar et al. (2006), assinala que:

A representação da favela tende a orientar-se por dois enfoques que, longe de serem excludentes, frequentemente se sobrepõem, o retrato da favela é feito com base em suas características intrínsecas, por outro, essa mesma imagem se constrói de forma relacional, sendo os elementos definidores traçados a partir da e com referência à cidade. Quando isso ocorre, o que chama a atenção, num primeiro plano, é a rígida demarcação que se estabelece entre ambas, fazendo com que a cidade seja vista como uma coisa e a favela como outra. Inúmeras são as referências musicais que tratam a favela como algo alheio, algo que não faz parte, algo, enfim, que é distinto da cidade, não importa a situação, os personagens ou os sentimentos que aí estejam envolvidos (Zaluar et al., 2006, p. 90).

Apesar de passados tantos anos, desde o seu surgimento, essa visão sobre a favela ainda é muito atual, sendo então caracterizada, como já dito, como um lugar da falta, à parte do resto da cidade, onde o direito à cidade não é respeitado. Prova deste fato é a classificação, adotada pelos órgãos oficiais, como no caso brasileiro, que é denominada pelo IBGE, como aglomerado subnormal, entendido como:

Um conjunto constituído de, no mínimo, 51 unidades habitacionais (barracos, casas...) carentes, em sua maioria de serviços públicos essenciais, ocupando ou tendo ocupado, até período recente, terreno de propriedade alheia (pública ou 
particular) e estando dispostas, em geral, de forma desordenada e densa (IBGE, 2011, p. 2).

$\mathrm{Na}$ contramão dessa representação que geralmente se tem a respeito das favelas, o Observatório de Favelas acredita que a sua definição não deve ser construída com base no que nela não existe, mas a partir da sua singularidade socioterritorial, servindo de referência para a elaboração de políticas públicas que atendam a sua realidade. Para essa instituição, portanto, a favela é um território constituinte da cidade e que se caracteriza, total ou parcialmente, pelas seguintes características:

\begin{abstract}
Insuficiência histórica de investimentos do Estado e do mercado formal, principalmente o imobiliário, financeiro e de serviços; Forte estigmatização socioespacial, especialmente inferida por moradores de outras áreas da cidade; Edificações predominantemente caracterizadas pela autoconstrução, que não se orientam pelos parâmetros definidos pelo Estado; Apropriação social do território com uso predominante para fins de moradia; Ocupação marcada pela alta densidade de habitações; Indicadores educacionais, econômicos e ambientais abaixo da média do conjunto da cidade; Níveis elevados de subemprego e informalidade nas relações de trabalho; Taxa de densidade demográfica acima da média do conjunto da cidade; Ocupação de sítios urbanos marcados por um alto grau de vulnerabilidade ambiental; Alta concentração de negros (pardos e pretos) e descendentes de indígenas, de acordo com a região brasileira; Grau de soberania por parte do Estado inferior à média do conjunto da cidade; Alta incidência de situações de violência, sobretudo a letal, acima da média da cidade; Relações de vizinhança marcadas por intensa sociabilidade, com forte valorização dos espaços comuns como lugar de convivência (Silva, 2009, p. 22-23).
\end{abstract}

Ainda de acordo com o documento do Observatório de Favelas "O que é a favela, afinal?", a representação que se tem das favelas e das pessoas que ali residem, "orienta políticas e projetos que, na maioria das vezes, se fundamentam em pressupostos equivocados, em geral superficiais, baseados em estereótipos que não permitem uma compreensão aprofundada sobre a realidade social, econômica, política e cultural em sua totalidade e complexidade" (Silva, 2009, p. 21).

$\mathrm{Na}$ Colômbia o termo usado para se referir às áreas populares da cidade como Siloé, é bairro popular, que guardadas as suas particularidades, se assemelham às favelas cariocas. Os bairros populares são definidos como:

Aquellos asentamientos que los mismos pobladores han autoconstruido para proveerse de un techo. En ese sentido, son aquellas unidades de desarrollo urbano formadas por la agrupación de predios individuales, con algunas áreas comunes; que en su mayoría son de carácter residual, han sido construidas por el propio pueblo - de allí lo de popular - mediante un proceso que demora varias décadas y que implica un esfuerzo enorme colectivo (barrio) y también familiar (casa). Estas características los distancian de otro tipo de barrios, como los residenciales para clases sociales más adineradas o los barrios obreros 
producidos por el Estado. Históricamente, los primeros barrios populares tienen su origen a finales del siglo XIX y principios del XX (Bayona, $\left.s / d^{5}, p .1-2\right)$.

Assim como no caso das favelas, os bairros populares também se originam, sobretudo, em decorrência do déficit habitacional nas ditas áreas formais, quando as pessoas, por falta de opção, são levadas a construir em locais com pouca ou nenhuma infraestrutura urbana, conforme Sepulveda Corzo (2012):

La falta de ofertas y oportunidades de vivienda han obligado a los habitantes en situación de pobreza a solucionar su necesidad de habitación y alojamiento a través de distintas modalidades que se encuentran por fuera del orden urbano y de la legalidad. Necesidad que se ha resuelto en varios casos mediante procesos de autoconstrucción y autogestión de vivienda, ya sea de forma individual, familiar, con acompañamiento técnico o sin él, a partir del apoyo de diferentes actores y organizaciones, cuyo interés se centra en mejorar las condiciones físicas y sociales, a través de la organización, la promoción y gestión de su propio hábitat y su entorno urbano. Esta dinámica se traduce en la conformación de sectores urbanos compuestos en su mayoría por barrios populares, que históricamente han sido gestionados por fuera del control y regularización del Estado, y que se encuentran inmersos en la denominada lógica de la necesidad (Sepulveda Corzo, 2012, p. 146).

Esses setores populares são geralmente caracterizados por uma:

Topografía y suelo exigente para la urbanización, la vulnerabilidad ante el riesgo ambiental, además de las dificultades para el acceso a los servicios básicos y equipamientos urbanos que brinda la ciudad en general, condiciones que, por lo regular, han llevado al desmejoramiento del entorno social (Sepulveda Corzo, 2012, p. 146).

Quanto à categoria território, Santos et al. (2007, p. 13) a descreve como sendo "o lugar em que desembocam todas as ações, todas as paixões, todos os poderes, todas as forças, todas as fraquezas, isto é, onde a história do homem plenamente se realiza a partir das manifestações da sua existência". Assim, para esse autor:

O território não é apenas o conjunto dos sistemas naturais e de sistemas de coisas superpostas; o território tem que ser entendido como o território usado, não o território em si. O território usado é o chão mais a identidade. A identidade é o sentimento de pertencer àquilo que nos pertence. $O$ território é o fundamento do trabalho; o lugar da residência, das trocas materiais e espirituais e do exercício da vida. O território em si não é uma categoria de análise em disciplinas históricas, como a geografia. É o território usado que é uma categoria de análise (Santos et al., 2007, p. 14).

\footnotetext{
${ }^{5}$ Sem Data.
} 
Esse é, portanto, um conceito com distintas interfaces o que o torna complexo e que se constitui de grande valia para a área das políticas públicas "no sentido de representar outros parâmetros que ultrapassem a segmentação de demandas ou a focalização de ações" (Dirce Koga, 2011, p. 40). Ainda de acordo com essa autora, sua dimensão de territorialidade, que está relacionada à forma singular das pessoas se apropriarem e fazer uso da terra e do território,

Traz elementos que permitem uma perspectiva de totalidade da questão social: já que trabalha não somente com os aspectos das necessidades, como se refere às próprias relações estabelecidas entre os sujeitos e seu cotidiano de vivência, esta relação dinâmica se contrapõe à corriqueira e simplista noção de necessitados ou carentes como comumente se referem as políticas direcionadas aos pobres, que os destitui da condição de sujeito (Koga, 2011, p. 40).

Deste modo, assim como Dirce Koga (2011), compreendemos o território para além dos seus aspectos objetivos da realidade vivida pelas pessoas, consideramos também a sua dimensão subjetiva, que se faz presente de forma concreta por meio das manifestações de perspectivas, anseios, sofrimentos, entre outros. O território representa, portanto:

O chão do exercício da cidadania, pois cidadania significa vida ativa no território, onde se concretizam as relações sociais, as relações de vizinhança e solidariedade, as relações de poder. É no território que as desigualdades sociais se tornam evidentes entre cidadãos, as condições de vida entre moradores de uma mesma cidade mostram-se diferenciadas, a presença/ausência dos serviços públicos se faz sentir e a qualidade destes mesmos serviços apresentam-se desiguais. Desta forma, o direito a ter direito é expresso ou negado, abnegado ou reivindicado a partir de lugares concretos: o morar, o estudar, o trabalhar, o divertir-se, o viver saudavelmente, o transitar, o opinar, o participar (Koga, 2011, p. 33).

No que diz respeito à categoria política pública de resíduos sólidos, utilizamos para o nosso embasamento, quando falamos do Brasil, a Política Nacional de Resíduos Sólidos, Lei 12.305/2010 e, em se tratando da Colômbia, a Política Nacional para la Gestión Integral de Residuos Sólidos, Documento CONPES 3874. Salientamos que versaremos de forma mais detalhada sobre ambas as políticas, no capítulo três.

Apesar da política pública de resíduos sólidos determinar caminhos que apontam para, além da redução, reutilização e reciclagem e novas práticas de destinação, a fim de evitar o aumento de vetores e o adoecimento das pessoas por contaminação pelos resíduos sólidos, bem como evitar acidentes ambientais na época das grandes chuvas, entre outros possíveis riscos, registramos que é muito recente a importância dada ao processo de gestão e gerenciamento dos 
resíduos, tanto nos municípios brasileiros quanto nos colombianos, bem como nos países pobres ou em desenvolvimento, de um modo geral. De acordo com Azevedo (2010), os:

Países do "terceiro mundo", também passaram a dar importância para o gerenciamento do lixo municipal recentemente, o que aumenta a importância do tema em termos mundiais. Uma das razões para tal mudança de postura é o fato de inúmeras pessoas que nunca tiveram acesso à renda, estarem se tornando vorazes consumidoras, o que resulta em um aumento do impacto ambiental e gera transtornos cada vez mais visíveis para a população (Azevedo, 2010, p.12).

Isso reforça a necessidade de que seja posta em prática, também nas áreas favelizadas e bairros populares, os preceitos da Política Nacional de Resíduos Sólidos - Lei 12.305/2010 (Brasil), assim como da Política Nacional para la Gestión Integral de Residuos Sólidos (Colômbia), pois o consumo nessas regiões tem aumentado significativamente, como no caso da Rocinha, que de acordo com Azevedo (2010, p. 42): "no que se refere à quantidade de resíduos produzidos, a comunidade da Rocinha apresenta números comparáveis aos de uma cidade média".

No entanto, o que tem sido demonstrado até pela observação de campo e levantamento dos dados, é o retrocesso legal na aplicabilidade das determinações da política pública de resíduos sólidos, visto que sua operacionalização tem evidenciado a incapacidade dos gestores públicos em efetivá-la, principalmente, em se tratando das áreas mais vulneráveis da cidade, como as favelas e os bairros populares.

Nesses espaços, geralmente o poder público para se eximir de sua responsabilidade, utiliza-se de justificativas como a falta de infraestrutura urbana adequada, que não oferece condições ideais para a coleta regular porta a porta, em função da existência de becos e vielas. Cabe salientar que, diante da realidade imposta, não identificamos esforços para que sejam disponibilizados recursos para a promoção da destinação adequada dos resíduos e rejeitos gerados, portanto, o próprio poder público, não garante ao cidadão morador de favela/bairro popular, na maioria das vezes, que esse possa dar um destino adequado ao resíduo por ele gerado; o que se verifica, com frequência, é o acúmulo excessivo de resíduo, ocasionador de danos, não só de ordem ambiental, mas de saúde e de baixa qualidade de vida para a população local.

Assim sendo, acreditamos que para o enfrentamento da problemática dos resíduos sólidos nesses territórios, faz-se necessário que a política pública de resíduos sólidos seja pensada conjuntamente com outras políticas públicas, que 
entendemos ter implicação direta nessa questão, como as políticas voltadas para o saneamento, habitação, uso e ocupação do solo, mobilidade, questões ambientais, para as políticas de desenvolvimento urbano em geral, entre outras.

O termo resíduo sólido perpassa todo o processo de construção da pesquisa e da escrita da tese propriamente dita. Esse termo é definido pela Norma Brasileira (NBR) $n^{\circ} 10.004 / 2004$ da Associação Brasileira de Normas Técnicas (ABNT), como:

\begin{abstract}
"Resíduos nos estados sólido e semissólido, que resultam de atividades de origem industrial, doméstica, hospitalar, comercial, agrícola, de serviços e de varrição. Ficam incluídos nesta definição os lodos provenientes de sistemas de tratamento de água, aqueles gerados em equipamentos e instalações de controle de poluição, bem como determinados líquidos cujas particularidades tornem inviável o seu lançamento na rede pública de esgotos ou corpos de água, ou exijam para isso soluções técnica e economicamente inviáveis em face à melhor tecnologia disponível" (ABNT, 2004, p. 1).
\end{abstract}

De acordo com Santaella et al. (2014),

O conceito de resíduos sólidos variou ao longo do tempo, em função dos avanços tecnológicos, da conscientização ambiental, e da necessidade financeira de reaproveitamento de materiais que não são mais úteis para um determinado fim, mas podem servir de matéria-prima para outro. Essa conceituação pode variar conforme a época, o lugar, o clima, a cultura, os hábitos e a condição socioeconômica de uma sociedade. Esse conceito é relativo, pois o que é inservível para determinada comunidade ou indivíduo, pode não ser para outros. (Santaella et al., 2014, p. 21).

No capítulo três que se dedicará a política pública de resíduos sólidos brasileira e colombiana, iremos trabalhar com a definição deste termo, tanto segundo a Política Nacional de Resíduos Sólidos (Lei 12.305/2010), quanto de acordo com a descrição da Política Nacional para la Gestión Integral de Residuos Sólidos (Documento CONPES 3874).

Trazemos também para melhor embasamento do nosso estudo, a categoria questão socioambiental, tendo em vista que nossa temática é atravessada pela discussão do debate ambiental, uma vez que os impactos causados pelo trato inadequado dos resíduos sólidos, ocasionam não só danos ao meio ambiente, mas também às pessoas. Silva (2016, p. 26), afirma que "é impossível refletir a dimensão social sem pensar o ambiental. Pois o social e o ambiental não estão em campos diferentes na sociedade capitalista. Desse modo, a expressão 'socioambiental' refere-se aos processos sociais resultantes da relação da sociedade com o meio ambiente". 
Nunes \& Silva (2013, p. 2-3) sinalizam que o 'termo 'sócio' inserido no 'ambiental' é justificado no sentido de evidenciar uma opção política para reforçar a compreensão de que não se pode separar dessa discussão o componente social do ambiental", tendo em vista que conforme aponta Nascimento \& Barbosa (2020), o ambiente é constituído a partir da relação homem e elementos naturais, sendo, portanto, o meio ambiente, resultado dessa interação. As autoras afirmam ainda, que a questão socioambiental é uma das novas expressões da questão social, cujos impactos intervêm de maneira crítica na vida humana.

Assim, certos dessa interação entre o social e o ambiental e de suas implicações nas expressões da questão social, assinalamos que as questões relativas ao trato com os resíduos sólidos e seus impactos na vida da população e do meio ambiente, têm relação direta com o atual padrão de desenvolvimento, que é gerador de desigualdade e de dependência - que não são naturais, que ocasiona impactos no território, que demanda as políticas de natureza urbana para qualificação dos espaços vulneráveis e para o qual chamamos à atenção da necessidade de desnaturalizar a incapacidade dos gestores públicos em relação à implementação das políticas públicas nos territórios vulnerabilizados cuja vulnerabilidade está fundamentada no padrão de desenvolvimento adotado ao longo dos anos.

O desenvolvimento urbano desigual tem, portanto, rebatimentos sobre as relações sociais, dessas relações com o território/ambiente, no qual também está inserida a discussão dos resíduos sólidos que, por vez, tem implicações em muitas das expressões da questão socioambiental de territórios populares como os deste estudo, ocasionando uma sobreposição de vulnerabilidades à população desses locais.

Conforme apontado no início deste trabalho, a pesquisa se dará na favela da Rocinha no Rio de Janeiro/Brasil e em Siloé em Cali/Colômbia, locais com um significativo adensamento populacional e com inúmeras expressões da questão socioambiental, que sofrem com forte estigmatização, conforme conceitua Goffman (2008), ao definir o termo, onde os que se intitulam "normais" estigmatizam com frequência os que habitam estes territórios populares da cidade. Esse comportamento é praticado, sobretudo, por àqueles que desconhecem a realidade vivenciada de fato nessas áreas e que acabam atribuindo a elas e à sua população, estigmas como os relativos à violência; à pobreza; à deficiência ou ausência de educação, de consciência, de cultura; os estigmas que envolvem a problemática dos resíduos sólidos, como se esses 
fossem os únicos responsáveis pelos danos a que eles próprios estão expostos; dentre outros. Os estigmatizadores agem como se os estigmatizados fossem anormais quando comparados aos que se enxergam como "normais", sendo, portanto, as populações dos territórios populares, depreciadas com frequência.

Após a escolha do lócus da pesquisa, nos perguntamos como seria esse estudo e após longas discussões acerca da questão, chegamos à conclusão de que a análise comparativa seria a que mais se aplicaria nessa situação, mesmo sabendo que não constituiria em uma tarefa fácil, pois conforme aponta Vidal (2013),

Quando se trata de comparar unidades diferentes, sejam elas regiões, países ou processos de mudança, a complexidade aumenta devido às diferenças culturais existentes, além da configuração de variáveis, fontes de dados disponíveis produzidas e construídas a partir de diferentes conceitos, técnicas e metodologias utilizadas (Vidal, 2013, p. 5).

Apesar dos desafios encontrados na pesquisa de cunho comparativo, essa vem ganhando espaço no campo acadêmico, sobretudo nos últimos anos; e, segundo Vidal (2013), tem se tornado elementar para a análise das causas e dos resultados concretos de algumas políticas públicas, bem como vem sendo essencial nas ciências sociais e humanas, contribuindo para analisar processos de mudança social, para a avaliação de programas, projetos, políticas públicas e sociais e da própria administração pública.

Ainda de acordo com Vidal (2013) "os estudos comparativos podem servir para o conhecimento e a aprendizagem mútua de experiências" (Vidal, 2013, p. 7), portanto, nos permitirá conhecer o caso de Siloé no tocante ao trato com os resíduos sólidos, de modo a compará-lo, no tempo presente, com a realidade da favela da Rocinha, suscitando em novos conhecimentos a partir da análise desenvolvida.

No estudo comparativo, Sartori et al. (1999) aponta que não é possível comparar o que é totalmente igual ou completamente diferente. Esse defende que os objetos comparados têm que apresentar tanto características similares quanto diferenças, pois se forem de todo idênticas ou díspares, seria inútil compará-los, conforme fala a seguir:

De lo afirmado hasta este punto puede concluirse que comparar implica asimilar y diferenciar en los límites. Si dos entidades son iguales en todo, en todas sus características, es como si fuesen la misma entidad, y todo termina ahí. A la inversa, si dos entidades son diferentes en todo, entonces es inútil compararlas, $y$ del mismo modo todo concluye aquí. Las comparaciones que sensatamente nos interesan se llevan a cabo entre entidades que poseen atributos en parte 
compartidos (similares) y en parte no compartidos (y declarados no comparables) (Sartori et al., 1999, p. 35).

Sartori et al. (1999) recomenda que ao nos propormos a fazer uma comparação, que sempre nos perguntemos: "são comparáveis em que aspectos?" E utiliza como exemplo, peras e maçãs que são comparáveis em muitos aspectos, por serem frutas, comestíveis, crescer em árvore; no entanto, diferem quanto a sua forma e sabor, por exemplo.

A partir dessa analogia, levando em consideração as similaridades e especificidades de cada um dos lócus da nossa pesquisa (Rocinha e Siloé), concluímos que esse método se aplica ao nosso estudo, nos permitindo comparar a temática em discussão, entre ambos os campos.

Ainda com base no pensamento de Sartori et al. (1999), quando fala de como realizar a comparação, esse assinala que após definirmos que uma coisa é comparável à outra, logo em seguida temos que determinar qual a estratégia comparativa a ser seguida, se destacaremos as semelhanças ou as diferenças, apontando que:

A veces el comparatista subrayará las similitudes, a veces las diferencias. Prestará atención a las diferencias en los contextos que son similares, o... buscará analogías en sistemas diferentes. Paralelamente se dan dos enfoques: elegir sistemas más semejantes, o bien elegir sistemas más diferentes (Sartori et al., 1999, p. 40).

Nesta pesquisa optamos por destacar, sobretudo as similaridades, porém não deixando de apontar, quando pertinente, as diferenças identificadas ao longo da análise.

O método comparativo é muito mais que uma simples técnica a ser aplicada em grandes estudos, pode ser utilizada também para "abordar os problemas e fenômenos sociais, com os quais está intimamente vinculado em questões de caráter epistemológico e de procura e construção do conhecimento" (Vidal, 2013, p. 8).

Esse mesmo autor sinaliza que esse método foi desenvolvido por Auguste Comte, Émile Durkheim e Marx Weber, ainda que tenha sido Marx, o pensador que provavelmente foi o primeiro a lançar mão da comparação histórica nos seus estudos voltados para as sociedades pré-capitalistas em sua obra "O Manifesto Comunista". A autora afirma ainda, que "os estudos comparativos se iniciaram na primeira metade do século passado, com os estudos dos sistemas educativos em vários países" (Vidal, 2013, p. 8). 
Vidal (2013, p. 9), traz alguns autores que definem a metodologia comparativa, apontando que em várias obras e escritos, a ênfase está situada nos distintos aspectos epistemológicos, conforme trecho que segue:

O método comparativo pode ser considerado como "inerente ao processo de construção do conhecimento nas ciências sociais" (Schmitt; Schneider, 1998, p.1), e "pertence a uma das formas mais antigas para o exame da realidade" (PICKEL; PICKEL; LAUTH, 2009). Outros autores reforçam o aspecto da aprendizagem mútua: "é uma abordagem baseada no respeito mútuo" (...) sendo a vez "um processo estruturado e um processo interpessoal" (...) na vontade de incluir, em abrir-se ao outro" (LESEMANN, 2000). Especificamente referindo-se à área dos estudos na Ciência Política, Arend Lijphart (1977) define a política comparada como sendo preocupada por questões relativas ao "método". Nas últimas duas décadas, tem aparecido uma "nova geração" de estudos metodológicos na Ciência política comparada cujas aportações e problemas metodológicos têm sido extensamente tratados, de tal forma que se fala inclusive de uma "nova metodologia qualitativa na Ciência Política" (REZENDE, 2011, p. 303). ${ }^{6}$

Como recorte da pesquisa e elementos que foram pontos analíticos neste estudo comparativo, temos: o processo de destinação dos resíduos sólidos gerados e suas formas de tratamento na Rocinha no Rio de Janeiro/Brasil e em Siloé em Cali/Colômbia, objetivando a identificação das práticas aplicadas em áreas populares no que diz respeito ao trato com os resíduos sólidos nos dois países.

$\mathrm{Na}$ Rocinha, quanto ao grupo de moradores, a ideia inicial era focarmos no Bairro Barcelos - situado na área plana, local onde o serviço de limpeza e coleta funciona mais próximo do que deveria ser e no sub-bairro 99 - localizado na parte alta, uma das áreas onde identificamos durante a nossa pesquisa de mestrado (2014-2016), um maior acúmulo de resíduo sólido descartado inadequadamente nas encostas. Porém devido à pandemia da Covid-19, conforme já citado, tivemos que fazer adaptações e, em função de tais ajustes no que diz respeito ao método de aplicação das entrevistas (formulário on-line), acabamos recebendo respostas de moradores de diversas áreas, uma vez que enviamos para alguém que conhecíamos ou para grupos de aplicativos (sobretudo via WhatsApp) como o "Rocinha Sem Fronteiras", e essas pessoas, por vezes, enviaram para outros residentes que conheciam, totalizando 32 formulários respondidos. Posteriormente realizamos uma seleção, utilizando como critério aqueles que estavam mais completos e que nos ofereceriam mais elementos para a nossa análise, além de atentar também para o sub-bairro em que o participante residia, visando contemplar áreas distintas da favela, chegando, portanto, a seleção de 10 formulários.

\footnotetext{
6 Todos os autores que aparecem neste trecho são citados por Vidal (2013, p. 9).
} 
Do mesmo modo, conforme dito anteriormente, nesse território enviamos o formulário online para a única organização de catadores identificada nessa região, que de pronto nos enviou o documento com as respostas.

Quanto aos demais grupos, realizamos entrevistas presenciais com: um representante da empresa de limpeza urbana (COMLURB), três representantes do comércio e três catadores de materiais recicláveis.

Em Siloé, no tocante ao grupo de moradores, nos atemos à parte plana, onde a exemplo do que acontece na Rocinha, os serviços são executados com maior qualidade e a algumas áreas dos bairros da parte alta, onde a coleta porta a porta e a varrição de rua não acontecem, tendo os habitantes, que levar os resíduos até um ponto de apoio. Nesse campo, as entrevistas foram presenciais e foram aplicadas com 09 pessoas, sendo uma dessas realizada durante o préteste, porém como ficou bem completa e não teve alteração no formulário inicial, optamos por incluí-la nas análises.

Nesse campo, como citado anteriormente, além das entrevistas presencias, enviamos também - via WhatsApp, formulários para alguns moradores e lideranças comunitárias, com vistas a obtermos o máximo possível de informações sobre a temática em discussão nesse território, porém o número de retornos obtido não foi tão expressivo como no caso da Rocinha, chegando a cerca de nove formulários respondidos, dos quais selecionamos três, por conterem mais elementos que algumas das entrevistas presenciais, fazendo, portanto, essa substituição. Desse modo, fechamos um total de 10 formulários selecionados para nossa análise no campo de Siloé, sendo 07 de entrevistas presenciais e 03 de formulários online.

Em relação aos outros grupos de Siloé, aplicamos entrevistas presenciais com: um representante da empresa de limpeza urbana (Ciudad Limpia), três representantes do comércio, três recicladores ${ }^{7}$ e duas organizações de catadores.

Em síntese, tivemos como sujeitos partícipes dessa pesquisa, cinco grupos: moradores (20 entrevistas selecionadas), representantes das empresas responsáveis pela limpeza urbana (02 entrevistas), catadores/recicladores (06 entrevistas), representantes de organizações de catadores/recicladores (03 entrevistas) e representantes do comércio (06 entrevistas), totalizando 37 participantes.

7 Recicladores é o nome dado às pessoas que exercem o trabalho de catação de materiais recicláveis na Colômbia, onde também são conhecidos como recuperadores. 
Assim sendo, mediante necessidade sentida no decorrer da pesquisa, sobretudo em relação à Siloé, decidimos atingir um público maior de entrevistados, pois o previsto inicialmente, no projeto de qualificação, era a realização de entrevista com pelo menos 01 representante de cada empresa que presta o serviço de limpeza urbana e com 08 representantes dos demais grupos (sendo 04 em cada país), o que totalizaria 10 entrevistas, distribuídas entre os dois lócus da pesquisa.

A nossa escolha por esses sujeitos a serem entrevistados, se prendeu a necessidade de coletarmos dados oriundos daqueles que executavam o trabalho, bem como dos que vivem e viviam a realidade nessas áreas. Assim sendo, consideramos que os representantes das empresas responsáveis pela limpeza urbana, além de nos fornecerem dados quanti-qualitativos para um melhor embasamento da pesquisa, também contribuiriam com o posicionamento enquanto órgão prestador do serviço. Já os demais grupos que vivenciam e/ou lidam de alguma forma com a questão socioambiental nesses campos, foram importantes, pois nos forneceram a partir das informações, o olhar de cada um em relação ao trato com os resíduos sólidos, e ainda como enxergam o serviço que é prestado pelas empresas de limpeza urbana.

A abordagem que melhor se aproximou do nosso propósito neste estudo, foi a de cunho qualitativo, pois, consubstanciada na visão de Minayo (2006), esse é o método que se aplica ao estudo da história, das relações, das representações, das crenças, das percepções e das opiniões, frutos das interpretações que os indivíduos realizam no tocante a como vivem, constroem seus artefatos e a si mesmos, sentem e pensam, deste modo, os enfoques qualitativos são os que melhor se acomodam no caso das investigações de grupos e segmentos delimitados e focalizados, de histórias sociais baseadas na visão dos sujeitos, de relações e para análises de discursos e de documentos.

Cassab (2007) aponta que a pesquisa qualitativa é voltada para um nível de realidade que não pode ser quantificado, onde a compreensão e a explicação da dinâmica das relações sociais, por serem carregadas de crenças, valores, atitudes e hábitos, correspondem a um espaço mais profundo, tanto das relações quanto dos processos, bem como dos fenômenos. Nesse tipo de pesquisa, dar-se ênfase a vivência, a experiência, a cotidianidade e, também, a compreensão das estruturas e instituições, enquanto resultados da ação humana objetivada, o que torna as práticas sociais, a linguagem e outros aspectos da vida social, aspectos intrínsecos um do outro. A pessoa que está pesquisando, ao empregar a abordagem qualitativa, averigua momentos 
distintos do caso observado enquanto testemunha-chave, atentando para o fato de como esses casos são determinados no contexto em que ocorrem, com predomínio da história e da cultura.

Quanto aos instrumentos de coleta de dados, lançamos mão da entrevista semiestruturada, isto porque, nesse tipo de abordagem, "o roteiro deve desdobrar os vários indicadores considerados essenciais e suficientes em tópicos que contemplem a abrangência das informações esperadas" (Minayo 2006, p. 191), dando ao entrevistado a possibilidade de discorrer sobre o tema em discussão, sem respostas ou condições pré-estabelecidas pelo pesquisador.

Tobar \& Yalour (2001), assinalam que as entrevistas semiestruturadas se baseiam no uso de uma relação de perguntas ou mesmo temas que as nortearam. Não tendo uma ordem exata nem no ato da realização das perguntas, nem no momento da escrita, uma vez que cada entrevistado é único, o que influenciará no desenrolar da entrevista. O pesquisador pode se deparar com novos desdobramentos do tema estudando, durante o andamento das entrevistas, sendo o formulário, um conjunto de instruções claras referentes às principais perguntas a serem feitas ou temas a serem explorados. Esse tipo de entrevista tem como objetivo a obtenção de um entendimento mais completo e detalhado possível, da questão abordada. $O$ formulário utilizado pelo pesquisador contribui para mostrar que esse tem clareza sobre seus objetivos, sendo o instrumento flexível a ponto de permitir ao pesquisador e ao pesquisado, encontrar e/ou seguir novas pistas.

Valemo-nos ainda da observação de campo, como ferramenta para apreensão de conhecimento relativo ao nosso objeto de estudo. Queiroz et al. (2007), afirma que esta é uma das formas mais empregadas pelo ser humano para o conhecimento e compreensão de uma dada realidade, seja ela relacionada a pessoas, situações, coisas ou acontecimentos. O ato de observar é, portanto, a aplicação dos "sentidos a fim de obter uma determinada informação sobre algum aspecto da realidade. É mediante o ato intelectual de observar o fenômeno estudado que se concebe uma noção real do ser ou ambiente natural, como fonte direta dos dados" (Queiroz et al., 2007, p. 277).

Ainda a esse respeito, Queiroz et al. (2007) aponta que o ato de observar sugere a aplicação dos sentidos, de forma atenta, ao que está sendo observado, para que a partir daí obtenha-se um conhecimento claro e preciso. Sendo a observação considerada como uma técnica científica a partir do momento em que é sistematizada, planejada, havendo controle da objetividade. No ato da observação, o pesquisador não é uma pessoa que está simplesmente olhando o 
acontecimento, ele está observando por meio de um olhar treinado em busca de determinados acontecimentos. Uma das principais vantagens da observação é o fato de o pesquisador ter a possibilidade de obter a informação no ato do ocorrido.

Queiroz et al. (2007), assinala que o ato de observar não é simplesmente ver, é necessário examinar, não se tratando apenas de entender, mas de auscultar. A observação é muito importante para a pesquisa, sobretudo a de cunho qualitativo, estando presente desde a formulação do problema, perpassando pela construção das hipóteses, coleta de dados, análise e interpretação deles. Segundo a autora, não é possível observar tudo ao mesmo tempo, nem tampouco podem ser observadas várias coisas ao mesmo tempo, sendo assim, uma das condições fundamentais para a observação adequada é a limitação e a definição precisa dos objetivos que se busca alcançar; isso se constitui de fundamental importância na ciência, se tornando uma das condições indispensáveis para a garantia da validade da observação.

No tocante ao levantamento bibliográfico e a pesquisa documental, enfocamos que foram ao longo dessa trajetória, ações sistemáticas e permanentes, tanto no período da pesquisa como durante a elaboração da tese, de modo a contribuir com nosso aperfeiçoamento e garantindo a atualização das informações para o embasamento teórico-metodológico.

A análise e sistematização dos dados nos possibilitaram a verificação das questões levantadas neste estudo, contribuindo para a construção textual da tese. Além disso, nos forneceram elementos que nos permitiram ultrapassar o empirismo sobre os fatos, chegando à esfera da geração de dados científicos, relevantes para a comunidade acadêmica e demais interessados na temática.

Em atenção ao rigor da pesquisa e respeito aos sujeitos envolvidos, na garantia do sigilo e respeito às individualidades, solicitamos autorização dos entrevistados para utilizarmos as informações concedidas para o nosso estudo, e para tanto lavramos um Termo de Livre Consentimento (modelo no apêndice), que foi lido e assinado pelos entrevistados para assegurá-los da confidencialidade e anonimato.

A tese está estruturada da seguinte forma: quatro capítulos e as considerações finais. Na sequência, apresentaremos de forma mais detalhada a sua estrutura.

Dentre os principais assuntos abordados no Capítulo I (Introdução) estão: breve apresentação dos campos da pesquisa, objetivo do estudo, percurso metodológico e a estrutura da tese. 
No capítulo II, intitulado "contextualizando a favela/bairro popular na América Latina: entre a Rocinha no Brasil e Siloé na Colômbia", buscamos contextualizar brevemente as cidades latino-americanas no século XXI, trazendo para o entendimento desse contexto, as agências multilaterais e sua relação com o desenvolvimento latino-americano. Posteriormente, discorremos sobre o desenvolvimento e os impactos no processo de urbanização das áreas populares das cidades latino-americanas, apresentando o caso do Rio de Janeiro e de Cali; na primeira cidade, buscamos entender o processo de urbanização dessa região e sua relação com o surgimento e/ou adensamento das favelas cariocas; do mesmo modo, em Cali, fazemos o mesmo exercício, objetivando compreender de que forma o processo de urbanização implicou no surgimento dos bairros populares nesse território. E encerramos esse capítulo, apresentando os dois campos dessa pesquisa: Rocinha e Siloé.

No capítulo III, denominado "Panorama da política pública de resíduos sólidos na América Latina com foco no Brasil e Colômbia", trazemos dados sobre a atual conjuntura dos resíduos sólidos na América Latina, afunilando logo em seguida, para o panorama da gestão dos resíduos sólidos no contexto brasileiro e colombiano. E fechamos esse capítulo, com a apresentação da política nacional de resíduos sólidos do Brasil e da Colômbia, onde também por fim, nos propomos a trazer alguns elementos para analisarmos os avanços e retrocessos dessas políticas em ambos os países.

No capítulo IV, intitulado "Rocinha e Siloé: apresentação e análise dos resultados a partir da fala dos sujeitos”, como já sugerido pelo título, são apresentados os resultados obtidos por meio da observação de campo e das entrevistas realizadas com os cinco grupos que integraram a pesquisa. Esse capítulo apresentará a visão dos moradores sobre a forma de destinação dos resíduos sólidos a partir dos lócus pesquisados; a visão das empresas de limpeza urbana em relação ao trabalho prestado; o olhar das organizações de catadores/recicladores sobre o trabalho executado; o labor dos catadores/recicladores e a realidade por eles vivenciada no dia a dia; e, também, trazemos elementos sobre a geração e destinação de resíduos sólidos pelo comércio local.

Por fim, porém não menos importante, apresentaremos nossas considerações finais, apontando resultados e sugestões de aperfeiçoamento do serviço de limpeza urbana prestado em áreas populares, a partir do nosso olhar consubstanciado pelo estudo realizado nas duas áreas - Rocinha no Brasil e Siloé na Colômbia, em relação ao processo de destinação dos resíduos sólidos 
gerados nos dois lócus e suas formas de tratamento. Mas, sobretudo, apontando caminhos para que as pessoas que vivem em áreas cuja política socioambiental nem sempre é prestada de forma adequada, possam ser visibilizadas, e que diante disso, novas alternativas de destinação adequada de resíduos sejam ofertadas na busca da melhor qualidade de vida para essa população, seja no Brasil, na Colômbia ou em áreas onde haja similaridades na composição dos serviços.

A título de esclarecimento, salientamos que mesmo tendo um rico acervo fotográfico tanto da Rocinha quanto de Siloé sobre a questão tratada, optamos por não colocar as fotos no corpo do texto, tendo em vista que o documento ficaria muito pesado, o que dificultaria o processo durante o período de escrita, por este motivo decidimos elaborar um documento à parte - nos apêndices. 


\section{2 \\ Contextualizando a favela/bairro popular na América Latina: entre a Rocinha no Brasil e Siloé na Colômbia}

Neste capítulo nos propomos a falar brevemente sobre as cidades latinoamericanas no século XXI, contexto no qual estão inseridos Rio de Janeiro e Cali; tratamos sobre as agências multilaterais, buscando entender que são essas instituições, além de pensar a sua atuação e influência na configuração do desenvolvimento latino-americano; apresentamos o desenvolvimento e os impactos no processo de urbanização das áreas populares das cidades latinoamericanas, trazendo o caso do Rio de Janeiro e de Cali, onde está situada a Rocinha e Siloé, respectivamente; e por último, apresentamos esses dois campos (Rocinha e Siloé), objeto desse estudo, trazendo um pouco da história, bem como dados da atualidade.

\section{1. \\ Cidades latino-americanas no século XXI: uma breve contextualização}

Empreender esforços para definir o que seria e quais países compõe a América Latina, seria um movimento interessante e que muito nos instigou no ato do levantamento para este início de capítulo, entretanto demandaria um investimento de tempo que para o presente estudo não seria possível, tendo em vista ser outro o foco. No entanto, em termos gerais e para fins de uma sucinta apresentação, podemos dizer que a América Latina é formada por nações que no passado foram territórios predominantemente colonizados por países, cujas línguas oficiais têm origem no latim (espanhol, português e francês), vindo daí, o nome dessa divisão e que se caracteriza pela sua relação de dependência, desde seus primórdios.

Cabe chamar a atenção para o fato de que não encontramos uma lista oficial dos países latino-americanos, bem como não identificamos um consenso sobre o que seria e quais as nações/territórios fazem parte dessa divisão, tendo relatos raros, porém encontrados na nossa primeira aproximação com o assunto, 
em canais da internet, que apontam inclusive a cidade de Quebec no Canadá, como sendo integrante da América Latina, uma vez que o idioma mais falado por lá é o francês. Enquanto isso, países como Guiana (idioma inglês) e Suriname (idioma holandês), que são países da América do Sul, não são integrantes desse bloco, segundo alguns desses relatos, por falarem idiomas que não são originários do latim. Assim, não foi encontrada uma classificação unânime de quais territórios compõem a América Latina, muito pelo contrário, não há um consenso a respeito da definição dessa categoria.

A América Latina diferente da América do Norte foi uma colônia de exploração, e acredita-se que daí originou o subdesenvolvimento desse bloco, pois os que aqui chegaram, no século $X V$, tinham tão somente como intuito, extrair as riquezas naturais existentes ou o que aqui fora produzido, para os países colonizadores. Não havia por parte dos exploradores, o interesse em investir no desenvolvimento deste território, porque aqui era um lugar de passagem e ainda hoje, em pleno século XXI, segundo Galeano (2020):

\begin{abstract}
A região continua trabalhando como serviçal, continua existindo para satisfazer as necessidades alheias, como fonte e reserva de petróleo e ferro, de cobre e carne, frutas e café, matérias-primas e alimentos, destinados aos países ricos que, consumindo-os, ganham muito mais do que ganha a América Latina ao produzilos. Os impostos que cobram os compradores são muito mais altos do que os valores que recebem os vendedores (Galeano, 2020, p. 17).
\end{abstract}

Em se tratando das cidades latino-americanas, assim como a noção de América Latina, também é uma tarefa hercúlea definir o que seria essa cidade, pois o que caracteriza uma, certamente não contemplaria com rigor, a definição de outra. De acordo com Gorelik (2005), essa dificuldade não está somente relacionada às realidades urbanas distintas de cada país, mas sim porque cada uma delas tem suas características próprias. Para ilustrar melhor, essa posição, encontramos alguns questionamentos levantados pelo autor que elucida a nossa afirmação, a saber:

Como agrupar em uma mesma categoria Ouro Preto, São Paulo e Brasília, no Brasil, ou Cartagena das Índias e Bogotá, na Colômbia? Que espécie de "cidade latino-americana" encarnaria cada uma delas? Que mapa pode ser delineado no conjunto? Se cada cidade apresenta qualidades distintas que dificultam sua integração, sem mais, numa categoria abrangente, seria absurdo tentar definir a cidade latino-americana por meio de um ideal de representação de um conjunto de características a ela atribuídas, como uma espécie de Frankstein urbano; tão absurdo seria o procedimento que ele poderia levar-nos rapidamente à conclusão de que a única cidade latino-americana realmente existente é Miami. Com efeito, a clássica indiferenciação da malha urbana norte-americana, visivelmente distinta de qualquer cidade latino-americana real, permitiu, no entanto, que nas últimas décadas se desenvolvessem em Miami múltiplos fragmentos de culturas urbanas 
de países latino-americanos, de modo que, da "pequena Havana" em diante, se formaram retalhos de paisagens urbanas dominicana, porto-riquenha, mexicana ou argentina, sendo possível percorrer a cidade como um parque temático de cidades latino-americanas (Gorelik, 2005, p. 111-112).

Portanto, para Gorelik (2005), a cidade latino-americana não pode ser entendida como algo dado, uma realidade natural, pois existe uma diversidade, não sendo possível definir todas a partir das características de uma, ainda que tenham similaridades, desse modo, devemos respeitar as especificidades de cada uma.

Assim, a cidade latino-americana existe "não como uma ontologia, mas como uma construção cultural" (Gorelik, 2005, p. 112). Ainda de acordo com o autor, foi entre os anos 1950 e 1970 que essa categoria foi produzida ao encontrar condições especiais que se articularam para tal, o que não significa que anterior a esse período, a cidade já não era importante, mas até os anos 1940, ela era pensada a partir do seu contexto nacional. Contudo, o autor sinaliza que nos anos de 1980:

\begin{abstract}
A "cidade latino-americana" deixou de expressar uma realidade teoricamente produtiva, e desde então sua figura encontra-se atravessada por uma ambivalência paralisante entre dois pólos opostos. Falamos de "cidade latinoamericana", por um lado, quando nos referimos de modo geral às grandes metrópoles e aos seus problemas prementes: pobreza e marginalidade, fragmentação e violência, encortiçamento dos centros históricos, urbanização descontrolada do campo, desequilíbrios regionais. E, de outro lado, nos últimos anos desenvolveu-se uma importante quantidade de estudos (históricos, sociológicos, antropológicos, urbanísticos) sobre cidades particulares da América Latina, que vêm demonstrando a impossibilidade ou, pelo menos, a esterilidade das comparações e das generalizações (Gorelik, 2005, p. 114).
\end{abstract}

Concordamos com Gorelik (2005) quando afirma que não é possível fazer generalizações no que concerne a definição do que seria uma cidade latinoamericana, por elas serem diversas, entretanto, entendemos ser viável fazer comparações, apontando as divergências e as similaridades existentes entre os campos comparáveis, como é o caso dos lócus desse estudo.

Em se tratando do processo de urbanização latino-americano, podemos dizer que os primeiros passos se dão nos territórios colonizados pelos espanhóis, sobre a base das cidades indígenas, tendo em vistas que ali já existiam cidades construídas pelos Astecas, enquanto em outros países, como no Brasil, por exemplo, ocorre inicialmente, com a formação de cidades no litoral, por onde se dava a extração do que interessava aos que exploraram esses territórios. 
Anos se passaram desde o período colonial e nos tempos mais recentes, podemos pensar a urbanização na América Latina, pelo viés da sua relação íntima com o capitalismo, que torna o direito à cidade, restrito ao grupo hegemônico detentor do capital. Capitalismo esse que em muitos momentos da história, acentua as desigualdades existentes entre as classes sociais, como, nos de 1960 e 1970, que foram muito marcantes, pois alguns países latinoamericanos experimentavam o milagre econômico e, ao mesmo tempo, viviam sob o comando de regimes ditatoriais, atrelado ao rápido processo de industrialização substitutiva. Esse período é muito marcado pelos grandes investimentos, tanto no setor de bens duráveis como de bens voltados para a produção. De acordo com Oliveira (2014), a combinação do:

Crescimento industrial e a urbanização acelerados viriam acompanhados da acentuação de uma série de desigualdades que se agravariam nas décadas seguintes e que ainda podem ser vistas nas grandes metrópoles. O crescimento industrial foi feito sob base de tecnologia intensiva em capital, mas em contraposição, empregos foram gerados no setor de serviços, cujo inchaço seria uma das características das grandes cidades na América Latina. (Oliveira, 2014, p. 170).

Com isso ocorre um desiquilíbrio no que concerne a estratificação social, sendo a classe média, beneficiada, passando a ser a principal consumidora dos bens duráveis, tornando-se os trabalhadores das grandes indústrias, a elite da classe trabalhadora, o que gera uma distinção entre este segmento e os demais trabalhadores, o que, no caso brasileiro, só intensificou a dificuldade de organização já imposta no período da ditadura. Assim, segundo Oliveira (2014):

Na grande cidade, o migrante vindo da zona agrária ou da região Nordeste, trabalhador da construção civil, passou a fazer parte da paisagem, não raro como membro das grandes periferias urbanas. O processo de urbanização também era, em si, criador de centros e periferias, urbanos e regionais (Oliveira, 2014, p. 171).

Entendemos, portanto, que a articulação entre capitalismo e urbanização, não só era como continua sendo, cada vez mais forte, um fator gerador de segregação socioespacial, privilegiando quem tem alto poder aquisitivo, que ocupa o espaço nobre das cidades, enquanto para aqueles com pouca ou nenhuma condição financeira, Ihes resta ocupar as regiões periféricas - favelas, bairros populares, subúrbios, etc.

Fatores como a tardia industrialização e a mecanização do campo, também contribuíram para esse cenário, pois levaram as pessoas das zonas rurais, a migrarem para os grandes centros urbanos, gerando um crescimento 
rápido e desordenado, e com isso as obrigando a ocuparem as áreas periféricas, ou espaços com pouca ou nenhuma infraestrutura. A dependência se tornou um dos fatores que caracterizam a América Latina e pode também nos ajudar a entender esse fenômeno, pois devido a essa condição, conforme afirmação abaixo:

Gran parte de la población de las zonas rurales y de las propias localidades semiurbanas enclavadas en las áreas rurales, es lanzada fuera de las estructuras ocupacionales y de relaciones económicas, que tienden a deteriorarse más rápidamente y a acentuar su situación de crisis ya bastante larga en el tiempo. Y esto ocurre precisamente en el mismo momento en que las tasas de crecimiento de la población de esas zonas tienden a alcanzar índices muy altos. De ese modo, la marginalización de la población rural encuentra una salida en la migración hacia las ciudades y las áreas donde la economía urbana está en expansión, y en esas áreas sólo puede encontrar las condiciones restrictivas del mercado de trabajo y del mercado en general y es, de nuevo, marginalizada y, esta vez definitivamente (Cortés, 2017, p. 6).

Esse movimento, portanto, é também reflexo da dependência, neste caso, dos lugares menos desenvolvidos em detrimentos daqueles onde se concentra o crescimento e as mudanças econômicas:

Produciéndose así un desnivel al interior de las sociedades en términos de desarrollo y modernidad. Con esto, se consolida una doble dependencia, pues el campo pasa a ser dependiente de la ciudad, amplificando y profundizando el "colonialismo interno" (Cortés, 2017, p. 6).

Isso se aplica tanto as áreas rurais quanto a realidade das favelas e bairros populares das grandes cidades. Visto que o processo intenso de saída do campo para a cidade em um curto intervalo de tempo, sobretudo entre $1950 \mathrm{e}$ 2000, implicou no inchaço dos centros urbanos, o que combinado com a falta de políticas públicas eficazes, foi decisivo para a configuração do atual cenário na América Latina e no Caribe, onde as áreas mais pobres, mesmo as centrais, padecem até hoje, sem a devida infraestrutura, sem condições dignas de habitabilidade e outras deficiências. Essa é a região que conta com a maior taxa de urbanização do mundo, chegando a cerca de $80 \%$ na primeira década do século XXI.

A título de evidenciar graficamente o que afirmamos, seguem dois mapas que demonstram de forma comparativa a evolução do processo de urbanização, entre os anos de 1950 e 2010. 
Figura 1 - Taxa de urbanização na América Latina e no Caribe: 1950

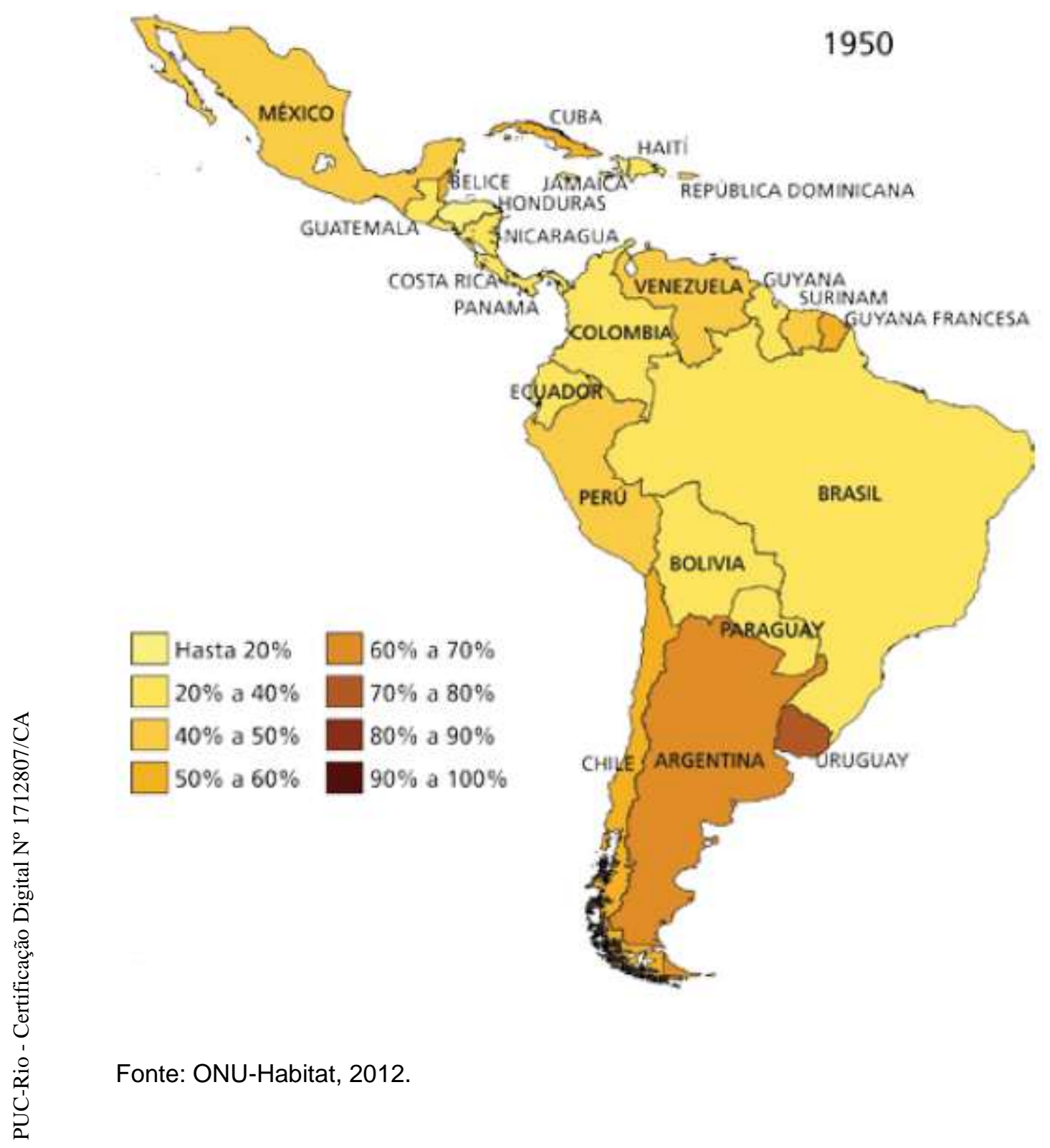


Figura 2 - Taxa de urbanização na América Latina e no Caribe: 2010

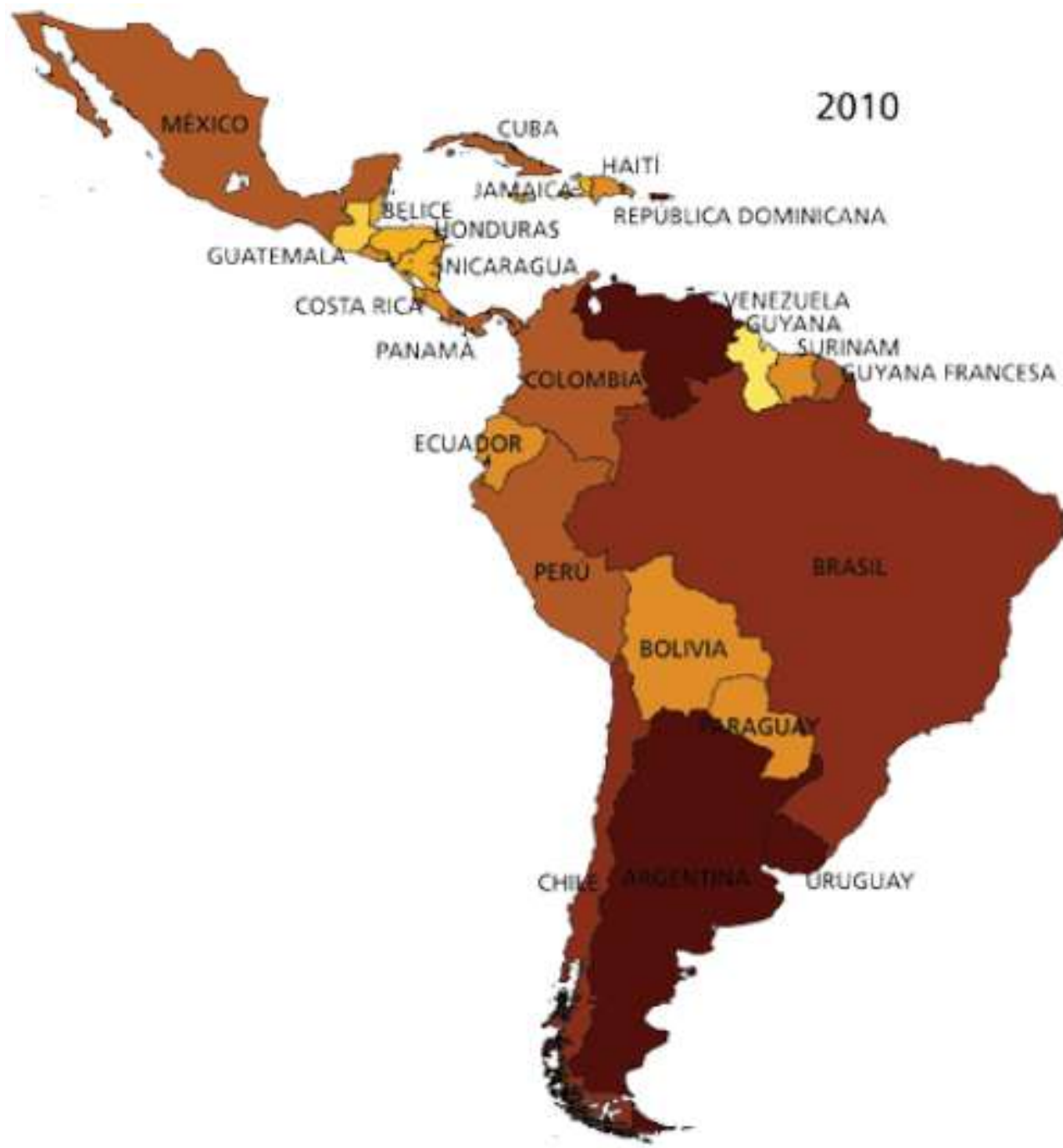

Fonte: ONU-Habitat, 2012.

Segundo o estudo realizado pelo Programa das Nações Unidas para os Assentamentos Humanos (ONU-Habitat), o Brasil e os países do Cone Sul, alcançaram uma taxa de urbanização de $90 \%$ em 2020 , sendo mais alta que nos países do norte europeu, onde a taxa é de $84,4 \%$, seguido pela América do Norte, cuja taxa é de $82,1 \%$. A urbanização do México e dos países que compõem a área andino-equatorial é de $85 \%$. Essas cifras no Caribe e na América Central são inferiores, no entanto seguem crescendo, de acordo com o referido estudo, devendo chegar, respectivamente, a 83\% e 75\% em 2050.

Na América Latina, nota-se grande concentração de pessoas nas cidades de maior porte, onde, de acordo com esse estudo, 34 \% estão vivendo nas urbes com mais de 1 milhão de habitantes e outros $20 \%$ residindo em centros 
metropolitanos, somando mais de 5 milhões de pessoas, somente nessas áreas. Nesse sentido, Gomes et al. (2020), aponta que:

\begin{abstract}
A América Latina abriga grandes centros urbanos, com milhões de pessoas, em razão da urbanização e do expressivo crescimento demográfico ocorrido entre os anos de 1950 e 2000. Dados da Comissão Econômica para a América Latina e o Caribe (CEPAL), demonstram que, entre os anos de 2000 e 2010, regiões metropolitanas, como Buenos Aires (Argentina), Santiago (Chile), Panamá (Panamá) e Montevidéu (Uruguai), abrigaram mais de 30\% de toda a população de seu respectivo país (CEPAL, 2019), evidenciando a influência das grandes metrópoles no desenvolvimento socioeconômico e socioambiental desses países (Gomes et al., 2020, p. 254-255).
\end{abstract}

É nas cidades onde se concentram as maiores riquezas, bem como onde, em contraposição, se observa muita pobreza e desigualdade social. Segundo o documento ONU-Habitat, nessas regiões, cerca de 111 milhões de pessoas vivem em áreas precárias, como nas favelas, por exemplo, onde cerca de 74 milhões de pessoas não têm acesso a saneamento adequado, nem tão pouco acessa adequadamente a serviços como: água potável, tratamento de esgoto e dos resíduos sólidos, dentre outros.

Essas desigualdades são visíveis na forma como estão estruturadas as cidades, onde é perceptível em muitos casos, que a riqueza mora ao lado da pobreza, porém não se mistura e onde jamais os que têm alto poder aquisitivo vivenciam determinados dissabores experimentados por aqueles que não dispõem de condições dignas de habitabilidade. Deste modo, podemos dizer que:

\begin{abstract}
A atual conjuntura urbanística reflete a evolução dos espaços urbanos e elucida as dinâmicas econômica, social e regulamentadora implementadas, uma vez que o território urbano compreende além dos aspectos estruturais, pilares econômicos, ambientais, sociais, políticos, jurídicos [...] (Gomes et al., 2020, p. 254).
\end{abstract}

Em Pase (2017, p. 3), a política pública está definida como "o que o governo escolhe fazer ou não"; e conforme é sabido, as ações dos governantes geralmente não se baseiam nas necessidades da população de menor poder aquisitivo, muito pelo contrário, são pensadas e implementadas, sobretudo, a partir das interações políticas tanto com o mercado quanto com a classe dominante e é nesse cenário onde também está inclusa a política urbana, que é responsável por definir a estrutura de uma cidade.

Compreende-se, deste modo, que o Estado assume um modelo de desenvolvimento que determina como será o espaço urbano e, quando olhamos, sobretudo para os grandes centros urbanos na América Latina, logo percebemos 
onde e quais territórios são privilegiados em detrimento de outros. Sem mesmo necessitar de um olhar mais atento, logo, se nota que as áreas empobrecidas são sempre as mais desfavorecidas e as que padecem devido à ausência e/ou ineficiência das políticas públicas urbanas. Onde, em termos mundiais, a Organização das Nações Unidas (ONU) vem imprimindo esforços visando:

[...] minimizar a problemática urbana, instrumentalizados por acordos internacionais, legislações urbanísticas e políticas públicas de ordenamento do espaço urbano. No entanto, questiona-se acerca da efetividade de tais medidas, dada a extensão e complexidade dos problemas suportados pela população urbana, sobretudo a que habita em favelas ou assentamentos irregulares, e enfrentam cotidianamente condições inadequadas de infraestrutura, saneamento, serviços de transporte, oferta de trabalho e serviços públicos (Gomes et al., 2020, p. 255).

É nesse cenário de configuração da urbe, a partir de processos urbanos permeados de intencionalidade, diante da estreita relação entre Estado, classe dominante e mercado, que também são formatadas as cidades do Rio de Janeiro e de Cali e onde, por sua vez, também se observa a atuação das agências multilaterais, sobre as quais discorremos a seguir.

\section{2. \\ As agências multilaterais no contexto latino-americano}

As agências multilaterais, segundo Makino (2015), são moldadas após a Segunda Guerra Mundial, a partir da evolução das teorias do desenvolvimento, que tinham relação com a preocupação das potências europeias, no que diz respeito à aceleração do crescimento das suas colônias que já se acercavam da descolonização. Ainda de acordo com esse autor,

Naquele momento, tomava-se crescimento econômico e desenvolvimento como sinônimos, enfatizava-se o papel do Estado nessa dinâmica e a importância do capital externo como indutor do crescimento. Além disso, esses bancos podem desempenhar um papel anticíclico importante, ao manter a liquidez em períodos de crise, quando os bancos privados tendem a diminuir a disponibilidade de crédito (FERRAZ et al, 2013). Os bancos multilaterais de desenvolvimento são como cooperativas de créditos nos quais os países-clientes também são sócios do banco (COUTO, 1999: 46-47). Já os bancos regionais de desenvolvimento são bancos multilaterais de desenvolvimento cujos beneficiários são definidos por critérios geográficos. 
Para Amaral (2018), a criação dos bancos multilaterais, foi uma tática dos Estados Unidos, que após a Segunda Guerra Mundial, estavam ainda mais fortes, em termos de hegemonia, o que representava "o ponto de partida para seu ciclo de acumulação privilegiado no sistema mundial. Na busca de se manter em tal espaço, o poder dominante norte-americano necessitaria de uma estratégia de gestão do sistema mundial, fornecendo certo grau de estabilidade e segurança aos demais Estados soberanos" (Amaral, 2018, p. 26). Assim, visando manter sua hegemonia,

Os EUA lançariam mão de artifícios como o incentivo à criação de agências multilaterais, sob sua liderança, que no contexto do pós-guerra teriam o mote de reconstrução das nações afetadas. Seria necessário sofisticar o aparato institucional para que a hegemonia norte-americana se sustentasse. Nesse sentido, Chesnais (2005) afirma que "não podia haver uma posição hegemônica, e mesmo um império econômico sistêmico, mesmo que ele fosse transitório, dos Estados Unidos vis-à-vis os outros continentes ou países, sem que para isso existisse um regime institucional que the servisse de suporte". Diante desse entendimento, instituições globais de poder como Fundo Monetário Internacional (FMI), Organização Mundial do Comércio (OMC), Banco Mundial e a Organização da Cooperação Econômica Europeia (OCEE) - esta última sob a égide do Plano Marshall - foram desenhadas com a finalidade primária de manter a posição norteamericana de hegemon [CHESNAIS, 2005a, p.19] (Amaral, 2018, p. 26).

Esses organismos são caracterizados como organizações compostas por representantes de diversos países e que financiam projetos de desenvolvimento ou proveem ajuda a países em dificuldade financeira, dentre os quais estão: o Banco Internacional para Reconstrução e Desenvolvimento (BIRD - Banco Mundial), o Banco Interamericano de Desenvolvimento (BID) e o Banco de Desenvolvimento da América Latina.

Costa et al. (2014, p. 59), aponta "os $\mathrm{BMDs}^{8}$ como sendo os principais atores no espaço de ação da cooperação financeira internacional denominado "financiamento para o desenvolvimento". Diz ainda que além dos bancos multilaterais, outras instituições também apresentam função similar, a saber: "as agências governamentais, agências bilaterais de cooperação, organizações das Nações Unidas, fundações privadas e o Fundo Monetário Internacional (FMI), cada uma apresentando características de governança e atuação particulares" (Costa et al., 2014, p. 59).

Essas organizações podem ser classificadas como: globais - exemplo: Banco Mundial; regionais - exemplo: BID; ou sub-regionais, que como exemplo, pode ser citado o Banco de Desenvolvimento da América Latina.

\footnotetext{
${ }^{8}$ Bancos Multilaterais de Desenvolvimento.
} 
As agências multilaterais têm como papel, o financiamento de projetos com vistas à geração de impacto no desenvolvimento econômico e social da nação onde se está investindo, sobretudo naquelas que são emergentes. E segundo Amaral (2018):

Muito além de apenas instituições econômicas, os Banco Multilaterais de Desenvolvimento (BMDs) são instituições políticas que carregam em suas atividades de financiamento e de capacitação técnica a suposta meta de ajudar o desenvolvimento de países considerados de média e baixa renda. As taxas de juros cobradas representam somente o retorno financeiro direto adquiridos pelos bancos, a ponta do iceberg. O resto do iceberg é a alimentação do poder do capital financeiro por meio de práticas que não colocam em risco sua hegemonia e nem dos países que neles possuem grande influência (Amaral, 2018, p.35).

Segundo Costa et al. (2014), na América Latina e Caribe, identificou-se dezenove BMDs operantes, consistindo na região onde se concentra a maior quantidade dessas organizações, sendo a maioria regional ou sub-regional, conforme quadro abaixo, que demonstra a distribuição por área geográfica de atuação, desses organismos, em termos mundiais:

Figura 3- Existência de Bancos Multilaterais e sua distribuição por área geográfica de atuação

\begin{tabular}{|c|c|c|c|c|c|}
\hline BMD & $\begin{array}{l}\text { América Latina e } \\
\text { Caribe }\end{array}$ & $\begin{array}{l}\text { Oriente Médio e } \\
\text { Africa do Norte }\end{array}$ & Africa Subsaariana & $\begin{array}{l}\text { Paclfico e Sudeste } \\
\text { Asiático }\end{array}$ & $\begin{array}{l}\text { Europa e Asia } \\
\text { Central }\end{array}$ \\
\hline Atuação global & 8 & 8 & 8 & 8 & 8 \\
\hline \multicolumn{6}{|l|}{ Grupo Banco Mundial } \\
\hline \multicolumn{6}{|l|}{ BIRD } \\
\hline \multicolumn{6}{|l|}{$\mathrm{CFI}$} \\
\hline \multicolumn{6}{|l|}{ IDA } \\
\hline \multicolumn{6}{|l|}{ Miga } \\
\hline \multicolumn{6}{|l|}{ GEF } \\
\hline \multicolumn{6}{|l|}{ Fida } \\
\hline \multicolumn{6}{|l|}{ BEI } \\
\hline \multicolumn{6}{|l|}{ NIB } \\
\hline Atuação regional & 4 & 2 & 2 & 2 & 1 \\
\hline \multicolumn{6}{|l|}{ Grupo BID } \\
\hline \multicolumn{6}{|l|}{ BID } \\
\hline \multicolumn{6}{|l|}{ FOE } \\
\hline \multicolumn{6}{|l|}{ CII } \\
\hline \multicolumn{6}{|l|}{ Fumin } \\
\hline \multicolumn{6}{|l|}{$A f D B$} \\
\hline \multicolumn{6}{|l|}{ FASD } \\
\hline \multicolumn{6}{|l|}{$A D B$} \\
\hline \multicolumn{6}{|l|}{ ADF } \\
\hline BERD & & & & & \\
\hline
\end{tabular}




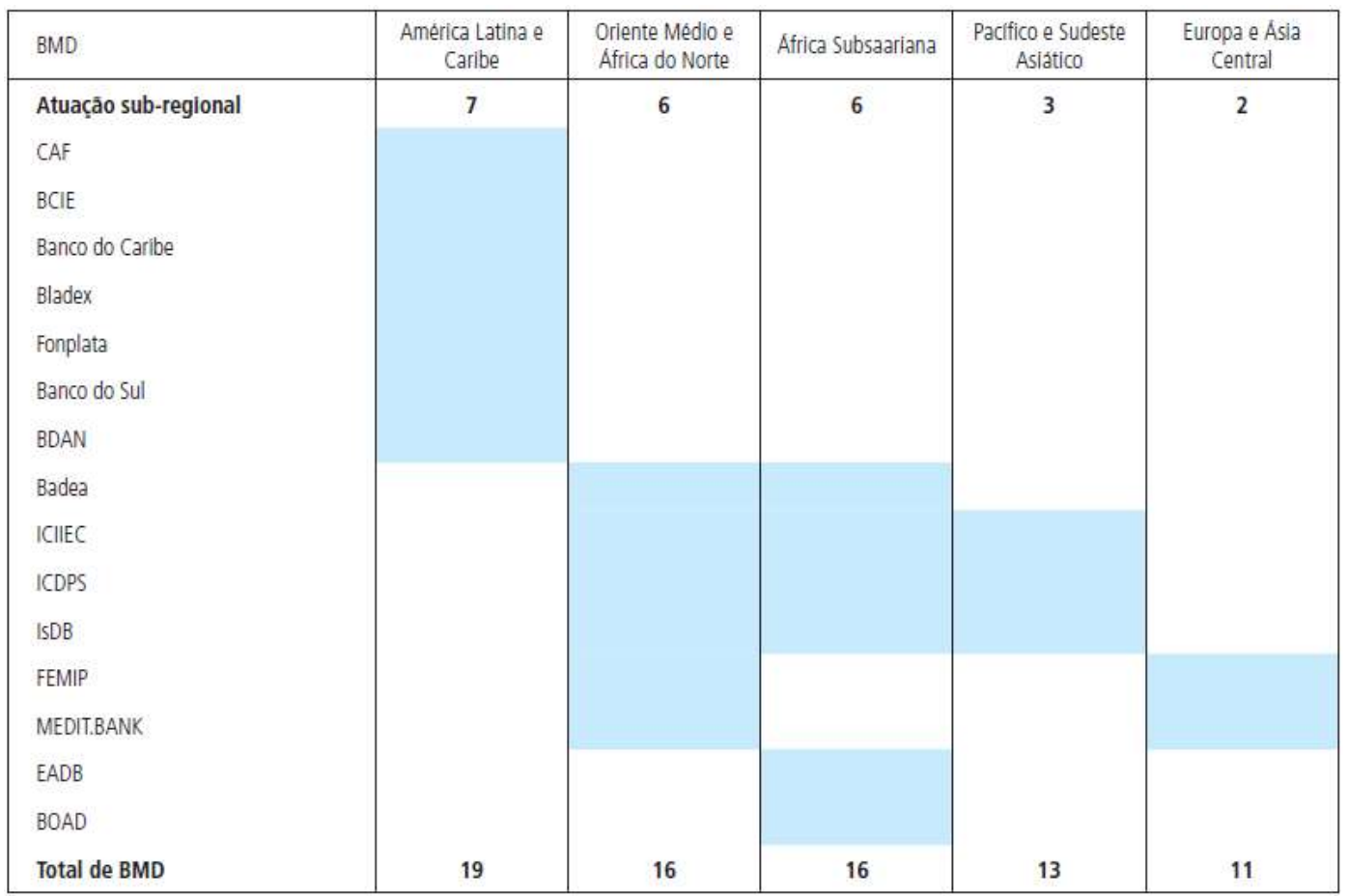

Fonte: Costa, 2014.

Especialistas do ramo como o economista Otaviano Canuto dos Santos Filho, que foi vice-presidente do BID, em matéria publicada em março de $2009^{9}$, afirma que nos anos que antecederam a crise econômica mais recente, e que até os dias atuais assola muitos países, as organizações multilaterais não estavam mais sendo necessárias, tendo que justificar a sua existência, pois como havia dinheiro entrando nos países em desenvolvimento, elas estavam se tornando desnecessárias. Porém o cenário mudou novamente, quando ocorreu o agravamento da instabilidade financeira, voltando essas instituições a assumirem um papel importante nessas nações e inclusive tendo problemas de cunho financeiro, devido à grande demanda que passaram a receber, implicando em limitações no tocante aos financiamentos.

Conforme já dito anteriormente, as agências multilaterais visam, ainda que teoricamente, o desenvolvimento dos países onde empregam capital. Falamos teoricamente, pois até mesmo o termo (desenvolvimento) em si, nesse contexto, está impregnado do sentido de controle das grandes potências, em relação aos países mais pobres.

Segundo Amaral (2018, p. 26), o conceito de desenvolvimento utilizado "sempre foi das instituições multilaterais lideradas pelos Estados Unidos,

${ }^{9}$ Disponível em: <http://memoria.ebc.com.br/agenciabrasil/noticia/2009-03-06/crise-resgata-papelde-agencias-multilaterais-diz-futuro-vice-presidente-do-banco-

mundial\#: :text=\%E2\%80\%9CO\%20papel\%20dessas\%20ag\%C3\%AAncias\%20\%C3\%A9,estrutur a\%20nos\%20pa\%C3\%ADses\%20em\%20desenvolvimento\%2C>. Acesso em: 23 fev. 2021. 
situando-se esse país e outros da Europa como referência de um ideal a ser perseguido". O que não deu muito certo, pois a realidade das nações de terceiro mundo era e continua sendo diferente da vivenciada pelos países de primeiro mundo. Deste modo,

A complexidade da realidade demonstrou a impossibilidade de aplicar receitas de maneira mecânica e com caráter universal. Esta circunstância explica, em boa parte, o processo de evolução que experimentou o mesmo conceito de desenvolvimento. Os sucessivos fracassos na tentativa de incorporar os países do Terceiro Mundo ao mundo desenvolvido obrigaram à reformulação deste conceito a fim de conseguir maior eficiência na cooperação internacional (Madri, 2015, p.6).

Até a década de 1970 a ideia de desenvolvimento esteve atrelada ao crescimento econômico, mantendo as agências multilaterais inicialmente, o foco nessa questão e para tal "perseguiam a configuração de sociedades industriais, cuja prioridade básica deveria ser o crescimento econômico" (Madri, 2015, p.6). Porém, sobretudo nessa mesma década, após um período expressivo de contínuo crescimento, viu-se que isso não era algo automático, que se um acontece o outro não está garantido, ficando comprovado nessa época que:

[...] o desenvolvimento não é alcançado, necessariamente, mediante o crescimento, o que significava que a cooperação para o desenvolvimento não tinha funcionado como motor de desenvolvimento, já que, inclusive, a lacuna entre os países ricos e pobres tinha aumentado. Por isso, sem renunciar ao desenvolvimento econômico, se começa a prestar atenção à questão redistributiva, sob o "enfoque das necessidades básicas". Com isso se toma ciência, definitivamente, de que qualquer proposta de desenvolvimento que não contemple a pobreza, a desigualdade e o desemprego não poderia garantir o desenvolvimento (Madri, 2015, p.7).

A partir de então, há uma "inflexão nessa compreensão, que passou a ser mais holística correspondendo a um conceito multidisciplinar de desenvolvimento humano" (Amaral, 2018, p. 30), tendo em vista a percepção de que o crescimento econômico não necessariamente viria acompanhado de melhorias nas condições de vida das pessoas, sobretudo devido às desigualdades existentes.

A luz desse novo entendimento, no ano de 1974 publica-se o documento Redistribuição com Crescimento, chancelado pelo Banco Mundial, passando a considerar como "imprescindível a redistribuição da riqueza rumo aos trabalhadores mais desfavorecidos e a atenção aos mais pobres mediante o desenvolvimento de serviços sociais" (Madri, 2015, p.7).

Nessa nova fase, o Banco Mundial passa então, buscando alcançar o desenvolvimento, a tratar de novas questões como saúde, educação e luta 
contra a pobreza, não se limitando somente aos problemas ligados a transporte, energia e infraestrutura, o que embora com limitações, foi importante para esse cenário. Porém, mesmo com esses avanços que não podem ser desconsiderados, segundo alguns autores, as ações dessas organizações continuaram sendo implementadas de cima para baixo, sem a devida escuta aos países que recebem os projetos, o que é preocupante, por ter grandes chances de não atender as reais necessidades das regiões atendidas, tendo em vista as particularidades de cada uma.

$\mathrm{Na}$ década de 1980, foi um período em que, sobretudo a América Latina, em função da crise da dívida externa, passou por um momento difícil tendo, que adotar:

Políticas baseadas em ajustes estruturais e reformas econômicas baseadas no chamado Consenso de Washington, cujas abordagens fundamentais eram a redução do déficit público, a liberalização econômica, a abertura aos mercados externos e o predomínio das forças do mercado como principal força reguladora. Isso significou uma inibição da atuação do Estado e a redução de seu tamanho e seus serviços, mediante privatizações, à mínima expressão. Os órgãos internacionais, como o Fundo Monetário Internacional ou o Banco Mundial, promoveram estes tipos de políticas ao condicionar a concessão de $A O D^{10}$ à realização de planos de ajustes elaborados de acordo com estas políticas (Madri, 2015, p. 8).

Nos anos de 1990 há uma nova mudança, deixando de ser o crescimento econômico o principal objetivo e passando a ser o ser humano, o principal foco para se atingir o desenvolvimento. Assim sendo, deveria haver investimento nas pessoas, ofertando-Ihes mais oportunidades. As pessoas que até então eram um meio de alcançar fins como o crescimento econômico, por exemplo, começam a ser vistas como o próprio fim para o alcance do desenvolvimento.

E de acordo com Amaral (2018), no século em que vivemos, ainda que a geopolítica do mundo não esteja mais conformada segundo as regras absolutas dos Estados Unidos, é a ideologia neoliberal que predomina em termos mundiais e, por conseguinte, afeta a forma de atuação dos bancos multilaterais e, assim sendo, "defende-se que as políticas de desenvolvimento dos BMDs não são necessariamente criações endógenas, mas sim reflexo das mudanças do contexto mundial, configurando estes como instrumentos da elite política, econômica e financeira mundial" (Amaral, 2018, p. 35). Ainda de acordo com esta autora,

${ }^{10}$ Ajuda Oficial ao Desenvolvimento. 
Ao longo dos anos, com a retomada da hegemonia financeira, os Bancos Multilaterais foram cooptados pelo capital financeiro, tornando-se instituições cada vez mais dependentes das decisões desse mercado. O que antes deveriam ser instituições soberanas governadas pelos bancos centrais dos países-membros, tornar-se-iam organismos com pouca autonomia dominados pelas finanças (Amaral, 2018, p. 36).

Tanto no Rio de Janeiro quanto em Cali, observa-se a atuação dessas instituições, por meio do financiamento de programas e estratégias econômicas, projetos de urbanização, obras de infraestrutura, programas de desenvolvimento social, combate à pobreza e outros, dependendo do que intenciona a política interna das agências multilaterais, em um dado contexto.

\section{3. \\ O desenvolvimento e os impactos no processo de urbanização das áreas populares das cidades latino-americanas: Rio de Janeiro e Cali}

Rio de Janeiro e Cali são cidades situadas consecutivamente no Brasil e na Colômbia, países latino-americanos, pertencentes à América do Sul e que são fronteiriços, apresentando diferenças quanto à extensão territorial e a população, porém guardadas as proporções e as singularidades, têm muitas características em comum. Em termos nacionais, segundo estimativas do IBGE, no ano de 2020 o Brasil tinha cerca de 211 milhões de habitantes, enquanto a Colômbia tinha aproximadamente 50 milhões nesse mesmo ano, de acordo com dados do Departamento Administrativo Nacional de Estadística (DANE), órgão oficial da Colômbia.

Com vistas à abertura deste item e a título de conhecimento e compreensão do atual cenário do Rio de Janeiro e de Cali, apresentaremos alguns dados, dentre os quais alguns têm relação direta com o tema desta pesquisa e outros não, porém os consideramos importantes para ampliação da nossa visão sobre os territórios, a saber: a densidade populacional, educação, economia, saúde, acesso a serviços públicos de abastecimento de água, esgotamento sanitário, coleta de resíduos sólidos, dentre outros.

No município do Rio de Janeiro, nos baseamos em informações disponibilizadas pelo IBGE, órgão oficial brasileiro, do ano de 2020 e em dados da Firjan (2017), a saber: 
Quadro 1 - Dados do Rio de Janeiro

\begin{tabular}{|c|c|c|}
\hline Informação & Indicador & Dado \\
\hline \multirow[t]{2}{*}{ População } & População estimada [2020] & 6.747.815 hab. \\
\hline & Densidade demográfica [2018] & $5.556 \mathrm{hab} . / \mathrm{Km}^{2}$ \\
\hline \multirow[t]{4}{*}{$\begin{array}{l}\text { Trabalho e } \\
\text { rendimento }\end{array}$} & $\begin{array}{l}\text { Salário médio mensal dos trabalhadores } \\
\text { formais [2018] }\end{array}$ & 4,2 salários mínimos \\
\hline & Pessoal ocupado [2018] & 2.524.428 pessoas \\
\hline & População ocupada [2018] & $37,7 \%$ \\
\hline & $\begin{array}{l}\text { Percentual da população com rendimento } \\
\text { nominal mensal per capita de até } 1 / 2 \\
\text { salário mínimo [2010] }\end{array}$ & $31,4 \%$ \\
\hline Educação & $\begin{array}{l}\text { Taxa de escolarização de } 6 \text { a } 14 \text { anos de } \\
\text { idade [2010] }\end{array}$ & $96,9 \%$ \\
\hline \multirow[t]{2}{*}{ Economia } & PIB per capita [2018] & $\begin{array}{l}\mathrm{R} \$ 54.426,08 \text { (cerca } \\
\text { de US } \$ 10.000)\end{array}$ \\
\hline & $\begin{array}{l}\text { Índice de Desenvolvimento Humano } \\
\text { Municipal (IDHM) [2010] }\end{array}$ & 0,799 \\
\hline Saúde & Estabelecimentos de Saúde SUS [2009] & 257 estabelecimentos \\
\hline \multirow{3}{*}{$\begin{array}{l}\text { Território e } \\
\text { Ambiente }^{11}\end{array}$} & Abastecimento de água [2015] & $98,3 \%$ \\
\hline & Coleta de esgoto [2015] & $83,1 \%$ \\
\hline & Tratamento de esgoto [2015] & $44,5 \%$ \\
\hline
\end{tabular}

Fonte: Elaboração própria baseada em dados do IBGE/Cidades 2020 ${ }^{12}$; Firjan, 2017; Data-Rio 2019; Sánchez, 2018.

No que concerne aos números relacionados aos resíduos sólidos, assim como o Índice de Desenvolvimento Humano (IDH), há uma nota do Índice de Sustentabilidade da Limpeza Urbana (ISLU) que vai de zero a 1, e quanto mais próximo de 1, maior é a adesão à Política Nacional de Resíduos Sólidos e quanto mais longe, menor. Segundo dados publicados pelo SELURB - Sindicato Nacional das Empresas de Limpeza Urbana (2019), esse índice na cidade do Rio de Janeiro, foi de 0,733 em 2019, ocupando o quarto lugar neste ranking, entre as cidades brasileiras.

Já no que concerne a Cali, nos fundamentamos em dados do Documento Cali en Cifras 2020 e no Informe Especial - Cámara de Comercio de Cali, 2020.

\footnotetext{
11 Grau de cobertura no município do Rio de Janeiro em 2015 (Firjan, 2017).

12 Disponível em: <https://cidades.ibge.gov.br/brasil/rj/rio-de-janeiro/panorama>. Acesso em 01 mar. 2021.
} 
Quadro 2 - Dados de Cali

\begin{tabular}{|c|c|c|}
\hline Informação & Indicador & Dado \\
\hline \multirow[t]{2}{*}{ População } & População estimada [2020] & 2.496.442 hab. \\
\hline & Densidade demográfica [2020] & $3.990 \mathrm{hab} / \mathrm{km}^{2}$ \\
\hline \multirow[t]{4}{*}{$\begin{array}{l}\text { Trabalho e } \\
\text { rendimento }\end{array}$} & $\begin{array}{l}\text { Salário médio mensal dos trabalhadores formais } \\
\text { [2019] }\end{array}$ & $\begin{array}{l}\text { 1,6 milhão de pesos } \\
\text { (US\$ 429.16) }\end{array}$ \\
\hline & $\begin{array}{l}\text { Renda média mensal dos trabalhadores } \\
\text { informais [2019] }\end{array}$ & 780 mil pesos \\
\hline & População ocupada [2019] & 1.255 .000 pessoas \\
\hline & Taxa de desemprego anual [2019] & $12.5 \%$ \\
\hline \multirow[t]{3}{*}{ Economia } & PIB per capita [2019] & US $\$ 6,474$ \\
\hline & Coeficiente GINI [2019] & 0.465 \\
\hline & $\begin{array}{l}\text { Índice de Desenvolvimento Humano Municipal } \\
\left(\text { IDHM) }[2018]^{13}\right.\end{array}$ & 0,785 \\
\hline Saúde & Unidades de Atenção [2019] & $\begin{array}{l}142 \\
\text { estabelecimentos }\end{array}$ \\
\hline \multirow[t]{3}{*}{$\begin{array}{l}\text { Território e } \\
\text { Ambiente }\end{array}$} & $\begin{array}{l}\text { Casas com serviço de esgotamento sanitário } \\
\text { [2019] }\end{array}$ & $84.7 \%$ \\
\hline & $\begin{array}{l}\text { Residências com acesso a rede de } \\
\text { abastecimento de água }(2018)^{14}\end{array}$ & $99,0 \%$ \\
\hline & Residências com acesso a coleta de lixo (2018) & $99,1 \%$ \\
\hline
\end{tabular}

Fonte: Elaboração própria baseada em dados do documento Cali en Cifras 2020; Informe Especial - Cámara de Comercio de Cali, 2020; Censo Nacional de Población y Vivienda 2018, Departamento Nacional de Estadística, DANE; Global Data-Labe, 2018.

No tocante a taxa de escolaridade, de acordo o nível educativo, da préescola até o nível de ensino médio, temos o seguinte cenário:

\footnotetext{
13 Disponível em:

$<$ https://globaldatalab.org/shdi/shdi/COL/?levels=1\%2B4\&interpolation=0\&extrapolation=0\&nearest real $=0$. . Acesso em: 12 maio 2021.

$\overline{14}$ Tanto o número de casas com acesso à rede de abastecimento de água, quanto com acesso a coleta de lixo, não inclui as residências que não responderam a estas perguntas, ou seja, não há o percentual dos que não informaram.
} 
Figura 4- Taxa de escolaridade segundo o nível educativo no município de Cali - 2013 a $2019^{15}$

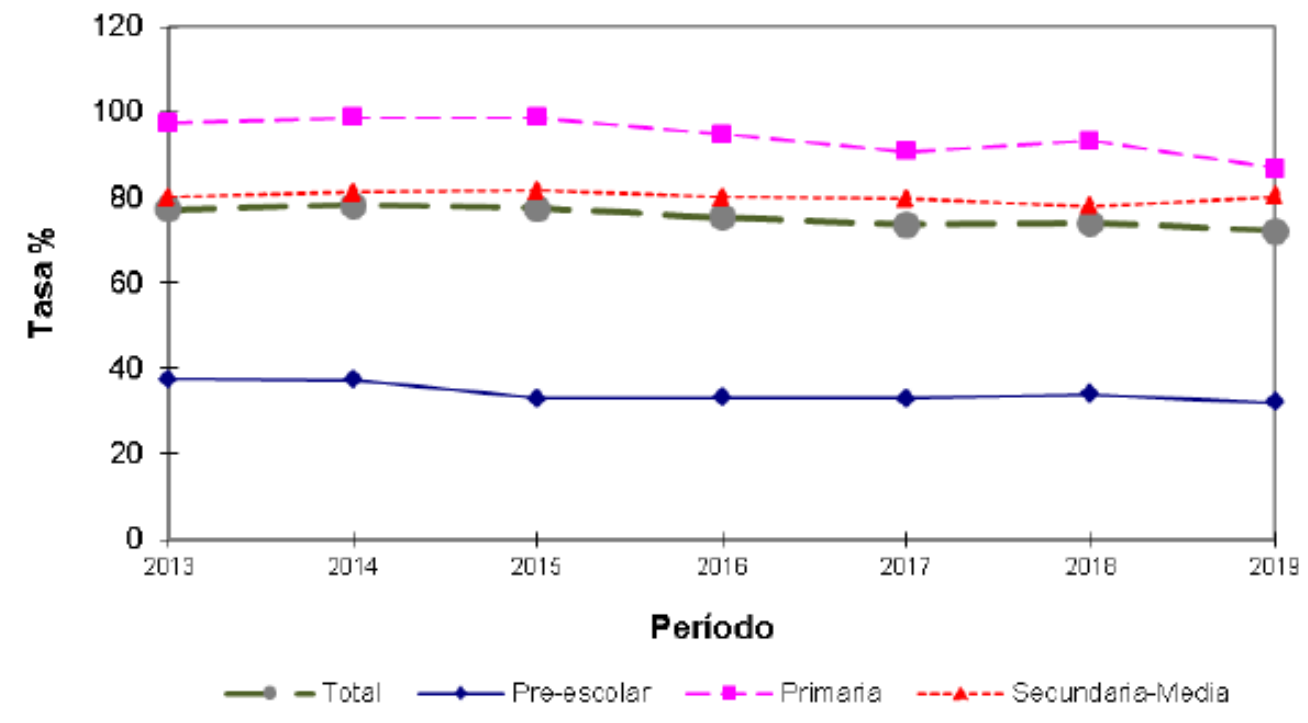

Fonte: Cali en Cifras, 2020.

Esses são somente alguns dados, com base nos números oficiais mais recente sobre ambos os municípios, realidade na qual está inserida a Rocinha e Siloé - campos de pesquisa deste estudo, que serão apresentados no próximo item.

Salientamos que a ideia deste preambulo, foi introduzir alguns indicadores que poderão instrumentalizar nossa análise, pois apesar de não ser o foco central de nosso estudo, tangencia aspectos importantes, que mesmo sem a pretensão de analisá-los, poderá contribuir para melhor entendimento da questão.

\subsection{1.}

\section{Rio de Janeiro: o processo de urbanização e as favelas}

A cidade do Rio de Janeiro, fundada em primeiro de março de 1565, é capital do estado que leva o mesmo nome. Está localizado na região sudeste do Brasil e faz fronteira com os municípios de Itaguaí, Nilópolis, Nova Iguaçu, Duque de Caxias, São João de Meriti e Mesquita. Sua extensão territorial é de

\footnotetext{
15 As idades escolares sofreram alteração em 2005, ficando da seguinte forma: Pré-escolar (3-5 anos, antes dos 5-6 anos), Primária (6-10 anos, antes dos 7-11 anos), Secundária e média (11-16 anos, antes dos 12- 17 anos).
} 
cerca de 1.200,329 km². Segundo estimativas de 2020 do IBGE, o município tem uma população de 6.747 .815 pessoas. A seguir pode ser observado o mapa de localização dessa cidade.

Figura 5 - Localização da cidade do Rio de Janeiro

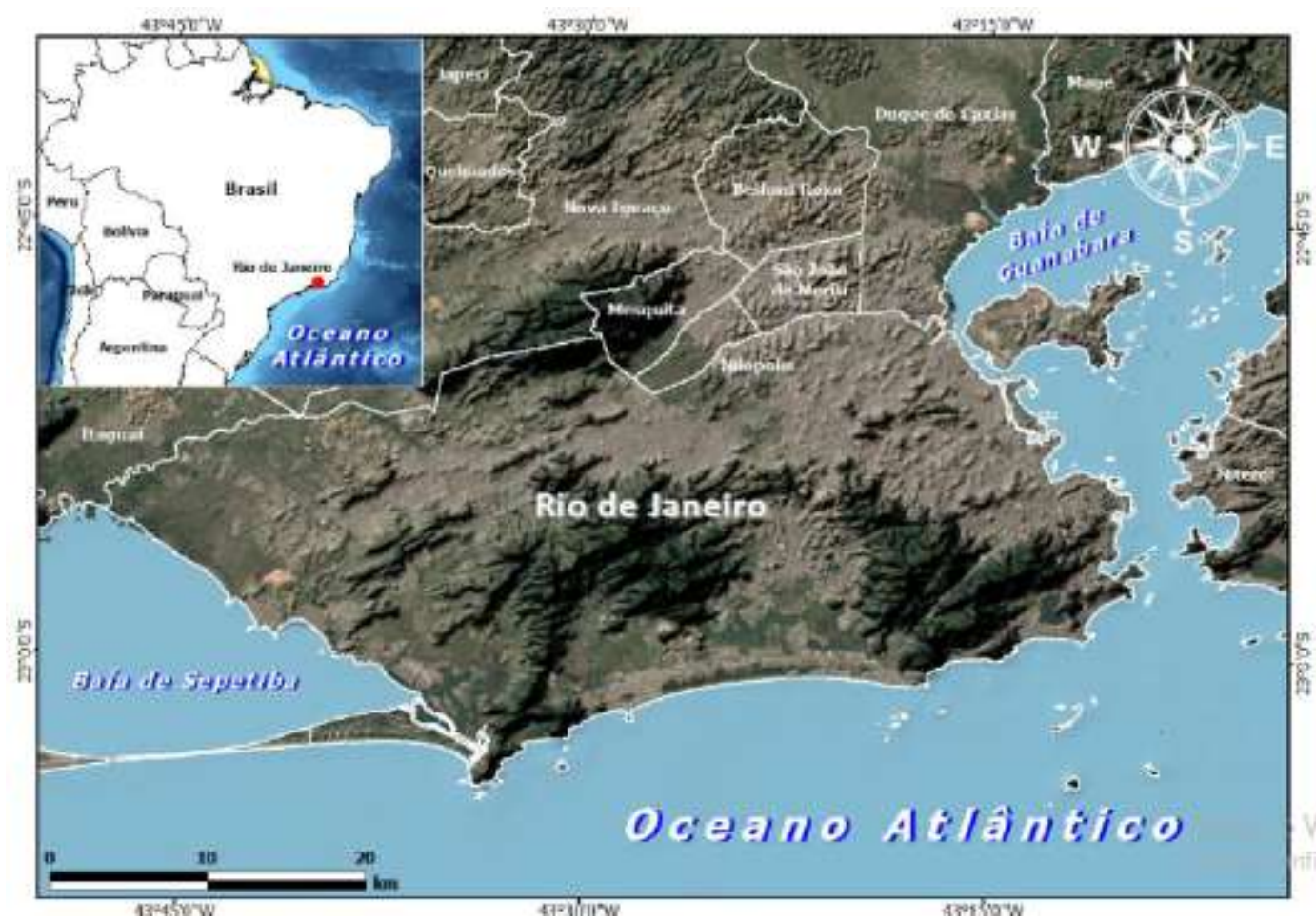

Fonte: Sánchez, 2018.

O Rio de Janeiro assim como muitas cidades, também teve uma urbanização acelerada e, por esse motivo, seu crescimento se deu sem o devido planejamento, tendo o Centro da cidade vias cujas condições não eram as desejáveis, pois eram estreitas, tinham muita umidade, eram sujas e a iluminação era insuficiente. Muitas dessas condições favoreciam o surgimento de doenças e, além disso, a situação do trânsito era caótica.

Tendo em vista esse cenário, sobretudo no final do século XIX e início do século $X X$, ganhou força uma onda de urbanização com vistas à modernização $e$ embelezamento da urbe com base no plano de remodelação de Paris, bem como visando à erradicação de epidemias que assolavam a cidade, devido às más condições sanitárias do território. O período quando mais se observa ações nesse sentido, estava no comando do país o presidente Rodrigues Alves e, como prefeito da cidade carioca, Pereira Passos (1902-1906), que juntos promoveram profundas mudanças neste cenário. 
Nesse período, após a demolição das habitações ocupadas pela classe de menor poder aquisitivo, situadas no Centro, foram muitas as mudanças no cenário da cidade: grandes avenidas como a então Avenida Central - hoje Rio Branco, foram construídas; foram erguidos grandes edifícios; houve a construção de novas redes de esgoto e de fornecimento de água; foram feitas melhorias na iluminação pública, havendo inclusive a substituição das luzes a gás por postes elétricos; dentre outras inovações.

Assim, sob o argumento de modernização da cidade e da erradicação de doenças, o projeto higienista e segregador de Pereira Passos ganhou forma e a população empobrecida que residia na área de interesse dos que detinham o poder, dali foram expulsas; e não tendo outra opção, alguns foram morar no subúrbio, enquanto outros, por não terem as mesmas condições financeiras, foram parar nos morros cariocas, onde começaram a habitar áreas, de igual maneira, sem nenhuma infraestrutura.

Nesse período o crescimento populacional aliado à política higienista do Rio de Janeiro, agravou muito o déficit habitacional. Segundo Maurício de Abreu (1992):

[...] o crescimento demográfico atingiu taxas muito elevadas (em 1890, por exemplo, a cidade já contava com 429.745 habitantes apenas em suas freguesias urbanas); por outro, o ritmo de construção de novas moradias não só não acompanhou a velocidade do crescimento populacional como, para piorar a situação, deu-se início, na mesma época, e em nome da higiene pública, a uma política deliberada de destruição das habitações coletivas da cidade, que servia de moradia a grande número de pessoas (Abreu, 1992, p. 89-90).

Deste modo, a reforma urbana executada durante o governo de Pereira Passos, teve grande impacto para as habitações populares coletivas, conforme aponta Maurício de Abreu (1992):

As picaretas demolidoras direcionaram-se sobretudo para os quarteirões operários da área central, que se deveria transformar agora em símbolo da modernidade urbana. Consequentemente, desse Centro renovado não poderiam mais fazer parte as habitações coletivas (Abreu, 1992, p. 90).

Para agravar a situação, as reformas dos poucos cortiços ainda existentes passaram a ser proibidas por meio de "decretos, leis, regulamentos e regimentos" (Abreu, 1992, p. 90), como também tornaram completamente inviável toda e qualquer ação de melhoria dessas habitações coletivas. Essa legislação "passou a dificultar a ocupação de outras áreas da cidade (especialmente dos subúrbios) pela população mais pobre" (Abreu, 1992, p. 90). 
Ao mesmo tempo, acontecia um grande processo migratório para o Rio de Janeiro, em função, sobretudo, do pós-abolição da escravatura, que aumentou significativamente a migração do campo para a cidade e das reformas urbanas que ocorreram na época.

Essa equação, onde havia pouca disponibilidade de opções legalizadas de moradia para os mais pobres e mais pessoas vindas para a região, impulsionou uma nova forma de habitação, a favela ${ }^{16}$, como afirma Abreu (1992):

\begin{abstract}
Atraindo grande quantidade de força de trabalho, e não oferecendo opções de residência legalizada na cidade, era inevitável que o Rio de Janeiro visse surgir, a partir de então, uma nova forma de habitação que, pela precariedade de sua construção, e pelo desafio que representava ao controle urbanístico, constitui-se em verdadeira negação da estética de modernidade que se procurava dar à cidade. Esta forma de habitação foi a favela (Abreu, 1992, p. 90).
\end{abstract}

A ocupação dos morros da cidade acabou por se tornar a melhor solução para o problema, pelo qual passava os mais pobres, devido à escassez de habitação popular naquela época, e o que era para ser algo provisório, logo se tornou algo definitivo e continua assim até os dias de hoje em várias regiões da cidade. O chamado processo de favelização dessas áreas, segundo Abreu (1992):

[...] tornou-se, então, irreversível. Apesar da repressão verificada nos primeiros anos (e que foi retomada em diversos períodos posteriores), a verdade é que, contraditoriamente, o mesmo processo de desenvolvimento capitalista que determinou a reforma urbana do início do século, exigiu também que contingentes crescentes de força de trabalho, mola mestra do processo de acumulação, passassem a ser demandados pelas atividades econômicas da cidade, incentivando, portanto, as migrações (Abreu, 1992, p. 93).

Maurício de Abreu (1992), quando trata sobre o surgimento da favela, considerando o seu início com a ocupação do morro da Providência, afirma que essa forma de moradia não surge por meio de uma invasão ou de forma arbitrária por parte dos que ali passaram a residir, mas sim com o consentimento de autoridades competentes, no período da Guerra de Canudos, como podemos observar a seguir:

\footnotetext{
${ }^{16}$ Aqui não nos ateremos às diversas versões sobre a origem da favela carioca, mas sim ao fato de que a cidade, paralelamente ao movimento de reurbanização modernizadora, também passa, em consequência da política higienista, por outras transformações no seu cenário, com o surgimento ou crescimento, dependendo do autor que discuta a temática, da população das favelas.
} 
Já presente embrionariamente na cidade desde 1897, quando foi dada autorização para que os praças retornados da campanha de Canudos ocupassem provisoriamente os morros da Providência e de Santo Antônio, esta forma de ocupação dos morros logo se revelou a solução ideal para o problema da habitação popular no Rio de Janeiro (Abreu, 1992, p. 90).

Assim sendo, por interesse dos que detinham o poder, "[...] de local de moradia provisório, esses morros da área central logo foram se transformando em opção de residência permanente" (Abreu, 1992, p. 90), de tal forma que já na década de 1920 e 1930 tinham presenças efetivas:

\begin{abstract}
[...] a favela já havia chegado a Botafogo (Pasmado), a Copacabana (Tabajaras e Leme), a São Cristóvão (Mangueira), e até a Madureira. Também já galgava as encostas da serra Carioca pelo lado do Catumbi (São Carlos, Querosene), da Tijuca (Salgueiro), e do Engenho Novo (Macaco). A vertente sul do maciço logo começou também a ser atacada com vigor (Rocinha, Dona Marta). Chegada à década de 1930, e no bojo do processo de expansão industrial da cidade e de crescimento acelerado de seus bairros oceânicos, a favela se expandiu ainda mais: Catacumba, Pavão, Pavãozinho, Ilha das Dragas, Praia do Pinto, Borel, Macedo Sobrinho, Turano, Formiga... (Abreu, 1992, p. 93).
\end{abstract}

Até então, mesmo crescendo a passos largos, a política pública para a favela, não havia sido pensada, sobretudo até a década de 1940, quando a paisagem começa a incomodar a sociedade; a partir daí, a gestão pública passa a adotar iniciativas no que diz respeito à questão urbana da cidade, e segundo Burgos (2006), surgem às primeiras políticas públicas para essas áreas, com a implementação dos parques proletários, voltados para uma parcela da população pobre. Como podemos verificar com a fala abaixo:

[...] a "descoberta" do problema favela pelo poder público não surge de uma postulação de seus moradores, mas sim do incômodo que causava à urbanidade da cidade, o que explica o sentido do programa de construção dos parques proletários, que tem por finalidade, acima de tudo, resolver o problema das condições insalubres das franjas do Centro da cidade, além de permitir a conquista de novas áreas para a expansão urbana (Burgos, 2006, p. 27).

Tal qual no final do século XIX e início do século $X X$, a presença dos pobres em determinadas áreas, continuava sendo relacionada à insalubridade, ao comprometimento da paisagem e do espaço urbano, aliado ao crescimento da violência, sendo um problema a ser resolvido, quando de alguma forma, incomodava a "nobre" vizinhança.

A favela carioca era e continua sendo, portanto, vista como algo alheio à cidade, ou seja, que dela não faz parte, ficando: 
[...] registrada oficialmente como área de habitações irregularmente construídas, sem arruamentos, sem plano urbano, sem esgoto, sem água, sem luz. Dessa precariedade urbana, resultado da pobreza de seus habitantes e do descaso do poder público, surgiram as imagens que fizeram da favela o lugar da carência, da falta, do vazio a ser preenchido pelos sentimentos humanitários, do perigo a ser erradicado pelas estratégias políticas que fizeram do favelado um bode expiatório dos problemas da cidade, o "outro", distinto do morador civilizado da primeira metrópole que o Brasil teve. Lugar do lodo e da flor que nele nasce, lugar das mais belas vistas e do maior acúmulo de sujeira, lugar da finura e elegância de tantos sambistas, desde sempre, e da violência dos mais famosos bandidos que a cidade conheceu ultimamente, a favela sempre inspirou e continua a inspirar tanto o imaginário preconceituoso dos que dela querem se distinguir quanto os tantos poetas e escritores que cantaram suas várias formas de marcar a vida urbana no Rio de Janeiro (Zaluar et al., 2006, p. 8).

Por muitos anos, por não ser reconhecida legalmente como parte integrante da dita cidade formal, a favela não aparecia nos mapas oficiais, o que só ocorreu muito recentemente em alguns estados do Brasil. No documentário "Todo mapa tem um discurso", esse assunto é retratado, levantando as principais questões simbólicas e práticas sobre as áreas marginalizadas que não fazem parte do mapa oficial da cidade. Buscamos documentos oficiais que informassem a partir de que ano algumas regiões favelizadas passaram a aparecer em determinados mapas, porém não encontramos tais dados. Mediante a esse fato, buscamos outros meios de informação e encontramos uma matéria de Ivan Leonardi (2014), no site Mundo Geo., onde está posto que:

\begin{abstract}
Apesar das tentativas de mapeamento colaborativo ou dos esforços de algumas instituições não governamentais, ainda existem áreas da cidade que são representadas como "vazios cartográficos". "Existe uma população que é invisível, porque nem num documento que deveria reconhecer toda a cidade, os moradores da favela fazem parte disso. A importância para a gente é... primeiro tem esse lado político, né?" Esclarece Eliana Sousa, presidente da Redes de Desenvolvimento da Maré. As favelas do Rio de Janeiro não são representadas nem nos mapas oficiais do Instituto Pereira Passos, nem nos mapas digitais do Google. Eram apenas nomeados e sinalizados como "favelas", mas suas ruas e vielas não eram demarcadas.

Porém, recentemente, a pedido da Prefeitura do Rio de Janeiro, possivelmente pela proximidade da Copa e dos Jogos Olímpicos, a palavra "favela" foi substituída por "morro" nos mapas do Google, o que sugere que tais regiões não são habitadas. Estamos falando de favelas como a Rocinha, Santa Marta, Maré, entre outras, que já são, inclusive, registradas como bairros. Em sua entrevista, Michel Silva, jornalista comunitário da Rocinha, explica: "A Rocinha é considerada bairro desde 1993, só que quando você olha no Google, não tem nenhuma rua, no caso, registrada. Só aquelas ruas lá da entrada. Não tem do Laboriaux, não tem a rua da Cachopa, são ruas tradicionais, que todo mundo conhece. A Rocinha, ela é conhecida internacionalmente e não tem nada no Google?" (Leonardi, 2014. p.1).
\end{abstract}

Apesar de algumas favelas aparecerem em determinados mapas, isso não se dá da mesma forma para cem por cento das regiões favelizadas, pois não são todas que constam nas cartografias, somente as que são oficialmente bairros. 
No caso da Rocinha, ainda hoje só aparecem nos mapas as vias principais. Além da questão da segregação socioespacial notadamente existente, outro fator que contribui para que seja dessa forma, é o fato de não existir o levantamento topográfico ${ }^{17}$ da maior parte das favelas cariocas. Essa é uma questão antiga, sendo a cartografia urbana um exemplo que ilustra as batalhas travadas visando à representação da favela como parte do retrato de identidade nacional.

No Rio de Janeiro, ainda que de uma forma negativa, é no Código de Obras de 1937, onde em termos de documentos oficiais, a favela aparece pela primeira vez, sendo reforçada a sua posição marginal e propondo-se a sua eliminação, bem como a proibição de novas construções e a melhoria das que já existiam.

A Rocinha, uma das maiores favelas do Rio de Janeiro, assim como as demais, também é produto do déficit habitacional, onde as pessoas, por não terem condições financeiras de residir nas áreas ditas formais, começam a povoar esse território, na década de 1930, sem nenhuma infraestrutura e vivenciando constante ameaça de demolição dos barracos, que inicialmente eram construídos com material de fácil remoção, até mesmo porque as pessoas não iriam investir em algo que poderia ser retirado a qualquer momento.

\subsection{2. \\ Cali: o processo de urbanização e os bairros populares}

Santiago de Cali, mais popularmente chamado de Cali, foi fundado em 1536 por Sebastián de Belalcázar, sendo instituído como município pela Lei 131 de 1863. O território urbano está organizado em comunas, sendo composto por 22 comunas $^{18}$ e pela área rural que é constituída por 15 Corregimentos. Está localizado no Valle del Cauca e faz fronteira com: La Cumbre, Yumbo, Palmira, Candelaria, Puerto Tejada, Jamundí, Buenaventura e Dagua. Tem uma superfície total de $561.7 \mathrm{Km}^{2}$ e segundo estimativas do Departamento

\footnotetext{
${ }^{17}$ Levantamento topográfico é um conjunto de operações com a finalidade de determinar a posição relativa de pontos na superfície terrestre. As determinações dão-se por meio de medições lineares e angulares, ligando (link) os pontos descritores dos objetos a serem representados com posterior processamento em modelo matemático adequado. Disponível em: http://www.ebah.com.br/content/ABAAAAUkcAE/topografia. Acesso em: 14 de fevereiro de 2016. ${ }^{18}$ En la figura 06 las 22 Comunas de Cali aparecen numeradas, y corresponden al casco urbano de la ciudad.
} 
Administrativo de Planeación da Alcaldía (Prefeitura) dessa cidade, no ano de 2020 havia 2.241 .491 pessoas.

Figura 6 - Localização de Cali

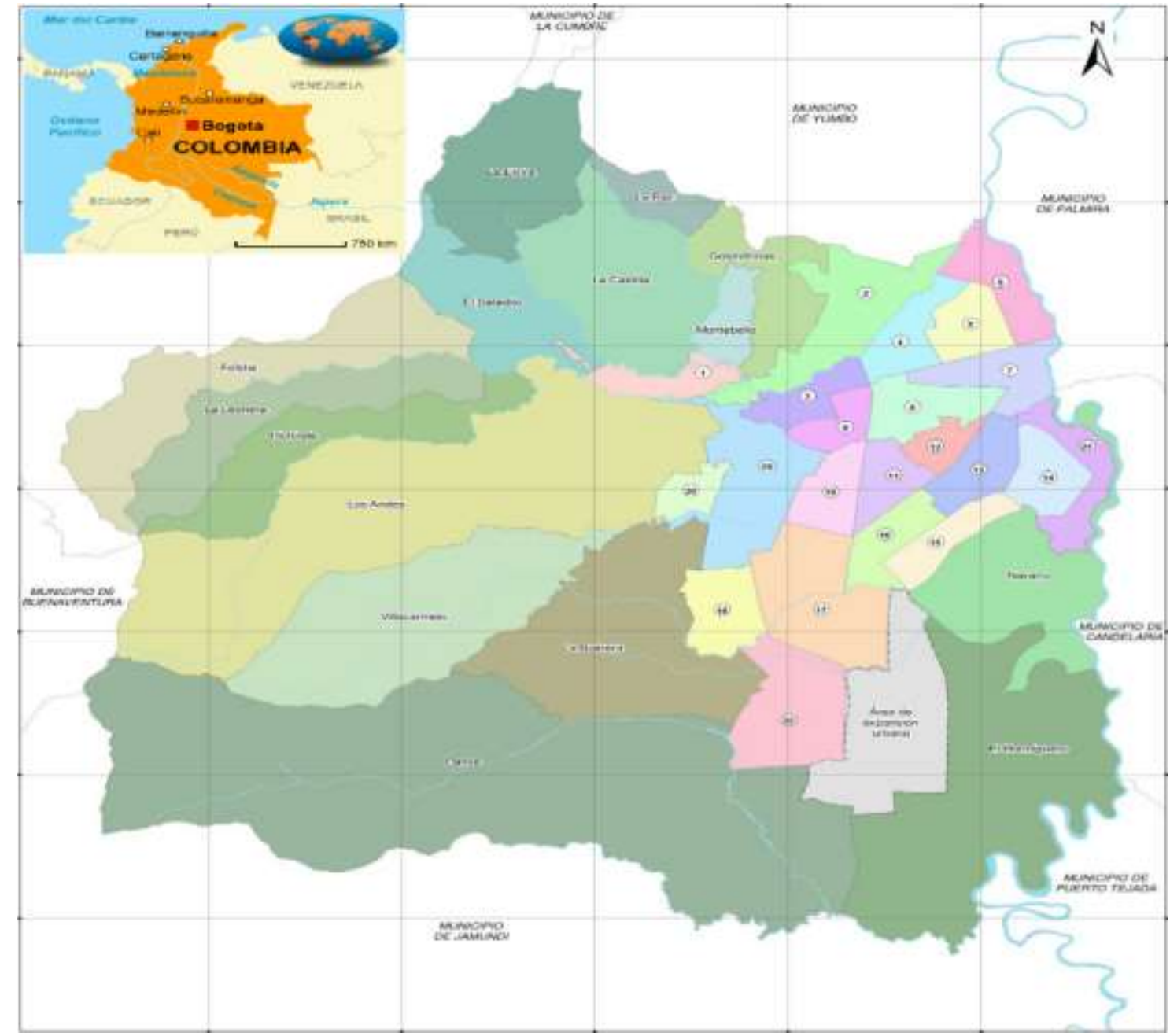

Fonte: adaptação própria com base no mapa de divisão político administrativo do documento Cali en Cifras 2020 e no Google imagens.

Devido a sua importância econômica e política, alcançada, sobretudo, entre o final do século XIX e início do século XX, Santiago de Cali se tornou capital do Departamento Valle del Cauca em 1910. O desenvolvimento econômico e urbano desta região está muito relacionado à produção de café, cana de açúcar e insumos agroindustriais.

Cali, anterior ao seu primeiro processo de urbanização mais significativo, que se deu no início do século $X X$, incentivado por ideias modernizadoras, era um pequeno povoado, pouco urbanizado e estava sujeito politicamente ao município de Popayán, onde as velhas estruturas políticas, sociais e econômicas coloniais permaneceram as mesmas até o final do século XIX. As mudanças ocorridas nesse período levaram Cali a se tornar a terceira cidade mais 
importante do país, bem como o polo de desenvolvimento do sudoeste da Colômbia. Dentre as transformações urbanas ocorridas nesse período estão:

La construcción del ferrocarril que conecta la ciudad con Buenaventura (1915), la apertura del puerto en este último municipio (1923), la construcción de redes terrestres que conectaban la ciudad con el resto del país, la consolidación de rutas comerciales, las olas migratorias y los proyectos de modernización. Todos estos sucesos consolidaron nuevas dinámicas (sociales, económicas, políticas y culturales) en la ciudad que le otorgaron un lugar significativo dentro del contexto nacional (Flórez, 2013, p. 12).

Outro marco muito importante no processo de urbanização de Cali foram os VI Jogos Pan-americanos de 1971, realizados no município, cuja estrutura criada para a recepção do evento contribuiu para a modernização urbana e ampliação da cidade.

Essa fase foi considerada por alguns estudiosos, segundo Varela et al. (2019), como a "segunda modernidade", mas segundo a autora poderia ser considerada na verdade, como a segunda "revolução urbana" de Cali, tanto na sua conjuntura, como estruturalmente falando. Visto que nesse período,

Sumado al desarrollo de infraestructuras institucionales importantes como la semaforización en la ciudad, los parqueaderos a niveles o por pisos, el Plan Muelas (la demolición de viejas casonas para ampliar las vías céntricas), la continuación de la carrera $1^{\underline{a}}$ entre la calle 15 y la autopista oriental, la construcción de la calle 15 entre carreras 1 a y 15, la construcción de la Avenida Guadalupe, la prolongación de la carrera 15 entre la calle 25 y la autopista sur, la repavimentación de la calle 25 a la altura de la estación del ferrocarril hasta la carrera 15, el mejoramiento y ampliación de la calle $5^{\underline{a}}$ desde la carrera $1^{\underline{a}}$ hasta el Hospital Departamental, la Avenida Joaquín Borrero frente a las Piscinas Panamericanas, el Coliseo y el velódromo, la Unidad Deportiva Panamericana, la construcción del Aeropuerto de Palmaseca, la construcción del Hotel InterContinental, la Central Interurbana de Transporte y la ciudad universitaria de Univalle en Meléndez (Varela et al., 2019, p. 15).

Essa onda de urbanização e crescimento econômico trouxe consigo importantes transformações na estrutura urbana e populacional da cidade, pois muitas pessoas passaram a migrar, principalmente das áreas rurais para a cidade em busca de melhores condições de vida e muitos também vinham fugindo da violência.

Esse processo veio acompanhado do déficit habitacional, não tendo essas pessoas onde morar e a exemplo do que ocorreu e ocorre em muitas cidades grandes, no que diz respeito ao acesso diferenciado ao solo urbano, "el territorio urbanizable se destinó a la clase pudiente de la sociedad, es decir, a la que denominan ciudadano" (Varela et al., 2019, p. 12). Deste modo, 
La ocupación del territorio por parte de estos nuevos habitantes chocó con barreras físicas. El terreno que conformaba la zona oriental del territorio de la ciudad se encontraba más de un metro por debajo de la cota del río Cauca lo que hacía que estos suelos se inundaran fácilmente y fueran difíciles de urbanizar. Algo parecido sucedía con la zona occidental donde las altas pendientes de los cerros actuaban como factores limitantes. De modo que, las posibilidades de expansión se presentaban hacia el sur y norte de la ciudad. Sin embargo, los terrenos que conformaban estas zonas presentaban otro tipo de limitantes: la mayoría de ellos pertenecían a haciendas que se dedicaban al cultivo de caña de azúcar. El alto rendimiento económico de estas haciendas otorgó un alto costo a este suelo lo que hizo que estos tendieran a ser ocupados por grupos sociales de clase alta (Flórez, 2013, p. 13).

Na primeira metade do século $\mathrm{XX}$, os limites encontrados pelos imigrantes os levaram a lutar por moradia, porém sem o devido êxito, começaram a ocupar tanto terras públicas (municipais e nacionais) quanto privadas, dando início ao surgimento dos bairros populares de Cali.

A esse respeito, no trecho que segue, em relação ao surgimento dos bairros populares de Cali, Varela et al. (2019) de uma forma resumida, relata como se deu inicialmente esse processo, assinalando que a classe dominante:

[...] comercializó ejidos y lotes en la periferia de la ciudad ubicados al oriente, nororiente y suroriente, es decir, los terrenos menos fértiles, inundables y alejados de la urbanización, los cuales fueron asumidos por sectores populares que incluían entre otros a población de escasos ingresos como también a desplazados por la violencia del conflicto interno. Esta clase desposeída y excluida formó parte del anillo periférico del desarrollo subnormal que correspondía a los cerros bajos de la ciudad en el noroccidente y occidente, como también a la planicie oriental adyacente a los ríos Cali y Cauca (Hurtado, 2010). Esta clase a la que se consideró marginal fue el apalancamiento político de la clase dirigente en el poder debido a que las elites lograron captar y capitalizar las demandas y necesidades de los sectores populares frente a la creación y legalización de los barrios periféricos. En ultimas, la implementación de políticas públicas territoriales definió la estructura urbana en relación a la conformación de una estructura de clases sociales (Sáenz, 2010) (Varela et al., 2019, p. 12).

Entre os anos de 1950 e 1979, Cali chega aos seguintes números (em hectares) quanto à ocupação em bairros tidos como irregulares:

Figura 7- Bairros irregulares em Cali - 1950 a 1979

\begin{tabular}{l|ccccc|}
\hline \multicolumn{5}{c}{ BAIRROS ILEGAIS EM CALI 1950 - 1979 EM HECTARES } & \\
& Antes de & Entre & Entre & Entre \\
& 1950 & $1950-1959$ & $1960-1969$ & $1970-1979$ \\
Bairros de Invasào & 139,7 & 157,2 & 84,2 & 141,9 \\
Bairros Piratas & 13,9 & 118,3 & 411,2 & 47,9 \\
Bairros Clandestinos & 15,2 & 62,0 & 183,0 & 37.7 \\
Controlados & 168,8 & 337,5 & 678,4 & 227,5 \\
\hline Total & & & & \\
\hline
\end{tabular}

Fonte: Varela, 2012. 
Varela (2012, p. 91) reforça que os bairros ditos "de invasão ou ocupações, como os piratas, foram criados nas áreas de limite do perímetro urbano, nas zonas de ladeira e nas zonas inundáveis do rio Cauca, em terrenos inadequados e sem serviços públicos".

Somente nos anos de 1980 devido às proporções que tomou a luta por moradia, é que o Estado temendo que a situação viesse a ficar mais intensa, começa a investir em infraestrutura ligada aos serviços públicos no setor popular de maior densidade em Cali, que é o Distrito de Aguablanca.

O fato de existir uma urbe crescendo para além dos muros das normas urbanísticas de Cali, "exigirá grandes esforços de normalização que lhe custará várias centenas de milhares de milhões de pesos à cidade e que por outro lado servirá de bandeira para alimentar às máquinas eleitoreiras dos partidos tradicionais" (Varela, 2012, p. 94).

A seguir apresentamos, com base em Varela (2012), um quadro cujos dados mostram alguns acontecimentos importantes do processo de urbanização de Cali, no que diz respeito ao crescimento populacional e a mudanças na sua estrutura urbana, entre os anos de 1970 e 1990.

Quadro 3 - Cali população e mudanças físicas décadas 1970-1990

\section{CALI POPULAÇÃO E MUDANÇAS FÍSICAS DÉCADAS 70-90}

\begin{tabular}{|c|c|c|c|}
\hline Década & População & Mudanças Físicas & Característica \\
\hline $\begin{array}{c}\text { Censo } \\
\text { de } 1973\end{array}$ & $\begin{array}{l}991.549 \\
\text { habitantes } \\
\text { Taxa } \\
\text { crescimento de } \\
6,13 \text { a } 4,75\end{array}$ & $\begin{array}{l}\text { Incorpora-se aprox. } 2.000 \text { novos } \\
\text { hectares, Cali segue crescendo } \\
\text { em todas as direções, como um } \\
\text { leque. } \\
\text { Legalmente se estende ao sul, } \\
\text { se apresenta uma renovação de } \\
\text { edificações nos bairros } \\
\text { próximos ao centro da cidade, } \\
\text { especialmente "Granada", } \\
\text { "Versalles" e "Centenario", } \\
\text { mudando as tradicionais } \\
\text { residências por edifícios. } \\
\text { Ao oriente e na ladeira se } \\
\text { instalam os estratos populares: } \\
\text { "informais, ilegais e } \\
\text { desordenados". }\end{array}$ & $\begin{array}{l}\text { Realização dos Jogos Pan- } \\
\text { americanos. } \\
\text { A Política Nacional fortalece } \\
\text { a construção. Entram as } \\
\text { CAV, UPAC. }\end{array}$ \\
\hline $\begin{array}{c}80 \\
\text { Censo } \\
\text { de } 1985\end{array}$ & $\begin{array}{l}1^{\prime} 429.026 \\
\text { habitantes } \\
300.000 \text { habitam } \\
\text { no oriente do } \\
\text { "Distrito de } \\
\text { Aguablanca" }\end{array}$ & $\begin{array}{l}\text { Explosão de urbanizações } \\
\text { piratas: } 3.200 \text { ha, } 1.600 \text { ha em } \\
\text { zonas inundáveis. }\end{array}$ & $\begin{array}{l}\text { Esta área que correspondia a } \\
30 \% \text { da cidade desenvolvida, } \\
12 \text { anos depois em 1991, se } \\
\text { inclui no perímetro urbano da } \\
\text { cidade. } \\
\text { Obriga à cidade a um } \\
\text { processo de reordenamento } \\
\text { urbanístico e à legalização } \\
\text { pontual de bairros } \\
\text { "subnormais". }\end{array}$ \\
\hline 90 & $\begin{array}{l}1 ' 847.176 \\
\text { habitantes }\end{array}$ & $\begin{array}{l}\text { Construção de Cidadela } \\
\text { "Desepaz" ou Comuna 21, com }\end{array}$ & $\begin{array}{l}\text { Iniciativa } \\
\text { significativa }\end{array}$ \\
\hline
\end{tabular}




\begin{tabular}{l|l|l|}
\hline Censo & formato de coroa entre a borda & No transcurso desta década \\
de rio Cauca e o Distrito de a área incluída dentro do \\
de 1993 & $\begin{array}{l}\text { Aguablanca. Essa comuna se perímetro urbano é de } \\
\text { encontra por fora do perímetro }\end{array}$ \\
& urbano e tem uma área de \\
& 483,21 hectares.
\end{tabular}

Fonte: Varela, 2012.

Varela (2012) quando trata da dinâmica de povoamento de Cali, traz a fala de dois professores, Urrea e Murillo (1990), durante a introdução de uma palestra, que apresentam as seguintes caracterizações:

Apresentam uma caracterização das duas zonas de bairros ilegais que emergem entre as décadas de setenta e oitenta, expressando como a cidade os percebia como grandes problemas, dado que ali se estabeleceu $30 \%$ da população da cidade. Zonas que correspondem aos assentamentos residenciais onde se concentram a maior parte dos setores populares, os quais compreendem: a) o corredor social da periferia pobre na parte plana da cidade, conformado pelo "Distrito de Aguablanca" (Comunas 13, 14 e 15) e comunas adjacentes com algumas características comuns, e b) o corredor social da periferia pobre da ladeira, nos quais se encontram as Comunas 1, 20, e a parte alta da Comuna 18 (Varela, 2012, p. 96).

É nesse cenário de disputa entre as classes sociais, onde em geral é a elite dominante que dita as regras, por ser detentora do poder e se destacar em suas interações sociais, que segundo Flórez (2013, p. 15), "hizo que se diera una distribución inequitativa del espacio, configurando un espacio fragmentado y segregado donde las clases altas ocupaban los mejores suelos de la ciudad, mientras que los sectores de bajos ingresos debieron ocupar suelos poco aptos para vivir".

Siloé sobre o qual discorremos adiante é parte desse cenário fragmentado, onde é visível a segregação socioespacial, notando-se a presença muito próxima de edifícios de luxo, onde só habita quem tem alto poder aquisitivo. Esse território, diferente de muitos outros que surgiram durante a chamada segunda "revolução urbana" de Cali, surge na primeira metade do século XX e já na década de 1940 é inserido oficialmente no perímetro urbano do município, abrindo caminho para o acesso a alguns serviços públicos, diferente do que ocorreu em outras áreas.

Desde a década de 1980, Siloé carrega o estigma de um território impenetrável e rebelde, e foi objeto de várias intervenções policiais à medida que a guerrilha urbana do M-19 concentrava suas operações nesta área; o que marcou uma etapa da história urbana da região e da cidade. Nas primeiras décadas do século 20, a influência do crime organizado aprofundou a luta pelo controle do território em Siloé. A configuração quebrada da terra e a 
marginalização histórica de seus habitantes fizeram dessa emblemática área de Cali, objeto de lutas pelo controle territorial e populacional de forças sociais inconformistas e de intervenções sociais do mundo institucional público e privado.

\section{4. \\ Dois mundos distintos e uma realidade comparável: a favela oficializada Rocinha e a comuna reconhecida como Siloé}

Neste início de subcapítulo nos propomos a expor imagens panorâmicas, tanto da Rocinha quanto de Siloé, para que ao alcançarmos a leitura sobre esses territórios, possamos ter uma melhor dimensão a respeito do que está sendo apresentado.

Figura 8 - Vista panorâmica da Rocinha
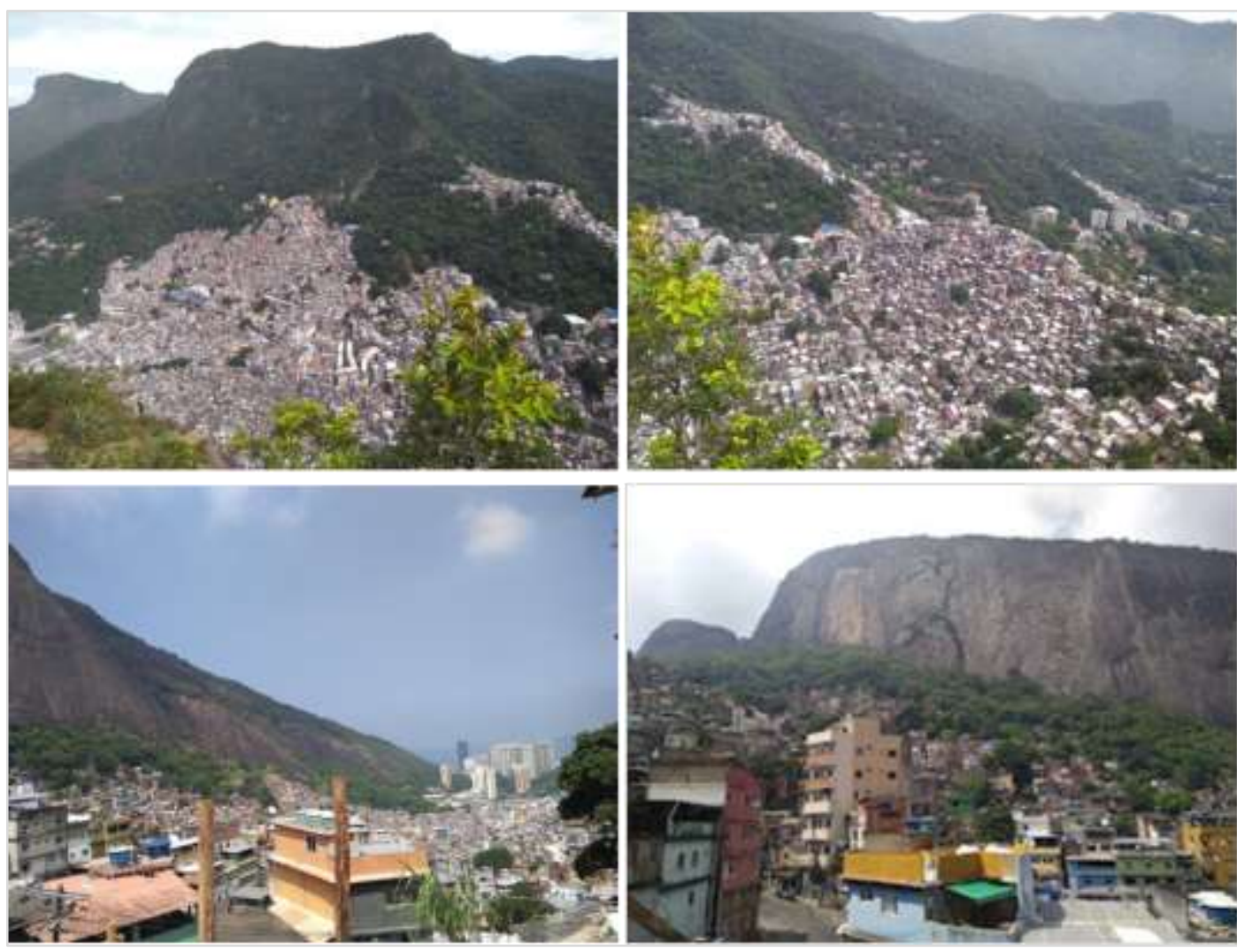

Fonte: Maria Izabel de Carvalho, 2020-2021. 
Figura 9 - Vista panorâmica de Siloé

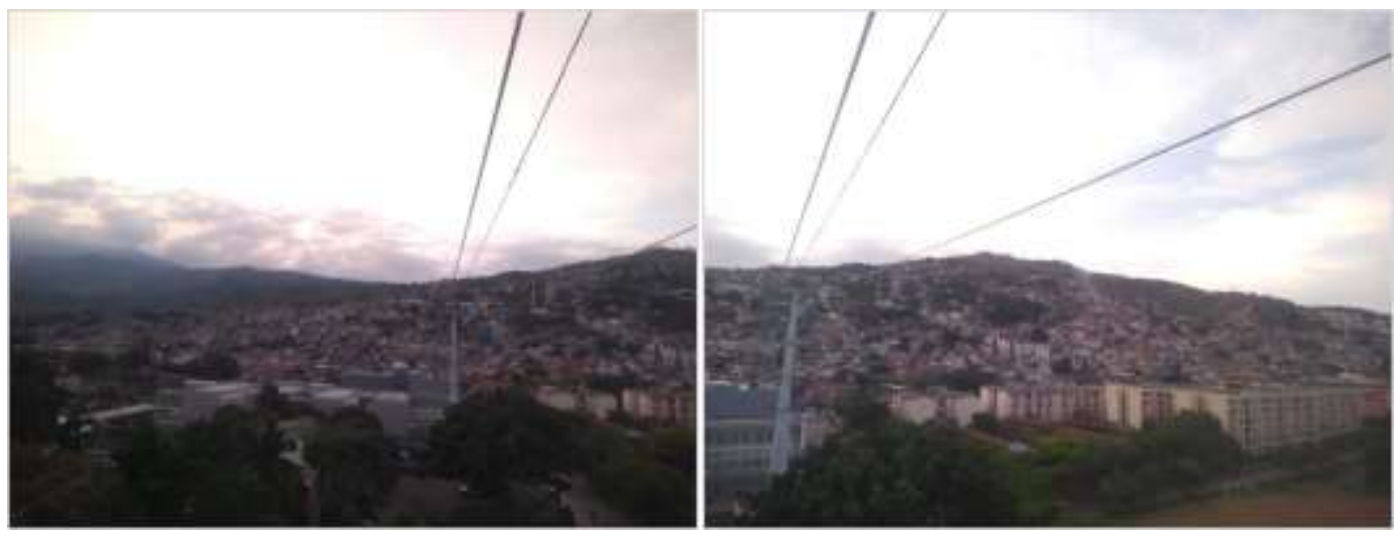

Fonte: Maria Izabel de Carvalho, 2019.

A favela da Rocinha, como já informado, se constitui como lócus da nossa pesquisa e está localizada na zona sul da cidade do Rio de Janeiro, entre os bairros da Gávea e São Conrado e seu surgimento tem registro na década de 1930. Que de acordo com Gonçalves (2013):

[...] constitui-se a partir do loteamento de uma fazenda de $550 \mathrm{mil} \mathrm{m}^{2}$ situada nos limites da parte oeste do bairro da Gávea (no alto do morro), incorporado pela empresa Castro Guidon em 1927. Segundo o Jornal Diário de Notícias, de 27 de maio de 1943, essa empresa já se encontrava em situação de concordata em dezembro de 1933, o que a impediu de prosseguir com as obras de urbanização do terreno. O loteamento não foi aprovado pelos organismos municipais competentes não só pela precariedade da urbanização, mas também pelo fato de que não respeitava as disposições estabelecidas, posteriormente, pelo Código de obras de 1937, e pelo Decreto $n^{\circ} 58$, de 10 de dezembro de 1938, que regulamentavam os loteamentos. Os compradores não puderam, portanto, obter o registro definitivo de seus títulos de propriedade. Os trabalhos de abertura do túnel Zuzu Angel (inaugurado em 1972), bem ao lado da favela da Rocinha, empregaram um grande número de moradores da favela, melhorando o acesso à sua parte plana, já no bairro de São Conrado (Gonçalves, 2013, p. 352).

Gonçalves (2013) aponta também que houve um grande crescimento populacional nesta área, no período de 1960 a 1970, devido à política de erradicação de favelas no Rio de Janeiro, fazendo com que as pessoas oriundas das áreas mais próximas à Zona Sul se instalassem, então, na favela da Rocinha. Segundo Brum (2009), "a maior parte das favelas removidas localizavase na Zona Sul, tendo sido removidas da orla da Lagoa e do Leblon as favelas da Catacumba, Jóquei Clube, Ilha das Dragas e Praia do Pinto" (Brum, 2009, p.3). 
Voltando um pouco na história, de acordo com Leitão (2004), na década de 1940, a maior parte dos moradores da Rocinha se concentrava mais especificamente em três regiões: "O trecho localizado no sopé da encosta, a faixa de terreno ao longo da Estrada da Gávea e os lotes situados naquela que é apontada como a primeira rua da comunidade, na época, não mais do que um caminho: o Caminho do Boiadeiro (Leitão, 2004, p. 79)".

Nessa época a Estrada da Gávea tinha uma importante função, que era ligar o bairro de São Conrado à Gávea, passando pela Rocinha, uma vez que ainda não existia o túnel Zuzu Angel, que veio a ser construído somente na década de 1970, conforme citado anteriormente.

Segundo Leitão (2004) é também nos anos de 1940, que a favela se torna um espaço importante para os candidatos, nos momentos que antecedem as eleições, passando-se a se observar "práticas clientelistas de políticos nestas comunidades. Na Rocinha, há que se destacar, nesse período, a atuação de um candidato a vereador, que se apresentava como proprietário de terras naquela área e incentivou a ocupação de terrenos na encosta, sobretudo, por migrantes vindos do nordeste do país" (Leitão, 2004, p. 79).

É na década de 1950, quando se inicia a ampliação da ocupação da região, que nas áreas inicialmente ocupadas, observavam-se muitos barracos de madeira. Nas partes mais altas das encostas, surgem também novas moradias, que de uma forma geral são muito precárias, com características análogas às existentes na fase inicial de ocupação da favela. De acordo com Leitão (2004) "a favela prosseguia, assim, na sua expansão morro acima, tendo a estrada da Gávea e as ruas Um, Dois, Três e Quatro como vetores de crescimento" (Leitão, 2004, p. 106).

Segundo Carvalho Filho (2005) a realidade de moradias feitas de barraco de madeira, começa a mudar a partir da década de 1960. Até então, sobretudo do seu surgimento até meados do século XX, "ser favelado na Rocinha era ser visto como um morador de um barraco de tábuas, coberto com telha de papelão pichado" (Carvalho Filho, 2005, p. 3). Porém,

[...] já na década de 1960, os principais imóveis situados ao longo da Estrada da Gávea, eram em sua maioria casas, havendo alguns prédios de dois andares de alvenaria, bem conservados. Por volta da década de 1970, o resto da favela já exibia impudentemente suas entranhas de tijolos, regurgitando, às vezes, uma touceira de canos d'água salientes, numa feição sempre inacabada. (Carvalho Filho, 2005, p. 3). 
No tocante ao acesso à água encanada, inicialmente, a rede era ineficiente e/ou inexistia em alguns locais em função do serviço ser muito caro, por esse motivo, na década de 1930, coletava-se água das nascentes nas encostas do morro ou nos tanques onde havia bicas coletivas. Para conseguir água, as pessoas tinham que enfrentar fila e era levada para as casas, conforme afirma Carvalho Filho (2005), em:

[...] latas de dezesseis litros, alimentando os latões de duzentos litros, antigos recipientes de querosene, tornados reservatórios d'água de cada barraco. Certos homens da "comunidade", sendo fortes e estando desempregados, eram contratados, por trocados, para encher esses recipientes domésticos. Vários favelados, para facilitar o acesso ao precioso líquido, abriram poços ou construíram, dependendo do fácil acesso de suas moradas para veículos motorizados, cisternas próximas aos seus barracos, alimentadas por caminhões de pipa d'água (Carvalho Filho, 2005, p. 4).

A seguir trazemos duas fotos de Fabio Costa da Silva, contidas no Varal de Lembranças (1983), que demonstram um pouco desse cenário:

Figura 10- Bicas coletivas de água na Rocinha

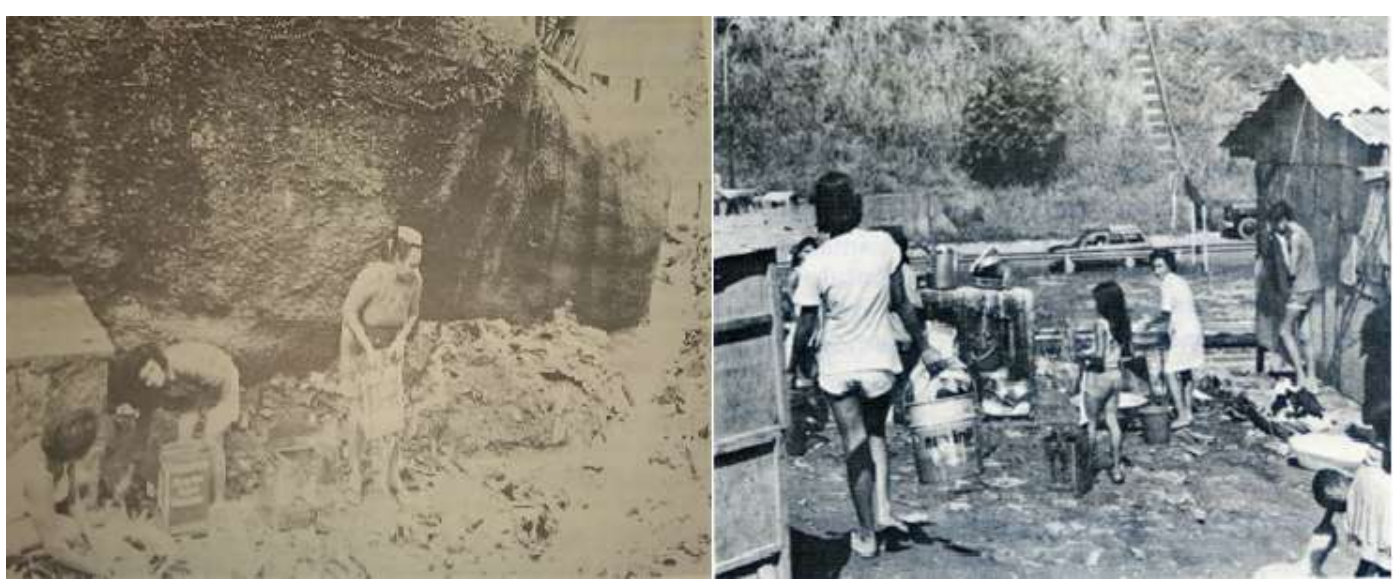

Fonte: Fonte: Varal de Lembranças, 1983.

$\mathrm{Na}$ década de sessenta, objetivando melhorar o abastecimento de água, um grupo de moradores conseguiu cerca de seis bicas novas e a abertura de um poço no Largo do Boiadeiro, utilizado pelos residentes, "aberto sob os auspícios do vereador Amando da Fonseca" (Carvalho Filho, 2005, p. 4). Ainda sobre a questão da água, encontramos relatos do morador José Martins de Oliveira, que afirma que na década de 1970, ocorreu uma nova mobilização para trazer fornecimento de água para a Rocinha: 
[...] Isso foi na década de 1970, e eu estava fazendo a reforma do meu prédio, quando o pai da minha companheira apareceu com um abaixo-assinado pedindo água para a Rocinha. Eu assinei, mas pensei: "Esse velho está caducando. Nunca vamos ter água aqui". Nessa época, apareceu na Rocinha o padre Cristiano, que também queria regularizar um terreno que ele havia comprado, que era da Aspa. Perguntei: "Padre, será que podemos fazer uma reunião na igreja?" E começamos a fazer encontros.

Na primeira reunião, o Cristiano abriu, eu falei das coisas, meio perdido ainda. Criamos uma pequena taxa para juntar dinheiro para fazer melhoramentos na pequena sede que tínhamos no Bairro Barcelos, uma reforminha pequena. Um belo dia, vem meu sogro com o projeto da Cedae debaixo do braço, dizendo: "Está aprovado". A Cedae aprovou o projeto dando toda a mão-de-obra, mas o material deveria ser pago pelos moradores, ao contrário do que é feito hoje. Aí surgiu a ideia de que o Batista, da grande comissão de luz da Rocinha, assumisse o projeto (Pandolfi, D. C.; Grynszpan, M. A favela fala. Rio de Janeiro, 2003. P. 37. Entrevista).

Nessa época a maior parte do esgotamento sanitário da favela, escoava pelas valas a céu aberto, somente alguns barracos contavam com fossas, ainda que muito precárias. O fato de não haver tratamento adequado do esgotamento sanitário contribuiu para a contaminação do lençol freático, inutilizando os poços até então construídos, isso também teve implicação direta para as lavadeiras que: "[...] nas décadas de 1940 e 1950, lavavam roupa nas águas ainda límpidas de um riacho corrente na favela, não podiam, na década de 1970, mais fazer: o córrego tornara-se um imenso valão porco e fétido condutor dos dejetos da favela (Carvalho Filho, 2005, p. 4-5)".

Somente no início da década de 1980, passados aproximadamente 50 anos é que os moradores conquistaram o acesso à água encanada. Inicialmente o sistema de distribuição se deu pela via aérea, onde os canos que levavam a água até às residências eram visíveis, e, atualmente, ainda é possível observálos:

[...] pendurados no beiral dos telhados, nas lajes ou cravados com buchas plásticas nas paredes. Essa escolha foi feita por serem as construções muito próximas, os terrenos acidentados, com pouco dinheiro para obras de infraestrutura, impedindo a danificação dos canos, ante o constante trânsito de pedestres e de cargas. Além disso, as redes aéreas apresentavam facilidades de reparos, assim como evitavam ligações clandestinas (Carvalho Filho, 2005, p. 5).

No tocante a saúde, o atendimento ocorria de duas formas: aqueles que contribuíam para a previdência social eram atendidos em uma clínica médica particular situada na Estrada da Gávea, nas proximidades da Igreja Nossa Senhora da Boa Viagem, pertencente ao Dr. Mário Dufles, que ainda é lembrado 
atualmente por moradores mais antigos. Já para os que estavam fora do mercado de trabalho formal ou que não tinham condições financeiras para pagar um tratamento médico, o atendimento era via saúde pública, no Hospital Miguel Couto. Conforme sinaliza Carvalho Filho (2005):

Com raridade, formavam-se redes de solidariedade entre médicos e pacientes, minorando o grau de vulnerabilidade de alguns. Dona Alda [moradora], por exemplo, possuía uma relação especial com um pediatra do Miguel Couto, um tal de Doutor Ovídio, o qual considerava um bom clínico, entregando a ele o cuidado de todos os seus filhos e de seus dois netos mais velhos. Essa afinidade permitiu que, por volta de 1954, quando um de seus filhos, então com oito meses de idade, teve crupe, ela, ante a gravidade da situação, tomasse a liberdade de ir da Rocinha à residência do pediatra em Ipanema, bairro nobre carioca, às duas horas da madrugada, rogar-Ihe atendimento (Carvalho Filho, 2005, p. 5-6).

Nos seus primórdios à educação apresentava um quadro crítico do ponto de vista do acesso e da permanência das crianças, pois a oferta de ensino público à população em idade escolar era muito precária. O que ficou evidente no censo de 1940, pois foi revelado que a taxa de analfabetismo do país era de $56,17 \%$ da população com mais de 15 anos de idade. Já em 1960, no final do governo Juscelino Kubitschek, registrou-se uma queda nos índices, pois passou para $39,35 \%$ de analfabetos entre essa mesma faixa da população. E na Rocinha não foi diferente, pois o índice de pessoas não alfabetizadas era muito alto, sobretudo, porque a maioria de seus moradores era advinda de áreas rurais, onde estudar não era prioridade. A história do migrante Bernardino Francisco de Souza retrata essa realidade:

[...] seu pai, um homem analfabeto, ante as possibilidades de sua parca e miserável vida rural no agreste nordestino, não via necessidade dele frequentar a escola, já que lá a 'leitura não dava comida a homem'. Então, 'a primeira caneta que [lhe] [...] deram', em sua terra natal, 'foi uma enxada' (Carvalho Filho, 2005, p. $6)$.

Hoje esse cenário tem mudado bastante, pois um maior número de pessoas tem um nível de escolaridade melhor que em outrora, há muitas pessoas com nível superior e até mesmo com pós-graduação.

No tocante ao acesso à luz elétrica apenas foi viabilizada em algumas residências na década de 1970. Segundo relato de moradores, só havia energia elétrica nas ruas, as moradias contavam com a iluminação de lamparinas alimentadas por querosene, de vela ou lampiões, o que não se distanciava muito 
da realidade vivida nas áreas rurais de onde vinha a maior parte dos moradores da Rocinha. Conforme afirma Carvalho Filho (2005):

\begin{abstract}
A fuligem gerada pela combustão do querosene irritava os olhos e as narinas, assim como enodoava as paredes do barracão. Então, a Rocinha guardava ainda um pouco do ritmo de vida rural: a falta de eletricidade nos barracos estimulava que grande parte de seus moradores se recolhesse por volta das vinte horas da noite. Tendo grande parte de sua população analfabeta, a grande forma de saber as informações eram a comunicação das novidades através das conversas, já que a inexistência de luz residencial impedia também o acesso às obtidas através do grande meio de comunicação do momento, o rádio. A iluminação elétrica nas casas chegou primeiro à Estrada da Gávea e seus habitantes, portanto, muitos moradores, inicialmente, só conseguiram a energia elétrica através da cessão realizada por aqueles favelados residentes naquela estrada (Carvalho Filho, 2005, p. 6).
\end{abstract}

Há relatos no Varal de Lembranças (1983), que apontam que a instalação dos postes para levar a energia elétrica para todos os domicílios, só aconteceu na década de 1980 e teve início "primeiro no Bairro Barcelos, depois na Vila União, posteriormente na Cachopa e em seguida em toda comunidade" (Varal de Lembranças, 1983, p. 145). De acordo com relatos encontrados nesse mesmo documento, o fato de individualizar o fornecimento de energia, significou o fim da exploração no que diz respeito às contas de luz, que eram muito altas, além de simbolizar a efetivação de um direito até então desrespeitado.

No que diz respeito à questão do reconhecimento oficial dos logradouros, a grande maioria dos moradores, enfrenta dificuldade, pois, por não terem seus imóveis reconhecidos formalmente, a entrega de serviços e/ou correspondências fica inviabilizada. E a alternativa encontrada para acessar esse que deveria ser um direito garantido é a utilização de endereços oficiais de amigos ou parentes em áreas da favela aonde chegam os prestadores de serviços ou da contratação dos serviços do "Correio Comunitário" existente. A empresa que presta esse serviço é conhecida como Carteiro Amigo e entrega as correspondências nas casas de moradores desde o ano 2000. Para passar a receber as correspondências em suas residências, os moradores têm que se inscrever e pagar atualmente, uma taxa mensal de $R \$ 25$ (vinte e cinco reais) por família, passando a usar o endereço da empresa como seu próprio. A loja onde funciona o "Correio Comunitário" tem que estar situada num local onde a correspondência dos Correios seja oficializada. Como coloca Carvalho Filho (2005):

Viver na Rocinha era ser, para muitos, um indivíduo "sem endereço". E não o ter significava não poder exercer atos simples da vida econômica, era portar sobre si 
uma identidade negativa que potencializava as dificuldades para superar a sua vulnerabilidade social. Porém, além disso, apresentar a Rocinha como endereço residencial significava quase uma imediata discriminação social, então, muitos negavam-no, assumindo, por vezes, endereços de parentes e amigos "do asfalto", ou substituíam a palavra Rocinha por São Conrado, elegante bairro contíguo. Dessa forma, as condições de vida nessa favela, não só pelo espaço desordenado e abandonado, mas também pela insuficiência de recursos financeiros advindos do trabalho, precarizavam seus habitantes, tornando-os sujeitos vulneráveis. Ou seja, toda essa comunicação é uma demonstração que a reprodução da força de trabalho era mais custosa para essa população do que para outros segmentos da população carioca (Carvalho Filho, 2005, p. 7).

Isso é sentido pelos moradores, por exemplo, quando precisam pegar um táxi, sobretudo no período da noite, sendo muitas vezes discriminados por residirem em área ditas de risco. Muitos taxistas e/ou outros prestadores de serviços, se recusam a entrar na favela.

No tocante ao recenseamento da Rocinha, o primeiro foi realizado somente em 1950, quando foi apontada:

[...] a existência de 4.513 habitantes numa área que, devido à dispersão das moradias e ao caráter rarefeito da ocupação, apresentava características distintas de outras favelas cariocas, onde se observava um maior adensamento de edificações. A paisagem da Rocinha remete, ainda, a um vilarejo rural, da "roça" (Leitão, 2004, p. 107).

Hoje a Rocinha é uma das maiores favelas do Brasil e segundo dados do IBGE - censo de 2010 - tem cerca de 70.000 mil moradores, o que será atualizado no próximo censo, tendo em vista que o dado populacional é contestado não somente pelas lideranças locais, mas também pelas empresas que prestam serviço no local, como é o caso da Light, empresa de energia elétrica, que afirma que nessa localidade há cerca de 150.000 mil moradores. Algumas lideranças locais, já há alguns anos vêm estimando que morem cerca de 200.000 mil moradores, portanto, não se tem contabilizado ao certo, o número de moradores da favela, o que por vezes prejudica a análise dos reais problemas existentes; essa divergência não consta dos dias atuais, pois na dissertação de mestrado de Vasconcelos (1990), está posto que:

Quanto à quantidade de moradores que habitam essas terras, tem havido uma polêmica: os dados oficiais diferem-se. Visualiza-se que: a) através dos setores de especiais de aglomerado urbano (SEAU's), $\mathrm{n}^{\circ}$ 152, 217 e 245 sob o título "Da Rocinha", de 1980, do Instituto Brasileiro de Geografia e Estatística (I.B.G.E.), o número é de 32.966 habitantes; b) através da Prefeitura do Rio de Janeiro, Secretaria Municipal de Planejamento, sob o título de "Aglomerações Humanas de Baixa Renda", de Janeiro de 1980, o número é de 97.954 habitantes. Alguns 
moradores estimam que, atualmente, existam aproximadamente, 250.000 habitantes na Rocinha (Vasconcelos, 1990, p. 37-38).

Mesmo diante de inúmeros problemas a serem enfrentados, a Rocinha vem avançando ao longo dos anos e alcançando algumas conquistas; hoje conta com uma gama de serviços, tanto na área comercial, tais como: bancos, lojas de roupas, supermercados, feira permanente de alimentos etc., quanto na área de serviços, como: unidades de saúde e de educação - públicas e privadas, transporte público, rádios comunitárias, associações de moradores, jornais comunitários, instituições religiosas, dentre outros.

No que diz respeito às políticas públicas, ainda há muito a ser feito, pois se registra além da precarização, o atraso na efetivação de alguns serviços, que ao longo dos anos, vem refletindo de forma negativa nos setores da vida na favela, mas o que foi possível evidenciar na gestão dos governos do período concernente a evocação do Rio de Janeiro como cidade olímpica foi a tentativa de recuperar o tempo, conforme afirma Pereira (2013):

\begin{abstract}
O que se observa é que a cidade vive um momento em que diversas políticas públicas são direcionadas para as favelas, envolvendo uma grande quantidade de recursos dos governos municipal, estadual e federal. No momento em que a cidade se prepara para sediar os dois maiores megaeventos esportivos do planeta (a Copa do Mundo de 2014 e os Jogos Olímpicos 2016), quais são as possibilidades para a construção de um futuro e uma cidade mais justa para a maior parte da população e não para uma minoria? (Pereira, 2013, p. 01).
\end{abstract}

No entanto, somos sabedores que todas as ações voltadas para as áreas favelizadas vêm carregadas de intencionalidades, muitas vezes obscuras, que passam desapercebidas aos olhos de muitos; nada é implementado pensandose unicamente no bem-estar dos que residem nessas regiões. Pereira (2013) faz um breve resumo sobre algumas das políticas públicas destinadas às favelas, desde a primeira metade do século $\mathrm{XX}$, onde isso de alguma forma fica evidente:

Desde a década de 1940, foram realizadas diversas intervenções nas favelas cariocas. Ora as políticas públicas pretendiam removê-las, ora visavam urbanizá-las (às vezes as duas coisas), dependendo do cenário político, da imagem da favela e dos interesses dominantes na sociedade brasileira. Como exemplos da via remocionista, podemos destacar: a construção dos Parques Proletários (no início da década de 1940); o Governo de Carlos Lacerda (na primeira metade dos anos 1960); e as ações da Coordenação da Habitação de Interesse Social da Área Metropolitana do Grande Rio - CHISAM (no período militar). Já, com o intuito de urbanizar as favelas, podemos destacar os trabalhos realizados: pela Fundação Leão XIII (1947 - 1954); pelo Serviço Especial de Recuperação das Favelas e Habitações Anti-higiênicas - SERFHA (na segunda 
metade dos anos 1950 e início dos anos 1960); pela Companhia de Desenvolvimento de Comunidades - CODESCO (1968); e pelo Programa Favela-Bairro (1994 - 2010). [...] o Programa de Aceleração do Crescimento PAC em complexos de favelas (desde 2008), as Unidades de Polícia Pacificadora - UPPs (desde 2008), a ameaça de remoção de favelas em pontos estratégicos em função dos megaeventos esportivos, a construção de muros para conter o crescimento de algumas favelas (2009) e de barreiras sonoras (2010) e o Programa Morar Carioca (2010) (Pereira, 2013, p. 3-4).

Portanto, podemos afirmar que o poder público nas favelas - e na Rocinha não é diferente, atua de acordo com os interesses políticos do momento, visando mascarar e/ou dar uma resposta à sociedade dominante. Um exemplo disso, foi a implementação do PAC 1, pois após forte pressão dos moradores de São Conrado, que sofrendo de alguma forma os impactos da guerra iniciada na Rocinha em 2004, interviram para que algum serviço público fosse implementado na favela, visando amenizar a violência nessa localidade para que eles parassem de sofrer as consequências. Conforme fala de um morador de São Conrado:

[...] São Conrado e Rocinha estão ligados por laços de trabalho e confiança. Por exemplo, a maioria dos funcionários aqui do bairro são da Rocinha e têm a chave dos depósitos, casas e dependências de onde trabalham. E não temos registro de problemas com isso. Temos uma boa convivência. O problema é que São Conrado já é um bairro pronto e a Rocinha precisa ser arrumada.

Mas foi em 2004 que todos nós formos surpreendidos por essa guerra. Eu continuava na presidência da Amasco e presenciei não só como morador, mas como dirigente da associação aquele desastre. Durante uma semana ninguém entrava nem saía daqui. Ficamos praticamente ilhados. O Fashion Mall, que é um grande shopping do Rio e que fica aqui em São Conrado, simplesmente parou. Ficou entregue às moscas. Uma das fachadas de um dos condomínios de alto luxo aqui de São Conrado recebeu um monte de bala no meio daquela guerra. E o governo nisso? Ah, o governo... Na época não procurou nenhum de nós, nem de São Conrado, nem da Barra - que fomos os bairros mais atingidos pela loucura que aconteceu. Nenhuma instância governamental se pronunciou sobre esse absurdo, nem para falar que sim, nem que não. Nada! Foi uma sensação de abano sem igual.

Quem nos procurava toda hora era a imprensa, como se estivesse fazendo cobertura de uma zona em conflito, como se fosse uma guerra. Dei inúmeras entrevistas que saíram em diversos jornais e em meio a isso tudo e aproveitando a visibilidade que a imprensa estava nos dando naquele momento eu pensei:

- Nós da Associação de Moradores de São Conrado temos que fazer algo, já que um serviço público básico, como a segurança, do qual temos direito não está acessível a nós, apesar de pagarmos o IPTU mais alto da cidade, de pagarmos taxas astronômicas e impostos exorbitantes para o governo... e nada. A única coisa que tínhamos de concreto era a violência que nos isolou do resto da cidade e o valor dos nossos imóveis caindo cada vez mais. 
Tínhamos de encontrar uma saída! (Sarayed-Din, 2009. p. 74 -75. Entrevista).

Já no tocante a Siloé em Cali na Colômbia, área que também se constitui como campo desta pesquisa, encontramos poucos registros a respeito da sua constituição, e o estudo de maior consistência após nossa revisão bibliográfica foi o do historiador Apolinar Ruiz López, do ano de 2016, denominado "Espacio y poblamiento en la ladera sur occidental de Cali: sector Siloé, décadas 19102010".

A partir dessa referência, informamos que esse território está localizado na ladeira Sul Ocidental de Cali e é formada por onze bairros, a saber: Belen, Belisario Caicedo, Brisas de Mayo, Lleras Camargo, Pueblo Joven, La Sultana, Siloé, Tierra Blanca, Urbanización Venezuela, Urbanización Cañaveralejo, Urbanización Cortijo.

Em relação à sua origem e surgimento, há divergências, pois existem relatos que apontam que esta área começou a ser povoada no início dos anos 1930, porém López (2016) aponta que segundo Fernando Mejía, algumas famílias já habitavam a parte baixa da ladeira desde 1927, indicando ainda que desde muito antes, a zona mineira de Siloé já vinha sendo povoada por pessoas vindas de Marmato, Santa Rosa de Osos e Supía, regiões de exploração de ouro da regiao do Viejo Caldas e o Departamento de Antioquia. López (2016), ainda assinala que a primeira onda demográfica desta área que impactou no seu crescimento, se justifica devido à violência originada pela Guerra de los Mil Días $^{19}$, que fez com que ocorresse um processo de migração da população mineira advinda de Viejo Caldas em direção à Cali.

De acordo com López (2016), a origem de Siloé, com seus bairros, se constituiu de forma muito particular diante da história de Cali, pois era uma área caracterizada como uma zona rural, pertencente à Cañavelarejo, com uma população densa, integrada à cidade por intermédio de um processo lento de reconhecimento oficial. Primeiro porque começou a se autodeterminar como bairro em 1935, devido ao número de habitantes, que à época eram arrendatários e inquilinos e trabalhavam na cidade; segundo porque a partir de 1945, começaram a chegar pessoas realocadas do bairro Alameda e de outros locais de Cali; terceiro porque o reconhecimento como bairro é conquistado com a criação da Junta de Fomento y Mejoras de Siloé, fundada em 1946, com personalidade jurídica e reconhecida pelo Ministério da Justiça; quarto porque

\footnotetext{
${ }^{19}$ Foi uma guerra civil colombiana entre liberais e conservadores, que durou de 1899 a 1902, quando foi firmado um acordo de paz entre as partes. Há relatos de que a guerra provocou mais de 100.000 mortes.
} 
urbanisticamente, esta área foi incluída na ampliação do perímetro urbano de 1948, passando a ter acesso aos primeiros serviços públicos urbanos, como a construção dos três primeiros depósitos de água, que se assemelhava a um chafariz, que ficavam na parte baixa do morro, construídos no ano de 1949. E finalmente em 1964, Siloé é reconhecido oficialmente como bairro pelo Concelho Municipal.

Quanto à origem do nome Siloé, segundo López (2016), há diversas versões, porém, grande parte dessas histórias coincide, ao dizer que foi dado por um estrangeiro e que é uma palavra de origem bíblica.

Diante disso, encontramos três versões a respeito, a primeira elucida que havia um poço que era tido como medicinal, cuja água sempre se mantinha morna e acreditava-se que era benéfica para a saúde, para curar ou melhorar de artrite, então o doutor Palacios, sujeito importante nessa região, tinha um familiar que vinha de San Fernando para tomar banho nas águas desse poço. Dizia-se que em outro lugar, não se sabe ao certo se no Egito, havia um tanque igual, que parece que se chamava Siloa, então Palacios colocou o nome de Siloé, no poço das terras colombianas, em homenagem ao outro poço que era medicinal e era localizado no Oriente.

A segunda versão enfoca que inicialmente a área era um terreno sem povoamento, onde havia em grande parte fazendas; ali se iniciou a exploração de minas de carvão existentes. Em seus arredores se instalaram, por exemplo, acampamentos de mineiros. Posteriormente ocorreu a imigração das pessoas vindas do campo, como do Departamento del Valle e de outros departamentos vizinhos, atraídas pelo desenvolvimento industrial de Cali e, além disso, nos últimos anos, deslocadas pela violência política; essas pessoas iam se acomodando nos terrenos disponíveis. Gradualmente, no decorrer de trinta anos, todo o lugar foi sendo povoado. Originalmente foi chamado pelo nome da antiga proprietária dona Isabel Pérez, rebatizada como Belén, por causa de um sacerdote domínico, porém os habitantes logo o chamaram de Siloé, nome de uma das minas de carvão existentes no local.

Já a terceira versão ilustra que o nome Siloé foi dado por um engenheiro das minas, o senhor Luis Chedé, em memória ao seu local de origem na França, que se chamava Siloé e foi dado o mesmo nome a primeira veia de carvão que tinha 180 metros de longitude.

Lopéz (2016) relata fatores que levaram Siloé a deixar de ser uma zona rural de exploração mineira para ser um setor popular da cidade, a saber: o primeiro fator está relacionado com a informalidade na qual se deu a exploração 
de carvão mineral nesta região, pois não existia uma companhia mineira própria do setor, eram minas arrendadas e lá trabalhavam várias pessoas que não tinham um vínculo de trabalho formal; trabalhava-se de maneira independente. $\mathrm{O}$ cidadão Fernando Mejía afirmava que era pago 1 peso colombiano por carro de material, se o mineiro tirasse 3 carros de material em um dia, ganhava 3 pesos. Mediante a exploração de carvão em diferentes e distantes áreas da ladeira, foi construída uma infraestrutura de vias por onde era feito o transporte do carvão mineral. Estas vias possibilitaram a mobilidade da população e a rápida construção de habitações, que abarcaria grande parte das áreas atuais dos bairros Siloé e Belén.

O segundo fator tem relação com os proprietários das terras (dentre as famílias estão: Gualtero, Garcés, Vicente López, Aristizabal) e com as pessoas encarregadas de liderar a exploração das minas, como é o caso de Luis Chedé, Pablo Marulanda, Eugenio Santamaría, Patricio Mira e a família Hernández, que se beneficiavam com a garantia da permanência da mão de obra no local, para a exploração das minas e com a produção e venda do que era produzido nessas terras; por isso, não se opuseram a construção de ranchos e habitações nessa ladeira. Tiveram ainda, benefícios econômicos, uma vez que venderam os terrenos.

O terceiro fator está relacionado com a luta dos habitantes pela permanência no local. Esses tendo conhecimento de que parte destas terras eram terrenos vazios da cidade, argumentaram para se defenderem e não permitirem que fossem desalojados dessa área. Cali se tornou um centro de atração de imigrantes vindos de outras cidades e regiões, o que levou a triplicação de sua população. A construção de habitações não acompanhou o ritmo do crescimento, havendo um déficit habitacional, o que acarretou um processo de autoconstrução por meio da mobilização social, que levou a compra de terras nesse setor, por parte do Instituto de Vivenda Popular de Cali INVICALI, para suprir as necessidades e atender as solicitações da população.

O quarto fator tem relação com a diminuição da quantidade e qualidade do carvão das minas dessa região. Já em 1945, Siloé tem perfil residencial, onde o custo dos aluguéis eram mais baixo se comparados com o centro da cidade, o que levou ao adensamento populacional desse setor, aonde chegaram pessoas deslocadas forçadamente dos seus lugares de origem, conforme fala a seguir:

\footnotetext{
"A éstas lomas llegaron muchos paisas del norte del Valle, por la violencia la gente
} llegaba acá a trabajar en las minas o a vivir, porque es muy económico vivir en 
Siloé. Era casi una regla general que la gente llegaba desplazada a la Casa Liberal y de ahí cogía a Siloé, éste era prácticamente un refugió de desplazados [...] Recuerdo que de niños la pasábamos jugando cogiendo pescaditos de colores en esos $\operatorname{charcos}^{20}$ (López, 2016, p. 96).

De acordo com os dados encontrados no estudo de López (2016), verificamos que este deslocamento de pessoas advindas de outras regiões do país para Siloé ganha registro a partir de 1951, período que o local contava com 14.000 habitantes, o que só aumentou nos anos subsequentes, visto que em 1954 contabilizava-se 16.000 habitantes e em 1958 levantaram-se dados que apontavam uma população de 20.000 mil moradores, com uma densidade de 1.460 habitantes por $\mathrm{Km}^{2}$. Nesse período as partes mais baixas eram as mais adensadas, constituída por uma população de predominância de mulatos e brancos.

Siloé ocupa a quarta escala em termos de densidade habitacional, cuja formação já foi citada anteriormente. Os dados mais recentes foram extraídos do documento denominado "Cali en Cifras 2020", que aponta que a população em 2020 era de 58.502 mil moradores, com projeção para 2021 de 58.827. É válido salientar que em um documento de mesmo nome do ano de 2015, consta que a população de Siloé neste ano (2015), era de 69.331 mil moradores, apresentando uma diferença significativa em relação ao dado exposto no documento do ano passado. O que pode indicar um equívoco, pois não observamos nenhum evento especial de saída de população desse território, que justificasse essa diferença. Ou também pode significar uma revisão dos dados ou uma nova abordagem metodológica por parte do organismo encarregado do censo.

No tocante ao número de habitações, em 2020 havia um total de 17.794 e estima-se que em 2021 esse número alcance 17.852 unidades habitacionais.

De acordo com o mapa 05, em 2020 Siloé tinha uma densidade habitacional, ou seja, o número moradia, entre 59 e 77 habitações por hectares quadrados, a qual resulta relativamente alta em relação ao resto da cidade, similar a outros setores populares urbanos localizados em morros, e mais baixa que nos bairros populares do Distrito de Aguablanca, que fica ao oriente de Cali.

${ }^{20}$ Entrevistado: Cesar Armando Silva, 2012. 
Figura 11 - Mapa da densidade habitacional em Cali em 2020

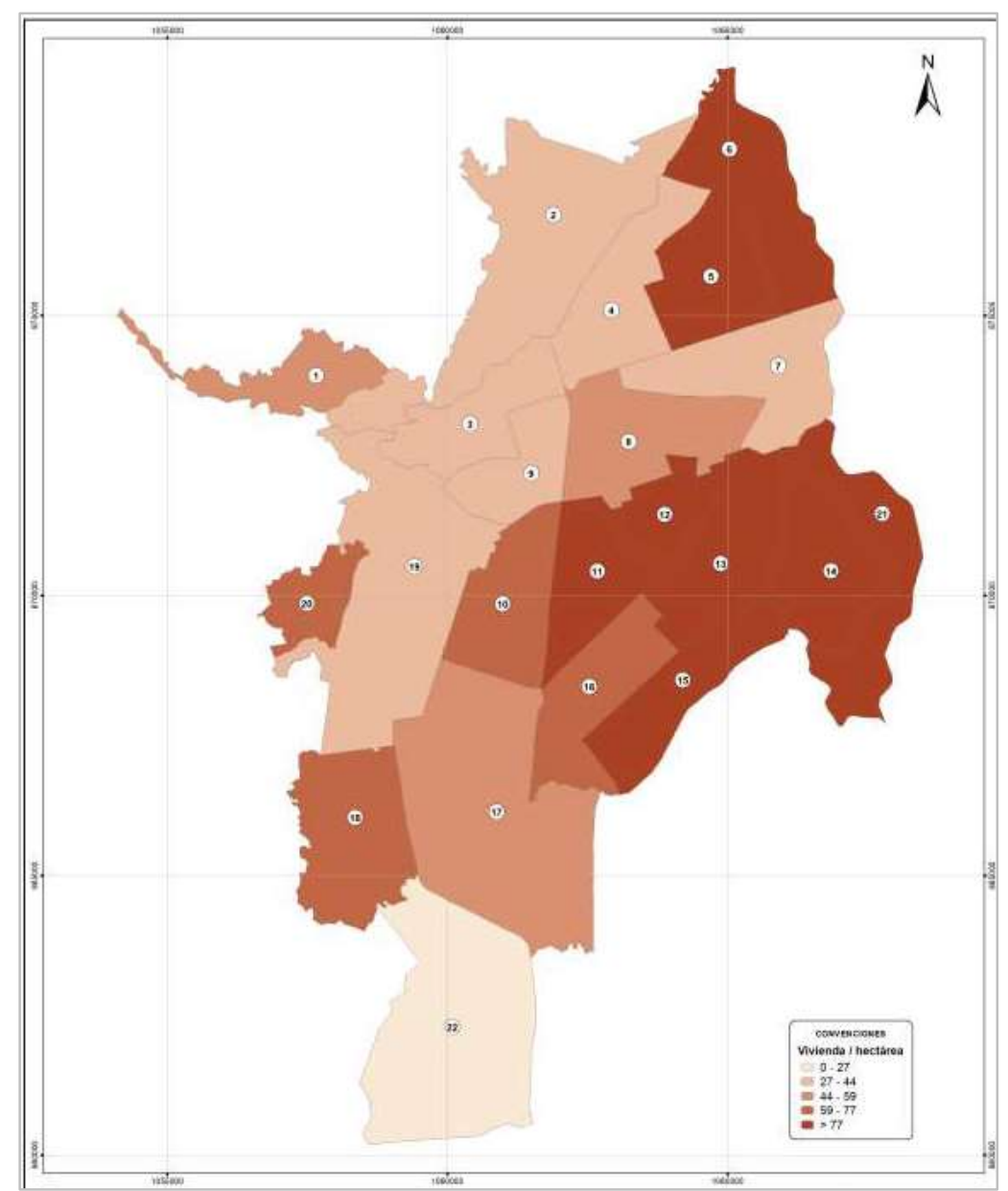

Fonte: COLOMBIA. Alcaldía de Santiago de Cali, Departamento Administrativo de Planeación, 2020.

Quanto à origem dos moradores Siloé, segundo López (2016) apresenta uma pesquisa amostral realizada com 179 famílias em 1958.

Figura 12 - Quadro ilustrativo referente à densidade habitacional em Cali em 2015

\begin{tabular}{|c|l|c|l|c|l|}
\hline $\begin{array}{c}\mathbf{N}^{\circ} \text { de } \\
\text { Habitantes }\end{array}$ & Departamento & $\begin{array}{c}\mathbf{N}^{\circ} \text { de } \\
\text { Habitantes }\end{array}$ & Departamento & $\begin{array}{c}\mathbf{N}^{\circ} \text { de } \\
\text { Habitantes }\end{array}$ & Departamento \\
\hline a. 578 & Valle del Cauca & e. 51 & Nariño & h. 11 & Boyacá \\
\hline b. 148 & Caldas & f. 32 & Tolima & i. 10 & Chocó \\
\hline c. 85 & Cauca & g. 22 & Cundinamarca & j. 2 & Santander \\
\hline d. 59 & Antioquia & h. 20 & Huila & k. 2 & Ecuador \\
\hline
\end{tabular}

Fonte: CINVA-OEA. SILOÉ. Serie: Trabajos de Clase № 6, López, 2016, p. 103. 
A partir dos dados desta tabela, verificamos que àquela época a maioria dos entrevistados eram originários do Valle del Cauca e em segundo lugar estavam os moradores advindos do Departamento de Caldas.

Em relação à infraestrutura e os principais serviços públicos de Siloé, tais como: água, energia elétrica e esgotamento sanitário, enfocamos que em seus primórdios existiam tanto fontes de água que serviam para o consumo humano como aquelas cuja água não poderia ser consumida porque era tóxica, podendo causar envenenamento ou problemas gastrointestinais, devido à presença de musgos vermelhos que ficavam presos às pedras.

Alguns locais vizinhos a Siloé, contavam com aquedutos comunitários ou poços profundos, de onde provinha a água para o consumo diário. Já para a parte de higienização das vestimentas, utilizava-se a água dos pequenos rios existentes nessa e nas regiões próximas, mas com o aumento populacional, essa infraestrutura não foi suficiente para atender a todos, uma vez que houve o aumento da demanda e as fontes de água acabaram sendo afetadas pelo desflorestamento e, mediante a esse fato, fez-se necessária à adoção de novas práticas para obtenção de água, o que exigiu um maior contato com a cidade, bem como com a gestão pública para a construção de aquedutos públicos e domiciliares. Inclusive, há relatos no estudo de López (2016), que mostram que em vários momentos, a maior parte dos residentes teve que passar a fazer o transporte de água, em vasos ou latas, de San Fernando, El Águila, ou instalações da fábrica El Cedro, locais esses que ficavam distantes de Siloé. Essas pessoas tinham que enfrentar filas longas e intermináveis, que se formavam a partir de nove ou dez horas da noite.

Diante dessa realidade, no ano de 1949 o município construiu reservatórios de água em diferentes partes, porém todos localizados na área plana do bairro, pois na parte alta, esses reservatórios só foram construídos entre os anos de 1956 e 1957. Aquelas pessoas que não podiam ou não queriam carregar a água nos ombros, pagavam um determinado valor por cada lata de água, que era transportada em cavalos ou mulas, até as suas residências.

A década de 1950 foi marcada pelo aumento da demanda por serviços públicos em Cali em função do crescimento da industrialização e do desenvolvimento demográfico e físico da cidade. Nesse período em Siloé, as formas de abastecimento de água em cinquenta por cento das casas, eram da rede municipal; o restante da população abastecia suas residências nos reservatórios públicos distribuídos na localidade e ainda havia outras situações 
em partes específicas de Siloé como água que vinha de aqueduto, poço profundo, armazenamento de água pluvial, retirada do rio Cañaveralejo ou ainda comprada.

No que concerne à energia elétrica está posto no trabalho de López (2016), que esse serviço chegou de forma fraudulenta, pois o local mais próximo onde havia energia, era em um prédio antigo, onde funcionava uma prisão para mulheres que se chamava El Buen Pastor. Foi daí de onde se extraiu a primeira fonte de energia, em um primeiro momento, para um prédio de um senhor chamado Aristizábal. Posteriormente, outras ligações foram sendo feitas até chegar a Siloé.

Os moradores se juntavam por setor e recolhiam dinheiro para a compra do material necessário para a instalação da energia em suas residências. Há relatos que apontam que esse modo de agir foi causador de vários conflitos entre vizinhos e até mesmo entre os setores, pois os vizinhos que eram mais acomodados esperavam os cabos passarem próximos as suas casas, para então ligarem a luz em suas moradias de forma fraudulenta.

No ano de 1958, 91\% da população tinha acesso à energia elétrica para iluminação do domicílio, no entanto, deve-se levar em consideração a fragilidade das instalações particulares e a necessidade de melhorar o serviço de iluminação pública. $O$ restante da população não tinha acesso à energia e se utilizava de outros meios como velas $(6,6 \%)$ e lamparinas a querosene $(2 \%)$, para iluminar as suas casas.

Quando ao esgotamento sanitário, Lopéz (2016) aponta que até a década de 1950 aproximadamente, não houve a oficialização desse serviço e o esgoto era canalizado para os pequenos rios que ali passavam. Até os dias atuais ainda há setores em que o esgotamento ainda mantem as mesmas características encontradas nos primórdios dessa região. Tanto esse serviço quanto à canalização das águas pluviais não tem cobertura total por parte das empresas municipais, o que acarreta problemas para a população local. Conforme descrito,

La falta de canalización de aguas lluvias ha generado graves problemas de erosión en todo el barrio pues las aguas destruyen a su paso la capa de fijación vegetal y deterioran cada vez más las vías existentes. En cuanto a la eliminación de excretas, Siloé tampoco dispone de red recolectora. La eliminación se realiza por varios sistemas: en algunos casos (13.9\%) las viviendas cuentan con baño o letrina interior que desagua en la quebrada o canales abiertos. En otros casos (15.5\%) la eliminación se hace por medio de letrina de pozo abierto y en la mayoría (54.3\%) las letrinas son en pozo de piso cerradas. Existen sin embargo algunas viviendas (16.6\%) que no cuentan con ningún medio de eliminación, agravando así la falta de sanidad ambiental del barrio (Lopéz, 2016, p. 115). 
Os serviços públicos foram e ainda são precários em muitos casos. A maioria só chegou à Siloé à medida que as áreas adjacentes, como o bairro Belisario Caicedo (1952), a urbanização Santa Isabel (1950) e Lido (década de 1960-1970), que ficam na parte baixa, foram recebendo esses serviços. Acreditamos que seja reflexo da segregação socioespacial a que estão submetidos esses sujeitos, por morarem em áreas periféricas da cidade, conforme descrito a seguir:

Respecto a la energía eléctrica, alcantarillado, recolección de basuras y realización de vías carreteables, el desarrollo es aún muy precario. Se evidencia de esta forma la segregación espacial y la tardía modernización en el proceso de urbanización de la ciudad de Cali (Lopéz, 2016, p. 115).

Pautados nas informações apresentadas, concluímos que a realidade de Siloé não difere muito da realidade da Rocinha no tocante aos serviços públicos, - que nos faz acreditar que o trato das questões básicas nas áreas empobrecidas é encarado, independente da nacionalidade, de forma estigmatizada e com precarização da prestação de serviços básicos, fator que torna as comunidades e famílias reféns da situação de risco, conforme afirma Rosane Janczura (2012) quando enfoca que:

Pessoas, famílias e comunidades são vulneráveis quando não dispõem de recursos materiais e imateriais para enfrentar com sucesso os riscos a que são ou estão submetidas, nem de capacidades para adotar cursos de ações/estratégias que Ihes possibilitem alcançar patamares razoáveis de segurança pessoal/coletiva.

A inclusão poderá viabilizar, assim, a melhoria das condições materiais de pessoas, famílias e comunidades, bem como o acesso a serviços públicos básicos (educação, saúde, habitação, nutrição, segurança pública, justiça, cultura e recreação) para esses grupos desenvolverem sua competência, autonomia, autodesenvolvimento e capacidade de ação. Os riscos e as vulnerabilidades emergem de uma multiplicidade de fatores interdependentes. Estratégias para reduzi-los e ampliar a inclusão requerem ações em várias frentes, exigindo o planejamento para que elas sejam executadas de forma integrada e complementar (Janczura, 2012, p.304). 


\section{3 \\ Panorama da política pública de resíduos sólidos na América Latina com foco no Brasil e na Colômbia}

Objetivamos neste capítulo, fazer uma breve exposição sobre a atual conjuntura dos resíduos sólidos na América Latina; apresentamos o panorama da gestão dos resíduos sólidos no contexto brasileiro e na realidade colombiana; e, além disso, nos propomos a versar sobre a política nacional de resíduos sólidos no Brasil e na Colômbia, trazendo alguns elementos sobre os avanços e retrocessos, após a implementação desta política em ambos os países.

\subsection{A atual conjuntura dos resíduos sólidos na América Latina}

O período em que o desenvolvimento industrial e econômico começa a se acentuar, sobretudo, com a chegada da revolução industrial e com a produção de bens de consumo em grande escala, levou as pessoas a consumirem em maior quantidade e, consequentemente, a gerarem mais resíduos, insuflando a problemática da geração e de seu descarte. Mas isso ainda não representava um motivo de preocupação maior, pois o que de fato interessava era o desenvolvimento e não se notava uma preocupação em relação aos problemas que isso poderia acarretar. Como podemos verificar com a fala de Padovani (2011):

A visão do lixo como problema a ser enfrentado só se firmou no século XIX, quando a Revolução Industrial instituiu um novo patamar de tecnologia, de conforto, de produtos - e de resíduos, montanhas de resíduos. O lixo, a partir daí, e empurrado pela comprovação científica de seu papel como causador de doenças várias, começou a ser um desafio para a humanidade. A industrialização incorporou ao cotidiano das pessoas uma série de novos produtos - e, mais que todos eles, o onipresente plástico, que, por demorar um século para se decompor e nunca desaparecer completamente, hoje enfeia ruas, praias, rios e até o fundo do mar. O impulso industrial também contribuiu para o surgimento das metrópoles - e, quanto mais gente confinada em determinado espaço, mais detritos se acumulam (Padovani, 2011, p. 1).

No século $X X I$ essa é uma questão que vem se tornando cada vez mais preocupante, pois as consequências são expressivas e as previsões são ainda 
mais assustadoras. A ONU prevê que se continuarmos no mesmo ritmo de crescimento, no ano de 2050 chegaremos à geração de 4 bilhões de toneladas de resíduos por ano. De acordo com uma matéria da revista "Em Discussão" do Senado, do ano de 2014, nas três últimas décadas a geração de resíduos sólidos urbanos aumentou três vezes mais rápido que a população, por esse motivo, os países vêm procurando saídas para enfrentar os altos custos relacionados à questão ambiental e, também, financeira.

$\mathrm{Na}$ América Latina e Caribe, segundo dados de um estudo realizado em 2018, pela Organização das Nações Unidas (ONU Meio Ambiente) em parceria com a Associação Brasileira das Empresas de Limpeza Pública e Resíduos Especiais (ABRELPE), a geração de resíduos sólidos urbanos nessa região vem aumentando constantemente. De acordo com as informações que constam nesse levantamento, em 2014 gerou-se cerca de 541.000 toneladas/dia, sendo que em média, metade desse volume é composta por resíduo orgânico.

Do total geral de resíduos gerados, somente cerca de $10 \%$ são reaproveitados. A taxa de reciclagem nessa região ainda é baixa, ficando em torno de 1 a $20 \%$.

Com base na taxa de geração atual, que é de 1,04 kg/hab./dia, estima-se que em 2050 o montante de resíduos sólidos gerados será de 671.000 toneladas /dia.

Atualmente, por dia 145.000 toneladas vão para os lixões, são queimados ou tem outros destinos inadequados, e desse total, 17.000 toneladas/dia são de resíduos de plástico.

Ainda de acordo com esse relatório, mesmo em uma região onde a área urbana é predominante, ocupando cerca de $80 \%$ do território, aproximadamente 40 milhões de pessoas não contam com o serviço de coleta, sendo as mais afetadas, as que vivem nas regiões mais pobres e em zonas rurais.

De acordo com o que está posto nesse estudo, apesar dos números apresentados indicarem a necessidade de avanços, tem-se que reconhecer que houve melhoras na cobertura do serviço de coleta, tanto em números quanto em qualidade, chegando a comtemplar $93 \%$ da população dessa região. $\mathrm{E}$ a modalidade mais presente de prestação desse serviço é o municipal direto. No tocante a cobertura, pode haver variação, dependendo do país ou mesmo entre as cidades de um mesmo país.

Na América Latina e Caribe, muitos são os resíduos sólidos especiais sem o devido tratamento, como os resíduos perigosos, os da área de saúde, do ramo da construção civil e os eletroeletrônicos, não estando nem mesmo, em muitas 
situações, devidamente identificados. Apesar de já haver avanços em relação à legislação voltada especificamente para esses tipos de materiais, não há controle por parte dos órgãos competentes e tampouco locais adequados para a sua devida manipulação e tratamento.

Segundo dados do relatório da ONU/ABRELPE, já se nota de alguma maneira, presente em cerca de um terço dos países latino-americanos e caribenhos, o princípio da responsabilidade compartilhada que compromete o produtor no retorno do produto no ciclo de produção, no entanto, ainda sendo necessários muitos avanços tanto na legislação quanto na sua efetivação.

No que concerne à atividade de reciclagem e reuso de materiais, isso não é algo novo nos países em desenvolvimento, porém na América Latina e Caribe, têm se intensificado as ações, principalmente por conta das constantes crises econômicas experimentadas por essa região, aliado as deficiências dos sistemas de gestão dos resíduos sólidos, como descrito no trecho que segue:

La recuperación de materiales aprovechables de la basura es una actividad de antigua data en los países en desarrollo pero que se agudizó, en el caso de ALC, con las sucesivas crisis económicas y la pobreza endémica de muchos de los países de la región. A esto es preciso añadir la carência generalizada en las ciudades de la región de sistemas de gestión integral de los residuos que especialmente incluyan la recolección diferenciada, lo que favorece la recuperación informal. Ambos factores -necesidad económica y la insuficiente gestión pública en relación con la recuperación de materiales proveniente de los residuos- crean un escenario propicio para el desarrollo de esta actividad por parte de los sectores más carenciados de la población (ONU \& ABRELPE, 2018, p. 182).

Assim, é notada a presença de catadores/recicladores, na maioria dos países dessa região, no entanto sem ser dada maior relevância a sua importância; essa categoria de trabalhadores informais contribui para que haja um maior potencial de coleta e seleção de resíduos sólidos urbanos, o que eleva o índice de reciclagem. Porém ainda há muito que avançar no caminho da formalização e profissionalização desse grupo, para que tenham melhores condições de trabalho e garantia de direitos.

Em um estudo realizado pelo BID em 2014, em alguns países da América Latina, apontado pelo estudo da ONU Meio e ABRELPE (2018), assinala que:

La baja producción de residuos en comparación con países desarrollados, la alta generación de residuos orgánicos y el tamaño limitado de la industria manufacturera imponen limitaciones a la actividad de reciclaje de residuos "secos". El mercado nacional de reciclaje en estos países se concentra principalmente en el aprovechamiento de papel, cartón, chatarra (metales ferrosos), algunos plásticos (PET y PEAD) y vidrio, mientras que el aprovechamiento de los residuos orgánicos es mínimo (ONU \& ABRELPE, 2018, p. 200). 
Apesar de ter sido identificado em 2013, que em alguns países estudados nessa região, o papel, o papelão e a sucata são os mais recuperados internamente, esses são também os que mais importam os ditos materiais. Sendo que em relação ao plástico, prevalece à exportação para a China e Estados Unidos. Já no que diz respeito ao vidro, não foram identificadas transações internacionais significativas.

Os Estados Unidos foram os principais exportadores de papel e papelão reciclado para os países da América Latina e houve comercialização desse material, entre países dessa região. Os principais destinos dessas importações foram: Colômbia, Chile e Equador. Em média a tonelada custava nesse período, para importação a USD 236,9 e para exportação a USD 234,6.

Nesse mesmo ano, na Colômbia, Equador, Panamá e Peru, as importações de sucata foram superiores às exportações, sendo a primeira de 600 mil toneladas e a segunda de 258 mil toneladas. A quantidade mais expressiva de importações de sucata, também foi originária dos Estados Unidos, chegando a 455 mil toneladas enviadas para Peru e Equador. Já as exportações desse material nesses países, tiveram como destino países da Ásia. A média de preço da importação foi de USD 326 por tonelada e da exportação foi de USD 214 por tonelada.

Nos mesmos países supracitados, no que diz respeito à comercialização do plástico, no mercado internacional, o que prevaleceu foram as exportações, chegando a 60 mil toneladas, tendo como países de destino à China que importou 41 mil toneladas vindas do Equador e do Peru, e os Estados Unidos, que recebeu 11 mil toneladas oriundas do Equador. Enquanto isso, as importações foram de 5,6 mil toneladas, aparecendo mais uma vez, os Estados Unidos como o principal exportador. O valor médio da importação foi de USD 882 por tonelada e da exportação foi de USD 739 por tonelada.

$\mathrm{Na}$ América Latina, a destinação adequada dos resíduos sólidos segue sendo um grande desafio, porém não há um investimento político com esforços dos governantes, para que esse cenário avance, no sentido da efetivação de uma gestão adequada, embora quase todos os países tenham políticas públicas destinadas especificamente ao trato com a gestão de resíduos sólidos urbanos

Existe uma carência expressiva na integração de informações ligadas à geração e destinação de resíduos sólidos urbanos, tanto a nível local e nacional, 
quanto entre os países dessa região, pois não há uma padronização dos indicadores, o que dificulta essa análise comparativa.

No tocante a comunicação e a campanhas educativas, nota-se ausência de uma política continuada e sistemática, portanto, há limitações; sendo as ações isoladas, não abrangentes e inconstantes. O mesmo ocorre quando falamos da participação da população usuária e dos demais envolvidos, na tomada de decisão, no que diz respeito ao sistema de gestão dos resíduos sólidos. No geral os serviços já vêm prontos, e assim são implementados, desconsiderando as especificidades locais.

Nas localidades, objeto de estudo desta tese, o cenário não diverge muito do apresentado aqui, pois se observa o aumento na geração de resíduos sólidos, sendo que uma grande quantidade deste material continua indo parar em locais ambientalmente inadequados, e onde também, são baixos os índices de reciclagem, conforme dados oficiais apresentados nos itens subsequentes.

\subsection{1. \\ O panorama da gestão dos resíduos sólidos no contexto brasileiro e colombiano}

No Brasil, de acordo com autores como Eigenheer (2009), por muitos anos, sobretudo até o início deste século, não havia uma precisão de dados em relação a um "panorama amplo e sistemático da questão da limpeza urbana" (Eigenheer, 2009, p. 93). Esse atribuiu isso ao fato de vivermos num país de dimensões continental, e que veio a se desenvolver de forma muito desigual, pois cada região apresenta ainda hoje, gigantescas diferenças em diversos aspectos, sejam culturais, educacionais, sociais, econômicas, entre outros.

Em face dessa questão e tendo em vista que o Rio de Janeiro é uma das cidades mais antigas do Brasil e, foi capital da colônia durante quase 200 anos, o tomaremos como parâmetro para falar sobre a história do tratamento e destinação de resíduos sólidos no país. E de início, encontramos na fala do Dr. Gama-Roza (1879) a seguinte questão:

\footnotetext{
É notável que esta cidade reúna em alto grau, e em tudo, as condições as mais anti-hygienicas. O que foi obra da ignorância e do puro acaso, visto hoje, na imponência ominosa do seu conjuncto, afigura-se ao hygienista haver sido o projecto assentado de uma conspiração obscurantista. É uma questão de elevado alcance para todo o paiz, o saneamento desta capital; direi mesmo, que esse
} 
melhoramento importa aos destinos futuros da nossa pátria. No estado de centralização extrema da administração o Rio de Janeiro é o Brazil. Só quem, por algum tempo, viveu em província, póde fazer idea cabal da dependência absoluta e irresistível desses logares ao centro (Gama-Roza, 1879, p. 4-10).

Com vistas a uma melhor compreensão sobre a temática do lixo no país, buscaremos aqui traçar em linhas gerais, alguns pontos que julgamos importantes para o entendimento do assunto, porém salientamos que não temos a pretensão de apresentar, na íntegra, a história da limpeza urbana no Brasil.

Os povos que ocuparam a costa brasileira há muitos anos, são considerados imprescindíveis nessa análise, pois deixaram um legado muito importante. Nesse sentido, iniciaremos abordando a questão voltando-nos para os sambaquis,

[...] caracterizados basicamente por ser uma elevação de forma arredondada que, em algumas regiões do Brasil, chega a ter mais de $30 \mathrm{~m}$ de altura. São construídos basicamente com restos faunísticos como conchas, ossos de peixe e mamíferos. Ocorrem também frutos e sementes, sendo que determinadas áreas dos sítios foram espaços dedicados ao ritual funerário e lá foram sepultados homens, mulheres e crianças de diferentes idades. Contam igualmente com inúmeros artefatos de pedra e de osso, marcas de estacas e manchas de fogueira, que compõem uma intrincada estratigrafia (Gaspar, 2000, p. 9).

Ao que tudo indica, os sambaquis foram uma das primeiras formas de destinação dos resíduos gerados pelos habitantes das terras brasileiras e notase a sua estreita relação "entre lixo, morte e memória" (Eigenheer, 2009, p. 94).

Documentos disponíveis e notícias demonstram que "o padrão higiênico das cidades brasileiras nos séculos XVI, XVII, XVIII e XIX deixaram muito a desejar" (Eigenheer, 2009, p. 94). Sobre essa questão, John Luccock (1951) faz a seguinte observação no tocante ao Rio de Janeiro, nos primeiros anos do século XIX:

Se dos dormitórios continuarmos para a cozinha, outras inconveniências não se farão esperar. Entre as piores, acha-se uma tina destinada a receber todas as imundícies e refugos da casa; que, nalguns casos, é levada e esvaziada diariàmente, noutros sòmente uma vez por semana, de acôrdo com o número de escravos, seu asseio relativo e pontualidade, porém, sempre que carregado, já sobremodo insuportável. Se acontece desabar um súbito aguaceiro, logo surgem em geral essas tinas, despeja-se-lhes o conteúdo em plena rua, deixando-se que a enxurrada o leve. Nas casas em que não se usa desses barris, toda espécie de detrito é atirada ao pátio, formando uma montoeira mais repugnante do que é possível a uma imaginação limpa fazer idéia. E ali fica, ajudando a criar os insetos e originando doenças, à espera de que as chuvas pesadas do clima tropical a levem. A água que cai no pátio, depois de assim impregnada, encaminha-se para a rua, por meio de canais que passam por debaixo do assoalho da casa, ou para dentro de um poço escavado bastante fundo para que comunique com a camada arenosa inferior ao nível das águas altas, em que se dissolve, ou através da qual uma parte encontra caminho para o mar (Luccock, 1951, p. 89). 
À época, eram as pessoas escravizadas que limpavam a cidade, fazendo uso de enxadas para retirar o lixo das ruas, que após recolhido era colocado em cestos de palha e, posteriormente, arremessado em uma carroça puxada a burros.

Quanto aos resíduos das residências, as pessoas escravizadas foram por muitos anos, obrigadas a exercer a função de limpar esses ambientes, sendo, portanto, imprescindíveis para o entendimento da história da limpeza urbana no Rio de Janeiro, pois:

\begin{abstract}
A repugnante tarefa de carregar lixo e os dejetos da casa para as praças e praias era geralmente destinada ao único escravo da família ou ao de menor status ou valor. Todas as noites, depois das dez horas, os escravos conhecidos popularmente como "tigres" levavam tubos ou barris de excremento e lixo sobre a cabeça pelas ruas do Rio. Os prisioneiros realizavam esse serviço para as instituições públicas (Karasch, 2000, p. 266).
\end{abstract}

Os escravizados ficaram conhecidos como "tigres" porque a pele ficava listrada, com uma mistura de faixas negras e descoloridas, devido à ação química dos excrementos que caiam sobre eles, pois os tonéis, geralmente eram feitos de madeira e:

\begin{abstract}
Os tampos inferiores na parte onde se firma a cabeça, com a infiltração constante da umidade, não raro, apodrecem, enfraquecendo a sua natural resistência. Um belo dia - catrapuz - a tábua carcomida desloca-se, parte-se e a extremidade circular do barril vem como um colar sobre o pescoço do negro. Esse desastre, que provoca sempre a alegria e o clamor dos outros negros, é comuníssimo até pelas ruas mais centrais, de maior trânsito, passagem obrigatória desses indesejáveis recipientes, afetando a forma estética de vaso grego; ânfora, porém, onde se não guardam perfumes (Edmundo, 200, p. 59).
\end{abstract}

Encontramos registros que dizem que "à noite, por brincadeira ou vingança, os "tigres" esbarravam de propósito nos passantes desavisados, fazendo respingar sobre eles a carga malcheirosa, deixando todos sujos e apavorados" (Bastos, 2014, p. 10).

As regiões urbanas do litoral brasileiro encontravam muita dificuldade para enterrar os dejetos domésticos e o lixo, nos terrenos pertencentes as suas residências ou nas proximidades, pois como as regiões geralmente eram pantanosas e apresentava muita umidade, uma vez que o lençol freático era muito alto, impedia que isso fosse posto em prática:

A impossibilidade de abrir fossas num terreno em que a água se encontra a dezoito polegadas de profundidade impede o uso de latrinas como em França; nenhuma tentativa deste gênero fora ainda feita por ocasião de minha partida. Ainda em 1852, comenta o vereador Dr. Thomas José Pinto: Um dos erros, que se 
tem cometido no sistema de despejos e limpeza desta cidade, é sem dúvida nenhuma querer-se por força que seja o mar receptáculo de todas as imundícies; estou intimamente convencido que este sistema tem concorrido e há de sempre concorrer para agravar o nosso mau estado sanitário (Eigenheer, 2009, p. 100).

Naquela época, quando as práticas de tratamento não existiam, o recolhimento e a destinação dos resíduos eram precários e muitos abusos eram cometidos. Quando a Corte Portuguesa chegou ao Rio de Janeiro, o Intendente Paulo Vianna baixou alguns editais buscando melhorar a situação, conforme sinalizado a seguir:

\begin{abstract}
Faço saber aos que este Edital virem ou dele tiverem notícia que sendo um dos cuidados da Polícia vigiar sobre o asseio da cidade não só para a comodidade de seus moradores, mas principalmente para conservar a salubridade [...] e impedir que se infeccione com as imundícies que das casas se deitam às ruas e constando aliás que muitos de seus moradores apartando-se culposamente do costume que nela sempre havia de mandarem deitar ao mar em tinas e vasilhas cobertas as águas imundas e outros despejos se facilitam impunemente a fazê-lo das janelas abaixo, os que nunca era de sua liberdade fazê-lo no centro de uma Corte que se está estabelecendo e que se procura elevar a maior perfeição [...] fica hoje em diante vedado por esta Intendência o abuso de se deitarem as ruas imundícies e todo aquele que for visto fazer os despejos [...] serão punidos em dez dias de prisão e com a pena pecuniária de dois mil réis para o Cofre da Polícia e todos os Oficiais e a mesma Intendência e da Justiça e qualquer do povo que der parte da infração e se verificar de plano e pela verdade sabida receberá a metade da condenação pecuniária (Eigenheer, 2009, p. 101).
\end{abstract}

A partir de meados do século XIX, na intenção de melhorar a situação, foi dado início ao ordenamento dessa prática e ficou estabelecido "horários para os tigres, locais determinados de despejo, barris fechados e carroças para o seu recolhimento" (Eigenheer, 2009, p. 101).

A Câmara Municipal também entrou no circuito e estabeleceu posturas em relação à limpeza da cidade, de forma a disciplinar a difícil situação em curso. No ano de 1854 o governo imperial passa a ser responsável pela limpeza da urbe, no entanto, quase nada mudou, não sendo percebidas transformações significativas.

O ano de 1864 foi marcante para a limpeza urbana do Rio de Janeiro, pois foi nesse período que ocorreu a implantação de um sistema de esgoto na cidade, por meio de uma companhia inglesa - a The Rio de Janeiro City Improvementes Company Limited, ainda que somente em uma parte da cidade. Apesar de não contemplar toda a região, representou um avanço significativo em relação à especialização na limpeza urbana, mais propriamente no tocante ao lixo. A execução desses serviços, 
[...] através ora da contratação de firmas particulares, ora com a organização de serviços públicos, esbarrava em inúmeros entraves técnicos, administrativos, financeiros e de costumes da população. Em 11/10/1876 contratou-se a firma de Aleixo Gary, que foi um marco importante para a limpeza urbana do Rio de Janeiro. Daí a designação até hoje de "gari" para alguns empregados da limpeza urbana. (Eigenheer, 2009, p. 102).

Outras novidades foram colocadas em prática, como a utilização de "canos especiais para coleta de lixo e irrigação das ruas, e até mesmo a instalação de quiosques urinários e latrinas" (Eigenheer, 2009, p. 102), porém:

[...] problemas perduraram, já que muitos serviços foram compartilhados com outras firmas. A empresa de Gary fica até 1891. Depois dela, os serviços de limpeza ficaram a cargo da Inspetoria de Limpeza Pública, que iniciou em 1895 a construção de um forno para queima de lixo em Manguinhos. A experiência fracassou (Eigenheer, 2009, p. 102).

Após esse novo fracasso, no ano de 1907 retoma-se a discussão acerca da incineração, o que perdura até a década de 1960, e atualmente a discussão por vezes entra em pauta, mas é uma prática combatida, principalmente pela organização dos catadores de materiais recicláveis, que justificam a extinção de postos de trabalho, caso seja uma prática adotada no Brasil.

Com os altos e baixos dos serviços prestado pelo setor público, recorre-se novamente às empresas particulares, que voltam a atuar em 1898. Todo esse contexto levou a criação da Superintendência de Limpeza Urbana, no ano de 1901, que só veio a ficar inteiramente organizada em 1904, no entanto, os serviços não melhoraram muito, e em 1940, criou-se a Diretoria de Limpeza Urbana (DLU), e, posteriormente, no ano de 1975, é fundada a Companhia de Limpeza Urbana - COMLURB, atuante até os dias de hoje na cidade do Rio de Janeiro.

No que diz respeito à destinação do lixo na cidade do Rio de Janeiro, Eigenheer (2009) aponta que a llha de Sapucaia foi utilizada para esses fins de 1865 até por volta de 1949, sendo transferido posteriormente para o aterro do Retiro Saudoso no bairro do Caju, do Amorim e de Cavalcanti - Marechal Hermes, mas na década de 1970 a ideia era promover a estruturação de um aterro sanitário e então:

[...] foi doada pelo INCRA à COMLURB, uma área de manguezal de 370.55 hectares, no fundo da Baía de Guanabara, município de Duque de Caxias, bairro Jardim Gramacho. A doação dessa área foi condicionada à implantação do Aterro Sanitário Metropolitano de Gramacho, para onde seriam levados todos os resíduos sólidos dos municípios da Região Metropolitana, a saber: Rio de Janeiro, Duque de Caxias, São João de Meriti, Nova Iguaçu, Nilópolis, Belford Roxo, Petrópolis e Guapimirim (Bastos, 2014, P. 11). 
Quando pensamos na geração de resíduos sólidos em nível nacional, no decorrer do século XX houve um aumento considerável e, consequentemente, sua disposição inadequada no meio ambiente. Assim, diante dos fatos, buscouse implementar inovações técnicas para o tratamento desse material. A cidade do Rio de Janeiro, como uma das principais cidades do país, acompanhou essa tendência, onde:

Inicialmente se buscou a alternativa da incineração e, posteriormente, das usinas de triagem e compostagem. Estas procuram aproveitar a parte orgânica para compostagem, e outra para reciclagem. Entretanto, após serem misturadas na fonte e no processo de coleta, fica difícil obter-se materiais de boa qualidade. Além disso, é grande a quantidade do refugo (Eigenheer, 2009, p. 102).

$\mathrm{Na}$ busca por melhor tratamento e disposição dos resíduos sólidos, implantou-se no Rio de Janeiro, por meio de recursos advindos do Programa de Despoluição da Baia de Guanabara - PDBG, uma Usina em Irajá em 1970, e em 1992, uma Usina no Caju, com infraestrutura e equipamentos. No entanto, essa experiência embora tenha sido difundida em todo o país, não obteve o êxito desejado, tanto no que diz respeito ao tratamento dos resíduos, como na absorção de mão de obra especializada geradora de emprego e renda como acontecia em outros países.

Os anos de 1980 também foram significativos para esse setor, pois nesse período foram dados os primeiros passos visando à diminuição dos resíduos sólidos que eram depositados diretamente no meio ambiente:

\begin{abstract}
A coleta seletiva foi implantada no Brasil a partir de 1985, inicialmente no bairro de São Francisco, Niterói. Foi uma iniciativa do Centro Comunitário de São Francisco (associação de moradores) e da Universidade Federal Fluminense. Em 1988, Curitiba se torna a primeira cidade a ter o sistema. [...] esta forma de coleta pressupõe a separação na fonte dos materiais que se deseja tratar (Eigenheer, 2009, p. 102).
\end{abstract}

Outro momento importante foi a Conferência das Nações Unidas sobre Meio Ambiente e Desenvolvimento, conhecida mundialmente como ECO-92, realizada no Rio de Janeiro no ano de 1992, pois dentre os documentos oriundos desse encontro, foi elaborada a "Agenda 21", que "indicava as bases para a despoluição do planeta e a construção de um modelo de desenvolvimento sustentável" (Bastos, 2014, p. 12), porém, pouco se avançou ao logo desses quase 30 anos.

Dando sequência aos compromissos ambientais que marcaram os dois séculos, mais uma vez ocorreu no Rio de Janeiro no ano de 2012, a Conferência 
das Nações Unidas sobre Desenvolvimento Sustentável, conhecida como Rio+20, para comemorar os vinte anos da primeira conferência no Brasil, quando participaram líderes dos 193 países membros da Organização das Nações Unidas. Porém, infelizmente, o resultado não foi o esperado, pois muitos impasses acerca da assunção de compromissos, sobretudo no tocante aos interesses dos países de primeiro mundo em detrimento aos de terceiro, frustraram as expectativas de êxito do evento no tocante as assinaturas de protocolos e tratados para diminuição dos efeitos do progresso no planeta.

Apresentada essa breve contextualização histórica, consideramos relevante expor dados referentes à geração e a destinação do lixo no Brasil, na atualidade, pois acreditamos que contribuirá para ampliarmos nossa visão sobre a temática e com isso redimensionarmos o olhar a respeito de que urge, que é a necessidade de ser colocado em prática o que preceitua a lei 12.305/2010, em termos de reduzir, reutilizar e reciclar os resíduos, pois, caso contrário, os prejuízos em termos de desastres ambientais serão incalculáveis.

Os resultados da Pesquisa Nacional por Amostragem de Domicílio de 2019, sobre o percentual de domicílios segundo o destino do lixo no Brasil, apontam que uma forma geral, há predominância da coleta direta realizada por serviço de limpeza urbana e,

[...] essa modalidade, além de ser a principal, vem, gradativamente, aumentando: 82,7\% em 2016, 82,9\% em 2017, 83,0\% em 2018 e em 2019 atinge seu maior valor, de $84,4 \%$. Secundariamente, havia a coleta feita em caçamba de serviço de limpeza $(7,0 \%)$, a queima do lixo na propriedade $(7,4 \%)$ e outro destino $(1,2 \%)$ (IBGE, 2019, p. 5).

$\mathrm{Na}$ figura que segue podemos observar estes percentuais tanto no Brasil como um todo, quanto em todas as regiões do país, individualmente. 
Figura 13 - Percentual de domicílios segundo o destino do lixo

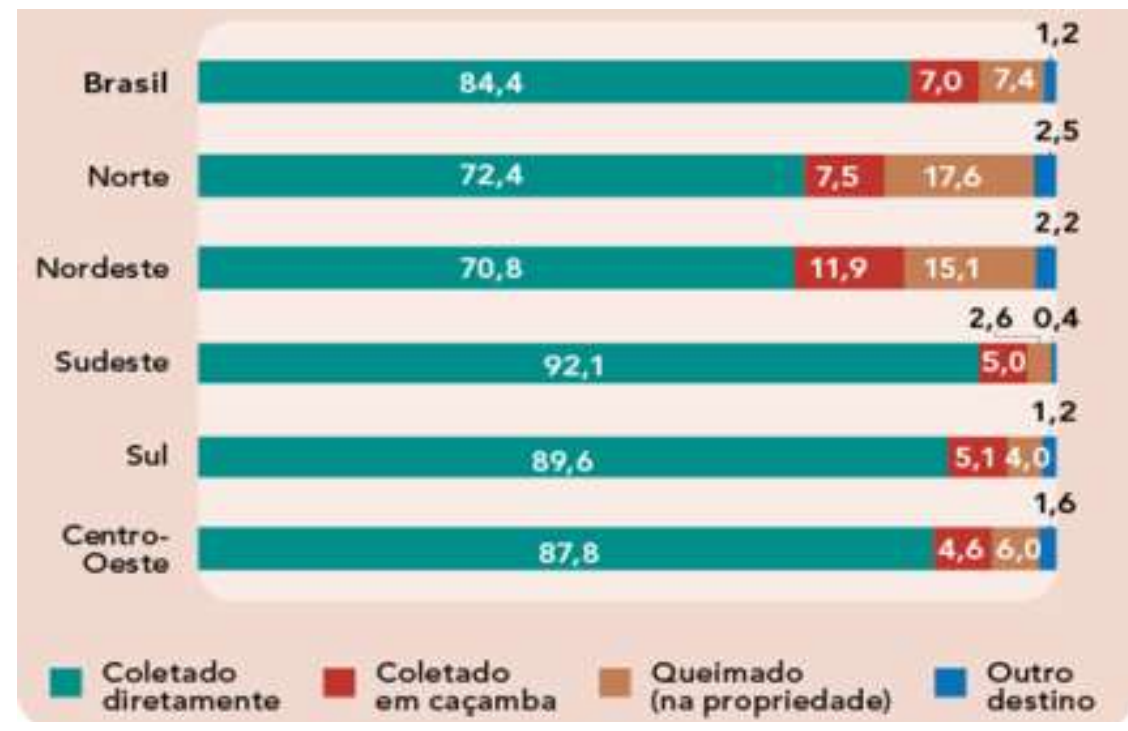

Fonte: IBGE, Diretoria de Pesquisas, Coordenação de Trabalho e Rendimento, PNAD Contínua 2019.

Este levantamento aponta ainda que entre 2018 e 2019 houve um crescimento na taxa de cobertura da coleta direta, chegando a 3,6\%, o que em termos absolutos, representa a inclusão de mais 2,1 milhões de unidades domiciliares que passaram a ser atendidas por este serviço. E em todas as regiões, identificou-se melhora em relação a essa modalidade de serviço:

\footnotetext{
Norte (de $70,8 \%$ para $72,4 \%$ ), Nordeste (de $69,6 \%$ para $70,8 \%$ ), Sudeste (de $91,1 \%$ para $92,1 \%$ ), Sul (de $87,3 \%$ para $89,6 \%$ ) e Centro-Oeste (de $85,7 \%$ para $87,8 \%$ ). Esse movimento foi acompanhado pela redução da participação da coleta em caçamba de serviço de limpeza nas regiões (IBGE, 2019, p. 5).
}

Se levado em consideração o percentual de domicílios, segundo o destino do lixo, a região Sudeste e Sul, sucessivamente, são as que contam com a maior cobertura de coleta direta, e são as que também apresentam, consequentemente, os menores percentuais de destinos alternativos de descarte de lixo, como queimar, enterrar ou até mesmo o descarte impróprio, como jogar em terreno baldio, por exemplo. Já as regiões Norte e Nordeste são as que apresentam os maiores percentuais de queima do lixo na propriedade e outros destinos, $20,1 \%$ e $17,3 \%$, respectivamente. Certamente um dos fatores que contribui para esse fato é a não realização da coleta direta em uma parcela dos domicílios.

No levantamento feito pela Associação Brasileira de Empresas de Limpeza Pública e Resíduos Especiais (ABRELPE) do período 2018/2019, realizada em 
todas as regiões do Brasil, sobre a geração de Resíduos Sólidos Urbanos (RSU), aponta que foram geradas no total, no ano de 2018 no Brasil, 79 milhões de toneladas, o que de acordo com os dados dessa instituição, representa um aumento de menos de $1 \%$ em relação ao ano anterior.

Do volume gerado, $92 \%$, ou seja, 72,7 milhões de toneladas foram coletadas, o que "significa uma alta de 1,66\% em comparação a 2017: ou seja, a coleta aumentou num ritmo um pouco maior que a geração. Por outro lado, evidencia que 6,3 milhões de toneladas de resíduos não foram recolhidas junto aos locais de geração" (ABRELPE, 2018/2019, p. 11).

Do montante coletado, cerca de 43,3 milhões de toneladas $(59,5 \%)$ foram destinadas para aterros sanitários e o remanescente, 29,5 milhões de toneladas $(40,5 \%)$, acabou tendo como destino os aterros controlados ou lixões, resíduo esse, oriundo de 3.001 municípios.

Diariamente, em 2018, foram geradas 216.629 mil toneladas de RSU, enquanto em 2017 houve uma geração de 214.868 mil toneladas por dia (aumento de $0,82 \%$ no intervalo de um ano); sendo que a geração per capita passou de 1,035 e 1,039 (aumento de 0,39\%) nesse mesmo período, conforme demostrado no gráfico que segue:

Figura 14 - Gráfico da geração total de RSU - 2017/2018

GERAÇÃO TOTAL

(toneladas/dia)

214.868216 .629

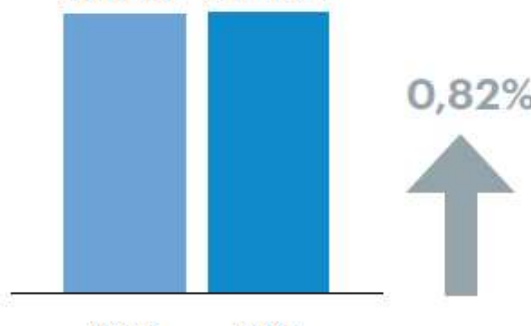

$2017 \quad 2018$
GERAÇÃO PER CAPITA

( $\mathrm{kg} / \mathrm{habitante} / \mathrm{dia})$

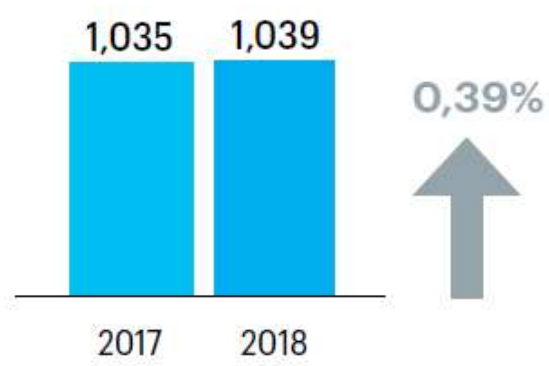

Fonte: ABRELPE, 2019.

Em 2018 foram coletadas 199.311 mil de toneladas de RSU/dia, o que indica que "o volume coletado cresceu mais que a geração [...]. Houve expansão em todas as regiões do Brasil, com exceção do Nordeste (a única em que a população encolheu entre 2017 e 2018, segundo as estimativas do IBGE)" (ABRELPE, 2018/2019, p. 12). 
Figura 15 - Gráfico da coleta de RSU - 2017/2018

COLETA TOTAL

(toneladas/dia)

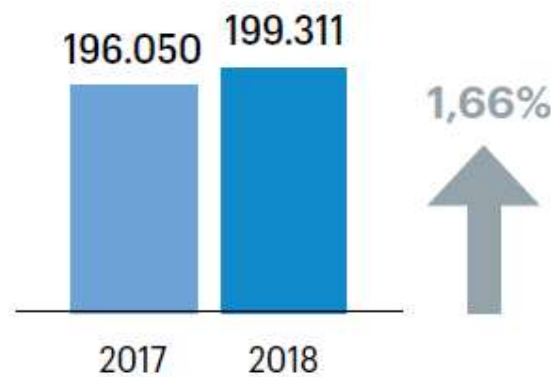

COLETA PER CAPITA

( $\mathrm{kg} /$ habitante/dia)

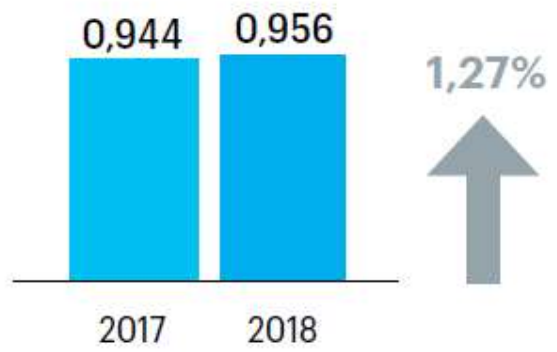

Fonte: ABRELPE, 2019.

Se comparada a quantidade de RSU produzida ( $216.629 \mathrm{t} / \mathrm{dia})$ e a coletada (199.311 t/dia) em 2018, chega-se à conclusão que durante esse período, 17.318 mil de toneladas (8\%) deixaram de ser coletadas diariamente no país e consequentemente foram destinadas de forma inadequada.

A seguir, pode ser observada, consecutivamente, a quantidade de RSU coletada nas cinco regiões e no Brasil de um modo geral (em números absolutos), a participação das regiões brasileiras no total de RSU coletado e o índice de cobertura da coleta RSU (os dois últimos em percentual), nos anos de 2017 e 2018.

Figura 16- Quantidade de RSU coletada nas regiões e no Brasil - 2017/2018

\begin{tabular}{|c|c|c|c|}
\hline \multirow{2}{*}{ Regiobes } & 2017 & \multirow{2}{*}{ Populaçäo 2018} & 2018 \\
\hline & $\begin{array}{l}\text { RSU Total } \\
\text { (tonelodre/dia) }\end{array}$ & & $\begin{array}{l}\text { RSU Total } \\
\text { (toneladas/dio) }\end{array}$ \\
\hline Norte & 12.705 & 18.182 .253 & 13.069 \\
\hline Nordeste & 43.871 & 56.760 .780 & 43.763 \\
\hline Centro-Oeste & 14.406 & 16.085 .885 & 14.941 \\
\hline Sudeste & 103.741 & 87.711 .946 & 105.977 \\
\hline Sul & 21.327 & 29.754 .036 & 21.561 \\
\hline BRASIL & 196.050 & 208.494 .900 & 199.311 \\
\hline
\end{tabular}

Fonte: ABRELPE, 2019. 
Figura 17- Participação das regiões no total de RSU coletado (em percentual) $2017 / 2018$

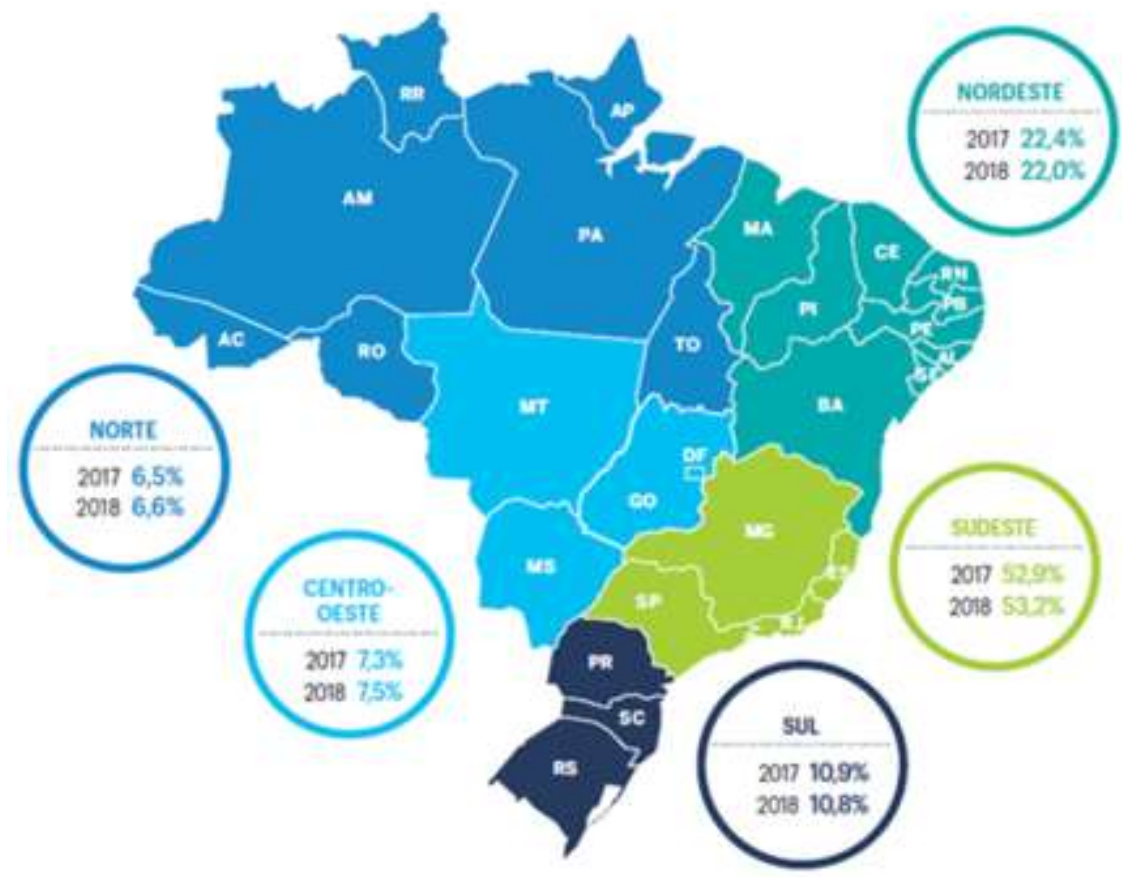

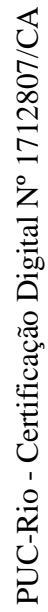

Fonte: ABRELPE, 2019.

Figura 18 - Índice de cobertura da coleta RSU (em percentual) - 2017/2018
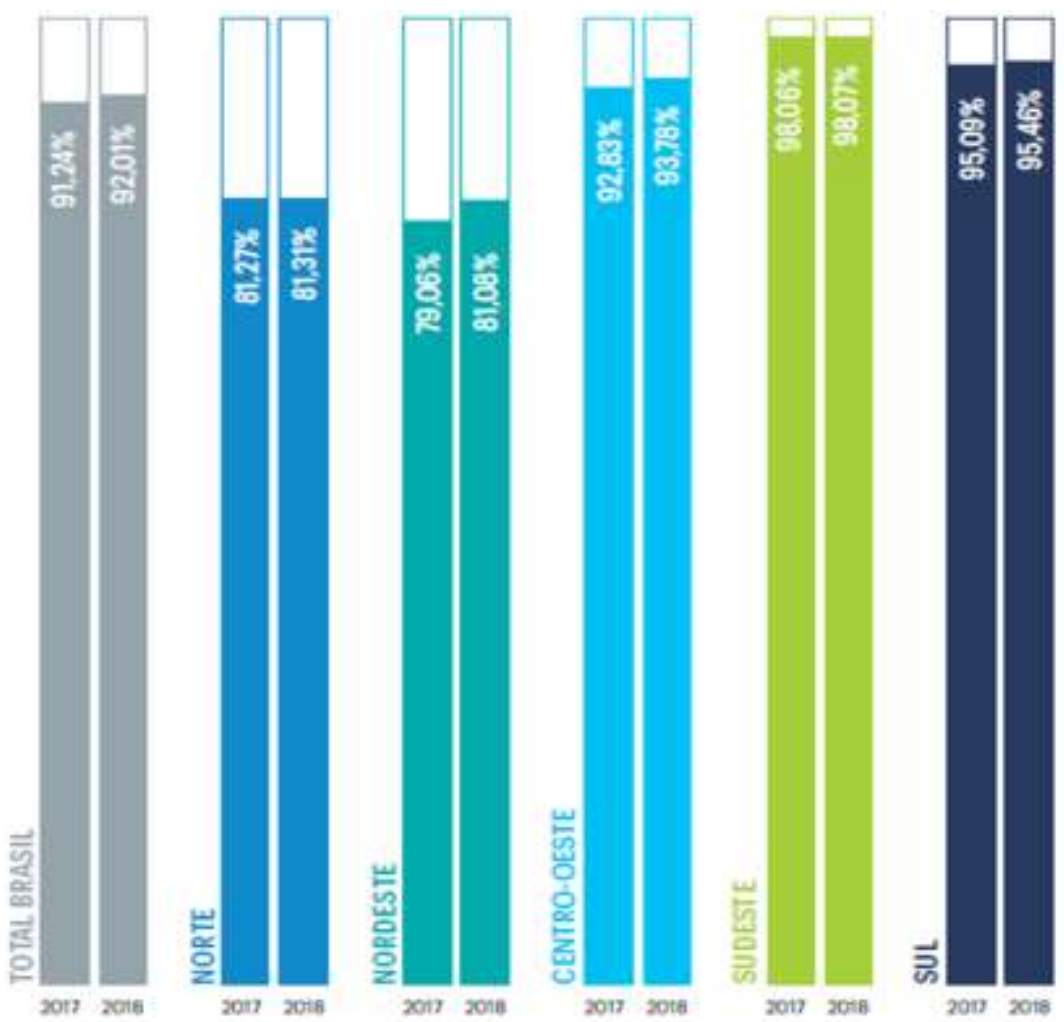

Fonte: ABRELPE, 2019. 
No tocante à situação do destino do RSU coletado, houve um pequeno aumento do volume que é levado para os aterros sanitários ${ }^{21}$ no Brasil, passando de $59,1 \%$ em 2017 , para $59,5 \%$ em 2018 . As formas de destinação mais danosas ao meio ambiente, como lixões e aterros controlados ${ }^{22}$, ainda persistem em todas as regiões do país, recebendo em 2018, 80.680 mil toneladas de resíduos por dia, o que gera grandes impactos socioambientais.

Vejamos a seguir, gráficos que trazem, nessa sequência, dados sobre a disposição final de RSU no Brasil por tipo de destinação (t/dia), a disposição final dos RSU coletados no Brasil (t/ano) e a quantidade de municípios por tipo de disposição final adotada:

Figura 19 - Disposição final de RSU no Brasil por tipo de destinação (t/dia) - 2017/2018
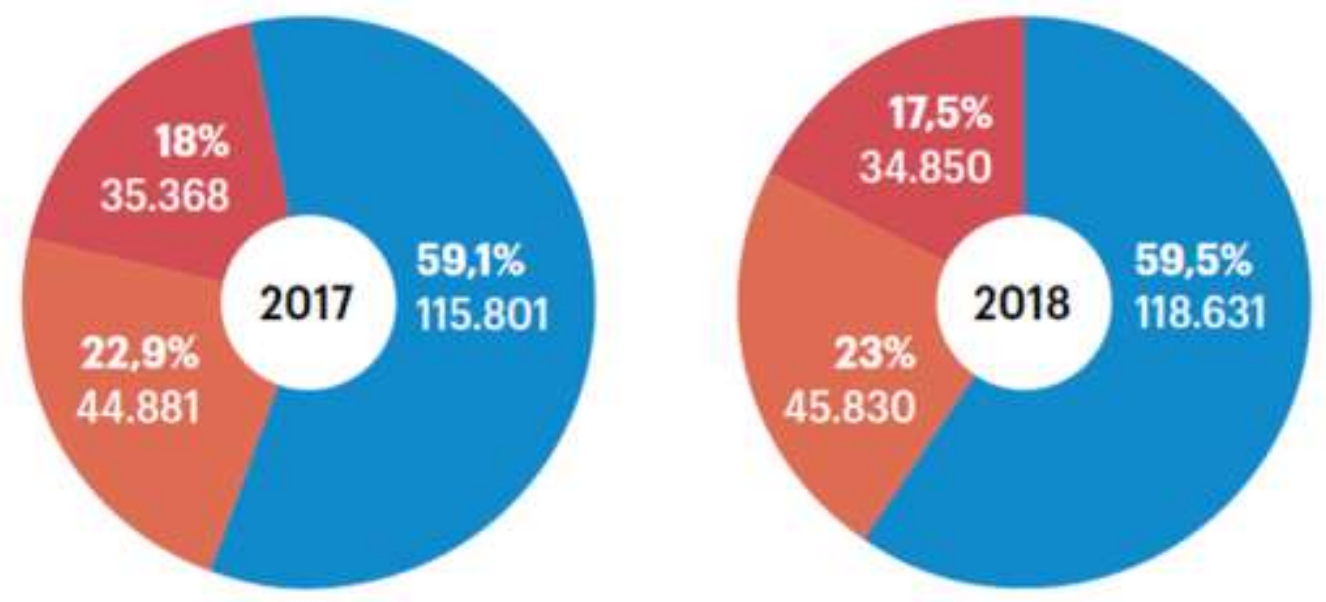

Aterro sanitário

Fonte: ABRELPE, 2019.

\footnotetext{
${ }^{21}$ Local onde o "solo é preparado antes da disposição dos resíduos sólidos com uma camada de argila ou coberto com mantas poliméricas (sintéticas) para impermeabilização. Deste modo, o chorume é drenado e conduzido a uma estação de tratamento de efluentes. Os gases produzidos (especialmente metano e sulfídrico) são coletados em extravasores e, posteriormente, queimados ou utilizados como combustível no próprio aterro. No aterro sanitário, os compartimentos para disposição dos resíduos sólidos são dimensionados de tal forma que devem ser preenchidos em períodos específicos. Os resíduos sólidos depositados são compactados com um trator e recobertos diariamente com cerca de $20 \mathrm{~cm}$ de solo, para não produzir maus odores e não atrair insetos, roedores e aves" (Santaella et al., 2014, p. 26).

22 Técnica inadequada de disposição final de resíduos sólidos, que oferece riscos à saúde pública e ao meio ambiente, em que os resíduos são dispostos no solo, sem impermeabilização prévia, em depressões ou escavações e são recobertos com camadas de solo. Além da falta de impermeabilização, no aterro controlado não há extravasores para gases gerados, nem captação do chorume produzido (Santaella et al., 2014, p. 26).
} 
Figura 20 - Disposição final dos RSU coletados no Brasil (t/ano) - 2017/2018

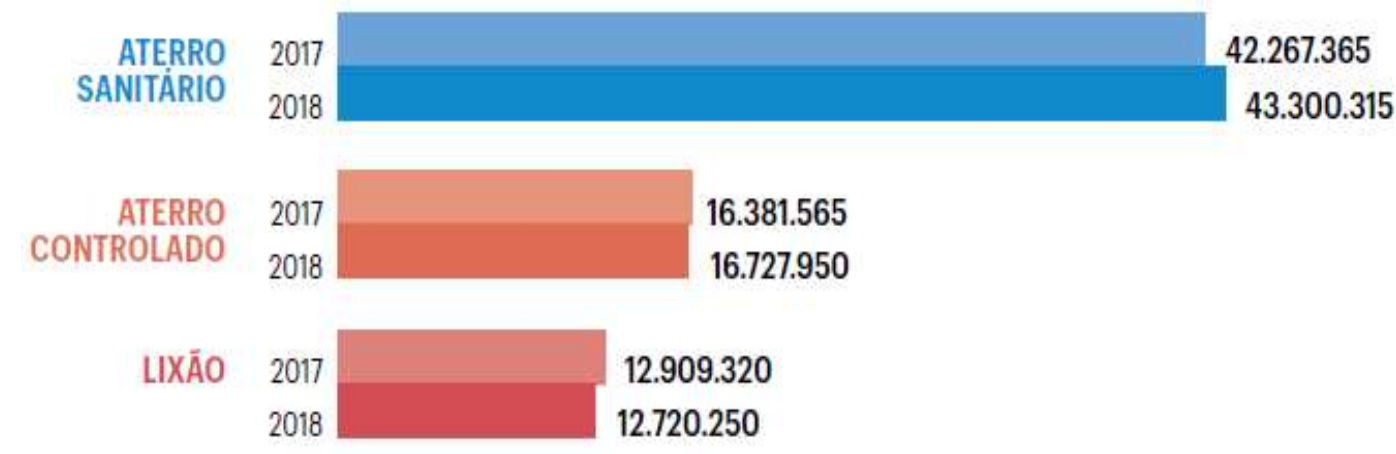

Fonte: ABRELPE, 2019.

Figura 21- Quadro indicando o total de municípios, por tipo de disposição final adotada $2017 / 2018$

\begin{tabular}{|c|c|c|c|c|c|c|c|}
\hline \multirow{2}{*}{$\begin{array}{l}\text { Disposictolo } \\
\text { Final }\end{array}$} & \multirow{2}{*}{$\begin{array}{l}\text { Brast } \\
2017\end{array}$} & \multicolumn{6}{|c|}{ Regloes e Brasil - 2018} \\
\hline & & Norte & Nordeste & Contro- & Sudesto & sul & Brasll \\
\hline $\begin{array}{l}\text { Aterro } \\
\text { Sanitárlo }\end{array}$ & 2.218 & 93 & 454 & 162 & 820 & 1.040 & 2.569 \\
\hline $\begin{array}{l}\text { Aterro } \\
\text { Controlado }\end{array}$ & 1.742 & 110 & 496 & 152 & 641 & 109 & 1.508 \\
\hline Luxâo & 1.610 & 247 & 844 & 153 & 207 & 42 & 1.493 \\
\hline BRASIL & 5.570 & 450 & 1.794 & 467 & 1.668 & 1.191 & 5.570 \\
\hline
\end{tabular}

Fonte: ABRELPE, 2019.

Concernente às iniciativas ligadas à coleta seletiva no ano de 2018, 4.070 municípios brasileiros desempenharam alguma iniciativa, porém em muitos desses, essas ações não contemplaram toda a área urbana. A região sudeste foi a que apresentou o maior número de municípios que contaram com atividades de coleta seletiva. Nota-se um ligeiro crescimento do número de munícipios que passaram a ter acesso a esse serviço, de um ano para o outro, o que pode ser apreciado nas imagens abaixo - a quantidade de municípios com ou sem iniciativas de coleta seletiva por região e a distribuição dos municípios com alguma atividade voltada para esse serviço, nos anos de 2017 e 2018: 
Figura 22 - Quantidade de municípios com ou sem iniciativas de coleta seletiva $2017 / 2018$

\begin{tabular}{|c|c|c|c|c|c|c|c|c|c|c|c|c|}
\hline \multirow{2}{*}{ Regiōes } & \multicolumn{2}{|c|}{ Norte } & \multicolumn{2}{|c|}{ Nordeste } & \multicolumn{2}{|c|}{ Centro-Oeste } & \multicolumn{2}{|c|}{ Sudeste } & \multicolumn{2}{|c|}{ Sul } & \multicolumn{2}{|c|}{ Brasil } \\
\hline & 2017 & 2018 & 2017 & 2018 & 2017 & 2018 & 2017 & 2018 & 2017 & 2018 & 2017 & 2018 \\
\hline Sim & 270 & 286 & 902 & 978 & 209 & 227 & 1.464 & 1.496 & 1.078 & 1.083 & 3.923 & 4.070 \\
\hline Não & 180 & 164 & 892 & 816 & 258 & 240 & 204 & 172 & 113 & 108 & 1.647 & 1.500 \\
\hline Iotal & & \multicolumn{2}{|c|}{1.794} & \multicolumn{2}{|c|}{467} & \multicolumn{2}{|c|}{1.668} & \multicolumn{2}{|c|}{1.191} & \multicolumn{2}{|c|}{5.570} \\
\hline
\end{tabular}

Fonte: ABRELPE, 2019.

Figura 23 - Distribuição dos municípios com ou sem iniciativas de coleta seletiva (\%)

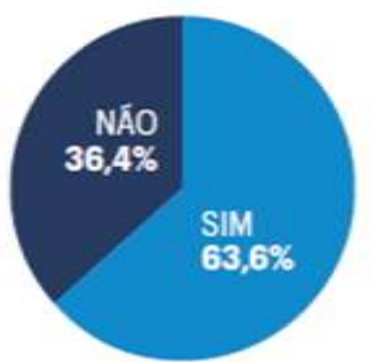

NORTE

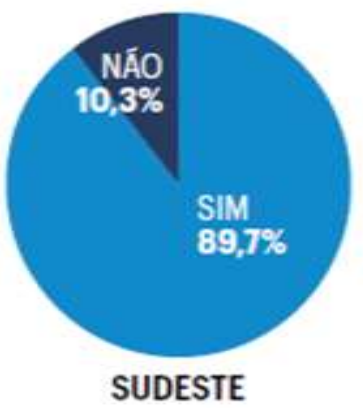

Fonte: ABRELPE, 2019.

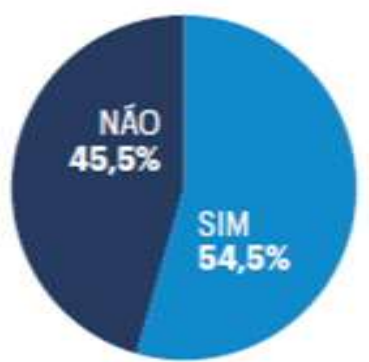

NORDESTE

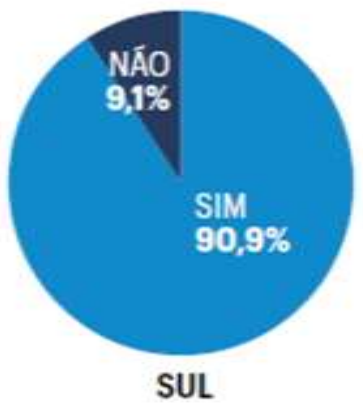

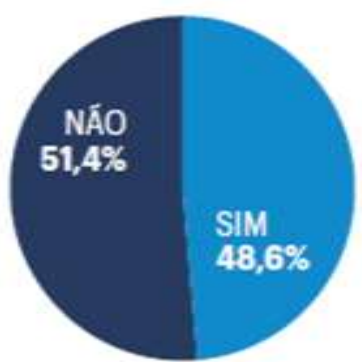

CENTRO-OESTE

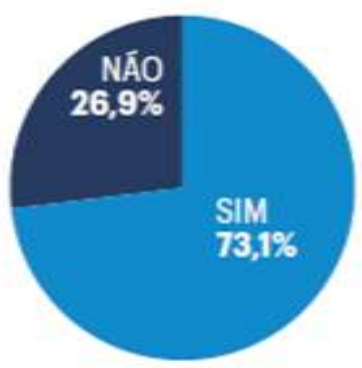

BRASIL

Em 2018 no Brasil aplicou-se em média R\$ 10,15 por habitante/mês referente a todos os serviços de limpeza urbana: varrição, limpeza, capina, manutenção de parques e jardins, limpeza de córregos, despesas com a destinação final dos RSU, entre outros. Houve uma redução de 0,16 nos recursos destinados aos demais serviços de limpeza urbana, não considerando aqui, os valores referentes ao serviço de coleta, isso quando comparados ao ano anterior. Podem ser apreciadas abaixo, duas tabelas, sendo que uma expõe os recursos aplicados na coleta de RSU - que também apresenta uma queda de 114 mil em relação aos recursos aplicados entre 2017 e 2018, enquanto o outro traz dados sobre os recursos aplicados nos demais serviços de limpeza urbana: 
Figura 24 - Recursos aplicados na coleta de RSU - 2017/2018

\begin{tabular}{|c|c|c|c|c|}
\hline \multirow{2}{*}{ Reglós } & \multicolumn{2}{|c|}{2017} & \multicolumn{2}{|c|}{2018} \\
\hline & $\begin{array}{c}\text { Total } \\
\text { (R5s milhows/no) }\end{array}$ & $\begin{array}{c}\text { Por habitante: } \\
\text { (Rs/mes) }\end{array}$ & $\begin{array}{c}\text { Total } \\
\text { (P6) milhises/ano) }\end{array}$ & $\begin{array}{l}\text { Por habltunte } \\
\text { (Fot/meat) }\end{array}$ \\
\hline Norte & 697 & 3,24 & 707 & 3,24 \\
\hline Nordeste & 2.163 & 3,15 & 2.139 & 3,14 \\
\hline Centro-Oeste & 597 & 3,13 & 604 & 3,13 \\
\hline Sudeste & 5.343 & 5,12 & 5.263 & 5,00 \\
\hline Sul & 1.345 & 3,78 & 1.318 & 3,69 \\
\hline BRASIL. & 10.145 & 4,07 & 10.031 & 4,01 \\
\hline
\end{tabular}

Fonte: ABRELPE, 2019.

Figura 25 - Recursos aplicados nos demais serviços de limpeza urbana - 2017/2018

\begin{tabular}{|c|c|c|c|c|}
\hline \multirow{2}{*}{ Regibes } & \multicolumn{2}{|c|}{2017} & \multicolumn{2}{|c|}{2018} \\
\hline & $\begin{array}{c}\text { Total } \\
\text { (Rt mithes/aro) }\end{array}$ & $\begin{array}{c}\text { Por habltante } \\
\text { (RS/mis) }\end{array}$ & $\begin{array}{l}\text { Total } \\
\text { (Rs minhesano) }\end{array}$ & $\begin{array}{c}\text { Por habitante } \\
\text { (Mathes) }\end{array}$ \\
\hline Norte & 1.062 & 4,93 & 1.073 & 4,92 \\
\hline Nordeste & 3.788 & 5,51 & 3.664 & 5,38 \\
\hline Centro-Oeste & 622 & 3,26 & 635 & 3,29 \\
\hline Sudeste & 8.668 & 8,31 & 8.452 & 8.03 \\
\hline Sul & 1.571 & 4,42 & 1.546 & 4,33 \\
\hline BRASIL & 15.711 & 6,30 & 15.370 & 6,14 \\
\hline
\end{tabular}

Fonte: ABRELPE, 2019.

Conforme pode ser observado nas informações acima, no que diz respeito à aplicação de recursos tanto para a coleta de RSU quanto dos demais serviços de limpeza urbana, foi na região sudeste, seguida da região nordeste, onde se empregou o maior volume de recursos (em reais) para a prestação desses serviços. $E$ as regiões centro-oeste e norte foram as que empregaram o menor valor (em reais).

Notamos, portanto, que avanços ocorreram em relação ao tratamento e a destinação dos resíduos sólidos no Brasil, embora haja um longo caminho a ser percorrido, na direção da efetivação do preceituado na Política Nacional de Resíduos Sólidos.

$\mathrm{Na}$ sequência apresentamos dados sobre o panorama da gestão dos resíduos sólidos no contexto colombiano.

Em relação à história da limpeza urbana na Colômbia, não encontramos muitos elementos que nos respaldassem historicamente, porém trazemos alguns dados contidos no trabalho de conclusão de curso de Dias \& Palacios (2017), 
que discorrem sobre a evolução do serviço de limpeza urbana em Bogotá capital deste país. O estudo enfoca que do período colonial até o século XVIII, os resíduos eram destinados nas áreas comuns e nos afluentes que passavam na cidade ou nas proximidades, sem tratamento. A limpeza das ruas ficava a cargo das chuvas torrenciais, que quando caíam, arrastavam o material depositado nessas áreas pela população, deixando-as momentaneamente limpas.

Esse modo de descarte, logo fez com que enfermidades surgissem, afetando o então já precário sistema de saúde, o que levou a cidade a lançar mão da:

[...] solución clásica del urbanismo español, que consistía en empedrar las calles para formar un declive y así canalizar hasta el zanjón que a manera de alcantarilla conducía los desechos a los ríos que rodeaban la ciudad. Lo que evitó formar un pantano vertiginoso entre las basuras y el lodo formado por el agua y el suelo no pavimentado de la época. Sin embargo, tan sólo a finales del siglo XVIII Bogotá extendió medianamente el empedrado a las calles "principales"; a causa de que sus arcas económicas estaban en quiebra (Dias \& Palacios, 2017, p. 37-38).

A junção do crescimento urbano acelerado conjugado com o restrito desenvolvimento da infraestrutura, no que diz respeito aos serviços públicos, trouxe sérios problemas, como fortes odores e atração de vetores, devido à quantidade de lixo que ia parar nos afluentes, sendo, portanto, o século XVIII, uma verdadeira catástrofe no que concerne a limpeza urbana nesse país.

As correntes de pensamento vindas da Europa no século XIX, após a independência da Colômbia, contribuíram para avanços significativos no país, deixando de ser uma monarquia e passando a ser um estado republicano democrático. A partir daí, esforços para melhorar os serviços públicos foram empreendidos, porém, no que concerne a limpeza urbana, a questão da coleta de lixo ainda preocupava, então como forma de melhorar o serviço, viu-se como solução o investimento de capital privado e são tomadas as seguintes medidas:

1831: Mediante acto normativo municipal, se dictamina que por cada manzana, que componía la ciudad habría un celador cuyas funciones era cuidar del orden, aseo y tranquilidad pública.1842: Se organiza sistemáticamente el servicio de aseo en conjunto con el servicio de cementerios, no funcionando y posteriormente son separados (Dias \& Palacios, 2017, p. 39).

A agudização da epidemia de cólera em 1849, que teve graves consequências para a população colombiana, levou a realização de campanhas de limpeza do lixo acumulado e ações visando sensibilizar a população, fazendo-a responsável pela limpeza das áreas junto às suas casas. 
Em 1856, para a limpeza das ruas e retirada do lixo acumulado nos rios de Bogotá, são designados 30 presidiários para execução da atividade de limpeza, conforme abaixo enfocado:

El 6 de Agosto el Cabildo acordó que los reclusos serian adaptados para la recolección de las basuras mediante carretillas, que pudieran ser manejadas cada una por dos hombres y determinó, que "el conductor de la carretilla tocará en cada casa, tienda u otro edificio habitado, a efecto de recibir la basura" (Moreno). De esta manera se abarcó una cobertura del $100 \%$ de los barrios legalmente constituidos a excepción de las expansiones urbanas que aún no estaban a cobijadas por estos actos (Dias \& Palacios, 2017, p. 40).

Mas surgiram muitas reclamações, alegando que a limpeza não estava sendo realizada a contento, uma vez que a população não cumpria as normas e continuava jogando lixo na rua, tanto restos de obras quanto os demais resíduos, o que se tornou fonte de proliferação de vetores e de odores. Fator que novamente necessitou de revisão e, a partir de 1872, novas mudanças ocorreram:

1872: Fue nombrado un Inspector de Policía por los barrios de Bogotá, que tenía las funciones de recolector de las basuras para ser transportarlas a los tres botaderos destinados en: San Diego, San Victorino y las Cruces (Rodríguez Gómez, 2000). 1877: Por el Acuerdo 22 de 1887, se organiza la policía de la ciudad y mediante sus disposiciones generales estableció un cuerpo cívico de policía encargado de velar por el aseo, ornato y salubridad de la ciudad. 1884: El servicio de recolección privado de basuras, comenzó en este año con la contratación de los empresarios Teófilo Soto y Manuel Moreno, mediante la opción de contratistas con 15 carros halados por mulas y bueyes, cobrando $\$ 1.800$ al mes por efectuar la recolección y transporte de los residuos a la disposición final de la época (Dias \& Palacios, 2017, p. 40-41).

O imposto pago pela taxa de limpeza à época ficou em torno de $\$ 2,22$ para cada pessoa, porém esse valor não incluía a varrição das ruas, pois não fazia parte do contrato que o Conselho Municipal havia firmado. Essa atividade era de responsabilidade da população, sendo fiscalizada pela polícia da cidade. Quatro anos depois, os contratados para a realização da limpeza, desistiram devido ao fato do imposto pago não gerar lucros. Os grupos responsáveis por tratarem da questão da limpeza urbana na cidade, as "juntas públicas", generalizaram as soluções para o problema, o que teve como consequência, conforme apontam Dias e Palacios (2017):

Una pérdida de cobertura y continuidad del servicio por errores administrativos y se descentralizara el servicio mediante la asignación a terceros y no directamente al Municipio. A lo anterior se le suma el crecimiento poblacional desmedido proveniente del desplazamiento forzado causado por las guerras civiles e innumerables revueltas, que transcurren en ese siglo trayendo consigo 
necesidades sanitarias en la ciudad, que para la época no estaba en capacidad de suplir las necesidades surgidas (Dias \& Palacios, 2017, p. 42).

No século $X X$, ainda que por certo tempo, a administração do serviço de limpeza saiu da gestão do Conselho Municipal e passou para o Governo Nacional. Retornando novamente para o nível municipal, devido às inúmeras reclamações voltadas para a então administração em nível nacional, pois:

La Junta encargada del servicio no daba abasto con la recolección y transporte de los residuos, que aumentaba conforme al crecimiento poblacional. Por lo que no fue contemplado el barrido de calles, la expansión urbana y actos administrativos, que restringiera hábitos de desaseo por parte de los ciudadanos (Multas, comparendos, campañas de sensibilización) (Dias \& Palacios, 2017, p. 42).

Mudanças neste setor continuaram acontecendo ao longo deste século e dentre outros acontecimentos na limpeza urbana, houve a criação de "una empresa autónoma encargada de la prestación del servicio de aseo de carácter público (EDIS) (Dias \& Palacios, 2017, p. 43). A seguir podemos observar alguns feitos importantes, ocorridos no século XX, nesse setor:

Quadro 4 - Acontecimentos na limpeza urbana de Bogotá

ANO

1926

1929

1936

1940

\section{ACONTECIMENTOS}

Hubo un cambio circunstancial en el medio de transporte de las basuras, dado que el Concejo Municipal de la ciudad autorizó la compra de los primeros camiones recolectores. Lo cual permitió poner en marcha el primer incinerador de basuras, al pasar de medios arcaicos a medios modernos de transporte de modo que minimizo el riesgo sanitario y aumento la seguridad y salud de los operarios; lo que evitó la exposición a los residuos recolectados y transportados al lugar de disposición final.

El Concejo Municipal autorizó a la Junta Administradora de Aseo, adquirir lotes para instalar hornos crematorios y reubicar botaderos de basura cercanos a éstos como estaciones de transferencia provisionales.

Se hizo explícita la relación entre basura, higiene y sanidad, por lo que la Administración de Higiene debió asumir la labor de limpieza de la ciudad y de administración de los hornos crematorios.

Se optó por la construcción de los Hornos Crematorios como solución definitiva para la ciudad. Sin embargo en 1943 los hornos se cerraron y volvieron a los botaderos debido a que el mantenimiento era excesivamente caro y el presupuesto municipal 


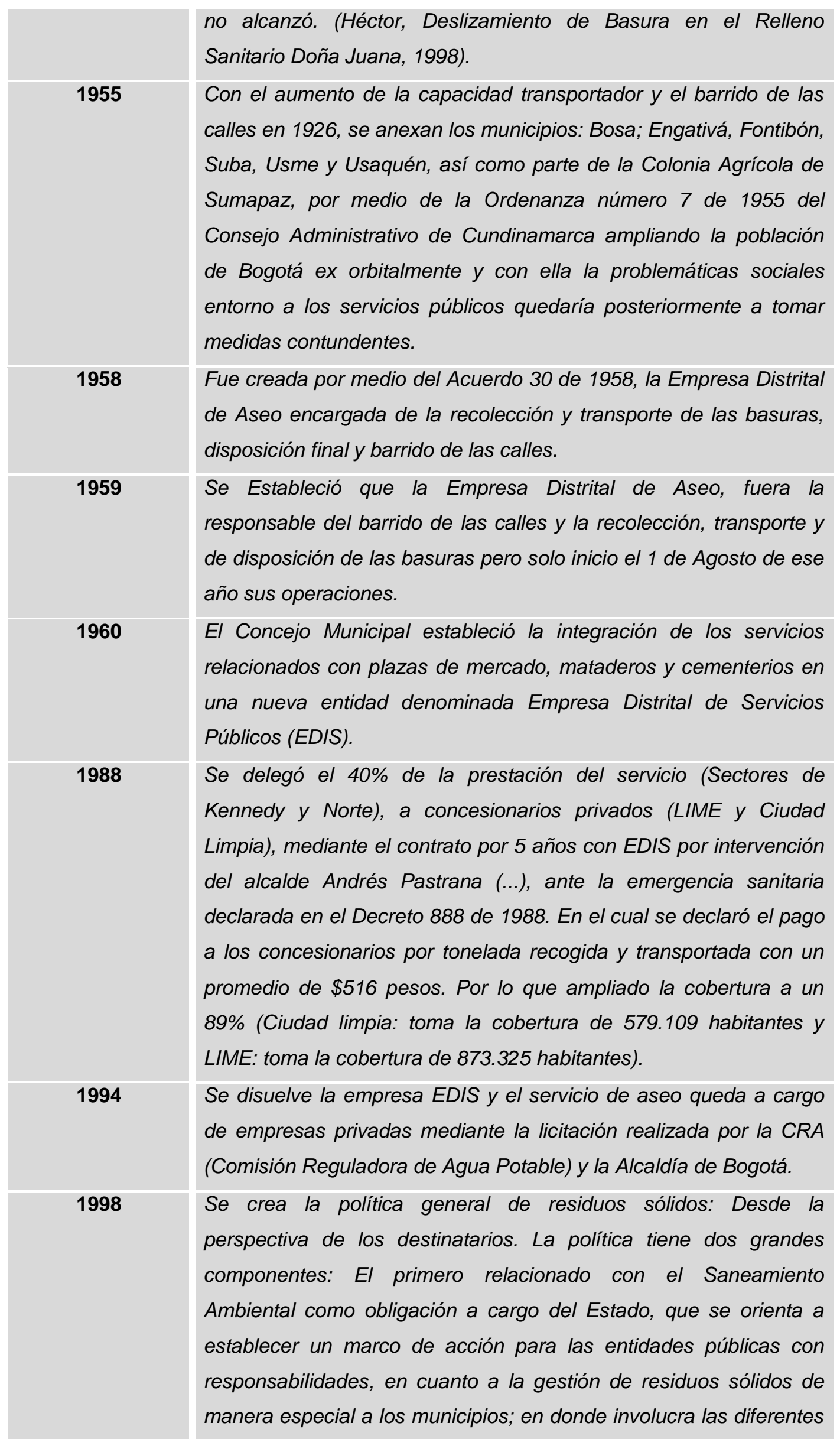


estrategias e instrumentos para fortalecer la acción del Estado en esta materia. El segundo referido a la vinculación que el sector privado tiene en cuanto a la generación de residuos.

Fonte: Dias \& Palacios, 2017.

Portanto, observa-se a partir da breve contextualização histórica acima, que na Colômbia, a preocupação com os resíduos sólidos surge nos centros urbanos a partir de demandas relacionadas às questões higiênicas e sanitárias, pois o fato de a população, inicialmente depositar os resíduos gerados em via pública, para dali serem levados pela chuva e, posteriormente por alguém, consistia em um problema, gerando a necessidade do estabelecimento do serviço público. À época não havia qualquer preocupação com o destino dado aos resíduos, cujos métodos de disposição final eram ao ar livre ou em corpos de água, o que segundo estudiosos, geraram uma cultura da disposição sem o devido controle. E segundo informações contidas na Política para la Gestión Integral de Residuos de 1998:

El primer intento por conocer la situación de los residuos sólidos en el país, lo efectuó el Ministerio de Salud, Dirección de Seneamiento Ambiental, en el año de 1975, la información que se obtuvo sirvió de base para formular el Programa Nacional de Aseo Urbano, "Prenasu". El diagnóstico identificó como problemas; bajos niveles de coberturas, uso de equipos inadecuados, ausencia de servicio de aseo en centros urbanos menores y zonas periféricas, cobro del servicio como impuesto y no como tarifa, entre otros; se destacó que ni un solo centro urbano utilizaba un proceso de disposición final controlado, pero sí tenían presencia importante las actividades de recuperación de papel, cartón, vidrio como envase, chatarra y hueso, entre los elementos de mayor mercado (Colombia, 1998, p. 9).

Após esse primeiro movimento para conhecer a situação dos resíduos sólidos na Colômbia, outros estudos também foram realizados, dentre os quais:

1) Contaminación Industrial en Colombia "editado en 1994, en su artículo "EL Estado del Ambiente en Colombia" realizado por Ernesto Sánchez y Carlos Herrera. La información fue procesada en 1992. 2) "Bases Técnicas para el Plan del Sector de Agua Potable y Saneamiento Básico" del Ministerio de Desarrollo, realizado en 1995. 3) Análisis Sectorial de Residuos Sólidos en Colombia (OPS, 1995), documento liderado por el Ministerio del Medio Ambiente y que contó con el apoyo de la OPS/OMS y el Banco Mundial, y en el cual se encuentra de manera detallada una presentación de la problematica y manejo de los residuos sólidos por municipios y regiones (Colombia, 1998, p. 9).

Neste último estudo foram atribuídos aos problemas ambientais ocasionados pelos resíduos sólidos, os seguintes aspectos: geração crescente dos resíduos e deficiências no tocante ao aproveitamento e valorização desses, práticas inadequadas em relação à disposição final dos resíduos, manejo dos 
resíduos sólidos ligados especificamente à prestação do serviço de limpeza urbana, baixo desenvolvimento institucional do setor, falta de conhecimento sobre a dimensão do problema e a falta de educação e participação cidadã no manejo ambiental desse material.

Anterior ao levantamento de dados realizado pelo Ministerio de Salud, Dirección de Seneamiento Ambiental, citado acima, identificamos que em 1974 na Colômbia, foi expedido o Decreto Lei 2811, chamado de Código de los Recursos Naturales, abrindo caminhos para novos progressos, ainda que no plano legal e atualmente há um ordenamento legislativo complexo pautado em uma política voltada para a gestão dos resíduos sólidos em nível nacional, conforme trecho a seguir, retirado do Diagnóstico Nacional de Salud Ambiental do Ministerio de Ambiente y Desarrollo Sostenible (2012), onde está posto que:

Colombia ha logrado estructurar, por lo menos en el plano legal, todos y cada uno de los objetivos trazados en el Capítulo 21 del PROGRAMA 21 de la Conferencia de las Naciones Unidas sobre Medio Ambiente y Desarrollo de 1992 (CNUMAD, 1997), en tópicos relevantes como la minimización de residuos, maximización del reuso y reciclaje bajo parámetros ambientales aceptables, promoción del tratamiento y disposición ambientalmente apropiado de los residuos y la expansión de la cobertura del servicio (Colombia, 2012).

No que concerne aos resíduos sólidos gerados nas residências, no ano de 2004 o Senado da República da Colômbia começou a manifestar interesse pela situação crítica vivenciada no país, pois em 1994 já eram produzidas cerca de 14.000 toneladas de resíduos por dia e a situação só ficou mais preocupante com o passar dos anos. Em 2004, esse volume passou para mais de 22.000 toneladas e em 2008 chegou a 28,8 mil toneladas, alcançando as 30.973 toneladas diárias de resíduos sólidos gerados no país em 2018, segundo dados do Informe de Disposición Final de Residuos Sólidos - 2018, com participação mais expressiva das seguintes cidades, neste último ano: Bogotá, Medellín, Cali, Barranquilla, Cartagena, Cúcuta, Soacha e Soledad.

De acordo com matéria do jornal Portafolio, de novembro de $2018^{23}$, das cerca de 12 milhões de toneladas de resíduos geradas no ano, somente $17 \%$ aproximadamente foram reciclados.

O Informe de Disposición Final de Residuos Sólidos de 2018 aponta que, considerando os resíduos descartados nas oito cidades acima descritas, sendo as mais populosas do país de acordo com o censo DANE 2018 e tomando como base a média do histórico de toneladas produzidas por dia entre 2010 e 2018,

23 Disponível em: <https://www.portafolio.co/economia/colombia-solo-recicla-el-17-de-las12-millones-de-toneladas-de-residuos-solidos-523236>. Acesso em: 05 jan. 2021. 
nota-se que houve um aumento de aproximadamente $26,13 \%$ nesse intervalo de tempo, sendo que quando analisado esse aumento de forma individual, ou seja, a cada ano, ao longo desse período, essa taxa fica em torno de $3 \%$.

Mesmo depois da implementação da política nacional de gestão integral de resíduos sólidos no ano de 2016, somada a incorporação da atividade de aproveitamento dos resíduos recicláveis, como parte do serviço público de limpeza urbana, nota-se que de 2016 para 2017, houve um aumento de 7,35\% no volume descartado. Atribui-se a não diminuição desse montante, em relação aos números, ao fato de a atividade de catação já existir de modo informal anteriormente. No entanto, quando analisado o período de 2017 para 2018, mesmo tendo havido um aumento em relação ao descarte de resíduos, observase que essa variação foi pouco expressiva, sendo somente de $0,37 \%$, o que pode estar relacionada com a melhora no tocante a separação na fonte, alcançada pelo incentivo de políticas públicas, bem como pelo crescimento do setor de reciclagem.

Segundo o documento supracitado, a zona que mais contribuiu para a geração de resíduos foi a andina, e as que menos produziram esse material foram as do sudeste colombiano, o que está certamente relacionado com o tamanho da população de cada uma dessas áreas.

Na Colômbia a disposição final de cerca de $52 \%$ dos resíduos sólidos do país é realizada no Distrito Capital e para outros três departamentos (Valle del Cauca, Atlántico e Antioquia), no entanto como existem trinta e dois departamentos no total, há registro de sobrecarga nessas áreas, para onde os resíduos são destinados, embora seja uma prática antiga, mas diante da realidade atual deveria sofrer alterações, evitando desequilíbrio na disposição final na nação.

A Colômbia é formada por 1.102 municípios e deste total 90,20\% (994), no período de 2018, deram como destinação final aos resíduos coletados, as áreas autorizadas, o que representa $97,80 \%$ dos resíduos recolhidos a nível nacional. Porém, 10,53\% (116) dos municípios ainda continuaram destinando 2,20\% do material gerado, para lugares não autorizados. Deste modo:

La disposición de residuos en Colombia a través del servicio público de aseo se realiza en 308 sitios de disposición final, divididos en autorizados y no autorizados, frente a los sitios autorizados, se poseen 174 rellenos sanitarios, 15 celdas de contingencia y 3 plantas de tratamiento, mientras que para los sistemas no autorizados, Colombia presenta 101 botaderos a cielo abierto y 15 celdas transitórias (Colômbia, 2019, p.34) 
$\mathrm{Na}$ sequência apresentamos dois gráficos, o primeiro apresenta a porcentagem de municípios atendidos e a média de toneladas/dia, de acordo com o tipo de destinação final em 2018 e o segundo traz os dados sobre a distribuição do sistema de destinação final dos resíduos sólidos.

Figura 26 - Municípios atendidos e média de toneladas/dia, segundo o tipo de destinação final - 2018

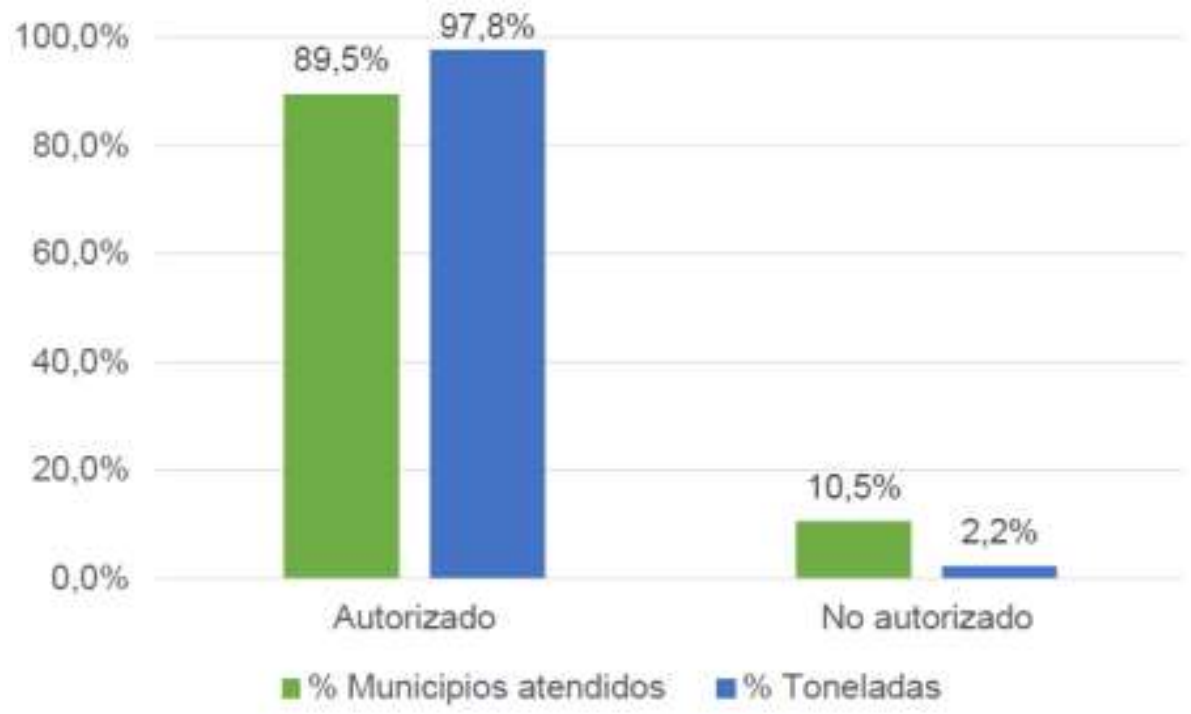

Fonte: SUI, requerimientos, visitas, DNP - Colômbia, 2019.

Figura 27 - Distribuição do sistema de destinação final

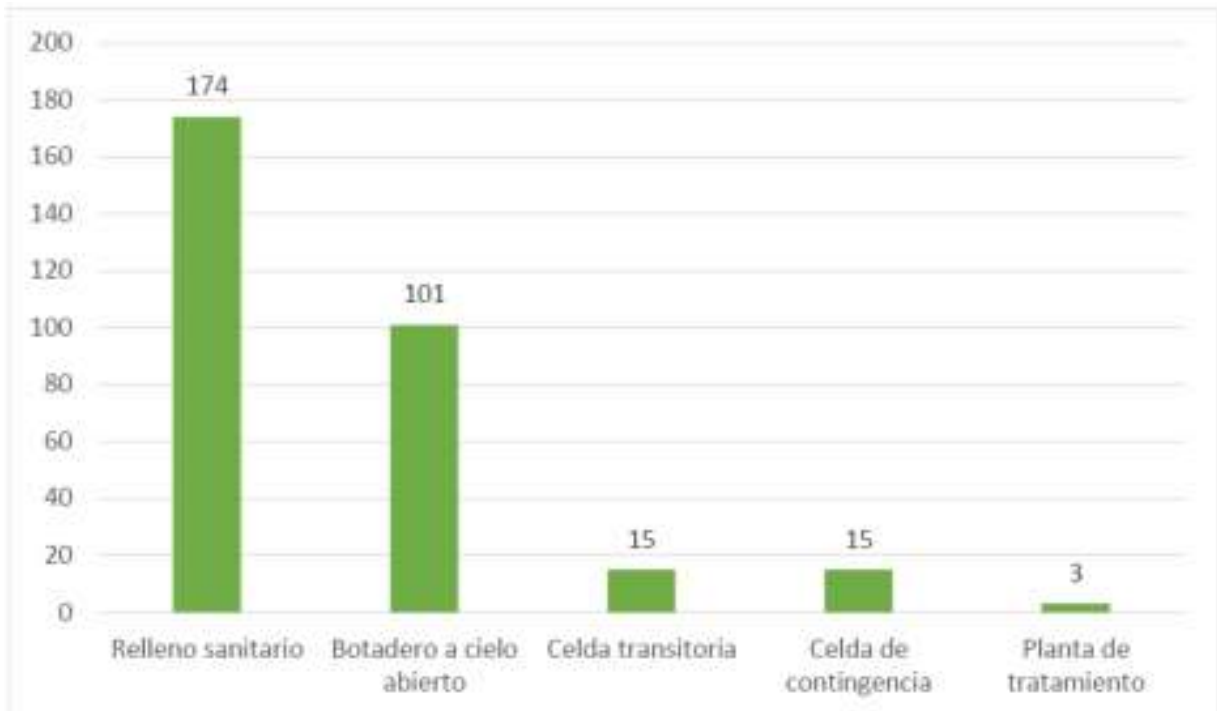

Fonte: SUI, requerimientos, visitas, DNP - Colombia, 2019. 
Observa-se, portanto, que os aterros sanitários são predominantes, representando $56 \%$ e logo depois vêm os lixões ${ }^{24}(33 \%)$, as células transitórias ${ }^{25}$ e as de contingência ${ }^{26}$ (cada uma com $5 \%$ ) e as estações de tratamento com 1\% de participação no sistema de disposição final dos resíduos sólidos.

Ainda em se tratando dos resíduos sólidos colombianos, segundo dados do Departamento Nacional de Planeación da Colômbia ${ }^{27}$, do ano 2016: está estabelecida uma meta de aproveitamento de 20\%, no Plano Nacional de Desenvolvimento, com vistas à redução do volume de resíduos que vai parar nos aterros sanitários, de modo a incentivar a reciclagem, o reuso e até mesmo a redução. No entanto, para garantir a disposição final adequada, será necessário investir em média 3,3 bilhões de pesos colombianos até 2026; assim como, acabar com as falhas na cobertura da coleta, tanto na área urbana como na rural. Em relação às pessoas que têm como ofício a catação de resíduos na Colômbia, os recicladores, devem se associar às organizações de recicladores para que se tornem oficialmente prestadores do serviço público de limpeza urbana, diferente do que preceitua a legislação brasileira que institui os catadores como parceiros da gestão integrada, mas organizados em cooperativas e/ou associações.

No tocante aos Planos de Ordenamento Departamental, esses devem dispor de áreas para infraestrutura e habilitar os usos do solo para aterros sanitários e estações de tratamento de resíduos e, por fim, aponta que $80 \%$ dos

\footnotetext{
24 Área de disposição final de resíduos sólidos sem controle e sem a adoção de medidas de prevenção e mitigação dos impactos ambientais e à saúde, como: erosão, sedimentação, atração de vetores, geração de chorume e outros.

${ }_{25}$ De acuerdo con el artículo 5 de la Resolución 1390 de 2005, eran celdas que inicialmente se tenían que diseñar y construir “...para una capacidad de disposición equivalente a la generación de residuos sólidos correspondiente a un período de hasta treinta y seis (36) meses, al vencimiento del cual, no se podrá disponer más residuos sólidos en dichas celdas". Este plazo fue ampliado por 3 años en total, tras la expedición de las Resoluciones 1684 de 2008, 1822 de 2009, 1529 de 2010 y 1890 de 2011. Su propósito era suministrar a los municipios una herramienta de carácter temporal, con el fin de facilitar la adecuada disposición final de residuos, en tanto lograban incluir en su gestión integral la disposición final en rellenos sanitarios licenciados por la autoridad ambiental competente, acorde con las políticas expedidas por el Gobierno Nacional (Colombia, 2019, p. 31).

26 De acuerdo con el artículo 3 de la Resolución 1890 de 2011, eran una alternativa para la disposición final con que cuentan los municipios que se acogieron a la Resolución 1390 de 2005 y sus modificaciones. Bajo este esquema, el municipio podía solicitar a la autoridad ambiental competente que el sitio donde funcionó una celda transitoria, pudiera ser incorporado dentro de un proyecto de construcción y operación de un relleno sanitario, como una alternativa dentro del Plan de Contingencias del sitio, en virtud de lo estipulado en la Resolución 1274 de 2006 (términos de referencia para la construcción de rellenos sanitarios) o aquella que la modifique o sustituya (Colombia, 2019, p. 31).

${ }^{27}$ Rellenos sanitarios de 321 municipios colapsarán en cinco años, advierte el DNP. Disponível em: <https://www.dnp.gov.co/Paginas/Rellenos-sanitarios-de-321-municipios-colapsar\%C3\%A1nen-cinco-a\%C3\%B1os,-advierte-el-DNP--.aspx>. Acesso em: 02 de jun. 2018.
} 
municípios de todo o país não atualizaram os seus Planos Municipais de Gestão Integral de Resíduos Sólidos, fator que não é diferente em território brasileiro.

$\mathrm{Na}$ Colômbia, observa-se que "la composición de residuos generados en el país presenta una alta prevalencia de residuos orgânicos" (Colômbia, 2019, p. 53). Em 2016 o volume desse tipo de resíduo correspondia a $61,5 \%$ da geração total (Colômbia, 2016, p. 33) e mesmo assim, não se tem registro da atividade de compostagem, o que poderia atender um trabalho de fertilização na área agrícola, assim como reduzir os impactos do orgânico transformado em chorume na natureza. Visto que essa produção impacta diretamente o contexto ambiental, se constituindo como uma fonte prejudicial e geradora de gases do efeito estufa, considerando que sua disposição final é realizada nos aterros sanitários ou outros meios de disposição final.

Como mencionado anteriormente, em novembro de 2016, foi aprovada na Colômbia, a Política Nacional para la Gestión Integral de Residuos Sólidos (PNGIRS), mais de seis anos após a lei brasileira do mesmo seguimento (a Política Nacional de Resíduos Sólidos - PNRS) ter sido sancionada. Na Colômbia a política é liderada pelo Ministerio de Vivienda, Ciudad y Territorio; Ministerio de Ambiente y Desarrollo Sostenible; pelo Departamento Nacional de Planeación (DNP); em articulação com o Ministerio de Educación Nacional; o Ministerio de Minas y Energía; entre outras entidades. Essa política será efetivada entre 2016 e 2030 e para sua implementação será necessário um investimento de 187.578 milhões de pesos colombianos.

$\mathrm{Na}$ sequência nos ateremos a apresentar mais informações sobre tais políticas - PNRS (Brasil) e PNGIRS (Colômbia).

\section{2. \\ A política nacional de resíduos sólidos no Brasil e na Colômbia}

As atuais políticas públicas voltadas para o trato com os resíduos sólidos, tanto no Brasil quanto na Colômbia, não datam de muitos anos atrás, conforme relatado no item anterior.

No Brasil até então não havia uma legislação específica voltada para o trato dos resíduos sólidos. A atual política, a PNRS, ficou em tramitação por cerca de 20 anos, até ser sancionada em 02 de agosto de 2010, tendo como pontapé inicial o "Projeto de Lei do Senado - PLS no 354/1989, um projeto que 
dispunha sobre o acondicionamento, a coleta, o tratamento, o transporte e a destinação final dos resíduos de serviços de saúde" (Figueiredo et al., 2020, p. 31 ), que foi sequenciado por alguns processos, dentre os quais os descritos a seguir, culminando na Lei 12.305/2010:

Quadro 5 - Processos que culminaram na PNRS

\begin{tabular}{|c|c|}
\hline ANO & ACONTECIMENTOS \\
\hline 1991 & $\begin{array}{l}\text { Projeto de Lei }(\mathrm{PL}) 203 / 1991 \text { - Dispõe sobre o acondicionamento, a coleta, o } \\
\text { tratamento, o transporte e a destinação final dos resíduos de serviços de } \\
\text { saúde. }\end{array}$ \\
\hline \multirow[t]{3}{*}{1993} & $\begin{array}{l}\text { Apensado o PL 3.333/1992 - Institui a Política Nacional de Resíduos e dá } \\
\text { outras providências. }\end{array}$ \\
\hline & Após são criados vários PLs - cerca de 100. \\
\hline & São criadas duas Comissões Especiais na Câmara, gerando substitutivos. \\
\hline 1998 & $\begin{array}{l}\text { Cria-se o Grupo de Trabalho dentro do CONAMA, do qual faziam parte } \\
\text { membros do governo e da sociedade civil, que teve como resultado a } \\
\text { Proposição CONAMA 259/99 - Diretrizes Técnicas para a Gestão de Resíduos } \\
\text { Sólidos, que mesmo tendo sido aprovada no Plenário do CONAMA não chegou } \\
\text { a vigorar. }\end{array}$ \\
\hline 2001 & A Câmara dos deputados cria a Comissão especial voltada para a PNRS. \\
\hline 2008 & Cria-se o Grupo de Trabalho que gerou nova subemenda substitutiva. \\
\hline \multirow[t]{2}{*}{2010} & $\begin{array}{l}\text { A proposta foi convertida na Lei 12.305/2010, que institui a Política Nacional de } \\
\text { Resíduos Sólidos; altera a Lei no 9.605, de } 12 \text { de fevereiro de 1998; e dá outras } \\
\text { providências. }\end{array}$ \\
\hline & $\begin{array}{l}\text { Decreto } 7.404 \text { de } 23 \text { de } 2010 \text { - Regulamenta a Lei no } 12.305 \text {, de } 2 \text { de agosto de } \\
2010 \text {, que institui a Política Nacional de Resíduos Sólidos, cria o Comitê } \\
\text { Interministerial da Política Nacional de Resíduos Sólidos e o Comitê Orientador } \\
\text { para a Implantação dos Sistemas de Logística Reversa, e dá outras } \\
\text { providências. }\end{array}$ \\
\hline
\end{tabular}

Fonte: Elaboração própria baseada em Fagliari (2017); Ribeiro (2018) e informações públicas.

A PNRS/2010 faz uma integração com a Política Nacional do Meio Ambiente e é articulada com: a Política Nacional de Educação Ambiental, Lei no 9.795, de 27 de abril de 1999; a Política Federal de Saneamento Básico, Lei no 11.445, de 2007, bem como com a Lei no 11.107, de 6 de abril de 2005, que dispõe sobre as normas gerais de contratação de consórcios públicos e dá outras providências. $\mathrm{E}$ ainda, cabe ressaltar que sofrerá alteração também pela Lei número 14.026/2020 que dispõe sobre o novo marco regulatório de 
saneamento - regulamentada pelo Decreto $\mathrm{N}^{\circ} 10.588$ de 24 de dezembro de 2020.

$\mathrm{Na}$ PNRS estão estabelecidos os princípios, objetivos e instrumentos, assim como também as diretrizes referentes à gestão integrada e ao gerenciamento de resíduos sólidos, abarcando os resíduos perigosos, estabelecendo às responsabilidades dos geradores e do poder público e tratando sobre os instrumentos econômicos aplicáveis. A política está estruturada em títulos, capítulos e seções e é composta pelos seguintes assuntos:

Figura 28 - Assuntos constantes na PNRS - Brasil

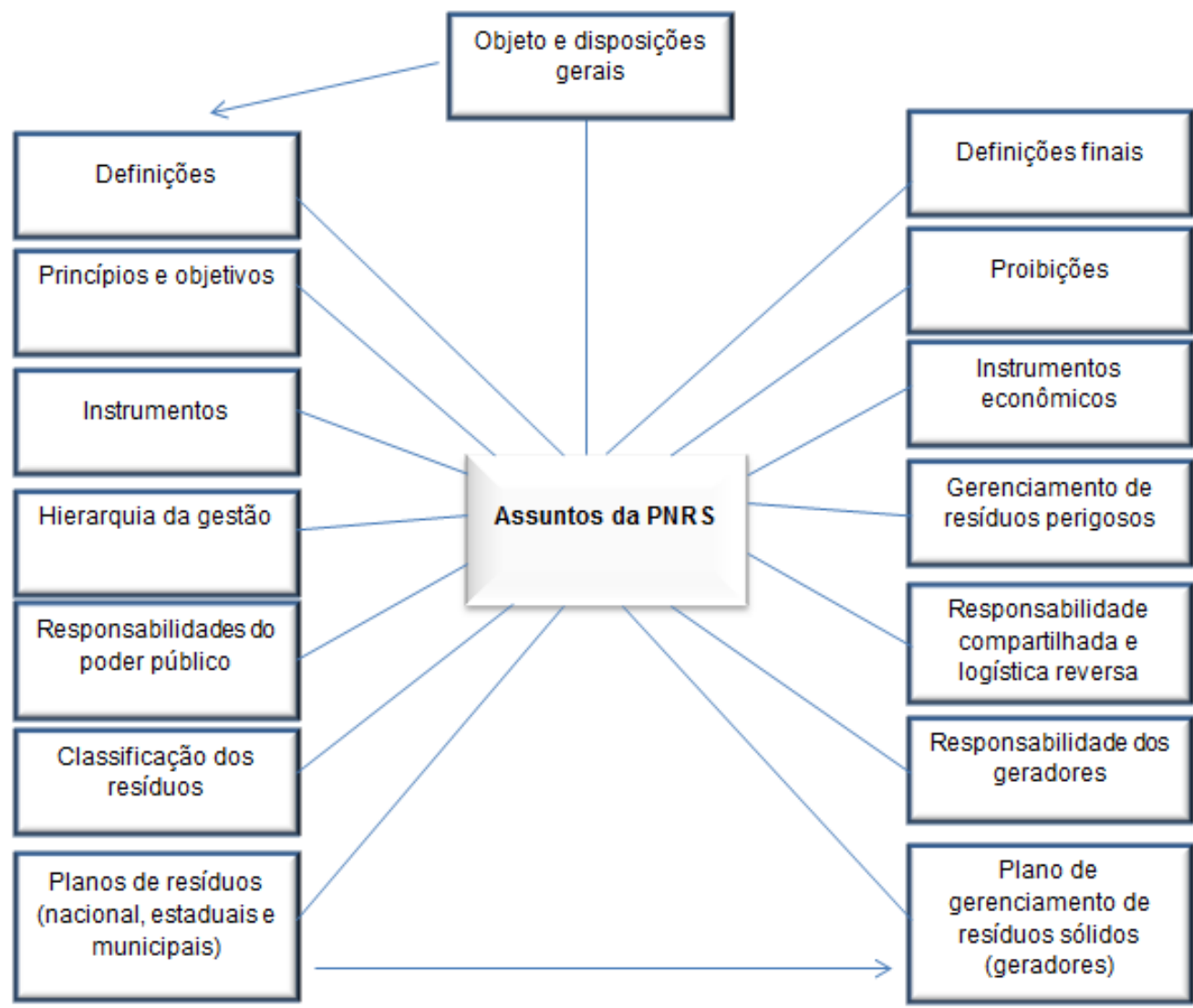

Fonte: Elaboração própria baseada em Ribeiro, 2018.

Dentre os assuntos que constam na PNRS, destacamos algumas definições, que julgamos importantes para uma melhor compreensão dessa discussão, tais como: resíduos sólidos, rejeitos, coleta seletiva, reciclagem, reutilização, ciclo de vida do produto, destinação final ambientalmente adequada e disposição final ambientalmente adequada: 
Quadro 6 - Definição de alguns conceitos segundo a PNRS

\begin{tabular}{|c|c|}
\hline CONCEITO & DEFINIÇÃO \\
\hline $\begin{array}{l}\text { Resíduos } \\
\text { sólidos }\end{array}$ & $\begin{array}{l}\text { Material, substância, objeto ou bem descartado resultante de } \\
\text { atividades humanas em sociedade, a cuja destinação final se } \\
\text { procede, se propõe proceder ou se está obrigado a proceder, nos } \\
\text { estados sólido ou semissólido, bem como gases contidos em } \\
\text { recipientes e líquidos cujas particularidades tornem inviável o seu } \\
\text { lançamento na rede pública de esgotos ou em corpos d'água, ou } \\
\text { exijam para isso soluções técnica ou economicamente inviáveis em } \\
\text { face da melhor tecnologia disponível. }\end{array}$ \\
\hline Rejeitos & $\begin{array}{l}\text { Resíduos sólidos que, depois de esgotadas todas as possibilidades } \\
\text { de tratamento e recuperação por processos tecnológicos disponíveis } \\
\text { e economicamente viáveis, não apresentem outra possibilidade que } \\
\text { não a disposição final ambientalmente adequada. }\end{array}$ \\
\hline Coleta seletiva & $\begin{array}{l}\text { Coleta de resíduos sólidos previamente segregados conforme sua } \\
\text { constituição ou composição. }\end{array}$ \\
\hline Reciclagem & $\begin{array}{l}\text { Processo de transformação dos resíduos sólidos que envolve a } \\
\text { alteração de suas propriedades físicas, físico-químicas ou biológicas, } \\
\text { com vistas à transformação em insumos ou novos produtos, } \\
\text { observadas as condições e os padrões estabelecidos pelos órgãos } \\
\text { competentes do Sisnama e, se couber, do SNVS e do Suasa. }\end{array}$ \\
\hline Reutilização & $\begin{array}{l}\text { Processo de aproveitamento dos resíduos sólidos sem sua } \\
\text { transformação biológica, física ou físico-química, observadas as } \\
\text { condições e os padrões estabelecidos pelos órgãos competentes do } \\
\text { Sisnama e, se couber, do SNVS e do Suasa. }\end{array}$ \\
\hline $\begin{array}{l}\text { Ciclo de vida } \\
\text { do produto }\end{array}$ & $\begin{array}{l}\text { Série de etapas que envolvem o desenvolvimento do produto, a } \\
\text { obtenção de matérias-primas e insumos, o processo produtivo, o } \\
\text { consumo e a disposição final. }\end{array}$ \\
\hline $\begin{array}{l}\text { Logística } \\
\text { reversa }\end{array}$ & $\begin{array}{l}\text { Instrumento de desenvolvimento econômico e social caracterizado } \\
\text { por um conjunto de ações, procedimentos e meios destinados a } \\
\text { viabilizar a coleta e a restituição dos resíduos sólidos ao setor } \\
\text { empresarial, para reaproveitamento, em seu ciclo ou em outros ciclos } \\
\text { produtivos, ou outra destinação final ambientalmente adequada. }\end{array}$ \\
\hline $\begin{array}{l}\text { Destinação } \\
\text { final } \\
\text { ambientalmente } \\
\text { adequada }\end{array}$ & $\begin{array}{l}\text { Destinação de resíduos que inclui a reutilização, a reciclagem, a } \\
\text { compostagem, a recuperação e o aproveitamento energético ou } \\
\text { outras destinações admitidas pelos órgãos competentes do Sisnama, } \\
\text { do SNVS e do Suasa, entre elas a disposição final, observando } \\
\text { normas operacionais específicas de modo a evitar danos ou riscos à } \\
\text { saúde pública e à segurança e a minimizar os impactos ambientais }\end{array}$ \\
\hline
\end{tabular}




\begin{tabular}{c|l}
\hline $\begin{array}{c}\text { Disposição } \\
\text { final }\end{array}$ & $\begin{array}{l}\text { Distribuição ordenada de rejeitos em aterros, observando normas } \\
\text { operacionais específicas, de modo a evitar danos ou riscos à saúde }\end{array}$ \\
$\begin{array}{c}\text { ambientalmente } \\
\text { adequada }\end{array}$ & $\begin{array}{l}\text { advera e à segurança e a minimizar os impactos ambientais } \\
\text { adversos }\end{array}$
\end{tabular}

Fonte: Elaboração própria baseada em Brasil, 2017.

É comum observarmos no cotidiano, até mesmo entre as pessoas que trabalham ou que têm alguma ligação direta com a temática, certa confusão em relação à definição de determinados conceitos, por exemplo, destinação final e disposição final. Percebe-se o desconhecimento sobre a diferença entre um e o outro e, por ser dessa forma, às vezes há o uso equivocado deles como se fosse sinônimo, o que não procede, segundo a descrição acima.

No tocante à disposição final, já existem discussões que questionam o uso dos aterros sanitários, sob justificativa de não ser uma forma ambientalmente adequada de disposição final, apontando-se como solução, mudanças na composição dos materiais, para que cada vez mais sejam potencialmente recicláveis, e que sejam de fato reciclados, bem como ações que objetivem evitar a ida dos materiais orgânicos para esses espaços.

Não raras vezes, outros dois termos também são confundidos. Frequentemente observamos a utilização da palavra reciclar, quando na verdade o termo correto a ser empregado seria reutilizar, tendo em vista que para reciclar, depende-se de um processo que sem as ferramentas necessárias, não é possível fazer. Apesar de a reutilização ser também muito importante nesse processo (pois aumenta o ciclo de vida do produto) e de fazer parte dos objetivos da PNRS, ela não pode ser vista como equivalente a reciclagem, pois o resíduo não passa por um processo de transformação, seja biológica, física ou físicoquímica.

Além da reutilização e da reciclagem, listadas no artigo 7ํㅜ da PNRS, outros itens nesta mesma linha de pensamento, são parte dos objetivos dessa política, a saber: não gerar, reduzir, tratamento dos resíduos sólidos, assim como a disposição final ambientalmente adequada dos rejeitos. Em se tratando de hierarquia, estão organizados da seguinte forma, sendo o topo da pirâmide, a atitude mais recomendada a ser adotada, para que quando se chegue à base dessa estrutura, pouco se tenha para ser disposto nos aterros sanitários. 
Figura 29 - Hierarquia do manejo de resíduos sólidos no Brasil

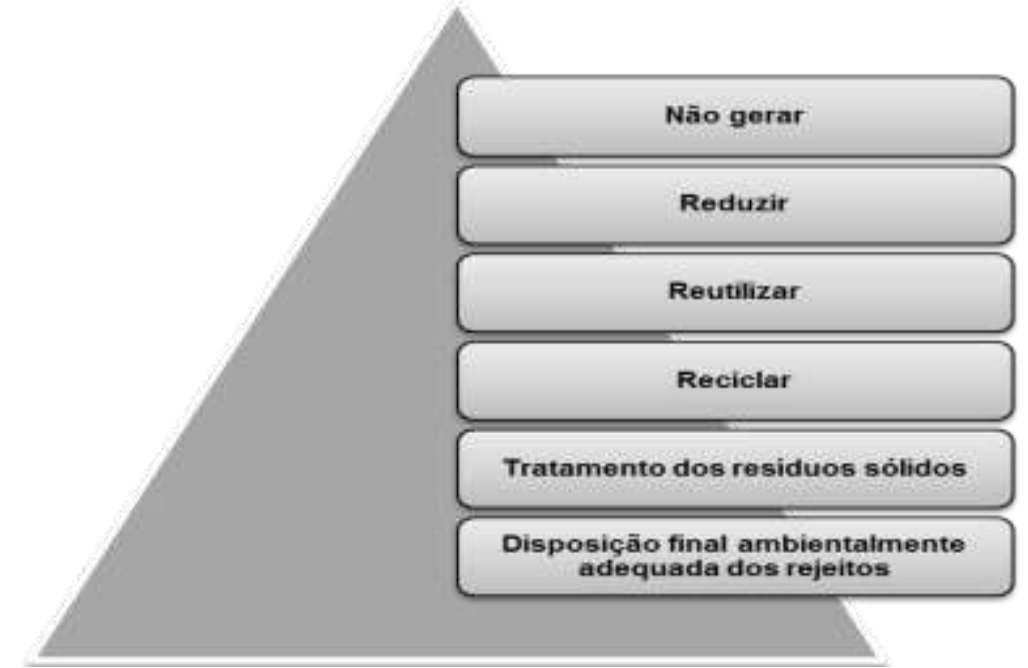

Fonte: Elaboração própria baseada no Art. 7ํ da PNRS - 3ª ed. (Brasil, 2017).

No que diz respeito ao não gerar e reduzir, os mais recomendados, segundo a hierarquia do manejo dos resíduos sólidos brasileiros, no mundo capitalista em que vivemos, o que se observa é justamente o contrário, pois os objetos, já na sua produção, são programados para durarem pouco tempo, para que assim, as pessoas logo os descartem e comprem outros produtos, é a chamada obsolescência programada.

Ainda em se tratando dos objetivos, destacamos: a proteção da saúde pública e da qualidade ambiental; estímulo à adoção de padrões sustentáveis, tanto de produção quanto de consumo; a adoção, o desenvolvimento e o aprimoramento de tecnologias limpas; reduzir o volume e a periculosidade no que diz respeito aos resíduos perigosos; articulação entre as diferentes esferas, tanto do poder público quanto dessas com o setor empresarial, com vistas à gestão integrada; capacitação técnica continuada; regularidade, continuidade, funcionalidade e universalização da prestação dos serviços públicos de limpeza urbana e de manejo de resíduos sólidos; a integração dos catadores de materiais recicláveis nas atividades relacionadas à responsabilidade compartilhada; avaliação do ciclo de vida do produto, devendo haver estímulo para investimentos previstos na lei, entre outros aspectos.

$\mathrm{Na}$ PNRS, os resíduos sólidos estão classificados quanto à sua origem e sua periculosidade. Quanto à origem, temos: resíduos domiciliares; resíduos de limpeza urbana; resíduos sólidos urbanos; resíduos de estabelecimentos comerciais e prestadores de serviços; resíduos dos serviços públicos de saneamento básico; resíduos industriais; resíduos de serviços de saúde; 
resíduos da construção civil; resíduos agrossilvopastoris ${ }^{28}$; resíduos de serviços de transportes; resíduos de mineração.

Quanto à periculosidade, são classificados como perigosos e não perigosos. Os primeiros são assim qualificados em função das suas "características de inflamabilidade, corrosividade, reatividade, toxicidade, patogenicidade, carcinogenicidade, teratogenicidade e mutagenicidade, apresentam significativo risco à saúde pública ou à qualidade ambiental, de acordo com lei, regulamento ou norma técnica" (Brasil, 2017). Os demais, aqui não enquadrados, são os nãos perigosos.

Conforme o Artigo 38 da PNRS, "as pessoas jurídicas que operam com resíduos perigosos, em qualquer fase do seu gerenciamento, são obrigadas a se cadastrar no Cadastro Nacional de Operadores de Resíduos Perigosos" (Brasil, 2017).

A PNRS institui a responsabilidade compartilhada, atribuindo aos fabricantes, importadores, distribuidores, comerciantes, consumidores e aos responsáveis pelos serviços públicos de limpeza urbana e de manejo dos resíduos sólidos, responsabilidades individualizadas e também encadeadas, com vistas à minimização da quantidade de resíduos sólidos e dos rejeitos gerados e consequentemente a redução dos impactos à saúde da população e ao meio ambiente, que são ocasionados pela má gestão do ciclo de vida dos produtos.

No tocante a produção das embalagens, todas deveriam ser fabricadas com tipos de materiais que permitissem a sua reutilização ou reciclagem, cabendo responsabilidade ao produtor, isto é, quem as manufatura, fornece materiais para a fabricação ou as coloca em circulação - em qualquer fase da cadeia de comércio, cumprir o que está previsto em lei, ou seja, o princípio do produtor-poluidor.

No que diz respeito à logística reversa, os fabricantes, importadores, distribuidores, comerciantes e consumidores, são responsáveis cada um no seu nível, pela destinação ambientalmente adequada das embalagens e dos produtos, devendo funcionar, de um modo geral, da seguinte forma: os consumidores devolvem após o uso, para os comerciantes ou distribuidores; os comerciantes e distribuidores, por sua vez, devolvem aos fabricantes ou aos importadores; e por fim, os fabricantes e os importadores darão destinação e disposição final ambientalmente adequada. Vide ilustração que segue:

\footnotetext{
28 Os gerados nas atividades agropecuárias e silviculturais, incluídos os relacionados a insumos utilizados nessas atividades (Brasil, 2017).
} 
Figura 30 - Fluxo simplificado de resíduos nos sistemas de logística reversa

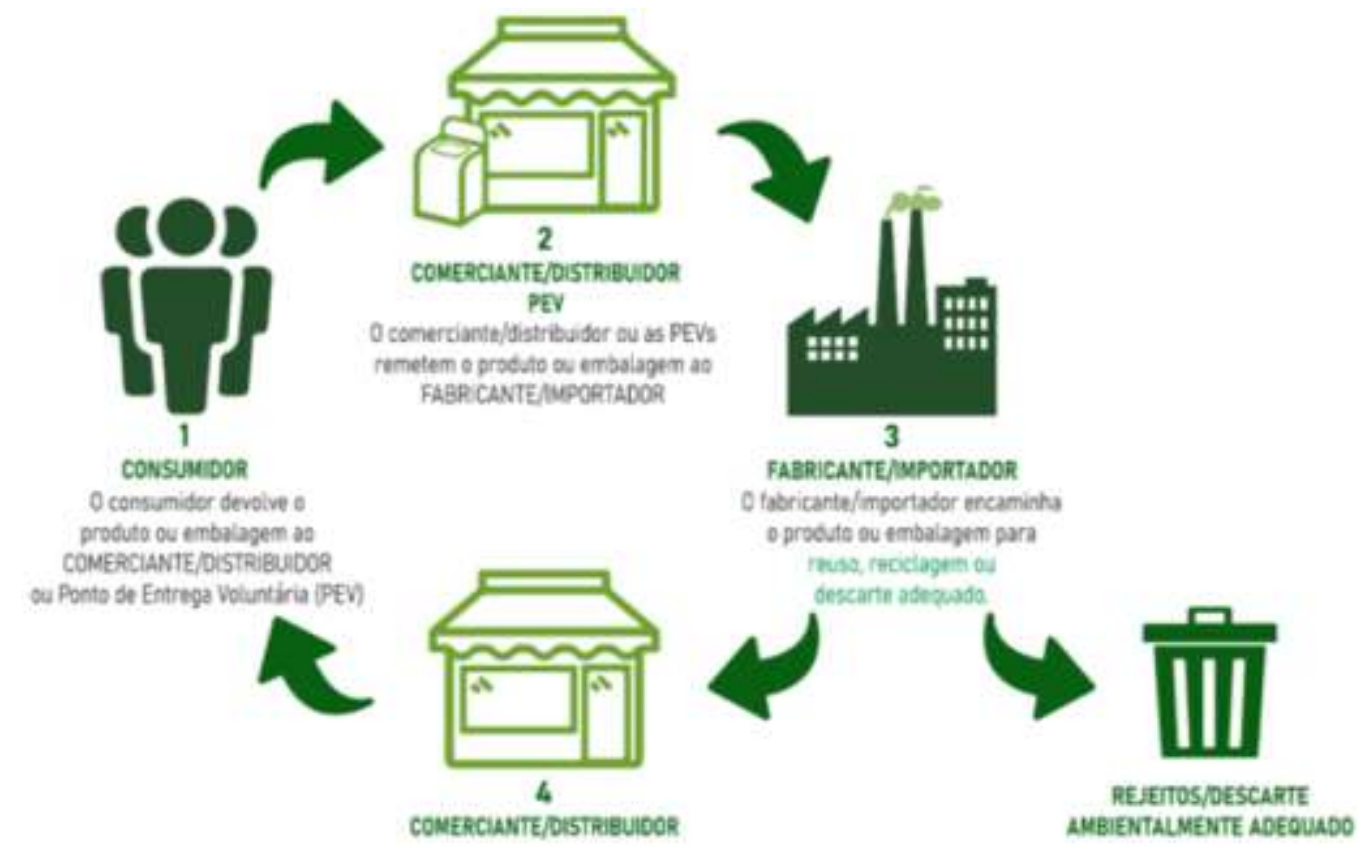

Fonte: https://sinir.gov.br/logistica-reversa.

Em relação aos instrumentos econômicos da Lei 12.3015/2010, no Artigo 42 está posto que o poder público tem o aval para estabelecer medidas indutoras e linhas de financiamento para atender, de forma prioritária às seguintes ações:

I - prevenção e redução da geração de resíduos sólidos no processo produtivo; II - desenvolvimento de produtos com menores impactos à saúde humana e à qualidade ambiental em seu ciclo de vida; III - implantação de infraestrutura física e aquisição de equipamentos para cooperativas ou outras formas de associação de catadores de materiais reutilizáveis e recicláveis formadas por pessoas físicas de baixa renda; IV - desenvolvimento de projetos de gestão dos resíduos sólidos de caráter intermunicipal ou, nos termos do inciso I do caput do art. 11, regional; V - estruturação de sistemas de coleta seletiva e de logística reversa; VI descontaminação de áreas contaminadas, incluindo as áreas órfãs; VII desenvolvimento de pesquisas voltadas para tecnologias limpas aplicáveis aos resíduos sólidos; VIII - desenvolvimento de sistemas de gestão ambiental e empresarial voltados para a melhoria dos processos produtivos e ao reaproveitamento dos resíduos (Brasil, 2017).

A partir dos assuntos aqui tratados, com base na política pública de resíduos sólidos do Brasil, entendemos que se devidamente implementada, inúmeros seriam os benefícios, mas o que se verifica a partir dos dados é que ainda há necessidade de investimentos mesmo passado uma década da lei sancionada. 
Na sequência apresentaremos alguns pontos da política que rege a gestão dos resíduos sólidos na Colômbia. A Política Nacional para la Gestión Integral de Residuos Sólidos (CONPES 3874, de 21 de novembro de 2016), foi a primeira a articular todos os atores do governo e foi antecedida pelas seguintes bases legais:

Quadro 7 - Evolução da base legal da gestão de RS na Colômbia de 1979 a 2016

\section{BASE LEGAL}

Lei 9 de 1979

Constituição

Política de

Colômbia 1991

Lei 142 de 1994 e

Decreto 605 de

1996

Lei de 5111999

Lei 632 de 2000

Decreto 1713 de

2002 e 1140 de

2003

Decreto 1505 de

2003

Decreto 838 de

2005

Lei 1252 de 2008

Decreto 2981 de 2013

Decreto 1077 de 2015

\section{OBJETIVO}

Estabeleceu as primeiras diretrizes sanitárias para o manejo do lixo e sua disposição final nos espaços autorizados pelo Estado.

Os Artigos 2, 49, 79, 80, 365, 366 e 369 estabelecem as diretrizes jurídicas e competências das agências estatais e a cidadania, com relação a meio ambiente, gestão de recursos naturais, e serviços públicos.

O Artigo 14 desta lei estabelece o esquema dos serviços púbicos da Colômbia, incluindo o serviço de saneamento e limpeza, além, do tratamento de resíduos sólidos segundo sua tipologia.

Estabeleceu o Dia Nacional do Reciclador e da Reciclagem.

A lei modifica parcialmente a Lei 142 e incorpora orientações para o tratamento de resíduos perigosos e patógenos.

Adiciona a gestão ambiental de resíduos como componente do serviço de limpeza e ordena a formulação dos Planos de Gestão Integrada de Resíduos Sólidos (PGIRS).

Atualiza o Decreto 1713 colocando a definição do aproveitamento e reciclagem no esquema de gestão integrada de resíduos sólidos.

Modificou o Decreto 1713 colocando precisões técnicas e tecnológicas para o planejamento, construção e operação do sistema de disposição final de resíduos, ou seja, dos aterros sanitários.

Criou as normas proibitivas em matéria ambiental, referente aos resíduos perigosos, a minimização e a redução dos riscos.

Cria definições e parâmetros para melhorar a qualidade do serviço de coleta e transporte de resíduos sólidos aproveitáveis e descartáveis, até o local de disposição final ou as áreas de segregação e reciclagem. Não aplica a aterros sanitários ou resíduos perigosos.

Regulamenta o setor de moradia, cidade e território, especificamente, para a formulação de políticas de 
Decreto 596 de

2016

Fonte: Sánchez, 2018. desenvolvimento territorial e planejamento urbano, com padrões de uso eficiente e sustentável dos solos, acesso a moradia, serviços públicos de água potável e saneamento básico.

Modificou o Decreto 1077 fixando a incorporação do esquema operativo de aproveitamento de resíduos ao serviço público de limpeza e, além disso, definiu o regime transitório para a formalização dos catadores e suas organizações.

Cabe salientar que é objeto da atual PNGIRS colombiana, os resíduos sólidos não perigosos. Os classificados como perigosos, são regidos pela Lei 632 de 2000, conforme descrito anteriormente.

A política pública de resíduos sólido da Colômbia é apresentada de forma distinta, ou seja, o Documento CONPES 3874 (PNGIRS/Colômbia) é composto por outros dados, além da parte que define os pontos da política em si, como, antecedentes e justificativa, marco conceitual, diagnóstico e recomendações, tudo no mesmo documento, sendo dedicado somente um item do documento para a definição da política, diferente da forma como está estruturada a PNRS/Brasil. Vejamos abaixo:

Quadro 8 - Definição da PNGIRS - Colômbia

\begin{tabular}{|l|}
\hline \multicolumn{1}{|c|}{ PNGIRS - COLÔMBIA } \\
\hline Objetivo general \\
\hline Objetivos específicos \\
\hline Plan de acción \\
\hline $\begin{array}{l}\text { Promover la economía circular, a través del diseño de instrumentos en el marco de la } \\
\text { gestión integral de residuos sólidos }\end{array}$ \\
\hline Promover la educación y la cultura ciudadana en la gestión integral de resíduos \\
\hline $\begin{array}{l}\text { Generar un entorno institucional propicio para la coordinación entre actores que } \\
\text { promueva la eficiencia en la gestión integral de residuos sólidos }\end{array}$ \\
\hline $\begin{array}{l}\text { Mejorar el reporte, monitoreo verificación y divulgación de la información sectorial para el } \\
\text { seguimiento de la política pública referente a la gestión integral de residuos sólidos }\end{array}$ \\
\hline Metas de la política \\
\hline Seguimiento \\
\hline Financiamiento
\end{tabular}

Fonte: Elaboração própria baseada em Colômbia - PNGIRS, 2016. 
No caso da PNGIRS da Colômbia, há um esforço para a sua implementação até 2030, devido à agenda internacional relacionada ao cumprimento das metas estabelecidas pelo país, no acordo COP 21 ; tendo como primazia a redução das emissões de gases do efeito estufa em $20 \%$. Além disso, no âmbito das finalidades de desenvolvimento sustentável, traz metas com objetivos relacionados às cidades e comunidades sustentáveis e com a produção e consumo responsável. Essa política completa, ainda, os requisitos para a entrada da Colômbia no Comitê da Política Ambiental da Organização para Cooperação e Desenvolvimento Econômico.

A Política Nacional para la Gestión Integral de Residuos Sólidos, enquanto uma política de interesse social, econômico, ambiental e sanitário, é composta por quatro eixos estratégicos, a saber:

El primer eje busca adoptar medidas encaminadas hacia (i) la prevención en la generación de residuos; (ii) la minimización de aquellos que van a sitios de disposición final; (iii) la promoción de la reutilización, aprovechamiento y tratamiento de residuos sólidos; y (iv) evitar la generación de gases de efecto invernadero. Como complemento, el segundo eje apunta a mejorar la cultura ciudadana, la educación e innovación en gestión integral de residuos sólidos para incrementar los niveles de separación en la fuente, de aprovechamiento y de tratamiento. Los dos ejes adicionales están relacionados con la generación de un entorno institucional propicio para la coordinación entre actores, que promueva la eficiencia en la gestión integral de residuos sólidos. En este sentido, el tercer eje propone asignar roles específicos y claros a las entidades participantes para que lideren las actividades correspondientes, como el tratamiento de residuos orgánicos y el fortalecimiento de los sistemas urbanos de reciclaje inclusivo, entre otros. Por último, el cuarto eje desarrolla acciones para mejorar el reporte de monitoreo, verificación y divulgación de la información sectorial para el seguimiento de la política pública de gestión integral de residuos sólidos (Colômbia, 2016, p. 3-4).

Para um melhor entendimento da PNGIRS colombiana, apresentaremos a seguir alguns termos, segundo o Documento CONPES 3874:

Quadro 9 - Definição de alguns conceitos segundo a PNGIRS

CONCEITO

Residuos sólidos

\section{DEFINIÇÃO}

Es cualquier objeto, material, sustancia o elemento principalmente sólido resultante del consumo o uso de un bien en actividades domésticas, industriales, comerciales, institucionales o de servicios, que el generador presenta para su recolección por parte de la persona prestadora del servicio público de aseo. Igualmente, se considera como residuo sólido, aquel proveniente del barrido y limpieza de áreas y vías públicas, corte de césped y poda de árboles. 


\begin{tabular}{|c|c|}
\hline Desecho & $\begin{array}{l}\text { Material que tras el término de su vida útil no es susceptible de } \\
\text { aprovechamiento. }\end{array}$ \\
\hline Aprovechamiento & $\begin{array}{l}\text { Actividad complementaria del servicio público de aseo que } \\
\text { comprende la recolección de residuos aprovechables, el transporte } \\
\text { selectivo hasta la estación de clasificación y aprovechamiento o } \\
\text { hasta la planta de aprovechamiento, así como su clasificación y } \\
\text { pesaje por parte de la persona prestadora. }\end{array}$ \\
\hline Reciclaje & $\begin{array}{l}\text { Proceso de transformación física o química o biológica de los } \\
\text { materiales procedentes de los residuos potencialmente } \\
\text { aprovechables, para su reincorporación en el ciclo productivo. }\end{array}$ \\
\hline Reutilización & $\begin{array}{l}\text { Es la prolongación de la vida útil de los residuos recuperados y que } \\
\text { mediante procesos, operaciones o técnicas devuelven a los } \\
\text { materiales su posibilidad de utilización en su función original o en } \\
\text { alguna relacionada, sin que para ello requieran procesos } \\
\text { adicionales de transformación física o química. }\end{array}$ \\
\hline $\begin{array}{l}\text { Ciclo de vida de } \\
\text { un producto }\end{array}$ & $\begin{array}{l}\text { Todas las etapas del desarrollo de un producto, incluidos su diseño, } \\
\text { la extracción o adquisición de materia prima, producción, } \\
\text { comercialización, uso, reutilización, reciclaje, y reincorporación al } \\
\text { ciclo productivo o hasta su disposición final. }\end{array}$ \\
\hline $\begin{array}{l}\text { Responsabilidad } \\
\text { extendida del } \\
\text { productor }\end{array}$ & $\begin{array}{l}\text { Enfoque de la política ambiental en el que la responsabilidad del } \\
\text { productor por un producto se extiende a la etapa de posconsumo } \\
\text { del ciclo de vida del mismo. }\end{array}$ \\
\hline $\begin{array}{l}\text { Disposición final } \\
\text { de residuos } \\
\text { sólidos }\end{array}$ & $\begin{array}{l}\text { Es el proceso de aislar y confinar los residuos sólidos en especial } \\
\text { los no aprovechables, en forma definitiva, en lugares especialmente } \\
\text { seleccionados y diseñados para evitar la contaminación, y los } \\
\text { daños o riesgos a la salud humana y al ambiente. }\end{array}$ \\
\hline
\end{tabular}

Fonte: Elaboração própria baseada Colômbia - PNGIRS, 2016.

Nem todas as definições presentes na PNRS do Brasil são encontradas na PNGIRS da Colômbia, o que já é esperado, tendo em vista estarmos falando sobre nações e realidades distintas, porém encontramos muitos termos iguais ou bem próximos dos que são utilizados na política brasileira.

Essa política busca por meio da gestão integral de resíduos sólidos a transição de um modelo até então linear - onde se extrai, produz, consume e descarta, para uma economia circular, descrita como o modelo que visa que o valor dos produtos, matérias e dos recursos, se mantenham circulando na economia, durante o maior tempo possível, com vistas à redução da geração de resíduos, para isso, fazendo uso da hierarquia da gestão dos resíduos sólidos, que é, em ordem de prioridade, de cima para baixo: 
Figura 31 - Hierarquia da gestão de resíduos sólidos na Colômbia

Prevenir

Reutilizar

Aprovechar

Tratar los materiales con fines de

valorización y para que se permita optimizar la operación de los rellenos sanitarios

En el caso de que no sea posible lo anterior, garantizar su eliminación o disposición final con el cumplimiento estricto de estándares ambientales

Fonte: Elaboração própria baseada em Colômbia - PNGIRS, 2016.

A política tem como objetivo, para a gestão integral de resíduos sólidos: a promoção da economia circular, a ser alcançada por meio da adoção de instrumentos; a promoção da cultura cidadã, da educação e de inovação, visando diminuir a geração de resíduos, a reutilização e o aumento do nível de separação na fonte e do aproveitamento; a criação de uma rede institucional que proporcione a coordenação entre os atores envolvidos, para que haja eficiência no processo; e por fim, a melhora no repasse, monitoramento, verificação e divulgação das informações, para que a política siga sendo monitorada.

O plano de ação da PNGIRS é pautado nos objetivos citados acima e aponta alguns caminhos para que em 2030, a Colômbia alcance a gestão integral dos resíduos sólidos, por meio de uma política clara, articulada, com uma visão de longo prazo, avançando para uma economia circular, de modo a contribuir para o desenvolvimento sustentável, para a adaptação e mitigação da mudança climática. Para isto, está previsto:

a) Incentivo ao aproveitamento: com previsão de ter sistemas de aproveitamento consolidados, sustentáveis e inclusivos, pelo menos nas treze principais cidades do país, tendo como meta, aproveitar $30 \%$ dos resíduos gerados.

b) Uso de tecnologias complementares e alternativas aos aterros sanitários, bem como torna obrigatório o emprego de sistemas para 
extração, captura ativa e passiva para manejar os gases e que haja a inclusão desse serviço dentro das tarifas do serviço público de limpeza.

c) Implementação de programas de responsabilidade estendida do produtor de recipientes e embalagens.

d) Criação de um plano para o encerramento de cem por cento dos lixões a céu aberto e demais formas inadequadas de disposição final.

e) Realização de um diagnóstico das instalações de gestão de resíduos, existentes no país, para que posteriormente seja expedido um instrumento normativo para a implementação dos elementos básicos de desempenho nesses locais.

f) Garantir o manejo adequado dos resíduos especiais, de modo a promover a reutilização/aproveitamento dos seus componentes.

g) Promoção de ações comunicativas no âmbito nacional, focadas na prevenção, reutilização e separação na fonte.

h) Desenvolvimento social e a formalização dos catadores, na prestação da atividade de aproveitamento dos resíduos, no marco do serviço público de limpeza urbana.

i) Criação de uma conta ambiental e econômica de resíduos sólidos, como ferramenta de informação oficial para o acompanhamento, controle e tomada de decisões referentes ao setor.

j) Dentre outros.

Para o alcance dos objetivos da política, em termos de financiamento, as entidades envolvidas na sua execução, de acordo com suas competências, farão a gestão, priorizando os recursos para o financiamento das estratégias propostas, com base no marco de gastos previstos para médio prazo. Está posto, que as fontes de recursos adicionais que forem necessárias para colocar em práticas as ações, deverão ser administradas pelas entidades governamentais do país, integrantes da política, de preferência por meio de mecanismos de cooperação internacional.

A seguir, poderemos observar na figura 32 , os custos totais estimados em milhões de pesos colombianos, necessários à implementação da política, no período de 2016 a 2030, conforme descrito no Documento CONPES 3874: 
Figura 32 - Financiamento estimado da PNGIRS-Colômbia

\begin{tabular}{|c|c|c|c|c|}
\hline \multicolumn{5}{|c|}{ Millones de pesos } \\
\hline Rubro & $2016-2020$ & $2021-2025$ & $2026-2030$ & Total \\
\hline Costo de la polftica & 67.614 & 72.584 & 47.380 & 187.578 \\
\hline Financiamiento $^{(a)}$ & 62.734 & 72.584 & 47.380 & 182.698 \\
\hline Recursos adiclonales requeridos ${ }^{(b)}$ & 4.880 & - & - & 4.880 \\
\hline
\end{tabular}

Fonte: Colômbia - PNGIRS, 2016.

Recomenda-se na PNGIRS, que seja realizada em 2026 uma avaliação para verificar:

El cumplimiento de las metas y la efectividad de los instrumentos de la responsabilidad extendida del productor en envases y empaques, de la internalización de los costos ambientales y a la salud, del incentivo al aprovechamiento y de la estrategia de comunicación para el incremento en los niveles y calidad de la separación en la fuente (Colombia, 2016, p. 57).

\subsection{1 \\ Um olhar sobre os avanços e retrocessos da política nacional de resíduos sólidos brasileira e colombiana}

Na sequência fazemos um exercício de voltar nosso olhar para o período pós-largada para a implementação da política pública de gestão de resíduos sólidos no Brasil e na Colômbia.

Deste modo, diante dos fatos apontados passaremos a analisar os avanços e retrocessos legais nos dois países, visto que consideramos que o exercício de olhar para trás e a partir de alguns pontos, analisar os acontecimentos e/ou dados, no decorrer desse período, se faz importante para entendermos que rumos vêm tomando ambas as políticas.

No Brasil, a PNRS completou dez anos em 2020, o que nos permite ter mais elementos para fazer a análise a que nos propomos. Diferente do que ocorre na Colômbia, onde a PNGIRS é do final de 2016, sendo um tempo relativamente pequeno, estando ainda, portanto, em processo de implementação, algumas ações para o alcance das metas, e, onde também, nos deparamos com a escassez de informações, porém traremos os dados possíveis de serem apresentados. 
No caso brasileiro, elencamos para nossa análise, alguns elementos, olhando para a Lei 12.305/2010 e com base no Panorama de 2020 da ABRELPE, que traz uma comparação dos dados entre 2010 e 2019. Adotaremos, portanto, para esse fim, algumas destas informações, que são apresentadas na tabela que segue:

Quadro 10 - Panorama dos RS no Brasil ${ }^{29}$ - comparação entre 2010 e 2019

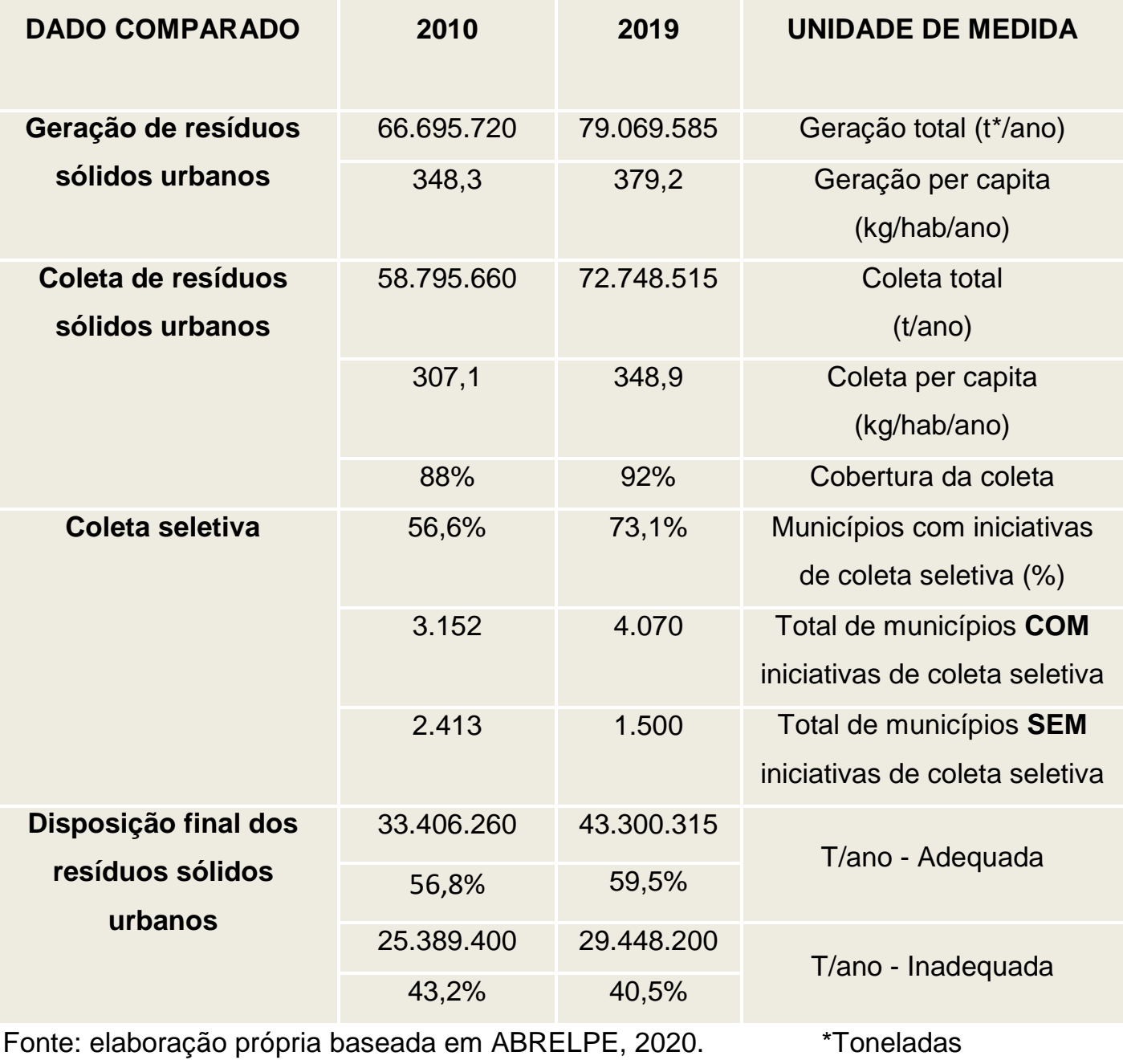

Dentre os principais objetivos da PNRS está a redução da geração de resíduos sólidos e a disposição final ambientalmente adequada, porém na contramão da política, o que se observa é que houve um aumento considerável na geração, bem como na disposição final inadequada, que é quando o resíduo vai parar em lixões e/ou aterros controlados.

No período analisado, registra-se que foram gerados no Brasil, cerca de 10 milhões de toneladas a mais do que na década anterior, o que representa um

${ }^{29}$ Total de municípios brasileiros em 2010: 5.565 e em 2019: 5.570. 
crescimento de 19\%, no índice de geração per capita. Também foi registrado aumento de 4 milhões de toneladas dispostas inadequadamente. Segundo a ABRELPE, no ano de 2019, 3.001 municípios brasileiros ainda realizavam a disposição final dos resíduos em locais inadequados, e se tomarmos por referência a quantidade de municípios brasileiros, mais de $50 \%$ continuam não atendendo o que a Lei $\mathrm{N}^{\circ} 12.305 / 2010$ determinava, a qual sofreu mudança legal em função da Lei 14.026/2020, que altera o Art. 54 da PNRS, e onde está posto que:

\begin{abstract}
A disposição final ambientalmente adequada dos rejeitos deverá ser implantada até 31 de dezembro de 2020, exceto para os Municípios que até essa data tenham elaborado plano intermunicipal de resíduos sólidos ou plano municipal de gestão integrada de resíduos sólidos e que disponham de mecanismos de cobrança que garantam sua sustentabilidade econômico-financeira, nos termos do art. 29 da Lei no 11.445 , de 5 de janeiro de 2007 , para os quais ficam definidos os seguintes prazos: I - até 2 de agosto de 2021, para capitais de Estados e Municípios integrantes de Região Metropolitana (RM) ou de Região Integrada de Desenvolvimento (Ride) de capitais; II - até 2 de agosto de 2022, para Municípios com população superior a 100.000 (cem mil) habitantes no Censo 2010, bem como para Municípios cuja mancha urbana da sede municipal esteja situada a menos de 20 (vinte) quilômetros da fronteira com países limítrofes; III - até 2 de agosto de 2023, para Municípios com população entre 50.000 (cinquenta mil) e 100.000 (cem mil) habitantes no Censo 2010; e IV - até 2 de agosto de 2024, para Municípios com população inferior a 50.000 (cinquenta mil) habitantes no Censo 2010. § 2o Nos casos em que a disposição de rejeitos em aterros sanitários for economicamente inviável, poderão ser adotadas outras soluções, observadas normas técnicas e operacionais estabelecidas pelo órgão competente, de modo a evitar danos ou riscos à saúde pública e à segurança e a minimizar os impactos ambientais (Brasil, 2020).
\end{abstract}

Os lixões que deveriam ter sido extintos até 2014, seguem sendo espaço de recebimento de resíduos. Em 2010 recebiam 11.351.865 toneladas/ano, passando a receber 12.720.250 milhões de toneladas em 2019, de acordo com a ABRELPE (2020), o que representa um aumento de $16 \%$. E as áreas mais castigadas são:

\begin{abstract}
Nordeste e Norte, regiões as quais se apresentam as maiores proporções de municípios, especialmente de pequeno porte, que destinam os resíduos em locais sem qualquer técnica de proteção ambiental e de saúde pública, que se denominam lixões e ainda mantém pessoas no garimpo dos resíduos potencialmente recicláveis de forma insalubre, penosa e perigosa (Figueiredo et al., 2020, p. 36).
\end{abstract}

A título de demonstração dos dados, segue um gráfico apresentando a comparação, com base nos tipos de disposição final entre 2010 e 2019: 
Figura 33 - Disposição final de RSU no Brasil, por tipo de destinação (t/ano)
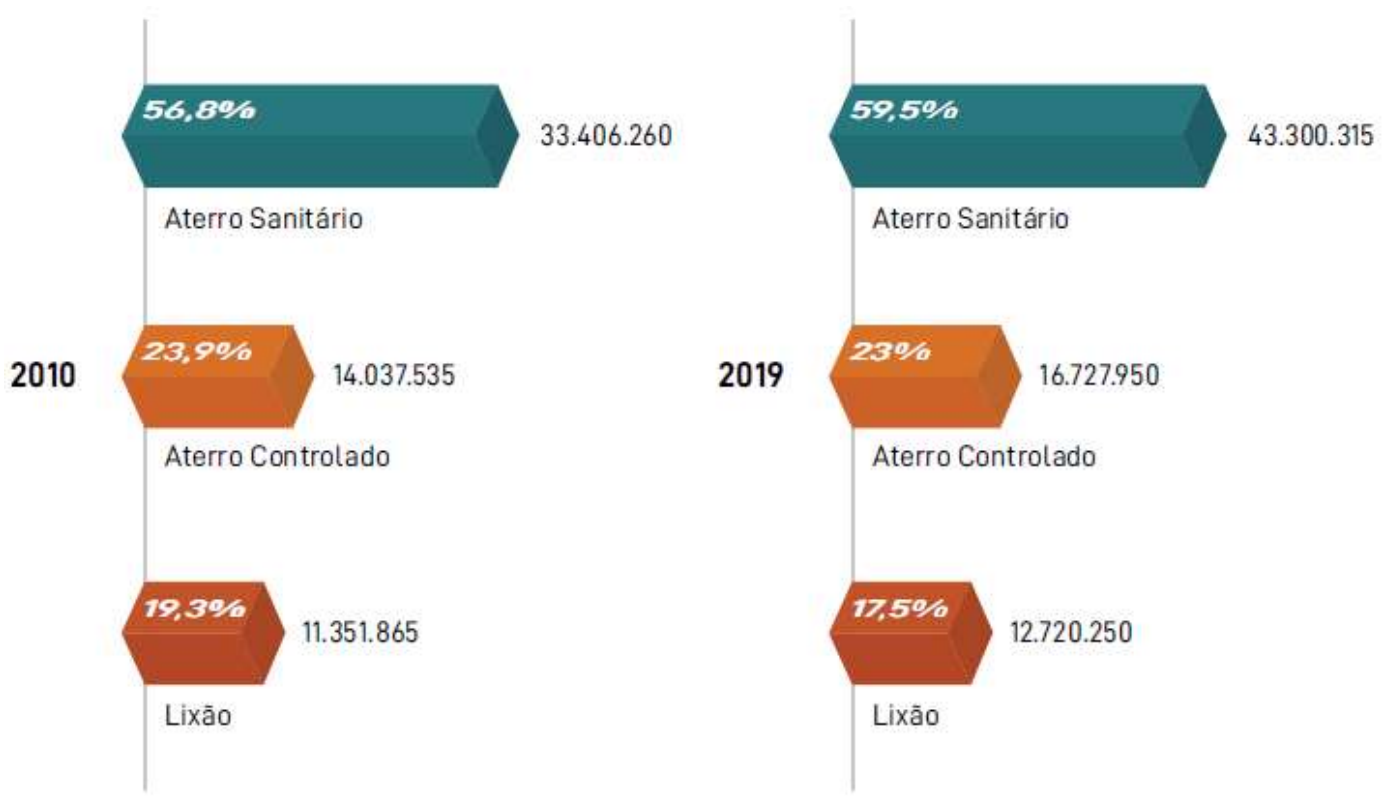

Fonte: ABRELPE, 2020.

A disposição final inadequada dos rejeitos nos lixões, além de não ter sido consolidada em quatro anos, de acordo com o previsto no artigo 54 da PNRS, será agravada, conforme já sinalizado, a partir da regulamentação por decreto do marco regulatório de saneamento (Lei 14.026/2020), "que novamente redimensiona o prazo de erradicação dos lixões no país, o que provavelmente, requer alteração na Lei 12.305/2010, conforme texto final da Lei $n^{\circ} 14.026$ de 15 de julho de 2020" (Figueiredo et al., 2020, p. 36-37).

Se continuarmos no ritmo atual de disposição final inadequada, as estimativas apontam que para o encerramento desta ação inadequada, seriam necessários mais 55 anos pela frente, conforme demonstrado no gráfico abaixo:

Figura 34 - Estimativa da evolução da disposição inadequada no Brasil

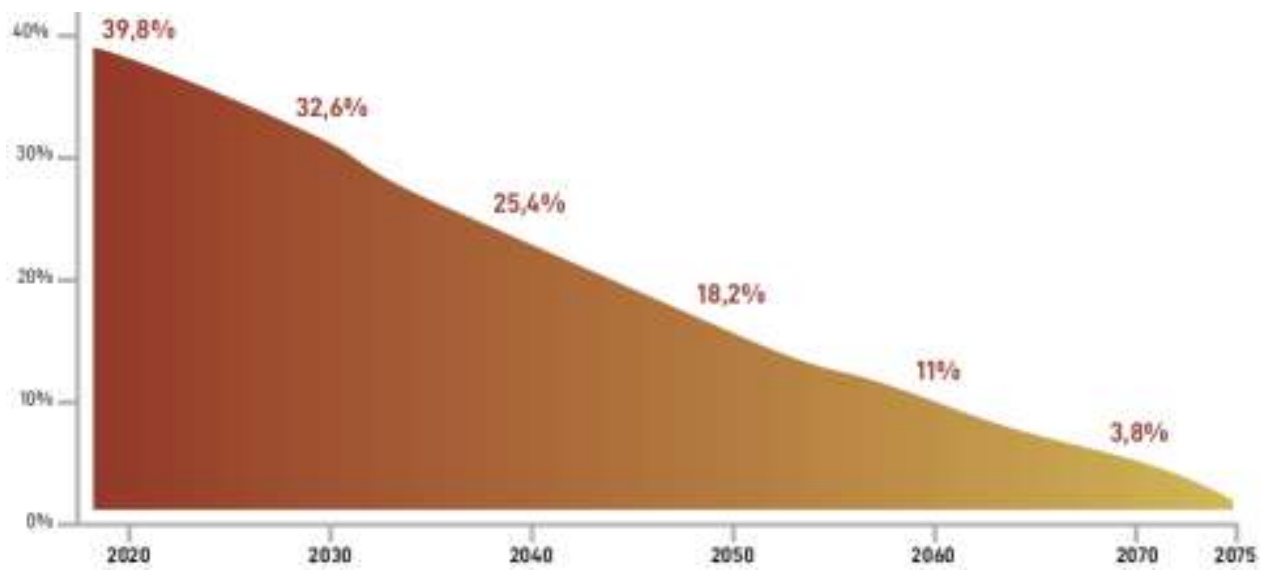

Fonte: ABRELPE, 2020. 
Alguns índices como o de cobertura da coleta de resíduos sólidos urbanos e de coleta seletiva, apresentam sinais, embora tímidos, de avanço. No entanto, no que concerne a coleta seletiva, ainda que em $2019,73,1 \%$ dos municípios tivessem alguma iniciativa, nem toda a área urbana dessas cidades foram comtempladas pela política pública de coleta seletiva, e as que contam com o serviço, ainda é muito elementar, conforme apontado pela ABRELPE (2020):

[...] a falta de separação dos resíduos reflete na sobrecarga do sistema de destinação final e na extração de recursos naturais, muitos já próximos do esgotamento. A consequência direta disso são os índices de reciclagem que, nesses dez anos da Lei Federal, permanecem em patamares inferiores a $4 \%$ na média nacional (ABRELPE, 2020, p. 33).

A coleta seletiva é um dos principais instrumentos para o alcance da meta que visa à disposição final ambientalmente adequada, pois à medida que é implementada, há o aumento dos níveis de reciclagem e mais materiais deixam de ser destinados aos aterros sanitários, porém a partir dos dados aqui expostos, é possível afirmar que a atividade não vem sendo implementada como preceitua a lei, e que em 2020, devido à pandemia ocasionada pelo Covid-19, houve mais um retrocesso, uma vez que a quantidade de resíduos recicláveis, sem o devido reaproveitamento, aumentou para aproximadamente 30\%, segundo dados da Compromisso Empresarial para Reciclagem (CEMPRE).

Os níveis de reciclagem no país ainda são muito baixos, consequência do pouco investimento em coleta seletiva, não ultrapassando os quatro por cento, apesar de decorridos dez anos da PNRS, segundo dados da ABRELPE (2020).

Apresentaremos na sequência, dados comparativos sobre a coleta e destinação correta de alguns produtos, cujo sistema de logística reversa já foi implantado, entre 2010 e 2019:

Quadro 11 - Evolução dos sistemas de logística reversa - comparação: 2010 e 2019

\begin{tabular}{|c|c|c|c|}
\hline PRODUTOS & $\mathbf{2 0 1 0}$ & $\mathbf{2 0 1 9}$ & UNIDADE DE MEDIDA \\
\hline Embalagens de defensivos & 31.266 & 45.563 & T/ano - reciclado \\
\hline agrícolas & 2.487 & $2.672^{30}$ & T/ano - incinerado \\
\hline Embalagens de óleo lubrificante & 1.149 & 5.036 & T/ano - recebido \\
\hline Pneus inservíveis & 1.118 & 4.718 & T/ano - reciclado \\
\hline & 312.000 & 471.000 & T/ano - recuperados \\
\hline
\end{tabular}

Fonte: elaboração própria baseada em ABRELPE, 2020.

${ }^{30}$ Além dessas embalagens, houve a incineração de 131 toneladas de embalagens com sobras pós-consumo líquidas e sólidas. 
Para outros produtos, também nocivos ao meio ambiente e a saúde humana se descartados inadequadamente, como medicamentos, eletroeletrônicos e seus componentes, baterias de chumbo-ácido inservíveis e embalagens de aço, é recente ou ainda segue em processo de implementação, o sistema de logística reserva, não sendo possível fazer uma comparação nesse período de dez anos, após a PNRS ser sancionada e os acordos setoriais terem sido implantados.

Quadro 12 - Celebração de Acordos Setoriais e outros instrumentos

\begin{tabular}{|c|c|}
\hline Acordos Setoriais/áreas & Status atual \\
\hline $\begin{array}{l}\text { Embalagens Plásticas de Óleos } \\
\text { Lubrificantes }\end{array}$ & $\begin{array}{l}\text { Acordo setorial celebrado em 19/12/2012 e publicado em } \\
\qquad 07 / 02 / 2013\end{array}$ \\
\hline $\begin{array}{l}\text { Lâmpadas Fluorescentes de Vapor } \\
\qquad \text { de Sódio e } \\
\text { Mercúrio e de Luz Mista. }\end{array}$ & $\begin{array}{l}\text { Acordo setorial celebrado em } 27 / 11 / 2014 \text {. Publicado em } \\
\qquad 12 / 03 / 2015 .\end{array}$ \\
\hline Embalagens em Geral. & $\begin{array}{l}\text { Acordo setorial celebrado em } 25 / 11 / 2015 \text {. Publicado } \\
\qquad \text { em } 27 / 11 / 2015 .\end{array}$ \\
\hline $\begin{array}{l}\text { Produtos Eletroeletrônicos e seus } \\
\text { Componentes. }\end{array}$ & $\begin{array}{l}\text { Acordo setorial celebrado em 31/10/2019. Publicado em } \\
\qquad 19 / 11 / 2019 . \\
\text { Decreto no } 10.240 \text { assinado em 12/02/2020. Publicado em } \\
13 / 02 / 2020 .\end{array}$ \\
\hline Embalagens de Aço & $\begin{array}{l}\text { Celebração de Termo de compromisso assinado em } \\
\text { 21/12/2018. Publicado em 27/12/2018, mas não } \\
\text { estabelecido como Acordo Setorial. }\end{array}$ \\
\hline Medicamentos & $\begin{array}{l}\text { Decreto no } 10.388 \text {, assinado e publicado em 05/06/2020, } \\
\text { mas não oficializado como Acordo Setorial. }\end{array}$ \\
\hline Pilhas e Baterias & Resolução nº 401 de 04/11/2008 \\
\hline Pneus & Resolução Conama no 416/2009 \\
\hline Agrotóxicos & Resolução Conama no 465/2014 \\
\hline
\end{tabular}

Fonte: Bastos, 2020 - adaptado das informações disponíveis em site do MMA ${ }^{31}$.

31 Informações cedidas por Valéria Pereira Bastos, de uma obra sua já aprovada, mas que aguarda publicação, por isso não consta nas referências bibliográficas. 
Não por acaso, o termo logística reversa aparece mais de setenta vezes na terceira edição da PNRS de 2017, porém é sabido que apesar de ser importante no ciclo de vida dos produtos, ainda não é posto em prática de acordo com a importância que Ihe foi atribuído na Lei 12.305/2010.

A inclusão socioprodutiva dos catadores nas atividades que englobam a responsabilidade compartilhada pelo ciclo de vida dos produtos, não vem ocorrendo como previsto, isto é, de forma sistemática e continuada, pois o que se observa são ações pontuais em eventos, mas sem continuidade. Os responsáveis pelos serviços públicos de limpeza urbana e de manejo de resíduos sólidos que deveriam priorizar o pagamento da prestação de serviços por cooperativas ou mesmo de outros formatos de associação de catadores de materiais potencialmente reutilizáveis e recicláveis, não o fazem, conforme previsto em lei. E como reflexo desse descaso, segundo Figueiredo et al. (2020):

[...] de um universo estimado de um milhão de pessoas, que afirmam retirar das atividades relacionas aos materiais recicláveis, menos de 50 mil atuam sob chancela das prefeituras (MNCR, 2019). Ou seja, temos uma massa cinzenta de trabalhadores desconhecidos que perambulam pelos lixões públicos e clandestinos e nas ruas das cidades brasileiras e que são responsáveis por abastecer a indústria da reciclagem em aproximadamente $90 \%$ de todo o material coletado (Figueiredo et al., 2020, p. 38).

São lentos ou mesmo estagnados, os passos rumo à implementação da PNRS. Muitas vezes os resultados são mascarados, sendo medidos "em horas de treinamento, eventos e seminários, passando a impressão para aqueles que não acompanham de perto, a sensação de que a PNRS realmente avança" (Teodósio, 2016, p. 32), porém quando analisados e comparados os dados, depois de dez anos, verificamos que foram poucos os avanços. $E$ isso se deve as fragilidades na sua efetivação, decorrentes, segundo Jardim (2018):

[...] da perda de relevância do tema resíduos no planejamento governamental de longo prazo, da baixa execução orçamentária e financeira das ações destinadas à implantação da PNRS, da descontinuidade do aporte de recursos aos entes federados e aos consórcios públicos para a elaboração de planos de resíduos sólidos, da baixa efetividade nas capacitações realizadas pelo Ministério do Meio Ambiente - MMA, da atuação insuficiente do Comitê Interministerial da PNRS no apoio e na estruturação da política e dos problemas relacionados à versão atual do Sistema Nacional de Resíduos Sólidos - SINIR, que não atende ao previsto no Decreto no 7.404/2010 (Jardim, 2018, p. 131-132).

E como consequência, passada uma década, Jardim (2018) aponta que o país até hoje não publicou o Plano Nacional de Resíduos Sólidos, são muitos os Estados que não têm pronto o seu Plano Estadual de Resíduos Sólidos e 
seguindo no mesmo caminho, uma parcela dos municípios do país, também não finalizou ou tornou público, o que está previsto em lei - o Plano Municipal de Resíduos Sólidos.

Portanto, a partir dos pontos que adotamos como base para nossa breve análise, é possível afirmar que o atual cenário da PNRS brasileira, não apresenta índices efetivos de práticas adequadas de disposição final de resíduos, tanto no que diz respeito a coleta e destinação final, bem como a inclusão socioprodutiva dos catadores de materiais recicláveis, pois o preceituado na Lei 12.305/2010, não tem se efetivado, deixando, dessa forma, as metas longe de serem alcançadas.

Em se tratando da política pública de gestão integrada dos resíduos sólidos da Colômbia, devido ao pouco tempo da lei sancionada, aliada à escassez de dados, conforme já mencionado, tomaremos como base para nossa análise os seguintes elementos: prevenção da geração de resíduos e erradicação das formas inadequadas de disposição final, conforme indicado no Documento CONPES 3874 e em dados dos informes nacionais de aproveitamento e de disposição final dos resíduos sólidos, dos anos de 2016 e de 2018 - último a ser disponibilizado.

Ao longo de 2016, a Colômbia destinou aproximadamente 11.300.794 de toneladas de resíduos sólidos, chegando em 2018, a cerca de 11.305.145. Os números apontam, portanto, que na contramão do Documento CONPES 3874, onde a prevenção da geração está prevista, que nesses dois anos, apesar de pequeno, ao invés de redução houve na verdade um acréscimo em torno de 4.351 toneladas do volume disposto, o que pode indicar que ocorreu um aumento na geração de resíduos.

No que concerne aos espaços onde esses resíduos são dispostos, segundo o Informe de Disposición Final de 2016, existiam 275 lugares destinados a receber os resíduos gerados no país, entre esses alguns adequados e outros inadequados. E em 2018, esse número sobe para 308, segundo o documento de mesmo nome - publicação de 2019. Quando comparamos os dados entre 2016 e 2018, temos o seguinte cenário:

Quadro 13 - Formas de disposição final dos RS na Colômbia - 2016 e 2018

\begin{tabular}{|c|c|c|c|}
\hline Sistemas & $\mathbf{2 0 1 6}$ & $\mathbf{2 0 1 8}$ & Classificação \\
\hline Aterros sanitários & 158 & 174 & Adequados \\
\hline Células de contingência & 13 & 15 & \\
\hline
\end{tabular}




\begin{tabular}{|c|c|c|c|}
\hline Plantas de tratamento & 6 & 3 & \\
\hline Lixões a céu aberto & 54 & 101 & \multirow[t]{3}{*}{ Inadequados } \\
\hline Células transitórias & 34 & 15 & \\
\hline $\begin{array}{c}\text { Outros (enterramento, } \\
\text { queima) }\end{array}$ & 8 & - & \\
\hline Sem informação & 2 & - & - \\
\hline
\end{tabular}

A partir destes números, nota-se que houve um aumento de pontos de disposição final considerados no país como ambientalmente adequado, passando de 177 em 2016, para 192 em 2018. Porém, ao mesmo tempo, também houve um crescimento do número de formas inadequadas, sendo contabilizadas 96 em 2016 e 116 em 2018, portanto, não dando os primeiros passos rumo à previsão de erradicação das formas inadequadas de disposição final, preceituada na PNGIRS.

Dos 1.102 municípios colombianos, no ano de 2016, 915 eram atendidos por sistemas adequados de disposição final, enquanto 105 utilizavam a disposição final inadequada e 82 municípios não informaram qual tipo de sistema empregavam. Em 2018, o número de municípios colombianos permaneceu o mesmo, porém, 994 passaram a usar a disposição final adequada, 116 continuaram a dispor seus resíduos em lugares considerados inadequados e para o restante dos municípios, não identificamos essa informação.

A meta de $83 \%$, prevista no Plan Nacional de Desarrollo 2014-2018, no tocante a quantidade de municípios cuja disposição final dos resíduos deveria ser em lugares autorizados, foi alcançada em seu último ano. Em 2016 essa taxa foi $82.21 \%$ e em 2018 alcançou os $83,76 \%$.

No que diz respeito à promoção do aproveitamento dos resíduos sólidos, no ano de 2016, de acordo com as informações passadas ao Sistema Único de Información (SUI), a Colômbia reciclou 97.905 mil toneladas. Já em 2018, os prestadores da atividade de reaproveitamento, informaram a essa instituição, ter recuperado cerca de 974.000 mil toneladas. Na sequência, apresentamos um gráfico com a comparação do volume aproveitado, entre os anos de 2016 e 2018: 
Figura 35 - Toneladas aproveitadas por ano - segundo informações passadas a SUI Colômbia

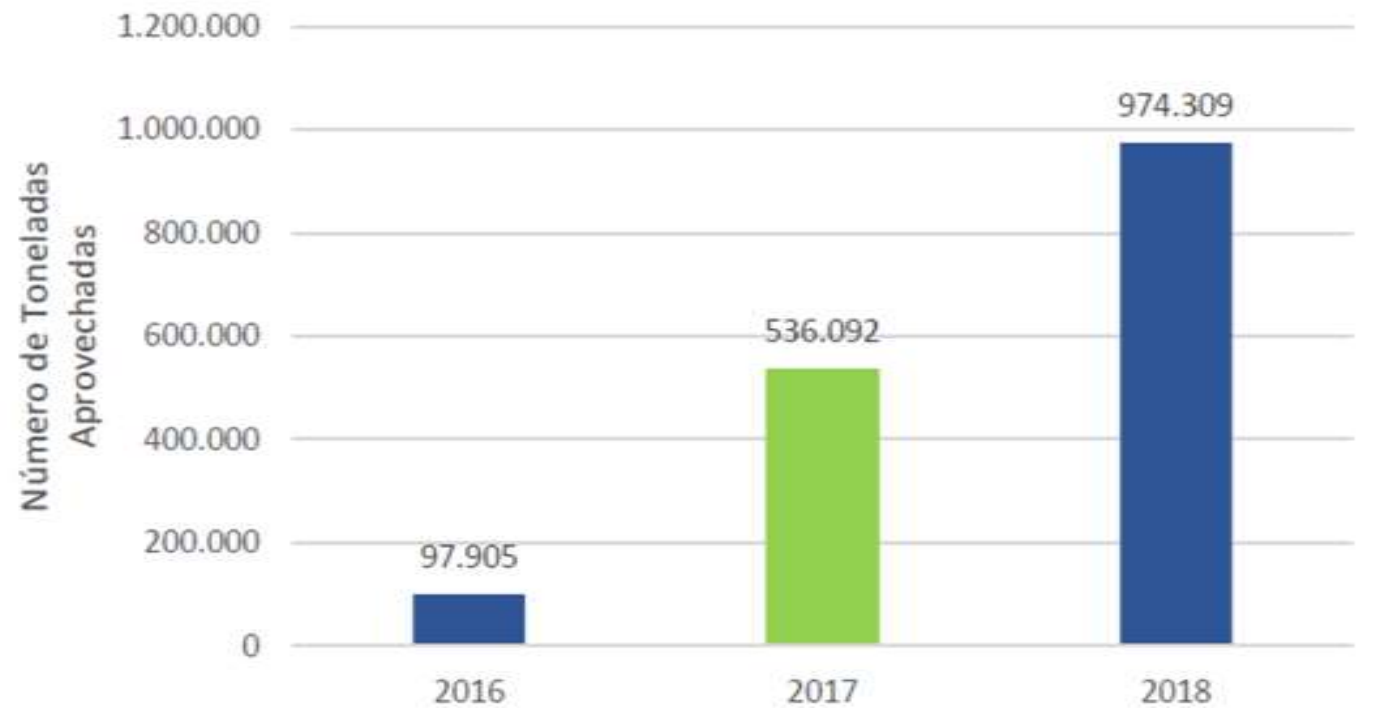

Fonte: Colômbia - Informe Sectorial de la Actividad de Aprovechamiento - 2018.

Os números apontam um crescimento muito expressivo, num curto espaço de tempo, porém deve ser levada em conta a formalização da atividade de aproveitamento no ano de 2016, fazendo com que as organizações de recicladores buscassem se tornar formais, passando, portanto, a ter de fornecer informações do volume de resíduos recuperados aos órgãos oficiais, uma vez que para receber o pagamento pelo serviço prestado, se faz necessário apresentar o balanço do montante recolhido, para posteriormente serem remunerados pelo serviço realizado, o que pode ter influenciado alguns resultados. $O$ exposto no trecho abaixo ratifica a afirmação:

Los prestadores de la actividad de aprovechamiento deben reportar mensualmente las toneladas efectivamente aprovechadas provenientes de la prestación integral del servicio. Con la información reportada, la SSPD realiza una publicación mensual a través de la página web, en donde se relaciona el reporte histórico de los prestadores a nivel nacional. De acuerdo con la información reportada, los operadores de recolección y transporte de no aprovechables realizan el cálculo tarifario para realizar el pago de la actividad a los prestadores de aprovechamiento (Colombia-SSPD, 2019, p. 17).

A figura 36, expressa o descrito acima, pois demonstra o crescimento no número de organizações de recicladores que passaram a fornecer informação a respeito da recuperação de recicláveis às instituições oficiais. 
Figura 36 - Total de organizações de recicladores que reportam informação da atividade de aproveitamento às instituições oficiais - 2016 a 2018

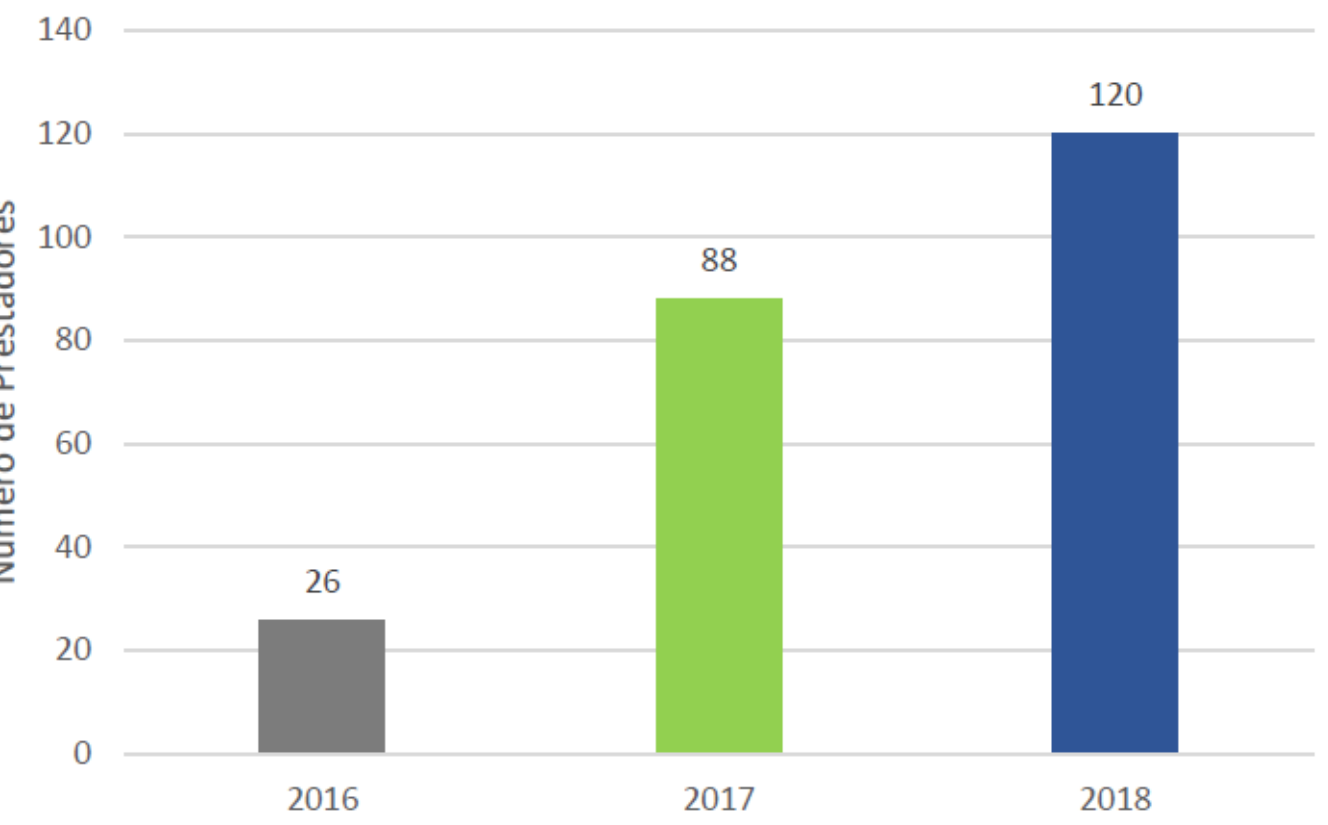

Fonte: Colômbia - SSPD, 2019.

Os catadores/recicladores são, portanto, tanto na Colômbia quanto no Brasil, trabalhadores importantíssimos no processo de reciclagem, contribuindo diretamente na redução do volume de material enviado para disposição final, e consequentemente para a preservação do meio ambiente, porém como veremos no capítulo IV, ainda são muitas as vulnerabilidades a que estão expostas essas pessoas.

Entendemos que o período analisado é curto e, além disso, não identificamos dados mais recentes, seja de 2019 ou de 2020, referentes aos resíduos sólidos colombianos, o que implica na existência de poucos elementos para análise, o que não nos permitiu avançar com base em um maior número de dados, como foi o caso da PNRS brasileira, que caminha rumo ao seu décimo primeiro ano. Porém, quando comparados os resultados desses dois anos, não identificamos muito avanços, o que aponta para a necessidade de maior empenho para que daqui a seis anos, não se olhe para trás e veja que o ponto de chegada não foi o almejado, como aconteceu no Brasil, em uma década da política. 


\section{4 \\ Rocinha e Siloé: apresentação e análise dos resultados a partir da fala dos sujeitos}

Cabe neste item evidenciar, inicialmente, que apesar do estudo ter como pano de fundo a questão das formas de destinação e tratamento dos resíduos sólidos em áreas precarizadas, o ponto central de nossa atenção tem relação direta com a importância da busca por melhores alternativas no que diz respeito a coleta de resíduos sólidos em favelas no Brasil e em bairros populares na Colômbia, objetivando a melhoria das condições da qualidade de vida das pessoas que são invisibilizadas nesses lugares, e muitas vezes culpabilizadas pelo trato e destinação inadequados dos resíduos gerados nos seus espaços de convivência.

Neste sentido, a temática dos resíduos sólidos em favelas e bairros populares, como a Rocinha no Rio de Janeiro/Brasil e em Siloé em Cali/Colômbia, tem se mostrado um problema pela ineficácia das políticas públicas; sobretudo as urbanas, nesses territórios.

Consideramos relevante evidenciar que conforme aponta Behring (2013, p. 12-13), o "estudo comparativo permite identificar tendências gerais, estabelecer correlações, apanhar mediações que se produzem na totalidade concreta, e identificar novos elementos a partir de um patamar de observação reposicionado".

Com esse sentido, buscaremos por intermédio das análises que serão apresentadas, traçar as linhas que permitam identificar compassos e descompassos entre o que existe no Brasil em termos de prática adequada ou inadequada de destinação de resíduos sólidos nas favelas, bem como identificar a posição dos moradores, dos agentes públicos, dos catadores e das organizações da área de reciclagem no caso da Rocinha, assim como as ações praticadas em Siloé na Colômbia, por meio dos mesmos segmentos sociais, apontando então o que os aproximam, bem como o que os diferenciam.

O consumo nessas áreas assim como nos demais setores da sociedade, tem aumentado consideravelmente, e consequentemente o volume de resíduos gerados e destinados inadequadamente também. A diferença é que nas áreas nobres da cidade os serviços de limpeza urbana apresentam uma qualidade que não é vista nas áreas populares, onde não são abrangentes, ou seja, não 
chegam diretamente à casa de inúmeras pessoas, e quando chegam, nem sempre são executados como deveriam, sendo, portanto, distinta a gestão dos resíduos sólidos, entre os bairros ditos formais e na favela/bairro popular.

A precarização de serviços nessas áreas há muitos anos vem sendo justificada pelo fato de as empresas de limpeza urbana esbarrarem na deficiente infraestrutura desses locais, como podemos ver no trecho de um texto intitulado "Solução para remoção de lixo nas favelas: um projeto de estudo", escrito em 1985:

A dificuldade das companhias de limpeza urbana em recolher o lixo, devido ao traçado irregular dos arruamentos, dimensões incompatíveis com os equipamentos convencionais e a topografia irregular da região são razões para que o serviço de limpeza retire apenas cerca de $30 \%$ do lixo produzido nas favelas, apesar de diversas tentativas e do esforço em se desenvolver tecnologias alternativas para viabilizar a solução do problema do lixo nas favelas (Cynamon et al., 1985, p. 35-36).

Portanto, esse é um problema que perdura ao longo dos tempos, havendo inclusive estudos, como o próprio texto citado acima, da década de 1980, onde a Escola Nacional de Saúde Pública apontava práticas adequadas de destinação, já naquela época, para que o serviço de coleta chegasse a todas às áreas, mesmo nos becos e vielas das partes altas das áreas populares, conforme trecho que segue:

c) Em certas situações de favelas de morros ou mesmo favelas planas irregulares, propõe-se um pequeno carrinho de mão especialmente desenhado para o transporte dos latões, que pode ser inclusive guiado através de degraus de escada até o ponto onde deve ser deixado para aguardar a coleta do caminhão. d) Sistema de transporte dos latões, por meio da transformação do teleférico atualmente em uso experimental, quando não for viável a descida do latão por meio do carrinho de mão (Cynamon et al., 1985, p. 37-38).

Partindo do princípio de que soluções existem, mas que por diferentes fatores não são operacionalizadas nas áreas de favelas e/ou em bairros populares, passaremos a apresentar nossas análises, considerando as falas dos sujeitos que elegemos como fundamentais para o estudo.

Apresentaremos nos itens que constituem o capítulo, os conteúdos das entrevistas, realizadas com cada segmento por entendermos que são relevantes, porém, conforme aponta (Gil, 1988, p. 58), um estudo comparativo "é caracterizado pelo estudo profundo e exaustivo de um ou de poucos objetos, de maneira que permita o seu amplo e detalhado conhecimento". Sendo assim, nos ateremos aos pontos específicos em cada grupo, buscando fazer a análise 
apoiada em autores que contribuirão para a fundamentação teórica das questões apresentadas.

Cabe ressaltar que apesar do instrumental da pesquisa ter sido construído com perguntas diferenciadas em razão da natureza e visão de cada grupo, algumas questões, como a voltada para 0 entendimento sobre a responsabilidade do descarte inadequado de resíduos sólidos, se mostrou presente nos diferentes grupos, mesmo sem uma indagação direta a respeito, e o que mais nos chamou atenção, foi a incidência de culpabilização dos menos favorecidos, ou seja, os moradores.

A culpabilização da pobreza perdura ao longo dos tempos, sendo o discurso culpabilizador observado nos mais diversos segmentos sociais, como se os pobres, que são os que mais sofrem as consequências decorrentes das desigualdades, fossem os responsáveis pelas diversas mazelas socioambientais a que estão expostos.

O percurso e o instrumental utilizado na pesquisa já foram explicitados na introdução, mas considerando a importância da preservação das identidades, empregaremos ao apresentar as falas e nossas análises, o uso de uma identificação através de siglas, objetivando resguardar o sigilo e a confidencialidade dos entrevistados, a saber:

Quadro 14 - Tabela de siglas de identificação dos sujeitos da pesquisa

\begin{tabular}{|c|c|c|}
\hline Grupo entrevistado & Siglas Rocinha & Siglas Siloé \\
\hline $\begin{array}{l}\text { Moradores brasileiros e } \\
\text { colombianos }\end{array}$ & $\begin{array}{l}\text { MBR1, MBR2, MBR3, MBR4, } \\
\text { MBR5, MBR6, MBR7, MBR8, } \\
\text { MBR9, MBR10. }\end{array}$ & $\begin{array}{lll}\text { MCOL1, } & \text { MCOL2, } & \text { MCOL3, } \\
\text { MCOL4, } & \text { MCOL5, } & \text { MCOL6, } \\
\text { MCOL7, } & \text { MCOL8, } & \text { MCOL9, } \\
\text { MCOL10. } & & \end{array}$ \\
\hline $\begin{array}{l}\text { Representante da empresa } \\
\text { de limpeza urbana brasileira } \\
\text { e colombiana }\end{array}$ & ELUBR1. & ELUCOL1. \\
\hline $\begin{array}{l}\text { Organização de catadores } \\
\text { brasileira e Organizações de } \\
\text { recicladores colombianas }\end{array}$ & OCBR1. & ORCOL1, ORCOL2. \\
\hline $\begin{array}{l}\text { Catadores de material } \\
\text { reciclável brasileiros e } \\
\text { Recicladores colombianos }\end{array}$ & CMRBR2, & RCOL1, RCOL2, RCOL3. \\
\hline $\begin{array}{l}\text { Comércio brasileiro e } \\
\text { colombiano }\end{array}$ & CBR1, CBR2, CBR3. & CCOL1, CCOL2, CCOL3. \\
\hline
\end{tabular}

Fonte: elaboração própria. 
A seguir apresentaremos as análises por grupos e procuramos organizar as informações por meio de um quadro demonstrativo onde serão ilustradas de um lado as falas e/ou características da Rocinha e do outro lado os dados referentes a Siloé, considerando os pontos, conforme já sinalizados, que nos permitiram conhecer, mensurar e identificar similitudes e diferenças, na busca de sistematização do contexto de comparações no que diz respeito às falas dos sujeitos pesquisados tanto no Brasil como na Colômbia .

4.1.

A visão dos moradores sobre a forma de destinação dos resíduos sólidos a partir de cada lócus pesquisado.

Consideramos relevante iniciar o item apresentando um breve quadro do perfil dos moradores entrevistados, no sentido de identificar a partir de algumas características como: idade, naturalidade, gênero, ocupação e tempo de residência nas áreas, o lugar de fala de cada um.

Quadro 15 - Perfil dos moradores entrevistados

PERFIL DOS MORADORES

\begin{tabular}{|c|c|c|}
\hline Questões & Rocinha & Siloé \\
\hline Idade & $\begin{array}{l}\text { Entre } 19 \text { e } 59 \text { anos, sendo que } \\
70 \% \text { têm acima de } 41 \text { anos. }\end{array}$ & $\begin{array}{l}\text { Entre } 32 \text { e } 78 \text { anos, sendo que } \\
60 \% \text { têm acima de } 57 \text { anos. }\end{array}$ \\
\hline Gênero e número & $\begin{array}{l}\text { Mulheres: } 04 \\
\text { Homens: } 06 .\end{array}$ & $\begin{array}{l}\text { Mulheres: } 07 \\
\text { Homens: } 03 .\end{array}$ \\
\hline Lugar de nascimento & $\begin{array}{l}\text { Rio de Janeiro: } 06 ; \\
\text { Vassouras: } 01 \\
\text { Duque de Caxias: } 01 \\
\text { Fortaleza: } 01 ; \\
\text { Mascote-Bahia: } 01 .\end{array}$ & $\begin{array}{l}\text { Cali: 06; } \\
\text { Cauca: 02; } \\
\text { Versalles: } 01 \\
\text { Tocaima: } 01 .\end{array}$ \\
\hline Ocupação/Profissão & $\begin{array}{l}\text { Assistente social: } 03^{32} \\
\text { Geógrafo: } 02 \\
\text { Pedagoga: } 01 \\
\text { Designer: } 01 \\
\text { Advogado/autônomo: } 01 \\
\text { Eletricista: } 01 \\
\text { Estudante: } 01\end{array}$ & $\begin{array}{l}\text { Jornalista/comunicador social: } 01 \\
\text { Pesquisador social: } 01 \\
\text { Comerciante: } 01 \\
\text { Autônomos: } 02 \\
\text { Dona de casa: } 05\end{array}$ \\
\hline Há quantos anos reside & Entre 12 e 45 anos, sendo que & Entre 04 e 60 anos, sendo que \\
\hline
\end{tabular}

32 Uma destas pessoas atua como Conselheira Tutelar no momento. 


\begin{tabular}{|c|c|c|}
\hline no território & $80 \%$ moram há 25 ou mais. & $70 \%$ moram há 32 ou mais. \\
\hline $\begin{array}{l}\text { Sub-bairro/bairro onde } \\
\text { reside }\end{array}$ & $\begin{array}{l}\text { Trampolim, Vila Verde, } \\
\text { Cachopa, Paula Brito, Dioneia, } \\
\text { Sete, Rua 2, Atalho e } \\
\text { Laboriaux. }\end{array}$ & $\begin{array}{l}\text { Belisário Caicedo, Cañavelarejo, } \\
\text { Lleras Camargo, Brisas de Mayo, } \\
\text { Siloé e San Francisco. }\end{array}$ \\
\hline
\end{tabular}

Fonte: elaboração própria com base nas entrevistas realizadas.

As pessoas entrevistadas têm entre 19 e 78 anos, sendo o número de participantes equilibrado entre homens e mulheres - com uma pequena diferença e a maioria é nascida nas cidades onde a pesquisa se deu. No campo da Rocinha, um número expressivo de entrevistados tem curso superior, enquanto em Siloé somente dois participantes da pesquisa têm esse grau de escolaridade, se sobressaindo nessa localidade, o número de donas de casa. O grupo de entrevistados reside nessas áreas entre 04 e 60 anos e moram em distintos lugares desses territórios, desde a parte baixa até a parte alta. Territórios esses, que segundo Santos et al. (2007), conforme apontado anteriormente, não são somente um conjunto de sistemas naturais e de sistemas de coisas superpostas, tendo que serem apreendidos enquanto territórios usados, o que implica pensálos não em seu sentido literal, tendo em vista que eles se constituem enquanto territórios usados, que quer dizer, o chão mais a identidade. Sendo a identidade, o sentimento de pertencer ao que nos pertence. O território configura-se, deste modo, como o fundamento do trabalho; como o lugar da morada, das trocas tanto materiais quanto espirituais e do exercício da vida.

A questão dos resíduos sólidos tanto na Rocinha quanto em Siloé, não muito diferente do que ocorre em muitas das áreas populares mundo afora, se constitui em um problema a ser pensado com a devida atenção que requer, porém nos dias de hoje:

\footnotetext{
Ainda existe muita resistência para que o processo de tratamento e gestão adequada dos RSU ocorra do modo esperado, principalmente nas favelas, o que desafia as atuações do poder público e dos planejadores urbanos. O destino desses resíduos, acrescido a outros problemas sanitários e ambientais, é uma questão que instiga o saneamento urbano (Schueler et el., 2018, p. 215).
}

Em se tratando dessa questão nos campos estudados, na Rocinha todos os entrevistados reconhecem que é um problema a ser enfrentado, apontando a deficiência do serviço prestado e algumas falas assinalam que a coleta seletiva (sobre a qual versamos no Capítulo III) seria uma aliada para amenizar essa questão, tendo em vista o grande volume de resíduo gerado e a riqueza do material descartado nesse território. No que diz respeito aos participantes de 
Siloé, uma parte entende que sim, que esse é um dos problemas da área onde vivem; quando avaliaram a questão positivamente, atribuíram isso ao serviço que é prestado, porém os que veem como um problema, o relaciona a falta de educação e a falta de consciência da população. A título de ilustração, a seguir trazemos algumas dessas falas:

Quadro 16 - Fala dos moradores sobre a problemática dos resíduos sólidos no seu local de moradia

\section{Rocinha}

problema do lixo [na Rocinha] é histórico e é inaceitável que ainda exista nos dias de hoje. É triste que não se tenha soluções para esse problema, ainda mais sabendo o potencial de parte do lixo, que poderia ser reciclado (MBR3. Entrevista concedida a Maria Izabel de Carvalho. Rio de Janeiro, 23 jun. 2020).

Muito sério, pois falta uma política de estado para educação socioambiental, e o mais triste, existem iniciativas nas favelas que as autoridades não querem dialogar; e mais, se omitem em se aproximar (MBR7. Entrevista concedida a Maria Izabel de Carvalho. Rio de Janeiro, 11 abr. 2020).

O problema do lixo é uma questão muito séria a ser discutida na Rocinha. Em 2019 no contexto das enchentes vivemos momento de terror na Favela, pessoas morreram em virtude das fortes chuvas, sabemos que o lixo é um aliado nesses momentos trágicos. A coleta de lixo da Rocinha não é pensada de forma efetiva, não contempla toda a população. Precisa-se

\section{Siloé}

El tema de las basuras, a pesar del servicio de recolección, es algo complejo. $\mathrm{La}$ comunidad no es suficientemente consiente del manejo de las mismas. El problema es que existen ciertos puntos destinados (algunas esquinas de las calles y espacios) para dejar las bolsas y residuos. Sin embargo, algunos habitantes botan la basura en cualquier lugar (MCOL4. Entrevista concedida a Maria Izabel de Carvalho. Cali, 06 nov. 2019).

Todavía hay que educar a la gente, para la selección de los residuos. Y sobre todo que cuando los que barren y recogen las basuras de las calles pase el carro y los recoja rápido para que los habitantes de calle no se roben las bolsas y el trabajo se pierde, porque riegan las basuras (MCOL1. Entrevista concedida a Maria Izabel de Carvalho. Cali, 22 out. 2019).

Ha mejorado, porque antes como vuelvo y te repito la basura la bota era allá en la cancha, entonces había como mucha cochineza, como muchos olores ¿si me entiende? porque la basura toda la botan era allá en la cancha, pero después se puso un plan sobre botar la basura abajo, porque eso ya no se podía hacer, por lo de la cañada que la tapaba, y que cuando llovía durísimo toda esa basura arrastraba hasta allá la nave. Entonces se 
entender que a Rocinha vai muito além das vias principais (Estrada da Gávea e Rua Nova), a Rocinha é atravessada por becos e vielas, onde mora a maior parte da população, nas mais diversas localidades. Por isso, podemos dizer com justificativas precisas que a Comlurb hoje não garante a coleta de lixo efetiva. Isso impacta nas mais diversas dimensões da saúde dos moradores e nas mais diversas faixas etárias, em especial às crianças que moram ainda hoje em condições precárias de moradia, em meio a valas a céu aberto pelo morro. Todo o lixo da Rocinha poderia estar sendo aproveitado de forma a garantir renda e trabalho para a população, a partir de políticas públicas e programa que potencializassem a coleta e a reciclagem do lixo na favela, impactando de forma positiva na economia local dos moradores (MBR1. Entrevista concedida a Maria Izabel de Carvalho. Rio de Janeiro, 28 abr. 2020).

Fonte: elaboração própria com base nas entrevistas realizadas.

Conforme sinalizado no preâmbulo deste capítulo, a culpabilização dos moradores é uma fala, que de alguma forma, perpassou todos os grupos entrevistados, sendo atribuída a esse segmento, a falta de educação, a falta de consciência, dentre outros desqualificadores, quase que como se isso fosse uma "patologia" das pessoas que vivem em áreas populares, como se tivessem uma "disfunção/desajuste" social e como se fosse intrínseco a esses indivíduos, o déficit educacional e a falta de capacidade. Esse discurso é incorporado inclusive pelo próprio grupo de moradores, que por vez, acaba reproduzindo a retórica entre si. Mediante essa visão sobre os moradores de áreas populares, temos assistido ao longo dos anos, como formas de enfrentamento: "o higienismo, educação e 'refuncionalização', adaptação (ou ajustamento corretivo) e 'inclusão social'. A solução da pobreza mediante a "autoajuda" e puso el este de irla a votar allá abajo, o sea, hay una parte qué le llamamos Lizandro, ahí dejan la basura y el carro de la basura viene y la recoge ahí (MCOL9. Entrevista concedida a Maria Izabel de Carvalho. Cali, 07 out. 2019). 
religião. O combate à pobreza mediante a "criminalização da pobreza" (Siqueira, 2014. p. 242).

A população dos territórios populares sofre, portanto, com o estigma que vem recaindo sobre ela ao longo dos tempos, como se as pessoas desse grupo fossem as estranhas, as diferentes, as indesejáveis, dentre outras adjetivações que lhes são atribuídas pelos ditos "normais" (os estigmatizadores), que criam preconcepções e as transformam em "expectativas normativas, em exigências apresentadas de modo rigoroso" (Goffman, 2008, p. 12). Porém, segundo Siqueira \& Cardoso (2011, p. 94), os que estigmatizam, com frequência ignoram estas preconcepções "até o surgimento de uma questão que seja efetiva para a realização de suas exigências. É neste momento que os normais podem perceber que fazem afirmações daquilo que o outro deveria ser". A esse respeito, Goffman (2008, p. 12) aponta que:

\begin{abstract}
Enquanto o estranho está à nossa frente, podem surgir evidências de que ele tem um atributo que o torna diferente de outros que se encontram numa categoria em que pudesse ser incluído, sendo, até, de uma espécie menos desejável - num caso extremo, uma pessoa completamente má, perigosa ou fraca. Assim deixamos de considerá-la criatura comum e total, reduzindo-a a uma pessoa estragada e diminuída. Tal característica é estigma, especialmente quando o seu efeito de descrédito é muito grande - algumas vezes ele também é considerado um defeito, uma fraqueza, uma desvantagem [...] (Goffman, 2008, p. 12).
\end{abstract}

Deste modo, para Goffman (2008, p. 11) "a sociedade estabelece os meios de categorizar as pessoas e o total de atributos considerados como comuns e naturais para os membros de cada uma dessas categorias".

Quanto à destinação dos resíduos sólidos pelos moradores nesses territórios, todos os entrevistados informaram fazer o descarte em alguns dos pontos estipulado pela empresa ou no caso daqueles que têm acesso a coleta porta a porta, entregam para a empresa; ou ainda, no caso de uma residente do único condomínio da Comuna 20, descarta nos dias de coleta, no próprio local, de onde o resíduo é retirado pela Ciudad Limpia. Participantes da pesquisa apontaram que algumas pessoas realizam o descarte em locais aonde a coleta não chega, como nos becos, nas encostas, etc. No caso da Rocinha, alguns entrevistados atribuíram isso às dificuldades existentes no território para a realização da destinação. Em Siloé também houve relatos de que algumas pessoas são observadas destinando o resíduo em locais indevidos, porém isso apareceu com menos frequência nas falas, nesse momento da entrevista, e quando surgiu, logo em seguida relataram que ultimamente notavam uma 
melhora no quadro; foi dito ainda, que se nota o descarte antes do dia ou hora previstos para a coleta. Vejamos as falas que seguem, sobre essa questão:

Quadro 17 - Fala dos moradores sobre a destinação dos resíduos sólidos

\section{Rocinha}

Eu jogo o meu lixo nos lugares determinados pela COMLURB, apesar de onde morar não possuir caçambas e precisarmos jogar num espaço reservado, podendo assim, acumular chorume no chão, dando mau cheiro e se tornando foco de bactérias. Meus vizinhos lamento não poder dizer o mesmo, visto que com certa frequência eles acumulam em frente a sua porta, sacolas de lixo, em vez de jogá-las fora assim que tiram de dentro de casa. Já vi moradores jogando seus lixos numa vala perto da minha casa também (MBR8. Entrevista concedida a Maria Izabel de Carvalho. Rio de Janeiro, 13 abr. 2020).

Alguns dos meus vizinhos assim como eu descartam o lixo na decida do morro, mas muitos colocam o lixo na rua para que o tratorzinho o pegue, porém, a frequência vária e por esse motivo muito lixo fica na rua, trazendo vetores e outras doenças a todos os moradores. Levar o lixo morro abaixo quando se trata de uma grande quantidade, como descarte de um móvel grande ou de entulho de obra, é bem complicado, uma vez que na favela não são oferecidos os mesmos serviços que são oferecidos nos bairros formalizados da cidade, onde $\mathrm{o}$ morador pode agendar a retirada destes dejetos pela COMLURB. Quem não tem força física ou dinheiro para pagar alguém, acaba descartando incorretamente seu lixo (MBR2. Entrevista concedida a Maria Izabel de Carvalho. Rio de Janeiro, 01 jun. 2020).

$\mathrm{Na}$ área que resido, o lixo é colocado na caçamba, tem o serviço de gari comunitário,
Siloé

Muchos vecinos esperan que pase el carro recolector, otros sacan sus bolsas desde temprano pero perros y recicladores escarban y dejan reguero de basuras. Por mi casa pasa el carro recolector los días martes, jueves y sábado en horas de la noche. En mi caso separo lo que se pudre de lo que no y entrego el material recuperable a recicladores y lo orgánico al carro recolector. (MCOL2. Entrevista concedida a Maria Izabel de Carvalho. Cali, 31 ago. 2019).

Eso es así, hay unos que saben qué días pasa el carro para recoger la basura, pero hay veces que se hacen los olvidados y no la sacan, entonces, la tienen; aunque ya ahora hoy en día ya mucha gente guarda la basura hasta el día que pasa el carro para sacarla; porque si no había veces que sacaban todas las bolsas de basura allá a la orilla del camino a dejarlas allí, pero bueno ahora ya no, ahora van acomodando la gente para sacar la basura los días que sale la basura que el carro; como decir los días martes, jueves y sábado, son 3 días en la semana (MCOL10. Entrevista concedida a Maria Izabel de Carvalho. Cali, 07 set. 2019).

La mayoría de las personas sacan las basuras el día que corresponde. 
mas não tem um sistema que comporte 0 volume diário de lixo descartado. Para alguns torna-se fácil levar até a caçamba, mas não é a realidade de muitos por questões diversas (MBR4. Entrevista concedida a Maria Izabel de Carvalho. Rio de Janeiro, 10 abr. 2020).

No tocante a destinação dos resíduos sólidos pelas pessoas que têm algum impedimento físico e que residem a longas distâncias dos pontos de descarte, foi dito que esse se constitui em um problema para esse grupo, tendo esses sujeitos que pagar alguém ou contar com a boa vontade dos vizinhos ou parentes para levar o seu resíduo; ou em último caso, realizar o descarte em locais inadequados.

Essa questão do pagamento a terceiros para que levem os resíduos até algum ponto determinado pela empresa de limpeza urbana apareceu nas falas de ambos os territórios, porém, com muita frequência, no caso de Siloé. Logo, em Siloé, quem reside nos becos e vielas, para não ter que se deslocar, às vezes opta por pagar uma pessoa que presta o serviço frequentemente, para não ter esse trabalho de ir até o ponto de descarte.

Quanto ao número de vezes por semana que os moradores retiram de suas habitações os resíduos sólidos por esses gerados, para serem entregues a empresa de limpeza urbana, identificou-se que metade dos entrevistados da Rocinha realiza o descarte todos os dias, havendo inclusive pessoas que fazem a retirada mais de uma vez por dia. Em se tratando de Siloé, oito dos dez entrevistados realizam o descarte três vezes por semana, ou seja, fazem a destinação, todos os dias que a coleta é realizada. Vide gráfico a seguir: 
Gráfico 1 - Vezes por semana que os moradores da Rocinha e de Siloé descartam os resíduos sólidos, segundo os entrevistados ${ }^{33}$

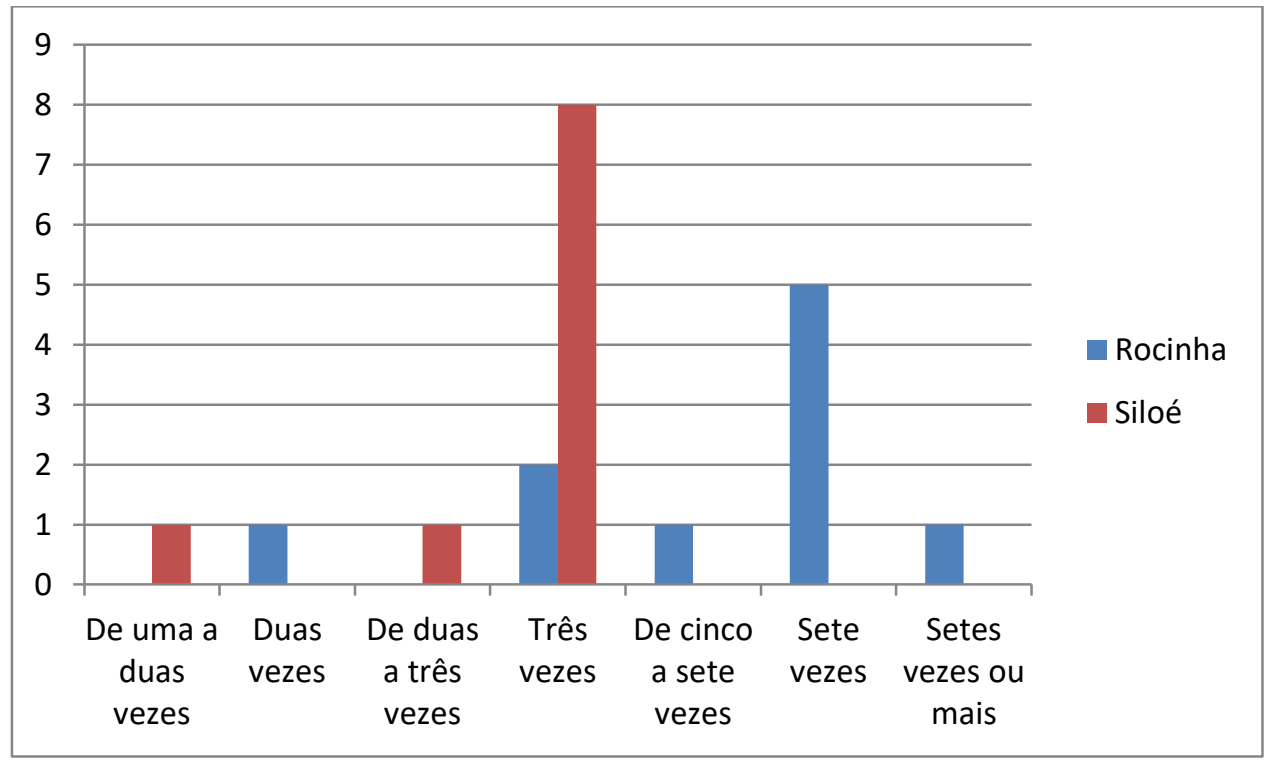

Fonte: elaboração própria com base nas entrevistas realizadas.

Com base nos números referentes ao volume de resíduos sólidos coletados na Rocinha e em Siloé, cerca de 700 toneladas por semana e aproximadamente 225 toneladas semanais consecutivamente, podemos dizer que a maior frequência de descarte semanal na Rocinha está relacionada, sobretudo, ao maior volume de resíduo gerado pela população desta localidade.

No que concerne ao descarte inadequado dos resíduos sólidos, no caso da Rocinha notamos uma pequena diferença do período das nossas entrevistas do mestrado (2015) para o atual momento, no que diz respeito à culpabilização dos moradores, pois agora, apesar de alguns entrevistados atribuírem exclusivamente a culpa pelo ato, aos residentes, foram muitas as falas que reconhecem também, a responsabilidade do poder público diante dessa situação. Notamos, sobretudo, mas não só, a culpabilização tão somente da população, entre os grupos com menor grau de instrução acadêmica, no entanto é válido ressaltar que há dentre essas pessoas, muitos que também atribuem ao poder público uma parcela de responsabilidade sobre essa problemática; assim como também há pessoas com um maior grau de instrução, que colocam a culpa pelo descarte inadequado, tão somente nos moradores. No caso de Siloé, a maioria dos entrevistados, atribuiu a culpa pelo descarte inadequado, tão somente aos moradores. A seguir trazemos algumas falas, a título de ilustração:

33 O número do eixo vertical indica o total de entrevistados (10 pessoas da Rocinha e 10 pessoas de Siloé) que responderam cada uma das opções do eixo horizontal. O mesmo se aplica para os gráficos seguintes desse subcapítulo. 
Quadro 18 - O que pensam os moradores sobre a destinação inadequada dos resíduos sólidos

\begin{tabular}{|c|c|}
\hline Rocinha & Siloé \\
\hline $\begin{array}{l}\text { O certo é colocar culpa no governo. Os políticos } \\
\text { pedem votos na comunidade nas épocas de } \\
\text { eleição, mas depois que ganham ninguém quer } \\
\text { investir na mesma. Não há uma política de } \\
\text { saneamento básico e coleta de lixo eficaz. As } \\
\text { favelas são esquecidas pelo Estado. Mas } \\
\text { também tem pessoas que não colaboram e } \\
\text { agravam a situação da insalubridade na Rocinha, } \\
\text { pois jogam seus lixos em lugares inadequados, } \\
\text { podendo inclusive, entupir bueiros (MBR8. } \\
\text { Entrevista concedida a Maria Izabel de Carvalho. } \\
\text { Rio de Janeiro, } 13 \text { abr. 2020). }\end{array}$ & $\begin{array}{l}\text { Pues creo que esto viene } \\
\text { primeramente por casa. Debemos } \\
\text { tomar conciencia, y segundo por los } \\
\text { entes encargados, que en ocasiones } \\
\text { no pasan por las basuras los días } \\
\text { indicados, o muy insuficiente el } \\
\text { suministro de Tinas o tanques de } \\
\text { basura para los barrios donde la } \\
\text { entrada de los camiones de } \\
\text { recolección no es tan fácil. (MCOL1. } \\
\text { Entrevista concedida a Maria Izabel } \\
\text { de Carvalho. Cali, } 22 \text { out. 2019). }\end{array}$ \\
\hline $\begin{array}{l}\text { As pessoas erradamente afirmam que a culpa é } \\
\text { dos moradores, mas ocorre que a culpa é de } \\
\text { diferentes esferas. Primeiramente não se tem } \\
\text { variedade e locais acessíveis para o descarte, } \\
\text { não existe um sistema que possa periodicamente } \\
\text { retirar esses lixos nas portas das casas em } \\
\text { determinado dia e horário. E mesmo quando o } \\
\text { lixo é jogado nas lixeiras da Comlurb, por } \\
\text { estarem em locais inapropriadas, esse lixo é } \\
\text { levado pela chuva. Além disso, falta a } \\
\text { conscientização da população sobre o descarte } \\
\text { correto, mas esse é um problema da base da } \\
\text { educação e deve ser ensino desde os pequenos } \\
\text { aos adultos (MBR3. Entrevista concedida a Maria } \\
\text { lzabel de Carvalho. Rio de Janeiro, } 23 \text { jun. 2020). }\end{array}$ & $\begin{array}{l}\text { Pues la culpa nos la echamos } \\
\text { nosotros mismos, porque nosotros } \\
\text { mismos somos los que hacemos la } \\
\text { basura y la dejamos en cualquier } \\
\text { parte (MCOL10. Entrevista } \\
\text { concedida a Maria Izabel de } \\
\text { Carvalho. Cali, } 07 \text { set. 2019). }\end{array}$ \\
\hline $\begin{array}{l}\text { A culpa é principalmente do morador da } \\
\text { localidade (MBR6. Entrevista concedida a Maria } \\
\text { Izabel de Carvalho. Rio de Janeiro, } 11 \text { abr. 2020). }\end{array}$ & $\begin{array}{l}\text { Pues se les echa la culpa a las } \\
\text { personas, porque es culpa de } \\
\text { nosotros las personas cuando no } \\
\text { sacamos la basura y la echamos } \\
\text { allá, cosas así... (MCOL9. Entrevista } \\
\text { concedida a Maria lzabel de } \\
\text { Carvalho. Cali, } 07 \text { set. 2019). }\end{array}$ \\
\hline
\end{tabular}

Fonte: elaboração própria com base nas entrevistas realizadas. 
Quando se trata do descarte inadequado dos resíduos sólidos em áreas populares, a análise requer a compreensão da complexidade do processo, visto que são muitos os fatores que devem ser levados em consideração, como, a dificuldade de mobilidade das pessoas que têm comprometimento da saúde e/ou idosas, tendo em vista que normalmente precisam caminhar longas distâncias para descartar os resíduos em um dos pontos determinados pelas empresas de limpeza urbana (o que é muito comum, sobretudo no caso da Rocinha), e o deslocamento por becos estreitos e escadarias, dentre outros obstáculos, são fatores de risco tanto a saúde das pessoas, como no comprometimento ambiental. Conforme, Schueler et al. (2018), apontam que:

\begin{abstract}
A alta densidade habitacional e o baixo percentual relativo de áreas públicas, complementado pela inexistência ou pouca quantidade de vias carroçáveis, torna as comunidades de baixa renda locais extremamente difíceis em relação a disposição e coleta dos RSU. O pouco espaço e as más condições para dispor os descartes diários, temporariamente, no interior das moradias, favorece que sejam dispostos nas ruas logo que gerados, normalmente muito antes do recolhimento público ser feito. Assim, as já estreitas ruas (quando existem) recebem esse lixo, que fica exposto a chuva, animais e transeuntes. No caso de comunidades situadas em encostas, a situação sanitária e ambiental tende a se agravar. A dificuldade do recolhimento junto com a necessidade de descarte muitas vezes leva o lixo para as encostas, o que aumenta a quantidade de vetores, contribui para a erosão do solo e reduz, ainda mais, a possibilidade de coleta (Schueler et al., 2018, p. 219).
\end{abstract}

Diversos fatores impactam essa realidade, um deles são as condições das moradias, pois reconhecemos o fato de muitas habitações serem pequenas e apresentarem más condições, contudo não devemos generalizar, tendo em vista também que há nesses locais, apesar de não ser regra, residências grandes e com excelentes condições de habitabilidade, logo, novamente ratificamos a complexidade de análise do contexto tanto na Rocinha como em Siloé, sendo necessário considerar todas as variáveis que envolvem a questão.

Deste modo, outro ponto que deve ser considerado é que as formas de destinação de resíduos sólidos também são determinadas pela diversidade de geradores locais, portanto, não são apenas as condições físicas das moradias que determinam um processo de geração e destinação favorável ou desfavorável. Embora as residências sejam (ou pareçam ser) o principal gerador de resíduos em bairros populares e favelas, o comércio e o setor institucional são importantes geradores nesses espaços.

Estes aspectos também ganham relevância na visão dos moradores, pois quando perguntados se já tiveram ou se conheciam alguém que teve problema ou prejuízo causado por incidente ou "acidente ambiental", em decorrência do 
descarte inadequado de resíduos sólidos, nove dos dez entrevistados tanto da Rocinha quanto de Siloé, disseram ter tido ou conhecido alguém que sofreu com essa situação, conforme dados expostos nos gráficos abaixo:

Gráfico 2 - Já teve ou conhece alguém que tenha tido problema relacionado ao descarte inadequado de resíduos sólidos - Rocinha e Siloé

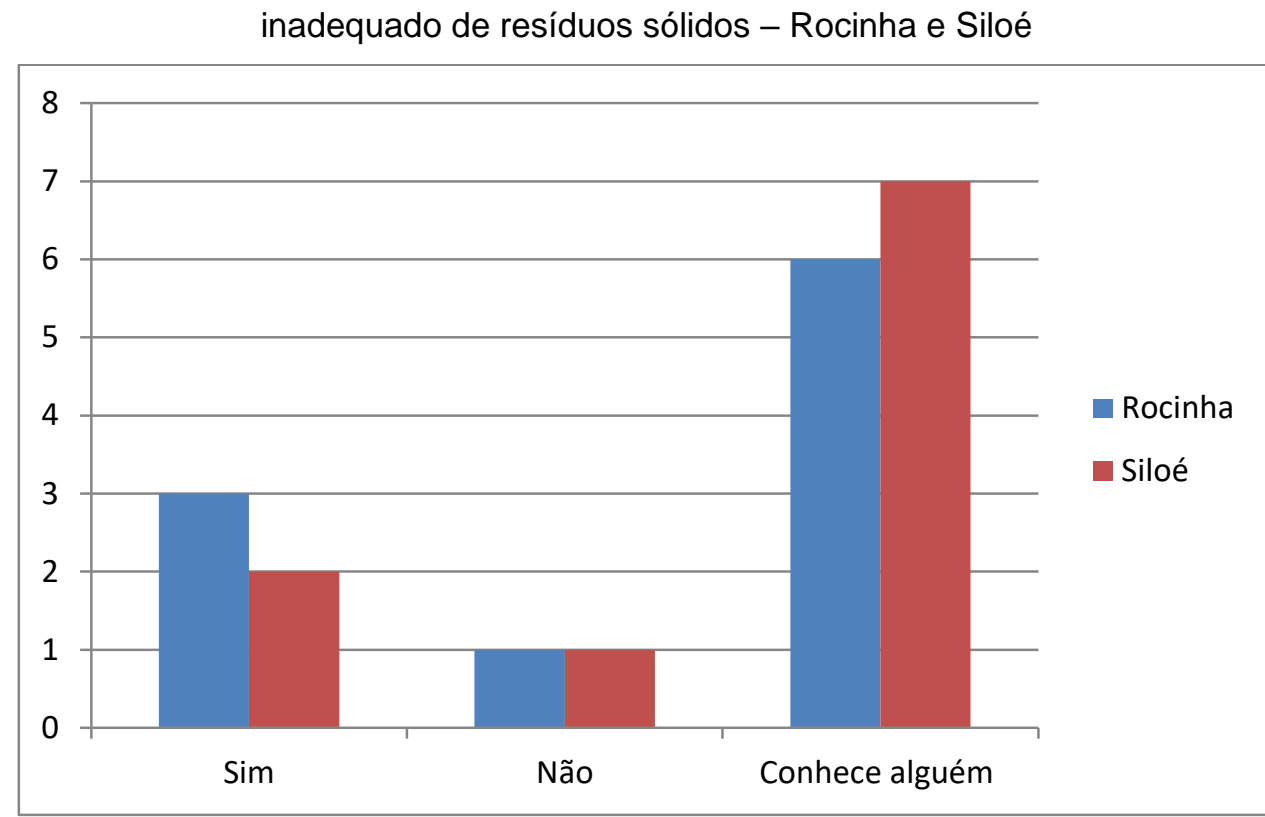

Fonte: elaboração própria com base nas entrevistas realizadas.

Dentre os problemas e/ou prejuízos relatados estão: infestação da residência por roedores e/ou outros insetos, doenças decorrentes de contaminação, alagamentos e casas inundadas em consequência do acúmulo de resíduos descartados inadequadamente em bueiros e encostas, gerando perdas materiais e até mesmo mortes ocasionadas por "acidentes ambientais". E nas análises relativas ao processo de contaminação, sete dos dez entrevistados da Rocinha informaram que já tiveram ou que conhecem alguém que já tenha contraído algumas destas doenças. Enquanto em Siloé, cinco dos dez entrevistados informaram ter tido ou conhecer alguém que tenha tido. $E$ dentre as doenças estão leptospirose, doenças de pele, chicungunha, dengue, diarreia e vômito. 
Gráfico 3 - Contraiu ou conhece alguém que tenha contraído doenças relacionadas aos resíduos sólidos - Rocinha e Siloé

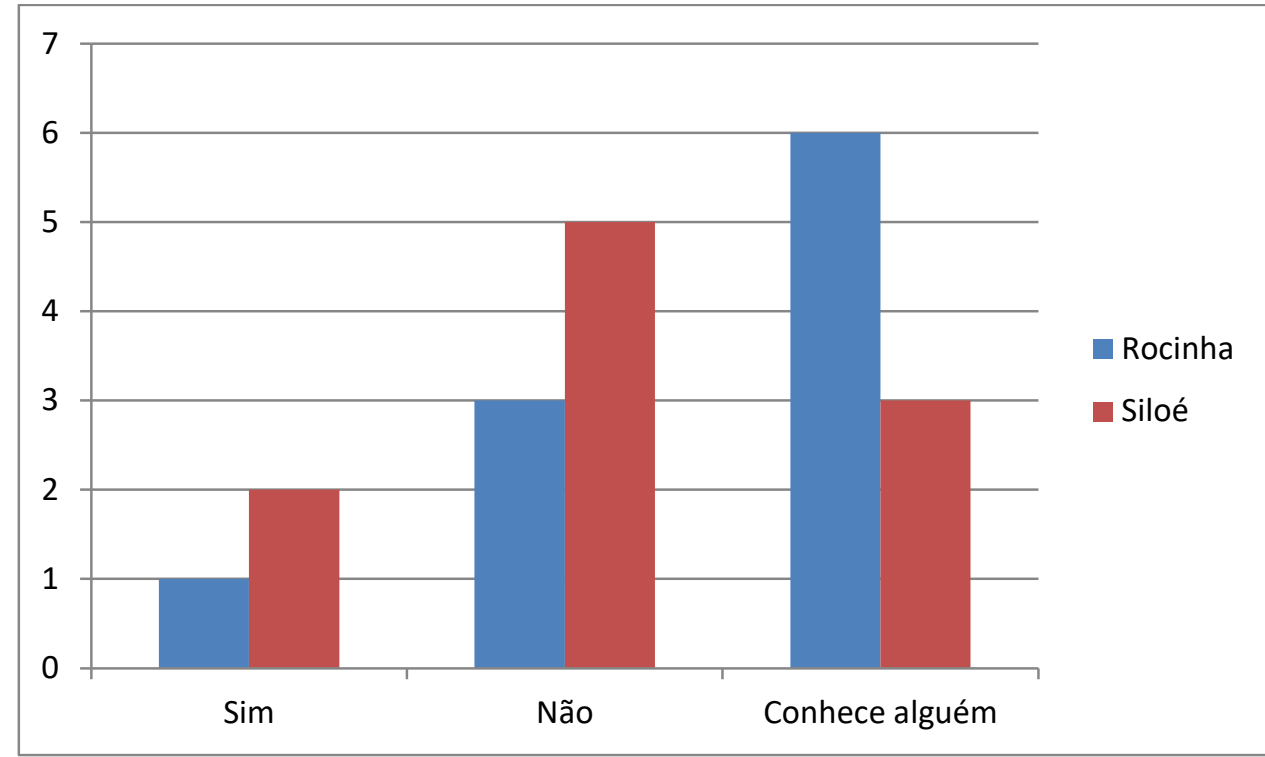

Fonte: elaboração própria com base nas entrevistas realizadas.

Neste parágrafo apresentamos a opinião dos moradores sobre os serviços prestados pelas empresas de limpeza urbana. Na Rocinha nota-se que são poucos os entrevistados que veem como bom ou regular o serviço prestado pela COMLURB; a maioria entende que o serviço não é eficiente, não dando conta de atender a demanda local. Em Siloé alguns entrevistados não avaliaram positivamente os serviços, porém a maioria os avalia como bons, entretanto surgiu o fato de que para ser completo, a empresa deveria disponibilizar o serviço de coleta seletiva, possibilitando aos moradores a separação dos resíduos sólidos, tendo em vista que atualmente todo o material coletado neste território é levado para o aterro sanitário; além disso apontaram também que mesmo em algumas ruas largas, o serviço de varrição nem sempre chega como deveria. Chamou-nos a atenção também que alguns moradores que não têm acesso direto ao serviço, ou seja, aonde a coleta porta a porta e a varrição não chegam, por serem becos, não se entendem como usuário direto, apontando que quem poderia avaliar tais serviços, seriam as pessoas da parte plana, por terem acesso direto aos benefícios das atividades de limpeza urbana. 
Quadro 19 - Opinião dos moradores sobre os serviços prestados pela empresa de limpeza urbana

\section{Rocinha}

A opinião dos moradores é de que o serviço não corresponde à necessidade, é um paliativo espalhar caçambas em determinados pontos que não contemplam todos e a falta de tratamento desse material (MBR4. Entrevista concedida a Maria Izabel de Carvalho. Rio de Janeiro, 10 abr. 2020).

Os que eu conheço falam que o serviço é ineficaz. Às vezes o lixo demora muito para ser retirado e há uma produção de lixo por parte dos moradores maior do que número de espaços para os lixos serem descartados (MBR8. Entrevista concedida a Maria Izabel de Carvalho. Rio de Janeiro, 13 abr. 2020).

Passam dia e noite. $\mathrm{O}$ recolhimento é adequado pelo volume (MBR9. Entrevista concedida a Maria Izabel de Carvalho. Rio de Janeiro, 15 abr. 2020).

Fonte: elaboração própria com base nas entrevistas realizadas.

E quando indagados sobre quais outros serviços, além dos já prestados, poderiam ser implementados pelas empresas de limpeza urbana, nesses territórios, obtivemos diversas sugestões, dentre as quais se sobressaíram na Rocinha, à necessidade de ampliação do projeto "Garis Comunitários", para que 
esses possam atuar em todas as áreas da favela aonde a COMLURB não chega e ganhou destaque a necessidade de implementação da coleta seletiva, dentre outros. No que diz respeito à Siloé, as sugestões foram mais voltadas para a melhoria dos serviços que já existem, como voltar a varrer ruas aonde o serviço chegava antes, porém não tem mais chegado; aumento da frequência da varrição em ruas onde segundo alguns entrevistados, a atividade só é realizada uma vez por semana; além da necessidade de implementar mais atividades voltadas para a sensibilização da população quanto aos resíduos sólidos, conforme falas expostas no quadro que segue:

Quadro 20 - Outros serviços que poderiam ser prestados pela empresa de limpeza urbana

\section{Rocinha}

Ampliação dos serviços prestados pelos chamados "garis comunitários". Serviço de coleta prestado por moradores como forma de qualificar a coleta para além das vias principais da favela (MBR1. Entrevista concedida a Maria Izabel de Carvalho. Rio de Janeiro, 28 abr. 2020).

Um serviço que não se limitasse à estrada da gávea, mas sim adentrasse nas vielas da comunidade, utilizando os próprios moradores que seriam capacitados e responsáveis pela manutenção de áreas específicas da favela. Sem dúvida a conscientização e respeito seria bem diferente, tendo alguém dali que mora e vive ali cuidando do local (MBR3. Entrevista concedida a Maria Izabel de Carvalho. Rio de Janeiro, 23 jun. 2020).

Uma campanha permanente cotidianamente em parcerias com secretarias de educação, assistência social e outras secretarias e comércio local (MBR7. Entrevista concedida a Maria Izabel de Carvalho. Rio de Janeiro, 11 abr. 2020).

Conscientização de reciclagem, eco pontos para recolhimento de materiais reciclável (MBR9. Entrevista concedida a Maria Izabel de Carvalho. Rio de Janeiro, 15 abr. 2020).

Um serviço de cadastramento a idosos e pessoas

\section{Siloé}

Pues para que no se amontone tanto material así, tenía que haber otro día de recolección, si quiera 4 días en la semana (MCOL10. Entrevista concedida a Maria Izabel de Carvalho. Cali, 07 set. 2019).

Sí pues yo les diría que trajeran en donde echar la basura, más recipientes para echar la basura (MCOL6. Entrevista concedida a Maria Izabel de Carvalho. Cali, 02 set. 2019).

Pues pedir como más días de barrido (MCOL5. Entrevista concedida a Maria Izabel de Carvalho. Cali, 02 set. 2019).

Hacer más educación ambiental, jornadas de sensibilización (MCOL2. Entrevista concedida a Maria Izabel de Carvalho. Cali, 31 ago. 2019). 
com dificuldade de locomoção e recolhimento do lixo deste em dias programados (MBR2. Entrevista concedida a Maria Izabel de Carvalho. Rio de Janeiro, 01 jun. 2020).

Fonte: elaboração própria com base nas entrevistas realizadas.

Em relação à participação em eventos, capacitações e/ou atividades em geral, voltadas para a educação ambiental, onde tenha sido abordada a temática dos resíduos sólidos, cinco dos dez entrevistados da Rocinha participaram de alguma ação direcionada a essa temática, enquanto os demais não tiveram nenhuma participação em tais discussões. Já em Siloé, seis dos dez que responderam à pesquisa, disseram ter participado dessas ações, conforme demostrado nos gráficos a seguir.

Gráfico 4 - Participação em atividades voltadas para a educação ambiental, onde tenha sido abordada a temática dos resíduos sólidos - Rocinha e Siloé

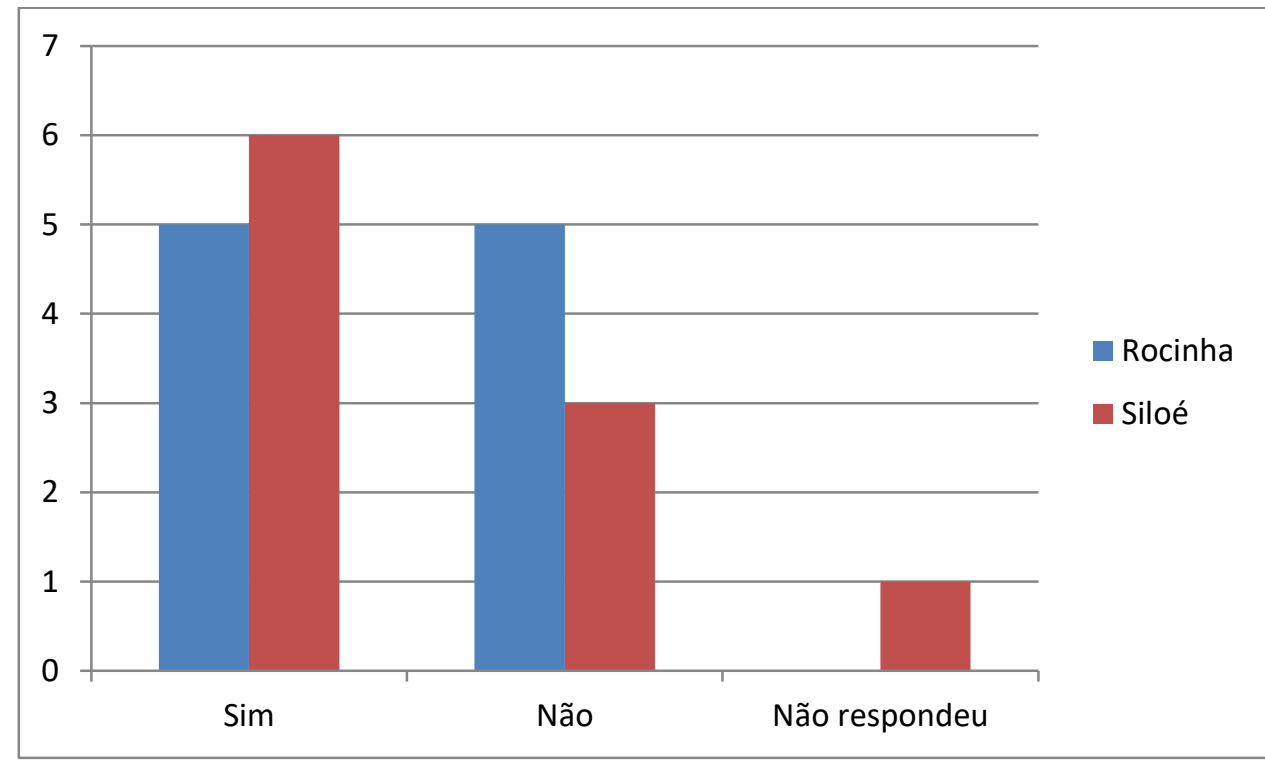

Fonte: elaboração própria com base nas entrevistas realizadas.

A maioria dos entrevistados da Rocinha entende que essas ações são importantes para que haja mudanças positivas no complexo panorama dos resíduos sólidos nesse território, porém acreditam que não pode ser algo pontual, nem tão pouco somente a título de repasse de informação, sendo necessário algo contínuo e que gere reflexão, contribuindo para a formação de um ser crítico, capaz de provocar mudanças no espaço onde vive. Em Siloé, todos os participantes da pesquisa veem essas atividades como importantes e 
apontaram que mudanças já foram notadas a partir de ações já realizadas. Vejamos as falas que seguem sobre essa questão:

Quadro 21 - Opinião dos entrevistados sobre as ações de educação ambiental - se é importante ou não para o contexto dos resíduos sólidos

\section{Rocinha}

Sim acredito que ajuda, mas não podemos deixar de lado a responsabilidade governamental com o lixo, pois pouco adiantará capacitar moradores se estes não tiverem onde descartar corretamente seu lixo (MBR2. Entrevista concedida a Maria Izabel de Carvalho. Rio de Janeiro, 01 jun. 2020).

Depende da capacitação, são precisas ações mais eficazes que aulas, palestras e bla bla bla (MBR3. Entrevista concedida a Maria Izabel de Carvalho. Rio de Janeiro, 23 jun. 2020).

Não só capacitação, pois essa é pontual, mas a conscientização contínua, essa é desafio. Capacitação vem e passa (MBR9. Entrevista concedida a Maria Izabel de Carvalho. Rio de Janeiro, 15 abr. 2020).

Fonte: elaboração própria com base nas entrevistas realizadas.

Entende-se como um fator positivo o fato de alguns entrevistados da Rocinha terem uma visão crítica de que ações pontuais como palestras, capacitações ou outras, não dão conta de provocar mudanças de comportamento/atitude no tocante ao descarte inadequado de resíduos sólidos, se fazendo necessárias ações mais concretas e contínuas, que no nosso entendimento, sejam pautadas, sobretudo, na educação ambiental crítica, que contribui para o desenvolvimento de um cidadão crítico, capacita-o para a realização de reflexões sobre o mundo no qual está inserido, de modo a interferir nesse espaço de acordo com as suas necessidades.

Acredita-se, portanto, que essa vertente da educação ambiental é a que melhor se conforma a realidade dos campos desta pesquisa para se pensar 
como estímulo para as mudanças quanto à problemática dos resíduos sólidos, por ela nos permitir olhar o mundo tendo em vista a sua diversidade, justamente por não ser algo estanque na sua forma de agir, partindo:

[...] do pressuposto de que sua natureza conflitiva, na diversidade e na disputa de concepções e espaços na sociedade, fortalece-a e a legitima nas institucionalidades acadêmicas, nas políticas públicas e nos movimentos sociais que buscam a garantia de direitos, a afirmação das diferenças, a superação das desigualdades de classe e a construção de outro patamar societário (Loureiro \& Layrargues, 2013, p. 54-55).

Essa vertente da educação ambiental teve sua identidade fortemente marcada pela "inserção dos que atuavam na educação popular e adotavam a pedagogia crítica libertadora de Paulo Freire [...] voltada para a formação humana, para a formação política" (Loureiro \& Layrargues, 2013, p. 65). Isso implica dizer que:

\begin{abstract}
O conceito central do ato educativo deixa de ser a transmissão de conhecimentos, como se isso per si fosse suficiente para gerar um 'sujeito ético' que se comportaria corretamente. É a própria práxis educativa, a indissociabilidade teoriaprática na atividade humana consciente de transformação do mundo e de autotransformação que ganha a devida centralidade. Isso implica favorecer a contínua reflexão das condições de vida, na prática concreta, como parte inerente do processo social e como elemento indispensável para a promoção de novas atitudes e relações que estruturam a sociedade (Loureiro \& Layrargues, 2013, p. $65)$.
\end{abstract}

Deste modo, ao darmos um lugar de destaque para a práxis educativa, crítica e dialógica, se torna necessária a estruturação de processos que sejam participativos e que:

Favoreçam a superação das relações de poder consolidadas e garantir o exercício da cidadania, principalmente daqueles que se encontram em situação de maior vulnerabilidade socioambiental. E isso significa dizer que não só a participação é fundamental, mas que a participação popular é determinante, posto ser a construção de processos em que os grupos expropriados e discriminados adquiram centralidade e condição para que as contradições e os conflitos da sociedade sejam explicitados, enfrentados e superados pelo protagonismo daqueles que portam materialmente o que é distinto do poder hegemônico portanto, a alternativa possível concretamente (Loureiro \& Layrargues, 2013, p. $65)$.

Assim sendo, entendemos que esse seria um dos caminhos viáveis para a construção de processos transformadores sólidos e duradouros, que aliados a políticas públicas eficazes, poderiam gerar mudanças significativas tanto na Rocinha quanto em Siloé, no tocante aos problemas relacionados aos resíduos sólidos. 
4.2.

\section{A visão das empresas de limpeza urbana em relação ao trabalho prestado}

A título de melhor referenciar brevemente as empresas de limpeza urbana que atuam nos lócus desta pesquisa e seus representantes, estruturamos o quadro que segue abaixo, apresentando algumas especificidades.

Quadro 22 - Dados dos representantes das empresas de limpeza urbana entrevistados

\begin{tabular}{|c|c|c|}
\hline \multicolumn{3}{|c|}{ PERFIL DAS EMPRESAS DE LIMPEZA URBANA } \\
\hline Tipo de informação & Rocinha & Siloé \\
\hline Nome da empresa & $\begin{array}{c}\text { Companhia Municipal de } \\
\text { Limpeza Urbana (COMLURB). }\end{array}$ & $\begin{array}{c}\text { Ciudad Limpia, Bogotá S.A E.S.P. } \\
\text { Empresa de Servicios Públicos. }\end{array}$ \\
\hline É pública ou privada & Empresa pública. & Empresa privada. \\
\hline \multicolumn{3}{|c|}{ PERFIL DOS REPRESENTANTES DAS EMPRESAS DE LIMPEZA URBANA } \\
\hline Cargo ou função & O entrevistado é subgerente. & $\begin{array}{l}\text { A entrevistada é chefe de } \\
\text { comunicações e relações públicas. }\end{array}$ \\
\hline $\begin{array}{l}\text { Tempo que trabalha } \\
\text { para a empresa }\end{array}$ & Cerca de 30 anos. & 07 anos. \\
\hline $\begin{array}{l}\text { Tempo que trabalha } \\
\text { no atual cargo }\end{array}$ & 07 anos. & Cerca de 06 anos. \\
\hline
\end{tabular}

Fonte: elaboração própria com base nas entrevistas realizadas.

Salientamos que na entrevista da empresa que realiza a limpeza urbana em Siloé, houve a participação de um segundo colaborador, por esse ter maior conhecimento dos dados sobre a coleta de resíduos sólidos.

Inicialmente perguntamos aos entrevistados se esses tinham conhecimento da extensão territorial $\left(\mathrm{Km}^{2}\right)$ dos campos objeto deste estudo, onde atuam, porém não souberam informar, assim como também, sobretudo a empresa que presta o serviço de limpeza urbana em Siloé, inicialmente não demonstrou muito domínio em relação às informações ligadas à coleta, como o volume de resíduos coletado da varrição de rua; informação esta que o representante da COMLURB não soube informar, alegando que todo o resíduo da varrição é contabilizado junto aos demais resíduos postos nos pontos de coleta. 
Conforme exposto no quadro acima, a Companhia Municipal de Limpeza Urbana da cidade do Rio de Janeiro e a Ciudad Limpia, Bogotá S.A E.S.P. Empresa de Servicios Públicos, são as empresas de limpeza urbana que atuam nos lócus desta pesquisa; sendo a primeira, a que opera na Rocinha; e a segunda, a que realiza o trabalho de limpeza urbana em Siloé, em Cali, embora seu nome tenha a palavra "Bogotá", sua cidade de origem.

A COMLURB é uma empresa pública e atua na cidade do Rio de Janeiro desde a década de 1970, conforme já mencionado anteriormente, enquanto a Ciudad Limpia é empresa privada e iniciou suas atividades em algumas comunas e corregimentos de Cali, no ano de 2009, quando venceu uma licitação da empresa pública que realizava esse trabalho antes, a Empresa de Servicio Público de Aseo de Cali (EMSIRVA).

Diferente do que ocorre na Rocinha, onde não há uma cobrança direta aos usuários pelos serviços de limpeza urbana, ou seja, não chega uma fatura no imóvel das pessoas para que elas paguem pela prestação de serviço de limpeza, em Siloé essa cobrança é realizada e chega aos usuários por meio de uma fatura mensal, onde também são cobrados outros serviços, como água, energia elétrica e taxa de esgoto. O que pode ser verificado a partir da fala da representante da Empresa Ciudad Limpia, em relação a como se dá esse processo:

Bueno... se cobra a través de los servicios públicos, del recibo de los servicios públicos de EMCALI, pero muchos de ellos tienen servicios ilegales por decirlo de alguna manera, instalados de manera irregular, por decirlo de otra manera. Ellos lo que hacen es conectarse a una red eléctrica, o poner un tubo y con tener acueducto, pues el alcantarillado es la quebrada más cercana, entonces nosotros tenemos que hacer un proceso permanente de censo, nosotros tenemos que verificar de manera permanente en el territorio cuándo hay más unidades residenciales, que se identifican como lugares que tengan por lo menos una cocina y un baño, esas son unidades residenciales adicionales, para eso se hace un censo permanente, a veces no es fácil hacer el censo por el tema de seguridad. Además porque ellos saben que si el muchacho va a hacerles censo, pues se les va a cobrar más, porque si yo tenía una casa de un piso y ahora tengo dos pisos arriba y dos pisos abajo, son diferentes unidades residenciales eso implica un cobro mayor, entonces en principio es así como se reporta, pero el pago llega directamente a través de los servicios públicos, y como te digo que muchos no están regularizados, entonces después llega el recibo, pero no lo pagan porque igual no lo van a cortar, porque no existen para la empresa. La otra cosa es que a veces cuando encontramos ese tipo de cosas lo que hacemos, es generar nuestra propia factura y les facturamos el servicio público de aseo, pero pues la posibilidad de que la gente pague no es mucha. Por eso una de nuestras carteras más grandes está ahí, en la comuna 20, porque además es súper antigua, porque cuando EMSIRVA estaba, ni siquiera conocía parte del territorio, entonces no tenía impacto allá la gente dice 'pero es que usted no me viene hasta acá a recoger', es cierto, pero de un modo u otro cuando bajan la basura, terminamos recogiéndola y todos los caleños pagamos por eso, porque en Cali, aquí se cobra... la tarifa surge por la cantidad de residuos que se generan en toda 
la ciudad, entonces en diciembre se recoge un montón de basura y esa basura se divide sobre todos los sectores de la ciudad, y 2 meses después a todos nos cobran la recolección de esa basura, ya, así es cómo funciona. A partir de una norma nacional que nos dice cómo debe ser el cobro de la tarifa (ELUCOL1. Entrevista concedida a Maria Izabel de Carvalho. Cali, 03 out. 2019).

Quando perguntada sobre o faturamento mensal da empresa no território, a entrevistada disse não ter acesso a essa informação e que também não sabia se o dado poderia se tornar público.

A título de ilustração, expomos abaixo duas dessas faturas, ambas da Comuna 20, sendo uma de um usuário da área que dispõe de maior infraestrutura, onde as pessoas a princípio têm melhores condições socioeconômicas (sendo o único condomínio existente nessa região, que fica em Belisário Caicedo, classificado como estrato 3) e a outra de um local onde as pessoas são de um nível socioeconômico mais baixo, que é El Cortijo (classificado como estrato 1). Essa classificação por estratos ${ }^{34}$ foi criada por meio da Lei 142 de 1994 do Congresso Nacional, que regulamenta os serviços públicos domiciliares, sob o princípio de subsídio cruzado, onde quem tem renda alta, ou seja, os estratos 5 e 6 , subsidia quem tem renda baixa, os estratos 0,1 , 2 e 3. O órgão responsável por manter a fiscalização quanto a essa estratificação, é o Departamento Administrativo Nacional de Estadística (DANE), equivalente ao IBGE, aqui no Brasil.

\footnotetext{
${ }^{34}$ La estratificación socioeconómica es una clasificación en estratos de los inmuebles residenciales que deben recibir servicios públicos. Se realiza principalmente para cobrar de manera diferencial por estratos los servicios públicos domiciliarios permitiendo asignar subsidios y cobrar contribuciones en esta área. De esta manera, quienes tienen más capacidad económica pagan más por los servicios públicos y contribuyen para que los estratos bajos puedan pagar sus facturas. El cobro de los servicios públicos domiciliarios en Colombia siempre ha sido diferente por grupos socioeconómicos o estratos. Hasta 1990, la estratificación la realizaba cada empresa con criterios y metodologías distintas, lo cual no permitía comparar los estratos obtenidos en las diversas regiones del país, ni garantizar la correcta asignación de los subsidios y el cobro de las contribuciones. Por esto, el Gobierno Nacional ha venido trabajando desde 1991 en el diseño de políticas orientadas a unificar los procesos de estratificación de los usuarios residenciales de los servicios públicos domiciliarios mediante estudios técnicos y transparentes que permitan el pago solidario de los servicios públicos domiciliarios. Disponível em: $<$ https://www.dane.gov.co/index.php/servicios-al-ciudadano/servicios-informacion/estratificacionsocioeconomica>. Acesso em: 07 abr. 2021.
} 
Figura 37 - Fatura de serviços públicos: usuário de Belisário Caicedo (estrato 3$)^{35}$
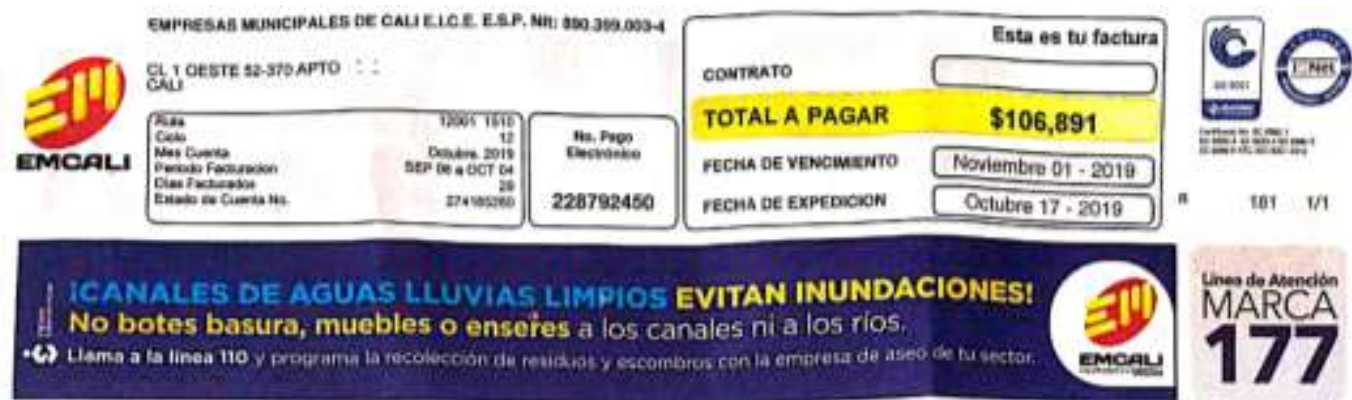

\section{ACUEDUCTO}
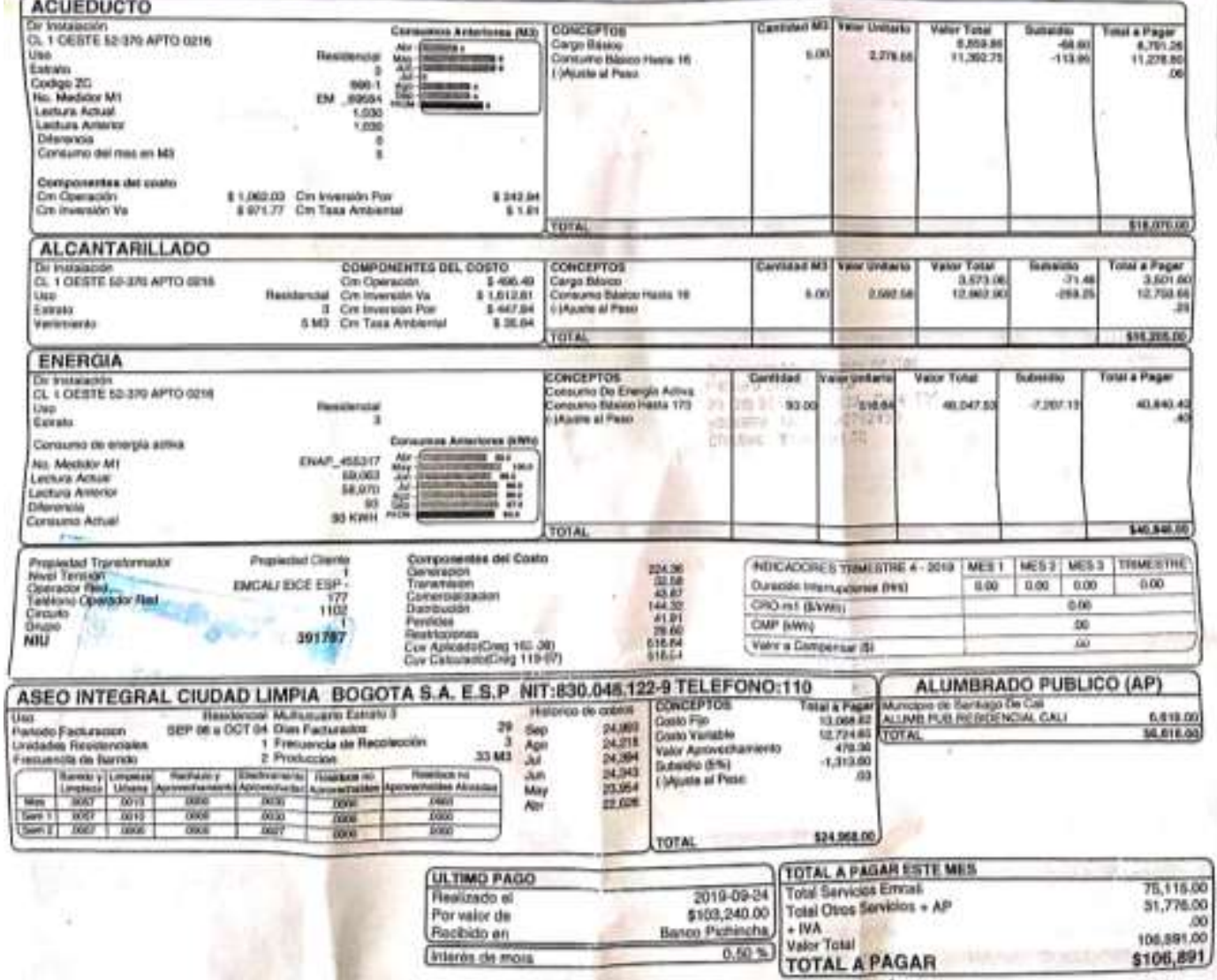

Fonte: documento cedido pelo usuário dos serviços públicos.

35 Valor total da fatura convertido para o real: cerca de $\mathrm{R} \$ 164,00$. Valor da taxa de limpeza urbana convertido para o real: cerca de $\mathrm{R} \$ 38,00$. 
Figura 38 - Fatura de serviços públicos: usuário de El Cortijo (estrato 1) $)^{36}$

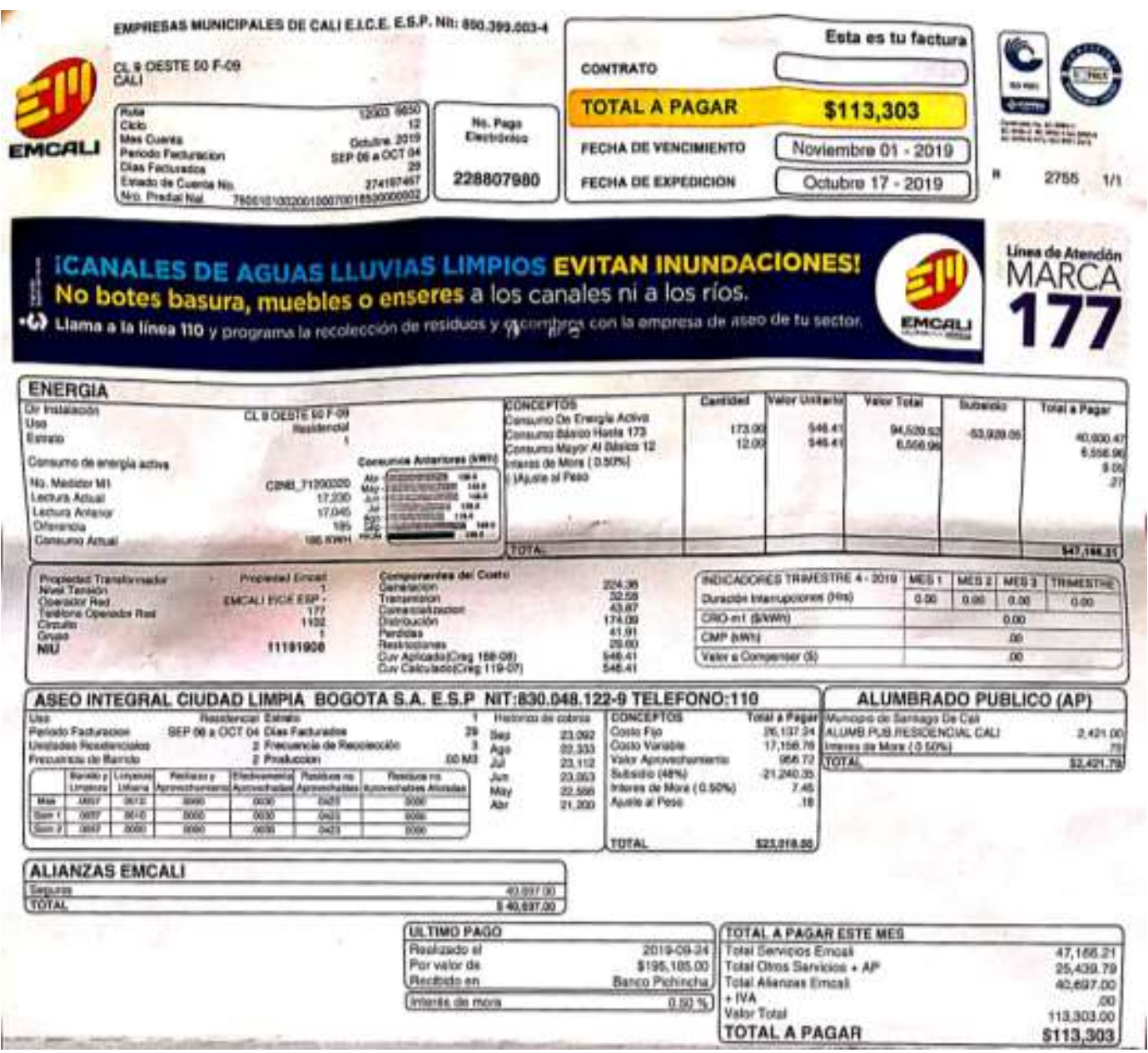

Fonte: documento cedido pelo usuário dos serviços públicos.

Em se tratando da prestação dos serviços de limpeza urbana, diferente de Siloé onde existe somente a empresa Ciudad Limpia, na Rocinha, a COMLURB conta com os Garis Comunitários, que é um projeto financiado com os recursos dessa instituição e administrado por uma das associações de moradores locais. Hoje segundo a empresa, trabalham nesse projeto 37 pessoas, distribuídas por toda a Rocinha, executando varrição, coleta e limpeza de vala, tendo como prioridade as duas últimas atividades. Esses trabalhadores desenvolvem essas ações, sobretudo nos locais onde anteriormente os garis da equipe direta da COMLURB não atuavam, conforme fala do subgerente:

O gari comunitário ele é um projeto da COMLURB, que fechou com a associação dos moradores, devido aquelas áreas que a gente não tinha acesso antigamente, mas que hoje a gente tem acesso; deu esse emprego pros moradores da comunidade, porque eles têm essa facilidade de conhecer toda a geografia da

${ }^{36}$ Valor total da fatura convertido para o real: cerca de $\mathrm{R} \$ 174,00$. Valor da taxa de limpeza urbana convertido para o real: cerca de $\mathrm{R} \$ 35,00$. 
área deles ali, da comunidade, e as pessoas os conhecem, então ficava mais fácil deles chegarem até lá do que a gente (ELUBR1. Entrevista concedida a Maria Izabel de Carvalho. Rio de Janeiro, 02 out. 2020).

O que se observa é que em algumas áreas, sobretudo nas de difícil acesso, ainda são os garis comunitários, que continuam atuando, porém cabe salientar que esse grupo tem sofrido uma redução significativa nos últimos anos, devido a uma ação do Ministério Público do Trabalho, que impede novas contratações $^{37}$. Deste modo, caso não haja nenhuma mudança, com o passar dos anos o projeto será extinto, uma vez que à medida que os antigos contratados vão se desligando, outros não são contratados.

No quadro que segue apresentamos os tipos de serviços que são prestados pelas empresas de limpeza urbana, na Rocinha e em Siloé, segundo os entrevistados.

Quadro 23 - Tipos de serviços prestados pelas empresas de limpeza urbana na Rocinha e em Siloé

\begin{tabular}{|l|c|c|}
\hline \multicolumn{1}{|c|}{ Tipos de serviço } & Rocinha & Siloé \\
\hline Coleta & $\mathbf{X}$ & $\mathbf{X}$ \\
\hline Varrição & $\mathbf{X}$ & $\mathbf{X}$ \\
\hline Limpeza pós-chuva & $\mathbf{X}$ & $\mathbf{X}$ \\
\hline Poda de árvore & $\mathbf{X}$ & - \\
\hline Limpeza de valas & $\mathbf{X}$ & - \\
\hline
\end{tabular}

Fonte: elaboração própria com base nas entrevistas realizadas.

De uma forma geral, estes são os serviços executados por ambas as empresas, porém cabe salientar que devido às condições da infraestrutura local, os serviços chegam a algumas partes desses territórios de forma distinta ou até mesmo não são executados em determinados locais, como é o caso da varrição e da coleta porta a porta, que não são oferecidos a uma parcela expressiva da população, sobretudo na Rocinha, onde nota-se um menor número de vias carroçáveis ao longo da favela, por onde possam chegar os equipamentos. A esse respeito, Schueler et al. (2018), aponta que mesmo tendo havido investimentos durante programas governamentais (por exemplo, o "Favela Bairro"), em algumas favelas cariocas, voltados para a infraestrutura, esses não

37 Disponível em: <https://anpt.jusbrasil.com.br/noticias/2257755/comlurb-assina-acordo-parcialpara-substituir-garis-comunitarios-rj>. Acesso em: 24 jun. 2021. 
se ativeram às demandas relativas ao tratamento adequado dos resíduos sólidos urbanos, nesses locais.

Porém entendemos que esse problema vai além da infraestrutura urbana, se considerarmos que adaptações são possíveis na perspectiva de fazer os serviços chegarem a esses lugares, como exemplo, pode ser citada a coleta que segundo o representante da COMLURB, é feita pelos garis comunitários, com a utilização de containers, em um sub-bairro da Rocinha chamado Terreirão, onde só é possível acessar por meio de escadas e becos. Desse modo, conclui-se que se há a possibilidade de chegar a esse local, o serviço também poderia ser estendido a todas as áreas onde não há acesso dos carros que realizam a coleta, facilitando aos usuários, a realização do descarte adequado, uma vez que se assim fosse, não teriam que se deslocarem grandes distâncias para descartar o resíduo por esses gerados. No entanto, não é isso o que acontece, pois a precarização das políticas públicas no ramo de manejo de resíduos sólidos para determinadas áreas se faz presente, evidenciando o que Acselrad (2004) vai denominar de zonas de sacrifício, aqui entendidas como áreas escolhidas para a concentração de ações que provocam graves danos ambientais, sobretudo, por não serem viabilizados melhores acessos e serviços dignos. Não por acaso, são nesses espaçosonde vivem as "populações mais pobres, suas moradias, espaços de lazer e convivência, materializando a distribuição desigual dos riscos" (Dutra, 2015. p. 185), aqui ganhando destaque os riscos ambientais, entendidos como:

\begin{abstract}
A contingência de acontecimentos como: deslizamentos, enchentes/inundações, as diversas formas de contaminação, seja por via atmosférica ou hídrica, ou ainda as decorrentes do contato com o lixo, entre outras. A possibilidade de perdas, que é inerente ao risco, incluído aí o ambiental, possui uma dimensão espacial. Assim, um evento desastroso pode resultar em danos materiais, doenças e até perda de vidas humanas em sua área de ocorrência (Esteves, 2011, p. 69).
\end{abstract}

São, portanto, nesses lugares onde se materializam as mais diversas expressões da questão socioambiental, bem como as injustiças ambientais, sendo essa última caracterizada pelo movimento de justiça ambiental, por destinar:

A maior carga dos danos ambientais a grupos sociais de trabalhadores ou grupos étnicos discriminados, entre outros segmentos em estado de maior vulnerabilidade social e econômica, ameaçando a integridade da saúde ambiental e comprometendo a sua reprodução social. Essa condição, reveladora dos mecanismos de desigualdade socioambiental, estabelece-se em sociedades desiguais por meio de mecanismos políticos, sociais e econômicos que concentram os processos decisórios e privatizam os bens públicos, tornando 
possível e legítimo a utilização dos bens coletivos e naturais para interesses privados. Essa distribuição desigual por classe é entendida como intrínseca às economias capitalistas e necessária à reprodução ampliada do capital. Assim, na sociedade capitalista o acúmulo material das classes dominantes se dá mediado pela expropriação ambiental dos trabalhadores, e as taxas de lucro das grandes corporações empresariais se vinculam à degradação ambiental dos espaços de vida e de trabalho desses grupos e classes expropriadas (Loureiro \& Layrargues, 2013, p. 63).

Deste modo, a noção de justiça ambiental, contribui para pensarmos esse contexto, por ser um movimento que ressignifica a questão ambiental, resultando de:

\begin{abstract}
Uma apropriação singular da temática do meio ambiente por dinâmicas sociopolíticas tradicionalmente envolvidas com a construção da justiça social. Esse processo de ressignificação está associado a uma reconstituição das arenas onde se dão os embates sociais pela construção dos futuros possíveis. E nessas arenas, a questão ambiental se mostra cada vez mais central e vista crescentemente como entrelaçada às tradicionais questões sociais do emprego e da renda (Acselrad, 2010, p. 108).
\end{abstract}

Quanto à prestação dos serviços de limpeza urbana por ambas as empresas e a possibilidade de chegarem a todas as áreas de difícil acesso, reconhecidamente existentes nos dois territórios em pauta, por ambos os entrevistados, observemos as falas na sequência:

Quadro 24 - Fala dos entrevistados sobre a prestação de serviços de limpeza urbana nas áreas de difícil acesso

\section{Rocinha}

A gente conta com a colaboração dos moradores, né? Porque em toda Estrada da Gávea você tem recipiente pra que possa ser armazenado o lixo, né? E assim, a gente ainda tem um tratorzinho que faz a Cachopa, que faz a Vila Verde, que faz a Dioneia.. a gente tem também um caminhãozinho que a gente chama de P26, que é um mini caminhão, que entra nessas áreas também, que a gente vai lá no Umuarama, no Laboriaux, pra fazer essa coleta. Agora onde são vielas, a gente tem a moto triciclo que faz a coleta aqui no Bairro Barcelos, ela faz aquelas travessa todinhas. O resto fica aí na responsabilidade dos moradores, trazer pros pontos estratégicos que a gente tem. Igual a gente tem uma caixa de 15 metros aqui na Roupa Suja, uma caixa

\section{Siloé}

La ley es clara si el vehículo no pasa por el frente del predio, yo tengo la obligación de presentarla por donde pasa el vehículo recolector, que son los puntos de acumulación; en la comuna hay solamente un sector donde hay cajas de tres yardas, que es en el sector de Brisas de mayo. Que desde hace cuánto están esas cajas, prácticamente desde que inició la operación. Allí se ubicaron dos cajas de 3 yardas para presentar los residuos, que es como la facilidad que le 
compactadora e mais uma caixa adempester. A gente tem mais uma caixa compactadora lá dentro da Rua do Valão, pras pessoas descer, armazenar seu lixo ali numa caixa de 15 metros, e mais uma caixa adempester. A gente tem mais uma caixa de 7 metros lá no Umuarama, que é pequena pro pessoal botar o lixo, que é compactadora... A gente tem mais uma de 15 metro lá no 199, que é também para os moradores que passam ali descer, que sai lá da Mina, sai ali da Vila Miséria, armazenar o seu lixo. A gente tem toda uma logística de armazenamento do lixo pelo morador (ELUBR1. Entrevista concedida a Maria Izabel de Carvalho. Rio de Janeiro, 02 out. 2020).

Fonte: elaboração própria com base nas entrevistas realizadas.

Segundo os entrevistados, não há previsão por parte das empresas, de utilização de estratégias futuras para que os serviços cheguem de forma direta a todas as áreas de difícil acesso, e de certa forma se justificaram apontando o que é ofertado atualmente; e, além disso, a representante da Ciudad Limpia se respaldou, conforme fala apresentada no quadro acima, mencionando o Plan de Gestión Integral de Residuos Sólidos de Santiago de Cali, onde está posto em relação à coleta, que:

La actividad de recolección de residuos sólidos tanto en zona urbana como rural debe realizarse utilizando el sistema puerta a puerta, es decir, que la recolección se realiza en el andén de la vía pública frente al predio del usuario, incluyendo los barrios que tengan pasajes, o en unidades de almacenamiento de residuos - UAR, con el fin de garantizar la cobertura del servicio público de aseo a todos los usuarios. Cuando existan restricciones de acceso para los vehículos recolectores, el prestador, previa evaluación técnica, podrá realizar la recolección utilizando cajas de almacenamiento o cualquier otro sistema alternativo que garantice su recolección (Cali, 2015, p. 240).

$\mathrm{Na}$ Rocinha no que concerne a limpeza de valas, conforme exposto anteriormente, é realizada pela COMLURB, tanto por garis da equipe direta da empresa quanto pelos garis comunitários. Já a Ciudad Limpia não realiza esta ação, por não ser de sua responsabilidade; apesar disso, a empresa informou que colabora com o órgão responsável, quando ele realiza a atividade de limpeza desses locais, conforme fala que segue: 
Bueno, por norma a nosotros no nos corresponde hacer la intervención a los cuerpos de agua, eso es una responsabilidad del municipio, a través de la autoridad ambiental que es el DAGMA, nosotros lo que hacemos es hacer la recolección de los residuos en los horarios y frecuencias de acuerdo a los puntos donde nos los presentan las personas; sin embargo, de manera permanente apoyamos jornadas de limpieza, ya sea yendo con nuestro personal a hacer la limpieza misma como operativos, o apoyando jornadas organizadas por la administración municipal, donde nosotros prestamos el servicio de recolección, pero directamente en cuerpos de agua quebradas nosotros no accedemos, porque de acuerdo a la ley colombiana no es responsabilidad de prestadores de servicios, sino de la autoridad ambiental garantizar la limpieza de estos y mantenimiento de estos sectores (ELUCOL1. Entrevista concedida a Maria Izabel de Carvalho. Cali, 03 out. 2019).

Do mesmo modo, a empresa informou que também não realiza a poda de árvores, por não Ihe caber fazer essa ação, nesse território, no presente momento.

Quanto à frequência em que os serviços são executados, nota-se diferença significativa entre os dois campos de estudo, tendo em vista a realidade de cada um. Na Rocinha, devido à existência de poucas ruas por onde possam chegar os equipamentos de coleta, a maioria dos pontos se concentra ao longo da via central, que corta a favela de uma ponta a outra, que é a Estrada da Gávea, sendo o serviço de coleta, realizado todos os dias da semana, duas vezes por dia em alguns pontos e três vezes em pontos onde há uma grande concentração de resíduos, como é o caso do ponto que fica ao lado do escadão da Vila Verde e dos containers situados ao lado do conjunto habitacional conhecido como prédio do PAC. A varrição acontece de segunda a sábado em alguns locais, como na Rua 4 e Rua 3, por exemplo, enquanto na Estrada da Gávea e no Bairro Barcelos é realizada todos os dias; neste último a varrição acontece duas vezes por dia, pela manhã e à tarde. Os demais serviços são efetivados à medida que as demandas chegam ou de acordo com a programação da empresa. Em Siloé os serviços são realizados em dias previamente determinados. A coleta acontece as terças, quintas e sábados, sendo que no período da manhã atende a parte alta e a noite a parte baixa. $A$ varrição é realizada as segundas e sextas-feiras na parte alta e as terças e quintas-feiras na parte baixa. A Limpeza pós-chuva se dá à medida que se faz necessária.

Os equipamentos utilizados em ambos os territórios pelas empresas, para a execução dos serviços de coleta e varrição, segundo os entrevistados, são: 
Quadro 25 - Equipamentos utilizados pelas empresas para a coleta e varrição

\begin{tabular}{|c|c|c|c|c|}
\hline \multirow[t]{2}{*}{ Serviços } & \multicolumn{2}{|c|}{ Rocinha } & \multicolumn{2}{|c|}{ Siloé } \\
\hline & Equipamentos & Quantidade & Equipamentos & Quantidade \\
\hline \multirow[t]{5}{*}{ Coleta } & Caminhão P7 & 3 & $\begin{array}{l}\text { Caminhão } \\
\text { compactador }\end{array}$ & 5 \\
\hline & $\begin{array}{l}\text { Caminhão P8 } \\
\text { (basculante) }\end{array}$ & 3 & $\begin{array}{l}\text { Caminhão } \\
\text { basculante }\end{array}$ & $\mathrm{NI}$ \\
\hline & Caminhão P26 & $\mathrm{Nl}^{*}$ & - & - \\
\hline & $\begin{array}{l}\text { Caixa } \\
\text { compactadora }\end{array}$ & 04 & - & - \\
\hline & $\begin{array}{l}\text { Caixa (média e } \\
\text { pequena) }\end{array}$ & $\mathrm{NI}$ & - & - \\
\hline \multirow[t]{3}{*}{ Varrição } & Vassoura & $\mathrm{NI}$ & Vassoura & $\mathrm{NI}$ \\
\hline & Pá & $\mathrm{NI}$ & Pá & $\mathrm{NI}$ \\
\hline & Container & $\mathrm{NI}$ & Biciclos & $\mathrm{NI}$ \\
\hline
\end{tabular}

Fonte: elaboração própria com base nas entrevistas realizadas. $\quad$ *NI: Não Informado

Os biciclos (uma espécie de carrinho com duas rodas e um apoio na frente que o equilibra) são utilizados pela Ciudad Limpia somente na parte baixa de Siloé. Sua estrutura é composta por: um local para colocar a vassoura, a pá e os sacos vazios e outro espaço onde os funcionários vão colocando, em um saco, o material coletado da varrição, conforme figura que segue.

Figura 39 - Biciclo - equipamento utilizado na atividade de varrição em Siloé

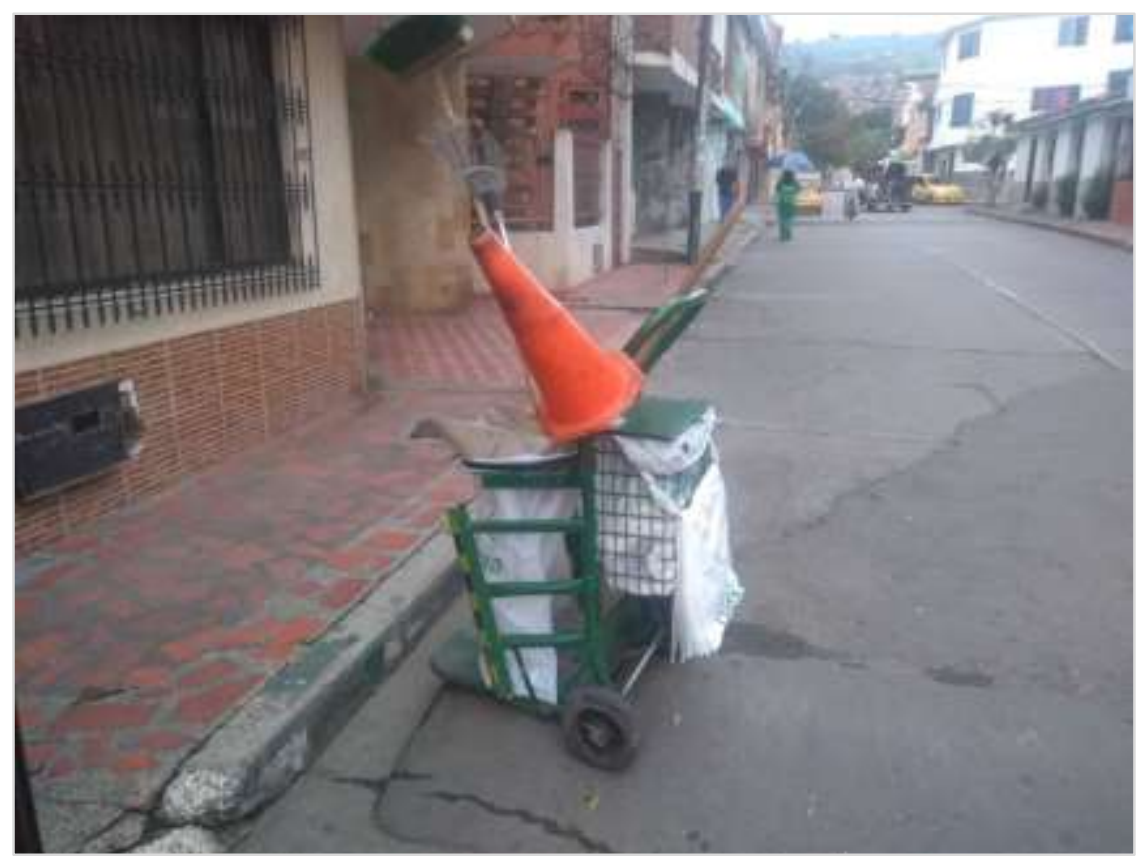

Fonte: Maria Izabel de Carvalho, 2019. 
$\mathrm{Na}$ Rocinha, segundo o representante da COMLURB, são coletadas diariamente cerca de 100 toneladas de resíduos sólidos, enquanto em Siloé esse volume chega a aproximadamente 75 toneladas/dia. As empresas de limpeza urbana não souberam informar com precisão a gravimetria dos resíduos nesses territórios, sendo apontado de uma forma mais genérica. Na Rocinha foi informado que cerca de setenta por cento do material coletado é orgânico; e em Siloé a representante da empresa relatou não saber informar, assinalando que: "no, no porque nosotros todo lo que recogemos, no miramos qué es sino que lo llevamos" (ELUCOL1. Entrevista concedida a Maria Izabel de Carvalho. Cali, 03 out. 2019). Apesar dessa fala, em outro momento da entrevista, a mesma relatou que os resíduos coletados incluem muito material reciclável, resíduos orgânicos e higiênicos.

Na Rocinha, observa-se um aumento da geração de resíduos, sobretudo no verão e uma diminuição no inverno, pois de acordo com o entrevistado, na temporada de calor as pessoas acabam consumindo mais, e o inverso acontece na estação mais fria, quando a população fica mais dentro de casa. Em Siloé, nota-se um aumento significativo nos períodos festivos, sobretudo no Dia das Mães (celebrado em maio), no dia do amor e da amizade (celebrado em setembro) e no período que antecede os festejos natalinos e do final de ano, quando o consumo aumenta e automaticamente o volume de resíduos também. A esse respeito, Schueler (2018) aponta que:

\begin{abstract}
A produção de RSU acaba por revelar a interação entre as atividades humanas e o meio ambiente. Os principais fatores que regem sua origem e produção têm vínculos diretos com os processos de industrialização e a maneira como se dá o consumo pela população. Por ser resultado dos rejeitos de inúmeras atividades humanas, apresenta-se bastante heterogêneo e varia de acordo com o espaço geográfico. Ao longo do tempo é possível observar que fatores como o número de habitantes, variações sazonais, condições climáticas, hábitos e costumes da população, nível educacional, poder aquisitivo, segregação na origem, disciplina e controle dos pontos produtores, entre outros, são determinantes para traçar diretrizes de planejamento e regulação específica para RSU. É preciso sublinhar que em época de chuvas fortes o teor de umidade dos RSU tende a crescer. Esse aspecto também pode ser observado com o aumento significativo, em períodos de férias escolares ou festas populares, do consumo de produtos embalados, em vidro, metais e matéria orgânica (Schueler et al., 2018, p. 215).
\end{abstract}

O descarte de bens inservíveis e de entulho na Rocinha, não conta com o serviço de retirada, como acontece nos bairros ditos formais da cidade do Rio de Janeiro. A própria população tem que levar esse material até um ponto de coleta, alguns a longas distâncias, o que acaba levando muitas pessoas a descartarem nas encostas e valas. Em Siloé, a população pode solicitar o serviço de retirada, 
porém tem que pagar uma taxa extra, além do valor que já paga mensalmente, o que leva muitas pessoas a realizarem o descarte irregular nas ruas, em terrenos baldios, em corpos d'água ou em locais onde sabem que em algum momento a empresa de limpeza urbana irá retirar. Vejamos na sequência a fala da entrevistada sobre essa questão:

Los residuos grandes y electrodomésticos, nosotros les llamamos inservibles, y la mayoría de las veces los recogemos en el momento de la recolección en los sitios donde los usuarios los han depositado o los habitantes de calle los han trasladado. Idealmente invitamos a la gente para que nos llamen, para hacer una programación de la recolección para que no lo dejen en el espacio público. Y los escombros es igual lo ideal es que llamen, sólo que a diferencia de los otros esos sí tienen un costo, el sitio de disposición es distinto, se le pide la gente que llame para solicitar el servicio, asumiendo el costo, pero la mayoría de la gente no lo hace y lo que terminamos haciendo es recolectarlo en el espacio público, con un proceso aparte al de la recolección. En la comuna 20 hay una particularidad, y es que no están acumulados en un solo sector, sino que están dispersas por todas partes, el dato más cercano de lo que se recogen la comuna 20, porque no hay grandes escombreras antes habían, ya no hay; entonces encontramos sectores como la calle primera dónde están por bultos regados, por toda la calle, uno sabe que son los mismos porque están del mismo color y todo, pero están regados por todas partes. (ELUCOL1. Entrevista concedida a Maria Izabel de Carvalho. Cali, 03 out. 2019).

No tocante ao descarte de entulho, um fato nos chamou a atenção durante a observação de campo na Rocinha, o que foi confirmado pelo entrevistado da COMLURB, que relatou que moradores de bairros nobres, por exemplo, Copacabana, Ipanema e Leblon, pagam determinadas pessoas da Rocinha que têm carro e que prestam esse serviço de forma irregular, para trazerem esse tipo de resíduo para serem descartados nas lixeiras da Rocinha, conforme demostrado na fala que segue:

Agora o morador daqui que tem carro, ele vai lá em Copacabana e retira lá, é... duzentos sacos de entulho, cobra 500 reais e traz tudo pra comunidade dele. E ninguém, nenhuma liderança aqui briga com o cara. Eu não tenho força pra brigar com esse cara. Eu não posso apreender o veículo dele. Eles aí têm, mas não acontece isso. Então é inadmissível o cara tirar da Zona Sul, ele tá ganhando, e sujar a comunidade dele. Agora, tenta tirar daqui e jogar lá pra ver se tu não vai preso. Prestam serviço lá pra Zona Sul, é Ipanema, Copacabana, Leblon... pegam os entulhos lá, ganham dinheiro, e traz pra cá. Porque o correto, eles têm que levar pro Caju, lá no Caju tem que passar na balança, aí você vai pagar uma taxa. Se você ganha 500 , vai perder 150, já vai fazer falta. Eu entendo dessa forma. Que que eles fazem? Eles não querem perder 150, então vêm pra cá, joga aqui, não dá nada pra ninguém... a gente vai lá, a gente tem que limpar. A COMLURB acaba fazendo esse serviço gratuitamente pra esses caras. São moradores daqui. E muitas das vezes quando eu paro eles... 'não, eu sou morador, peguei lá da minha casa'. Mas a gente tá vendo que não é entulho da casa dele. A gente conhece o que é entulho da Zona Sul e o que é entulho da comunidade. Entulho da comunidade é cascalho, tijolo, essas coisas... Agora da Zona Sul não, vem poda de árvore, pedaço de azulejo, negócio de gesso... Isso tudo a gente sabe 
que é da Zona Sul, não é deles aqui (ELUBR1. Entrevista concedida a Maria Izabel de Carvalho. Rio de Janeiro, 02 out. 2020).

Quando perguntado ao entrevistado por que a população dos bairros nobres da cidade, optavam por descartar de forma irregular os entulhos, mesmo tendo a opção de solicitar a retirada pela COMLURB, este aponta:

\begin{abstract}
Porque você quando chama a COMLURB pra tirar alguma remoção de dentro da sua casa, ou você contrata uma caixa, você tem que pegou, encheu aquela caixa, não pode ultrapassar a base dela. E quando você chama a COMLURB, 1746, os sacos têm que ser padronizados, e você vê ali que o cara não tem o saco padronizado, ele bota num saco de 60 , aí vem madeira misturada com folha, com galho, com tudo... A COMLURB tira, mas ela tira padronizado, você tem que padronizar. Tem algumas coisas reaproveitadas lá dentro da usina, entendeu? Aqui não, aqui ele mistura tudo e joga ali (ELUBR1. Entrevista concedida a Maria Izabel de Carvalho. Rio de Janeiro, 02 out. 2020).
\end{abstract}

O representante da empresa de limpeza urbana, afirmou que essa é uma ação corriqueira e antiga na Rocinha.

Nesse território no que diz respeito à geração e destinação de resíduos sólidos pelo comércio, a COMLURB ratificou o que foi identificado durante as entrevistas com os representantes desse segmento, como pode ser visto no item 4.5; informou que não há contratação de empresas particulares para a coleta dos resíduos, pelo comércio, mesmo boa parte sendo grande gerador. Relatou que sexta, sábado e final de mês, são os períodos em que se nota um maior volume de resíduos gerado por este grupo. Além disso, relatou que muitos restaurantes não querem os resíduos que eles próprios geram, na sua porta, então descartam na porta de comércios de outros ramos, prejudicando-os. Vide trecho abaixo:

Aqui na Rocinha ninguém contrata. Eu quando vim pra cá, achei um absurdo isso. É até estranho. A maioria das lojas aí... é tudo loja que trabalha na informalidade, poucas dela são legais. Vou te dar um exemplo porque eu fui lá; quando eu vim pra cá a gente fez um trabalho ai de conscientização, porque tinha, por exemplo, dentista botando lixo misturado com lixo comum. E a gente detectou isso, aí veio até o Ministério Público pra cá. Aí a gente foi notificar aquela loja de ferragem que tem lá no Boiadeiro... Pra minha surpresa, aquele cara ele não era legalizado. Uma loja de ferragem daquele porte... CPF no nome dele, ele não tinha CNPJ. Então a maioria das lojas aí, é tudo desse jeito. Aí você não tem como notificar. O restaurante é lá em cima, mas o cara não bota o lixo na porta dele, ele bota lá embaixo. Porque ele sabe que se ele botar na porta dele, vai ter cagada. Porque o catador vai chegar lá, vai abrir, vai sujar tudo. Aí o que que ele faz? Dá um guaraná, dá uma cachaça ou dá uma quentinha para o sujeito, para o sujeito botar lá embaixo na porta do outro. $E$ aquela moça que trabalha com biscoito, que não suja nada, está sendo sacrificada. O cara do bar tira daqui, bota lá na porta do cara do eletrodoméstico. Porque o cara do eletrodoméstico também não suja nada. O cara do bar suja, porque ele tem resto de pó de café, resto de comida, ele 
num vai botar na porta dele, porque sabe que de manhã vai tá tudo sujo. Essa comunidade tem essa... Mas é muita gente aí que é grande gerador, se fosse lá pra baixo [bairros formais], estava tudo pagando 800,900 reais para uma empresa particular, para ser coletado o seu lixo (ELUBR1. Entrevista concedida a Maria Izabel de Carvalho. Rio de Janeiro, 02 out. 2020).

O entrevistado citou ainda, lojas como as Casas Bahia - que é classificada como "grande geradora" (ver classificação no item 4.5), apontando que nos bairros ditos formais são obrigadas a contratar o serviço particular de coleta, mas que na Rocinha não o faz, se beneficiando com o descarte irregular de grandes volumes.

A empresa de limpeza urbana de Siloé informou que nesse território não há presença expressiva de grandes geradores (ver discrição no item 4.5), e que só tem conhecimento de um comércio que é de uma grande rede de supermercados de Cali. Os comerciantes têm os resíduos coletados pela empresa nos mesmos dias dos demais usuários.

Quanto aos vendedores ambulantes, tanto na Rocinha como em Siloé, os representantes das empresas de limpeza urbana relataram que eles não são organizados quanto ao descarte dos resíduos e, que não há um controle, para saber ao certo qual o volume de resíduos por eles gerados. Na Rocinha, segundo o entrevistado, nota-se um aumento expressivo desse grupo, nos últimos três anos, e por ser uma atividade comercial, também vem contribuindo para o aumento no volume dos resíduos sólidos desta localidade.

Em se tratando dos resíduos sólidos no período chuvoso, a COMLURB avaliou positivamente o atual cenário, comparando com períodos anteriores, quando disse que descia da parte alta para a parte baixa, muito resíduo que era descartado inadequadamente. Justificou dizendo que os garis vêm fazendo o trabalho de limpeza das valas e, que por isso, estes locais estão limpos, facilitando a drenagem, prova disso é que nas últimas chuvas fortes, não aconteceu nenhum problema grave, segundo ele.

Apesar de apontar melhoria quanto a essa questão, o entrevistado relatou que ainda desce muito lixo durante as chuvas, sobretudo o que fica depositado no chão, seja na rua ou mesmo nos pontos de coleta, pois cabe salientar que ainda que o representante da COMLURB tenha afirmando que há locais adequados para o armazenamento dos resíduos, em alguns dos pontos de coleta, como na Rua 1 e no caminho do Boiadeiro, por exemplo, o resíduo é depositado no chão e fica exposto, então quando a chuva vem, o leva. Deste modo, mesmo o usuário trazendo o resíduo para depositar em pontos estipulados pela empresa de limpeza urbana, não podemos dizer, que o destino 
foi adequado, não porque ele descartou numa vala ou numa encosta, mas sim porque alguns desses pontos de coleta não apresentam infraestrutura adequada para tal.

No período da temporada de chuva, em Siloé, a empresa relatou fazer ações pedagógicas e comunicativas junto aos usuários, para que esses só descartem os resíduos nos dias e horários de coleta, pois assim como na Rocinha, uma parte considerável dos resíduos são depositados por quem reside onde a coleta porta a porta não chega, em pontos sem nenhuma infraestrutura e a céu aberto, conforme pode ser visto no apêndice - documento fotográfico de Siloé.

Em Siloé, segundo a entrevistada, em dois anos subsequentes (2017 e 2018), ocorreram duas grandes tragédias, causadas pelo descarte inadequado de resíduos sólidos, combinado com grandes volumes de água durante as chuvas, que obstruiu corpos d'água e deu origem a situações como as descritas a seguir:

\begin{abstract}
El año pasado [2018], dos adultos mayores fallecieron, porque la quebrada Isabel tiene varias particularidades, es una quebrada que hace muchos años fue entamborada, fue tapada, o sea, no es una quebrada que esté abierta, sino que está tapada. $Y$ en la parte alta de la quebrada hay un basurero, un basurero a cielo abierto, de la comunidad de San Francisco, entonces qué pasa, que en el nacimiento de la quebrada o dónde empieza a volverse más grande la quebrada, lo que ocurrió fue que en la zona alta de Siloé durante muy poco tiempo llovió muy duro, cayeron muchos milímetros de agua en un momento muy corto. Entonces la quebrada como está entamborada y está llena de basura, con toda esa cantidad de agua no pudo sacar la basura por debajo y de un modo u otro la naturaleza buscó su camino y normal, o sea, el camino que tenía antes de que existiera la gente, entonces, rebosa en taponamiento, sale con mucha fuerza, muchísima fuerza, porque fue una gran acumulación de agua, tumba una pared de una casa, que no estaba construido en las mejores condiciones, habían dos adultos mayores los arrastra y desafortunadamente ellos fallecen. $Y$ aparecen en la parte baja, sobre la calle primera, muertos en medio de lodo, de basura, de escombros; una situación muy difícil. El año inmediatamente anterior a esa fue en el 2017, ocurrió una tragedia parecida, porque también cayó mucha agua en algún momento, y en una casa había seis niños que se estaban resguardando, es un lugar donde los niños llegaban después del colegio, y la acumulación de basuras hizo que busque salidas el agua, porque no tiene por donde circular y la fuerza del agua tumbó la pared y mató a los seis niños. Fue una situación absolutamente terrible, nuevamente estuvimos ahí a los pocos minutos garantizando que las ambulancias pudieran entrar, pero fue muy difícil (ELUCOL1. Entrevista concedida a Maria Izabel de Carvalho. Cali, 03 out. 2019).
\end{abstract}

Conforme já dito anteriormente, a população das áreas populares é exposta de forma desigual aos danos ambientais, como os desastres citados nesse trecho, quando pessoas tiveram suas vidas ceifadas. Gonçalves (2018) traz essa discussão e respaldado por Enrico Quarantelli (1998), aponta que os desastres são: 
[...] acontecimentos que articulam fenômenos físicos e a elaboração cultural que os define e que levanta questionamentos no seio da sociedade, dada a ausência de medidas preventivas e as dificuldades da gestão de suas consequências. Os diferentes impactos dos desastres nas áreas urbanas revelam igualmente injustiças ambientais, estabelecendo conexões concretas entre o processo de degradação do meio ambiente e os modelos desiguais de ocupação do espaço urbano (Gonçalves, 2018, p. 8).

Quando se trata de áreas populares, nas situações de desastre como as citadas acima, é muito comum a culpa recair sobre os que vivenciaram o evento e soma-se a isso a justificativa do grande volume de água, como se não houvesse responsabilidade de outros entes, pois certamente era de conhecimento desses, a existência do risco de tal acontecimento; porém, ao que tudo indica, medidas efetivas não foram adotadas até aquele momento, acarretando o desastre. Conforme aponta Gonçalves (2018),

O desastre não pode ser analisado como mera consequência de um evento climático pretensamente imprevisível. Os desastres ligados às chuvas mostram a vulnerabilidade estrutural das áreas mais pobres da cidade. Embora as chuvas atinjam a cidade de maneira cíclica, toda nova enxurrada é divulgada como uma quebra da normalidade para justificar a incapacidade dos poderes públicos de gerenciar os riscos, enquanto que os favelados, por sua vez, são acusados de conhecer os riscos dos locais onde vivem. Observa-se, assim, que o discurso ambiental tornou-se uma expressão vaga e perigosa (Gonçalves, 2018, p. 9).

Deste modo, como aponta Gonçalves (2018), é necessário que os desastres deixem de ser entendidos como algo que não pode ser previsto, como uma fatalidade ou outras adjetivações similares, mas sim como uma expressão da questão social, pois:

\begin{abstract}
Suas consequências negativas são distribuídas de maneira desigual, recaindo frequentemente sobre os mais pobres. $O$ desastre deve ser compreendido como um processo e não somente como um epifenômeno. Isso se torna claro quando se analisa os impactos sociais de fenômenos naturais correlatos em situações distintas, onde a capacidade de prever o risco e de gerenciar o desastre são diferentes (Gonçalves, 2018, p. 11-12).
\end{abstract}

Em se tratando dessa questão na Rocinha, desastres inclusive com a perda de vidas, também já ocorreram em distintos momentos, porém nos últimos tempos estão mais relacionados com desabamento de encostas, não tendo relação direta com 0 acúmulo de resíduos sólidos descartados inadequadamente.

Conforme determinado na política pública de resíduos sólidos, a disposição final dos resíduos sólidos desses territórios se dá para aterros sanitários. No caso da Rocinha, primeiro é levado para a estação de tratamento 
e usina de reciclagem no Caju, onde, conforme fala do representante da COMLURB, na medida do possível é feita a separação do material reciclável e o que resta é enviado para o aterro sanitário de Seropédica. O caso de Siloé é similar, pois os resíduos também são levados para uma estação de transferência em Palmaseca, que fica em Palmira e depois é destinado para o aterro sanitário de Yotoco - ambos ficam em municípios vizinhos a Cali; a diferença é que todo o resíduo que é coletado pela empresa de limpeza urbana, em Siloé, é enterrado, não havendo nenhum tipo de separação do material reciclável durante esse processo. Desse modo, tendo em vista a fala do entrevistado da COMLURB, quando usa a expressão "na medida do possível" em relação à separação de material reciclável e o processo de destinação dos resíduos de Siloé, entende-se que em ambos ainda não é dado, aos resíduos sólidos, o tratamento ideal defendido pelas instituições ambientais, pois mesmo que no primeiro caso a coleta seletiva seja realizada na unidade de reciclagem, ao que tudo indica, ela ainda não é cem por cento eficiente. Corroborando com esse assunto, Miranda (2018), assinala que:

\begin{abstract}
A destinação do total de resíduos sólidos para aterros sanitários, contudo, também não representa a melhor alternativa, pois esses materiais levam centenas de anos para serem degradados, enquanto ocupam espaços que poderiam ser destinados a outros usos. Coletar bens descartados pela sociedade, transportá-los a um local e enterrá-los não parece a solução mais eficiente, considerando-se o fato de que esses bens possuem valor comercial e representam uma possibilidade de renda para uma parcela da população (Miranda, 2018, p. 7).
\end{abstract}

Em termos de fiscalização e/ou avaliação dos serviços prestados pelas empresas de limpeza urbana, visando o monitoramento das ações executadas, nenhum desses procedimentos acontece no caso da Rocinha, ou seja, não há fiscalização do trabalho que é desenvolvido pela COMLURB, e também não há segundo o entrevistado, nenhum processo avaliativo interno ou junto à população, que afira o alcance e a qualidade dos serviços executados nesta área, apesar de no Plano Municipal de Gestão Integrada de Resíduos Sólidos da Cidade do Rio de Janeiro (PMGIRS), está posto que deva ser aplicada, além de outros processos avaliativos do trabalho desenvolvido pela empresa, uma Pesquisa de Satisfação, que:

Tem como objetivo avaliar a satisfação da população carioca em relação aos serviços prestados pela COMLURB e é feita através de entrevistas individuais realizadas de forma aleatória com transeuntes da região de cada uma das Gerências Operacionais. Os entrevistados devem avaliar os serviços de: "Coleta de Lixo"; "Varrição das Ruas"; "Limpeza das Praias"; "Papeleiras"; "Limpeza de Parques"; "Capina"; e "Limpeza da Cidade" atribuindo a cada serviço os seguintes 
níveis de satisfação: "Excelente"; "Bom"; "Regular"; "Ruim"; e "Péssimo". Posteriormente, os dados coletados são trabalhados, atribuindo-se a cada serviço os pesos respectivos de $25 \% ; 30 \% ; 15 \% ; 10 \% ; 5 \%$; e $10 \%$. Feitos os cálculos os resultados são tabulados, gerando o relatório final de cada mês com os indicadores específicos de cada Gerência, cada Diretoria Operacional e da Cidade como um todo (Rio de Janeiro - PMGIRS, 2015, p. 27).

O entrevistado justifica a não realização dessas ações nesse território, fazendo a seguinte colocação: "até porque se você entrar com uma prancheta ali fazendo pergunta... nego já fica tudo te olhando atravessado... 'Não, num quero falar, num quero falar, num quero falar"' (ELUBR1. Entrevista concedida a Maria Izabel de Carvalho. Rio de Janeiro, 02 out. 2020).

Diferente do que ocorre na Rocinha, a empresa Ciudad Limpia informou que a EMSIRVA faz uma espécie de supervisão permanentemente e que, além disso, por serem prestadores do serviço público de limpeza, estão sujeitos ao monitoramento e controle da superintendência de serviços públicos - ente nacional. Vejamos como se dá esse processo:

\begin{abstract}
Pues no de manera recurrente, sino espontánea, llegan piden todo y vigilan y controlan el hecho de que nosotros cumplamos con toda la normatividad. Nosotros toda la información que generamos tenemos que... nosotros y todos los prestadores tenemos que subirla a una plataforma, que tiene la superintendencia que se llama SUI, donde mensualmente se indica cuál es la cantidad de toneladas, de residuos, las rutas... es un montón de información que puede dar cifras exactas, de lo que es el manejo de los residuos y como esto es objeto de control por parte de las entidades de... como la contraloría, que de todas maneras son recursos públicos. A nosotros ellos no nos vigilan, ellos vigilan a Emsirva, porque Emsirva es el ente tarifario, entonces quien decide cuánto se cobran es Emsirva y por ser una información delicada, porque tiene que ver con los recursos públicos o dineros de los ciudadanos, pues son objeto de control de ellos, pero nosotros básicamente préstamos el servicio y la empresa de servicios públicos municipales de Cali se encarga de hacer la facturación; nosotros le pagamos y ellos nos entregan el dinero que nos corresponde, sacando los dineros de subsidios y contribuciones que se le entregan directamente al municipio. Entonces por eso a nosotros no nos controla la contraloría, pero sí a Emsirva que es el ente tarifario que nos lidera a nosotros (ELUCOL1. Entrevista concedida a Maria Izabel de Carvalho. Cali, 03 out. 2019).
\end{abstract}

No caso colombiano, há também, com base na lei nacional, a avaliação por meio de indicadores de eficiência no que diz respeito à qualidade $\mathrm{e}$ continuidade dos serviços prestados; e caso a empresa não atenda o estabelecido, tem que reembolsar o usuário. A representante da Ciudad Limpia informou nunca ter sido necessário fazer nenhum pagamento aos seus clientes, vide trecho que segue:

Mira, la norma Nacional dice que hay unos indicadores de eficiencia calidad y continuidad que, ¿cómo funcionan los indicadores? Si llega a haber alguna no prestación del servicio en la frecuencia, eso tiene que cuantificarse, tiene que 
cuantificarse en sistema que llega al SUI, y llega un momento en que si eso supera cierta cantidad de horas, nosotros tenemos que pagarle a los usuarios por no haber prestado el servicio, o sea, ya hay todo un sistema que genera la norma nacional indica que cuando la calidad de la prestación o la continuidad de la prestación no se da, hay que pagarle al usuario. Nosotros nunca hemos tenido que devolver un solo centavo, porque incluso en situaciones que se salen de nuestra responsabilidad. Tenemos por ejemplo, la estación de transferencia que queda en Palmira tiene problemas, no lo esperamos nosotros, nosotros somos usuarios de ellos, pero ellos no son eficientes, obviamente se nos retrasa toda la operación (ELUCOL1. Entrevista concedida a Maria Izabel de Carvalho. Cali, 03 out. 2019).

A empresa Ciudad Limpia relatou ainda que há uma avaliação amostral realizada anualmente, visando verificar o nível de satisfação dos usuários, que em 2019 estava em 95\%. Segundo a entrevistada, no ato pregunta-se: "cuál es la percepción frente a la calidad, continuidad de servicio e incluso pedimos que nos den como posibilidades, oportunidades de mejora" (ELUCOL1. Entrevista concedida a Maria Izabel de Carvalho. Cali, 03 out. 2019).

E quanto à existência de um canal de comunicação das empresas com os usuários ou vice-versa, para apresentação das demandas, reclamações ou outros, os entrevistados informaram que:

Quadro 26 - Canal de comunicação entre as empresas de limpeza urbana e os usuários

\section{Rocinha}

Tem. Aqui no caso da Rocinha, a gente usa mais a associação dos moradores. Eles levam a demanda deles pra associação dos moradores e aí o presidente da associação, nos traz essa demanda. A mesma coisa lá na RA [Região Administrativa], quando tem alguma poda de árvore... $\mathrm{E}$ alguns moradores que têm meu telefone entra em contato comigo, a maioria das vezes (ELUBR1. Entrevista concedida a Maria Izabel de Carvalho. Rio de Janeiro, 02 out. 2020).

\section{Siloé}

Bueno, la ley nacional exige que las empresas prestadoras de servicios tengan una página web donde los usuarios puedan acceder a un formulario que les permita hacer solicitudes quejas y reclamos, obviamente la de nosotros funciona $y$, aparte de eso, tenemos nuestro sistema de atención al usuario donde pueden acercarse en un horario muy amplio para presentar su requerimiento. Igual nosotros tenemos un equipo de personas que de manera permanente está haciendo el seguimiento de los usuarios desde el área comercial y pues todos somos, todos podemos recibir alguna inquietud de los usuarios; también de manera permanente y por línea telefónica, también de manera virtual, como te digo, a través de la página web enviando correos electrónicos. (ELUCOL1. Entrevista concedida a Maria Izabel de Carvalho. Cali, 03 out. 2019).

Fonte: elaboração própria com base nas entrevistas realizadas. 
$\mathrm{Na}$ Rocinha as principais demandas recebidas são voltadas para a limpeza de valas e retirada ou poda de árvores. Já em Siloé, está mais direcionada a faturamento do serviço.

No que concerne à realização de ações ou campanhas educativas, que busquem munir a população de informações sobre a destinação adequada dos resíduos sólidos, o entrevistado da COMLURB informou não haver nada nesse sentido na Rocinha e complementa: "até porque esse trabalho tinha que partir da comunidade. Gente, pra isso aí tem, eu conheço uma porção. Conheço muita gente que faz esse tipo de trabalho, mas independente, como voluntário" (ELUBR1. Entrevista concedida a Maria Izabel de Carvalho. Rio de Janeiro, 02 out. 2020). Ou seja, além de não realizar ações nesse sentido, ainda atribui à população local, a responsabilidade pela efetivação delas. A representante da Ciudad Limpia informou que desenvolve ações em parceria com os líderes locais, com entidades públicas e junto aos usuários de um modo geral. Relatou não fazer uso de material impresso, por ser uma política da empresa, uma vez que as pessoas não dão importância a esse tipo de material e que acaba parando nas lixeiras, então a equipe lança mão do contato direto com o usuário, das redes sociais e dos demais meios de comunicação, da replicação das informações por meio dos líderes comunitários e da realização de concursos pedagógicos. A seguir a entrevistada discorre sobre essa questão:

Tenemos estrategias de intervención, tenemos jornadas informativas, tenemos jornadas lúdico-pedagógicas, tenemos intervenciones en espacio público, en recuperación de espacio público, que han sido muy efectivos para mejorar condiciones sobre todo en la comuna 20 ... Esas son como básicamente nuestras estrategias, y lo que hacemos es tener un contacto directo con nuestros clientes que son todos nuestros usuarios, y cada vez que vemos oportunidades de mejora, trabajamos para buscar aliados estratégicos, ya sea con entidades o con las comunidades mismas, para poder mejorar y garantizar la prestación del servicio (ELUCOL1. Entrevista concedida a Maria Izabel de Carvalho. Cali, 03 out. 2019).

Visando identificar como são desenhadas essas estratégias pedagógicas, ou seja, se é algo que vem pronto ou se é pensado conjuntamente com os usuários, indagamos à entrevistada, que apontou que:

Hay de todo, hay cosas que pensamos directamente acá de acuerdo a las necesidades puntuales, trabajamos como desde el área de comunicación de la compañía a nivel nacional, trabajamos con una visión un poco más amplia, para que no sea tan local, sino que todas las piezas que generemos puedan fusionar a nivel de ciudades, de todas las ciudades, y hay ejercicios que trabajamos de la mano con las comunidades, entonces a veces hacemos intervenciones en espacios públicos, que es una de las estrategias, las hacemos de la mano de los líderes comunitarios porque sabemos que en la medida que la gente participa y se involucra, pues puede tener continuidad y sobre todo preservarse a largo plazo 
este tipo de recuperación. Trabajamos de la mano también de las entidades públicas de la alcaldía que aportan desde sus razones de ser para las actividades, entonces hay de todo un poco. Lo que se busca es conseguir resultados duraderos, donde a veces tenemos procesos de ensayo y error, donde hacemos algo no nos funciona, entonces buscamos otra oportunidad o buscamos otro escenario, buscamos otras salidas para tratar de disminuir el impacto en espacio público y mejorar las condiciones del servicio, básicamente (ELUCOL1. Entrevista concedida a Maria Izabel de Carvalho. Cali, 03 out. 2019).

Salientamos que durante o nosso processo de observação de campo nesse território, não identificamos ações com características voltadas para a formação de seres críticos, baseadas na educação ambiental crítica - citada anteriormente, com vistas à promoção de transformações a partir da realidade vivenciada pelos sujeitos locais, sendo as atividades observadas, mais a título de repasse de informação sobre o descarte adequado dos resíduos sólidos.

A visão que as empresas têm sobre os usuários quanto à geração e destinação dos resíduos sólidos, não difere muito das que temos observado ao longo dos anos, enquanto pesquisadoras dessa temática em áreas populares. Essa população é, na maioria das vezes, taxada como a que não tem educação, e não é consciente, dentre outras características que lhes são atribuídas, conforme falas que seguem:

Quadro 27 - Visão do representante da COMLURB e Ciudad Limpia sobre a população

Rocinha

É que morador também às vezes não colabora muito, né?! É muito mais fácil você pegar o seu lixo, tá descendo, vê uma encosta e você jogar seu lixo lá na encosta e descer com a mão vazia. Pra quando você chegar ao ponto do ônibus que muitas das vezes num para nem no ponto, e você também não chegar lá na ponta pra jogar seu lixo e voltar para o ponto. Você acaba

\section{Siloé}

Pues yo diría que hay de todo también, trabajamos a diario para generar conciencia ambiental, para que la gente sepa que el trabajo no es solo nuestro, que la ciudad limpia no es la que más se barre, sino la que menos se ensucia y que mantener la ciudad limpia es responsabilidad de todos, no solo nuestra hay usuarios muy juicios, pero también hay otros muy indisciplinados, hay gente que no valora la importancia del servicio, no paga el servicio, no le interesa pagar. En la comuna 20 tenemos una cartera muy alta, hay personas que opinan que primero es una obligación, porque también hay una visión asistencialista, entonces 'soy pobre me tienen que dar y usted tiene plata entonces recójame gratis', no hay... en algunos casos no hay conciencia frente a la importancia de lo que hace el operario, entonces le tiran la bolsa desde el tercer piso, está barriendo y le tira la basura para que tenga trabajo ¿Si?, a la calle; entonces estamos trabajando en ese proceso de generar conciencia, sobre todo en la responsabilidad de las 
deixando a bolsa de lixo no meio do caminho pra facilitar pra que você consiga pegar tua condução sem despreocupação nenhuma. Falta educação. Falta educação e um pouco de vontade da liderança, conforme eu estou te falando. (ELUBR1. Entrevista concedida a Maria Izabel de Carvalho. Rio de Janeiro, 02 out. 2020).

Fonte: elaboração própria com base nas entrevistas realizadas. personas y de lo importante y valioso que es lo que hacemos, y pues buscando también que la gente sea un poco más consciente de que es necesario pagar los servicios públicos, porque si bien no se presta el barrio en todas las escaleras y en los caminos peatonales, sí se está pagando la limpieza de toda la ciudad. Entonces sí falta conciencia y bastante, y cuando uno ve situaciones como las tragedias de las que hablamos, uno se da cuenta de que a la gente le pasa y le pasa y no entiende que su efecto, que cada cosa tienen efecto y puede ser un efecto muy grave, pero hay otras comunidades donde uno dice, sí, evidentemente aquí sí hay compromiso, están dispuestos, trabajan por ello, están comprometidos. Entonces hay de todo, pero a veces si pesa mucho eso sobre todo por las consecuencias nefastas que puede llegar a tener (ELUCOL1. Entrevista concedida a Maria Izabel de Carvalho. Cali, 03 out. 2019).

Quanto a essa questão o representante da COMLURB dividiu os moradores em dois grupos: o morador raiz e o morador nordestino; vejamos como ele classifica cada um desses:

\begin{abstract}
Morador raiz da Rocinha é aquele que você vê hoje ainda morando lá na Macega, lá em cima, aquele barraquinho mais simplesinho, mais humilde. Morador raiz da Rocinha é todo aquele que permitiu que hoje em dia a casa dele é no terceiro andar ou no segundo, porque ele deu a casa dele embaixo, ele permitiu que alguém fizesse uma loja embaixo, fazendo uma laje, dando a casa dele em cima, porque ele não tinha condições de fazer. Esse é o morador raiz. Porque o moramorador nordestino, ele não é ganancioso, ele é um cara que quer o melhor. Os maiores donos de comércio aí são pessoas nordestinas. Eles vêm aqui com a vontade de subir na vida, de crescer. Você tem uma casa, você é dono de um bar embaixo e aluga uma loja em cima pra um nordestino. E esse nordestino, ele é vigia ou ele é síndico, trabalha num... porteiro de um prédio. Ele vai guardando um dinheiro. Quando você pensa que não, ele compra a casa de cima. Quando você pensar que não ele já comprou o bar e aquele cara que era dono vira cliente dele de cachaça. Eles são grandes consumidores. Você é nordestina, você gosta de fartura. Porque a maioria deles teve dificuldade no Nordeste, então quando chega pra cá, que a vida melhora pra eles, é natural você ter fartura, você não deixar faltar para o teu filho aquilo que te faltou lá (ELUBR1. Entrevista concedida a Maria Izabel de Carvalho. Rio de Janeiro, 02 out. 2020).
\end{abstract}

O entrevistado fez essa distinção entre os moradores, alegando que o nordestino é uma pessoa que consume muito e consequentemente acaba gerando grandes quantidades de resíduos sólidos, enquanto o "morador raiz" é 
um consumidor mais comedido e que, portanto, gera menos resíduo. Logo segundo essa fala, os nordestinos, que são maioria na Rocinha, seriam os maiores responsáveis pela geração de resíduos sólidos nesse território.

No parágrafo em tela, trazemos informações referentes a forma como as empresas de limpeza urbana se relacionam ou não com as organizações de catadores/recicladores e/ou catadores/recicladores individuais. Identificamos que não há por parte da empresa de limpeza urbana que presta serviço na Rocinha, articulação com esse segmento. A representante da Ciudad Limpia relatou que a articulação que a empresa tem com esse grupo acontece de forma indireta. Vejamos como se dá esse processo e qual a visão da entrevistada sobre ele:

Pues nosotros no nos articulamos con ellos de manera directa, ¿por qué?, porque el municipio está en un proceso de cumplimiento de una sentencia, la sentencia T291, que dice que municipio debe generar acciones afirmativas, para garantizar que los recicladores de oficio se vuelvan empresarios. La ciudad lleva 15 años en ese proceso, si no más, y ha sido bastante traumático y al mismo tiempo poco eficiente ese proceso, y existen en este momento como 35 asociaciones de recicladores, pero ninguna... nosotros no podemos dar fe de que ninguna pueda ser eficiente o cumplidora, entonces nosotros no recomendamos a nadie, qué hacemos, por norma, por compromiso, además social y por contrato, nosotros promovemos la separación en la fuente y el trabajo con los recicladores de oficio, pero no recomendamos a nadie. Entonces si una unidad residencial nos dice 'mire yo, usted me está diciendo que tengo que trabajar con un reciclador de oficio, dígame con cuál' le damos todo el listado que nos entrega el municipio, de cuáles son esos recicladores de oficio, para que ellos deciden con quién trabajar. Porque tenemos muchos inconvenientes, porque ellos no son muy consecuentes, ni tienen continuidad en la prestación del servicio, porque pues, tienen unas condiciones muy complejas y adicionalmente, porque las bodegas de reciclaje de los sitios de acopio y reciclaje, generalmente para nosotros son un basurero enfrente. El año 2016-2017, no en el 2018 empezó a regir una norma que dice que estos recicladores de oficio tienen 5 años para volverse empresarios y que en la medida que ellos se inscriben dentro de la... superservicios como empresa prestadora de servicio de aseo ESP y se inscriban y cumplan con todos los requisitos para ser una ESP, el prestador que ellos elijan de sus zonas de operaciones, pueden cobrar un valor adicional que les pagan a ellos por tarifa. En este momento ya hay como 10 asociaciones y empresas privadas que están reclamando recursos de tarifa; y esa es la otra relación que tenemos con ellos, es que somos como quienes cobran y les pagamos a ellos ese recurso, porque la ley nos obliga a hacerlo; entonces hacemos todo el proceso de comercialización, a través de nuestra factura se cobra y a ellos se les paga el porcentaje y ellos nos pagan por ese servicio que hacemos, pero básicamente esa es nuestra relación y ese es el cumplimiento de una norma nacional (ELUCOL1. Entrevista concedida a Maria Izabel de Carvalho. Cali, 03 out. 2019).

Em relação à coleta seletiva, salientamos que em nenhum dos campos essa atividade é executada pelas empresas, bem como não há nenhuma previsão para que esse serviço seja implementado nessas áreas, no atual momento. 
Um dos pontos citados espontaneamente pelos entrevistados foi o fato de que a presença de carros estacionados nas vias é prejudicial à realização do serviço de coleta em ambos os territórios, impedindo, no caso de Siloé, que o caminhão acesse alguns locais; e no caso da Rocinha, gerando engarrafamento nos horários de retirada dos resíduos sólidos, sendo muitas vezes atribuída injustamente a empresa a responsabilidade pelas interrupções no trânsito.

\section{3. \\ As organizações de catadores/recicladores e o olhar sobre 0 trabalho executado}

Inicialmente cabe salientar que devido à pandemia da Covid-19, a entrevista com o representante da organização de catadores da Rocinha foi realizada por meio do envio de formulário online, o que pela própria natureza do formato, nos impediu de além de observar as estruturas locais e a convivência entre os trabalhadores no espaço de trabalho, também nos impediu de ampliar a conversa através de desdobramentos que na entrevista presencial seria possível.

Como nos outros itens, segue abaixo um quadro identificando algumas especificidades sobre as organizações e seus representantes.

Quadro 28 - Perfil dos representantes das organizações de catadores

\begin{tabular}{|c|c|c|c|}
\hline \multicolumn{4}{|c|}{ PERFIL DOS REPRESENTANTES DAS ORGANIZAÇÕES DE CATADORES } \\
\hline Questões & $\begin{array}{l}\text { Cooperativa } \\
\text { Rocinha } \\
\text { Recicla }\end{array}$ & ASO DE CORES & ARCO 20 \\
\hline $\begin{array}{ll}\text { Tipo } & \text { de } \\
\text { organização } & \end{array}$ & Cooperativa. & $\begin{array}{l}\text { Asociación de fami- } \\
\text { bodegueros y recicladores. }\end{array}$ & $\begin{array}{l}\text { Asociación de Recicladores } \\
\text { de la Comuna } 20 .\end{array}$ \\
\hline $\begin{array}{l}\text { Cargo/função do } \\
\text { entrevistado }\end{array}$ & Coordenador. & Representante legal. & Representante legal. \\
\hline $\begin{array}{ll}\text { Tempo } & \text { de } \\
\text { trabalho } & \text { na } \\
\text { organização } & \end{array}$ & $\begin{array}{l}2 \text { anos e } 3 \\
\text { meses. }\end{array}$ & $\begin{array}{l}\text { Desde su creación, } 17 \\
\text { años. }\end{array}$ & $\begin{array}{l}\text { Llevo informalmente en } 12 \\
\text { años, y ya formalizado } 5 \text { años. }\end{array}$ \\
\hline $\begin{array}{l}\text { Já trabalhou em } \\
\text { outro } \\
\text { cargo/função na } \\
\text { organização }\end{array}$ & Não. & No. & $\begin{array}{l}\text { No, siempre he sido como el } \\
\text { representante legal, me ha } \\
\text { nombrado la misma } \\
\text { asamblea. }\end{array}$ \\
\hline Idade & 50 anos. & 55 años. & 40 años. \\
\hline Gênero & Masculino. & Masculino. & Masculino. \\
\hline Escolaridade & $\begin{array}{l}\text { Superior } \\
\text { Incompleto. }\end{array}$ & $\begin{array}{l}\text { Primaria, bachillerato y } \\
\text { carrera técnica, tengo } \\
\text { hasta carrera técnica. Yo } \\
\text { soy técnico en manejo } \\
\text { integral de residuos sólidos } \\
\text { del SENA. }\end{array}$ & Primaria. \\
\hline
\end{tabular}




\begin{tabular}{|c|c|c|c|}
\hline Renda mensal & $\mathrm{R} \$ 700,00$ & $\begin{array}{l}2 ' 000.000 \text { (pesos). } \\
\text { [equivalente a cerca de } R \$ \\
3.119,00 \text { ] }\end{array}$ & $\begin{array}{l}\text { Al principio no tenía ningún } \\
\text { ingreso, trabajabamos eran } \\
\text { como líderes, acompañando, } \\
\text { ahora, pues más o menos } \\
\text { está entre } 1 \text { '000.000 en } \\
\text { promedio. } \\
\text { [equivalente a cerca de } R \$ \\
1.559,00 \text { ] }\end{array}$ \\
\hline $\begin{array}{l}\text { Horas diárias } \\
\text { trabalhadas }\end{array}$ & 4 horas. & $\begin{array}{l}12 \text { horas (7:00 a.m. a 7:00 } \\
\text { p.m.). }\end{array}$ & $\begin{array}{l}\text { Alrededor de } 15 \text { horas } \\
\text { (llegamos a las } 7 \text { a.m. o } 6 \\
\text { a.m. y a veces son las } 10 \\
\text { p.m., } 11 \text { p.m. y estamos } \\
\text { todavía por acá volteando). }\end{array}$ \\
\hline $\begin{array}{ll}\text { Lugar } & \text { de } \\
\text { nascimento } & \end{array}$ & RJ. & Cajamarca Tolima. & Cali. \\
\hline $\begin{array}{ll}\text { Lugar } & \text { de } \\
\text { residência } & \end{array}$ & Jacarepaguá. & Lido. & Siloé. \\
\hline
\end{tabular}

Fonte: elaboração própria com base nas entrevistas realizadas.

Os sujeitos entrevistados são os representantes legais das organizações, portanto, responsáveis pela administração dos serviços executados na área de coleta e triagem dos resíduos sólidos, ações, por vez, realizadas pelos catadores (Brasil) e recicladores (Colômbia).

No caso da Rocinha identificamos somente uma organização de catadores, a Cooperativa Rocinha Recicla, que hoje é vinculada ao projeto "De olho no Lixo" que é resultado da cooperação técnica entre a Secretaria de Estado do Ambiente (SEA), Instituto Estadual do Ambiente (Inea) e o Viva Rio Socioambiental, com recursos da Associação dos Supermercados do Estado do Rio de Janeiro (Asserj), tendo como objetivo principal, a geração de emprego e a minimização do impacto negativo provocado pelos resíduos sólidos no local.

Em Cali, sobretudo em Siloé, registra-se um número expressivo de organizações, que lá são conhecidas como Associações de Recicladores. Contudo, segundo um dos entrevistados, três dessas (Asobosur, Asodecores y Asobose) apresentam uma particularidade, que é o fato de terem as famibodegas, que são espaços geralmente menores, destinados ao recebimento, separação, armazenamento e até mesmo comercialização do material adquirido pelos recicladores. Essas se vinculam as associações de recicladores formalizadas, para obterem os benefícios destinados a este grupo, como por exemplo, o recebimento da taxa de aproveitamento, sobre a qual falaremos mais adiante. No caso da ASODECORES (Asociación de Recicladores de Ofício e Fami-bodegueros), uma das associações que participou desta pesquisa, das 20 fami-bodegas ligadas a ela, doze estão situadas dentro de Siloé, a maioria concentrada na parte baixa. As fami-bodegas são, portanto, nas palavras do entrevistado: 
Son recicladores con mucho juicio, que ahorraron su plata y montaron una bodega, o fami-bodegueros que son familiares de recicladores, el sobrino, el tío que fueron aprendiendo y fueron teniendo un poquito más de vínculo y metieron eso, pero no son grandes comerciantes sino que vienen del mismo gremio (ORCOL2. Entrevista concedida a Maria Izabel de Carvalho. Cali, 21 set. 201

Apesar de serem conhecidos também como recuperadores, os recicladores preferem que essa nomenclatura não seja atribuída à categoria, pois segundo eles, essa é uma forma genérica de se dirigirem ao grupo, podendo incluir inclusive, quem separa na sua casa, nas empresas ou em outros lugares, e de acordo com a visão de um dos entrevistados, esses grupos poderiam começar a reivindicar uma remuneração por tal atividade, o que de alguma forma, desvalorizaria e prejudicaria o trabalho e o ganho do reciclador, o que seria prejudicial para ele, uma vez que outras pessoas, que não são recicladoras, poderiam se beneficiar com o uso desse termo, sem sequer exercer o trabalho de catação, como relatou o representante de uma das associações:

\begin{abstract}
Nosotros los recicladores de oficio de la República de Colombia que estamos bajo la Norma y protegidos por la sentencia $P$ 291, no aceptamos la palabra recuperadores, sino recicladores, recicladores de oficio, porque el gobierno es muy vivo y está intentando meternos recuperadores y así recuperadores son muchas, que pueden abrir y expandir para que entren otros gremios que no tiene nada que ver con nosotros. Somos recicladores de oficio, entonces luego sale una Norma que va a decir, los recuperadores de Santiago de Cali tienen tal beneficio y pueden hacer, entonces se nos va entrando gente porque 'yo soy recuperador', porque yo recupero desde mi casa, yo recupero desde mi empresa, pero el gremio como tal de recicladores de oficio si se deja cambiar el nombre van a entrar más... (ORCOL2. Entrevista concedida a Maria Izabel de Carvalho. Cali, 21 set. 2019).
\end{abstract}

Em relação a experiência e ganhos dos representantes legais dessas instituições, identificamos que na Rocinha o tempo de atuação é de dois anos e meio aproximadamente, enquanto em Siloé o tempo de experiência é bem maior, chegando a dezessete anos. Os entrevistados têm entre 40 e 55 anos, são do gênero masculino e apresentam distintos graus de escolaridade, indo do ensino fundamental ao nível superior incompleto. Suas remunerações vão de $R \$$ 700,00 a $R \$ 3.119,00$ e os participantes de Siloé cumprem uma extensa carga horária, podendo trabalhar até 15 horas por dia, enquanto o representante da Rocinha trabalha quatro horas/dia. No tocante ao local de moradia, somente um destes reside na área da pesquisa.

Na América Latina e o Caribe, no que diz respeito às organizações de catadores, Terraza \& Sturzenegger (2010), sinalizam que: 
Hasta hace unos treinta años, existían muy pocas organizaciones de recicladores en América Latina y el Caribe. Sin embargo, a partir de los años ochenta comenzaron a florecer en la región diversas cooperativas y otras formas de asociación (Terraza \& Sturzenegger, 2010, p. 15).

Assim como Sánchez (2018), acreditamos que a organização e a formalização dos catadores/recicladores, seja através de cooperativas ou outras formas organizacionais, podem:

\begin{abstract}
Melhorar suas condições socioeconômicas através do acesso e fortalecimento de suas ferramentas técnicas, tecnológicas e operativas. Isto também objetiva o aumento de sua capacidade de coleta e transporte, o aumento da sua taxa de renda derivada da comercialização direta e a redução de sua dependência no que diz respeito aos intermediários e grandes atacadistas de recicláveis. Contudo, ressaltamos que esse processo de organização e formalização continua sendo um espaço de luta pelo direito ao trabalho e da sua inclusão nas políticas de gestão de resíduos (Sánchez, 2018, p. 142).
\end{abstract}

Silva (2017, p. 25), assinala que "as cooperativas e as associações são vistas como potenciais instrumentos de inserção social, por proporcionarem uma série de vantagens e melhores condições de trabalho" aos catadores. Essa autora aponta ainda que:

A gestão de um empreendimento coletivo - como no caso de uma cooperativa não é algo trivial e exige conhecimento especializado em diferentes áreas para sua consolidação. São diversas as etapas básicas de funcionamento que precisam ser controladas em uma cooperativa de catadores, tais como o transporte, a triagem, o beneficiamento e a comercialização dos materiais, além de apoio para a formação técnica e a gestão interna de conflitos. Ou seja, gerenciar uma cooperativa de catadores envolve controlar cada uma de suas atividades e as relações necessárias entre elas: organização do trabalho, estabelecimento de objetivos e metas, formulação de planos de trabalho e acompanhamento das ações previstas (Silva, 2017, p. 25).

No que concerne a essas organizações em Cali, as que são formalizadas, devem:

Reportar de manera mensual el cargue denominado Estaciones de Clasificación y Aprovechamiento, en el cual se relacionan las toneladas recibidas en la ECA para clasificación y aprovechamiento y las toneladas de material de rechazo de la actividad de clasificación que tiene como destino final el relleno sanitario y que son recolectados por el prestador de recolección y transporte de residuos no aprovechables. En este reporte se identifica el tipo de vehículo en el cual ingresó o salió el material, así como la cantidad de material en toneladas (Colombia - SSPD, 2019, p. 19).

Quanto à coleta de materiais recicláveis e/ou outros recursos, uma das organizações de Siloé relatou que isso se dá por meio do contato com unidades habitacionais ou outros usuários, que possam firmar parceria para a retirada dos 
resíduos recicláveis. Na Rocinha não houve nenhum relato da cooperativa nesse sentido. Em Siloé se dá da seguinte forma:

Sí nosotros vamos, buscamos conseguir el número telefónico, agendamos la cita, vamos a la cita, presentamos todos los documentos, les decimos qué hacemos, qué tenemos, si no tienen reciclador se lo presentamos, se lo colocamos, porque ellos necesitan que les den un documento de los residuos sólidos que salen, sólo los pueden dar las organizaciones como nosotros a través de nuestros logos. Todo dándole cumplimiento al... de Santiago de Cali y eso es lo que tienen. Porque el 596 dice, no sé si te han dicho que existe la sentencia T 291 del 2009, que protege el reciclador de oficio, eso salió para Santiago de Cali, pero ya está a nivel nacional, qué se dice que el reciclaje domiciliario es exclusivo para el reciclador de oficio, o sea, el reciclaje que producen las unidades y las casas domiciliarios, que es donde vivimos todos, es exclusivo para el reciclador de oficio; entonces nosotros recogemos en las unidades y en las casas, casas de un piso, 2 pisos, 5... y todos los condominios o unidades residenciales, donde haya. (ORCOL2. Entrevista concedida a Maria Izabel de Carvalho. Cali, 21 set. 2019).

No caso das organizações de Siloé, após firmar parceria com os usuários citados acima, essas têm que programar a retirada do material reciclável nestes locais de acordo com o dia que a coleta é realizada pela empresa de limpeza urbana, conforme descrito a seguir:

De acuerdo a las frecuencias, qué significa las frecuencias, los carros prestadores de servicio Ciudad Limpia, Promo, Emas... Ellos sí a una unidad van el lunes, vuelven el miércoles y vuelven el viernes y si van el martes, vuelven el jueves y vuelven el sábado, pero hay unidades que son muy grandes que tienen que ir todos los días. Entonces se llama frecuencia la primera frecuencia es el lunes o martes, la segunda es el miércoles o jueves y la tercera es el viernes o sábado, depende de la frecuencia que va llevando. Entonces un reciclador va tres veces por semana a un condominio (ORCOL2. Entrevista concedida a Maria Izabel de Carvalho. Cali, 21 set. 2019).

Para a retirada do material reciclável dos condomínios ou outros locais, as organizações de recicladores de Siloé, fazem uso de:

Tracción humana; casi todos utilizamos carretas y utilizamos carros que vamos pagando con nuestro propio dinero, carros viejos porque no tenemos músculo financiero para comprar un carro nuevo, el estado no nos ha financiado, ni nos ha ayudado tengo que decirlo; el estado, el dueño municipal de alguna manera no sirve para nada en este país en esto, sacó la norma, muy bueno, eso es una bandera y la muestro, es una belleza, pero no le ha metido recursos ni nada. Ese aprovechamiento del que estamos beneficiando con el que compramos todo esto que es producto, y pagarle a todos, eso es lo que paga el usuario, el estado no te da una moneda de 100, es muy tirano en ese sentido. Bueno, entonces, nosotros todo es con recursos propios (ORCOL2. Entrevista concedida a Maria Izabel de Carvalho. Cali, 21 set. 2019).

Em relação ao quadro de catadores/recicladores associados às organizações, a que apresenta o maior número de colaboradores é a 
ASODECORES, seguida da ARCO 20, ambas de Siloé. Na cooperativa da Rocinha, esse número é muito pequeno, se comparado às duas anteriores, sobretudo porque não conta hoje, com uma estrutura física adequada para o desenvolvimento do trabalho. Nota-se que 0 maior percentual de catadores/recicladores, nas organizações participantes da pesquisa, é do sexo masculino, conforme quadro abaixo:

Quadro 29 - Total de catadores/recicladores associados às organizações de catadores/recicladores e divisão por gênero

\begin{tabular}{|c|c|c|c|}
\hline Associações & $\begin{array}{c}\text { Total de } \\
\text { catadores/recicladores }\end{array}$ & Homens & Mulheres \\
\hline $\begin{array}{c}\text { Cooperativa } \\
\text { Rocinha Recicla }\end{array}$ & 38 & 20 & 18 \\
\hline ASODECORES & 315 & 189 & 126 \\
\hline ARCO 20 & 190 & 155 & 35 \\
\hline
\end{tabular}

Fonte: elaboração própria com base nas entrevistas realizadas.

Segundo as organizações de Siloé, o trabalho dos recicladores é organizado por turnos, ou seja, alguns profissionais trabalham pela manhã, outros a tarde e os demais à noite. Isso facilita o processo, uma vez que em algumas associações não existe um número de carrinhos (burrinho sem rabo) equivalente ao número de recicladores, até mesmo porque esse tipo de veículo é um produto relativamente caro para a realidade dessas associações, que disseram custar por volta de $\$ 400.000$ (quatrocentos mil pesos colombianos, equivalente a cerca de $\mathrm{R} \$ 625,00)$.

Quanto à remuneração dos catadores/recicladores associados, foram identificadas três formas distintas de realizar o pagamento deles. Na cooperativa da Rocinha, o material é acumulado durante um mês, podendo ultrapassar um pouco mais que isso, porque às vezes é necessário esperar até que o volume coletado seja suficiente para encher as carretas/containers, para só então vender; somente após a venda, é que é feito o rateio do montante, em valores iguais entre os cooperados, independente da quantidade que cada um recolheu.

Diferente do que ocorre na cooperativa da Rocinha, nas associações de Siloé, o pagamento é feito de forma individual, à medida que o reciclador traz o material que coletou. $\mathrm{E}$ além do valor que é pago pelo material coletado individualmente, os recicladores recebem ao final de cada mês, um valor referente ao aproveitamento de resíduos sólidos, conforme estipulado no Decreto 596 de 11 de abril de 2016, que dispõe sobre: "el esquema de la 
actividad de aprovechamiento del servicio público de aseo y el régimen transitorio para la formalización de los recicladores de oficio, y se dictan otras disposiciones" (Colombia, 2016).

Para que os recicladores recebam a remuneração pelos serviços prestados, enquanto colaborador da atividade de aproveitamento, os usuários dos serviços de limpeza urbana de Cali pagam mensalmente uma taxa referente ao serviço de aproveitamento dos resíduos sólidos, valor esse que ao final de cada mês, é repassado para as associações, as quais por vez fazem a transferência deste dinheiro para os recicladores; essa quantia fica em torno de $R \$ 150.000,00$ pesos colombianos (equivalente a cerca de $R \$ 234,00$ ), para cada reciclador. Para que recebam esse valor, o setor responsável pela parte administrativa das organizações alimenta constantemente plataformas da Superintendência de Serviços Públicos, que fica em Bogotá, quando é informada a quantidade de resíduos recicláveis coletado pelos associados e o que foi vendido aos compradores. Vejamos na fala a seguir, como se dá esse processo, segundo um dos entrevistados:

El muchacho sale en la carreta recoge en esa unidad este material, lo trae aquí a la bodega y lo vende, pero cuando lo vende le genera un documento que es una factura tanto de cartón, tanto de archivo, tanto unitario, tantos kilos total y entonces dice 1.000 kilos digamos $\$ 1^{\prime} 000.000$, no 100.000 pesos. Este documento nos lo pasan a nosotros, que es lo que cogen ellos de las 20 fami-bodegas de los 315 recicladores, cuando venden, venden tres veces a la semana, entonces le hacen una suma total de toda la semana y generan un documento, nosotros lo digitamos y lo subimos a 2 plataformas diferentes, eso que le recibimos a él, el primero el 2 y el 3 abren las plataformas en Bogotá, de la Superintendencia de Servicios Públicos, ya abierta, la secretaría de acá empieza a generar, a enviar a la plataforma de Bogotá la SUI, se van a allá, el 3 a medianoche cierran. Ellos comienzan a revisarnos, lo que ella no sube son esas facturas, haber le explico, lo que la fami-bodega le compró, compró 10 toneladas de materiales diferentes, supongamos que compró una tonelada de cartón y archivo cuando ellos lo venden al intermediario de la empresa, nosotros le generamos una factura porque nosotros le vendemos y generamos la factura de venta, esa factura de venta suma un promedio de 500 toneladas mes, de las 20 fami-bodegas, ella lo coge y lo digita, y el primero los coge y los entra y lo sube a la plataforma las 500. La superintendencia de servicios públicos en Bogotá la revisa y ve que todas estas facturas están legales, pagaron los impuestos, retefuente y como el 10 vuelven a abrir la pantalla y sale todo el listado de las asociaciones, de sus toneladas a las cuales dijo págame, entonces Asodecores paguele 500 toneladas que subió correctamente, eso fue cuando lo vendió (ORCOL2. Entrevista concedida a Maria Izabel de Carvalho. Cali, 21 set. 2019).

Uma das organizações de recicladores de Siloé, visando um controle maior sobre os valores a serem recebidos pela associação, em função do trabalho que presta aos usuários dos serviços de limpeza urbana, contrata contadores e 
assessores voltados para a parte financeira, para não correr o risco, segundo o entrevistado, de não receberem o valor devido. Vide fala a seguir:

Tenemos contador, tenemos asesor comercial y tenemos asesor para cobro y aprovechamiento, porque hasta eso, le cuento así por encima, si nosotros no tuviéramos... tuvimos que contratar a una persona que supiera manejar la factura de cobro de los servicios públicos y que diga cuánto le corresponde al retroactivo y todo eso, porque o si no, nos habían tumbado, en las empresas prestadoras de aseo tampoco se puede confiar, nos tocó contratar a alguien que sabía todo eso, y le damos el 5\% del comercial que nosotros recibimos, si recibimos 10'000.000 le damos el $5 \%$, yo por lo menos que recibí 16 en este pago le di $\$ 800.000$, pero él hace que me paguen lo justo y lo que es, como es y cuando van habiendo retroactivos de meses anteriores, él pasa y exige de acuerdo a la normativa y nos lo cancela, si nosotros no tuviéramos eso nos tumban, porque eso es así; nunca hemos tenido dinero y llegamos a una empresa de esas y dicen vea 20'000.000 les corresponde a ustedes yo salgo feliz '20'000.000', pero no eran 20 eran 28, 25. Ellos todavía se equivocan (ORCOL2. Entrevista concedida a Maria Izabel de Carvalho. Cali, 21 set. 2019).

Em Siloé, no tocante ao pagamento aos recicladores associados, sondamos se havia alguma diferença em relação à remuneração entre homens e mulheres, porém segundo os entrevistados não há nenhuma distinção, pois o pagamento é feito de acordo com o volume de material coletado por cada pessoa, independente do gênero. E segundo uma das associações desse território, é muito comum haver casais desenvolvendo a atividade de catação.

Em Cali, as associações de recicladores passaram a pagar impostos, a partir do então Decreto 596, quando foi legalizada a atividade de reciclagem, vide abaixo:

Sí, nosotros le pagamos impuestos a la DIAN, reteica, retefuente, industria y comercio, creo que esos no más, por eso todos tenemos una contadora o un contador para que nos lleve. Asodecores paga un promedio mensual de casi 5 millones en impuestos, porque el gobierno sacó el 596 también para legalizar el reciclaje y poder coger estos rubros, porque el reciclaje era informal y resulta que haciendo números desde que comenzó con este 596 que estamos hablando de casi 2 años y pedacito, ha recogido más de 100.000 millones de pesos, que nosotros los recicladores le hemos aportado al Estado. Ahh y también me falta, yo pago los parafiscales, hago mi contribución al SENA, todo lo legal, y tenemos la seguridad social a la planta administrativa. No a los muchachos, porque ellos todavía no la necesitan, pero la parte administrativa sí (ORCOL2. Entrevista concedida a Maria Izabel de Carvalho. Cali, 21 set. 2019).

No que concerne à disponibilização de equipamentos de proteção individual (EPI) pelas organizações de catadores/recicladores, para o desenvolvimento do trabalho de catação, foi informado pelos representantes dessas instituições, que os catadores/recicladores recebem esse material, que em geral são: luvas, botas, máscara, camisa e calça. Em relação à reposição desses EPIs, a cooperativa da Rocinha relatou que repõe o material à medida 
que ocorre o desgaste. Já uma das associações de Siloé, disse entregar a cada seis meses, porém às vezes encontra dificuldade, por não ter os equipamentos. Há ainda uma dessas organizações, que relatou não dispor do material, por falta de recursos, mas que estava buscando meios para adquiri-los.

Em caso de acidentes envolvendo os catadores/recicladores, as organizações informaram que esses são devidamente amparados. Na Rocinha Recicla quando há alguma situação de acidente, é feito o acompanhamento do cooperado e mesmo não estando trabalhando, durante o período que se mantiver em recuperação, permanece recebendo a sua remuneração mensal. Nas associações de Siloé, os recicladores contam com as Administradoras de Riesgos Laborales, que é um tipo de seguro que cobre as despesas geradas por acidentes de trabalho e doenças ocupacionais. Uma das organizações de Siloé relatou haver um orçamento para o pagamento do seguro, enquanto isso, na outra associação, o representante disse pagar somente cerca de cinquenta por cento desse custo, ficando a cargo do associado, o restante do valor. Segundo os responsáveis pelas organizações, não é comum acontecer esses tipos de ocorrências e geralmente quando ocorrem, são de pequeno porte, como algum corte nas mãos, por exemplo, conforme dito abaixo:

\begin{abstract}
No, mira que hasta el momento no se presentan accidentes que sean graves, de pronto una cortada, pero que son más, ¿sí me entiendes? Porque depronto no se puso el guante o alguna cosa, pero es muy... para eso se está capacitado, hay una persona que capacita y explica a la gente cómo debe estar para no cometer errores, pero desde que nosotros estamos gracias a Dios no ha pasado nada. De pronto un accidente en carro, que de pronto un carro gira y atropella a algún reciclador, si puede haber, pero en el caso de nosotros no (ORCOL1. Entrevista concedida a Maria Izabel de Carvalho. Cali, 16 set. 2019).
\end{abstract}

No que concerne ao patrimônio das organizações de catadores/recicladores, dentre os bens materiais estão: carrinhos para a catação, caminhões para o transporte do material, computador e EPI's, conforme podemos observar no quadro que segue:

Quadro 30 - Bens materiais que compõem o patrimônio das organizações de catadores/recicladores

\begin{tabular}{|c|c|c|}
\hline Organização & $\begin{array}{c}\text { Bens materiais que a organização } \\
\text { possui }\end{array}$ & \begin{tabular}{c} 
Quantidade (unidade) \\
\hline Cooperativa
\end{tabular}$\quad$ Carrinho para catação \\
\hline Rocinha Recicla & Prensa & 01 \\
\hline & Paleteira manual & 01 \\
\hline
\end{tabular}




\begin{tabular}{|c|c|c|}
\hline ASODECORES & $\begin{array}{c}\text { Carro (camionete e caminhão) } \\
\text { Carrinho para catação }\end{array}$ & 100 \\
\hline & $\begin{array}{c}\text { Material de escritório (computador, } \\
\text { impressora, etc.). }\end{array}$ & \begin{tabular}{c} 
Não informada. \\
\hline ARCO 20
\end{tabular} \\
\hline Carrinho para catação & 80 \\
\hline & Material de escritório (computador, & Não informada. \\
\hline
\end{tabular}

Fonte: elaboração própria com base nas entrevistas realizadas.

Nenhuma delas é proprietária do lugar onde estão situadas. A Cooperativa Rocinha Recicla ficava em um terreno no sub-bairro Roupa Suja, porém em novembro de 2018, a Prefeitura do Rio fez a desapropriação, prejudicando assim, o desenvolvimento do trabalho que vinha sendo realizado, quando essa organização acabou perdendo espaço para o armazenamento do material coletado pelos catadores, o que repercutiu diretamente na diminuição do número de cooperados, que à época chegava a cerca de 50 e mais recentemente, no segundo semestre de 2020, contava apenas com 38 catadores - conforme informado anteriormente. Hoje desenvolve seu trabalho, em um container, nas proximidades do CIEP $^{38}$ Airton Senna. Das organizações de Siloé, uma paga o aluguel do galpão de onde está situada e a outra faz uso de um espaço cedido pelo poder público, lugar esse que anteriormente pertencia ao narcotráfico, e que segundo o representante da associação, para não ter despesas com a manutenção desse lugar, por exemplo, com um vigilante que deveria ficar ali durante todo o dia, o governo cedeu para uso pela organização. O entrevistado informou pagar impostos, luz e água. Sobre essa questão, esse afirma:

Sede propia no, está es del gobierno esto está en extinción de dominio, eso se llama cuando le quitan los bienes a un narcotraficante, este es un bien de extinción de domínio. Digamos esto se lo quitaron a un personaje, entonces tienen que tener un vigilante día y un vigilante noche, ellos no tienen este tipo de personas, entonces casi lo dejan en absoluto abandono, por eso los bienes que ellos recuperan casi todos terminan destruidos, muy buenas casas, muy buenas cosas y usted pasa los 2 años y eso está derrumbado lo han robado y de todo porque no hay un doliente. Entonces esto nos lo entregaron para que nosotros cuidaremos toda esta malla y no se la robaran, derrumbaran esos edificios despedazandolos y robándose todo y cosas así; y como nosotros tenemos una protección del Estado...( ORCOL2. Entrevista concedida a Maria Izabel de Carvalho. Cali, 21 set. 2019).

${ }^{38}$ Centro Integrado de Educação Pública. 
No tocante ao transporte do material reciclável até o comprador, uma das associações de Siloé conta com transporte próprio, chegando inclusive a comprar os recicláveis de outras associações, que não tem esse recurso, por um valor mais baixo e vende com uma margem de vantagem para cobrir os custos e ter o mínimo de lucro, enquanto às demais organizações participantes da pesquisa alugam caminhões para o deslocamento do material.

Em relação à infraestrutura e os equipamentos de que dispõem essas organizações, necessários ao desenvolvimento do trabalho, Silva (2017) assinala que:

\begin{abstract}
A literatura especializada aponta que, para alcançar bons níveis de eficiência, os empreendimentos de catadores necessitam de um conjunto de infraestrutura e equipamentos que é fundamental para o exercício de sua atividade, tais como: sede própria, barracão com espaço adequado para triagem e armazenamento dos resíduos, caminhão para a coleta seletiva e transporte dos resíduos, telefone, computadores com acesso à internet, mesas e bags para triagem, prensas para comprimir os resíduos, carrinhos manuais para transporte, entre outros. $O$ acesso diferenciado a esse conjunto de fatores implica resultados econômicos diferentes no final do exercício (Silva, 2017, p. 28).
\end{abstract}

A venda do material adquirido pelas organizações, em geral é feita para o comprador que oferecer o melhor preço. A Cooperativa Rocinha Recicla, costuma receber o pagamento no prazo de três a quatro dias após a venda e as associações de Siloé, recebem o pagamento no ato ou em um prazo de 8 a 15 dias após a transação.

Todos os representantes das organizações relataram existir algum tipo de capacitação voltada para os catadores/recicladores, sendo em geral, desenvolvidas em formato de palestra, podendo ser ministrada para os catadores/recicladores, como também, no caso da ARCO 20 de Siloé, para outras instituições como o SENA (Servicio Nacional de Aprendizaje), falando sobre como fazer reciclagem; quando segundo o representante da associação, há na verdade uma troca, pois a associação ensina o conteúdo e, por vez, recebe do SENA o certificado de que é especialista na temática. Na cooperativa da Rocinha, os assuntos tratados estão voltados para a administração financeira pessoal, para a alfabetização e aulas de inglês. Enquanto nas associações de Siloé, os temas versam sobre cuidados com a saúde, prevenção e como agir em caso de acidente, aumento da autoestima, sobre valores éticos, morais e pessoais, sobre convivência, competências laborais, cuidados com determinados tipos de materiais por ser prejudiciais à saúde, dentre outros. 
Os problemas enfrentados pelas organizações, dizem respeito principalmente: à falta de apoio do poder público, que apesar da criação de legislações voltadas para os catadores/recicladores, não às põe em prática como deveria, muito pelo contrário, segundo a fala dos representantes, sobretudo das associações de Siloé; a falta de subsídios e de infraestrutura para a realização do trabalho - como sede própria, equipamento, carros para manejo do material e outros; a não existência ou deficiência da coleta seletiva, pois se houvesse, facilitaria o trabalho dos catadores/recicladores, como dito pelos entrevistados das associações de Siloé:

Los principales problemas, el estado crea normas para protegernos, pero hasta ahí, el estado no hace inversiones en nosotros, la sentencia dice vuelvanlos empresarios, es que una sentencia de un país la dictó la Corte Constitucional, en todos los países hay Corte Constitucional; hay diferentes ramas abogados y todas estas cosas; hasta que llega a la corte constitucional es la que saca una ley y todos tienen que cumplirla de acuerdo a la población que va dirigida o al estamento y todo dentro de un Estado. Después de ahí para arriba para mí sería, Jesucristo, no puede haber un humano por encima de la corte. Entonces si ellos dicen, la corte le dice al gobierno municipal de Santiago de Cali: el reciclaje domiciliario es exclusivo para los recicladores de oficio, denles las herramientas necesarias, sáquenlos de la informalidad y vuélvanlos empresarios, tener las herramientas necesarias. Son como 45 punticos, la sentencia está dirigida a proteger el mínimo vital de nosotros, no está diciendo vuélvalos ricos, ni nada, porque cuando cerraron el basurero vinieron unos empresarios a tratar de coger esto y nos querían sacar. Entonces demandaron todo esto, abogados dijeron no, estos señores han trabajado acá por más de 50 años, por herencia les pertenece a ellos; entonces la corte les dio órdenes, no les dio sugerencias, el Estado municipal de Santiago de Cali no nos ha cumplido. Bueno, de alguna manera nos sacó de la informalidad, porque estamos pagando impuestos, la berraquera, pero no nos dieron las herramientas, todo esto que está aquí, salió de nuestro dinero y de lo poquito que recibimos de ellos. ¿Cuáles son las herramientas? Háganos la ruta selectiva, toquemos puerta a puerta, hagamos la campaña, eduquemos a la gente; y mi viejito que sale para llenar dos tulas, se demora cinco kilómetros de aquí para allá y 5 viniendo, un viejito de 50 - 60 años, con granitos en las axilas de jalar, si me hace una ruta selectiva yo le juro, yo le digo, que mi señor en dos cuadras me llena dos tulas y le quito $4 \mathrm{~km}$ y medio de encima, es más, le dejo esa tula ahí y le mandó un camión a que lo recoja y le digo, vaya tranquilito para su casa. El Estado eso es lo que tiene que dar, herramientas, es que estamos pagando camiones de segunda, endeudados nosotros, porque el Estado no dijo: tenga este capital semilla o vamos a FANALCA (Fábrica Nacional de Autopartes) 0 dónde venden los carros aquí en esta ciudad, la asociación va a sacar de 4 o 5 carros, nosotros le vamos a dar la mitad, un ejemplo, y ustedes van a pagar la otra mitad, las compactadoras, las herramientas, todo esto y la ECA (Estaciones de Clasificación y Aprovechamiento). Mire, yo trabajo, porque me dieron esto, si no nosotros no estaríamos, entonces no es el Estado el que me protege. Entonces cuando viene del estado y me dice qué necesitan, yo le digo: deme lo que dice la sentencia, las herramientas, para volverme empresario de reciclaje, con mis recicladores; no me dé plata, yo no le estoy pidiendo plata, yo no le estoy diciendo deme 50 millones yo compro el camión, no, deme las herramientas, la plata, la hacemos nosotros. El gobierno da unas leyes, pero se queda muy corto, demasiado corto y no cumple con órdenes como las de la corte; entonces tenemos una orden de la corte constitucional, que es la sentencia T 291 del 2009, tenemos el Auto 118, tenemos una política pública, tenemos una mesa inclusión y tenemos el decreto 596 del cobro del aprovechamiento. Son 5 cosas y sólo nos estamos 
beneficiando del aprovechamiento, las otras cuatro no sirven, porque no las hacen efectivas (ORCOL2. Entrevista concedida a Maria Izabel de Carvalho. Cali, 21 set. 2019).

Lo que nosotros hacemos lo hacemos con las uñas, de igual forma eso es lo que nosotros hemos venido trabajando y nos ha tocado solos [...] Hay una sentencia que les ordenó a los municipios o alcaldías, entregarle centros de acopio y nunca lo hicieron y hasta el momento nunca lo harán, porque a ellos no les interesa que las organizaciones salgan con su operación del reciclaje, eso lo quieren manejar ellos, los privados, es lo que han querido hacer, pero habemos algunas que todavía estamos dando la lucha (ORCOL1. Entrevista concedida a Maria Izabel de Carvalho. Cali, 16 set. 2019).

Outra queixa de uma das associações de Siloé, está relacionada ao monopólio que existe em Cali, sobre os preços dos materiais recicláveis, que em determinados momentos ficam muito baixos, prejudicando assim os recicladores, pois muitas dessas organizações não conseguem se manter e acabam fechando por falta de recursos e, também, por não contarem com o apoio governamental. $E$, além disso, tem ainda a concorrência das empresas privadas, que segundo o representante dessa organização de recicladores, não é justa, por não seguir as mesmas determinações que essa segue. Vejamos:

Hay un monopolio, aquí en Cali hay mucho monopolio del material, cuando menos pensamos los materiales se vienen al piso y ahí es cuando empiezan a perder las organizaciones, entonces ahí es donde nos deben dar equilibrio para podernos sostener, esa es una de las determinaciones que muchas veces como organización buscamos. Patrocinio podría ser, pero no existen, que el municipio de pronto invierta en otro tipo de actividad, los invierte, pero legalice siempre unos recursos del $10 \%$ se lo están dando al reciclador, pero en cosas como insignificantes, como para ellos después poder presentarle a la Corte Constitucional, que es lo que ellos hacen. Siempre han hecho ese tipo de esquema de operación ellos, y al reciclador es al que siempre le va mal porque mediante esos procesos el reciclador o le va mal o estamos peor. Entonces nos ha tocado en la organizaciones. $Y$ ahora con el tema de las empresas privadas es peor, que ya en estos momentos la ley le dio la cobertura para que usted también opere, mientras que en nuestra organización tenemos que cubrir el tema de aprovechamiento para pagarle al reciclador, el privado no le paga a nadie. Nada, él se echa toda su plática al bolsillo y no tiene quien le exijan, pero las organizaciones si tenemos un ente de control y nos están vigilando lo que estamos haciendo, cuando verdaderamente estamos trabajando como recicladores. Entonces son cosas que a nosotros como organización nos afecta porque lo poco que llega, pues no es suficiente para poder solventar los gastos de las organizaciones, pagos de arriendo, carretas, alquiler de camiones, porque son cosas que nos han tocado, adaptarnos poco a poco al sistema porque si no nos sacan del ciclo del reciclaje, y eso se nos ha presentado a nosotras las organizaciones; hay muchas que ya han sellado entonces imagínate todo (ORCOL1. Entrevista concedida a Maria Izabel de Carvalho. Cali, 16 set. 2019).

Nas associações de Siloé, segundo os entrevistados, o poder público deveria disponibilizar as ECAs (Estaciones de Clasificación y Aprovechamiento), 
destinadas ao desenvolvimento do trabalho por estas organizações, porém não

é isso o que vem acontecendo, de acordo com eles, como descrito abaixo:

Entonces mire que ya en este momento se han muerto 10 líderes de nosotros, que en este momento nunca alcanzaron a ver una ECA y solamente llegaron hasta los recursos en diagnósticos de miles de millones de pesos en diagnósticos, pero de ahí no pasa; si no sale un problema de que no pudieron comprar la ECA, o sino es que no dejaron vender, que el sitio no era adecuado, en últimas que se gastaron la plática y quien lleva del bulto son los recicladores, porque hasta el momento estamos hablando del medio ambiente, y era para que en este caso Cali tuviera unas ECAS montadas aquí en Cali. Pero en el momento no existen es una situación que se ha presentado durante muchos años. $Y$ a nivel nacional el proceso ha sido casi igual, no solamente Cali está presentando esta situación, porque aquí solamente quieren los privados, pero si usted va a ver empresas privadas, ellos ya tienen sus ECAS certificadas y todo eso, ¿cómo lo hicieron?, manejan el monopolio, el billetico y controlan la movida, es así. Hay muchas empresas que ya tienen ECA acá y no se supo cómo lo hicieron, pero para las organizaciones si hay mucha cantidad de problemas, y nunca nos han logrado entregar una ECA, y las pocas que existimos si no cumplimos con la norma, pues también las sellan, aquí ha sido una lucha, pero tremenda con ellos (ORCOL1. Entrevista concedida a Maria Izabel de Carvalho. Cali, 16 set. 2019).

Como possível solução para tais problemas, os representantes das associações apontaram a vontade política, ou seja, que os governantes cumpram a legislação já existente, o que segundo estes, até então, não aconteceu como está posto. Vejamos abaixo:

Que tengamos, primero que todo, acompañamiento político, que exista lo que la norma exige, la sentencia. La sentencia habla de cumplimiento de unas ECAS, dedicamos un tema económico para las organizaciones que... hay mucho tipo de actividades que mediante las leyes se les han ordenado, pero hasta el momento los entes municipales hacen caso omiso, en estos momentos a ellos no les importa, hacen caso omiso. Ellos hablan de que nosotros somos grupos vulnerables, pero solamente cuando ellos quieren ganarse sus recursos, o mejor dicho como dicen vulgarmente, se quieren robar la plata que les envían para el proceso de los recicladores, porque hasta cierto punto llega y se desaparece o se gastan la plata en otros proyectos que no tienen nada que ver, entonces ahí es donde desgastan el tema del reciclaje y ahí es donde muchos líderes tomamos represalias contra ellos, porque ellos no hacen el acompañamiento como debería ser; entonces eso es lo que ha afectado el gremio de recicladores. Hasta ahora y nunca hasta el momento se ha hecho algo bien por los recicladores, no lo han hecho, hemos estado en falencia por ellos hasta el momento, y cuando no hay ese querer ayudar realmente a las organizaciones, muchas veces buscan que el líder fracase y en muchos casos han logrado que muchos líderes sean sacados de las organizaciones, o tengan otro tipo de información frente al reciclador; entonces mucha lucha que hemos dado para el tema de que... Muchas entidades que no nos conocían a nivel nacional, ha tocado que viajar con sus propios recursos hasta llegar a otras ciudades, para poder escuchar reuniones o asambleas de otros gremios de recicladores; y en general es casi todo lo mismo. El monopolio del Estado, es tremendo, un monopolio, pero super inmenso, desde donde uno dice no pasa nada, hasta que alguien de pronto le de perfección a lo que nosotros buscamos, pero eso está muy difícil (ORCOL1. Entrevista concedida a Maria Izabel de Carvalho. Cali, 16 set. 2019). 
As organizações avaliam como sendo uma das principais questões, quando se fala da problemática relacionada aos resíduos nos campos de pesquisa, a falta de conscientização por parte da população, no tocante ao descarte desse material, como vemos a seguir:

Esa loma tiene más de 100.000 habitantes, hay mucha gente, entonces todo ese material lo recuperan los recicladores y lo venden acá abajo, que hay 11012 bodegas, pero allá arriba hay como unas 10 bodegas diferentes, pero hay mucha problemática con los residuos sólidos: digamos de vivienda, eso se llama enseres, tiran un colchones, tiran muebles, tiran una cama, tiran escritorios, y entonces eso tapona y forma los desórdenes, y hay mucho basurero crónico. La persona llegó nadie lo vio y lo tiró allí en un lote; ya otra señora abrió una chuspa y así sucesivamente, hasta que habían 40 - 50 bolsas. Y eso día tras día... y eso se vuelve un basurero crónico. Nuestra comuna 20 tiene 7 quebradas, usted no las ve, porque eso no salta agua, pero si usted va allá, las encuentra están los nacederos arriba, entonces nosotros tenemos contratos para limpiarlas, meternos a sacar los colchones, los muebles y dejarla limpiecita otra vez. A los 3, 4 días pasa usted otra vez y está casi lo mismo que hace como cinco días, o sea, que no hay como sensibilización de la gente para que cuiden ellos mismos sus espacios (ORCOL2. Entrevista concedida a Maria Izabel de Carvalho. Cali, 21 set. 2019).

Existe pouca conscientização e isso dificulta a coleta de resíduos (OCBR1. Entrevista concedida a Maria Izabel de Carvalho. Brasil, 04 jul. 2020).

Segundo o representante de uma das associações de Siloé, é possível notar algumas mudanças no comportamento das pessoas, no que diz respeito à problemática dos resíduos sólidos, alcançadas por meio de ações realizadas por essas organizações, mas segundo o entrevistado, essa mudança de comportamento da população se dá, sobretudo, quando ocorre algum evento negativo, como enchentes, desabamento e, principalmente, quando alguém vem a óbito em consequência de algum acidente causado pelo descarte inadequado de resíduos sólidos, pois é algo que impacta os indivíduos, como aconteceu há cerca de três anos em Siloé, num local chamado "Quebrada Isabel Pérez" - já citado anteriormente - acontecimento esse, citado por muitas pessoas durante as entrevistas, o que denota que foi algo que os marcou muito. A seguir, trazemos a fala de um dos participantes da pesquisa de Siloé, sobre esse assunto:

Pues mira que cuando nosotros no trabajábamos como trabajamos ahorita, si se han visto soluciones, porque ya no es mucho el material que se va digamos a la entidad de Yotoco, a la exposición final. Con nuestras organizaciones se ha logrado como se dice digamos de un $100 \%$, se ha logrado un $70 \%$ de recuperación. Ya nosotros trabajamos también dentro de las quebradas y los ríos, ya no hay tanta contaminación como antes que usted venía. Inclusive, hace poco, hace 2 años, una avalancha, una quebradita que usted no cree, un riachuelito que no tiene más de $10 \mathrm{~cm}$ de altura el agua, y eso ocasionó una avalancha tremenda que inclusive se llevó casas y todo. Esa, Isabel Pérez. Y nosotros empezamos a intervenirla y a limpiarla, esa es una de las partes que la comunidad nos agradece mucho a las organizaciones. Y cada vez que nosotros pasamos les decimos no 
deben arrojar esto a la cañada, porque se tapan los ductos; el escombro, que sí era más complicado, porque llegaban y hacían sus obras y tiraban los escombros ahí a la quebrada, y claro, esto iba formando represa y represa, hasta que a lo último pasó lo que tenía que pasar. Entonces ahí es donde muchas veces la gente ha tomado conciencia. $Y$ a veces a nosotros que nos conocen, nos preguntan, vienen y se asesora la gente que: ¿Qué deben hacer? ¿Cómo sacar la basura? Tratar de separar los materiales. Y la gente nos ha copiado mucho. Pues digamos que ha sido lo más bueno que hemos podido tener frente a la comunidad (ORCOL1. Entrevista concedida a Maria Izabel de Carvalho. Cali, 16 set. 2019).

Esse grupo assume, portanto, um importante papel diante dessa questão, revelando um potencial educativo, que em sua interação com a população pode tornar-se um agente educador capaz de provocar mudanças no que diz respeito ao trato com os resíduos sólidos.

Para a problemática dos resíduos sólidos, foi apontado pelos representantes das organizações de catadores/recicladores, como possível solução a aplicação de multa para quem não realizasse o descarte adequado, mas também disseram que deveria ser feitas atividades para conscientização, bem como deveria existir fiscalização, conforme trecho ilustrativo abaixo:

Multas, no hay más de otra, hacerles talleres, hacer las capacitaciones, decirles, poner un dron a girar por el barrio y ver quién lo hace, cuando saca los residuos sólidos, debería pasar un supervisor antes y va pasando va mirando y va diciendo este residuo es orgánico, pero está con lo de reciclaje, usted no lo puede colocar así, usted tiene que separarlo, eso se llama separación en la fuente, la fuente es su casa, entonces apunta el número de casa y le llega $\$ 50.000$ de multa; cuando este señor tenga que pagar $\$ 50.000$ al otro día ya tiene las dos bolsitas separaditas, y así sucesivamente, nos vamos por la parte de atrás, toda está quebrada quedó impactada, cuántas casas hay en esta quebrada, 100 casas, no podemos decir qué casa lo botó, pero le vamos a cobrar a todas, entonces uno va a cuidar del otro, 'oiga usted porque lo tira, si luego me van a cobrar a mí', cosas así... (ORCOL2. Entrevista concedida a Maria Izabel de Carvalho. Cali, 21 set. 2019).

\section{4. \\ Catadores/recicladores: o labor e a realidade vivenciada no dia a dia}

Inicialmente fazemos o exercício de trazermos um quadro com alguns dados para que tomemos conhecimento do perfil dos catadores/recicladores entrevistados, tanto na Rocinha quanto em Siloé. 
Quadro 31 - Perfil dos catadores/recicladores entrevistados

\begin{tabular}{|c|c|c|}
\hline \multicolumn{3}{|c|}{ PERFIL DOS CATADORES/RECICLADORES ENTREVISTADOS } \\
\hline Questões & Rocinha & Siloé \\
\hline Idade & Entre 40 e 42 anos. & Entre 65 e 82 anos. \\
\hline Gênero & Masculino. & Masculino. \\
\hline $\begin{array}{l}\text { Lugar de } \\
\text { nascimento }\end{array}$ & $\begin{array}{l}02 \text { são originários da Rocinha e } 01 \\
\text { do Rio Grande do Norte. }\end{array}$ & $\begin{array}{l}01 \text { em Cali (Valle del Cauca), } 01 \\
\text { em Toribio e } 01 \text { em Timba } \\
\text { (ambos em Departamento de } \\
\text { Cauca). }\end{array}$ \\
\hline $\begin{array}{l}\text { Lugar de } \\
\text { residência }\end{array}$ & Rocinha e Queimados. & $\begin{array}{l}\text { Todos residem em Siloé (Siloé, } \\
\text { Tierra Blanca e Lleras Camargo). }\end{array}$ \\
\hline Escolaridade & $\begin{array}{l}02 \text { têm ensino fundamental } \\
\text { incompleto ( } 2^{\circ} \text { e } 8^{\circ} \text { ano) e } 01 \text { tem } \\
\text { ensino médio completo. }\end{array}$ & $\begin{array}{l}02 \text { fizeram até o segundo de } \\
\text { primaria e } 01 \text { primaria y bachiller. }\end{array}$ \\
\hline $\begin{array}{l}\text { Tempo na } \\
\text { Profissão }\end{array}$ & Entre 07 e 10 anos. & Entre 15 e 30 anos. \\
\hline $\begin{array}{l}\text { Horas diárias } \\
\text { trabalhadas }\end{array}$ & $\begin{array}{l}\text { Entre } 8 \mathrm{~h} \text { e } 12 \mathrm{~h}, \text { podendo ser mais } \\
\text { em alguns dias. }\end{array}$ & Entre 6 h e 9h, podendo variar. \\
\hline $\begin{array}{l}\text { Trabalha quantos } \\
\text { dias por semana }\end{array}$ & $\begin{array}{l}\text { Um catador trabalha de segunda a } \\
\text { sexta-feira, o outro de segunda a } \\
\text { sábado e outro todos os dias. }\end{array}$ & $\begin{array}{l}02 \text { trabalham de segunda a } \\
\text { sábado e } 01 \text { trabalha três dias } \\
\text { por semana. }\end{array}$ \\
\hline
\end{tabular}

Fonte: elaboração própria com base nas entrevistas realizadas.

Os catadores/recicladores entrevistados têm entre 40 e 82 anos e são todos do gênero masculino; a maioria reside nos campos da pesquisa; têm graus distintos de escolaridade, indo do ensino fundamental ao ensino médio, porém prevalecendo o ensino fundamental incompleto; estão na profissão de catador/reciclador entre 07 e 30 anos; trabalham entre oito e doze horas por dia e a maioria trabalha seis ou sete dias por semana.

A faixa etária dos entrevistados da Rocinha mostra que os catadores dessa região, são pessoas jovens, diferente dos entrevistados de Siloé, onde todos têm acima de 65 anos. O representante de uma das organizações de recicladores deste território traz a seguinte fala sobre essa questão:

Yo digo que de adulto mayor está en un 40\%, está el que comenzó a trabajar hace 20 o 30 años en esto, y ya no supo hacer nada más y ya no consiguió otro empleo en otra parte; luego tenemos una edad estándar moderada y también tenemos una edad muy joven de menos de 20 años y tenemos menores de edad [..] Un $40 \%$ de adultos mayor y otro $40 \%$ de edad estándar, y tendríamos un $20 \%$ de jóvenes entre menores de edad y muy jóvenes. (ORCOL2. Entrevista concedida a Maria Izabel de Carvalho. Cali, 21 set. 2019). 
Dos catadores entrevistados na Rocinha, um relatou ter residência em um dos sub-bairros, porém montou uma estrutura próxima de um dos pontos de coleta, onde dorme e passa os dias e onde faz a catação do material reciclável. Um segundo entrevistado desse território, informou que mora em Queimados, entretanto fica de segunda a sexta-feira na Rocinha, dormindo em um espaço destinado ao quadro de luz de um prédio, em uma das travessas no Bairro Barcelos, pois devido à distância e ao custo com passagem, não seria possível seu deslocamento todos os dias para onde tem residência.

Salientamos que tanto na Rocinha quanto em Siloé, se observa a presença de catadores/recicladores, porém em maior quantidade e de forma mais organizada estão os grupos do segundo território, pois como já dito anteriormente, para receberem a taxa referente à atividade de aproveitamento, enquanto colaboradores do serviço de limpeza urbana, devem estar associados às organizações de recicladores, conforme fala do representante de umas das organizações de recicladores de Siloé:

\begin{abstract}
El reciclador organizado, que somos nosotros la normatividad, la sentencia, todo esto dice que los beneficios es para el reciclador organizado, o sea que debe pertenecer a una asociación para que pueda levantar su información, su número de cédula, como se llama, eso es lo que levantamos nosotros organizado; el reciclador informal que no le gusta, no quiere pertenecer a ninguna parte, simplemente recicla y va vende, que hay muchos, estamos hablando que en la ciudad hay más de 1.000 recicladores así y organizados podemos decir que tenemos unos 4.000 (ORCOL2. Entrevista concedida a Maria Izabel de Carvalho. Cali, 21 set. 2019).
\end{abstract}

No concernente a esses profissionais, entendemos que os dados que seguem não são recentes e que são abrangentes, por se tratar da América Latina e Caribe como um todo, porém eles nos dão uma dimensão sobre o quantitativo de pessoas que executam a atividade de catação, nessa região.

En todas las grandes ciudades de América Latina y el Caribe (ALC) existe una multiplicidad de personas que recolectan, separan y comercializan materiales tales como cartón, papel, vidrio, plástico o metal, y hacen de esta actividad su principal fuente de ingresos. Genéricamente se los conoce como "recicladores informales". Aunque se trata de una población flotante y no se tengan estimaciones exactas, los datos recogidos por la última Evaluación Regional arrojan que existen en la región más de 200.000 familias (aproximadamente 500.000 personas) que se dedican a la recolección, separación y comercialización informal de residuos. Otras fuentes estiman que el número de recicladores en ALC es significativamente mayor, alcanzando los 3,8 millones personas (Terraza \& Sturzenegger, 2010, p. 13).

Acreditamos que esses números são ainda maiores neste momento, devido a atual conjuntura pandêmica, tendo em vista que muitas pessoas 
perderam seus empregos e, em muitos casos, não tendo outra opção, passaram a realizar o trabalho de catação para sobreviver.

Quanto à classificação dos catadores/recicladores, Terraza \& Sturzenegger (2010), assinalam a existência de distintas categorizações, conforme trecho que segue:

Son varias las clasificaciones que pueden hacerse de los recicladores. Una clasificación relacionada con el lugar o ámbito de trabajo en el que se desenvuelven los divide en dos grandes grupos: (i) aquellos que realizan las tareas en sitios de disposición final y (ii) aquellos que lo hacen en la vía pública. Otra clasificación posible está relacionada con el nivel de dedicación a esta actividad. Según este criterio, la población de recicladores puede dividirse en dos categorías: (i) recicladores ocasionales, que reciclan de acuerdo con oportunidades y circunstancias particulares de sus necesidades, compartiendo la recolección con otras actividades y (ii) recicladores de oficio, que reconocen el reciclaje como su actividad principal y permanente de trabajo. Finalmente, los recicladores pueden ser categorizados según su nivel de organización en (i) recicladores no organizados y (ii) recicladores organizados, siendo el punto de diferenciación pertenecer o no a una organización, sea cooperativa, gremio o asociación (Terraza \& Sturzenegger, 2010, p. 14-15).

Sánchez (2018), quando fala dessa categoria em termos de Brasil e Colômbia, aponta que:

\begin{abstract}
A trajetória da população catadora do Brasil e Colômbia torna-se especialmente relevante pelos seus processos organizativos locais, visto que têm avançado nas últimas décadas desde grupos independentes localizados em áreas municipais urbanas até a conformação de grandes corpos nacionais como o Movimento Nacional de Catadores de Materiais Recicláveis (MNCR), criado em 2001 no Brasil, ou a Asociación Nacional de Recicladores (ANR), instituída em 1986 em Colômbia (Sánchez, 2018, p. 143).
\end{abstract}

Todos os catadores entrevistados na Rocinha trabalham por conta própria, enquanto isso, dentre os de Siloé, um é associado a uma organização de recicladores e dois trabalham por conta própria. Nos dois campos, durante o processo de observação, conversamos com alguns desses profissionais e ratificando a amostra, nenhum dos catadores da Rocinha pertencia a alguma organização de catadores, diferente de Siloé, onde se notava uma presença maior de associados a estas instituições. Terraza \& Sturzenegger (2010), afirmam que:

Los recicladores vinculados a una forma organizativa se caracterizan por tener mejores condiciones laborales. Los beneficios que obtienen aquellos que trabajan de manera organizada se derivan fundamentalmente de mayores volúmenes de venta, una menor dependencia de los intermediarios y mayores posibilidades de adicionar valor a los materiales (Terraza \& Sturzenegger, 2010, p. 17). 
De uma forma geral, em relação ao trabalho dos catadores, Terraza \& Sturzenegger (2010), apontam que:

En su gran mayoría, los recicladores desarrollan su actividad en precarias condiciones sanitarias, expuestos a una alta inestabilidad laboral, sin ningún tipo de seguridad ocupacional ni vinculación con el sistema de protección social y, en muy pocos casos, integrados al sistema formal de gestión de residuos sólidos municipales (RSM). Sus jornadas de trabajo suelen ser prolongadas, contando generalmente para la recolección con rudimentarios medios de trabajo y dependiendo con frecuencia de una gama de intermediarios que les fija el precio de los materiales y las formas de pago (Terraza \& Sturzenegger, 2010, p. 13).

Um fato que nos chamou a atenção foi que todos os catadores da Rocinha catam ali mesmo, enquanto entre os recicladores de Siloé, somente um cata durante alguns dias da semana nesse território, mas também exerce sua atividade em outras áreas; os demais preferem se deslocar para outros bairros em busca de material. Quando perguntados sobre o motivo pelo qual não catavam ali, disseram que apesar de em Siloé ter muito resíduo reciclável para catação, encontram mais material valioso em outros bairros e, também, porque "la gente que lo conoce a uno se coloca a criticarlo a uno y a mí no me gusta eso, que me critique nadie. Yo soy libre, yo ando mejor por allá donde nadie me conoce" (RCOL3. Entrevista concedida a Maria Izabel de Carvalho. Cali, 12 set. 2019).

Dos tipos de materiais mais coletados pelos catadores da Rocinha, estão o alumínio e a pet, enquanto entre os profissionais de Siloé estão o papelão e o plástico. E dentre todos os materiais que encontram, foram apontados como mais valiosos, em ambos os territórios: cobre, alumínio, sucata, etc.

Tanto na Rocinha como em Siloé, os catadores/recicladores recebem o pagamento pelo material no ato da venda. Alguns preferem juntar uma quantidade maior de recicláveis, para então vender, enquanto outros vendem à medida que catam. No caso da Rocinha, o material é vendido para os ferros velhos, sendo alguns situados na Rocinha e outros localizados em outros bairros, mas que vêm à Rocinha para comprar o material dos catadores. Em Siloé, mesmo os que não são associados, geralmente vende para as associações de recicladores existentes no território.

O processo de venda dos recicláveis, pelos catadores/recicladores, acaba segundo Bastos (2014), se constituindo, dependendo da situação, em uma forma de exclusão ou inclusão dessa categoria, conforme descrito no trecho que segue: 
A outra forma de exclusão/inclusão existente é a relação estabelecida entre o catador com aquele que compra o produto do seu trabalho, sucateiro, pois embora seja ele partícipe da cadeia industrial produtiva, só se inclui no momento da captura do material que garimpa na frente de serviço, pois, na hora da remuneração o processo de excluí-lo dos lucros do produto é uma constante (Bastos, 2014, p. 150).

A remuneração dos catadores/recicladores de ambos os territórios está entre um e dois salários mínimos aproximadamente (um salário mínimo no ato das entrevistas era de: Brasil: $\mathrm{R} \$ 1.045,00$; Colômbia: $\$ 828.000$ mil pesos colombianos - equivalentes a cerca de $\mathrm{R} \$ 1.294,00)$.

Quanto ao uso de Equipamento de Proteção Individual (EPI), a maioria dos entrevistados de ambos os campos da pesquisa, não os utiliza e os que relataram utilizar em algum momento, disseram usar bota e luva - no tocante a essa última a sua utilização é ainda mais rara. Uma das alegações para o não uso de EPI, foi o fato de terem que comprar com recursos próprios.

Somente um dos entrevistados (este de Siloé) dentre todos os participantes das entrevistas, relatou não ter sofrido nenhum acidente durante a execução da atividade de catação. Na Rocinha, todos os acidentes relatados pelos catadores, foram causados por objetos perfurocortantes, como vidro e lâmpadas quebradas e pregos. Nesse local, os catadores disseram encontrar muitos desses materiais descartados sem serem envoltos em algo, são geralmente postos junto com os demais resíduos, sem nenhum cuidado com quem faz a catação dos recicláveis. Em Siloé, os acidentes citados foram: atropelamento e uma queda de um piso para o outro, causada por um empurrão (quando a pessoa fraturou um braço), devido à desavença entre dois recicladores, originada pela disputa por ponto de catação; questão presente na fala de outros entrevistados desse campo e que acontece, sobretudo, entre os que catam nas ruas, ou seja, que não têm uma unidade fixa para catação.

No que concerne à disputa por pontos de coleta, notamos que apesar dos catadores da Rocinha terem mencionado que os melhores pontos (escadão da Vila Verde, antiga Casa da Paz, contêineres que ficam em frente à unidade habitacional construída durante as obras do PAC 1 e lixeira do sub-bairro 199) são muito concorridos, não houve nenhum relato de embate ou violência, motivados por essa questão.

$\mathrm{Na}$ Rocinha, onde os resíduos sólidos são encontrados a qualquer hora do dia, todos os dias da semana, nos pontos de coleta, os catadores não apontaram dias melhores para a realização da catação, diferente do exposto 
pela maior parte dos recicladores de Siloé, que relataram que os melhores dias são os dias de coleta, antes da empresa de limpeza urbana passar.

Uma das questões da entrevista tratava sobre o rompimento das sacolas, no ato da catação nas ruas, para verificar se nelas continha material reciclável ou não, algo muito notado durante o processo de observação de campo, em ambos os territórios. Todos os catadores da Rocinha relataram ter que rompêlas, alegando que só assim seria possível verificar o conteúdo, enquanto todos os recicladores entrevistados de Siloé informaram não romper as sacolas, pois disseram usar da experiência enquanto reciclador, empregando o tato para sentir o que tem ali dentro, e somente quando é necessário as abre, mas as fecham novamente; porém relataram que sim, existem recicladores que procedem dessa forma. A seguir, algumas falas a respeito desse fato:

Quadro 32 - Fala dos catadores/recicladores sobre o rompimento de sacolas na Rocinha e em Siloé

\section{Rocinha}

Geralmente a gente rasga o saco. Não tem como, porque se a gente não rasgar o saco a gente não tem como fazer a coleta (CMRBR3. Entrevista concedida a Maria Izabel de Carvalho. Rio de Janeiro, 07 out. 2020).

É, tem que fazer assim (CMRBR2. Entrevista concedida a Maria Izabel de Carvalho. Rio de Janeiro, 06 out. 2020).

\section{Siloé}

No, yo no las rompo, yo lo que veo lo safo y después las amarro y si veo un papel por ahí tirado yo lo meto otra vez, yo no soy cochino (RCOL3. Entrevista concedida a Maria Izabel de Carvalho. Cali, 12 set. 2019).

No, yo no rompo, abro. La rompe el que lleva mal sistema, yo soy muy correcto y me da rabia lo incorrecto (RCOL2. Entrevista concedida a Maria Izabel de Carvalho. Cali, 12 set. 2019).

Fonte: elaboração própria com base nas entrevistas realizadas.

Como uma das possíveis soluções para essa questão (os catadores da Rocinha que relataram não ter outra forma além de romperem as sacolas, tendo em vista a maneira como é feito o descarte hoje), a população passar a trazer os resíduos recicláveis já separados - pois hoje segundo os mesmos, são poucas as pessoas que fazem isso, e ainda assinalaram que nos pontos de coleta deveria haver um recipiente específico para depósito desse material. Um dos catadores relatou que um grupo já tentou improvisar um recipiente destinado para esse fim, que foi posto ao lado de um dos pontos de descarte estipulado 
pela COMLURB, e que as pessoas estavam aderindo à ideia, porém a Prefeitura veio e retirou, conforme fala que segue:

A gente fez um projeto aqui, um projeto não... Como a gente sabe como coletar, a gente fez, botou caixa de água, umas caixas de água grande, que a gente pegava nas... Aí colocava nos cantinho aqui, ai a pessoa vinha e jogava a garrafa. Ai ficava fácil pra gente. Aí na maioria das vezes a gente não precisava rasgar o saco. Aí já sabia já, os moradores já estavam acostumados, mas a prefeitura barrou, aí a gente parou, entendeu? Eles vieram com fiscal e tiraram tudo. Eles estavam com o uniforme da prefeitura e pediram pros garis, é... tirar as coisas. Disseram que não podia não, que estava... como é que chama? Sujando a paisagem. Era muita coisa que a gente colocava aqui. Ficava lotado (CMRBR3. Entrevista concedida a Maria Izabel de Carvalho. Rio de Janeiro, 07 out. 2020).

Essa fala explicita a forma de agir do poder público, o qual deveria implementar ações em cumprimento à PNRS (no caso brasileiro), porém o que se observa, são ações justamente na contramão do que prega essa lei. No PMGIRS da cidade do Rio de Janeiro está dito que:

\begin{abstract}
Nas comunidades com Unidades de Polícia Pacificadora - UPPs, as parcerias entre a SMAC, SECONSERVA, IPP, SMH, SMAS, dentre outros órgãos da administração municipal, empresas privadas e ONGs, vem fortalecendo a implantação de iniciativas alternativas de segregação de recicláveis em comunidades, com a participação de moradores locais. Esta ação permite a geração de trabalho e renda para os moradores que se envolvam nas atividades de coleta e venda dos recicláveis (Rio de Janeiro, 2015, p. 33).
\end{abstract}

No entanto, não é isso o que vem sendo observado na Rocinha, muito pelo contrário, pois o que se nota é o tolhimento de iniciativas que partem da própria população catadora, como no caso da situação supramencionada.

Dentre os principais problemas enfrentados pelos catadores, assinalados pelos entrevistados da Rocinha, estão: o fato de trabalharem longas horas sem se alimentarem devidamente, a discriminação e o preconceito. A respeito desses dois últimos apontamentos, Bastos (2014), quando fala de um contexto específico, porém aplicável ao que vivencia a categoria de um modo geral, assinala que "a realidade vivida pelos catadores do território de Jardim Gramacho Ihes aponta um cenário permeado por elementos discriminativos que levam esses trabalhadores a ter um sentimento de eterna convivência com o rejeito, fazendo-os crer que sua condição de vida é diferente das demais pessoas" (Bastos, 2014, p. 152). Isso foi observado na fala e na forma como se comportam esses profissionais, durante a pesquisa de campo.

Entre os profissionais de Siloé, a disputa por pontos aparece mais uma vez; além disso, apontaram também como um problema, a presença de usuários de drogas que também catam nas ruas, muitos para alimentarem o seu vício, e 
que às vezes acabam entrando em conflito com os demais recicladores. Vejamos a fala dos entrevistados sobre esse assunto:

Quadro 33 - Principais problemas enfrentados pelos catadores/recicladores na Rocinha e em Siloé

\section{Rocinha}

Os principais problemas é mais é de alimentação. Às vezes a gente até vende, a gente até ganha um dinheiro, mas ai alimentação, num tem como a gente fazer... A gente fica passando fome porque às vezes a gente num consegue comer direito, fica trabalhando pra lá e pra cá. Ai num consegue se alimentar direito, só isso. É geralmente tem uns que discrimina a gente né? Porque a gente faz a coleta de lixo. Quase todo dia. Geralmente a gente tá fazendo uma coisa, aí vai fazer outra... Eles acham que a gente não lava a mão, que num toma banho. Mas a gente faz tudo isso, toma banho, lava a mão... (CMRBR3. Entrevista concedida a Maria Izabel de Carvalho. Rio de Janeiro, 07 out. 2020).

É o preconceito né, tem muita gente tem preconceito, acha que isso não é um trabalho. Tem muita gente que acha que isso não é trabalho (CMRBR2. Entrevista concedida a Maria Izabel de Carvalho. Rio de Janeiro, 06 out. 2020).
Siloé

Problemas a veces son esos locos que le tiran la basura a uno o tiene que aguantar se ciertas cosas, pues no es así constante de vez en cuando y a veces que se disgustan porque uno pasa por cierta parte, y si hay alguna basura regada no la han visto y apenas pasa uno es que 'ivea que usted regó esa basura!' o qué tal cosa y a veces uno sin haber tocado nada, entonces pues esos son los problemas que a veces uno tiene en la calle, como a mí me ha pasado, que no sé los demás (RCOL1. Entrevista concedida a Maria Izabel de Carvalho. Cali, 28 ago. 2019).

Que me encuentre con otro reciclador y que me quiera sacar de la vía. Ese es el problema, que yo ya tengo mi sector y llega otro a sacar. (RCOL2. Entrevista concedida a Maria Izabel de Carvalho. Cali, 12 set. 2019).

Fonte: elaboração própria com base nas entrevistas realizadas.

Os catadores da Rocinha veem como possíveis caminhos para a melhoria de tais problemas, a realização de campanhas e a organização do trabalho dos catadores. Já os recicladores de Siloé não fizeram nenhum apontamento, diante das questões assinaladas.

No que concerne a atual conjuntura, tanto os catadores da Rocinha, quanto o representante de uma das associações de recicladores de Siloé, relataram que têm notado um maior número de pessoas vivendo da catação, devido à perda de emprego em função da pandemia da COVID-19. 


\section{5. \\ O comércio: geração e destinação de resíduos sólidos}

Neste item, apresentaremos o perfil dos sujeitos pesquisados, apontando a sua função e informações a respeito do estabelecimento comercial tais como: tempo de existência do estabelecimento no local, tipo de produto comercializado, dentre outros aspectos considerados relevantes para compreensão.

Quadro 34 - Perfil dos comércios

\begin{tabular}{|c|c|c|}
\hline \multicolumn{3}{|c|}{ PERFIL DOS COMÉRCIOS } \\
\hline Questões & Rocinha & Siloé \\
\hline Cargo/função & Os entrevistados são gerentes. & $\begin{array}{l}\text { Os entrevistados são } \\
\text { administradores. }\end{array}$ \\
\hline $\begin{array}{l}\text { Tipo de estabelecimento } \\
\text { comercial }\end{array}$ & $\begin{array}{lll}01 \quad \text { supermercado, } & 01 \\
\text { restaurante e } 01 \text { hortifrúti. } & \end{array}$ & $\begin{array}{l}01 \text { supermercado, } 01 \\
\text { restaurante e } 01 \text { galeria (venda } \\
\text { de produtos diversos). }\end{array}$ \\
\hline $\begin{array}{ll}\text { Localização } & \text { dos } \\
\text { estabelecimentos } & \end{array}$ & $\begin{array}{l}\text { Via Ápia e Largo do Boiadeiro } \\
\text { (áreas centrais da Rocinha). }\end{array}$ & $\begin{array}{l}\text { El Cortijo (Diagonal 50) (área } \\
\text { central de Siloé). }\end{array}$ \\
\hline $\begin{array}{l}\text { Há quanto tempo os } \\
\text { estabelecimentos existes } \\
\text { nestas localidades }\end{array}$ & Entre 04 e 26 anos. & Entre 05 e 27 anos. \\
\hline
\end{tabular}

Fonte: elaboração própria com base nas entrevistas realizadas.

Tanto na Rocinha quanto em Siloé, observa-se uma grande concentração de comércio na parte baixa desses lugares, considerando a geografia de cada local, e é onde também, por ser uma área estratégica, estão situados os maiores estabelecimentos comerciais.

Os estabelecimentos comerciais classificados como grandes geradores ${ }^{39}$ são um dos grandes responsáveis pela geração de resíduos sólidos em áreas populares como na Rocinha e Siloé. No Rio de Janeiro, onde está situado um dos campos desse estudo, de acordo com Martarello (2013):

A primeira referência à figura do pequeno e grande gerador de resíduos ocorreu por meio do Decreto Municipal no 9.287/1990, que aprova os Regulamentos de Limpeza Urbana e de Controle de Vetores do Município do Rio de Janeiro. Porém

39 GRANDES GERADORES DE RESÍDUOS SÓLIDOS - GG: São todos os proprietários, possuidores ou titulares de estabelecimentos públicos e privados, institucionais, de prestação de serviços, comerciais e industriais, entre outros, exceto residenciais, cujo volume produzido de resíduos sólidos seja superior a 120 (cento e vinte) litros ou 60 (sessenta) quilogramas de resíduos por dia de coleta. (Lei Estadual no 7.634/2017, com limites estabelecidos pela Lei Municipal no $3.273 / 2001)$. 
era exclusivamente direcionado aos geradores de entulho e galhada ou folhagem, considerando grande gerador imóveis residenciais que produzissem quantidade superior a 100 sacos de entulho de capacidade volumétrica de 20 litros e $2 \mathrm{~m}^{3}$ de galhada ou folhagem. A lei ํㅜ $3.273 / 2001$ ampliou o escopo quando incluiu os resíduos tipificados como domiciliar produzido em estabelecimentos comerciais, de serviços, unidades industriais, instituições públicas ou privadas e unidades de saúde, e passou a chamar de lixo extraordinário. Para esses resíduos delimitou a figura dos pequenos e grandes geradores e estabeleceu responsabilidades (Martarello, 2013, p. 18).

Já em Cali, onde está inserido Siloé, no Plan de Gestión Integral de Residuos Sólidos - PGIRS 2015-2027 desse município, os usuários são divididos em residenciais e não residenciais, sendo o primeiro grupo, classificado como as pessoas que produzem resíduos sólidos derivados da atividade residencial e que se beneficia da prestação do serviço público de limpeza urbana, e os "ubicados en locales que ocupen menos de veinte (20) metros cuadrados de área, exceptuando los que produzcan más de un (1) metro cúbico mensual" (Cali, 2015, p. 704); enquanto o segundo grupo, é "la persona natural o jurídica que produce residuos sólidos derivados de la actividad comercial, industrial y los oficiales que se benefician con la prestación del servicio público de aseo" (Cali, 2015, p. 704). Este último é divido entre pequenos e grandes geradores.

A seguir podemos observar uma comparação entre a definição dos pequenos e grandes geradores, tanto no município do Rio de Janeiro quanto em Cali.

Quadro 35 - Definição de pequenos e grandes geradores de resíduos sólidos no Rio de Janeiro e em Cali

\begin{tabular}{|c|c|c|c|c|}
\hline \multirow[t]{2}{*}{ Conceito } & \multicolumn{2}{|c|}{ Definição } & \multicolumn{2}{|c|}{$\begin{array}{c}\text { Responsabilidade da } \\
\text { coleta, destinação e } \\
\text { disposição final }\end{array}$} \\
\hline & Rio de Janeiro ${ }^{40}$ & Cali & RJ & Cali \\
\hline $\begin{array}{l}\text { Pequeno } \\
\text { gerador }\end{array}$ & $\begin{array}{l}\text { Geração de resíduos } \\
\text { que possam ser } \\
\text { assimilados aos } \\
\text { resíduos domiciliares. } \\
\text { Geração até } 120 \text { litros } \\
\text { ou } 60 \mathrm{~kg} \text { diários. }\end{array}$ & $\begin{array}{l}\text { Son los suscriptores y/o } \\
\text { usuarios no residenciales } \\
\text { que generan y presentan } \\
\text { para la recolección } \\
\text { residuos sólidos en } \\
\text { volumen menor a un (1) } \\
\text { metro cúbico mensual. }\end{array}$ & COMLURB & $\begin{array}{c}\text { Empresa } \\
\text { de } \\
\text { Limpeza } \\
\text { Urbana }\end{array}$ \\
\hline
\end{tabular}

${ }^{40}$ Segundo a Lei 3.273/01, que dispõe sobre a gestão do sistema de limpeza urbana no município do Rio de Janeiro. 


\begin{tabular}{l|l|l|l|l} 
Grande & Geração de resíduos & Suscriptores y/o usuarios & Do gerador & Empresa \\
gerador & que não possam ser & no residenciales que & de \\
assimilados aos & generan y presentan para & Limpeza \\
resíduos domiciliares. & la recolección residuos & Urbana \\
Geração superior a & sólidos en volumen igual & \\
120 litros ou $60 \mathrm{~kg}$ & o superior a un metro \\
diários. & cúbico mensual.
\end{tabular}

Fonte: Elaboração própria com base em Martarello, 2013 e no Plan de Gestión Integral de Residuos Sólidos de Cali - PGIRS 2015-2027.

Segundo as informações coletadas durante as entrevistas, a maior parte do comércio dá como destino ao resíduo gerado, os pontos de coleta das empresas de limpeza urbana, que se junta, por exemplo, aos resíduos das residências.

$\mathrm{Na}$ Rocinha, mesmo a maioria dos participantes da pesquisa sendo grandes geradores, cuja geração é superior a 120 litros ou 60 kg diários de acordo a Lei 3.273/01, conforme citado acima, não há contratação de uma empresa privada para a coleta do que é gerado. Somente em um desses estabelecimentos (hortifrúti), o entrevistado afirmou devolver para os fornecedores o material onde os produtos vêm armazenados, como: papelão, caixotes de madeira e de plástico e outros, pois caso não façam a devolução tem que pagar por isso. Além disso, relataram que doam os produtos que já não dá mais para vender, mas que ainda pode ser consumido; e as frutas podres são doadas para quem têm criação de animais, sendo essa, segundo o entrevistado, uma forma de reduzir os rejeitos que vão para o descarte. Os demais resíduos que sobram inclusive os orgânicos, que segundo o entrevistado chega a cerca de 80 litros diários, são coletados pela COMLURB.

$\mathrm{Na}$ Rocinha em 2016, durante nossas entrevistas do mestrado, um dos representantes comerciantes - grande gerador, havia informado que tinha passado a contratar os serviços de coleta de uma empresa particular (pela primeira vez), como manda a Lei 3.273/01, após a implantação da Unidade de Polícia Pacificadora (UPP) na Rocinha, instalada em 2011- projeto agora em decadência; no entanto, segundo essa mesma pessoa, em entrevista, desta vez para o doutorado, relatou que a empresa particular que fazia a coleta, era a única que prestava esse tipo de serviço na Rocinha e que deixou de atuar nesse território desde 2016 aproximadamente, ou seja, segundo a fala do entrevistado, hoje todos os estabelecimentos da Rocinha, seja ele grande ou pequeno 
gerador, destina o seu resíduo para coleta pela COMLURB, o que representa um retrocesso no que preceitua a lei supracitada.

No caso de Siloé, dois dos três estabelecimentos que integraram a pesquisa, são considerados pequenos geradores, de acordo com o volume que relataram gerar; e o terceiro é um grande gerador pertencente a uma grande rede de supermercados de Cali, o qual informou contratar os serviços de uma empresa privada para a coleta dos resíduos orgânicos e o material reciclável é enviado para uma fundação dessa rede de supermercado que vende o material e reverte o dinheiro em benefício de crianças que são contempladas com suas ações.

O representante de um dos estabelecimentos comerciais, um dos maiores restaurantes da Rocinha, informou que o óleo de cozinha usado, cerca de 50 litros por semana, é recolhido por uma empresa que não é da Rocinha, e que em troca eles oferecem como recompensa para o estabelecimento material de limpeza.

Mesmo os estabelecimentos que não têm nenhuma ação voltada para o reaproveitamento e/ou reciclagem, que representa a maior parcela dos participantes desta pesquisa, também não têm parceria com catadores/recicladores, o que acontece em alguns casos, sobretudo em Siloé, é a colocação do material na rua, que depois é coletado pelos recicladores que por ali passam, contudo não há parceria fixa com um determinado grupo ou reciclador individual.

Nenhum dos estabelecimentos disponibiliza para o consumidor, ações de recebimento de embalagens ou produtos pós-uso, atividade que faz parte da logística reversa no caso brasileiro (sobre a qual discorremos no Capítulo III) e em vias de aproximação do tema, na Colômbia seria a responsabilidade estendida do produtor, que conforme trecho a seguir:

"La responsabilidad del productor por un bien puesto en el mercado se extiende durante todo el ciclo de vida. De esta forma, se debe generar desplazamiento de la responsabilidad (física o económica; total o parcialmente) hacia el productor, así como proporcionar incentivos a los productores para incorporar las consideraciones ambientales en el diseño de sus productos (ecodiseño). (Colômbia, 2016, p. 45).

Tanto no Rio de Janeiro quanto em Cali, há legislação que versa sobre o uso/disponibilização das sacolas plásticas pelos estabelecimentos, por meio das quais passa a haver o repasse para os consumidores dos custos referentes ao produto, com vistas a incentivar as pessoas a utilizarem sacolas retornáveis. 
Assim, pretende-se que haja uma redução na geração do resíduo plástico. No Rio de Janeiro a Lei № 8.473 de 15/06/2019, é a que está vigente atualmente quanto a essa questão e "dispõe sobre a substituição de sacolas plásticas não recicláveis ou não reutilizáveis, distribuídas pelos estabelecimentos comerciais localizados no Estado do Rio de Janeiro, como forma de colocá-las à disposição do ciclo de reciclagem e proteção do meio ambiente fluminense" (Rio de Janeiro, 2019). A lei determina que:

Art. $2^{\circ}$ As sociedades comerciais e os empresários, de que trata o art. 966 do Código Civil, titulares de estabelecimentos comerciais com mais de 10 (dez) funcionários, localizados no Estado do Rio de Janeiro, ficam proibidos de distribuir, gratuitamente ou não, sacos ou sacolas plásticas descartáveis, compostos por polietilenos, polipropilenos e/ou similares. $\S 1^{\circ}$ As sacolas e/ou sacos plásticos reutilizáveis/recicláveis de que fala o caput desse artigo, quando destinadas ao acondicionamento e transporte de produtos pelos consumidores, deverão ter resistência de no mínimo 4 (quatro), 7 (sete) ou 10 (dez) quilos e ser confeccionadas com mais de 51 \% (cinquenta e um por cento) de material proveniente de fontes renováveis e o percentual restante preferencialmente proveniente de material reciclado nas cores verde, para resíduos recicláveis; e cinza, para outros rejeitos, de forma a auxiliar o consumidor na separação dos resíduos e facilitar a identificação para as respectivas coletas de lixo. $\S 2^{\circ}$ As sacolas e/ou sacos plásticos reutilizáveis/recicláveis de que fala o caput desse artigo, poderão ser distribuídos mediante cobrança máxima de seu preço de custo, neste incluídos os impostos (Rio de Janeiro, 2019).

Em Cali, com vistas ao desestímulo do uso de sacolas plásticas, a legislação que atualmente regula essa questão é a Resolução 668 de 2016 e a Lei 1819 de 2016 (legislações nacionais), que tratam consecutivamente, sobre a proibição da fabricação de bolsas plásticas, que não respeitem as determinações descritas nessa resolução; e a segunda, na qual é destinado um trecho que versa sobre o imposto ao consumo de bolsas plásticas. Conforme trecho que segue:

Resolución 668 de 2016 (01 de junio de 2016) - Prohibición: El Ministerio de Ambiente y Desarrollo Sostenible, prohíbe la fabricación de bolsas plásticas cuyas medidas sean inferiores a $30 \mathrm{~cm}$ x $30 \mathrm{~cm}$ y el calibre sea inferior a 0.9 milésimas de pulgada. Adicionalmente ordena que las bolsas que se fabriquen deban tener un mensaje ambiental relacionado con el uso racional del uso de bolsas plásticas en un tamaño mínimo del 10\% del área de una de sus caras. Reforma Tributaria Estructurada Ley 1819 de 2016 (01 de Julio de 2017) - Impuesto al consumo de bolsas plásticas: Él impuesto se cobrará por cada bolsa adquirida en grandes superficies y almacenes de cadena cuya destinación sea el transporte de productos enajenados (VARGAS, 2017, p. 10).

No que diz respeito a essa questão na Rocinha, não houve nenhum relato que chamasse a atenção em relação ao uso das sacolas, após a lei passar a 
vigorar. Em Siloé, um dos representantes comerciais relatou fazer uma campanha toda semana, sempre no mesmo dia, chamada:

Martes de la no bolsa, donde invitamos a nuestros clientes que traigan sus bolsas reutilizables para que ellos lleven su mercado y así se protege el medio ambiente, ya que pues usted sabe que un plástico para deteriorarse se demora por lo menos 25 años, entonces la idea es fomentar el día de la no bolsa (CCOL2. Entrevista concedida a Maria Izabel de Carvalho. Cali, 14 set. 2019).

Observamos em Siloé, com frequência, pessoas que para não ter que pagar o valor referente à sacola plástica, lançava mão de estratégias como utilizar os sacos plásticos que geralmente ficam próximos ao setor hortifrúti, para colocar as suas compras, pois alguns são grandes e cabem muitos produtos.

Outra questão apontada por um dos comerciantes de Siloé foram os roubos que passaram a acontecer após as pessoas começarem a trazer as bolsas retornáveis, quando então, segundo o entrevistado, tiveram que proibir a entrada de clientes com bolsas desse tipo e continuaram a utilizar as sacolas plásticas, assumindo os custos do imposto que deveria ser repassado aos clientes, conforme fala que segue:

Entonces ese cambio en el mercado ha sido muy fuerte en el robo en estos almacenes de autoservicio. Nosotros con esa bolsa grande, en vez de darnos una ayuda... se genera una ayuda al medio ambiente pero nos genera un problema de robo a nosotros inmenso. En este sector nosotros no tenemos la cultura todavía de una señora venga llene ese bolso y después pague. Lo que ha hecho el ladrón es utilizar ese sistema para robar más fácil, entonces coge la bolsa que venden hoy en día en los almacenes, la llenan y, si tienen la forma de irse, se van sin pagar. Ha sido un manejo muy difícil. Nosotros en esa parte, usted quiera tener una conciencia, porque nosotros entre la casa como que intentamos llegar a esa consciencia de cuidar, pero llegamos a este medio dónde aquí toca eso cancelarlo, porque eso me genera una pérdida muy grande. Nosotros nunca hemos dejado de utilizar la bolsa plástica, pero hay compradores que están acostumbrados, gente que viene a robar que utiliza esa cultura que se está generando para utilizarlo en el robo. Aquí se gasta mucha bolsa, se gasta mucha bolsa y muy pocos tienen la cultura de llevar sin bolsa, muy pocos (CCOL1. Entrevista concedida a Maria Izabel de Carvalho. Cali, 28 ago. 2019).

O entrevistado citou ainda dois bairros nobres de Cali, onde deixa a entender que há diferença em relação à cultura dos que compram no comércio de Siloé e dos que compram nesses bairros:

Entonces ya me voy a comprar por ejemplo al carulla de Ciudad Jardín, o me voy a comprar al Éxito de San Fernando, entonces la cultura es que allá manejamos las bolsas grandes para no utilizar la bolsa plástica. Mira lo que pasa ahí también, lo que pasa es que en la parte cultural ayuda mucho todo esto, vos de pronto en estratos más altos compras sin bolsa y es común, vos llegas, coges y metes en tu carro la maleta y ya. Para el comprador de acá todavía no se han adaptado a eso, por qué, porque en estas zonas el mercado todavía era muy... como muy 
tradicional (CCOL2. Entrevista concedida a Maria Izabel de Carvalho. Cali, 28 ago. 2019).

A falta de cultura, educação e outros qualificadores similares a esses, já mencionados anteriormente, atribuídos às pessoas mais pobres, assim como nos outros grupos, também aparece na fala de alguns representantes comerciais, sobretudo em Siloé.

E quando perguntado a esse grupo como enxerga a problemática dos resíduos sólidos de uma forma geral, obtivemos respostas como:

Quadro 36 - Fala de representantes comerciais sobre a problemática dos resíduos sólidos na Rocinha e em Siloé

\section{Rocinha}

Olha, eu já morei na... por exemplo, já morei na Muzema. A Rocinha... é super organizada, acho que em relação a isso. Cê pode ver que as ruas... de vez em quando tá suja, mas na maioria das vezes são limpas, tem gari comunitário, tem a COMLURB aqui dentro... então eles cuidam direitinho, em relação a outras comunidades (CBR1. Entrevista concedida a Maria Izabel de Carvalho. Rio de Janeiro, 06 out. 2020).

Acredito que antigamente, antes de ter

\section{Siloé}

Mi opinión de este sector sobre las basuras es muy descuidada, no le prestamos la suficiente atención a eso, $y$ hay muchos establecimientos que sacan la basura la tiran allá a la calle y entonces la gente que anda en la calle, los recicladores o la gente que vive en la calle, la riegan, hasta los mismos perros porque sienten el olor a comida, el olor a hueso, lo riegan; entonces todo el tiempo hay basura. Y los de Ciudad Limpia vienen y barren, pero nuevamente vuelven y la riegan porque los establecimientos a toda hora sacan la basura, sin tener en cuenta la hora en que pasa el camión para recoger; es muy descuidada por ese lado y hay gente que no le presta atención a eso. Entonces el sector se ve muy sucio, se ve mucha basura en la calle. Toda esta parte es comercial como hay muchos restaurantes muchas zonas de comida para no tener almacenamiento de basuras adentro sacan la basura a la calle, como es comida la gente riega, los perros riegan, entonces todo el tiempo hay basura regada en la calle (CCOL3. Entrevista concedida a Maria Izabel de Carvalho. Cali, 14 set. 2019).

Esto es cultural, usted pasa por allá y ve lleno 
esse pessoal catando lixo, dá o nome é de reciclagem né... era muito lixo na Rocinha e num tinha... agora não, agora tem um pessoal que cata os lixo, leva tudo, tira todo o detrito que é necessário pra uso, de reciclagem... e agora o lixo aqui tem um destino que acredito que ele dá muita coisa mesmo pra essas pessoas que necessitam mesmo, né, tem seus empregos... esse pessoal que trabalha ali na boca do túnel, um pessoal que tem um emprego, um emprego pra ir se mantendo né... Então vejo que o lixo é bem aproveitado na Rocinha, bem aproveitado mesmo (CBR2. Entrevista concedida a Maria Izabel de Carvalho. Rio de Janeiro, 07 out. 2020). de basura, usted sabe qué es lo que ocurre, nadie tiene conciencia ni de saber dónde botar la basura, ni cómo la debo botar, ni cómo las debo reciclar. Si con medios más altos con gente con más estructura académica que no lo hacen, porque la gente todavía tiene... Esto es un barrio muy popular en donde la gran problemática la generan madres cabezas de familia, la mayoría de familias no están compuestas completamente, sino que son madres cabezas de familia, entonces son personas que tienen que irse a las 5 de la mañana, levantarse, hacer un desayuno y un almuerzo, tienen dos o tres hijos, los hijos todo el día se manejan solos. Llegan a las 5 o 6 de la tarde y los pelados sueltos (CCOL1. Entrevista concedida a Maria Izabel de Carvalho. Cali, 28 ago. 2019).

Fonte: elaboração própria com base nas entrevistas realizadas.

$\mathrm{Na}$ Rocinha todos os representantes comerciais, avaliaram de forma positiva a questão dos resíduos sólidos, atribuindo qualidade ao serviço prestado pela empresa de limpeza urbana, bem como reconhecendo a importância dos catadores nesse processo. Em Siloé, todos os entrevistados reconhecem que há um problema a ser solucionado e atribuem mais uma vez a isso, a falta de cultura da população. Mediante ao apresentado, indagamos aos participantes da pesquisa nesse território, quais seriam as possíveis soluções para esses problemas:

Entonces ahí debería entrar una parte de escuelas, de colegios, estos niños quedan sueltos todo el día, entonces nadie esa cultura se la están inculcando, no se la están induciendo para que tengan este conocimiento, sino que... Y eso genera todo lo otro, drogadicción, delincuencia, prostitución, todo eso. Entonces esa misma parte social, es el mismo manejo; a veces parece que no tiene que ver, pero la parte de ese manejo de basuras también tiene que ver con esa parte (CCOL1. Entrevista concedida a Maria Izabel de Carvalho. Cali, 28 ago. 2019).

Pues sería, sería, la solución para eso sería crear cultura con la gente, darle cultura, pues es duro darle cultura a la gente por acá pero... porque la gente por acá tiene la cultura muy dura, digamos así. Las personas, si hay algún producto por ahí en vez de recogerlo lo patean, entonces es duro, es dura la cultura. Pero yo creo que sería como comenzar a hacer en esta comuna un grupo o algo así como que 'limpiamos el barrio' un ejemplo (CCOL2. Entrevista concedida a Maria Izabel de Carvalho. Cali, 14 set. 2019). 


\section{5 \\ Considerações Finais}

A presente tese teve como proposta realizar por intermédio da metodologia de estudo comparativo, uma análise que nos levou a compreender similaridades e diferenças diante do processo de destinação dos resíduos sólidos urbanos gerados tanto na favela da Rocinha no Brasil como em Siloé na Colômbia, onde procuramos compreender as formas de destinação e tratamento praticadas e como os sujeitos, sobretudo as pessoas residentes nesses locais, as compreendem e as praticam na busca de evitar adoecimento e garantir melhor qualidade de vida, assim como melhores condições para o trato das questões socioambientais planetárias.

Por outro lado, não podemos deixar de registrar que a experiência vivenciada na realização dessa pesquisa, foi enriquecedora, pois para além da investigação propriamente dita, nos proporcionou vivenciar situações inovadoras como o intercâmbio realizado, quando moramos durante dez meses em Cali na Colômbia, período que costumamos dizer, constituído de várias sensações e novas experiências, porque ao mesmo tempo, vivemos momentos de grande aprendizado, tanto enquanto pesquisadora como em termos pessoais, ao experimentar uma nova cultura, um novo idioma e novas vivências, porém ao mesmo tempo, nos foi custoso do ponto de vista emocional por estarmos distantes de tudo e de todas as pessoas do nosso convívio. Houve dias em que a saudade das pessoas, dos abraços, do lugar, da comida e de tantas outras coisas, era tão forte que chegava a doer, mas ao mesmo tempo, experimentávamos inúmeras situações que nos acalentavam.

Fomos recebidas de braços abertos pelo nosso coorientador Ricardo Rodriguez Quintero, pela Pontifícia Universidad Javeriana de Cali e pelos nossos irmãos colombianos que, de um modo geral, demostraram carinho e cuidado ao longo de todo o intercâmbio.

Hoje, já em terras brasileiras, e valorizando ainda mais tudo o que nos rodeia nesse território, sentimos saudades das pessoas, do lugar e de tantos momentos bons vividos enquanto residimos na Colômbia, pois somos um pouco de tudo o que experimentamos ao longo de nossas vidas, em cada lugar por nós vivenciado/experimentado, como aponta Santos et al. (2007) é no território onde 
a história das pessoas se realiza plenamente a partir das manifestações da sua existência.

Não podemos deixar de registrar que o aprendizado foi relevante, tanto em nível de cultura e de vivência, como também a respeito do estudo que nos propusemos a realizar, enquanto assistente social, cuja base da pesquisa apesar de ter sido viabilizada pelo interesse de compreender, a partir da perspectiva socioambiental, quais as formas de destinação e tratamento praticadas nos dois países em relação aos resíduos sólidos urbanos, seja em áreas favelizadas ou nos bairros populares, teve como foco central às pessoas; ou seja, as formas como elas se organizam e sobrevivem diante da precarização de políticas públicas, que mais as excluem do que as incorporam como sujeitos de direitos.

Ressaltamos que ao longo do estudo, procuramos ter prudência ao realizar as comparações nas duas áreas, pois apesar de apresentarem uma realidade socioeconômica semelhante e uma geografia que nos indicavam possibilidades analíticas, sabíamos que todo cuidado no tratamento dos dados e nas análises se constituía de fundamental importância para evitarmos equívocos de compreensão dos fatos: legais, ambientais, políticos, sociais, culturais entre outros.

Apoiados na fundamentação de Gorelik (2005), entendemos que não é possível fazer generalizações em relação às cidades latino-americanas, o que também se aplica as demais situações, inclusive às questões referentes às áreas populares que integram essas cidades. $E$ foi justamente isso, o que trabalhamos em nossas análises, ou seja, partimos da premissa de que a favela da Rocinha e o bairro popular de Siloé são únicos, contudo, apresentam características em comum, o que nos permitiu comparar o processo de destinação dos resíduos sólidos gerados e suas formas de tratamento nesses lócus, assim como a relação que as pessoas têm no trato com eles.

Em se tratando da pesquisa, desde o período da qualificação indicávamos algumas indagações a respeito das duas áreas estudadas, que pretendemos recuperar e tecer algumas considerações, no decorrer deste item.

Quanto à política pública nacional que regulamenta a geração, destinação e tratamento dos resíduos sólidos, questionávamos se em sua elaboração levouse ou não em consideração a efetivação de sua prática nas áreas populares, tanto no Brasil como na Colômbia e, ao longo da pesquisa, identificamos que a política de resíduos sólidos de ambos os países, não pensa especificamente essas áreas, sendo composta por elementos abrangentes que não atende as 
especificidades destes locais, o que tem consequências diretas na forma como o serviço é prestado nesses territórios.

Deste modo, entendemos que a segregação socioespacial, vivenciada por esse segmento da sociedade, tem consequências diretas na qualidade de vida dessa população, uma vez que as políticas públicas e os serviços públicos não são pensados respeitando as particularidades desses territórios, não apresentando no ato de sua implementação a mesma qualidade do que é ofertado para as regiões "nobres" da cidade. O que se observa, portanto, nesses lugares, é a precarização dos serviços e pouco investimento em infraestrutura, não Ihes sendo garantidas condições dignas para o pleno desenvolvimento enquanto cidadão de direito.

Essa deficiência na prestação dos serviços dá margem para o surgimento de situações como a identificada na Rocinha durante a nossa observação de campo, quando um morador relatou que, tendo em vista o fato da coleta porta a porta não chegar à maioria esmagadora das residências, um habitante, por iniciativa própria, começou a oferecer esse serviço de forma particular e informou inclusive ter um projeto escrito para o desenvolvimento da atividade, que segundo o mesmo tinha como um dos objetivos, a redução do descarte inadequado nas áreas aonde a coleta porta a porta da COMLURB não chega. $O$ "projeto" funcionava da seguinte forma: inicialmente era feita uma abordagem aos habitantes e quem aderisse, teria que fazer um cadastro, quando era fixado no imóvel, um selo de identificação, para que quem viesse fazer a coleta (pessoa contratada por quem pensou a ação), soubesse que ali residia alguém que contratou o serviço, pelo qual era cobrada uma taxa de dois reais semanais, para ter o resíduo coletado em sua casa, entre três e quatro vezes por semana; e além da coleta, a cada 50 moradores do mesmo beco que contratassem o serviço, o grupo que estava prestando-o, também varria o local. A pessoa que coordenava o "projeto" chegou a contratar cerca de 12 funcionários para executar o serviço, que teve a adesão de quase quatro mil residentes. Porém, segundo relatado pela pessoa que nos apresentou essa situação, a COMLURB ao tomar conhecimento, adotou as medidas cabíveis para proibir a ação, chegando o caso inclusive, a envolver a polícia.

Diante dos fatos, consideramos importante sinalizar como uma das alternativas de viabilização do que preceitua a Política Nacional de Resíduos Sólidos do Brasil e a Política Nacional para la Gestión Integral de Residuos Sólidos da Colômbia e também por ser socioambientalmente correta no contexto social, à adoção de novas posturas, que possibilitem aos sujeitos das áreas 
populares, o acesso a ações que estimulem a prática da redução, reutilização e reciclagem dos resíduos sólidos, sobretudo por meio da efetivação da educação ambiental numa perspectiva crítica, objetivando construir novas formas de lidar com o trato dos resíduos sólidos, uma vez que essa vertente é a que melhor se conforma na compreensão desta questão, tendo em vista que, conforme apontando por Loureiro \& Layrargues (2013), busca pensar cada contexto partindo de uma análise consciente da complexa conjuntura da realidade, buscando os fundamentos necessários para o questionamento das condicionantes sociais que foram produzidas ao longo da história, que implicam a reprodução social e que suscitam desigualdades e conflitos ambientais; age de modo a trabalhar a autonomia e a liberdade dos agentes sociais diante das relações de opressão, expropriação e dominação, características do sistema capitalista; e também visa a transformação da forma mais radical possível, do atual padrão societário que é predominante.

Quanto à indagação referente às formas de destinação e tratamento dos resíduos sólidos na Rocinha e em Siloé, os resultados apontaram que estas se assemelham, embora tenhamos que ressalvar e respeitar as singularidades, assim como os processos de prestação dos serviços ofertados pelas empresas de limpeza urbana em cada local. Na sequência trazemos alguns elementos, com vista à elucidação desse questionamento.

Identificamos que o fato da densidade populacional de Siloé ser menor que a da Rocinha, tem implicação direta no volume de resíduo sólido que é gerado e destinado nesse primeiro território, onde a coleta é realizada três dias por semana e em cada dia é retirado aproximadamente 75 toneladas de resíduos, enquanto na Rocinha são coletadas cerca de 100 toneladas diariamente.

Entendemos que as características dos campos desta pesquisa implicam diretamente na questão da destinação, assim, sinalizamos que notamos que há semelhança no tocante à topografia, porém há diferença entre Siloé e a favela da Rocinha, no que concerne a infraestrutura urbana, sobretudo no que diz respeito à quantidade de ruas carroçáveis por onde pode chegar o carro que faz a coleta dos resíduos sólidos, o que no primeiro campo, favorece o escoamento dos resíduos, uma vez que os moradores, mesmo os que residem em becos, geralmente têm próximo à sua casa, uma rua por onde passa o carro da coleta, diferente do que ocorre na favela da Rocinha, onde um número considerável de pessoas tem que trazer o resíduo até a Estrada da Gávea, que é a rua principal, onde está concentrada a maioria dos pontos de coleta estipulados pela empresa de limpeza urbana; a distância entre essa via e a moradia de quem vive nas 
partes mais altas, onde não tem ruas carroçáveis, é grande e em determinadas localidades chega a ter um quilômetro ou mais de distância, o que dificulta não somente o descarte adequado dos resíduos sólidos do dia-a-dia, mas também compromete outras questões, dentre as quais a dificuldade de destinação adequada de bens inservíveis e entulho, o não acesso a transporte para o deslocamento interno até essas áreas, a dificuldade de locomoção das pessoas que têm algum problema de saúde ou mesmo os idosos, entre outros fatores.

A esse respeito, recomendamos que as empresas de limpeza urbana implementem adaptações que facilitem aos usuários que moram à longas distâncias dos pontos de coleta, o descarte dos resíduos por meio da coleta porta a porta ou em pontos próximos às suas residências, o que acreditamos que contribuiria para a diminuição do descarte inadequado, melhorando as condições desses territórios, implicando diretamente na melhoria da qualidade de vida da população local, bem como reduziria os danos ambientais.

Vimos no decorrer desse estudo, que soluções para a coleta nos becos e escadarias, por meio de um container-carrinho ou até mesmo de um carrinho transportador, que poderia auxiliar no deslocamento do recipiente onde os resíduos seriam depositados, apontada na década de 1980 em estudos realizados naquela época, são soluções possíveis e viáveis e que inclusive já vem acontecendo em uma parte do sub-bairro 199 da Rocinha (parte alta), segundo relatos do representante da COMLURB, onde os garis comunitários, fazem a coleta, utilizando um container, pois com este equipamento é possível transitar pelos becos e escadarias. Portanto, esses equipamentos, a nosso ver, viabilizariam tal ação, podendo ser implementada em um curto prazo, pois não requer mudanças em termos de infraestrutura, apenas investimento em recursos humanos e em tais equipamentos, que inclusive já existem no mercado, e no caso do container, já é até mesmo utilizado por uma dessas empresas, a COMLURB.

No que diz respeito à destinação dos resíduos sólidos pelos moradores, nos dois territórios, mesmo aqueles que levam o seu resíduo até um ponto estipulado pelas empresas de limpeza urbana, que constitui a maioria, temos elementos que nos levam a afirmar que mesmo assim não está garantido a essas pessoas o direto ao descarte adequado, tendo em vista que em muitos desses pontos de coleta, o resíduo é depositado direto no chão e fica exposto a céu aberto, e ainda que por pouco tempo, acaba atraindo animais e insetos, além de que, em caso de chuva forte, o material desce rua abaixo, acarretando sérios danos à população e ao meio ambiente. Portanto, entendemos que as 
empresas de limpeza urbana deveriam estudar soluções para viabilizar ao morador que tem que levar o seu resíduo até um ponto de coleta, o efetivo descarte adequado, segundo as regras das políticas públicas de resíduos sólidos de cada território.

Outro ponto observado em relação à destinação dos resíduos sólidos foi que em Siloé, o fato de o serviço de coleta ser realizado em dias previamente determinados, em praticamente todo o território, acaba gerando um hábito na população usuária, ou seja, a leva a descartar os resíduos sólidos somente nesses dias, o que contribui para que se note uma maior limpeza nas ruas dessa localidade. Porém, cabe salientar que ainda assim, é possível notar resíduos, embora que em pouca quantidade, em alguns dos pontos de coleta estipulados pela empresa de limpeza urbana, em dias que o serviço não é realizado. Entendemos que na Rocinha, levando em consideração o atual cenário, não seria possível realizar a coleta seguindo esse modelo, tendo em vista o grande volume de resíduo gerado diariamente. Nesse território, esse preceito poderia ser pensado para o sistema de coleta por nós sugerido acima, para os becos e/ou escadarias, o que inclusive começou a ser executado em algumas partes da Rocinha, pelo grupo particular que mencionamos anteriormente.

Em relação ao descarte em locais indevidos, como terrenos baldios e valas, notamos que tanto na Rocinha quanto em de Siloé, há concentração de resíduos, como bens inservíveis, entulho, entre outros, nesses locais. No primeiro território, atribuímos esse comportamento da população, sobretudo, a dificuldade de acesso aos pontos de coleta, conforme apontado ao longo desse estudo. Enquanto isso, no segundo campo de pesquisa, a ação está mais relacionada ao fato dos usuários terem que pagar uma taxa extra pelo recolhimento de bens inservíveis e de entulho.

Tanto nas falas dos entrevistados como durante o processo de observação de campo, identificamos que nos setores onde há uma grande circulação de pessoas, sobretudo, nas áreas comerciais, há maior concentração de resíduos sólidos a qualquer hora do dia, tanto nos pontos de coleta próximos a esses locais, bem como um maior volume de resíduos descartados inadequadamente nas ruas. Deste modo, entendemos que o comércio se constitui em uma peça importante nessa situação, a partir do qual poderiam ser pensadas ações com vistas a melhorias no que diz respeito ao trato adequado dos resíduos sólidos.

No tocante à disposição final e tratamento dos resíduos sólidos, identificamos que tanto da Rocinha quanto de Siloé, esse material vai para aterro sanitário, sendo que no primeiro campo, o material inicialmente é levado para a 
estação de tratamento e usina de reciclagem no Caju, onde, de acordo com o relato do representante da COMLURB, na medida do possível é feita a separação do material reciclável e o que resta é enviado para o aterro sanitário. Em Siloé os resíduos também são destinados para uma estação de transferência e depois é destinado para o aterro sanitário, porém nesse campo de pesquisa, todo o resíduo que é coletado pela empresa de limpeza urbana, é enterrado, não havendo, portanto, nenhum tipo de tratamento do material reciclável durante esse processo. Assim, mediante o relato do entrevistado da COMLURB, quando usa a expressão "na medida do possível" em relação à separação do material reciclável e o processo de disposição dos resíduos de Siloé, concluímos que em ambos os casos ainda não é dado, aos resíduos sólidos, o tratamento ideal defendido pelas instituições ambientais, pois mesmo que no primeiro caso a coleta seletiva seja realizada na unidade de reciclagem, ao que tudo indica, ela ainda não é totalmente eficiente.

Quanto à questão relativa ao tipo de cobrança efetuada pela população residente nos campos de pesquisa aos órgãos de limpeza urbana em relação à destinação inadequada dos resíduos sólidos domiciliares em face das peculiaridades locais, tanto do ponto vista de localização (geográfico) como pelo volume gerado diariamente, identificamos que há uma visão mais crítica a esse respeito, sobretudo na Rocinha, porém não identificamos nenhum tipo de cobrança efetiva por parte dos usuários à empresa de limpeza urbana, percebese que a reclamação fica quase sempre nos bastidores e não chega aonde deveria chegar.

No que diz respeito à avaliação do serviço de limpeza urbana, de uma forma geral os usuários demonstram satisfação em relação ao serviço prestado pela empresa Ciudad Limpia, com algumas ressalvas, como por exemplo: atraso nos horários da coleta e irregularidade em relação à varrição de determinadas ruas - alguns moradores relataram durante a observação de campo, que em certas ruas, o serviço não é realizado nos dias previamente determinados e outros apontaram também, que há ruas onde antes acontecia a varrição, mas que há certo tempo não vem mais sendo executada. No que diz respeito a essa questão na Rocinha, nota-se que são poucos os usuários que avaliam positivamente, sem ressalva, o serviço prestado pela COMLURB; a maioria entende que o serviço não é totalmente eficiente, não dando conta de atender a demanda local.

Outro ponto de indagação era se, tanto na Rocinha quanto em Siloé, a prática de culpabilizar a população local pelos danos ambientais em decorrência 
da destinação inadequada dos resíduos é uma atitude cotidiana que além de ser utilizada pelos poderes constituídos, também é apropriada pela população residente nas favelas e bairros populares, o que verificamos ser uma realidade, pois a fala sobre a falta de cultura, educação e consciência, dentre outros desqualificadores, atribuída aos moradores, perpassou praticamente todos os grupos entrevistados, inclusive o deles próprios, bem como foi ouvido frequentemente durante o processo de observação de campo, o que denota uma visão carregada de preconceitos sobre esse segmento, como se sofresse de uma "disfunção", surgindo como solução, a partir dessa forma de pensar, conforme apontado por Siqueira (2014), ações dignas de muitos questionamentos, por exemplo, o higienismo, o ajustamento corretivo, a "refuncionalização", a "autoajuda" entre outros, sendo a pobreza criminalizada, como de costume.

No que concerne aos investimentos efetivados pelo poder público ou privado na Rocinha e em Siloé, voltados para a questão da educação ambiental, não identificamos na Rocinha nenhuma ação contínua nesse sentido, o que há são ações esporádicas e pontuais, sendo que o mesmo ocorre em Siloé, tendo sido relatado pela empresa de limpeza urbana a realização de ações visando o repasse de informações voltadas, sobretudo, para a importância do descarte adequado dos resíduos sólidos. Salientamos a esse respeito, que mais da metade dos entrevistados relataram já ter participado de atividades voltadas para a educação ambiental, onde tenha sido abordada a temática dos resíduos sólidos e apontaram que ações como estas não deveriam ser pontuais, mas sim contínuas.

No que diz respeito à atuação das organizações da sociedade civil voltadas para a defesa da questão socioambiental na Rocinha e em Siloé, não identificamos a presença muito forte de tais instituições em nenhum dos territórios. Na Rocinha, dentre os grupos que atuam nessa linha, nos chamou a atenção o fato de todos os grupos entrevistados, conhecerem ou já terem ouvido falar sobre o "Projeto de Olho no Lixo", projeto esse que segundo lideranças locais, à época da sua implantação nesse território, no ano de 2016, não foi discutido com o público-alvo, já vindo pronto para ser executado, sem respeitar as particularidades e anseios da população da Rocinha. Esse projeto, conforme já dito anteriormente, quando falamos da Cooperativa Rocinha Recicla, que dele faz parte, sofreu sérios impactos em novembro de 2018, quando teve o terreno onde estava instalado, na localidade conhecida popularmente como "Roupa Suja", na Rocinha, desapropriado pela Prefeitura da Cidade do Rio de Janeiro. 
No que diz respeito a outros pontos trabalhados nessa pesquisa, como quando tratamos sobre as organizações de catadores, identificamos que na Rocinha a presença dessas instituições se resume a uma única cooperativa, que é de pequeno porte, diferente do que ocorre em Siloé e nas suas proximidades, onde há um número expressivo dessas organizações, que contam com uma quantidade significativa de associados.

Verificamos que são muitos os problemas enfrentados por esse segmento, sobretudo no que diz respeito à falta de apoio do poder público, que apesar das legislações vigentes voltadas para essa categoria, não às põe em prática devidamente. Além disso, outros problemas foram constatados, como: a falta de infraestrutura para a realização do trabalho - sede própria, equipamento, carros para manejo do material e outros; a não existência da coleta seletiva nos campos de pesquisa ou sua deficiência em outras áreas onde também atuam os catadores/recicladores; o monopólio sobre os preços dos materiais recicláveis, que em determinados momentos caem muito, prejudicando assim os associados, levando muitas dessas organizações a encerrarem suas atividades devido à falta de recursos e também por não contarem com o devido apoio governamental.

Em relação à categoria catador/reciclador de material reciclável, que é um segmento diverso, podendo estar ou não ligado a uma organização, identificamos que tanto na Rocinha quanto em Siloé, há esses profissionais, no entanto em maior quantidade e de forma mais organizada, estão os grupos de Siloé, o que atribuímos ao fato de terem que ser associados às organizações de recicladores para receberem a taxa referente à atividade de aproveitamento, como colaboradores do serviço de limpeza urbana. No entanto, tendo em vista as diversas realidades vivenciadas por esse grupo, mesmo em Siloé, onde identificamos uma maior organização, existem aqueles que, assim como os catadores entrevistados da Rocinha, exercem o trabalho na informalidade, estando ainda mais expostos que os demais, as vulnerabilidades que acometem essa categoria.

Chamamos a atenção para o fato de que os catadores/recicladores são, tanto no Brasil quanto na Colômbia, profissionais importantíssimos para o processo de reciclagem, contribuindo diretamente para a redução do volume do material que vai para a disposição final, o que tem consequência direta na preservação do meio ambiente. No entanto, essa categoria ainda não tem sua importância devidamente reconhecida, sendo necessários avanços tanto no que 
diz respeito à garantia dos seus direitos como no tocante ao reconhecimento do seu importantíssimo papel na sociedade.

Identificamos que as empresas de limpeza urbana não mantêm relação próxima nem com os catadores/recicladores nem com as organizações de catadores/recicladores, seja na Rocinha ou em Siloé. Neste último território, a única articulação que a empresa tem com esse grupo, acontece de forma indireta, tendo em vista o cumprimento da lei, que estabelece o repasse do valor referente à atividade de aproveitamento para as organizações de recicladores. Percebemos, portanto, certa animosidade das empresas, sobretudo a de Siloé, em relação a essa categoria. Acreditamos que isso se deve, sobretudo, ao conflito de interesses entre a empresa e os recicladores e/ou organização de recicladores, uma vez que a empresa de limpeza urbana é remunerada pela quantidade de resíduo que coleta e à medida que mais material é destinado para reciclagem, menor é o volume a ser coletado pela mesma e, consequentemente, menores são os valores arrecadados.

No Brasil, no atual governo, vivemos o desmonte das políticas públicas, dentre elas as ambientais, que sofrem graves retrocessos, como, a alteração sofrida pela PNRS, por intermédio da Lei 14.026/2020 que dispõe sobre o novo marco regulatório de saneamento e que foi regulamentada pelo Decreto $\mathrm{N}^{\circ}$ 10.588 de 24 de dezembro de 2020, o que irá agravar ainda mais a situação dos resíduos sólidos no país, ao postergar o prazo de encerramento dos lixões, que deveriam ter sido extintos até 2014 , porém não foram e seguem sendo espaço de recebimento de resíduos, observando-se inclusive, um aumento de $16 \%$ da quantidade de resíduos que são destinados para esses locais, entre 2010 e 2019, segundo a ABRELPE (2020). Com essa alteração, o encerramento dos lixões se estende, dependendo das características do município, até 2024 - para os municípios com população inferior a 50.000 (cinquenta mil) habitantes no Censo 2010, o que implica em graves danos ao meio ambiente.

Por fim, conscientes de que os resultados obtidos com esta pesquisa não são estáticos e de que não foram e não serão jamais esgotados, chamamos a atenção para o fato de que se torna importante para futuras pesquisas, o aprofundamento do tema abordado neste estudo, levando em consideração a sua complexidade e importância para a sociedade como um todo, pois apesar das especificidades da Rocinha e de Siloé, o conhecimento aqui produzido, pode contribuir para a compreensão da problemática dos resíduos sólidos em outras áreas populares. 
Reconhecemos a importância dessa pesquisa, contudo devemos ter clareza de que ela nos proporcionou um conhecimento relativo e inacabado, uma vez que a sociedade está em constante transformação, o que implica reconhecer que todos os setores que a compõem estão em constante mudança. Assim como Minayo (2006), entendemos que a realidade estará sempre aberta para várias direções, por causa dos novos achados do contexto ou das novas perguntas que serão formuladas. 


\section{Referências Bibliográficas}

ASSOCIAÇÃO BRASILEIRA DE NORMAS TÉCNICAS. ABNT NBR 1004: resíduos sólidos: classificação. Rio de Janeiro, 2004.

ABRELPE. Panorama dos resíduos sólidos no Brasil 2018/2019. São Paulo, 2019. Disponível em: <https://abrelpe.org.br/panorama/>. Acesso em: $8 \mathrm{dez}$. 2020.

Panorama dos resíduos sólidos no Brasil 2020. São Paulo, 2020. Disponível em: <https://abrelpe.org.br/panorama-2020/>. Acesso em: 4 fev. 2021.

ABREU, M. A. A cidade, a montanha e a floresta. In: (Org.). Natureza e sociedade no Rio de Janeiro. Rio de Janeiro: Prefeitura do Rio de Janeiro, 1992. p. 54-103.

ACSELRAD, H. Ambientalização das lutas sociais: o caso do movimento por justiça ambiental. Estudos Avançados, São Paulo, v. 24, n. 68, p. 103-119, 2010. Disponível em: <http://www.scielo.br/pdf/ea/v24n68/10.pdf>. Acesso em: 20 ago. 2015.

Justiça Ambiental e construção social do risco. Desenvolvimento e Meio Ambiente, Curitiba, n. 5, p. 4-60, jan./jun. 2002. Disponível em: <https://revistas.ufpr.br/made/article/view/22116/14480>. Acesso em: 14 maio 2021.

De "bota-foras" e "zonas de sacrifício": um panorama dos conflitos ambientais no Estado do Rio de Janeiro. In: (Org.). Conflito social e meio ambiente no Estado do Rio de Janeiro. Rio de Janeiro: Relumé Dumará, 2004. p. 7-18.

AMARAL, R. D. O financiamento multilateral do desenvolvimento: o Estado brasileiro e os bancos multilaterais de desenvolvimento no planejamento territorial: o caso do Ceará. 2018. 283p. Tese (Doutorado) - Faculdade de rquitetura e Urbanismo, Universidade de São Paulo, São Paulo, 2018.

AZEVEDO, B. D. Análise e proposta de diretrizes para um sistema logístico de recolha e beneficiamento dos resíduos sólidos para áreas de favela em sintonia com os preceitos da GrSCM. 2010. 133f. Dissertação (Mestrado em Engenharia de Produção) - Departamento de Engenharia Industrial, Pontifícia Universidade Católica, Rio de Janeiro, 2010.

BASTOS, V. P. Profissão: catador: um estudo do processo de construção da identidade. Rio de Janeiro: Letra Capital, 2014.

BASTOS, V. P. O fim do lixão de Gramacho: além do risco ambiental. O Social em Questão, Rio de Janeiro, ano 18, n. 33, p. 265-288, 2015. Disponível em: $<$ http://osocialemquestao.ser.puc-rio.br/media/OSQ_33_10_Bastos.pdf >. Acesso em: 14 maio 2021. 
BEHRING, E. R. França e Brasil: realidades distintas da proteção social, entrelaçadas no fluxo da história. Serviço Social e Sociedade, São Paulo, n. 113, p. 7-52, jan./mar. 2013. Disponível em:

$<$ https://www.scielo.br/scielo.php?pid=S0101-

66282013000100002\&script=sci_abstract\&tlng=pt>. Acesso em: 14 maio 2021 .

BRASIL. Congresso Nacional. Câmara dos Deputados. Política Nacional de Resíduos Sólidos. Série Legislação, 3. ed. reimp. Brasília, DF: Câmara dos Deputados, 2017. (Série Legislação).

Ministério do Meio Ambiente. Política Nacional de Resíduos Sólidos. Linha do tempo. Brasília, DF: Ministério do Meio Ambiente, [2016]. Disponível em:

<http://www.mma.gov.br/cidades-sustentaveis/residuos-solidos/politica-nacionalde-residuos-solidos/linha-do-tempo>. Acesso em: 7 mar. 2016.

Presidência da República. Lei no 14.026, de 15 de julho de 2020. Atualiza o marco legal do saneamento básico e altera a Lei no 9.984, de 17 de julho de 2000, para atribuir à Agência Nacional de Águas e Saneamento Básico (ANA) competência para editar normas [...]. Diário Oficial da União, Brasília, DF, 16 jul. 2020. Disponível em: <http://www.planalto.gov.br/ccivil_03/_Ato20192022/2020/Lei/L14026.htm\#art13>. Acesso em: 18 mar. 2021.

BRUM, M. S. De favelados a favelados: a Cidade Alta (Rio de Janeiro) e as memórias e re-significações da favela num conjunto habitacional. In: SIMPÓSIO NACIONAL DE HISTÓRIA, 25., 2009, Fortaleza. Anais... Fortaleza ANPUH, 2009. Disponível em: <https://anpuh.org.br/uploads/anais-simposios/pdf/201901/1548772007_0f52e3e8022251645107898e53ff367f.pdf>. Acesso em: 9 dez. 2020.

BURGOS, M. B. Dos parques proletários ao Favela-Bairro / as políticas públicas nas favelas do Rio de Janeiro. In: ZALUAR, A.; ALVITO, M. (Org.). Um século de favelas. 5. ed. Rio de Janeiro: Editora FGV, 2006. p.25-60.

CALI (Colombia). Alcadia. Cali en cifras 2020. Cali: Departamento Administrativo de Planeación, 2020. Disponível em:

$<$ https://www.cali.gov.co/planeacion/publicaciones/137803/documentos-cali-encifras/>. Acesso em: 1 mar. 2021.

CÁMARA DE COMERCIO DE CALI. Informe especial: informalidad laboral y empleo en Cali y 13 ciudades. Cali, Colombia: Cámara de Comercio, mar. 2020. Disponível em: <https://www.ccc.org.co/file/2020/03/Informe-Especial-N03.pdf>. Acesso em: 1 nov. 2019.

CARVALHO, M. I. A favela da Rocinha e a destinação inadequada de lixo: entendendo os meandros da questão. 2016. Dissertação (Mestrado em Serviço Social) - Departamento de Serviço Social, Pontifícia Universidade Católica, Rio de Janeiro, 2016.

CARVAJALINO BAYONA, $H$. Barrios populares: alternativa a la crisis habitacional, desde los pobladores. Credencial Historia, Colombia, n. 349, 2019. Disponível em: <https://www.banrepcultural.org/biblioteca- 
virtual/credencial-historia/numero-349/barrios-populares-alternativa-la-crisishabitacional>. Acesso em: 21 abr. 2021.

CARVALHO FILHO, S. A. de. "Até parece um céu no chão". O reverso da representação poética: condições de vida na favela da Rocinha no Rio de Janeiro (1930-1990). In: SIMPÓSIO NACIONAL DE HISTÓRIA, 23. 2005, Londrina. Anais... Londrina: Associação Nacional de História - ANPUH, 2005. Disponível em: <https://anpuh.org.br/uploads/anais-simposios/pdf/201901/1548206568_be8bcb8feb8b6eae8dd63bc58bf98e4c.pdf>. Acesso em: 17 maio 2021.

CASSAB, L. A. Tessitura investigativa: a pesquisa científica no campo humanosocial. Revista Katálysis, Florianópolis v. 10, n. esp., p. 55-63, 2007. Disponível em:<https://www.scielo.br/scielo.php?pid=S1414-

49802007000300006\&script=sci_abstract\&tlng=pt>. Acesso em: 14 maio 2021.

COLOMBIA. Departamento Nacional de Planeción. Rellenos sanitarios de 321 municipios colapsarán en cinco años, advierte el DNP. [Bogotá: DNP, 2015?]. Disponível em: <https://www.dnp.gov.co/Paginas/Rellenos-sanitarios-de-321municipios-colapsar\%C3\%A1n-en-cinco-a\%C3\%B1os,-advierte-el-DNP--.aspx>. Acesso em: 2 jun. 2018.

Departamento Nacional de Estadística (DANE). Resultados censo nacional de población y vivienda 2018. Cali, Valle del Cauca: DANE, Julio 2019. Disponível em: <https://www.dane.gov.co/files/censo2018/informaciontecnica/presentaciones-territorio/190711-CNPV-presentacion-valle.pdf>. Acesso em: 28 fev. 2021.

Disposición final de residuos sólidos: informe nacional - 2016. Bogotá: Superintendencia de Servicios Públicos Domiciliarios, 2017. (Edicíon, n. 9). Disponível em:

<https://www.superservicios.gov.co/sites/default/archivos/SSPD\%20Publicacione s/Publicaciones/2018/Oct/informenacional2016disposicionfinalderesiduossolidos 1.pdf>. Acesso em: 4 jan. 2021.

Informe de disposición final de residuos sólidos - 2018. Bogotá: Superintendencia de Servicios Públicos Domiciliarios, 2019. (Edicíon, n. 11). Disponível em:

$<$ https://www.superservicios.gov.co/sites/default/archivos/Publicaciones/Publicaci ones/2020/Ene/informe_nacional_disposicion_final_2019_1.pdf>. Acesso em: 4 jan. 2021.

Informe nacional de aprovechamiento: informa nacional 2016. Bogotá: Superintendencia de Servicios Públicos Domiciliarios, 2017. (Edición, n. 1). Disponível em:

<http://www.andi.com.co/Uploads/22.\%20Informa\%20de\%20Aprovechamiento\% 20187302.pdf>. Acesso em: 4 jan. 2021.

Informe sectorial de la actividad de aprovechamiento 2018. Bogotá: Superintendencia de Servicios Públicos Domiciliarios, 2019. (Edición, n. 11). Disponível em:

<https://www.superservicios.gov.co/sites/default/archivos/Publicaciones/Publicaci ones/2020/Ene/informe_sectorial_aprovechamiento_2018.pdf >. Acesso em: 4 jan. 2021. 
Ministerio de Ambiente y Desarrollo Sostenible. Diagnóstico nacional de salud ambiental. Bogotá: Ministerio de Ambiente y Desarrollo Sostenible, 2012. Disponível em:

<https://www.minsalud.gov.co/sites/rid/Lists/BibliotecaDigital/RIDE/INEC/IGUB/Di agnostico\%20de\%20salud\%20Ambiental\%20compilado.pdf>. Acesso em: 2 jun. 2018.

. Ministerio de Vivienda, Ciudad y Territorio. Decreto 596 del 11 de abril de 2016. Hoja, Bogotá, 2016. Disponível em:

<https://dapre.presidencia.gov.co/normativa/normativa/DECRETO\%20596\%20D EL\%2011\%20DE\%20ABRIL\%20DE\%202016.pdf>. Acesso em: 21 set. 2020.

Ministerio del Medio Ambiente. Política para la gestión integral de resíduos. Santafé de Bogotá, D.C: Ministério del Medio Ambiente, Julio 1998. Disponível em:

$<$ https://www.minambiente.gov.co/images/AsuntosambientalesySectorialyUrbana /pdf/Polit\%C3\%ACcas_de_la_Direcci\%C3\%B3n/Pol\%C3\%ADtica_para_la_gesti $\%$ C3\%B3n_integral_de_1.pdf>. Acesso em: 4 jan. 2021.

Política nacional para la gestión integral de residuos sólidos CONPES 3874. Bogotá: Consejo Nacional de Política Económica y Social, 2016. Disponível em:

<https://colaboracion.dnp.gov.co/CDT/Conpes/Econ\%C3\%B3micos/3874.pdf>. Acesso em: 13 mar. 2018.

COLOMBIA recicla el $17 \%$ de las 12 millones de toneladas de residuos. Portafolio, Bogotá, 11 nov. 2018. Disponível em:

$<$ https://www.portafolio.co/economia/colombia-solo-recicla-el-17-de-las-12-

millones-de-toneladas-de-residuos-solidos-523236>. Acesso em: 12 jan. 2021.

CORTÉS, A. Aníbal Quijano: Marginalidad y urbanización dependiente en América Latina. Polis, Santiago, v. 16, n. 46, p. 1-14, 2017.

COSTA, C. E. L.; GONAZÁLEZ, M. J. F.; ALMEIDA N. F. da. A lógica de funcionamento dos bancos multilaterais de desenvolvimento e 0 seu relacionamento com o Brasil no período 1990-2012. Boletim de Economia e Política Internacional, Brasília, DF, n. 16, jan./abr. 2014. Disponível em: <http://repositorio.ipea.gov.br/bitstream/11058/3793/1/BEPI_n16_l\%C3\%B3gica> . Acesso em: 23 fev. 2021.

CYNAMON, S. E. Solução para remoção de lixo nas favelas: um projeto de estudo. Cadernos de Saúde Pública, Rio de Janeiro, v. 1, n. 1, p. 35-40, jan./mar. 1985, Disponível em:

<https://www.scielo.br/pdf/csp/v1n1/v1n1a05.pdf>. Acesso em: 12 mar. 2021.

DIAS, L. F. V.; PALACIOS, N. I. B. Evolución de la prestación del servicio de aseo en Bogotá, producto del cambio de esquema que se presentó en el 2012. 2017. Monografía (Trabajo de conclusion del curso) - Universidad Distrital Francisco José de Caldas, Bogotá, 2017.

DUTRA, A. S. Problematizando o conceito de risco. O Social em Questão, Rio de Janeiro, ano 18, n. 33, p. 177-192, 2015. Disponível em: $<\mathrm{http}$ ://osocialemquestao.ser.puc-rio.br/media/OSQ_33_6_Dutra.pdf>. Acesso em: 15. abr. 2018. 
EDMUNDO, L. O Rio de Janeiro o tempo dos vice-reis: (1763-1808). Brasília, DF: Senado Federal, Conselho Editorial, 2000.

EIGENHEER, E. M. A história do lixo: a limpeza urbana através dos tempos. Porto Alegre: Gráfica Pallotti, 2009. Disponível em:

<http://www.lixoeeducacao.uerj.br/ imagens/ pdf/ ahistoriadolixo.pdf >. Acesso em: 10 mar. 2016.

ESTEVES, C. J. de O. Risco e vulnerabilidade socioambiental: aspectos conceituais. Caderno IPARDES: Estudos e Pesquisas, Curitiba, v. 1, n. 2, p. 6279, jul./dez. 2011.

FAGLIARI, R. A. Política Nacional de Resíduos Sólidos: histórico, cenário da gestão e os acordos setoriais no Estado de São Paulo. 2017. 119p. Dissertação (Mestrado em Ciências Ambientais) - Programa de Pós-graduação em Ciências Ambientais, Universidade Federal de São Carlos, São Carlos, 2017.

FIGUEIREDO, F. F.; BASTOS, V. P; MENESES, C. G. R. Uma década da Política Nacional de Resíduos Sólidos: O que mudou?. Revista Ciências da Sociedade, Pará, v. 4, n. 8, p. 30-42, jul./dez 2020.

FIRJAN. Publicações. Publicações de Economia. Saneamento no estado do Rio de Janeiro: cobertura e oportunidades de investimento. Rio de Janeiro, nov. 2017. Disponível em:

<https://www.firjan.com.br/publicacoes/publicacoes-de-economia/saneamentono-estado-do-rio-de-janeiro-cobertura-e-oportunidades-de-investimento.htm>.

Acesso em: 19 mar. 2021.

FLÓREZ, A. M. V. El proceso de urbanización de la Comuna 22: estudio sobre sus repercusiones en el barrio Valle del Lili. 2013. 53p. Monografía (Trabajo de grado) - Facultad de Derecho y Ciencias Sociales, Universidad ICESI, Santiago de Cali, 2013. Disponível em:

$<$ https://repository.icesi.edu.co/biblioteca_digital/bitstream/10906/76524/1/proces o_urbanizacion_comuna.pdf>. Acesso em: 28 fev. 2021.

GALEANO, E. H. As veias abertas da América Latina. Tradução de Sergio Faraco. Porto Alegre, RS: L\&PM, 2020.

GAMA-ROZA. Algumas ideias sobre o saneamento do Rio de Janeiro. Rio de Janeiro, Typ. Imp. e Const. de J. de Villeneuve, 1879.

GASPAR, M. Sambaqui: arqueologia do litoral brasileiro. Rio de Janeiro: Zahar Editores, 2000.

GIL, A. C. Como elaborar projetos de pesquisa. São Paulo: Atlas, 1989.

GOFFMAN, E. Estigma: notas sobre a manipulação da identidade deteriorada. Tradução de Márcia Bandeira de Mello Leite Nunes. 4. ed. Rio de Janeiro: LTC, 2008. Disponível em:

$<$ https://edisciplinas.usp.br/pluginfile.php/4216053/mod_resource/content/0/AUL A\%2012_Goffman\%20-\%20Estigma.pdf>. Acesso em: 02 jun. 2021.

GOMES, A. da S. et al. Evolução dos aglomerados urbanos na América Latina: uma análise do direito à cidade. Revista de Direito da Cidade, Rio de Janeiro, v. $12, \quad$ n. 2,2020 . Disponível em: <https://www.e- 
publicacoes.uerj.br/index.php/rdc/article/view/50061/33970>. Acesso em: 24 jul. 2020.

GONÇALVES, R. S. Favelas do Rio de Janeiro: história e direito. Rio de Janeiro: Editora Pallas/ PUC-Rio, 2013.

Desastres e favelas cariocas: a cobertura midiática das chuvas de 2010. In: ENCONTRO NACIONAL DE PESQUISADORES EM SERVIÇO SOCIAL, 17. 2018, Vitória. Anais... Vitória: Associação Brasileira de Ensino e Pesquisa em Serviço social, 2018. Disponível em: <https://periodicos.ufes.br/abepss/article/view/22117>. Acesso em: 15 abr. 2021.

GORELIK, A. A produção da "cidade latino-americana". Tradução de Fernanda Arêas Peixoto. Tempo Social: Revista de Sociologia da USP, São Paulo, v. 17, n. 1, p. 111-133, 2005.

GRANDRA, A. Quase metade dos municípios ainda despeja resíduos em lixões: Brasil tem alto índice de destinação incorreta do lixo. Agência Brasil, Brasília, DF, 5 ago. 2020. Disponível em:

$<$ https://agenciabrasil.ebc.com.br/geral/noticia/2020-08/quase-metade-dosmunicipios-ainda-despeja-residuos-em-lixoes>. Acesso em: 20 mar. 2021.

INSTITUTO BRASILEIRO DE GEOGRAFIA E ESTÍSTICA. Síntese de indicadores sociais: uma análise das condições de vida da população brasileira 2013. Rio de Janeiro: IBGE, 2013. (Estudos e pesquisas. Informação demográfica e socioecônomica, n. 32). Disponível em:

$<$ http://biblioteca.ibge.gov.br/visualizacao/livros/liv66777.pdf>. Acesso em: 25 abr. 2015.

Estatísticas. Censo demográfico 2010. Aglomerados subnormais informações territoriais. Rio de Janeiro: IBGE, 2010. Disponível em: $<$ https://www.ibge.gov.br/estatisticas/sociais/populacao/9662-censodemografico-2010.html?edicao=9678\&t=sobre >. Acesso em: 4 abr. 2015.

População estimada [2020]. Rio de Janeiro: IBGE, 2020. Disponível em: $<$ http://cidades.ibge.gov.br/xtras/temas.php? lang=\&codmun $=330455 \&$ idtema $=85 \&$ search=rio-de-janeiro|rio-de-janeiro|censodemografico-2010:-resultados-do-universo-aglomerados-subnormais->. Acesso em: 17 maio. 2021.

Agência IBGE Notícias. Censo 2010 aprimorou a identificação dos aglomerados subnormais. Rio de Janeiro: IBGE, 15 dez. 2011. Disponível em: $<$ https://agenciadenoticias.ibge.gov.br/agencia-sala-de-imprensa/2013-agenciade-noticias/releases/14152-asi-censo-2010-aprimorou-a-identificacao-dosaglomerados-subnormais\#: :text=Editoria\%3A\%20Geoci\%C3\%AAncias,O\%20IBGE\%20adotou\%20inova\%C3\%A7\%C3\%B5es\%20em\%202010\%20par a\%20atualizar\%20e\%20aprimorar,\%2C\%20palafitas\%2C\%20entre\%20outros)>. Acesso em: 17 maio 2021.

Pesquisa Nacional por Amostra de Domicílios Contínua. Características gerais dos domicílios e dos moradores 2019. Rio de Janeiro: IBGE, 2020. Disponível em:

$<$ https://biblioteca.ibge.gov.br/visualizacao/livros/liv101707_informativo.pdf>. Acesso em: 15 dez. 2020. 
JANCZURA, R. Risco ou vulnerabilidade social?. Textos \& Contextos, Porto Alegre, v. 11, n. 2, p. 301-308, ago./dez. 2012.

JARDIM, W. A. V. A Política Nacional de Resíduos Sólidos, seus avanços e retrocessos: uma análise a partir de sua implementação no município do Arraial do Cabo. 2018. 262p.Tese (Doutorado em Serviço Social) - Departamento de Serviço Social, Pontifícia Universidade Católica, Rio de Janeiro, 2018.

KARASCH, M. C. A vida dos escravos no Rio de Janeiro. 1808- 1850. São Paulo: Companhia das Letras, 2000.

KOGA, D. Medidas de cidades: entre territórios de vida e territórios vividos. 2. ed. São Paulo: Cortez, 2011.

LEITÃO, G. Dos barracos de madeira aos prédios de quitinetes: uma análise do processo de produção da moradia na favela da Rocinha, ao longo de cinquenta anos. 2004. Tese (Doutorado) - Universidade Federal do Rio de Janeiro, Rio de Janeiro, 2004.

Dos barracos de madeira aos prédios de quitinetes: uma análise do processo de produção da moradia na favela da Rocinha, ao longo de cinquenta anos. Niterói: Eduff, 2009.

LEONARDI, I. Documentário: Todo mapa tem um discurso. Mundo GEO, Curitiba, 16 maio 2014. Disponível em:

<http://mundogeo.com/blog/2014/05/26/documentario-todo-mapa-tem-um-

discurso/>. Acesso em: 18 mai. 2016.

LOPÉS, A. R. Espacio y poblamiento en la Ladera Sur Occidental de Cali: Sector Siloé, 1910-2010. 2016. Trabajo de fin de curso (Graduação) Universidad del Valle, Cali, Colômbia, 2016.

LOUREIRO, C. F. B.; LAYRARGUES, P. P. Ecologia política, justiça e educação ambiental crítica: perspectivas de aliança contra-hegemônica. Trabalho,

Educação, Saúde, Rio de Janeiro, v. 11, n. 1, jan./abr. 2013.

LUCCOCK, J. Notas sobre o Rio de Janeiro e partes meridionais do Brasil. 2. ed. São Paulo: Livraria Martins Editora S.A., 1951.

MAKINO, R. Bancos multilaterais de desenvolvimento e capacidade estatal: o BID, o Brasil e a Argentina. 2015. 261p. Tese (Doutorado em Ciências Sociais) - Instituto de Ciências Sociais, Universidade de Brasília, Brasília, 2015. Disponível em:

<https://repositorio.unb.br/bitstream/10482/19164/1/2015_Rog\%c3\%a9rioMakino .pdf>. Acesso em: 23 fev. 2021.

MINAYO, M. C. S. O desafio do conhecimento: pesquisa qualitativa em saúde. 9. ed. São Paulo: Editora Hucitec, 2006.

MIRANDA, R. A. Gestão integrada e gerenciamento de resíduos sólidos urbanos em favelas e loteamentos precários. In: SEMINÁRIO NACIONAL SOBRE URBANIZAÇÃO DE FAVELAS, 3., 2018, Salvador. Anais... Salvador: UFBA, 2018. Disponível em:

<http://www.sisgeenco.com.br/sistema/urbfavelas/anais2018a/ARQUIVOS/GT217-133-20180820214941.pdf>. Acesso em: 12 mar. 2021. 
NASCIMENTO, L. L. do; BARBOSA, N. R. Reflexão da questão socioambiental sob a ótica do Serviço Social. O Social em Questão, Rio de Janeiro, ano 23, n. 48, p. 97-118, set./ dez. 2020. Disponível em: <http://osocialemquestao.ser.pucrio.br/media/OSQ_48_Art_4.pdf>. Acesso em: 2 jun. 2021.

NUNES, L. S; SILVA, A. G. de M. O debate em torno da questão socioambiental na formação profissional do assistente social. Congresso Catarinense de Assistentes Sociais. In: CONGRESSO CATARINENSE DE ASSISTENTES SOCIAIS, 1., 2013, Florianópolis. Anais... Florianópolis: Conselho Regional de Serviço Social, 2013. Disponível em: <http://cress-sc.org.br/wpcontent/uploads/2014/03/O-debate-em-torno-da-quest\%C3\%A3o-

socioambiental-na-forma\%C3\%A7\%C3\%A3o-profissional.pdf>. Acesso em: 02 jun. 2021.

OLIVEIRA, A. C. O que a pandemia da covid-19 tem nos ensinado sobre adoção de medidas de precaução?. Texto e Contexo Enfermagem, Santa Catarina, v. 29, e20200106, 2020. Disponível em: <https://www.scielo.br/pdf/tce/v29/pt_1980265X-tce-29-e20200106.pdf>. Acesso em: 30 abr. 2021.

OLIVEIRA, M. F. A teoria do desenvolvimento e a problemática da urbanização na América Latina: uma primeira aproximação. Revista Brasileira de Estudos Urbanos e Regionais, Rio de Janeiro, v. 16, n. 2, p. 167-184, nov. 2014.

PADOVANI, W. F. Os desafios da era do lixo. Veja, [São Paulo], 2016. Disponível em: <http://planetasustentavel.abril.com.br/noticia/lixo/desafios-eralixo-detritos-transformar-riqueza-urbanidade-sujeira-681764.shtml> Acesso em: 10 mar. 2016.

PANDOLFI, D. C.; GRYNSZPAN, M. (Org.). A favela fala: depoimentos ao CPDOC. Rio de Janeiro: Editora FGV, 2003.

PASE, H. L. A virada das políticas públicas na américa latina no século XXI. In: CONGRESSO LATINO-AMERICANO DE CIÊNCIA POLÍTICA, 9., 2017, Montevideu. Anais... Montevideu: Associação Latino-americana de Ciência Política, Associação Uruguai da Ciência Política, 2017. Disponível em:

<http://www.congresoalacip2017.org/arquivo/downloadpublic2?q=YToyOntzOjY6 InBhcmFtcyl7czozNToiYToxOntzOjEwOiJJRF9BUIFVSVZPIjtzOjQ6IjlxMDgiO30i O3M6MToiaCl7czozMjoiZGFjMTE2ZTUzYjhIZDdkODg1NDQ3Njk3NjFIYjFIMmQi O30\%3D>. Acesso em: 28 jul. 2020.

PEREIRA, L. A. S. As recentes políticas públicas nas favelas cariocas: mais do mesmo?. In: OBSERVATORIO GEOGRÁFICO DE AMÉRICA LATINA. Processos Ambientales. [S.I., 2011?]. Disponível em:

<http://observatoriogeograficoamericalatina.org.mx/egal13/Procesosambientales/ Impactoambiental/45.pdf>. Acesso em: 20 maio 2016.

PLAN de gestión integral de residuos sólidos 2015-2027. Bogotá: Unidad Administratica Especial de Servicio Público - UAESP, 2015. Disponível em: http://www.uaesp.gov.co/uaesp_jo/images/direccion/PGIRS_FINAL_18-12-

2015.pdf. Acesso em: 28 fev. 2021.

PROGRAMA DE LAS NACIONES UNIDAS PARA LOS ASENTAMIENTOS HUMANOS (ONU-Habitat). Estado de las ciudades de América Latina y el Caribe 2012: rumbo a una nueva transición urbana. Nairobi: ONU-Habitat, 2012. 
Disponível em: <http://estaticog1.globo.com/2012/08/21/Estado-de-las-Ciudadesde-America-Latina-y-el-Caribe-2012.pdf>. Acesso em: 24 jul. 2020.

PROGRAMA DE LAS NACIONES UNIDS PAA EL MEDIO AMBIENTE (ONU Medio Ambiente). Perspectiva de la gestión de residuos en America Latina y Caribe. Ciudad de Panamá: ONU Medio Ambiente, 2018. Disponível em: https://wedocs.unep.org/handle/20.500.11822/26448. Acesso em: 25 nov. 2020.

QUEIROZ, D. T. et al. Observação participante na pesquisa qualitativa: conceitos e aplicações na área da saúde. Revista de Enfermagem UERJ, Rio de Janeiro, v. 15, n. 2, p. 276-283, abr./jun. 2007. Disponível em:

<https://edisciplinas.usp.br/pluginfile.php/2020779/mod_resource/content/1/Obse rva\%0B\%C3\%A7\%C3\%A30\%20Participante.pdf>. Acesso em: 30 out. 2020.

RELATÓRIO especial: o papel das organizações multilaterais no desenvolvimento econômico e social da América Latina. Madrid: LLorente \& Cuenca, set. 2005. Disponível em: <https://ideas.llorenteycuenca.com/wpcontent/uploads/sites/5/2015/09/150910_DI_relatorio_multilaterais_BR.pdf>.

Acesso em: 10 set. 2020.

RIBEIRO, F. M. Política Nacional de Resíduos Sólidos (PNRS). São Paulo: Escola Superior da CETESB, 2017. Apresentação para a Disciplina de Políticas Públicas Ambientais. Disponível em: <https://cetesb.sp.gov.br/posgraduacao/wpcontent/uploads/sites/33/2017/08/Aula-9-Politica-Nacional-de-

Res\%C3\%ADduos-S\%C3\%B3lidos-Fl\%C3\%A1vio-de-Miranda-Ribeiro.pdf>.

Acesso em: 14 dez. 2020.

RIO DE JANEIRO. Lei no 8473 de 15 de junho de 2019. Adequa a legislação que dispõe sobre a substituição de sacolas pláticas não recicláveis e não retornáveis distribuídas pelos estabelecimentos comerciais localizados no estado do Rio de Janeiro. Diário Oficial do Estado, Rio de Janeiro, 16 jul. 2019. Disponível em: <https://www.legisweb.com.br/legislacao/?id=379722>. Acesso em: 14 abr. 2021.

RIO DE JANEIRO. Secretaria Municipal de Meio Ambiente. Plano municipal de gestão integrada de resíduos sólidos - PMGIRS da cidade do Rio de Janeiro: base de dados - dez/2014. Rio de Janeiro, 2015. Disponível em: <http://www.rio.rj.gov.br/dlstatic/10112/3372233/4160602/PMGIRS_Versao_final _publicacao_DO_dezembro2015_19_ABR_2016_sem_cabecalho1.pdf >. Acesso em: 19 abr. 2021.

SÁNCHEZ, W. D. P. S. Inclusão de catadores na gestão integrada de resíduos sólidos: análise comparativa entre Bogotá e o Rio de Janeiro. 2018. 194p. Dissertação (Mestrado em Políticas Públicas, Estratégias e Desenvolvimento) - Instituto de Economia, Universidade Federal do Rio de Janeiro, Rio de Janeiro, 2018.

SANTAELLA, S. T. et. al. Resíduos sólidos e a atual política ambiental brasileira. Fortaleza: UFC; LABOMAR; NAVE, 2014. (Coleção Habitat, v. 7.)

SANTOS, M. et al. Território, territórios: ensaios sobre o ordenamento territorial. 3. ed. Rio de Janeiro: Editora Lamparina, 2007.

SARAYED-DIN, L. F. L. A ponte do Rio. Rio de Janeiro: E-papers, 2009. 
SARTORI, G; MORLINO, L. La comparación en las Ciencias Sociales. Revista Española de Educación Comparada, Madrid, n. 5, p. 279-280, 1999. Disponível em:

<https://www.ses.unam.mx/curso2017/bibliografia/Sartori,\%20G_Comparaci\%C3 \%B3n\%20y\%20m\%C3\%A9todo-1.pdf>. Acesso em: 10 jun. $201 \overline{8}$.

SCHUELER, A. S.; KZURE, H.; RACCA, G. B. Como estão os resíduos urbanos nas favelas cariocas?. URBE: Revista Brasileira de Gestão Urbana, Paraná, v. 10 , n. 1, p. 213-230, jan./abr. 2018. Disponível em: $<$ https://www.scielo.br/pdf/urbe/v10n1/2175-3369-urbe-10-1-213.pdf>. Acesso em: 12 mar. 2021.

SEGALA, K.; MARTARELLO, S. Gestão dos resíduos sólidos no Município do Rio de Janeiro - RJ. Rio de Janeiro: Rio Como Vamos, 2013 Disponível em: $<$ https://docplayer.com.br/1893030-Gestao-dos-residuos-solidos-no-municipiodo-rio-de-janeiro-rj-karin-segala-e-silvia-martarello.html>. Acesso em: 17 maio 2021.

SEPULVEDA CORZO, J. G. Barrios populares: hacia la búsqueda de la producción social del hábitat en Bogotá. Revista Bitácora Urbano Territorial, Bogotá, v. 20, n. 1, p. 145-156, 2012. Disponível em:

<https://www.redalyc.org/pdf/748/74824041014.pdf>. Acesso em: 22 abr. 2021.

SÍNDICATO DAS EMPRESAS DE LIMPEZA URBANA. Índice de sustentabilidade da limpeza urbana. 4. ed. São Paulo: SELURB, 2019. Disponível em: <https://selur.org.br/wp-content/uploads/2019/09/ISLU-20197.pdf>. Acesso em: 20 de mar. 2021.

SILVA, J. S. e et al. (Org.). O que é favela, afinal?. Rio de Janeiro: Observatório de Favelas, 2009. Disponível em: <http://observatoriodefavelas.org.br/wpcontent/uploads/2013/09/o-que-\%C3\%A9-favela-afinal.pdf>. Acesso em: 06 de fev. 2016.

SILVA, S. P. A organização coletiva de catadores de material reciclável no Brasil: dilemas e potencialidades sob a ótica da economia solidária. Rio de Janeiro: Ipea, 2017. (Texto para discussão, n. 2268). Disponível em: <http://repositorio.ipea.gov.br/bitstream/11058/7413/1/td_2268.PDF>. Acesso em: 19 de abr. 2021.

SILVA, T. P. da. Questão socioambiental e suas inter-relações com o Serviço Social. 2016. Dissertação (Mestrado em Serviço Social) - Programa de Pós-graduação em Serviço Social da Faculdade de Ciências Humanas e Sociais, Universidade Estadual Paulista "Júlio de Mesquita Filho", Franca, 2016. Disponível em:

$<$ https://repositorio.unesp.br/bitstream/handle/11449/144584/silva_tp_me_fran.pd f?sequence=3\&isAllowed $=y>$. Acesso em: 2 jun. 2021.

SIQUEIRA, L. A pobreza como "disfunção" social: a culpabilização e a criminalização do indivíduo. Argumentum, Vitória, v. 6, n. 1, p. 240-252, jan./jun. $2014 . \quad$ Disponível em: <https://periodicos.ufes.br/argumentum/article/view/6032/5764>. Acesso em: 14 de abr. 2021. 
SIQUEIRA, R. de; CARDOSO, H. O conceito de estigma como processo social: uma aproximação teórica a partir da literatura norte-americana. Imagonautas, Vigo, v. 2, n. 1. p. 92-113, 2011. Disponível em:

$<$ https://dialnet.unirioja.es/servlet/articulo?codigo=4781280>. Acesso em: 2 jun. 2021.

TEODÓSIO, A. S. S.; DIAS, S. F. L. G.; SANTOS, M.C. L. dos. Procrastinação da Política Nacional de Resíduos Sólidos: catadores, governos e empresas na governança urbana. Ciência e Cultura, Campinas, v. 68, n. 4, p. 30-33, out./dez. 2016. Disponível em: <http://cienciaecultura.bvs.br/pdf/cic/v68n4/v68n4a11.pdf>. Acesso em: 15 jan. 2021.

TERRAZA, H.; STURZENEGGER, G. Dinámicas de Organización de los Recicladores Informales: tres casos de estudio en América Latina. Washington: Banco Interamericano de Desarrollo, 2010. (Nota técnica, n. 117).

TOBAR, F.; YALOUR, M. R. (Org.). Como fazer teses em saúde pública: conselhos e ideias para formular projetos e redigir teses e informes de pesquisa. Rio de Janeiro: Fiocruz, 2001.

TORRES, D. I. Q. El papel de la gestión territorial en la ubicación de rellenos sanitarios. Caso de estudio: relleno sanitario Doña Juana, Bogotá, Colombia. Perspectiva Geográfica, Tunja-Boyacá, v. 21, n. 2, p. 251-276, jul./dic. 2016. Disponível em: <http://www.scielo.org.co/pdf/pgeo/v21n2/v21n2a04.pdf>. Acesso em: 1 jun. 2018.

UNIÃO PRÓ-MELHORAMENTOS DOS MORADORES DA ROCINHA. Varal de lembranças: histórias da Rocinha. Rio de Janeiro: União Pró-Melhoramentos dos Moradores da Rocinha, 1983.

VARGAS, L. F. B. Impuesto nacional al consumo de bolsas plásticas de utilización desechable en Colombia. 2017. 56p. Monografía - Facultad de Educación a Distancia, Universidad Militar Nueva Granada, Bogotá, 2017. Disponível em:

https:<//repository.unimilitar.edu.co/bitstream/handle/10654/16746/BernalVargas LuisaFernanda2017. pdf?sequence=3\&isAllowed=y>. Acesso em: 14 abr. 2021.

VALLADARES, L. P. A invenção da favela: do mito de origem a favela.com. Rio de Janeiro: Editora FGV, 2005.

VARELA, A. C. O significado das lutas populares pelo território urbano em Cali, na Colômbia: um estudo das dimensões sociopolíticas do assentamento de Polvorines. 2012. 153p. Tese (Doutorado) - Programa de Pós-Graduação em Serviço Social, Universidade Federal de Pernambuco, Recife, 2012.

VARELA, R. V.; CALDERÓN, J. E. A.; VÁSQUEZ, M. E. R. Congestión urbana en Santiago de Cali, un estudio de caso de política pública. Territorios, Bogotá, n. 42, p. 1-29, 2020. Disponível em:

<https://revistas.urosario.edu.co/xml/357/35762653008/35762653008.pdf>.

Acesso em: 28 fev. 2021.

VASCOCELOS, A. M. Práxis profissional: uma experiência de vida na Rocinha. 1990. Dissertação (Mestrado) - Departamento de Serviço Social, Pontifícia Universidade Católica, Rio de Janeiro, 1990. 
VIDAL, J. P. Metodologia comparativa e estudo de caso. Belém: Núcleo de Altos Estudos Amazônicos, 2013. (Papers do Naea, n. 308).

VÁSQUEZ, E. Historia del desarrollo económico y urbano en Cali. Boletín Socioeconómico, [S.I.], n. 20, abr. 1990. Disponível em:

<https://bibliotecadigital.univalle.edu.co/bitstream/handle/10893/5486/Historia\%2 0del\%20desarrollo\%20historico\%20y\%20urbano\%20en\%20Cali.pdf;jsessionid=1 C01B2D6739A5C8171C063F799ABF5E7?sequence=1>. Acesso em: 28 fev. 2021.

ZALUAR, A.; ALVITO, M. (Org.). Um século de favelas. 5. ed. Rio de Janeiro: Editora FGV, 2006. 


\title{
Apêndices
}

7.1.

Apêndice 1 - Formulário: moradores da Rocinha

\author{
PONTIFICIA UNIERSIDADE CATÓLICA DO RIO DE JANEIRO \\ Doutorado em Serviço Social \\ PONTIFICIA UNIVERSIDAD JAVERIANA CALI \\ Grupo de Investigação em Processos e Meios de Comunicação
}

Tese de Doutorado em Serviço Social a cargo da doutoranda Maria Izabel

de Carvalho

FORMULÁRIO: MORADORES ROCINHA

\begin{tabular}{|c|c|c|c|}
\hline $\begin{array}{c}\text { Data da } \\
\text { entrevista }\end{array}$ & dia & mês & ano \\
\cline { 2 - 4 } & & & \\
\hline
\end{tabular}
a) Nome:
b) Idade:
c) Gênero:
d) Lugar de nascimento:
e) Ocupação:
f) Há quantos anos reside na Rocinha:
g) Sub-bairro onde reside:
h) Lugar da entrevista: 
1. Como residente da favela da Rocinha, você conhece qual é a opinião dos moradores dos bairros de classe média alta, como são Conrado e Gávea, por exemplo, sobre o lugar onde você reside?

2. Como morador da favela da Rocinha, como você classifica a prestação dos serviços sociais (Educação, Saúde, Lazer, Limpeza Urbana) nesta localidade?

3. O que você pensa sobre o problema do lixo na Rocinha?

4. O que fazem os seus vizinhos com o lixo gerado por eles todas as semanas, levam até um ponto determinado pela COMLURB, ou jogam ao relento? Uns são ordenados, outros não? É fácil ou difícil para os seus vizinhos descartar o lixo adequadamente? Você, o que faz ou onde coloca o seu lixo? (para que depois não cause um problema com ele?)

5. O que fazem as pessoas que têm impedimentos físicos e que vivem longe da rota da coleta, para levar o lixo até os pontos indicados pela COMLURB?

6. Em sua casa, quem tem a tarefa de recolher e descartar o lixo? Por que é essa pessoa, especificamente?

7. Quantas vezes por semana você retira o lixo da sua casa?

8. Onde há mais ou menos lixo jogado na rua, na parte alta ou na parte baixa? Por que isso acontece?

9. Você já teve algum problema ou prejuízo por incidente ou acidente ambiental, em decorrência do descarte inadequado do lixo? Ou conhece pessoas ou familiares que tenham passado por alguma destas situações?

10. Você já contraiu ou conhece alguém que tenha contraído alguma doença por contato com o lixo jogado nas ruas, encostas e valas ou causada por animais ou insetos relacionados com o lixo, como moscas, mosquitos, baratas ou ratos? Em caso afirmativo, fale um pouco sobre isso.

11. Quando se acumula lixo em casa, quando se formam amontoados de lixo na rua, quando se contaminam as fontes de água com lixo, de quem é a culpa, da pessoa da casa, do vizinho, da COMLURB que presta o serviço de limpeza urbana, do governo, de quem? Em quem se coloca a culpa com mais frequência na Rocinha, pelo problema do lixo?

12. Qual a opinião dos moradores da Rocinha sobre os serviços ofertados pela COMLURB?

13. Conhece alguma instituição ou alguma organização dedicada a coleta de resíduos recicláveis, aqui na favela da Rocinha? Por exemplo, projetos, cooperativas, ONG. Qual ou quais?

14. Já participou de eventos e/ou cursos de capacitação sobre educação 
ambiental, sobre o cuidado com a natureza e o meio ambiente, onde tenham falado de lixo, aqui na Rocinha?

15. Você acha que as capacitações ajudam as pessoas a melhorarem seu comportamento, por exemplo, a colocar o lixo no local adequado, a não jogálo na rua, a animar os vizinhos a serem cuidadosos com a limpeza da Rocinha?

16. Em sua opinião, a problemática da violência local interfere na qualidade do serviço prestado pela COMLURB? Se positivo, de que forma e o que poderia ser feito nesses casos?

17. Em sua opinião, além dos serviços já prestados pela COMLURB, quais outros poderiam ser prestados para a limpeza do seu sub-bairro? 
7.2.

Apêndice 2 - Guia de conversación con pobladores de Siloé

PONTIFICIA UNIVERSIDADE CATÓLICA DO RIO DE JANEIRO

Doctorado en Servicio Social

PONTIFICIA UNIVERSIDAD JAVERIANA CALI

Grupo de Investigación en Procesos y Medios de Comunicación

Tesis Doctoral en Servicio Social

a cargo de la doctoranda Maria Izabel de Carvalho

\section{GUIA DE CONVERSACIÓN CON POBLADORES}

\begin{tabular}{|c|c|c|c|}
\hline $\begin{array}{c}\text { Fecha de } \\
\text { entrevista }\end{array}$ & día & mes & año \\
\cline { 2 - 4 } & & & \\
\hline
\end{tabular}
a) Persona entrevistada (nombres y apellidos):
b) Edad:
c) Género:
d) Lugar de nacimiento:
e) Ocupación:
f) Cuántos años reside en la Comuna 20:
g) Barrio en que reside:
h) Lugar de la entrevista: 
1. ¿Cómo habitante de un barrio de la Comuna 20 de Cali, conoce usted cuál es el decir, la opinión, de los caleños de otros barrios de estratos más altos (El Lido, Cristales) sobre el lugar donde usted reside?

2. Como habitante de la Comuna 20 , qué opina de los servicios de educación, salud, recreación y limpieza urbana que se ofrecen en esta Comuna?

3. ¿Qué piensa sobre la cuestión de las basuras en la Comuna 20? En su barrio?

4. ¿Qué hacen los vecinos con sus basuras todas las semanas? ¿Las sacan cuando va a pasar Ciudad Limpia? ¿Las sacan a destiempo? ¿Unos sí son ordenados, otros no? ¿Es fácil o difícil para sus vecinos sacar las basuras adecuadamente? ¿Usted qué hace o dónde bota la basura? (¿para qué no se cause un problema después con ella?)

5. ¿Qué hacen las personas que tienen impedimentos físicos, y que viven lejos de la ruta de recolección, para sacar la basura hasta los puntos indicados por Ciudad Limpia?

6. ¿En su casa, ¿quién tiene la tarea de recoger y sacar la basura? ¿Por qué es esa persona, precisamente?

7. ¿Cuántas veces a la semana usted saca la basura de su casa?

8. ¿Dónde hay más y dónde hay menos basura botada en la calle, en la loma o en la parte baja? ¿Por qué eso ocurre?

9. ¿Alguna vez se ha sentido perjudicado a causa de un problema en el medio ambiente, ocasionados por la basura tirada en lugares no adecuados? ¿O ha conocido personas o familias que hayan sido perjudicadas seriamente por la acumulación de basuras en esos lugares?

10. ¿ Ha contraído o conoce a alguien que haya contraído alguna enfermedad por contacto con las basuras tiradas en calles, caños, ríos o quebradas o debida a animales relacionados con las basuras, como moscas, zancudos, cucarachas o ratas? En caso afirmativo, hable un poco sobre eso.

11. Cuando se amontona la basura en la casa, cuando se forman basureros en la calle, cuando se contaminan las cascadas de agua con basura, ¿de quién es la culpa? ¿De la persona de la casa, del vecino, de Ciudad Limpia que presta el servicio de limpieza urbana, del gobierno, de quién? ¿A quién se le echa la culpa con más frecuencia en el barrio por el problema de basuras?

12. ¿Qué opinan los habitantes del barrio sobre la empresa de aseo Ciudad Limpia?

13. ¿Conoce alguna institución o alguna organización dedicada a la recolección de basura reciclable aquí en el barrio o en la Comuna 20? Por ejemplo, 
proyectos, cooperativas, ONG, pequeñas empresas particulares. ¿Cuál o cuáles?

14. ¿Ha ido alguna vez o ha oído de capacitaciones sobre educación ambiental, sobre el cuidado de la naturaleza y el medio ambiente, donde hayan hablado de las basuras, aquí en el barrio o en la Comuna?

15. ¿Usted cree que las capacitaciones ayudan a las personas a mejorar su comportamiento, por ejemplo, a sacar la basura a tiempo, a no botarla en la calle, a animar a los vecinos a ser aseados con el barrio?

16. En su opinión, la problemática de la violencia en los barrios de la Comuna impide que se preste un buen servicio de aseo en esos sectores o barrios? ¿De qué formas lo impiden? ¿Cómo podría hacerse en esos casos?

17. En su opinión, además de los servicios ya prestados por Ciudad Limpia, ¿qué otros servicios podrían prestar para la limpieza de su barrio, de la Comuna? 


\title{
7.3.
}

Apêndice 3 - Formulário: empresa de limpeza urbana - Rocinha

\author{
PONTIFICIA UNIERSIDADE CATÓLICA DO RIO DE JANEIRO \\ Doutorado em Serviço Social \\ PONTIFICIA UNIVERSIDAD JAVERIANA CALI \\ Grupo de Investigação em Processos e Meios de Comunicação
}

$\underline{T e s e}$ de Doutorado em Servico Social a cargo da doutoranda Maria Izabel

de Carvalho

\section{FORMULÁRIO: EMPRESA DE LIMPEZA URBANA}

\begin{tabular}{|c|c|c|c|}
\hline $\begin{array}{c}\text { Data da } \\
\text { entrevista }\end{array}$ & dia & mês & ano \\
\cline { 2 - 4 } & & & \\
\hline
\end{tabular}
a) Nome da empresa:
b) Pessoa entrevistada:
c) Cargo ou função:
d) Há quanto tempo trabalha para a empresa: No cargo:
e) Cidade:
f) Área urbana de referência para este estudo, onde presta serviços de limpeza (denominação político administrativa e extensão em quilômetros Área: quadrados):
g) Lugar da entrevista: 
1. Tipo de serviço de limpeza urbana executado (coleta porta a porta, em pontos fixos de coleta estipulados pela empresa, varrição, etc.), localidades atendidas e equipes que trabalham na área de referência.

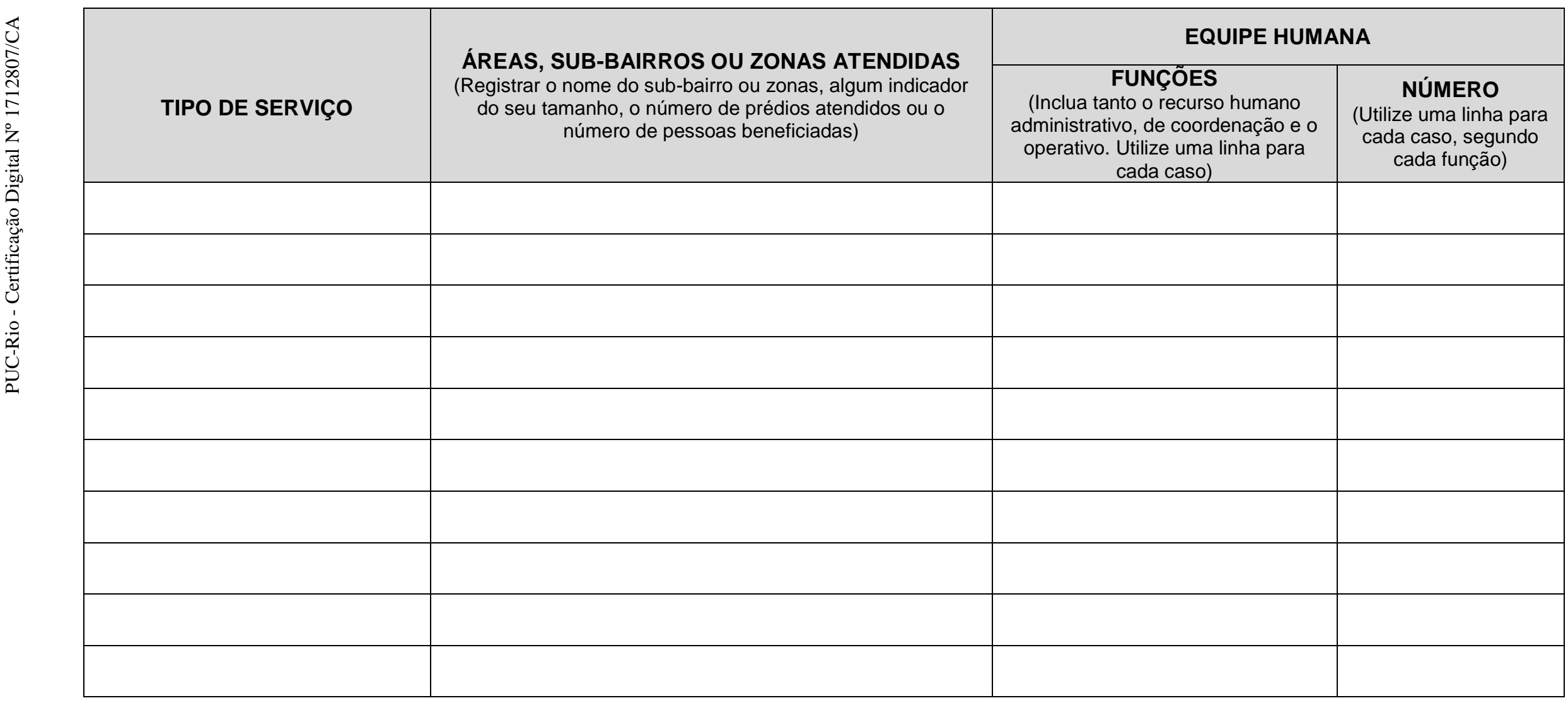

2. Existem áreas de difícil acesso onde as equipes e os veículos não conseguem chegar para prestar os serviços de coleta e varrição? Se positivo, a empresa tem estratégias para fazer a coleta porta a porta e a varrição em tais setores ou pensa implementar alguma nova estratégia para essas áreas? Em caso de implementar novas estratégias, quais? 
3. Caracterização dos serviços de coleta de resíduos sólidos e varrição de ruas.

\begin{tabular}{|c|c|c|c|c|}
\hline \multicolumn{5}{|c|}{ COLETA } \\
\hline $\begin{array}{l}\text { ÁREA, SUB-BAIRRO OU ZONA } \\
\text { ATENDIDA }\end{array}$ & FREQUÊNCIA & $\begin{array}{c}N^{N} \text { DE } \\
\text { VIAGENS }\end{array}$ & $\begin{array}{l}\text { VOLUME COLETADO } \\
\text { (Indicar volume diário } \\
\text { aproximadan a unidade de } \\
\text { medida de peso adotada a } \\
\text { empresa) }\end{array}$ & $\begin{array}{l}\text { EQUIPAMENTO } \\
\text { UTILIZADO }\end{array}$ \\
\hline & & & & \\
\hline & & & & \\
\hline & & & & \\
\hline & & & & \\
\hline & & & & \\
\hline & & & & \\
\hline & & & & \\
\hline & & & & \\
\hline & & & & \\
\hline
\end{tabular}




\begin{tabular}{|c|c|c|c|}
\hline \multicolumn{4}{|c|}{ VARRIÇÃO } \\
\hline $\begin{array}{l}\text { ÁREA, SUB-BAIRRO OU ZONA } \\
\text { ATENDIDA }\end{array}$ & FREQUÊNCIA & $\begin{array}{l}\text { VOLUME DE RESIDUOS } \\
\text { SOLIIDSOS DA VRRICGAO } \\
\text { (Indicar volume diário aproximado na } \\
\text { unididade de medida de peso adotada } \\
\text { pela empresa) }\end{array}$ & EQUIPAMENTO UTILIZADO \\
\hline & & & \\
\hline 晋 & & & \\
\hline 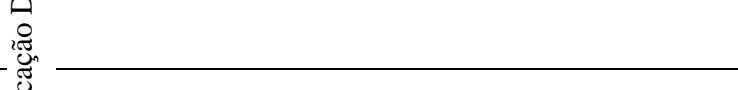 & & & \\
\hline & & & \\
\hline 㝘 & & & \\
\hline こ & & & \\
\hline & & & \\
\hline & & & \\
\hline & & & \\
\hline & & & \\
\hline
\end{tabular}


4. Como se dá o manejo dos resíduos sólidos de grande porte (eletrodomésticos, escombros de obras, etc.)?

5. Comente sobre a geração, destinação e os tipos de resíduos sólidos gerados pelos estabelecimentos comerciais.

6. Comente sobre a geração, destinação e os tipos de resíduos sólidos gerados pelos vendedores ambulantes.

7. Qual a relação existente entre o manejo de resíduos sólidos pela população e pela empresa, e a temporada de chuvas?

8. Qual é a situação do manejo de resíduos sólidos pela população e pela empresa, no que diz respeito aos depósitos naturais de água, as valas e as encostas existentes na área?

9. A geração de resíduos sólidos pela população e pelas atividades econômicas nesta área tem temporadas em que aumenta ou diminui? Se positivo, quais são esses períodos e como se explica cada um?

10. Tipos de resíduos sólidos coletados pela empresa na área da pesquisa:

\begin{tabular}{|c|c|c|}
\hline TIPO & $\begin{array}{c}\text { ÁREA, SUB-BARRIO, ZONA OU INSTITUÇÃO } \\
\text { QUE GERA MAIOR VOLUME DE CADA TIPO } \\
\text { DE RESIDUO }\end{array}$ & $\begin{array}{c}\text { VOLUMES } \\
\text { APROXIMADOS }\end{array}$ \\
\hline \multicolumn{3}{|l|}{ Residencial } \\
\hline \multicolumn{3}{|l|}{ romercial } \\
\hline \multicolumn{3}{|l|}{ dustrial } \\
\hline \multicolumn{3}{|l|}{ stituições de Saúde } \\
\hline \multicolumn{3}{|l|}{ sి stituições Educativas } \\
\hline \multicolumn{3}{|l|}{ I scombros } \\
\hline \multicolumn{3}{|l|}{ e varrição } \\
\hline$\frac{2}{\sigma}$ ?riados & & \\
\hline utros & & \\
\hline
\end{tabular}

11. A empresa dispõe de dados sobre a composição dos resíduos sólidos coletados?

( ) Sim ( ) Não

Em caso afirmativo, indique a medida percentual aproximada de cada item:

\begin{tabular}{|l|l|}
\hline \multicolumn{1}{|c|}{ Item } & $\%$ \\
\hline Resíduos orgânicos & \\
\hline Metal & \\
\hline Papel & \\
\hline Vidro & \\
\hline Plásticos & \\
\hline Escombros & \\
\hline Outros & \\
\hline
\end{tabular}

12. Qual o destino dos resíduos sólidos coletados, para onde são levados?

13. Os resíduos sólidos coletados recebem algum tipo de tratamento? Se positivo, qual(is)?

14. Os serviços da empresa são monitorados ou fiscalizados por algum organismo de controle público? Qual ou quais são estes organismos e como 
se dá esse processo?

15. Os usuários dos serviços contam com algum canal de comunicação com a empresa, para realizar solicitações, reclamações, etc.? Se positivo, como funciona?

16. A empresa realiza campanhas educativas sobre o processo de geração, destinação adequada e tratamento dos resíduos sólidos? Se positivo, qual a vertente da educação ambiental que segue, quais são os públicos, os conteúdos, a frequência, as estratégias pedagógicas e os meios utilizados? Há indicadores para avaliar a efetividade do trabalho educativo?

17. A estratégia pedagógica e os materiais educativos são pensados e desenhados a partir da realidade local, possivelmente com a participação dos residentes ou vêm pré-desenhados e se aplicam como tal?

18. Qual é a percepção da empresa em relação aos usuários dos serviços, no que concerne à geração e destinação dos resíduos sólidos?

19. A empresa possui uma metodologia para avaliar a qualidade da sua relação com os usuários? Existe uma equipe dedicada a este trabalho?

20. Em um território controlado pelo poder paralelo, quais são as reais implicações para a prestação do serviço de limpeza urbana?

21. A empresa conta com indicadores que permitam avaliar de forma quantitativa ou qualitativa a eficiência dos serviços de limpeza urbana que presta? Se positivo, quais são?

22. A empresa reconhece e se articula com catadores ou com organização de catadores na Rocinha? Se positivo, como se dá essa articulação? Em caso de articulação com organizações de catadores, com quais?

23. A empresa tem conhecimento do perfil e da quantidade de catadores que trabalham na Rocinha?

Sua colaboração foi muito importante. Obrigada! 
7.4.

Apêndice 4 - Guia de indagación sobre la empresa de limpieza urbana-Siloé

\author{
PONTIFICIA UNIERSIDADE CATÓLICA DO RIO DE JANEIRO \\ Doctorado en Servicio Social \\ PONTIFICIA UNIVERSIDAD JAVERIANA CALI \\ Grupo de Investigación en Procesos y Medios de Comunicación
}

Tesis Doctoral en Servicio Social a cargo de la doctoranda Maria Izabel de

Carvalho

\title{
GUIA DE INDAGACIÓN SOBRE LA EMPRESA DE LIMPIEZA URBANA
}

\begin{tabular}{|c|c|c|c|}
\hline $\begin{array}{l}\text { Fecha de } \\
\text { entrevista }\end{array}$ & día & mes & año \\
\cline { 2 - 4 } & & & \\
\hline
\end{tabular}

a. Nombre de la empresa:

b. Persona entrevistada (nombres y apellidos):

C. Cargo o función:

d. Antigüedad (años). En la empresa: En el cargo:

e. Ciudad:

f. Área urbana de referencia para este estudio, donde presta servicios de limpieza (denominación político administrativa y extensión en kilómetros cuadrados): Área:

g. Lugar de la entrevista: 
1. Tipo de servicio de limpieza urbana ejecutado (recolección puerta a puerta, en puntos fijos de recolección estipulados por la empresa, barrido, etc.), localidades atendidas y equipo que suele trabajar en el área de referencia.

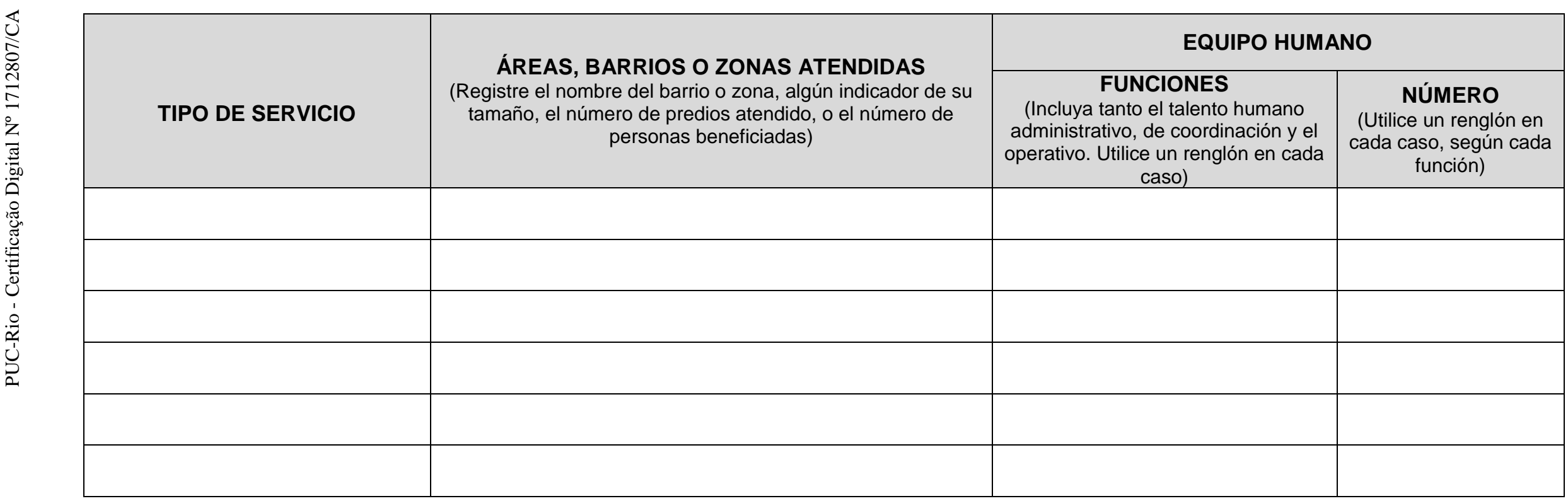

2. ¿Existen áreas de difícil acceso donde los equipos humanos y los vehículos no logran llegar para prestar alguno de los servicios de recolección o barrido? ¿Si es así, la empresa tiene estrategias para hacer recolección puerta a puerta y barrido en estos sectores o piensa implementar alguna nueva estrategia en estas áreas? En caso de implementar nuevas estrategias, ¿cuáles serían? 
3. Caracterización de los servicios de recolección de residuos sólidos y barrido de calles.

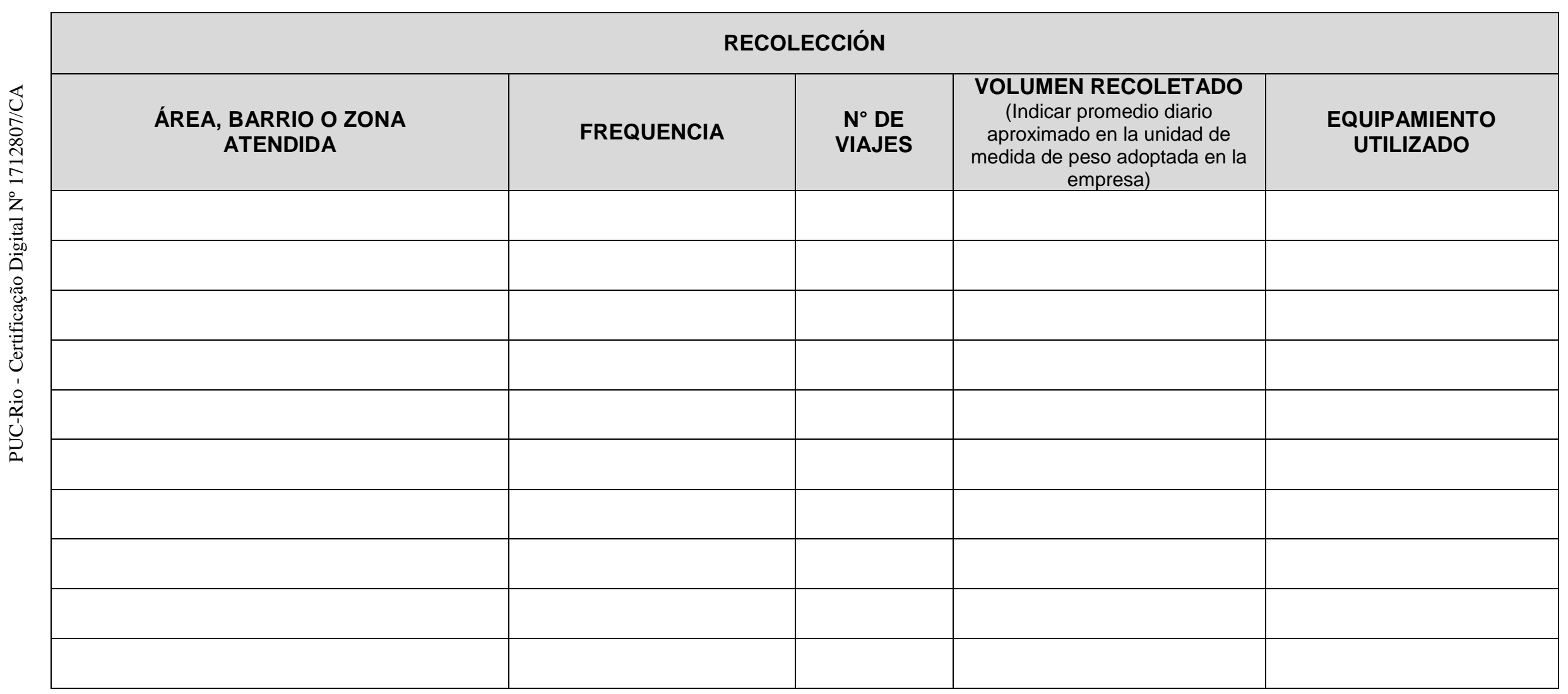




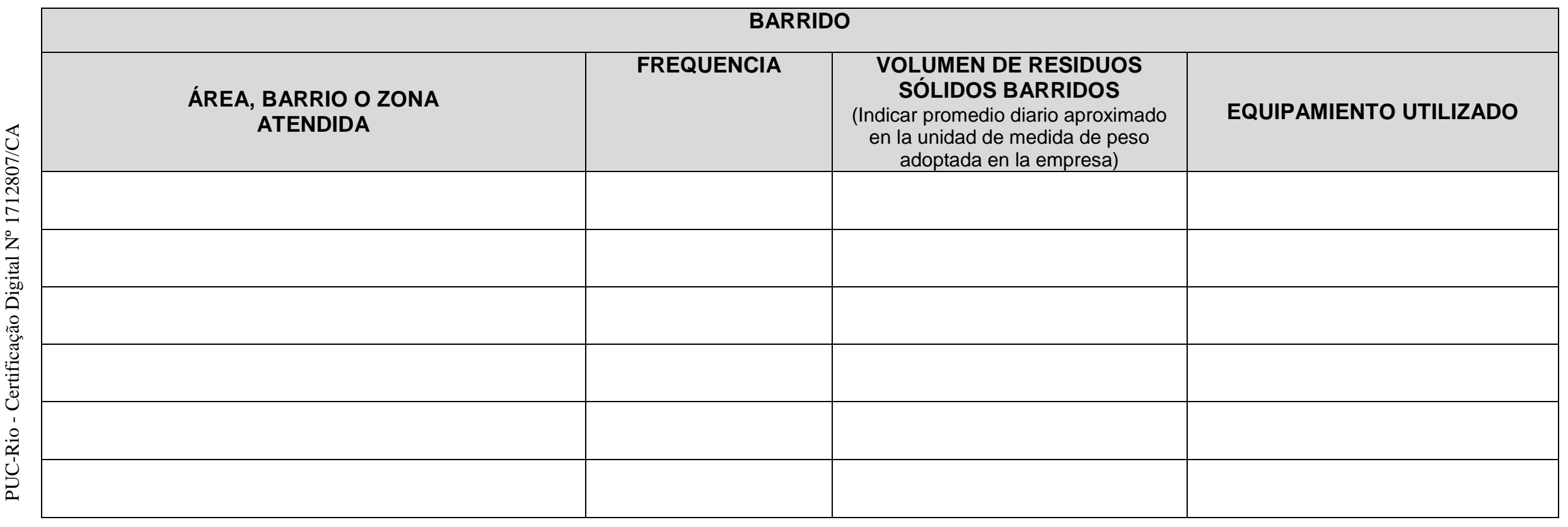


4. ¿Cómo se manejan los residuos sólidos de gran tamaño (electrodomésticos y escombros de obras, etc.)?

5. ¿Cómo es la generación, destinación y tipos de residuos sólidos en los negocios y locales comerciales?

6. ¿Cómo es la generación, destinación y tipos de residuos sólidos por los vendedores ambulantes?

7. ¿Qué relación existe entre el manejo de residuos sólidos por la población y por la empresa, y la temporada de lluvias?

8. ¿Cuál es la situación del manejo de residuos sólidos por la población y por la empresa en cuanto a los depósitos naturales de agua, las corrientes naturales existentes en el área?

9. ¿La generación de residuos sólidos por la población y por las actividades económicas en el área tiene temporadas en que aumenta o disminuye? Si esto es cierto, ¿cuáles son esos periodos y cómo se explica cada uno?

10. Tipos de residuos sólidos recolectados por la empresa en el área de investigación:

\begin{tabular}{|c|c|c|}
\hline TIPO & $\begin{array}{c}\text { ÁREA, BARRIO, ZONA O } \\
\text { INSTITUCIÓN QUE GENERA } \\
\text { MAYOR VOLUMEN DE CADA TIPO } \\
\text { DE RESIDUO }\end{array}$ & $\begin{array}{l}\text { VOLUMENES } \\
\text { APROXIMADOS }\end{array}$ \\
\hline Residencial & & \\
\hline Comercial & & \\
\hline Industrial & & \\
\hline $\begin{array}{l}\text { Instituciones de } \\
\text { Salud }\end{array}$ & & \\
\hline $\begin{array}{l}\text { Instituciones } \\
\text { Educativas }\end{array}$ & & \\
\hline Escombros & & \\
\hline De barrido & & \\
\hline Días festivos & & \\
\hline Otros & & \\
\hline
\end{tabular}

11. ¿La empresa dispone de datos sobre la composición de los residuos sólidos recolectados?

( ) $\mathrm{Si} \quad$ ( ) No

En caso afirmativo, indique la medida porcentual aproximada de cada ítem:

\begin{tabular}{|l|l|}
\hline \multicolumn{1}{|c|}{ Ítem } & $\%$ \\
\hline Residuos orgánicos & \\
\hline Metal & \\
\hline Papel & \\
\hline Vidrio & \\
\hline Plásticos & \\
\hline Escombros & \\
\hline Otros & \\
\hline
\end{tabular}

12. ¿Cuál es el destino de los residuos sólidos recolectados, adónde son llevados?

13. ¿Los residuos recolectados reciben algún tipo de tratamiento? ¿Cuál(es)? 
14. ¿Los servicios prestados por la empresa son monitoreados o fiscalizados por algún organismo de control público? ¿Cuál o cuáles son estos organismos y cómo se da dicho proceso?

15. ¿Los usuarios del servicio tienen canales de comunicación con la empresa para realizar solicitudes, quejas, etc.? Si es así, ¿cómo funciona?

16. ¿La empresa realiza campañas educativas sobre el proceso de generación, destinación adecuada y tratamiento de residuos sólidos? ¿Si es afirmativo, ¿cuál es la tendencia sobre educación ambiental que se sigue, cuáles son los públicos, los contenidos, las frecuencias y las estrategias pedagógicas y los medios utilizados? ¿Se tienen indicadores para evaluar la efectividad de la labor educativa?

17. ¿La estrategia pedagógica y los materiales educativos son pensados y diseñados a partir de la realidad local, posiblemente con participación de los residentes, o vienen prediseñados y se aplican tal cual?

18. ¿Cuál es la percepción que tiene la empresa sobre los usuarios de los servicios, en lo concerniente a la generación y destinación de los residuos sólidos?

19. ¿La empresa posee una metodología para evaluar la calidad de su relación con los usuarios? ¿Existe un equipo dedicado a esa labor?

20. En un territorio controlado por un poder paralelo, ¿cuáles son las reales implicaciones para la prestación del servicio de limpieza urbana?

21. ¿La empresa cuenta con indicadores de permitan evaluar de forma cuantitativa o cualitativa la eficiencia de los servicios de limpieza urbana que presta? ¿Cuáles son?

22. ¿La empresa reconoce y se articula con recicladores o con organizaciones de recicladores en la Comuna 20? ¿En caso afirmativo, en qué consiste esa articulación? En caso de que se trate de articulación con organizaciones de recicladores, ¿cuáles son dichas organizaciones?

23. ¿La empresa tiene conocimiento del perfil y cantidad de recicladores que trabajan en el área de la Comuna 20?

24. ¿Cómo se realiza el cobro de los servicios de limpieza urbana en la Comuna 20, y cómo se controla el cumplimiento de los pagos por la población?

25. ¿Es posible conocer los montos recolectados por el cobro de los servicios prestados por la población de la Comuna 20, y el nivel de no pago que se da en el área?

Su colaboración ha sido muy importante. ¡Muchas gracias! 


\title{
7.5.
}

Apêndice 5 - Roteiro: organização de catadores - Rocinha

\author{
PONTIFICIA UNIERSIDADE CATÓLICA DO RIO DE JANEIRO \\ Doutorado em Serviço Social \\ PONTIFICIA UNIVERSIDAD JAVERIANA CALI \\ Grupo de Investigação em Processos e Meios de Comunicação
}

Tese de Doutorado em Servico Social a cargo da doutoranda Maria Izabel

de Carvalho

\section{ROTEIRO: ORGANIZACÃO DE CATADORES DA ROCINHA}

\begin{tabular}{|c|c|c|c|}
\hline $\begin{array}{c}\text { Data da } \\
\text { entrevista }\end{array}$ & dia & mês & ano \\
\cline { 2 - 4 } & & & \\
\hline
\end{tabular}
a) Nome:
b) Tipo de organização (associação, cooperativa):
c) Cargo/função:
d) Tempo de trabalho na organização:
No cargo:
e) Já trabalhou em outro cargo/função na organização:
Qual:
f) Idade:
g) Gênero:
h) Escolaridade:
i) Renda mensal:
j) Horas diárias trabalhadas:
k) Lugar de nascimento:
I) Lugar de residência (bairro e/ou sub-bairro):
m) Lugar da entrevista: 
1. Informações sobre o quadro de catadores-sócios e demais integrantes da organização, local de trabalho e o número de pessoas em cada processo de trabalho:

\begin{tabular}{|c|c|c|}
\hline PROCESSO DE TRABALHO & $\begin{array}{l}\text { LOCAL DE TRABALHO } \\
\text { (Indicar onde estão alocados os trabalhadores em } \\
\text { cada processo de trabalho) }\end{array}$ & $\begin{array}{l}\text { NÚMERO } \\
\text { (indicar o total } \\
\text { de pessoas em } \\
\text { cada processo } \\
\text { de trabalho) }\end{array}$ \\
\hline $\begin{array}{l}\text { Coleta na rua (indicar o nome dos } \\
\text { locais onde a catação é realizada) }\end{array}$ & & \\
\hline Trabalho interno de seleção de material & & \\
\hline Prensagem & & \\
\hline Comercialização & & \\
\hline $\begin{array}{l}\text { Contato com instituições para captação } \\
\text { de materiais recicláveis e/ou outros } \\
\text { recursos }\end{array}$ & & \\
\hline A inistrativo & & \\
\hline 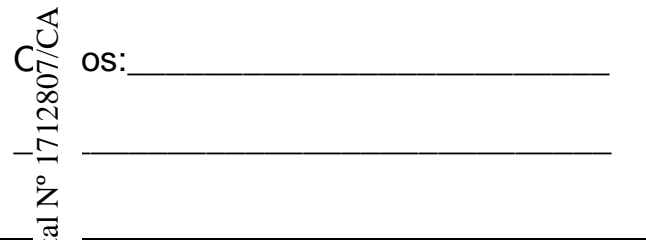 & & \\
\hline
\end{tabular}

2. Dos(as) catadores(as) que trabalham na organização, qual a quantidade de homens e de mulheres?

3. Como é feita a remuneração dos catadores e qual a renda média mensal de cada catador(a)?

4. Os catadores recebem equipamentos de proteção individual (boné, luva, botas, máscara, etc.)? Se positivo, quais e a cada quanto tempo?

5. Em caso de acidentes, quais são as providências tomadas pela organização, em amparo aos catadores(as)?

6. Quais bens materiais a organização possui (sede própria, carrinhos para a catação, caminhões para o transporte do material, computador, internet, EPI's, etc.)?

7. Com quais tipos de materiais recicláveis a organização trabalha e qual o volume total que a organização maneja mensalmente?

Indique a quantidade aproximada de cada item:

\begin{tabular}{|l|l|}
\hline \multicolumn{1}{|c|}{ Item } & $\begin{array}{c}\text { Volume } \\
\text { (unidade de } \\
\text { medida: } \mathrm{Kg} \text { ) }\end{array}$ \\
\hline Metal & \\
\hline Papel & \\
\hline Plástico & \\
\hline Vidro & \\
\hline Outros: & \\
\hline
\end{tabular}


8. Para quem é vendido o material reciclável adquirido pela organização?

9. Existe algum tipo de capacitação voltada para os catadores? Se positivo, qual(is), como é desenvolvida e qual o tipo de conteúdo aplicado?

10. Quais os principais problemas enfrentados pela organização e quais as possíveis soluções para tal?

11. De uma forma geral, como você avalia a problemática (geração, destinação e tratamento) dos resíduos sólidos nesta localidade e quais as possíveis soluções? 
7.6.

Apêndice 6 - Guia de conversación con organización de recicladores - Siloé

\author{
PONTIFICIA UNIVERSIDADE CATÓLICA DO RIO DE JANEIRO \\ Doctorado en Servicio Social \\ PONTIFICIA UNIVERSIDAD JAVERIANA CALI \\ Grupo de Investigación en Procesos y Medios de Comunicación
}

Tesis Doctoral en Servicio Social a cargo de la doctoranda Maria Izabel de

Carvalho

GUIA DE CONVERSACIÓN CON ORGANIZACIÓN DE RECICLADORES EN

LA COMUNA 20

\begin{tabular}{|c|c|c|c|}
\hline $\begin{array}{l}\text { Fecha de } \\
\text { entrevista }\end{array}$ & día & mes & año \\
\cline { 2 - 4 } & & & \\
\hline
\end{tabular}

a. Nombre de persona entrevistada:

b. Edad:

c. Género:

d. Lugar de nacimiento:

e. Lugar de residência (bairro o sector):

f. Estudios (nivel máximo de estudio alcanzado):

g. Tipo de organización (cooperativa, asociación, pequeña empresa):

h. Cargo o función:

i. Tiempo que lleva en la organización: Tiempo que lleva en el cargo o función:

j. ¿Ha tenido otro cargo o función en la organización? ¿Cuál(es)?

k. Ingreso mensual aproximado:

I. Horas diarias trabajadas

m. Lugar da la entrevista: 
1. Información sobre el grupo de recicladores miembros y demás personas que integran la organización, lugares donde trabajan y cantidad de personas en cada parte del proceso de recuperación:

\begin{tabular}{|c|c|c|}
\hline PROCESO DE TRABAJO & $\begin{array}{c}\text { LUGAR DE TRABAJO } \\
\text { (Indicar donde están localizados los trabajadores en } \\
\text { cada parte del proceso de trabajo) }\end{array}$ & $\begin{array}{l}\text { NÚMERO } \\
\text { (indicar el } \\
\text { número total de } \\
\text { personas en } \\
\text { cada parte del } \\
\text { proceso de } \\
\text { trabajo) }\end{array}$ \\
\hline $\begin{array}{l}\text { Recolección en la calle (indicar el nombre de } \\
\text { los barrios o sectores donde se realiza la } \\
\text { recolección) }\end{array}$ & & \\
\hline Trabajo interno de selección de material & & \\
\hline Prensado & & \\
\hline Come alización & & \\
\hline 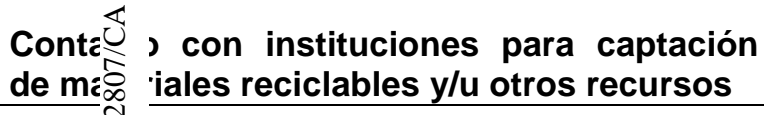 & & \\
\hline Admi & & \\
\hline 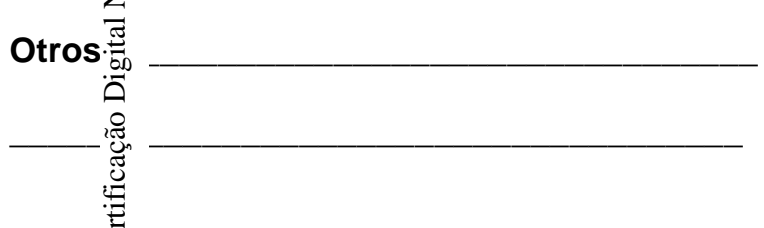 & & \\
\hline
\end{tabular}

2. ¿Cuántos hombres y cuántas mujeres trabajan en la labor de recuperación en esta organización?

3. ¿Cómo se paga a los recicladores y recicladoras, y cuál es el ingreso mensual promedio de cada uno de ellos y de ellas? ¿Hay diferencias entre hombres y mujeres?

4. ¿Los recicladores reciben equipos o dotación para su protección individual? (gorra, guantes, botas, máscaras, etc.) Si es así, ¿cuáles reciben y cada cuánto tiempo?

5. ¿En caso de accidentes cuáles son las reglas de la organización para la atención de los recicladores?

6. ¿Cuáles equipos posee la organización para su trabajo? (sede propia, carritos para recolección, camiones para transporte del material, computador, internet, equipo de protección en el trabajo - gorra, guantes, botas, máscara, etc.)?

7. ¿Con cuáles tipos de materiales reciclables trabaja la organización y cuál es el volumen total aproximado que se maneja mensualmente? 
Indique la cantidad mensual aproximada de cada tipo de material:

\begin{tabular}{|l|l|}
\hline \multicolumn{1}{|c|}{ Material } & $\begin{array}{c}\text { Volumen } \\
\text { (unidad de } \\
\text { medida: } \mathrm{Kg} \text { ) }\end{array}$ \\
\hline Metal & \\
\hline Papel & \\
\hline Plástico & \\
\hline Vidrio & \\
\hline Otros: & \\
\hline
\end{tabular}

8. ¿A quién se le vende el material reciclable recuperado por la organización?

9. ¿Existe algún tipo de capacitación dirigida a los recicladores? ¿Si es afirmativo, cuáles capacitaciones, en qué consisten las actividades y cuáles son los contenidos?

10. ¿Cuáles son los principales problemas enfrentados por la organización, y cuáles son las posibles soluciones para estos problemas?

11. En general, ¿qué opina usted, como evalúa la problemática de los residuos sólidos o basuras en este barrio y en la Comuna 20 (generación de basuras, donde se depositan, qué se hace con ellas finalmente), y cuáles podrían ser las soluciones? 
7.7.

Apêndice 7 - Roteiro: catadores da Rocinha

\author{
PONTIFICIA UNIERSIDADE CATÓLICA DO RIO DE JANEIRO \\ Doutorado em Serviço Social \\ PONTIFICIA UNIVERSIDAD JAVERIANA CALI \\ Grupo de Investigação em Processos e Meios de Comunicação
}

Tese de Doutorado em Servico Social a cargo da doutoranda Maria Izabel

de Carvalho

ROTEIRO: CATADORES DA ROCINHA

\begin{tabular}{|c|c|c|c|}
\hline $\begin{array}{c}\text { Data da } \\
\text { entrevista }\end{array}$ & dia & mês & ano \\
\cline { 2 - 4 } & & & \\
\hline
\end{tabular}
a) Nome:
b) Idade:
c)
Gênero:
d) Lugar de nascimento:
e) Lugar de residência (bairro e/ou sub-bairro):
f) Escolaridade:
g) Tempo de profissão:
h) Horas diárias trabalhadas
i) Trabalha quantos dias na semana:
j) Lugar da entrevista: 
1. Trabalha por conta própria ou está vinculado(a) a alguma organização? Se associação ou cooperativa, qual?

2. Quantos quilos de material reciclável você coleta por dia trabalhado?

3. Quais os principais tipos de materiais encontrados (metal, plástico, papel, vidro, etc.)? Entre estes, quais compensam mais, financeiramente falando, na hora de vender?

4. Como é feito o pagamento pelo material que você vende, na hora da venda ou mensalmente?

5. Quanto aproximadamente, você ganha por mês?

( ) Menos da metade de 1 salario mínimo ( $R \$ 522,50)$

( ) Até 1 salario mínimo $(\mathrm{R} \$ 1.045,00)$

( ) De 1 a 2 salários mínimos ( $\mathrm{R} \$ 1.045,00$ a $\mathrm{R} \$ 2.090,00)$

( ) De 2 a 3 salários mínimos ( $R \$ 2.090,00$ a $R \$ 3.135,00)$

( ) Mas de 3 salários mínimos ( $\mathrm{R} \$ 3.135,00)$

6. Você utiliza algum Equipamento de Proteção Individual (boné, luva, botas, máscara, etc.)? Se positivo, quais?

7. Já sofreu algum acidente de trabalho? Se positivo, qual(is)?

8. Já participou de alguma atividade voltada para a capacitação de catadores? Se positivo, qual(is)? E para o que lhe serviu essa atividade?

9. Como é realizado o trabalho de catação, quais os melhores horários e quais os melhores pontos para fazer a catação?

10. Você rasga sacos ou vê seus companheiros rasgando-os para verificar se ali tem material reciclável?

( ) Sim ( ) Não

Em caso afirmativo, nessa situação, o que deveria ser feito para facilitar o trabalho do catador?

11. Quais os principais problemas encontrados na profissão? Por que esses são os principais problemas e como poderiam ser resolvidos?

12. Em sua opinião, o que as demais pessoas pensam sobre o trabalho dos catadores? 
7.8.

Apêndice 8 - Guia de conversación con recicladores de Siloé

\author{
PONTIFICIA UNIVERSIDADE CATÓLICA DO RIO DE JANEIRO \\ Doctorado en Servicio Social \\ PONTIFICIA UNIVERSIDAD JAVERIANA CALI \\ Grupo de Investigación en Procesos y Medios de Comunicación
}

Tesis Doctoral en Servicio Social a cargo de la doctoranda Maria Izabel de

Carvalho

GUIA DE CONVERSACIÓN CON RECICLADORES EN LA COMUNA 20

\begin{tabular}{|c|c|c|c|}
\hline $\begin{array}{c}\text { Fecha de } \\
\text { entrevista }\end{array}$ & día & mes & año \\
\cline { 2 - 4 } & & & \\
\hline
\end{tabular}

a) Nombre:

b) Edad:

c) Género:

d) Lugar de nacimiento:

e) Lugar de residencia (barrio o sector):

f) Estudios (nivel máximo de estudio alcanzado):

g) Tempo en el oficio:

h) Horas diarias trabajadas

i) Cuántos días a la semana trabaja:

j) Lugar da la entrevista: 
1. ¿Trabaja por cuenta propia, o está vinculado(a) a alguna cooperativa, asociación o grupo? ¿A cuál cooperativa, asociación o grupo?

2. ¿Cuántos kilos de material reciclable que usted recoge en cada día de trabajo?

3. ¿Cuáles son los principales materiales encontrados (metal, plástico, papel, vidrio, cartón, etc.)? De todos esos materiales, ¿cuáles son los que se venden a mejor precio?

4. ¿Cómo le pagan por el material que usted vende, en el momento de la venta o se lo anotan y le pagan semanal o mensualmente?

5. ¿Cuánto se gana al mes (valor aproximado)?

( ) Menos de la mitad de 1 salario mínimo (414 mil 58 pesos)

( ) Hasta 1 salario mínimo (828 mil 116 pesos)

( ) De 1 a 2 salarios mínimos (828 mil 116 pesos hasta 1.656 mil 232 pesos)

( ) De 2 a 3 salarios mínimos (1.656 mil 232 pesos hasta 2.484 mil 348 pesos)

( ) Mas de 3 salarios mínimos (2.484 mil 348 pesos)

6. ¿Utiliza algún equipo de protección en el trabajo (gorra, guantes, botas, máscara, etc.)? ¿Cuál o cuáles?

7. ¿Ha tenido algún accidente de trabajo? ¿Cuál?

8. ¿Ha participado o participa de alguna actividad de capacitación para recicladores? ¿En cuál o cuáles? ¿Para qué le han servido esa o esas capacitaciones?

9. ¿Cómo tiene organizado su trabajo de reciclaje o recuperación, cuáles son los mejores días, las mejores rutas, los mejores horarios, los mejores sitios o barrios para recoger el reciclaje?

10. ¿Usted tiene que romper las bolsas de basura para darse cuenta si tienen material reciclable?

( ) Sí ( ) No

Si es así, ¿qué debería hacerse para facilitar esa parte de su trabajo, y no tener que romper las bolsas?

11. ¿Cuáles son los principales problemas de su oficio? ¿Por qué son los problemas más grandes? ¿Y cómo se podrían resolver?

12. ¿En su opinión, cómo ven las demás personas el trabajo de los recicladores? 
7.9.

Apêndice 9 - Roteiro: estabelecimentos comerciais - Rocinha

\author{
PONTIFICIA UNIERSIDADE CATÓLICA DO RIO DE JANEIRO \\ Doutorado em Serviço Social \\ PONTIFICIA UNIVERSIDAD JAVERIANA CALI \\ Grupo de Investigação em Processos e Meios de Comunicação
}

Tese de Doutorado em Servico Social a cargo da doutoranda Maria Izabel

de Carvalho

\title{
ROTEIRO: ESTABELECIMENTOS COMERCIAIS
}

\begin{tabular}{|l|l|l|l|}
\hline $\begin{array}{l}\text { Data da } \\
\text { entrevista }\end{array}$ & dia & mês & ano \\
\cline { 2 - 4 } & & & \\
\hline
\end{tabular}
a) Nome:
b) Cargo/função:
c) Tipo de estabelecimento comercial:
d) Nome do estabelecimento:
e) Localização do estabelecimento:
f) Há quanto tempo o estabelecimento existe nesta localidade:
g) Lugar da entrevista: 
1. Indique os tipos de resíduos sólidos gerados no estabelecimento e o volume diário aproximado de cada um?

\begin{tabular}{|c|c|}
\hline $\begin{array}{c}\text { Tipo } \\
\text { (Papel, plástico, vidro, metal, etc.) }\end{array}$ & $\begin{array}{c}\text { Volume } \\
\text { (unidade de medida:Kg) }\end{array}$ \\
\hline & \\
\hline & \\
\hline & \\
\hline & \\
\hline & \\
\hline & \\
\hline
\end{tabular}

1.1 Caso não tenha a informação sobre a quantidade de cada tipo de resíduos sólidos gerados, informar o volume total aproximado:

2. Que destino é dado aos resíduos sólidos gerados no estabelecimento (é coletado pela empresa de limpeza urbana, contrata uma empresa particular, etc.)?

3. O estabelecimento executa algum projeto/ação visando à redução da geração de resíduos sólidos? Se positivo, qual e como funciona?

4. Existe parceria com alguma organização de catadores (associação, cooperativa) de material reciclável ou com catadores individuais, para doação do material reciclável pelo estabelecimento, para estes grupos? Se positivo, como se dá essa parceria? Em caso de parceria com organizações, com qual(is)?

5. Existe algum projeto de responsabilidade compartilhada entre o estabelecimento e o consumidor, ou seja, existe no estabelecimento, algum espaço destinado ao cliente para que o mesmo devolva, após o uso, os resíduos remanescentes (materiais recicláveis), dos produtos comprados no estabelecimento? Se positivo, como isso se dá e para onde é destinado esse material, após o recebimento?

6. De uma forma geral, como você avalia a problemática (geração, destinação e tratamento) dos resíduos sólidos nesta localidade e quais as possíveis soluções? 
7.10.

Apêndice 10 - Guia de conversación con el establecimiento comercial - Siloé

\author{
PONTIFICIA UNIVERSIDADE CATÓLICA DO RIO DE JANEIRO \\ Doctorado en Servicio Social \\ PONTIFICIA UNIVERSIDAD JAVERIANA CALI \\ Grupo de Investigación en Procesos y Medios de Comunicación
}

Tesis Doctoral en Servicio Social a cargo de la doctoranda Maria Izabel de

Carvalho

\title{
GUIA DE CONVERSACIÓN CON EL ESTABLECIMIENTO COMERCIAL
}

\begin{tabular}{|c|c|c|c|}
\hline $\begin{array}{l}\text { Fecha de } \\
\text { entrevista }\end{array}$ & día & mes & año \\
\cline { 2 - 4 } & & & \\
\hline
\end{tabular}

a. Nombre de la persona entrevistada

b. Cargo o función:

c. Tipo de establecimiento comercial:

d. Nombre del establecimiento comercial:

e. Localización del establecimiento:

f. Años de existencia del establecimiento en la Comuna 20:

g. Lugar de la entrevista: 
1. Indique los tipos de residuos sólidos generados por el establecimiento y el volumen diario aproximado de cada uno.

\begin{tabular}{|c|c|}
\hline $\begin{array}{c}\text { Tipo } \\
\text { (Papel, plástico, vidrio, metal, etc.) }\end{array}$ & $\begin{array}{c}\text { Volumen } \\
\text { (unidad de medida: } \mathrm{Kg} \text { ) }\end{array}$ \\
\hline & \\
\hline & \\
\hline & \\
\hline & \\
\hline & \\
\hline
\end{tabular}

1.1 En caso de no tener información sobre la cantidad de cada tipo de residuos generados, haga una aproximación del volumen total de residuos generado diariamente.

2. ¿Qué destino se le da a los residuos sólidos generados en el establecimiento (lo recoge la empresa de limpieza urbana, contrata a una empresa o persona particular, etc.)?

3. ¿El establecimiento ejecuta algún tipo de actividad para disminuir la cantidad de residuos sólidos que genera? De ser así, ¿cuál es y cómo funciona?

4. ¿Existe alianza 0 acuerdo con alguna organización de recicladores o recicladores (asociación, cooperativa, pequeña empresa) o con recicladores individuales, a quienes se les dona o regala el material reciclable que genera el establecimiento? ¿Si es así, como se da esa relación? ¿Y cuáles son esas organizaciones o esas personas?

5. ¿Existe alguna iniciativa o acuerdo entre el establecimiento comercial y sus clientes en cuanto a materiales reciclables, por ejemplo, que los clientes traigan esos materiales reciclables (empaques, bolsas, envases, frascos, pilas, etc.) que fueron comprados en el establecimiento? ¿En caso afirmativo, en qué consiste la iniciativa, qué materiales traen los clientes y qué se hace con ellos después?

6. En general, ¿qué opina usted, como evalúa la problemática de los residuos sólidos o basuras en este barrio y en la Comuna 20 (generación de basuras, donde se depositan, qué se hace con ellas finalmente), y cuáles podrían ser las soluciones? 


\subsection{1.}

\section{Apêndice 11 - Termo de consentimento livre e esclarecido - Rocinha}

O presente termo em atendimento à Resolução CNS 196/96, destina-se a esclarecer ao participante da pesquisa intitulada "Entre a Rocinha no Brasil e Siloé na Colômbia, quais são as similaridades? Estudo comparativo do processo de destinação de resíduos sólidos gerados nos dois lócus e suas formas de tratamento". A pesquisa se dará sob a responsabilidade da pesquisadora Maria Izabel de Carvalho, aluna do curso de Pós-Graduação do Departamento de Serviço Social da PUC-Rio, ressalvando os seguintes aspectos:

Objetivo: analisar o processo de destinação dos resíduos sólidos gerados e suas formas de tratamento na favela da Rocinha (Rio de Janeiro) e em Siloé (Cali), por meio de uma análise comparativa que possibilite a identificação das práticas empreendidas em áreas empobrecidas pelos agentes locais.

Metodologia: realizar-se-á pesquisa de campo através de roteiro/formulário, com o objetivo de apreender as percepções dos entrevistados sobre o processo de destinação dos resíduos sólidos gerados e suas formas de tratamento na Rocinha (Rio de Janeiro) e em Siloé (Cali), analisando os resultados da entrevista.

Justificativa e Relevância: faz-se necessária a pesquisa sobre o processo de destinação dos resíduos sólidos gerados e suas formas de tratamento na Rocinha (Rio de Janeiro) e em Siloé (Cali), porque permitirá ao público acadêmico e aos demais interessados na temática, ter acesso às informações atualizadas a partir dessa pesquisa. Assim sendo, para a academia será de grande contribuição, tendo em vista que permitirá que outros pesquisadores possam partir dos dados desse estudo, para aprofundar ou propor novas metodologias de recolhimento de resíduos sólidos na favela, o que muito contribuirá para diminuição dos riscos ambientais existentes. Ainda que não tenhamos diretamente essa pretensão, esse estudo também poderá apontar possíveis soluções para os problemas relacionados ao trato, de forma geral, com os resíduos sólidos na favela da Rocinha e em Siloé.

Confidencialidade do estudo: o estudo dar-se-á na favela da Rocinha e em Siloé e os dados serão compilados pela pesquisadora. A identidade dos voluntários 
participantes será preservada. Os entrevistados, quando citados no estudo, serão nomeados por iniciais de seus nomes.

Garantia de esclarecimento: os voluntários participantes terão todas e quaisquer formas de esclarecimento e informações sobre a pesquisa, dúvidas, bem como da metodologia da pesquisa adotada a todo e qualquer momento.

Participação Voluntária: a participação dos sujeitos da pesquisa no projeto é voluntária e livre de qualquer forma de remuneração e que o mesmo pode retirar seu consentimento em participar da pesquisa a qualquer momento.

Consentimento para participação: eu estou de acordo com a participação no estudo descrito acima. Eu fui devidamente esclarecida(o) quanto os objetivos da pesquisa e aos procedimentos. Os pesquisadores me garantiram disponibilizar qualquer esclarecimento adicional a que eu venha solicitar durante o curso da pesquisa e o direito de desistir da participação em qualquer momento, sem que a minha desistência implique em qualquer prejuízo à minha pessoa, sendo garantido anonimato e o sigilo dos dados referentes à minha identificação, bem como de que a minha participação neste estudo não me trará nenhum benefício econômico.

$\mathrm{Eu}$,

Aceito livremente participar do estudo intitulado "Entre a Rocinha no Brasil e Siloé na Colômbia, quais são as similaridades? Estudo comparativo do processo de destinação de resíduos sólidos gerados nos dois lócus e suas formas de tratamento", desenvolvido pela pesquisadora Maria Izabel de Carvalho, orientador desta pesquisa para o trabalho Tese de Doutorado.

Doutoranda: Maria Izabel de Carvalho

Professor (a) Orientador (a): Prof. a . Dra . Valéria Pereira Bastos

Coorientador: Professor Dr. Ricardo Rodriguez Quintero

Contato do Departamento de Serviço Social da PUC-Rio: (+55 21) 3527-1290 
7.12.

Apêndice 12 - Consentimiento informado - Siloé

\section{PONTIFICIA UNIVERSIDAD JAVERIANA CALI / PONTIFICIA UNIVERSIDADE \\ CATÓLICA DO RIO DE JANEIRO \\ GRUPO DE INVESTIGACIÓN EN PROCESOS Y MEDIOS DE \\ COMUNICACIÓN \\ 2019}

CONSENTIMIENTO INFORMADO

Nombre del (de la) entrevistador(a):

Señor(a):

le

estamos invitando a participar en un trabajo de investigación académica de la Pontificia Universidad Javeriana Cali, y la Pontificia Universidad Católica de Rio de Janeiro (Brasil).

Términos de la participación:

1. La decisión de participar en el trabajo es completamente libre y voluntaria. Esto quiere decir que puede negarse a participar o retirarse, en el momento que lo desee, agradeciendo que nos informe las razones, pero con plena seguridad de que serán respetadas.

2. No recibirá beneficio económico alguno de este trabajo.

3. La información obtenida en este trabajo se mantendrá en estricta confidencialidad; los datos personales serán reservados y sólo conocidos por los estudiantes entrevistadores y el profesor.

4. El objetivo de esta investigación es conocer sus opiniones en relación con la problemática de las basuras en la Comuna 20 y en su barrio.

5. Habrá un cuestionario, un conjunto de preguntas que se utilizará en la investigación como guía de la entrevista, la cual permitirá hacer un diálogo, una conversación sobre sus opiniones.

Se recuerda que la identidad del entrevistado o entrevistada es confidencial y que sus datos no serán revelados públicamente. 
En caso de que tenga dudas sobre sus derechos como participante o que desee obtener alguna información sobre la temática, póngase en contacto con Maria Izabel de Carvalho al 314-5885149.

De acuerdo con lo anterior y después de haber aclarado y discutido con los entrevistadores sobre los objetivos de la investigación, y en pleno uso de mis capacidades, yo,

manifiesto mi aceptación para la participación en la investigación de forma voluntaria.

En constancia, firmo este documento de consentimiento informado, en la Ciudad de , del día del mes de del año

Firma del participante:

Cédula de ciudadanía $\mathrm{N}^{\circ}$. 


\subsection{3.}

Apêndice 13 - Documento fotográfico da Rocinha

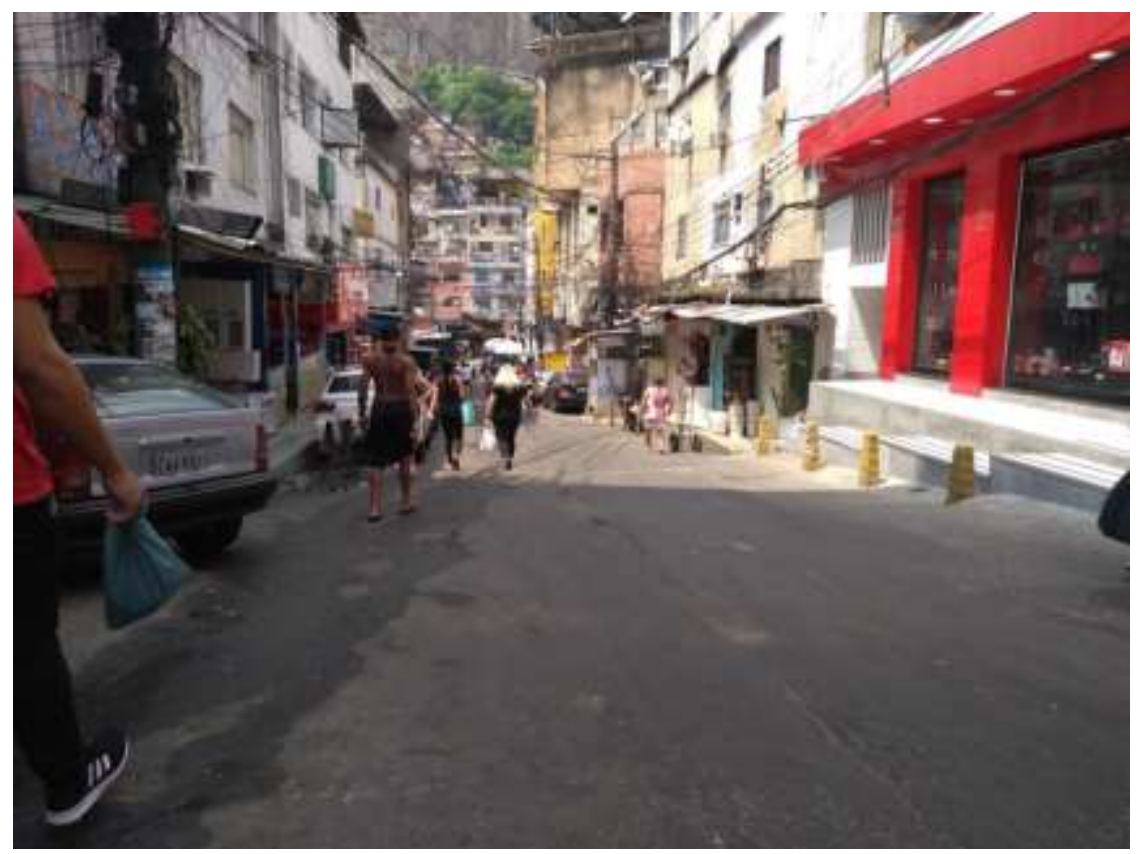

Figura 40 - Ruas da Rocinha - Caminho do Boiadeiro. Fonte: Maria Izabel de Carvalho, mar. 2021.

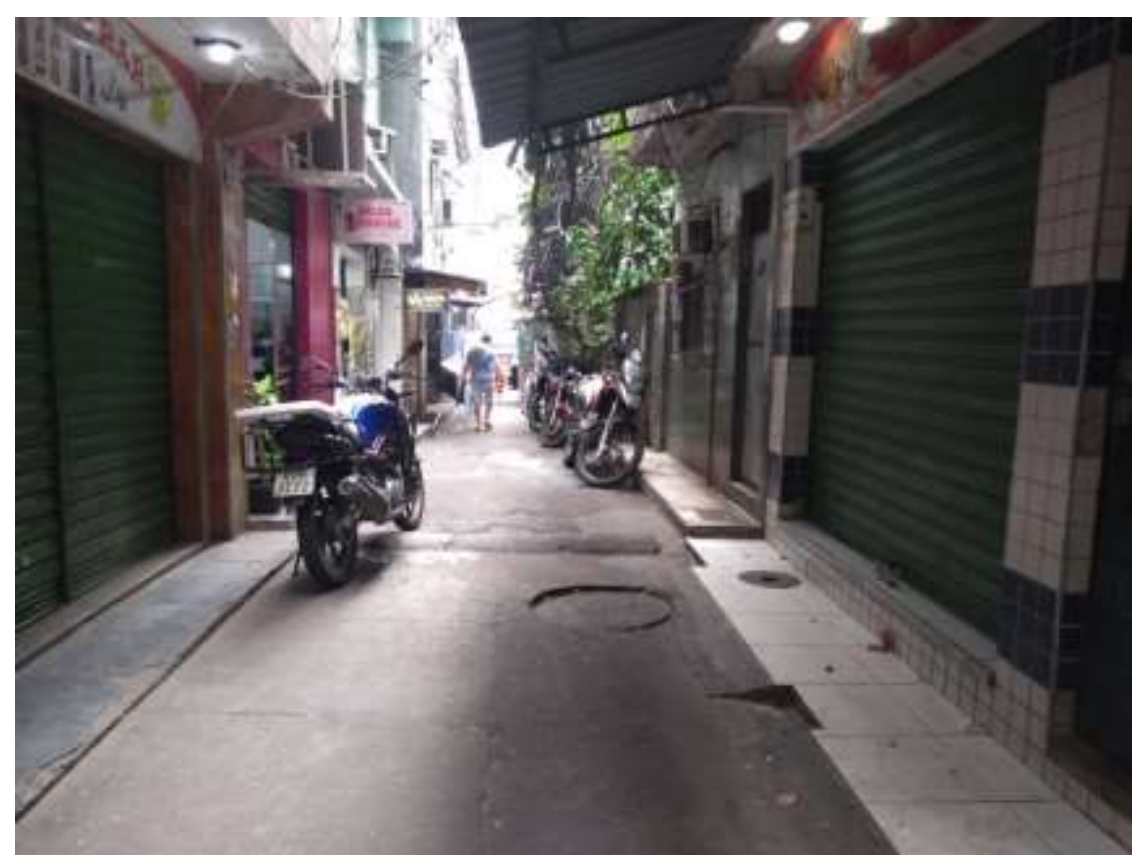

Figura 41 - Vielas da Rocinha - Bairro Barcelos.

Fonte: Maria Izabel de Carvalho, mar. 2021. 


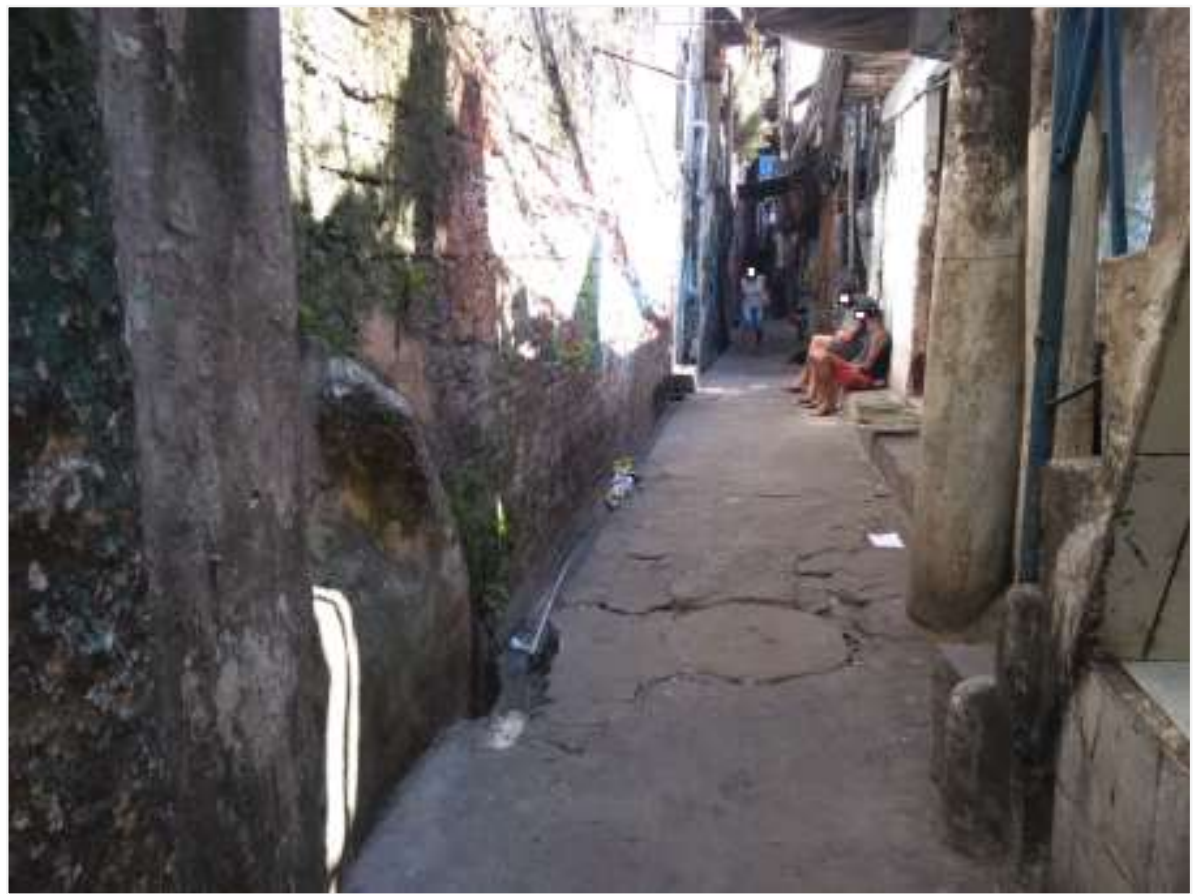

Figura 42 - Becos da Rocinha - sub-bairro 99.

Fonte: Maria Izabel de Carvalho, mar. 2021.

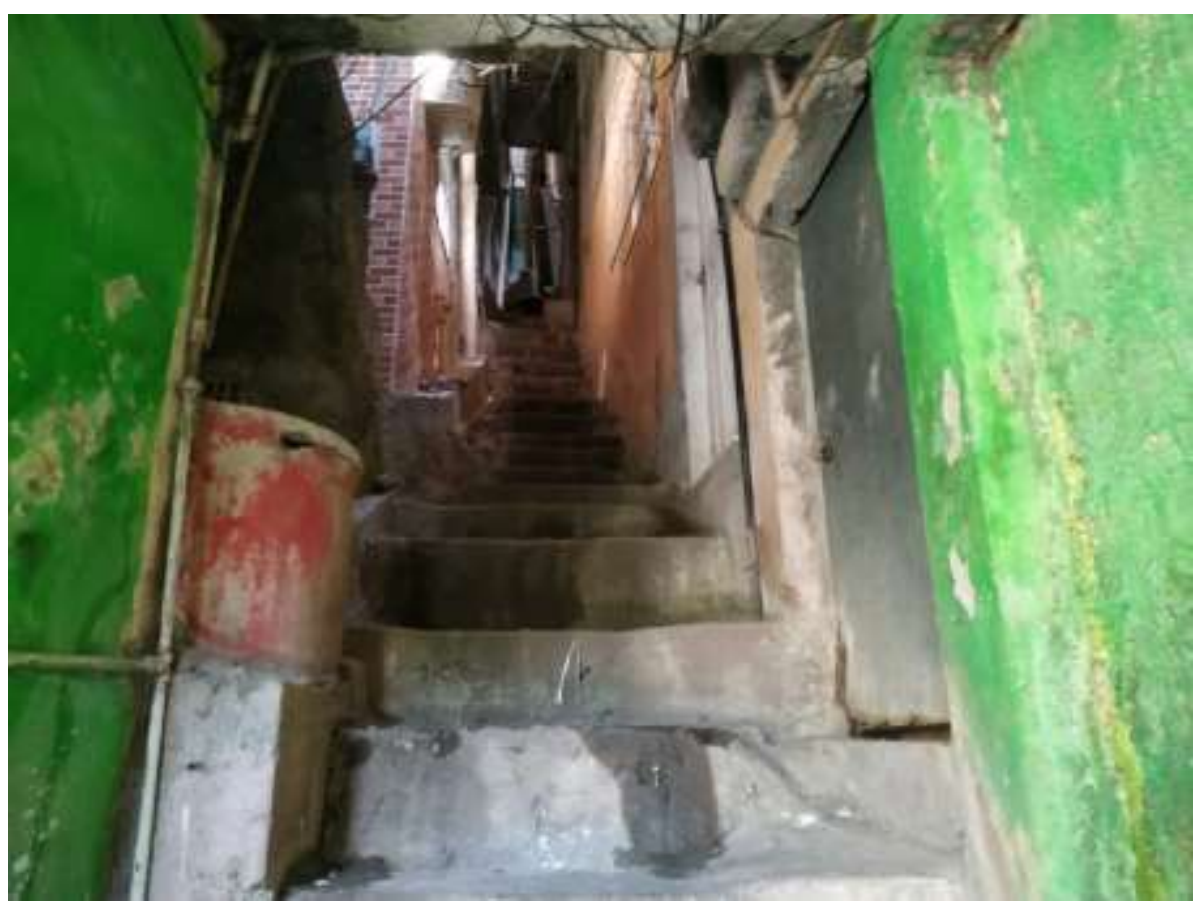

Figura 43 - Escadarias em becos da Rocinha - sub-bairro Vila Verde. Fonte: Francisco Helton de Carvalho, maio. 2021. 


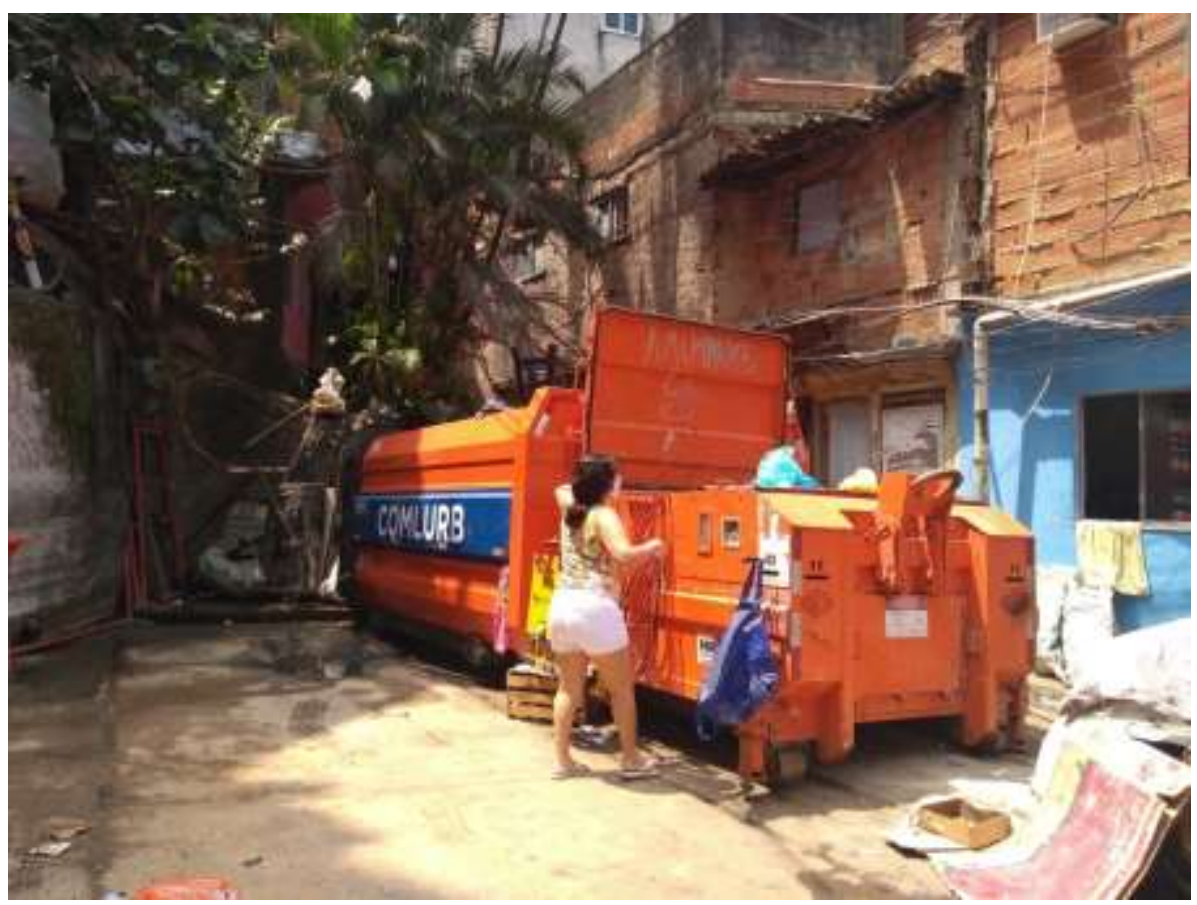

Figura 44 - Ponto de coleta - compactadora do Valão.

Fonte: Maria Izabel de Carvalho, mar. 2021.

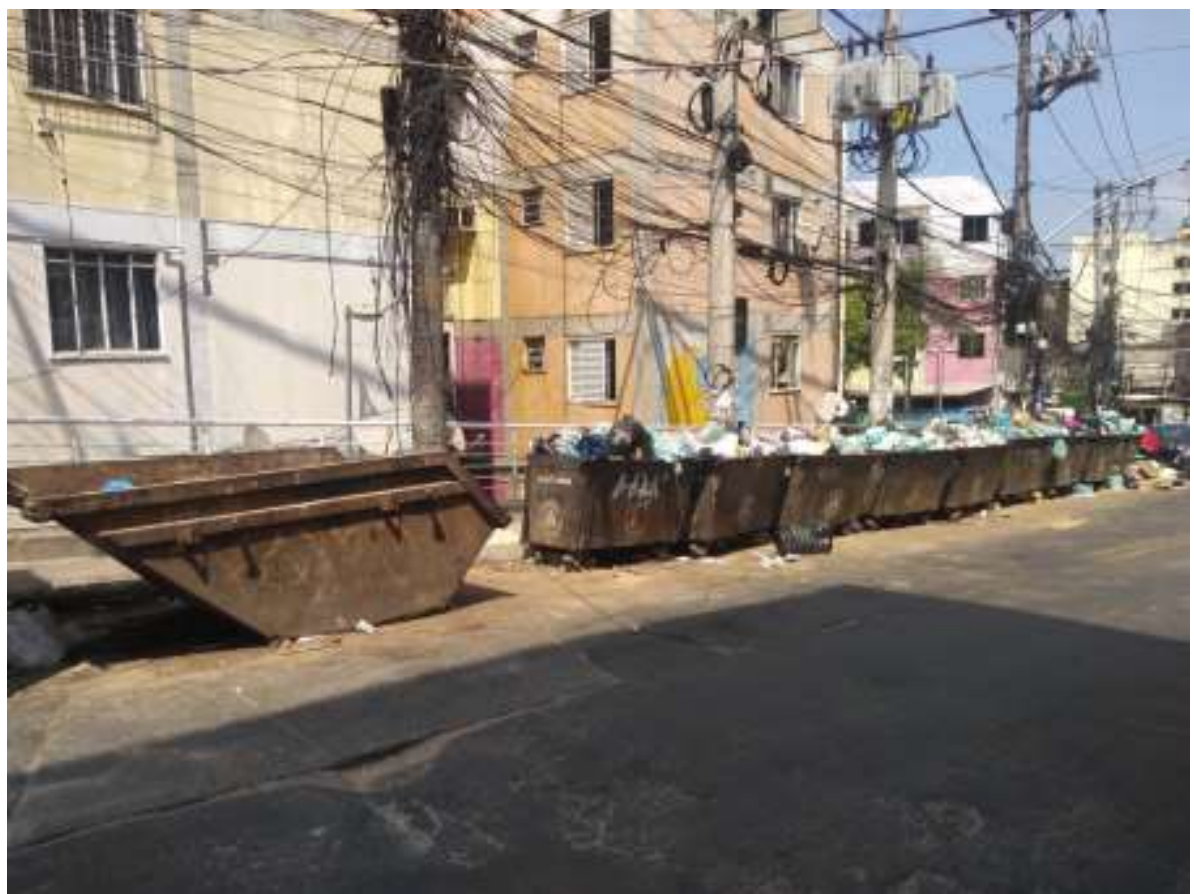

Figura 45 - Ponto de coleta prédios do PAC (Estrada da Gávea) - caixas para depósito dos resíduos sólidos.

Fonte: Maria Izabel de Carvalho, mar. 2021. 


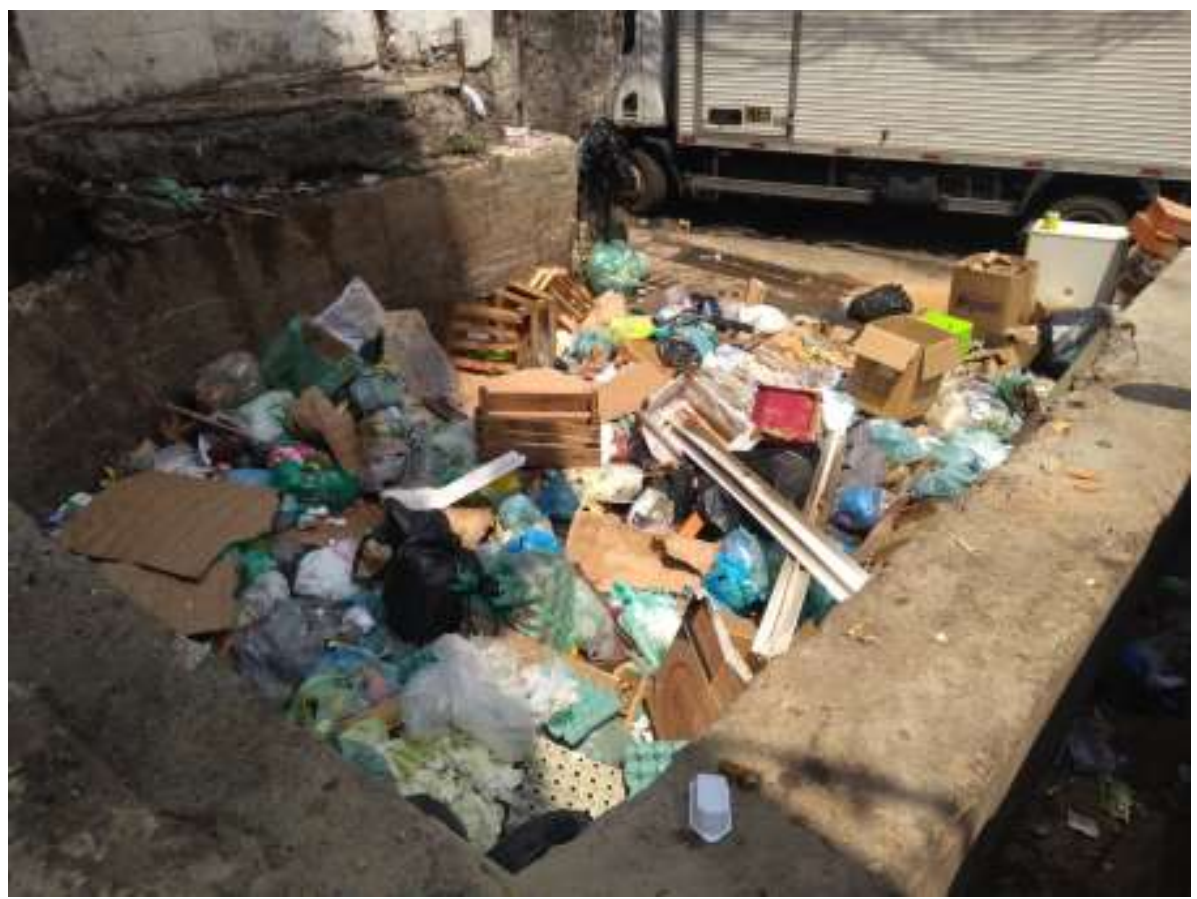

Figura 46 - Ponto de coleta do Caminho do Boiadeiro - resíduos sólidos depositados direto no chão e a céu aberto.

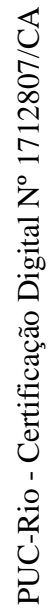
Fonte: Maria Izabel de Carvalho, mar. 2021.

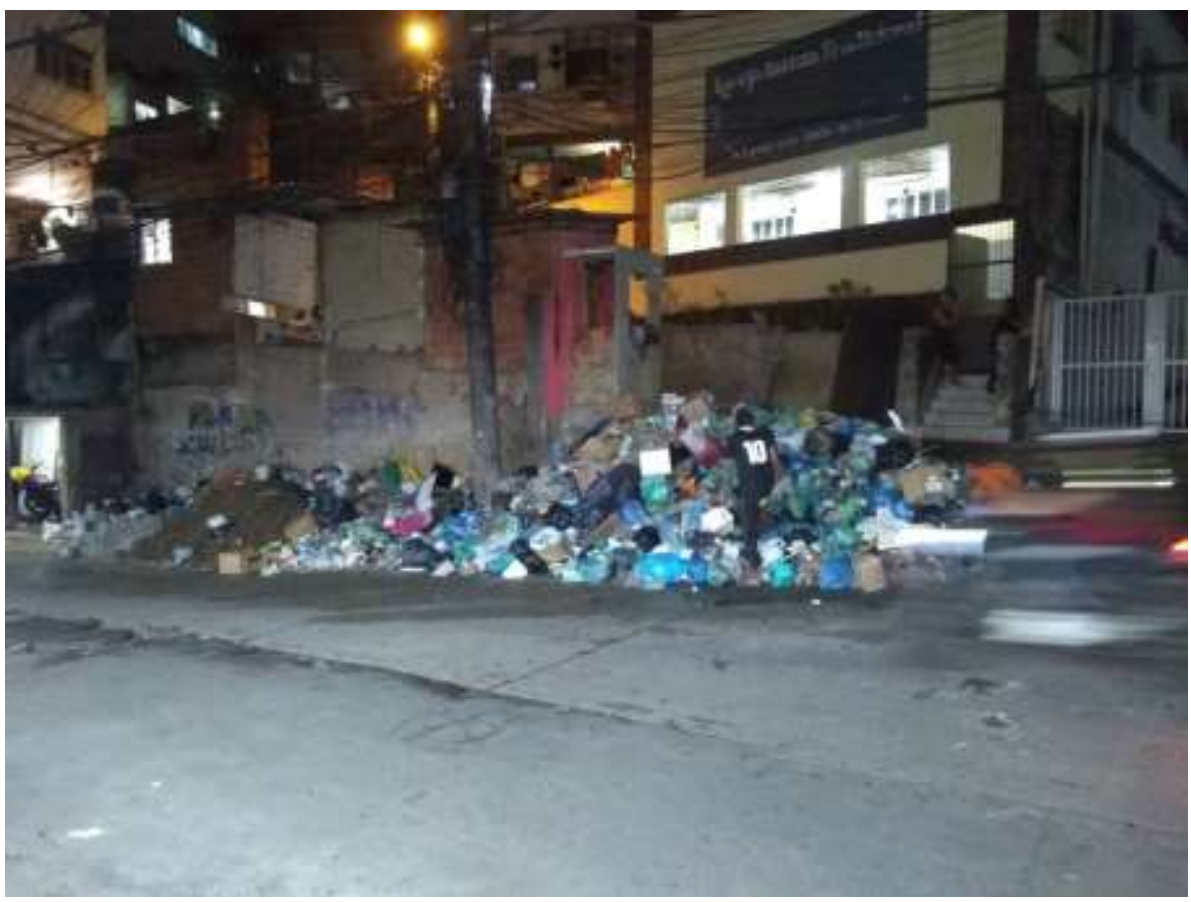

Figura 47 - Ponto de coleta em frente à antiga Casa da Paz (Estrada da Gávea). Fonte: Maria Izabel de Carvalho, maio. 2021. 


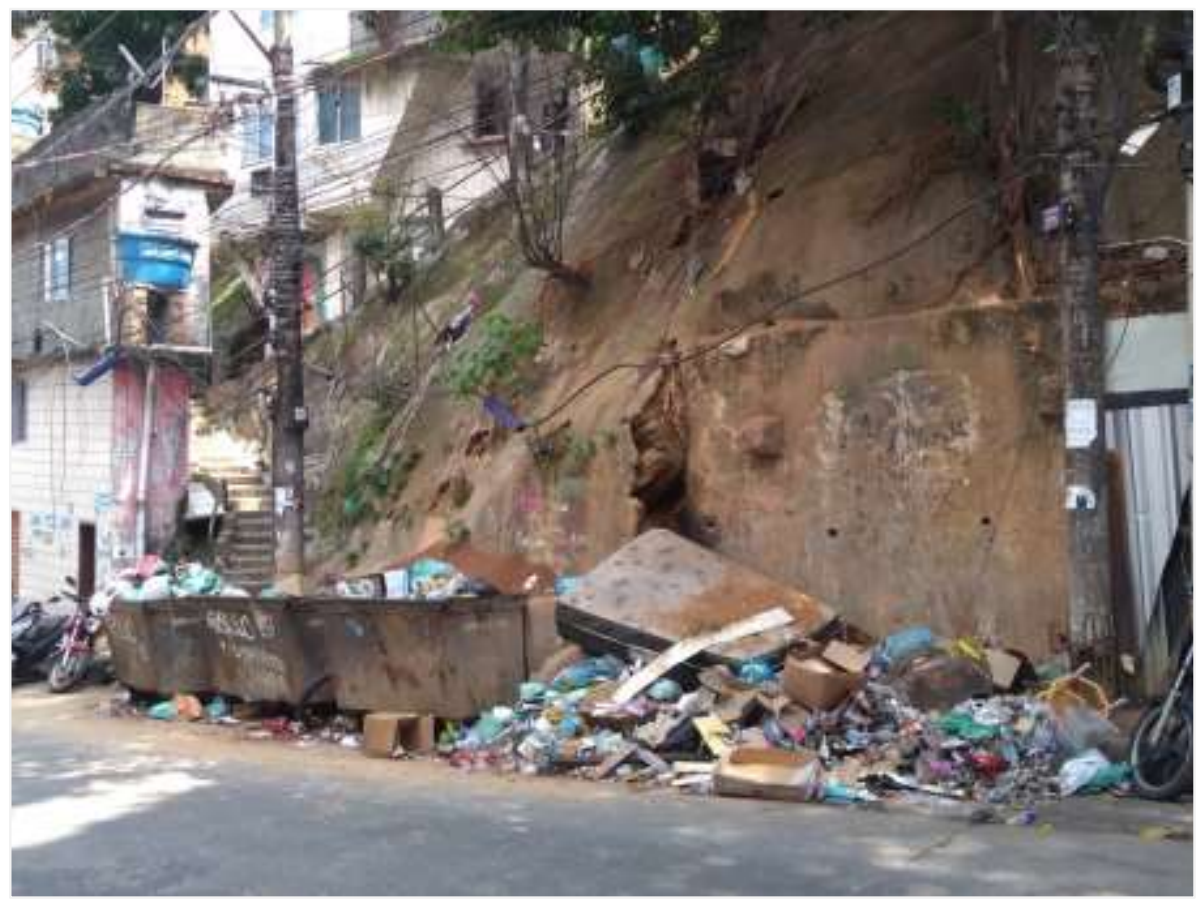

Figura 48 - Ponto de coleta - sub-bairro Sete (Estrada da Gávea). Fonte: Maria Izabel de Carvalho, mar. 2021.

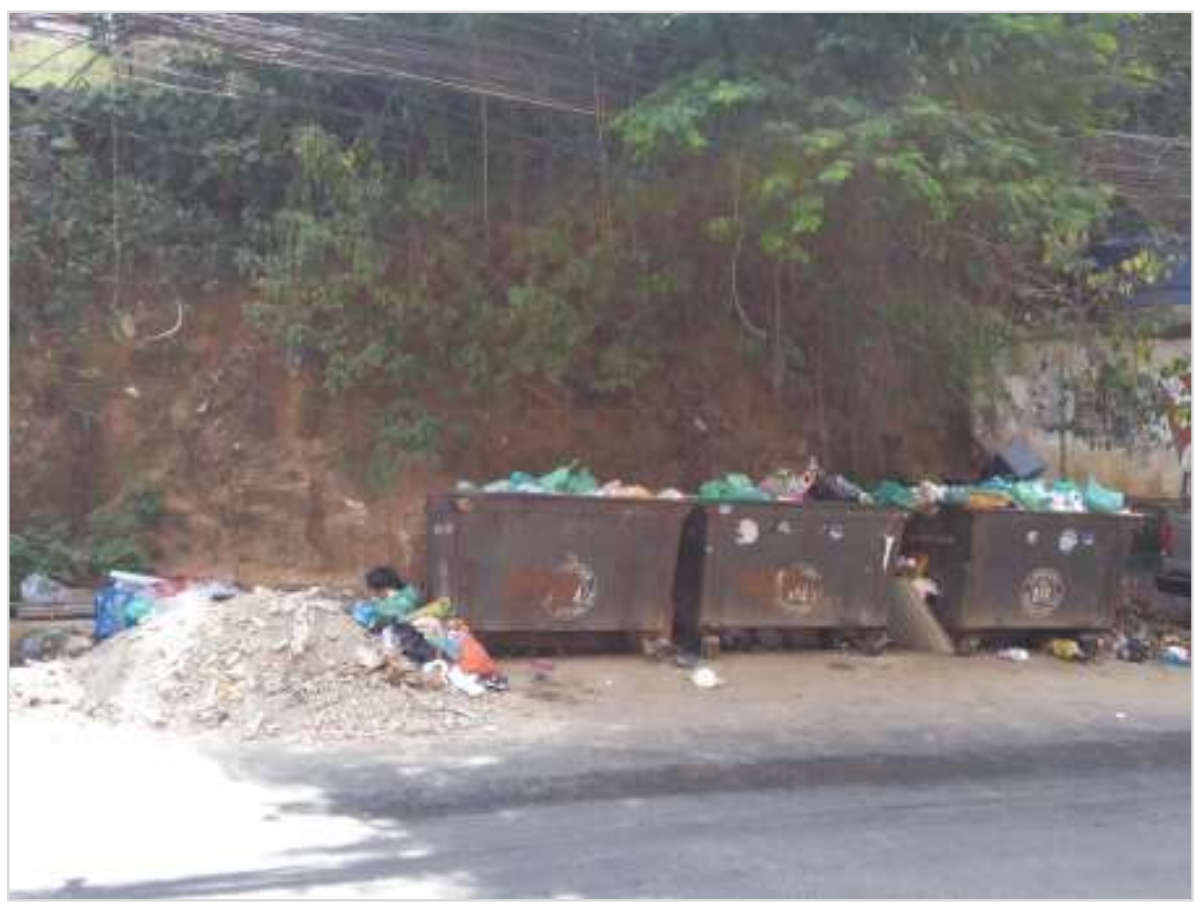

Figura 49 - Ponto de coleta próximo ao sub-bairro Atalho (Estrada da Gávea). Fonte: Maria Izabel de Carvalho, mar. 2021. 


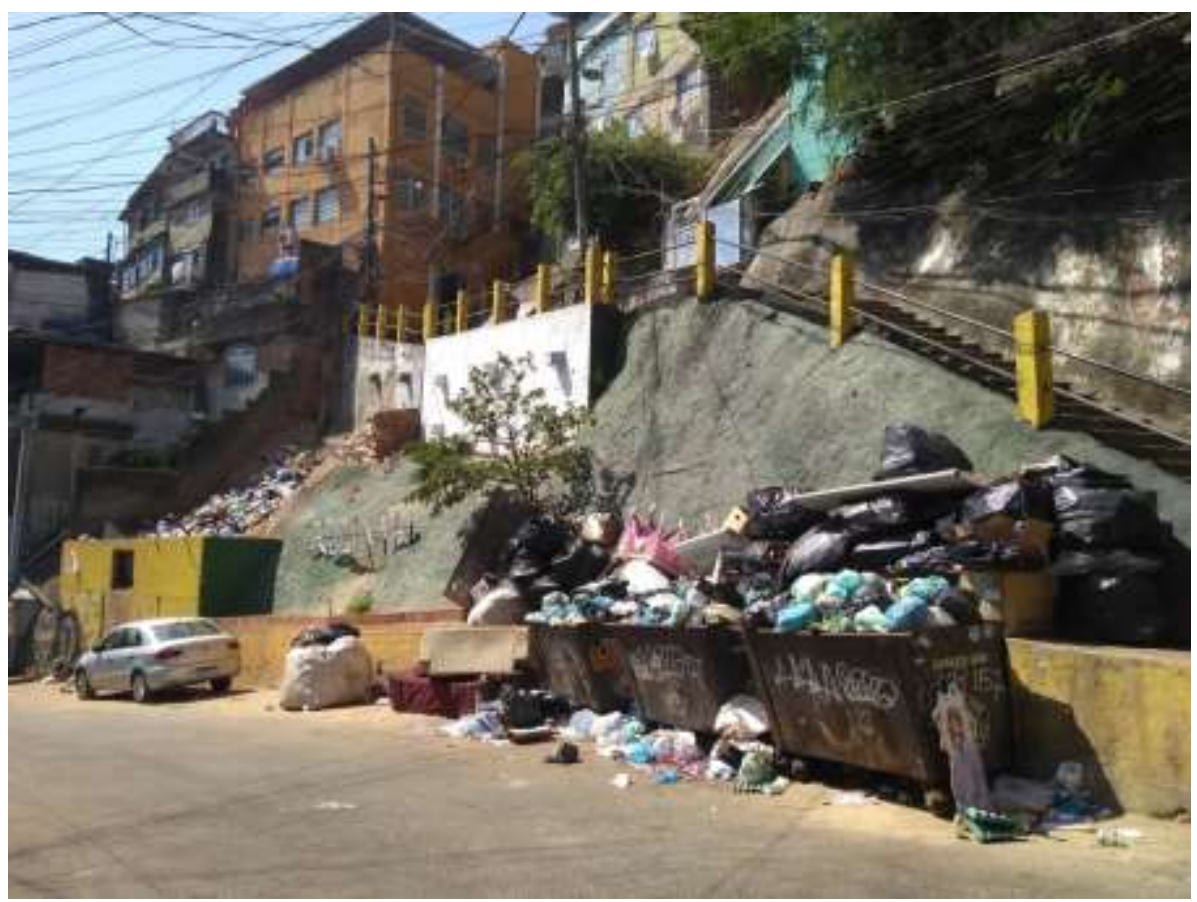

Figura 50 - Ponto de coleta na altura do sub-bairro Vila Vermelha (Estrada da Gávea).

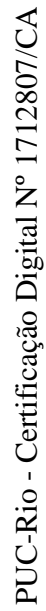

Fonte: Maria Izabel de Carvalho, mar. 2021.

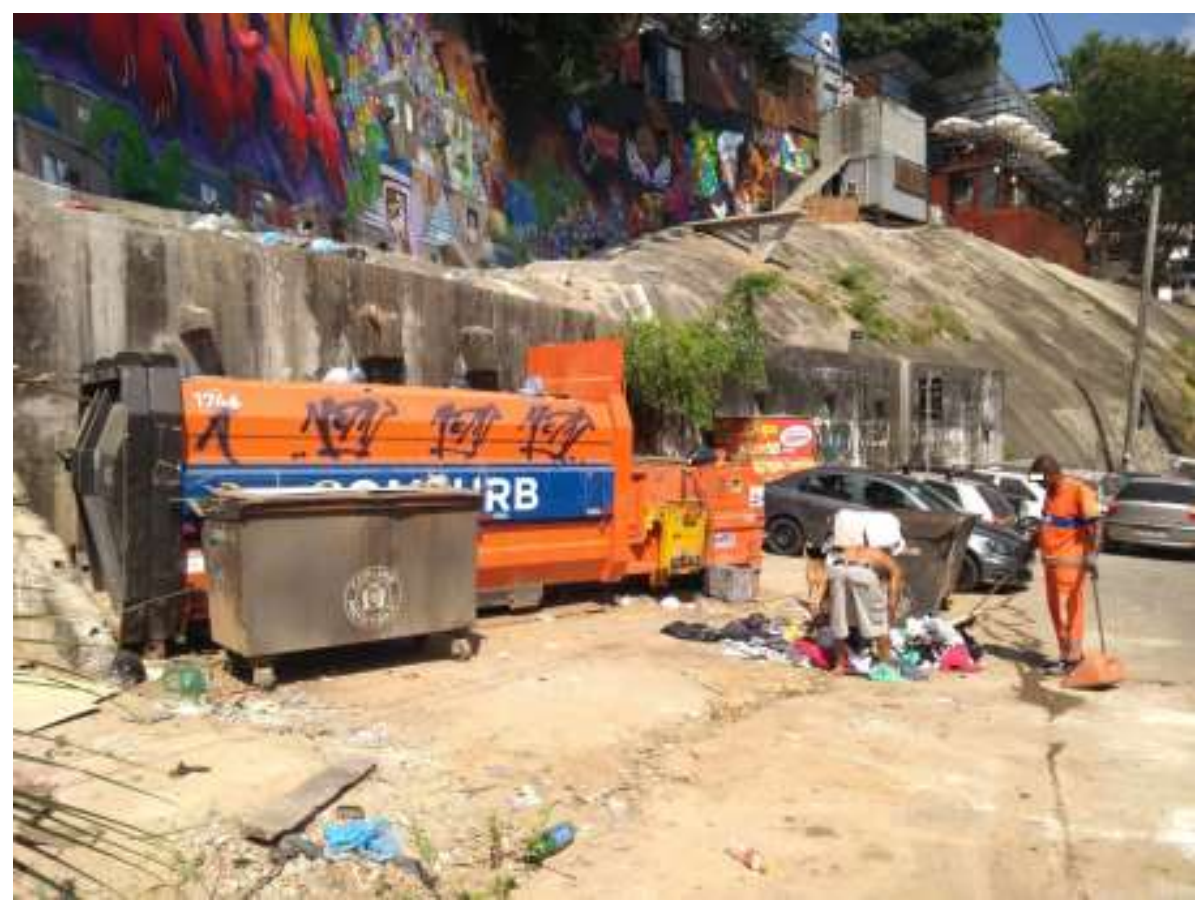

Figura 51 - Ponto de coleta entre o Setor 199 e Vila Cruzado (Estrada da Gávea) - compactadora e caixas para depósito dos resíduos sólidos.

Fonte: Maria Izabel de Carvalho, mar. 2021. 


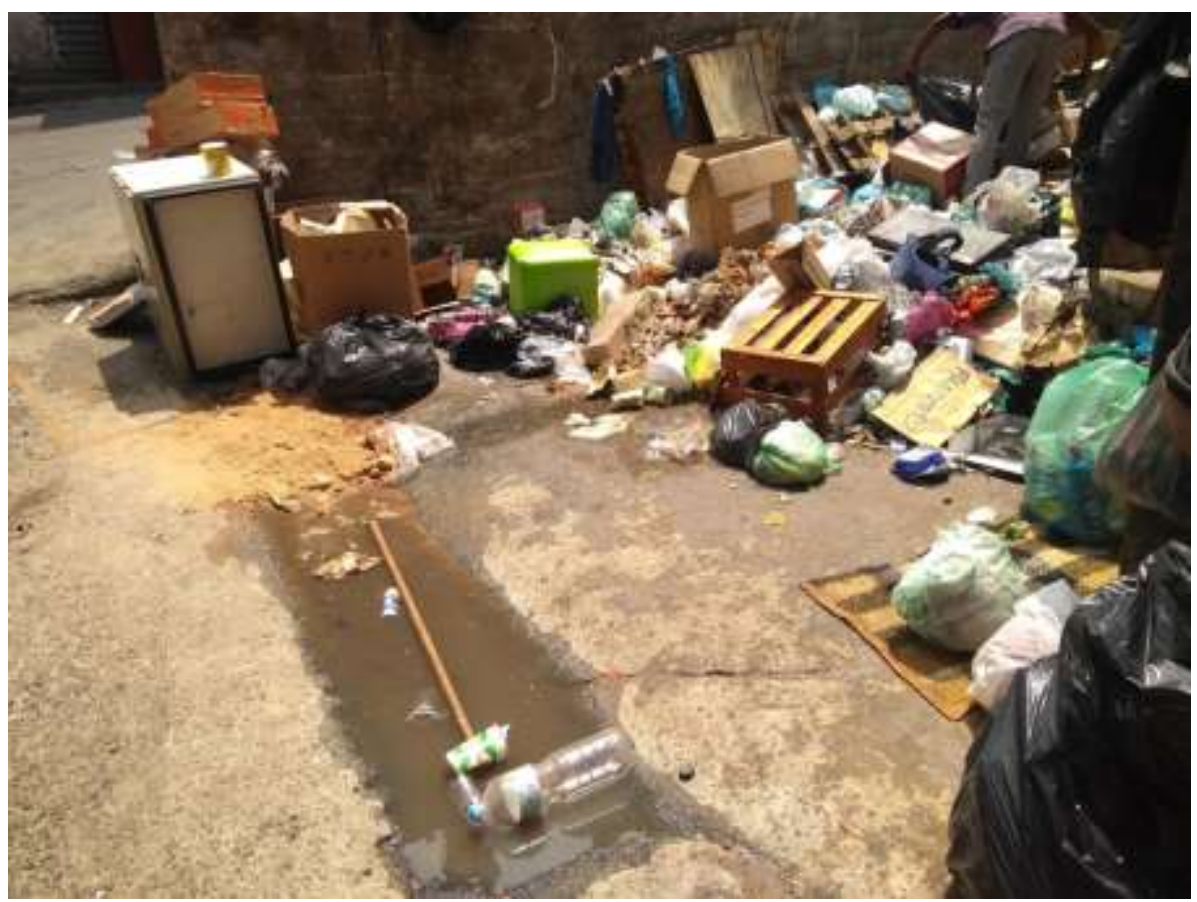

Figura 52 - Ponto de coleta - chorume escorrendo para a rua. Fonte: Maria Izabel de Carvalho, mar. 2021.

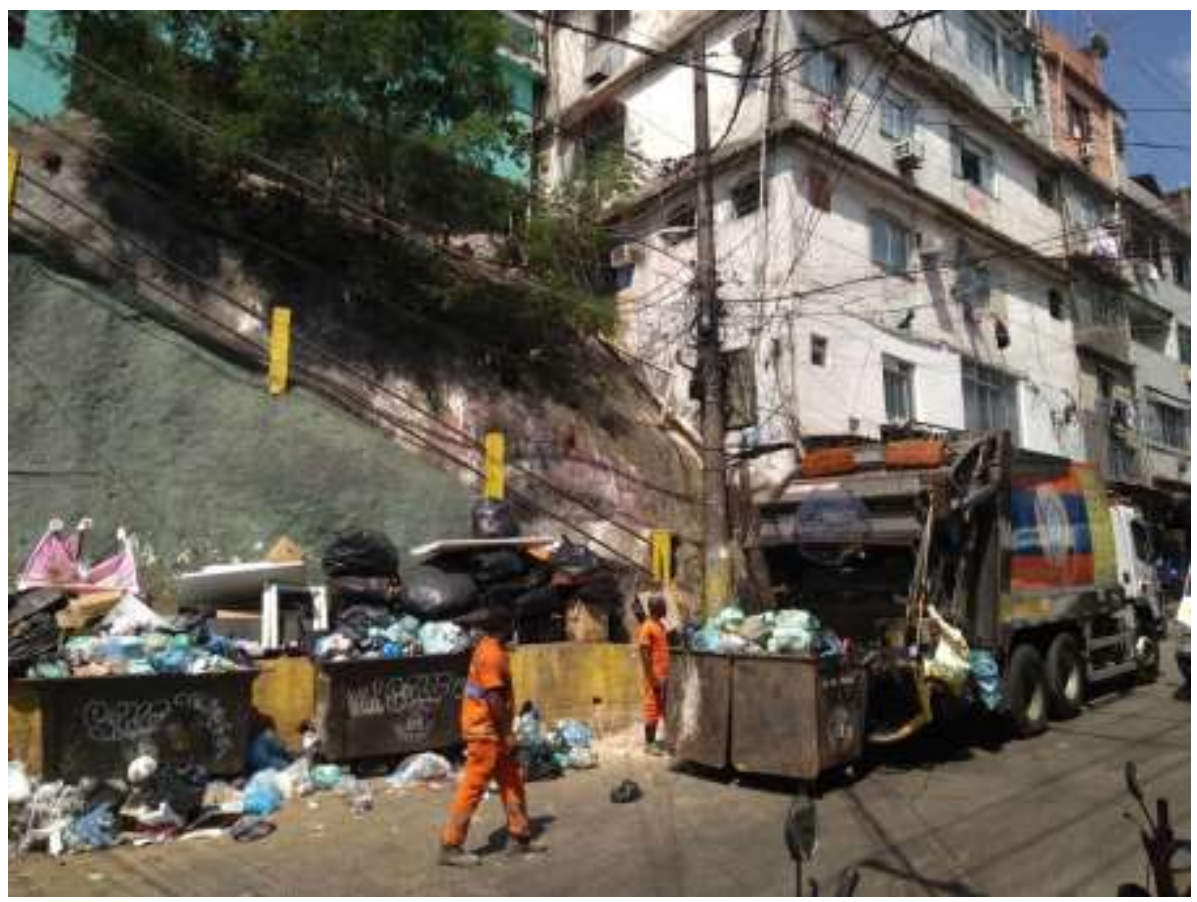

Figura 53 - Realização da coleta pela COMLURB - escadão da Vila Vermelha. Fonte: Maria Izabel de Carvalho, mar. 2021. 


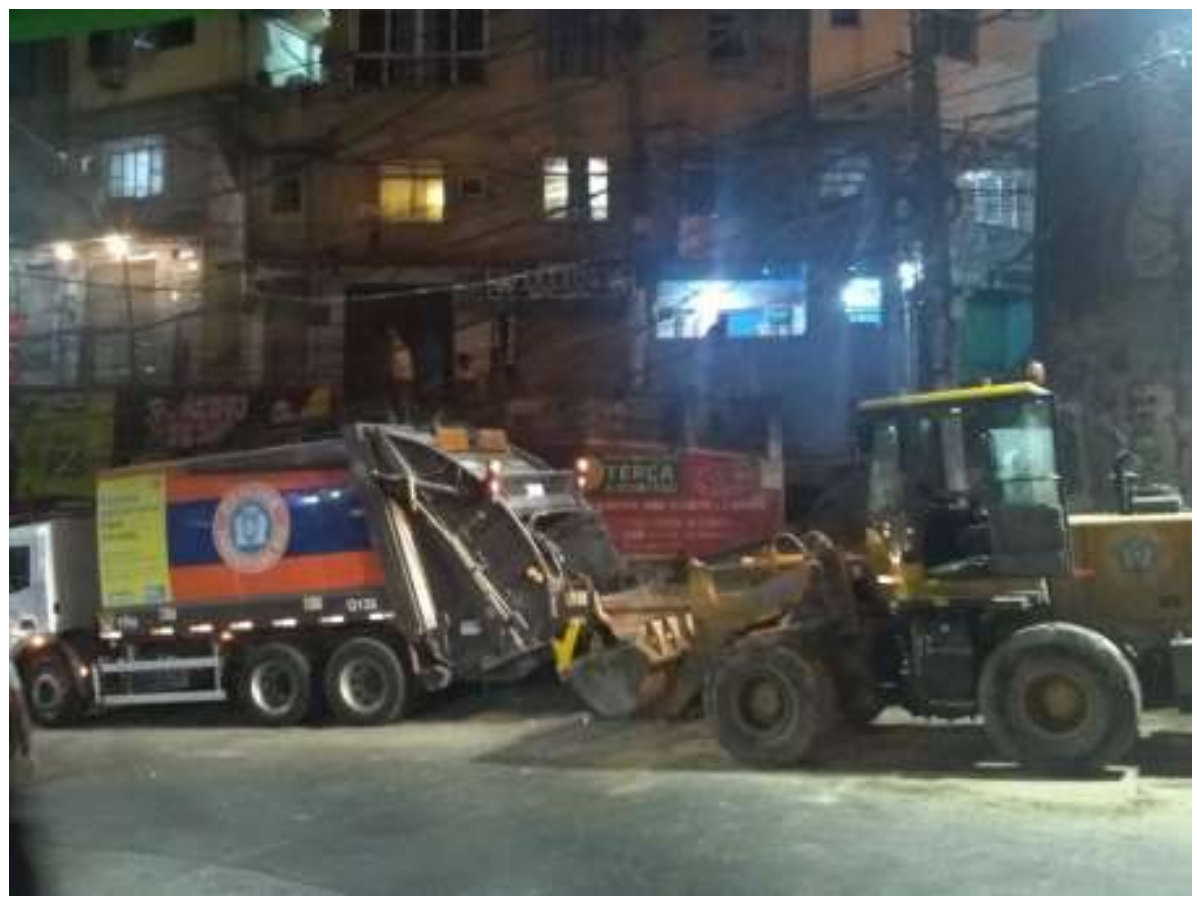

Figura 54 - Realização da coleta pela COMLURB - escadão da Vila Verde. Fonte: Maria Izabel de Carvalho, ago. 2020.

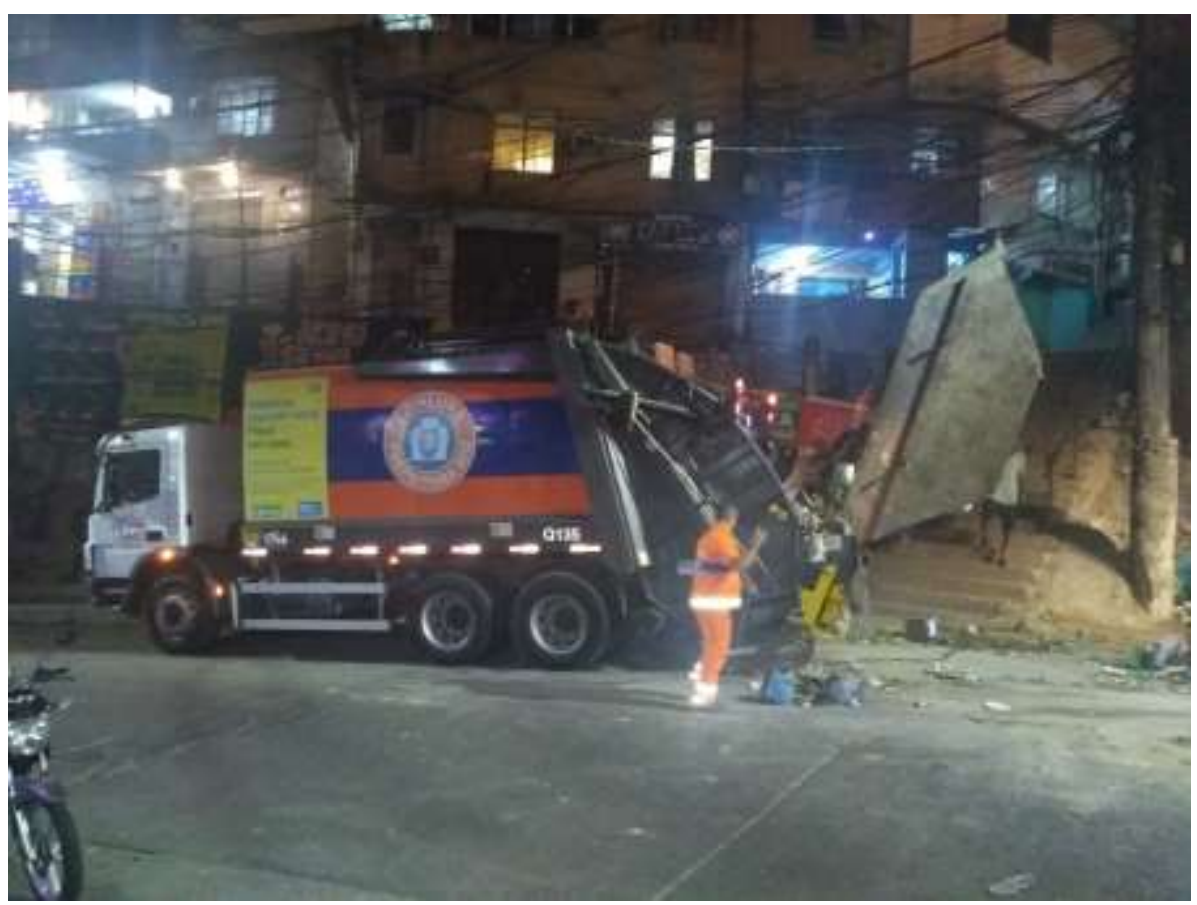

Figura 55 - Realização da coleta pela COMLURB - - escadão da Vila Verde. Fonte: Maria Izabel de Carvalho, ago. 2020. 


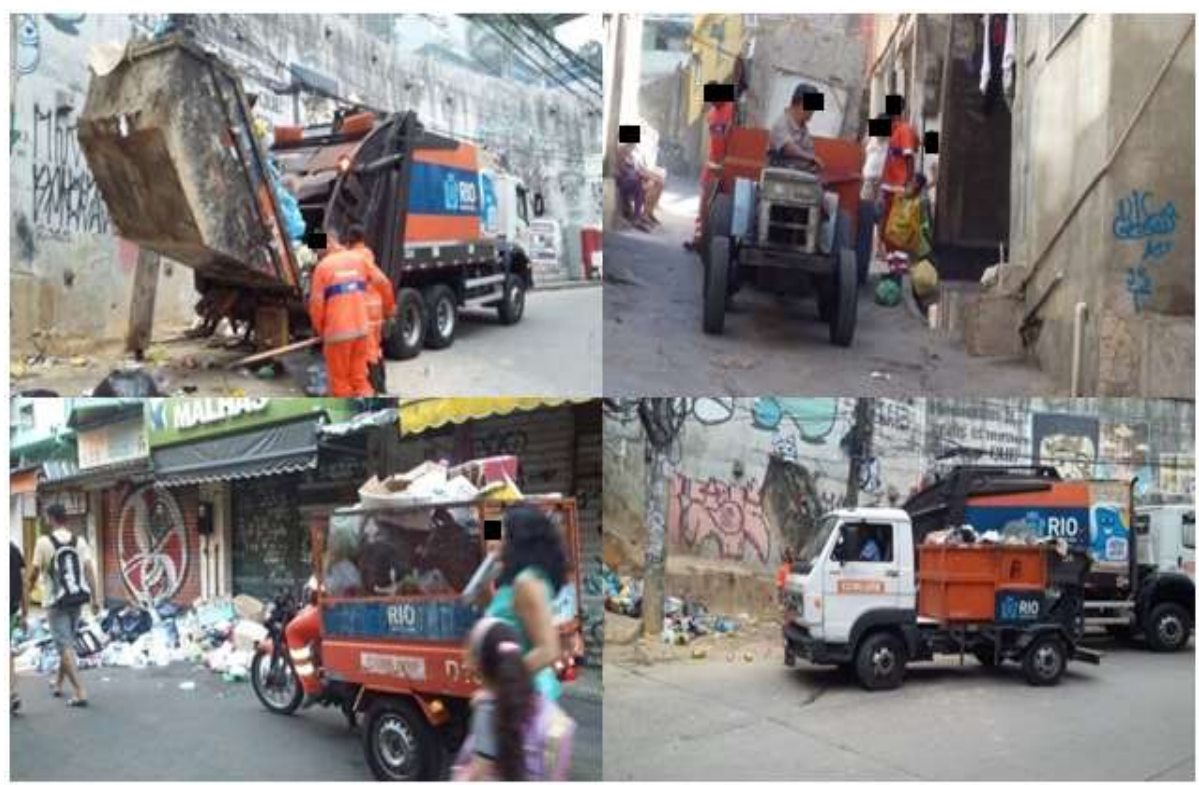

Figura 56 - Equipamentos de coleta - Rocinha Fonte: Maria Izabel de Carvalho, mar. 2021.

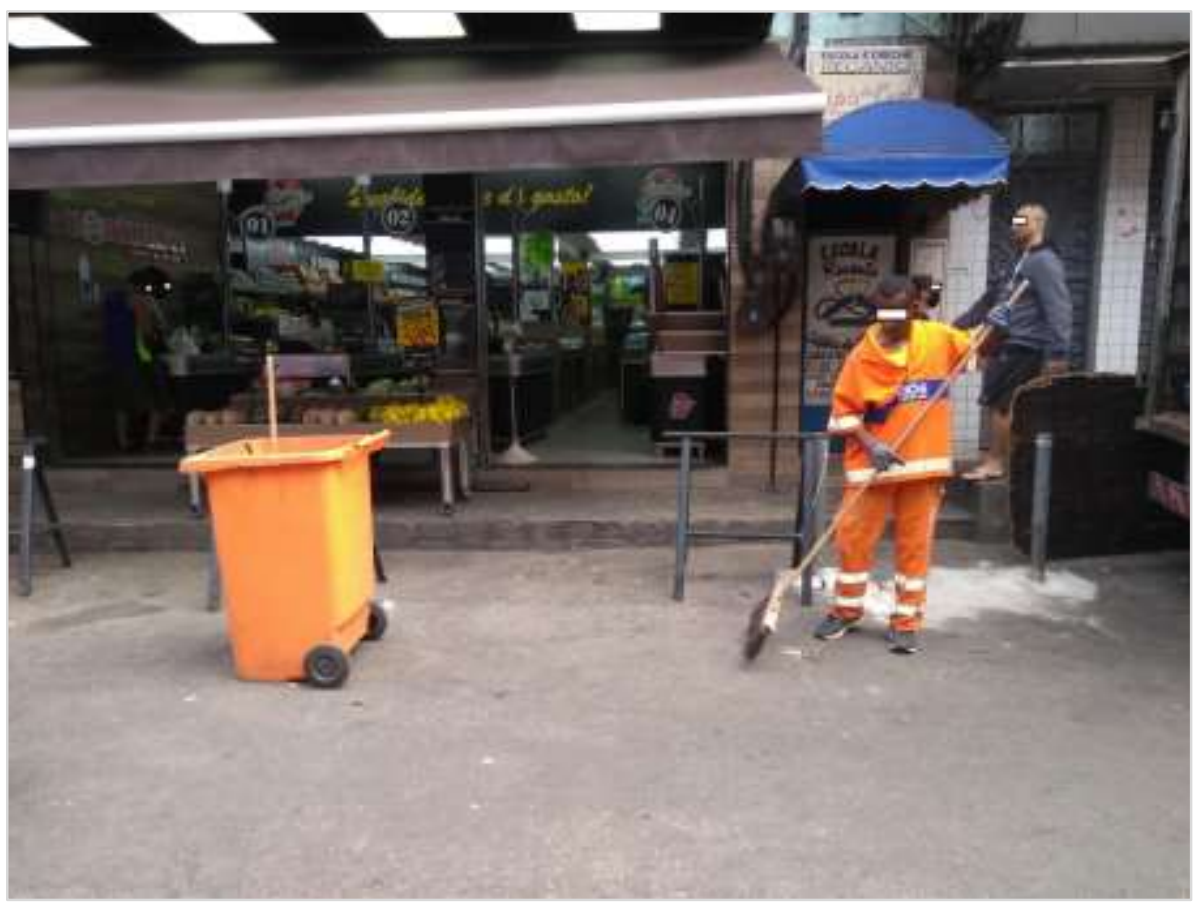

Figura 57 - Realização da varrição pela COMLURB - Via Ápia. Fonte: Maria Izabel de Carvalho, maio. 2021. 


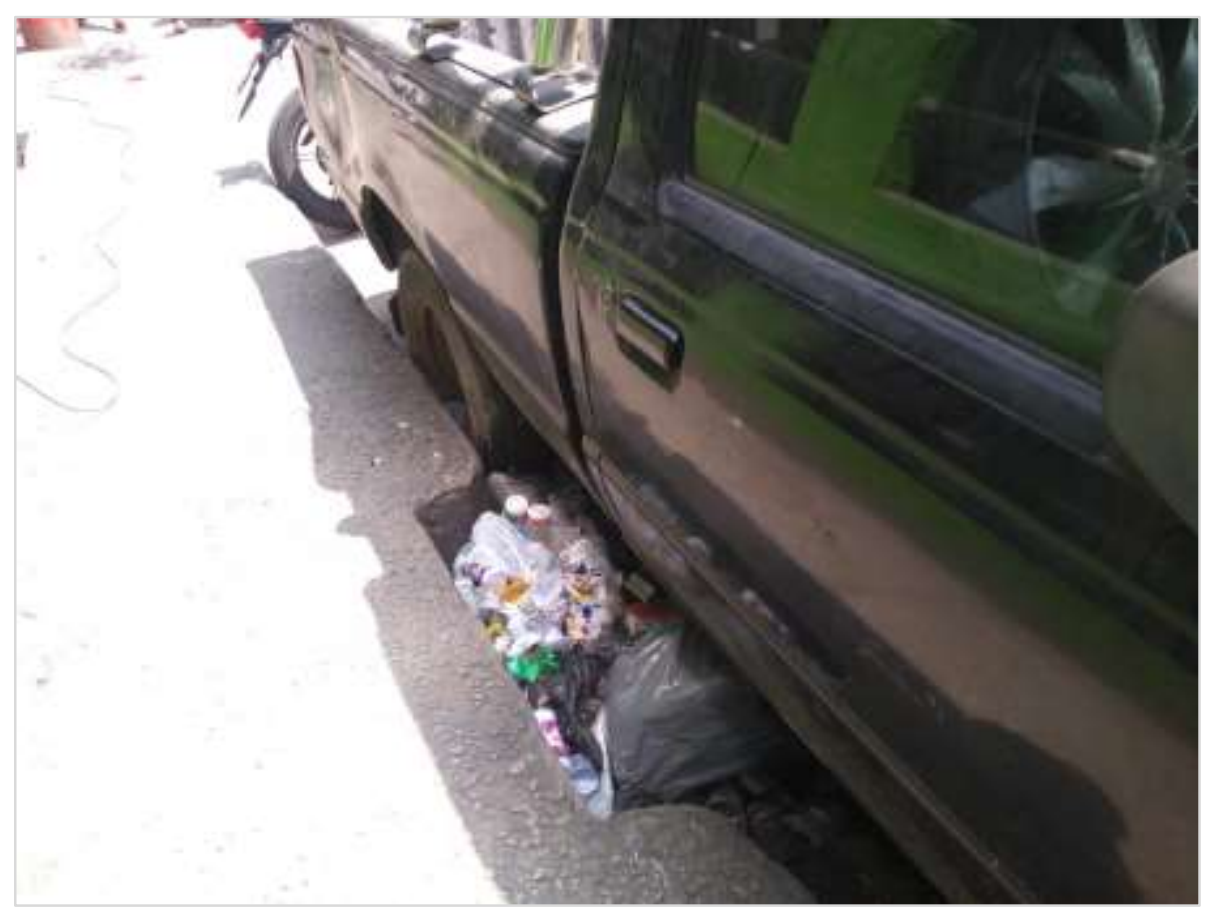

Figura 58 - Resíduo sólido descartado inadequadamente na rua - Estrada da Gávea.

Fonte: Maria Izabel de Carvalho, mar. 2021.

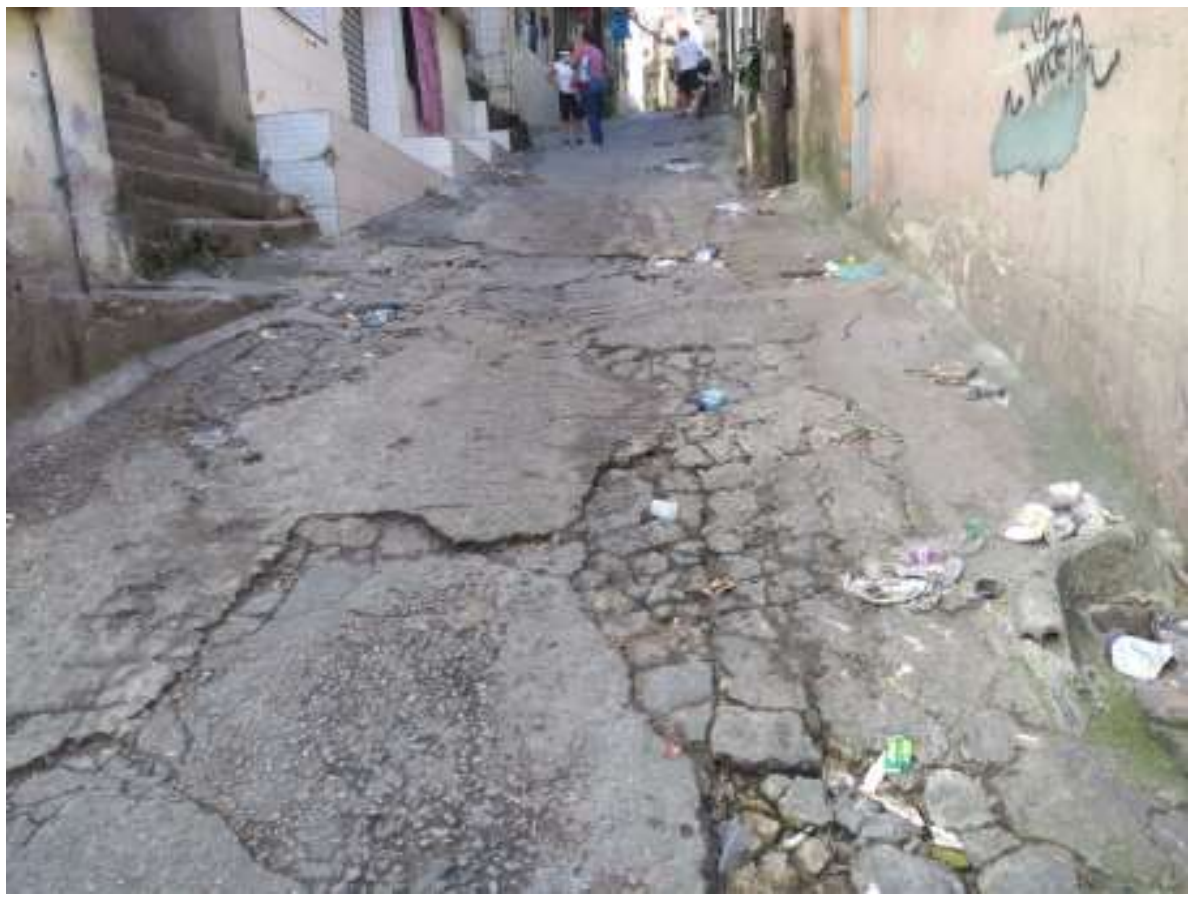

Figura 59 - Resíduo sólido descartado inadequadamente na rua - Rampa da Vila Verde.

Fonte: Maria Izabel de Carvalho, maio. 2020. 


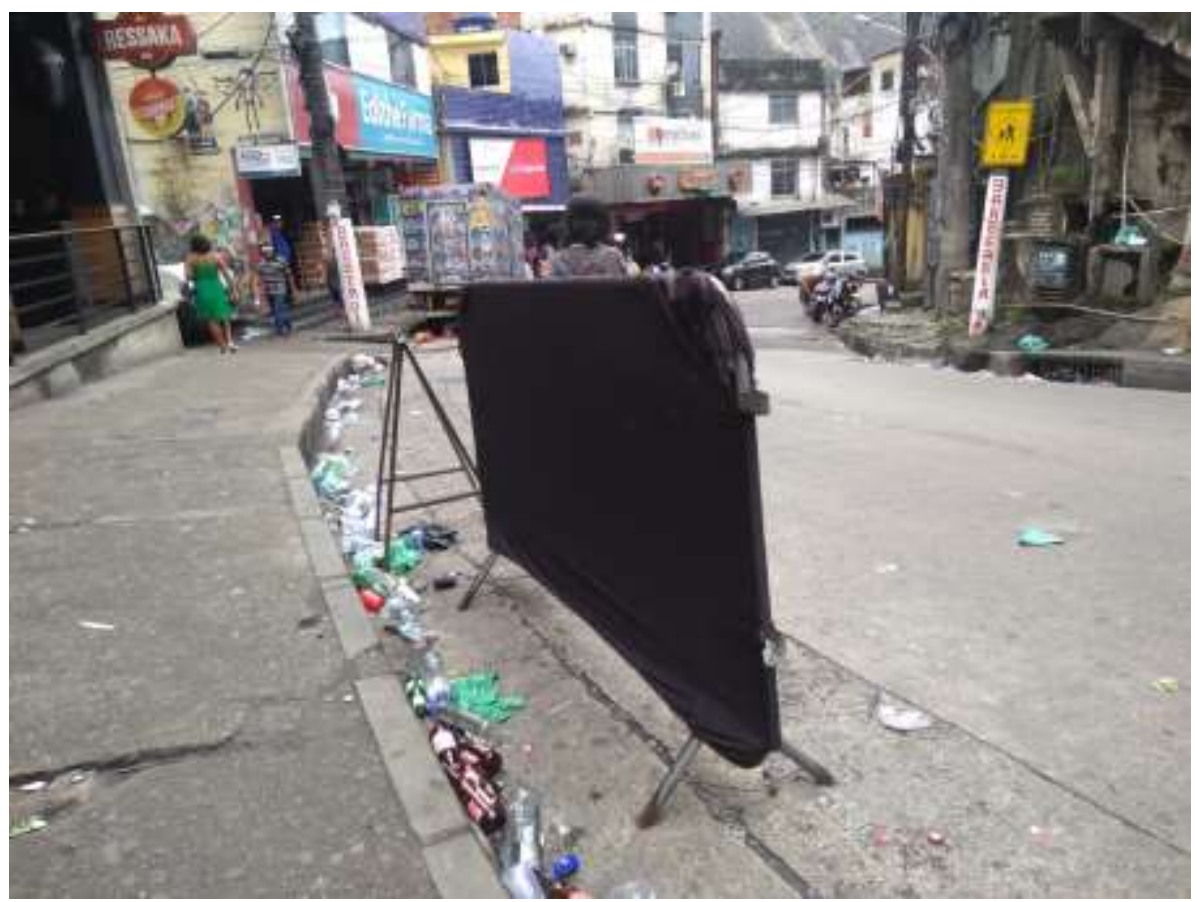

Figura 60 - Resíduo sólido descartado inadequadamente próximo ao comércio Estrada da Gávea.

U

Fonte: Maria Izabel de Carvalho, maio. 2020.

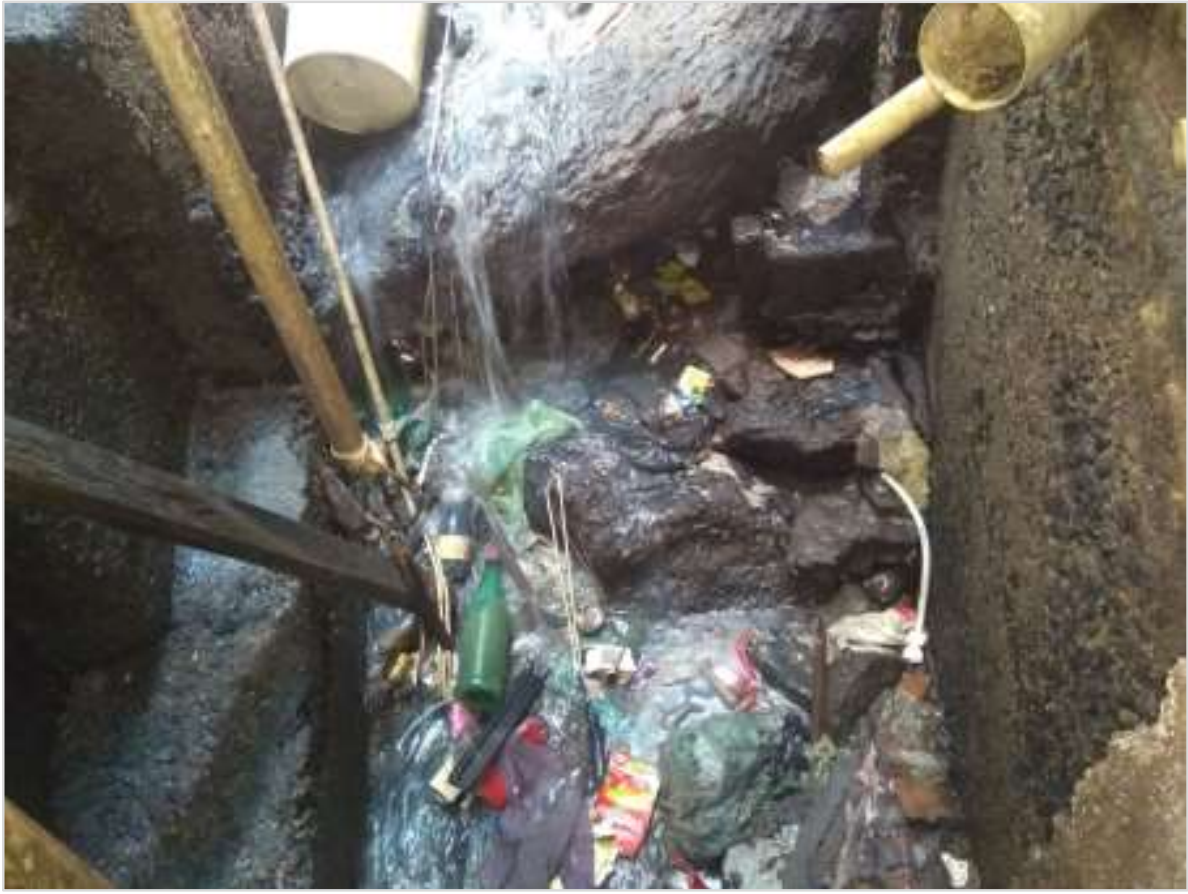

Figura 61 - Resíduo sólido descartado inadequadamente em corpos d'água. Fonte: Maria Izabel de Carvalho, fev. 2020. 


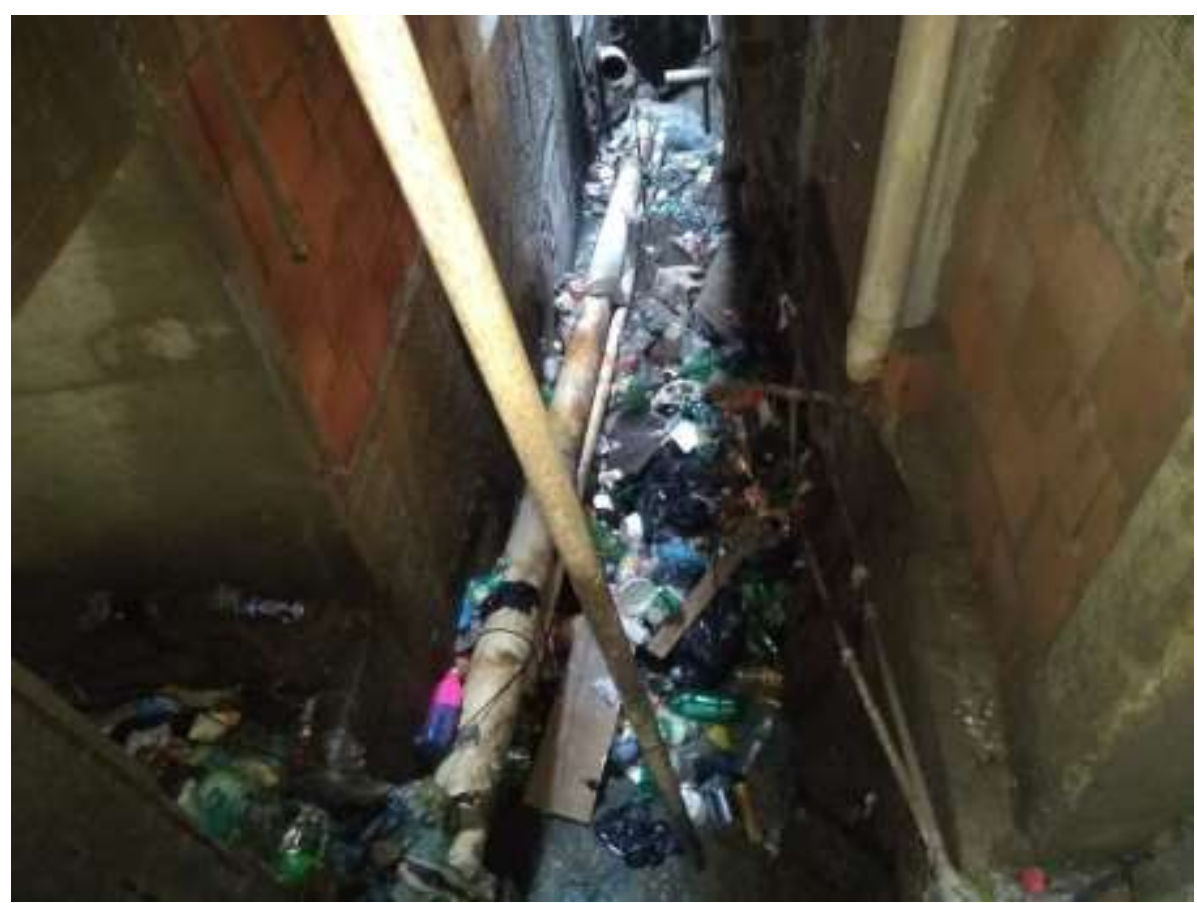

Figura 62 - Resíduo sólido descartado inadequadamente em corpos d'água. Fonte: Maria Izabel de Carvalho, maio. 2021.

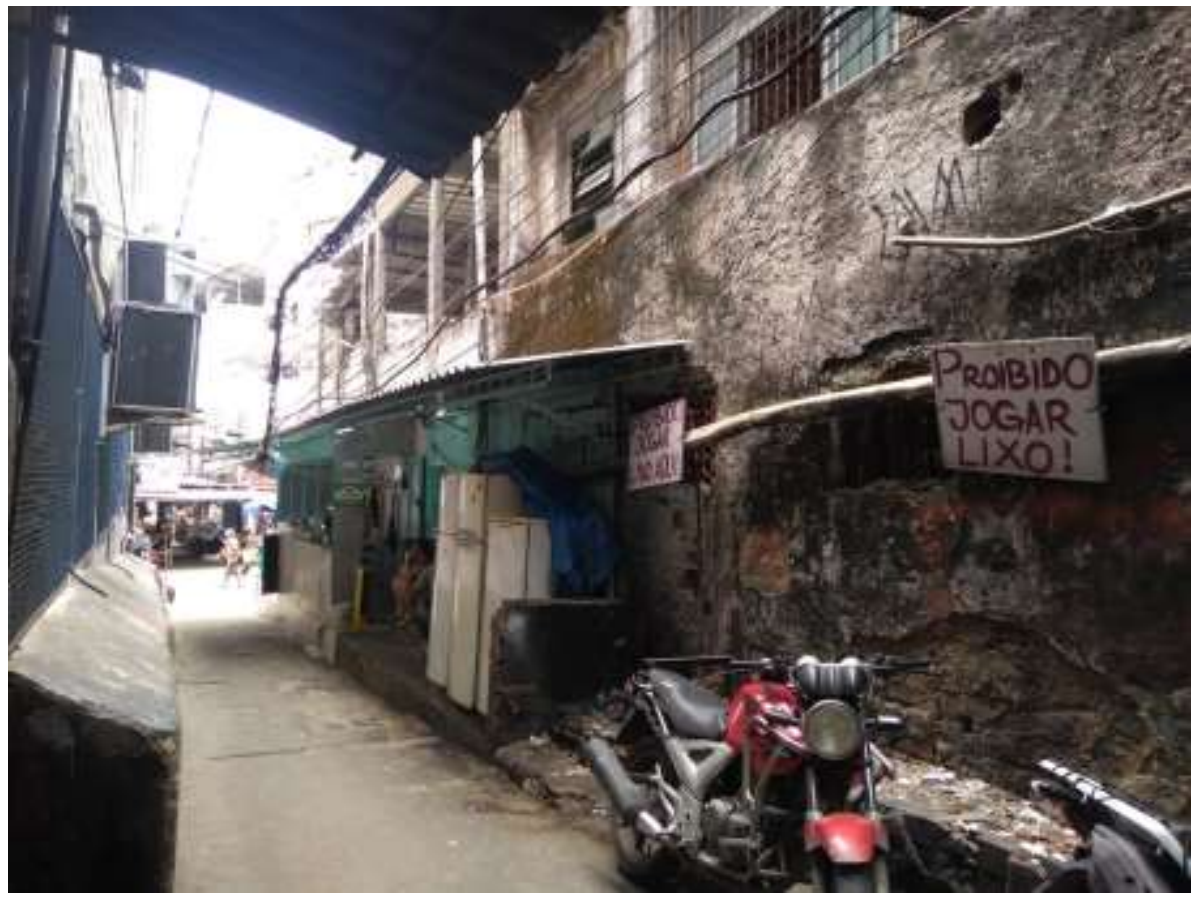

Figura 63 - Placas de "Proibido Jogar Lixo" - Bairro Barcelos. Fonte: Maria Izabel de Carvalho, mar. 2021. 


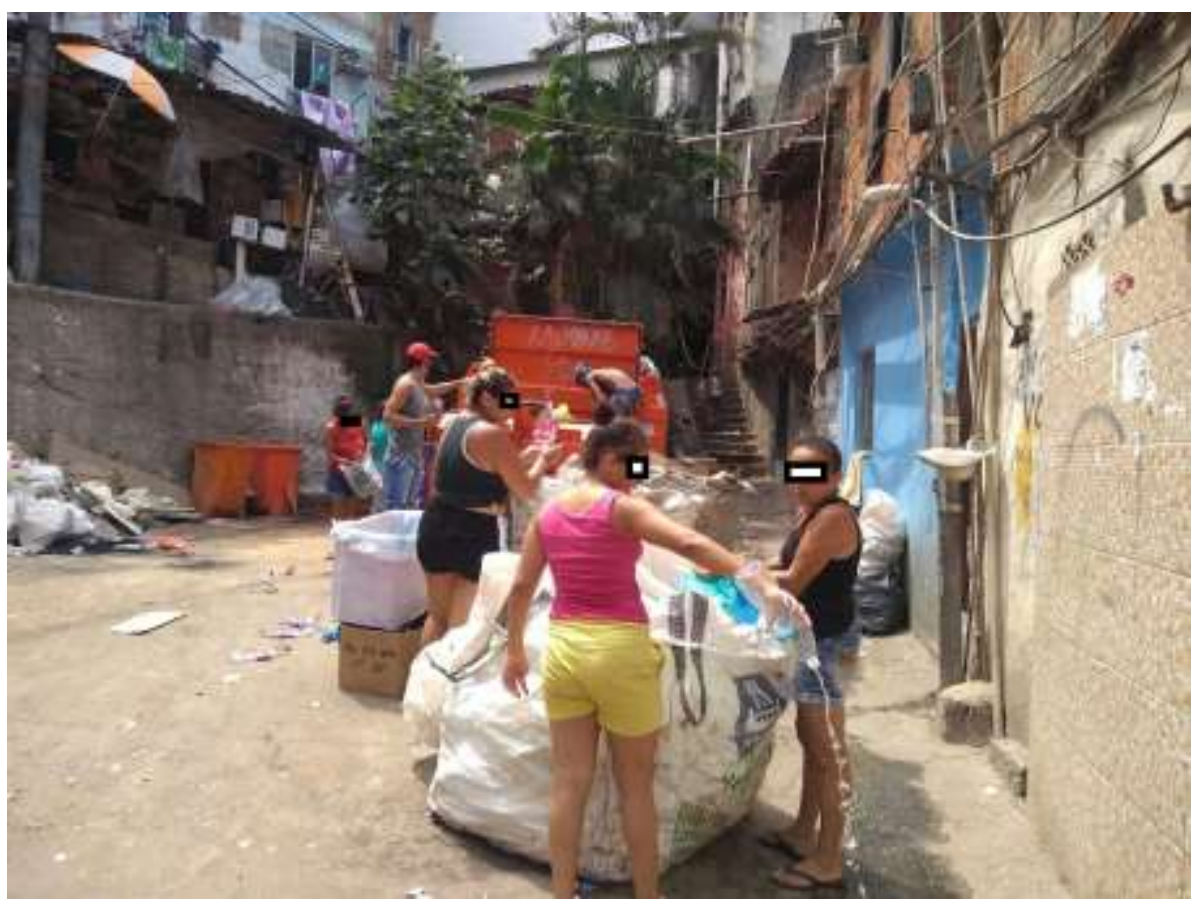

Figura 64 - Catadores de material reciclável - no Valão - Rocinha. Fonte: Maria Izabel de Carvalho, mar. 2021.

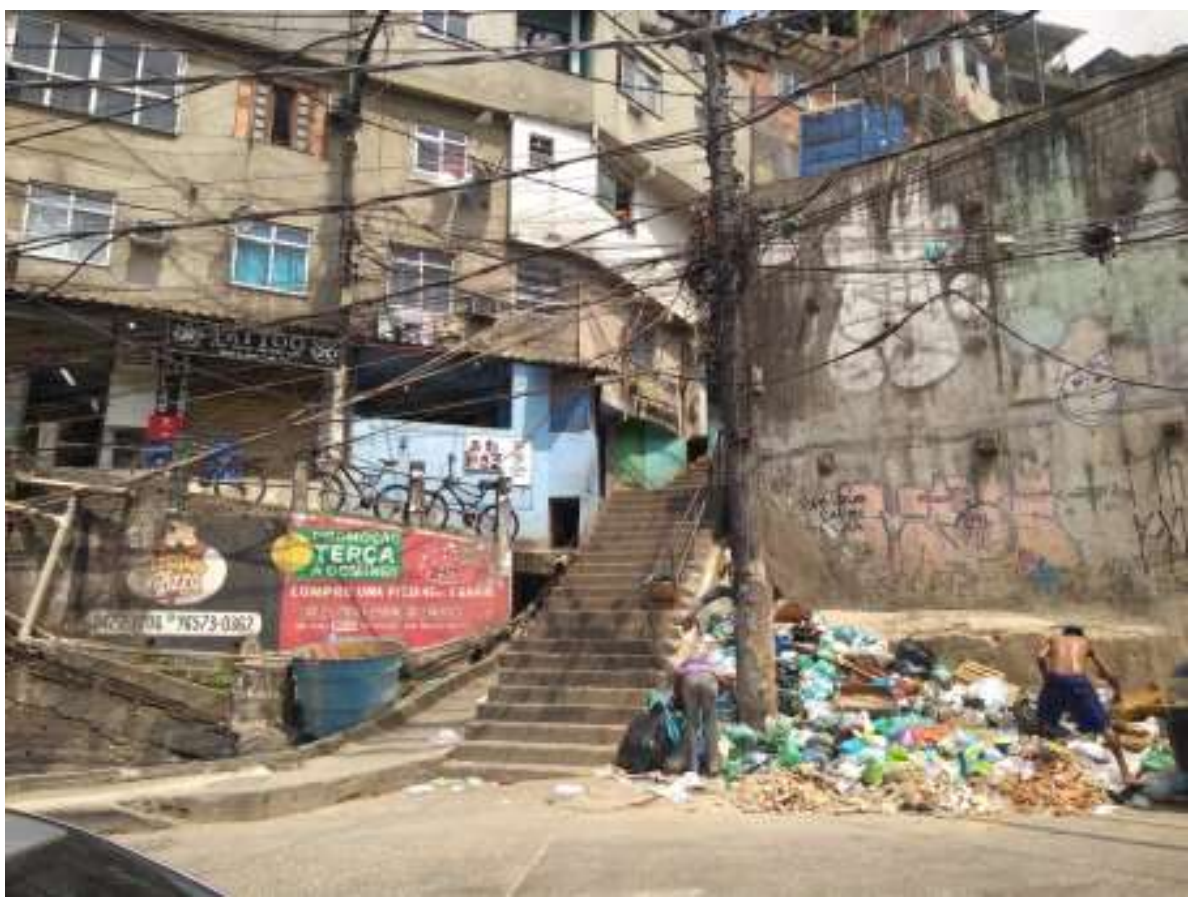

Figura 65 - Catadores catando material reciclável - ponto de coleta escadão da Vila Verde

Fonte: Maria Izabel de Carvalho, mar. 2021. 


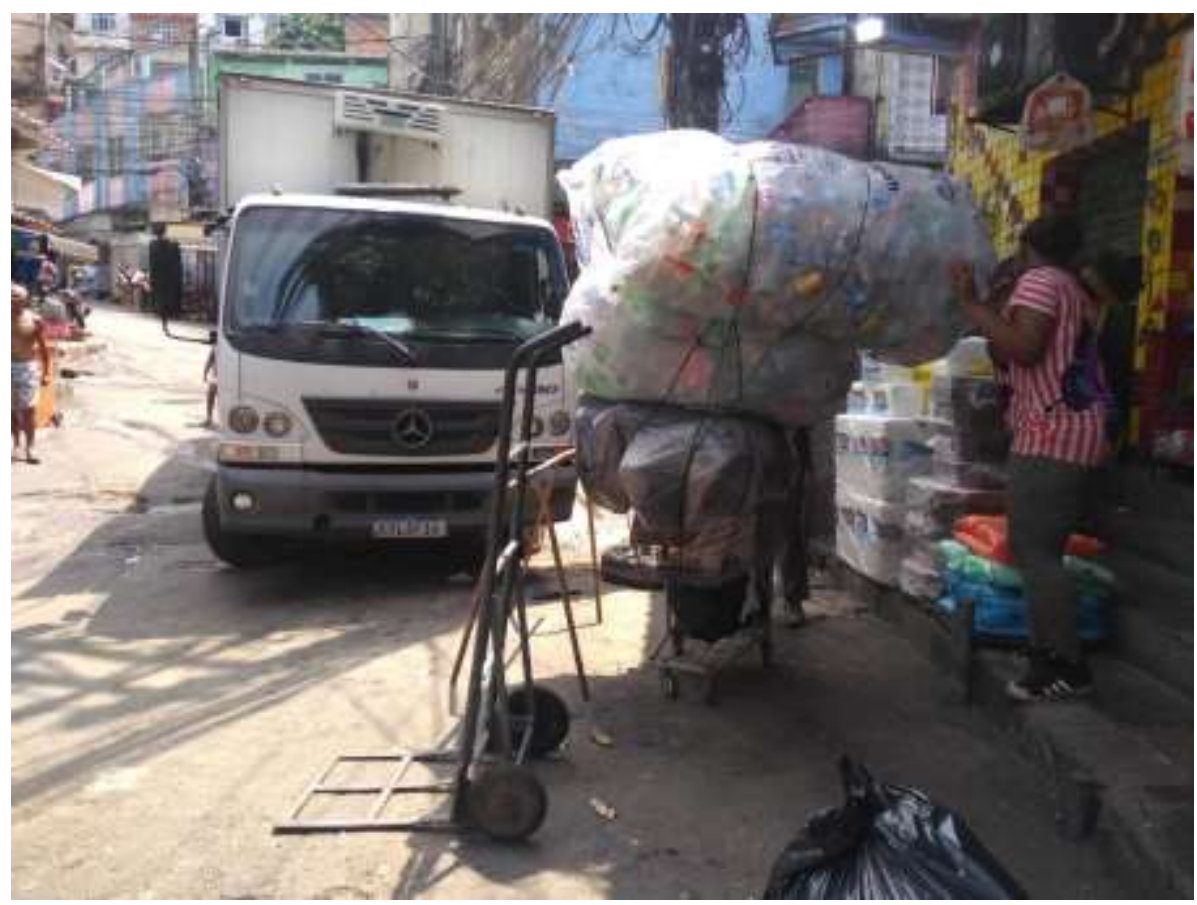

Figura 66 - Catadoras fazendo o manejo do material reciclável. Fonte: Maria Izabel de Carvalho, mar. 2021.

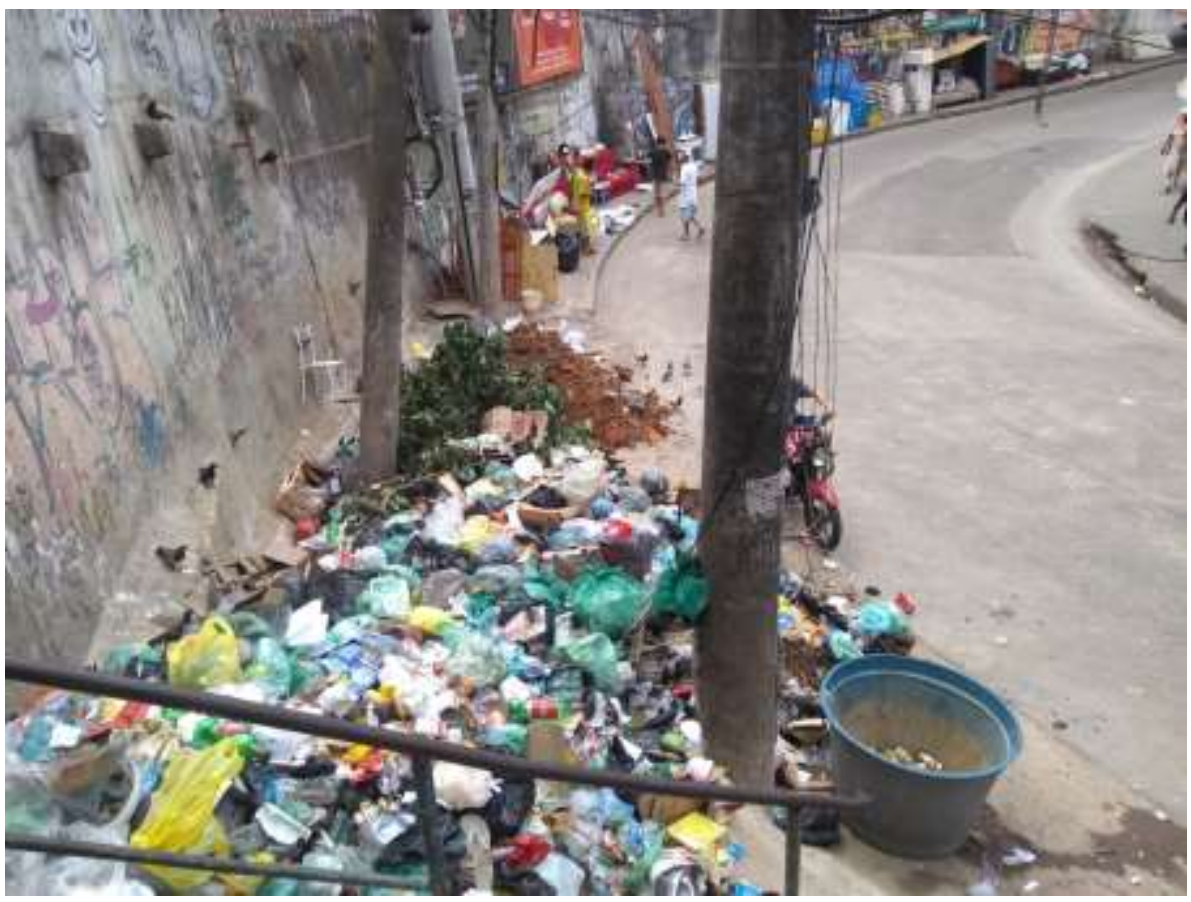

Figura 67- Recipiente improvisado por catadores para depósito de material reciclável pelos moradores - ponto de coleta escadão da Vila Verde (não está mais no local atualmente).

Fonte: Maria Izabel de Carvalho, ago. 2020. 


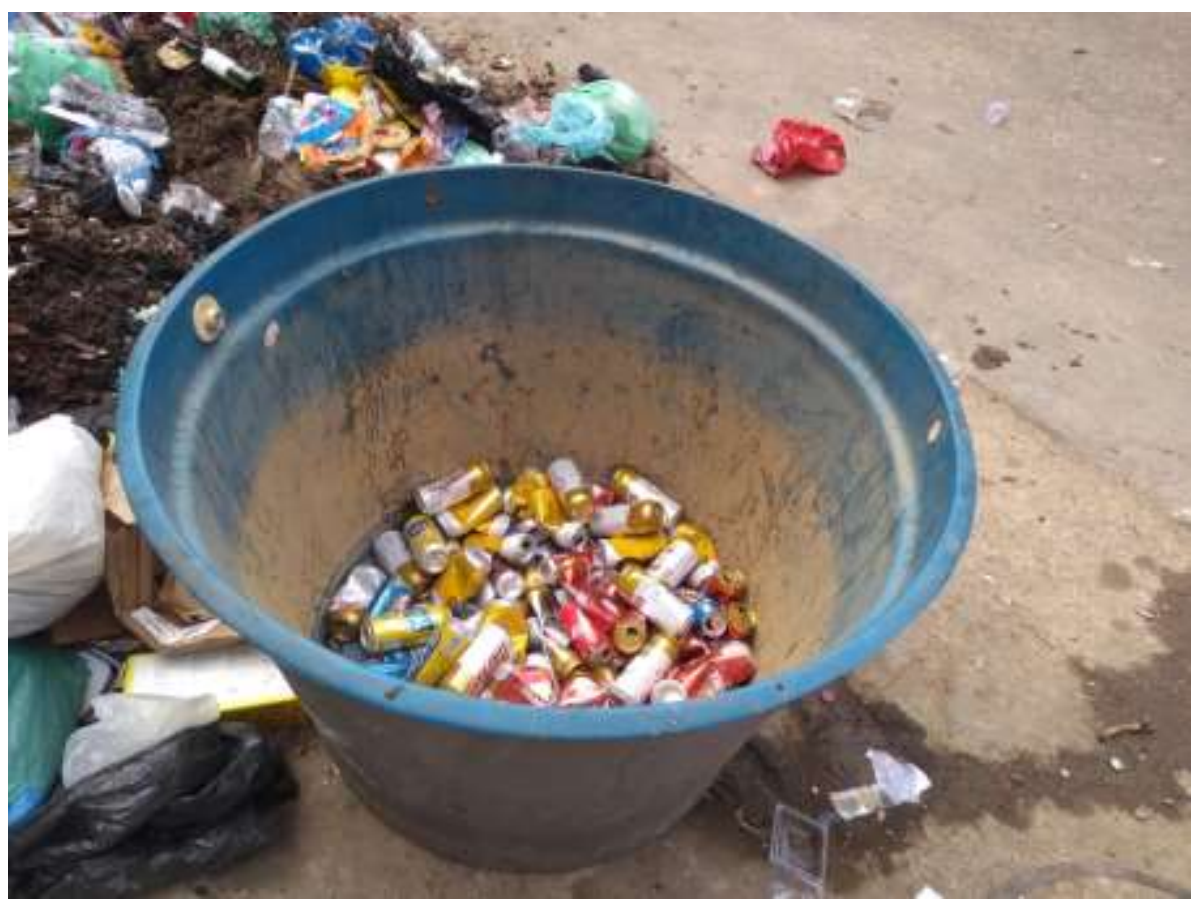

Figura 68 - Recipiente improvisado por catadores para depósito de material reciclável pelos moradores - ponto de coleta escadão da Vila Verde (não está mais no local atualmente).

Fonte: Maria Izabel de Carvalho, ago. 2020.

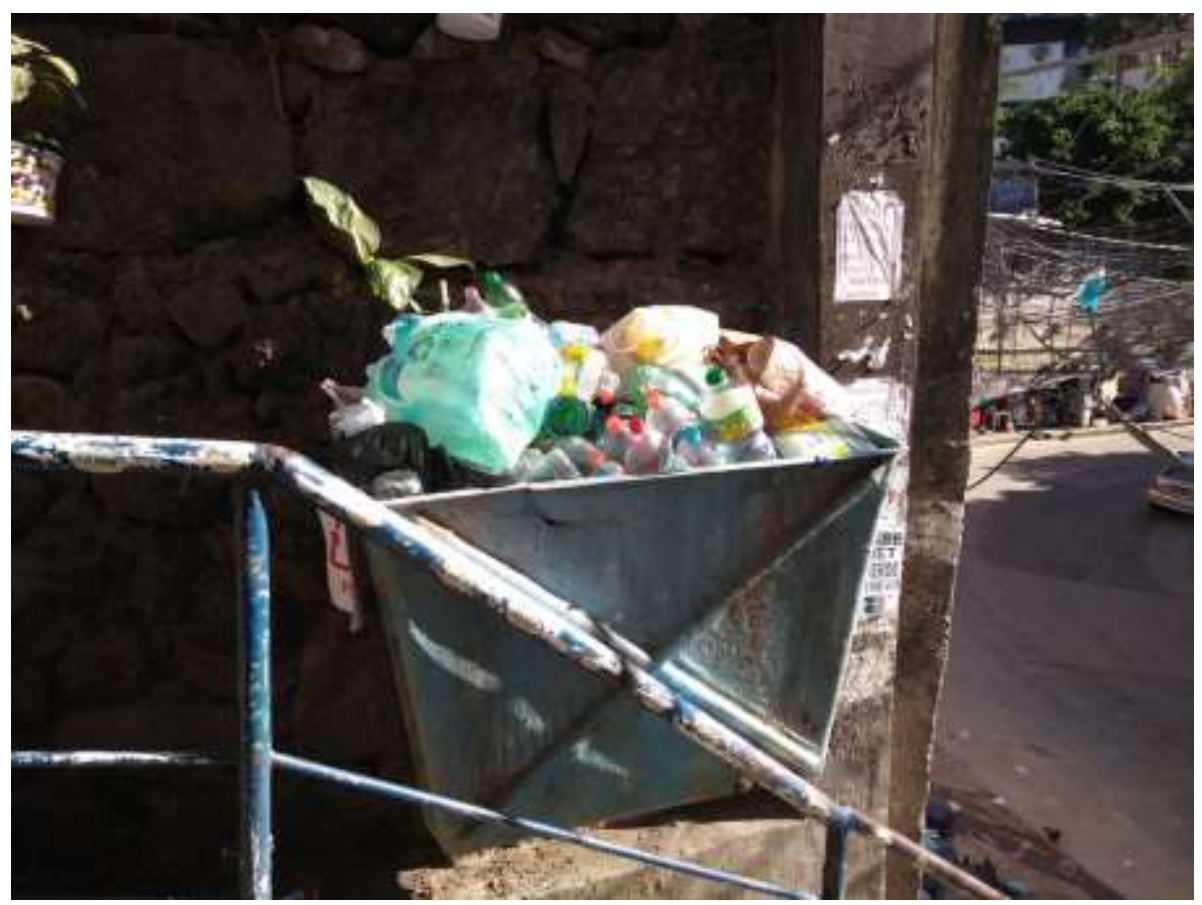

Figura 69 - Recipiente improvisado por catadores para depósito de material reciclável pelos moradores - ponto de coleta escadão da Vila Verde (não está mais no local atualmente).

Fonte: Maria Izabel de Carvalho, fev. 2021. 


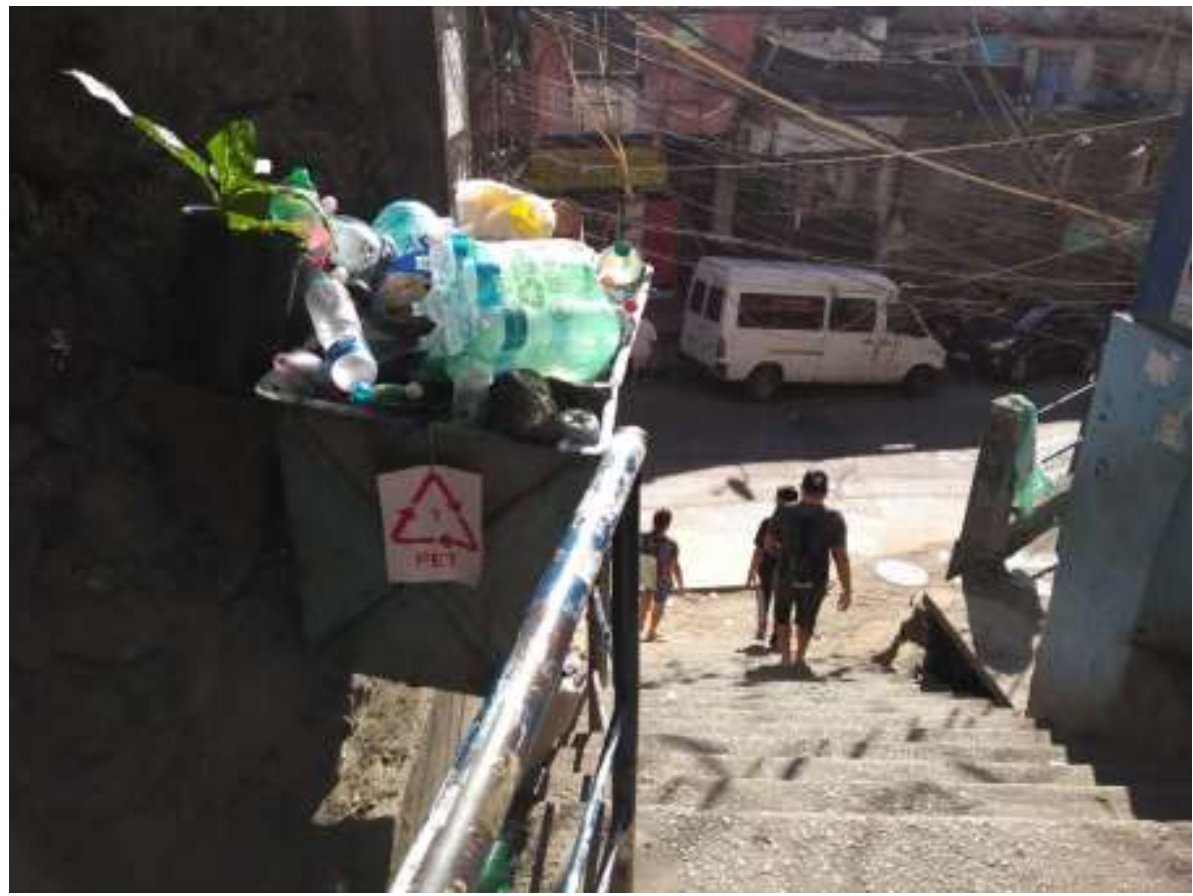

Figura 70 - Recipiente improvisado por catadores para depósito de material reciclável pelos moradores - ponto de coleta escadão da Vila Verde (não está mais no local atualmente).

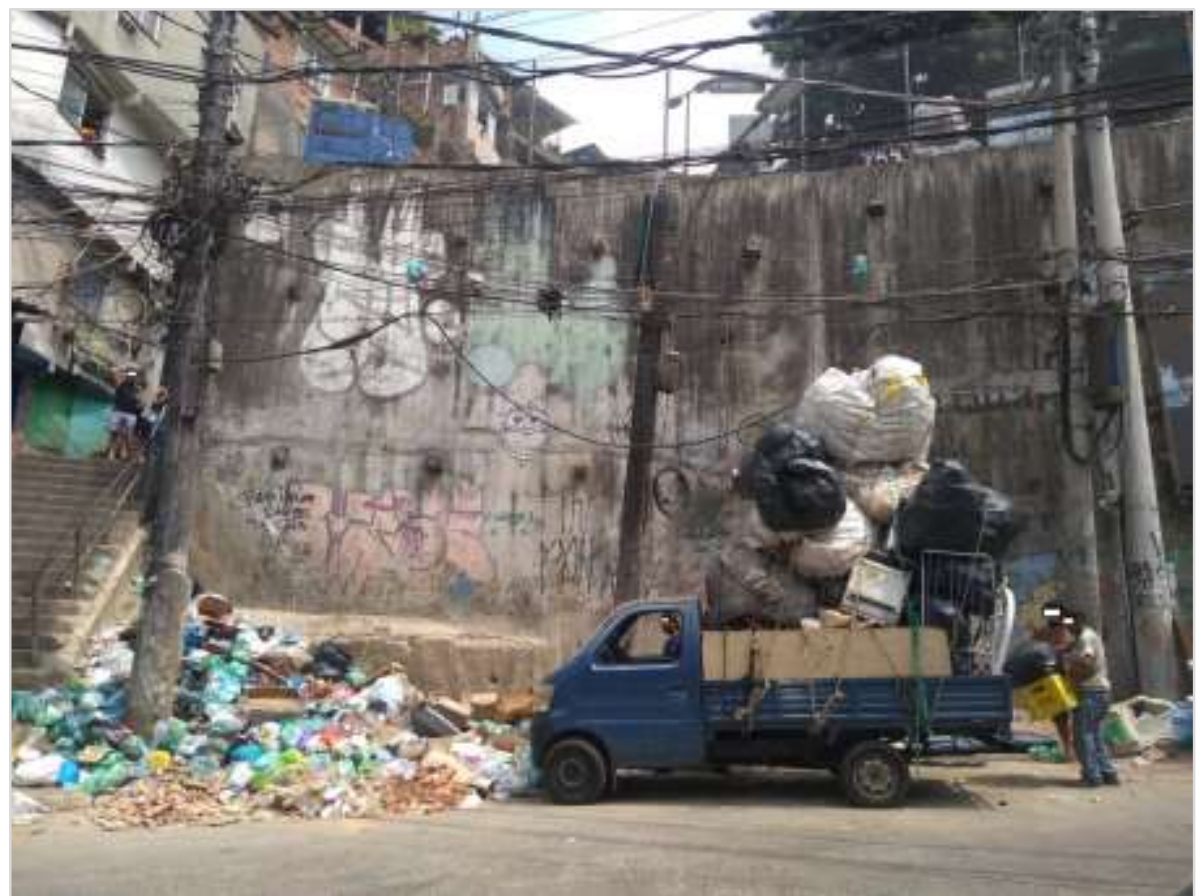

Figura 71 - Comercialização de material reciclável com compradores que vêm de outros bairros - ponto de coleta escadão da Vila Verde.

Fonte: Maria Izabel de Carvalho, mar. 2021. 


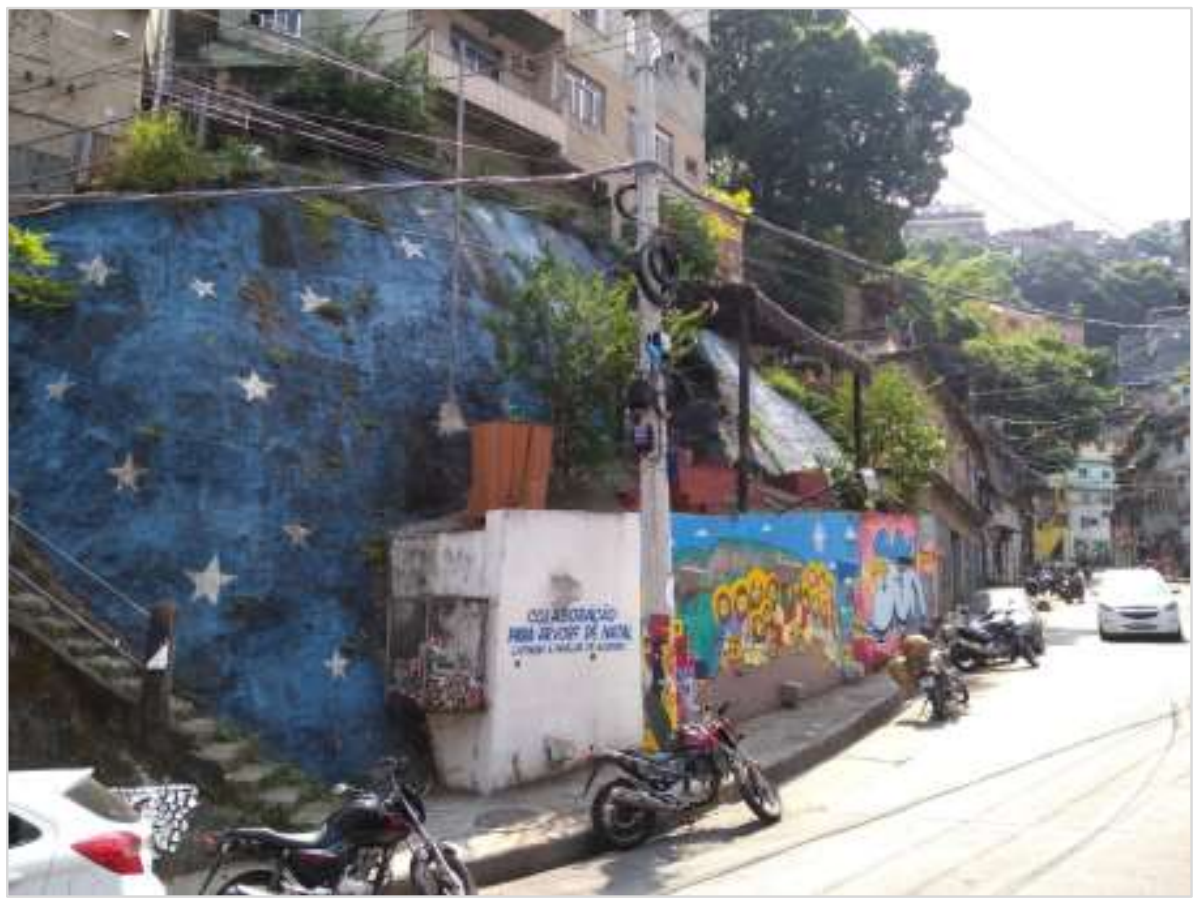

Figura 72 - Arrecadação de latinhas e panelas de alumínio para venda e montagem da árvore de natal neste local - sub-bairro Sete.

U

Fonte: Maria Izabel de Carvalho, mar. 2021.

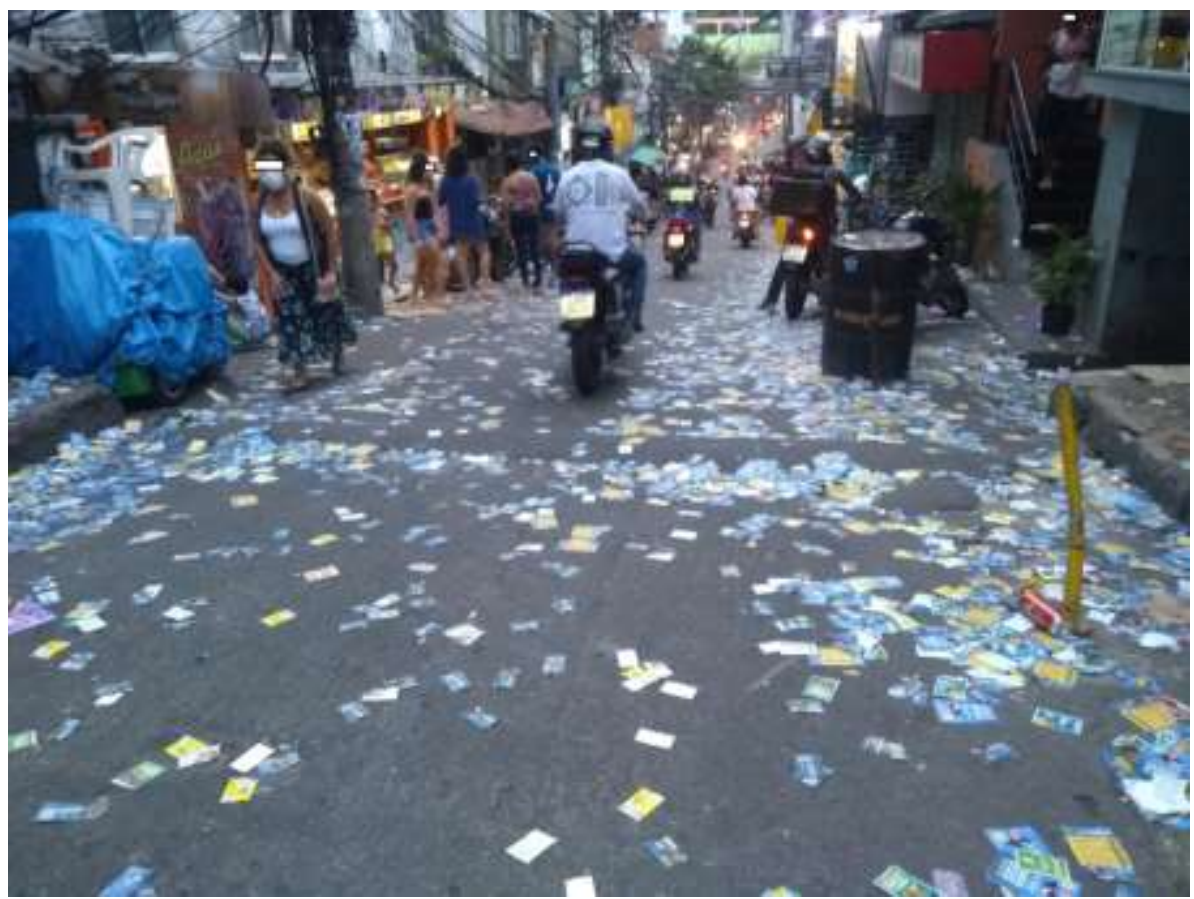

Figura 73 - Ruas da Rocinha em dia de votação - eleições de 2020 - Via Ápia. Fonte: Maria Izabel de Carvalho, nov. 2020. 
7.14 .

Apêndice 14 - Documento fotográfico de Siloé

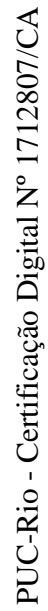

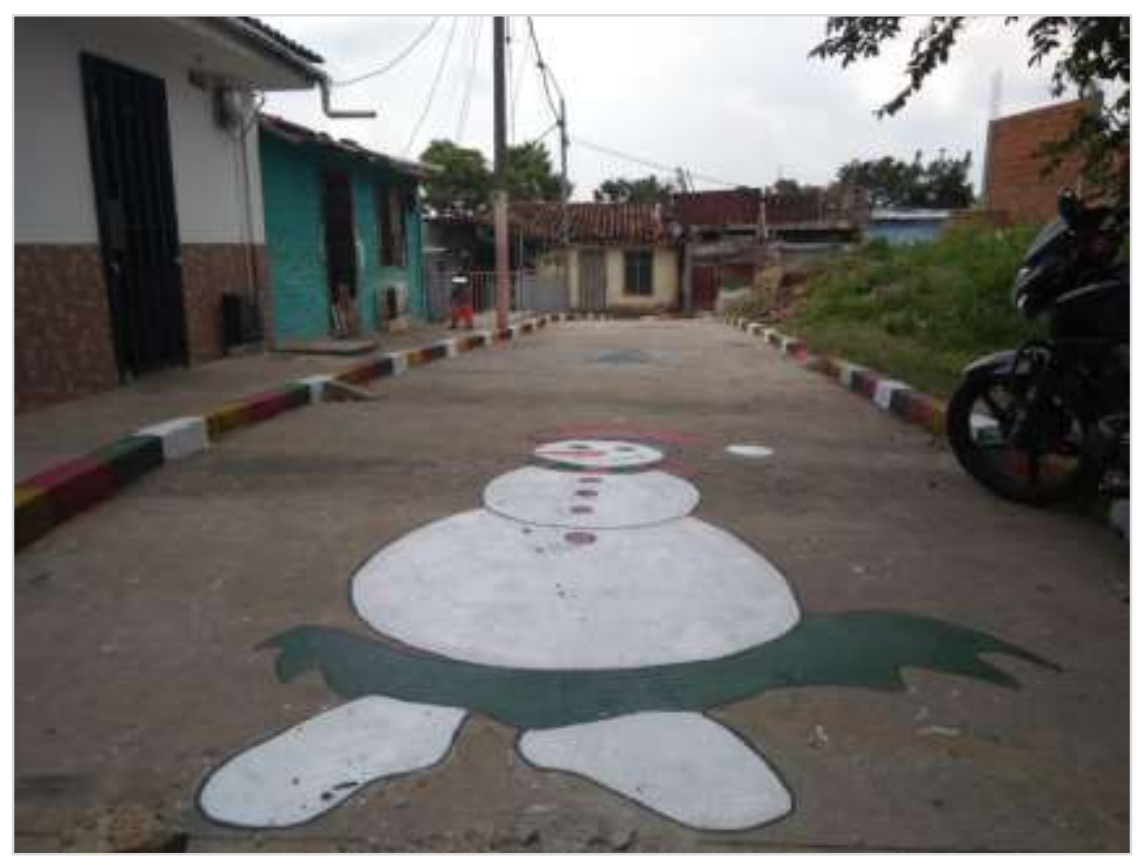

Figura 74 - Rua em La Estrella - parte alta. Fonte: Maria Izabel de Carvalho, dez. 2019.

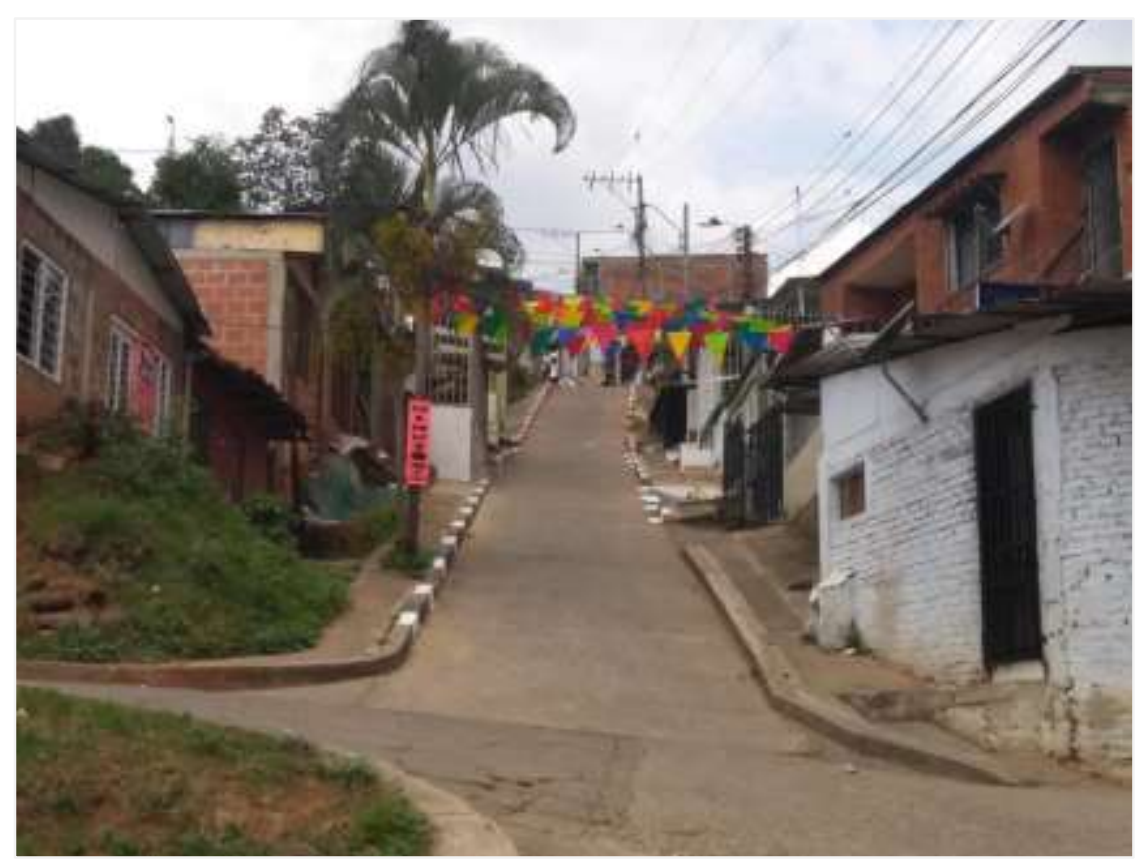

Figura 75 - Rua em La Estrella - parte alta.

Fonte: Maria Izabel de Carvalho, dez. 2019. 


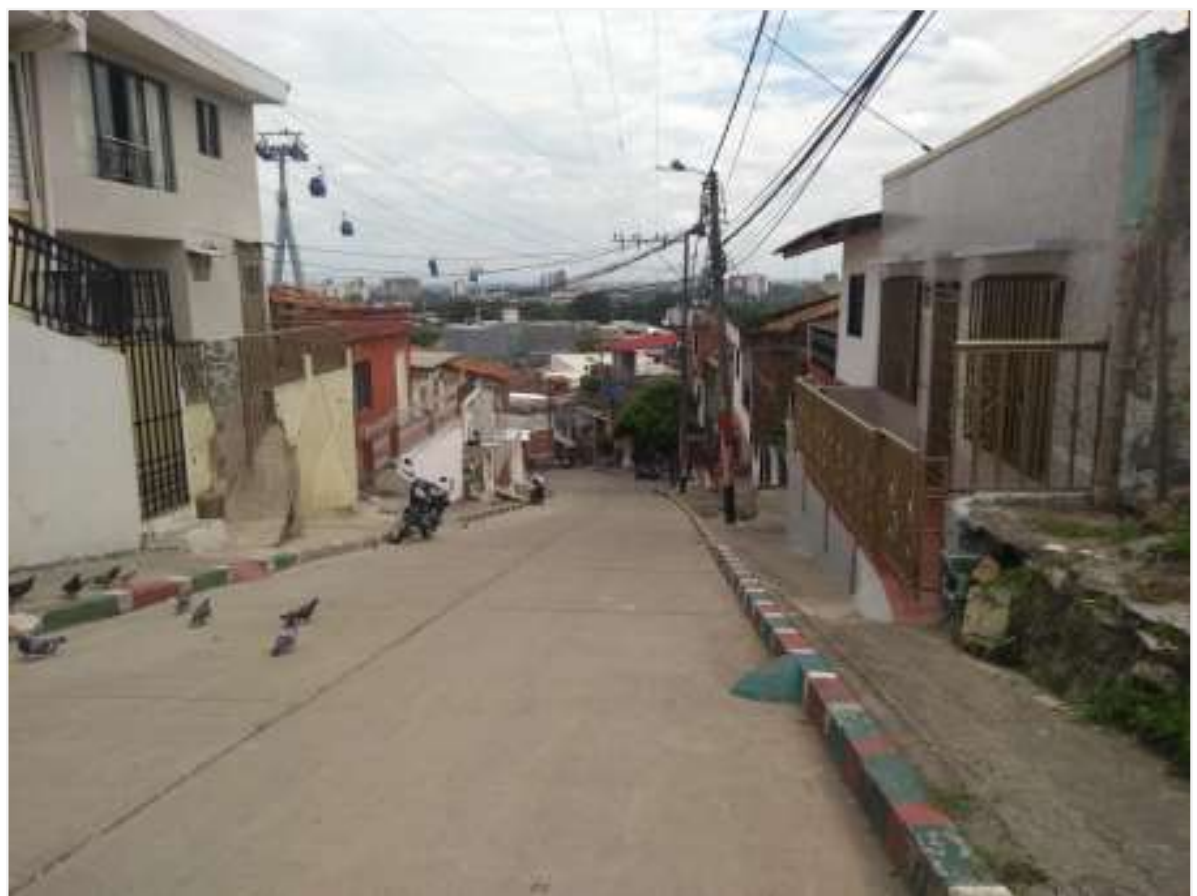

Figura 76 - Rua no Sector Los Pomos - parte baixa.

Fonte: Maria Izabel de Carvalho, out. 2019.

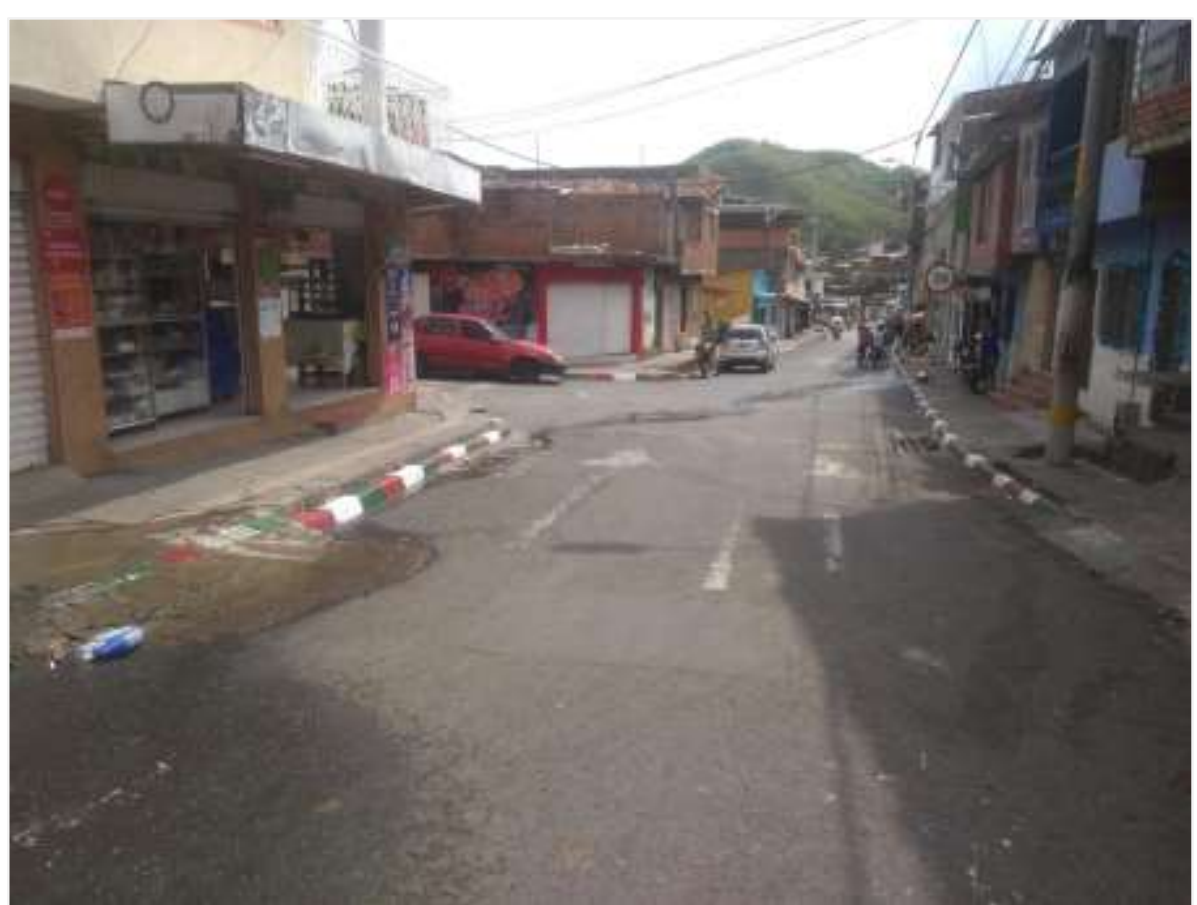

Figura 77 - Rua no bairro El Cortijo - parte baixa.

Fonte: Maria Izabel de Carvalho, dez. 2019. 


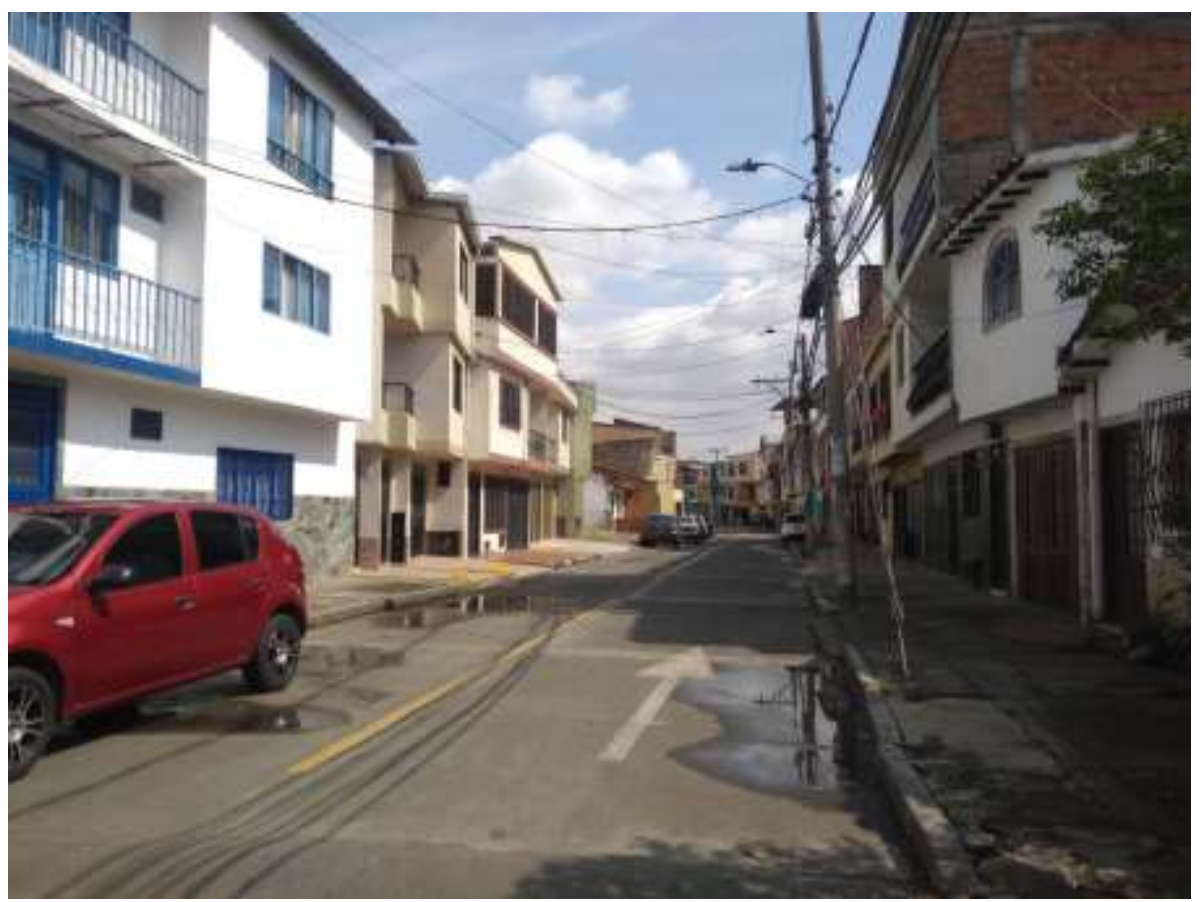

Figura 78 - Rua no bairro Belisário Caicedo - parte baixa. Fonte: Maria Izabel de Carvalho, dez. 2019.

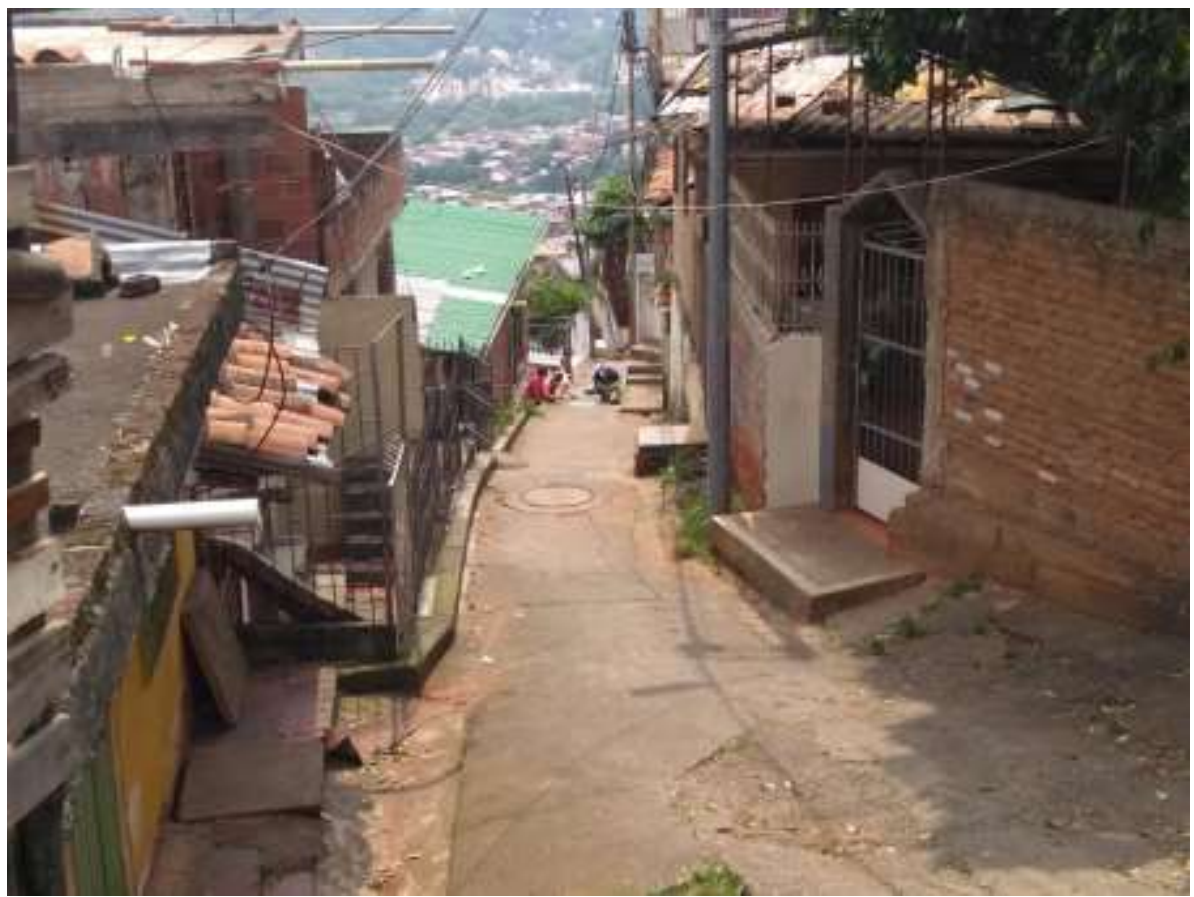

Figura 79 - Viela em Lleras Camarga - parte alta.

Fonte: Maria Izabel de Carvalho, dez. 2019. 


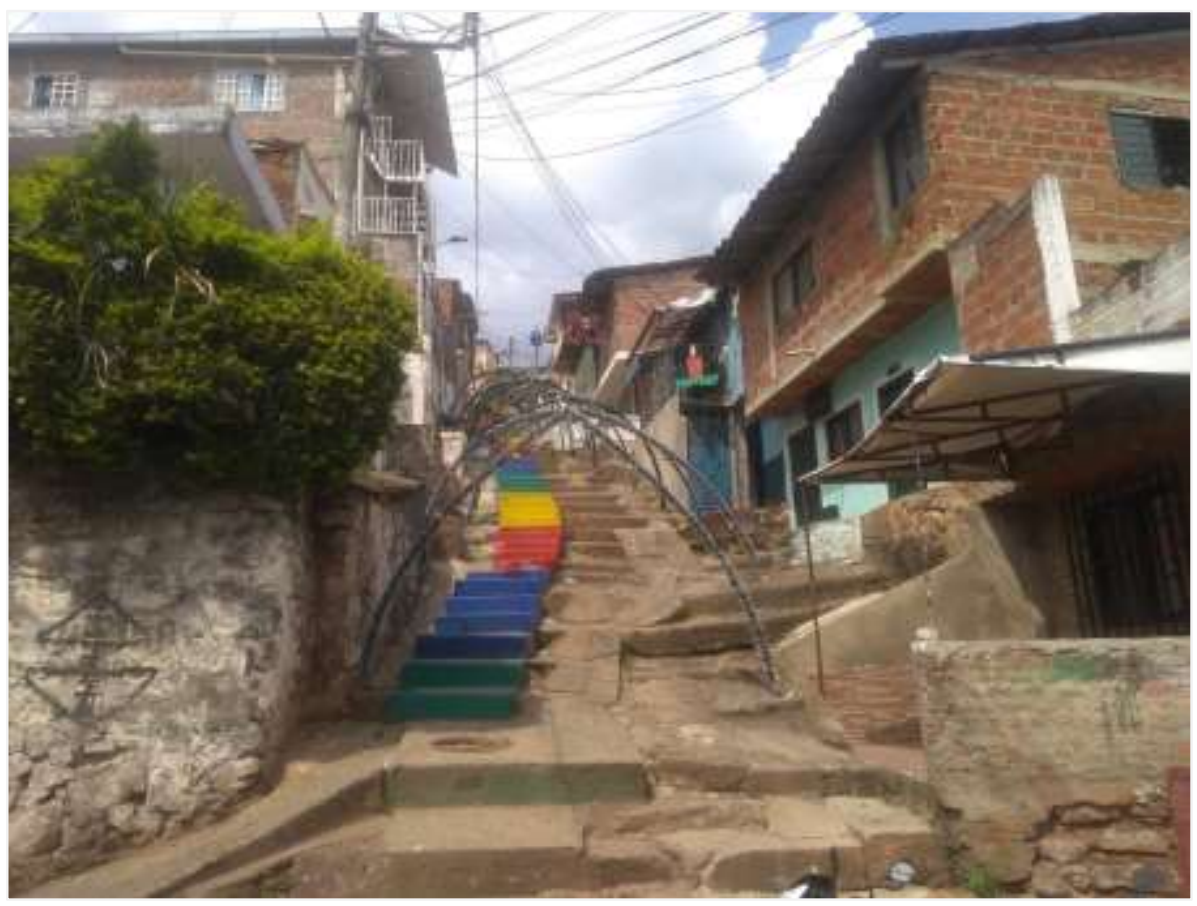

Figura 80 - Escadaria em Lleras Camargo - parte alta. Fonte: Maria Izabel de Carvalho, dez. 2019.

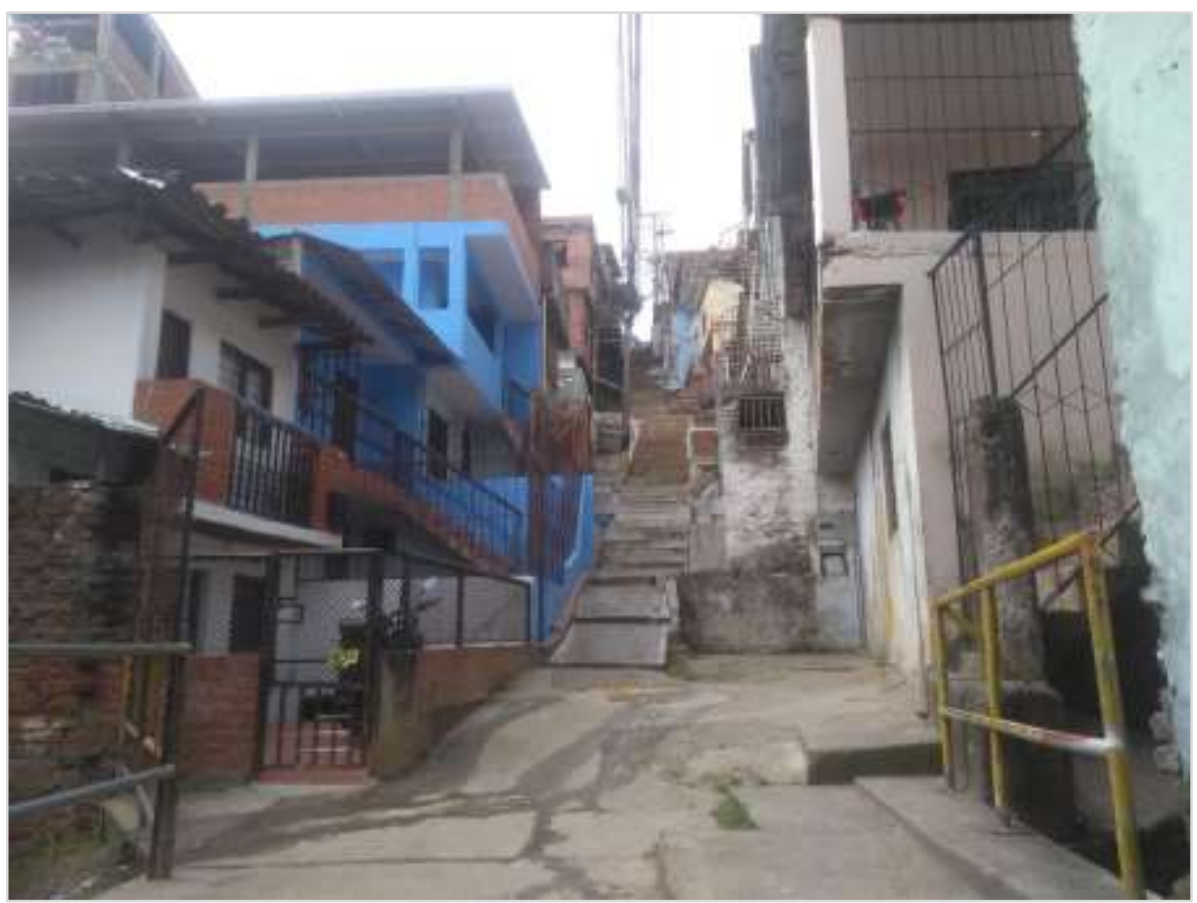

Figura 81 - Escadarias em El Cortijo - parte baixa. Fonte: Maria Izabel de Carvalho, dez. 2019. 


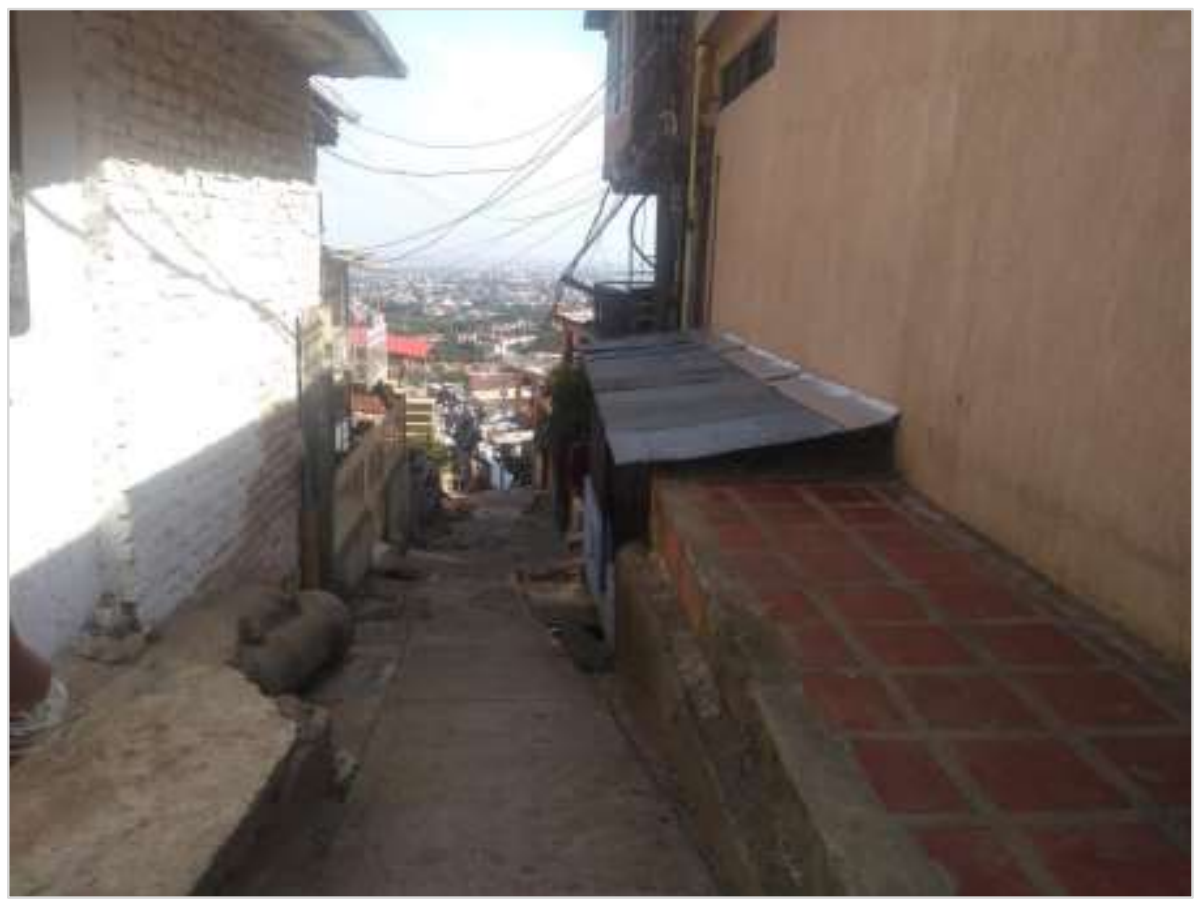

Figura 82 - Beco em Brisas de Mayo - parte alta. Fonte: Maria Izabel de Carvalho, dez. 2019.

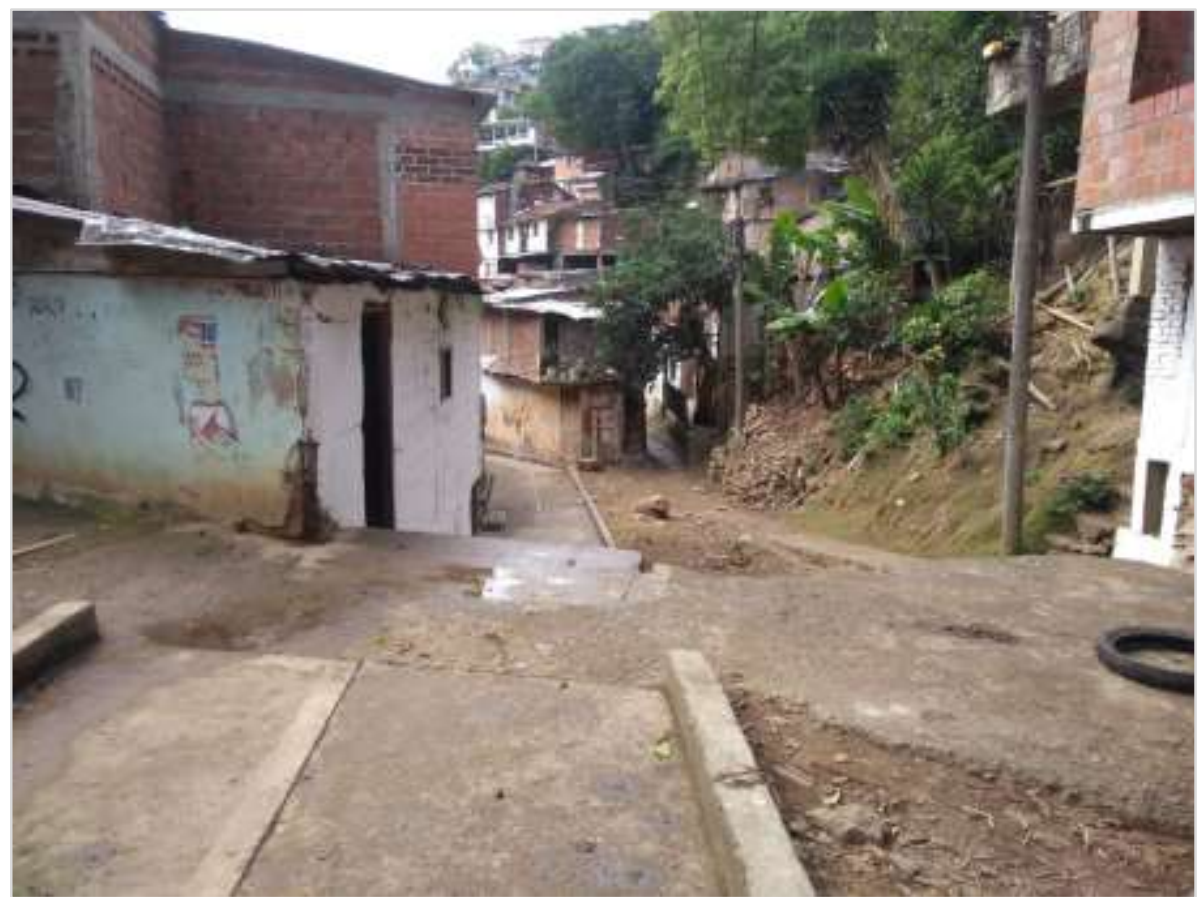

Figura 83 - Becos e vielas em San Francisco junto à quebrada Isabel Pérez. Fonte: Maria Izabel de Carvalho, fev. 2019. 


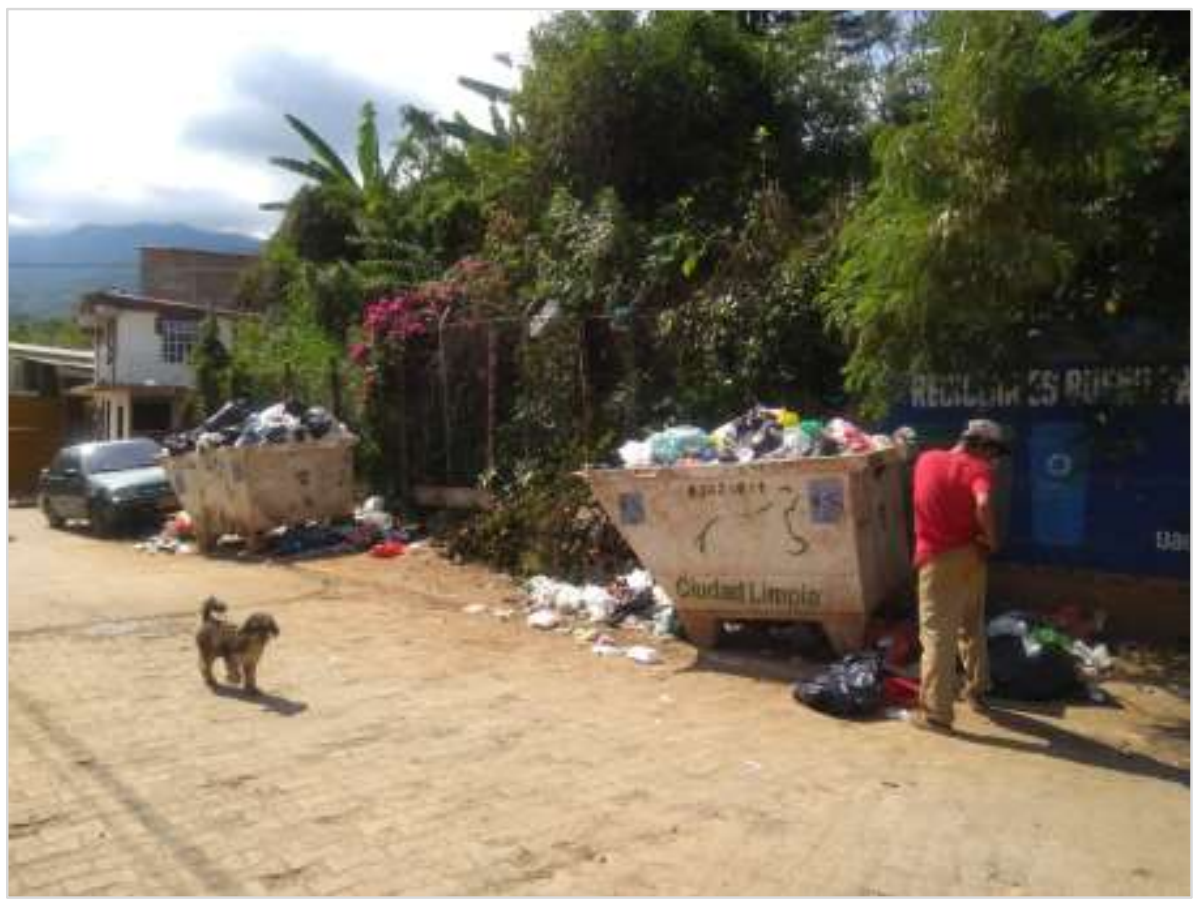

Figura 84 - Ponto de Coleta - Brisas de Mayo - parte alta - não era dia de coleta. Fonte: Maria Izabel de Carvalho, dez. 2019.

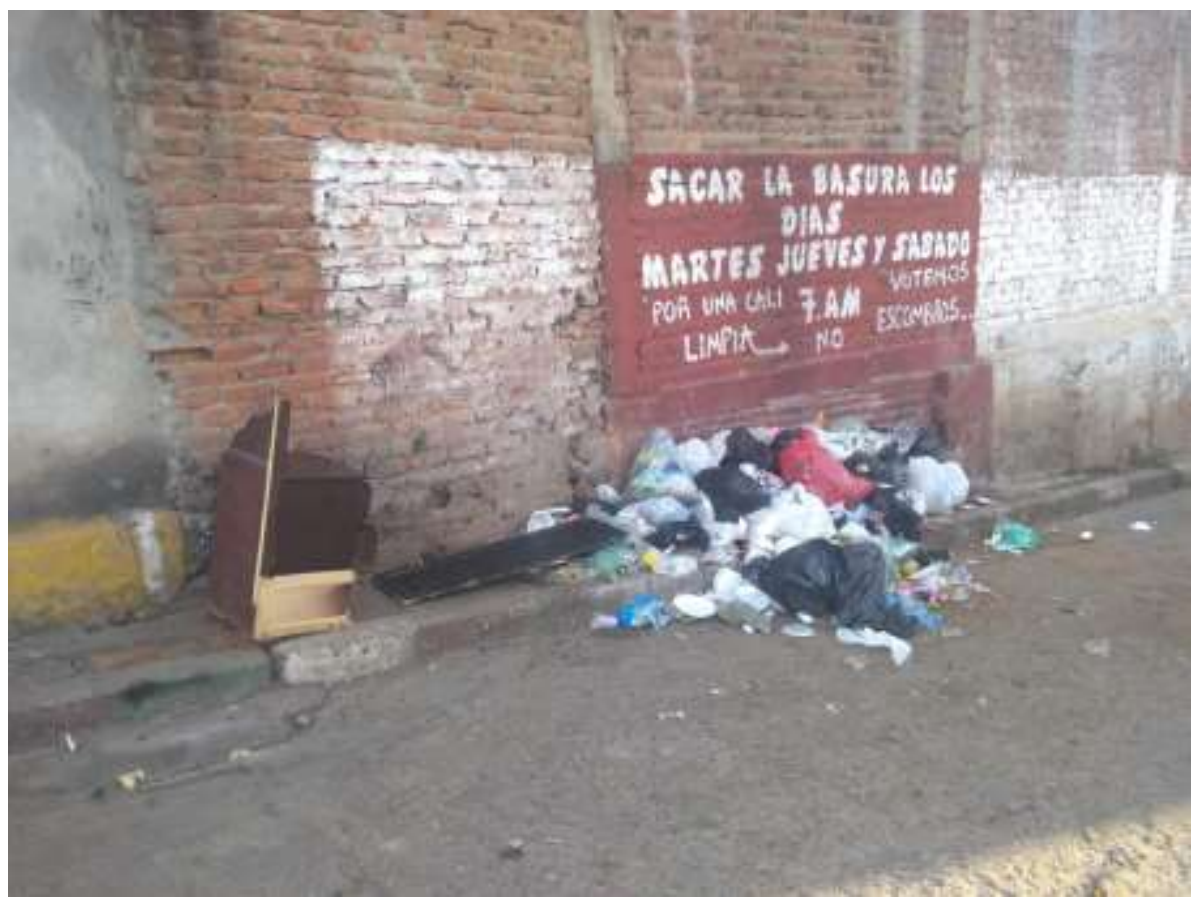

Figura 85 - Ponto de Coleta - Brisas de Mayo - parte alta - não era dia de coleta. Fonte: Maria Izabel de Carvalho, set. 2019. 


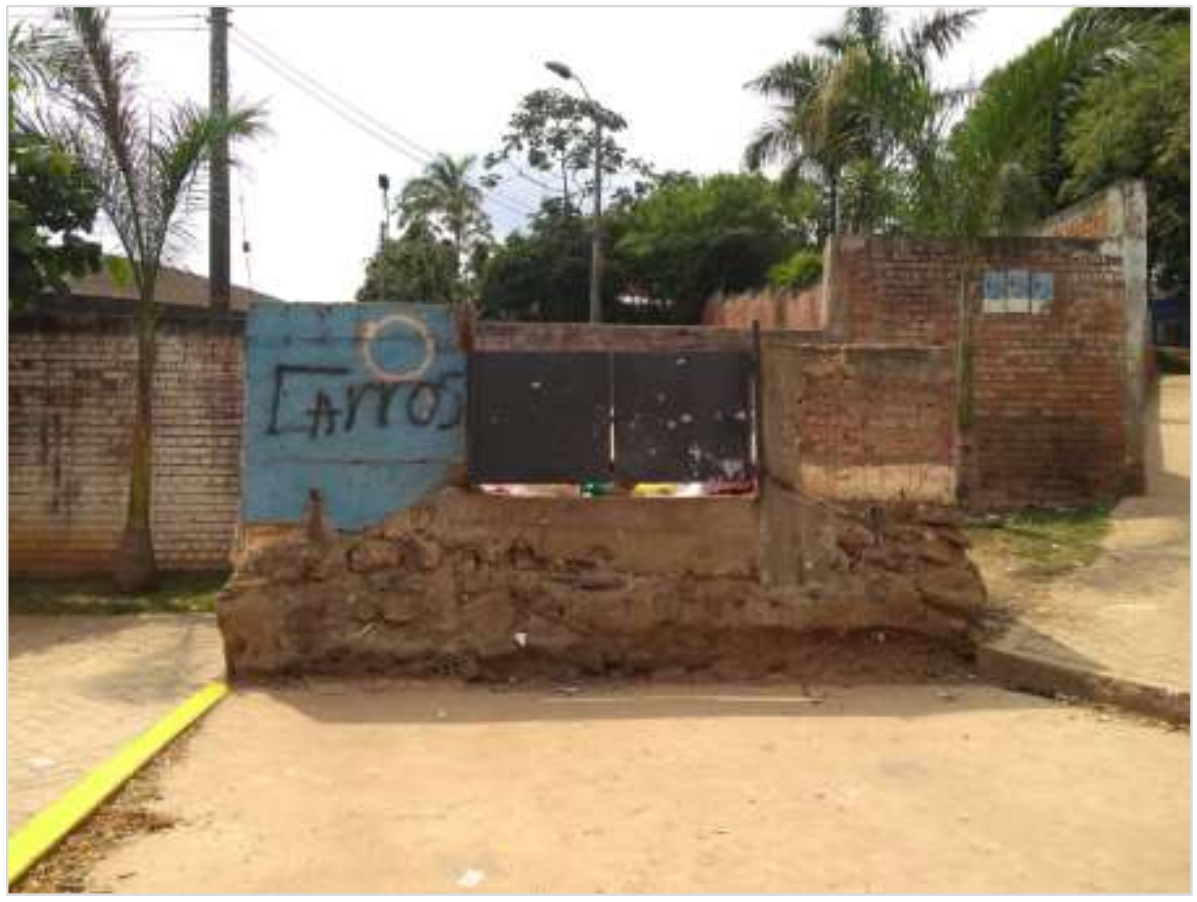

Figura 86 - Ponto de Coleta - La Estrella - parte alta.

Fonte: Maria Izabel de Carvalho, dez. 2019.

U

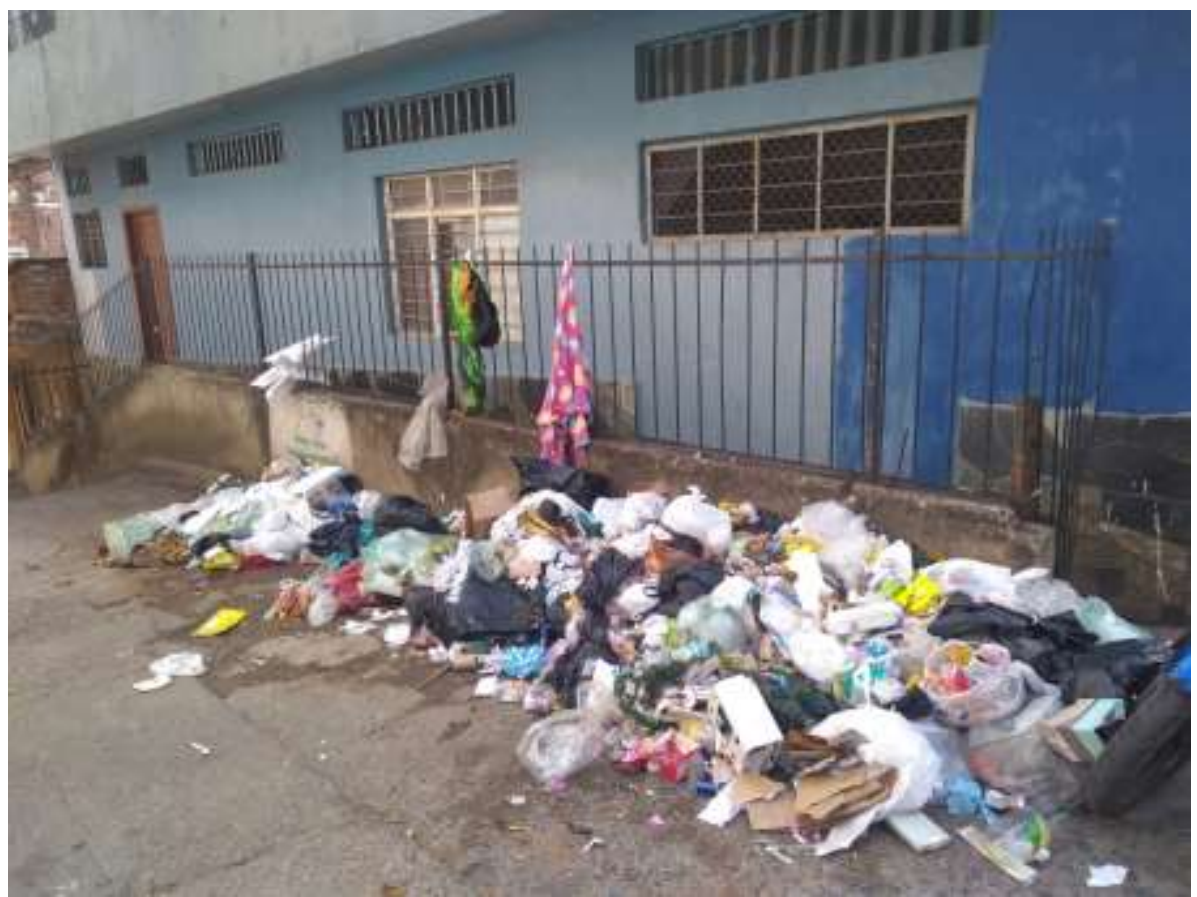

Figura 87 - Ponto de Coleta - Lleras Camargo - parte alta.

Fonte: Maria Izabel de Carvalho, ago. 2019. 


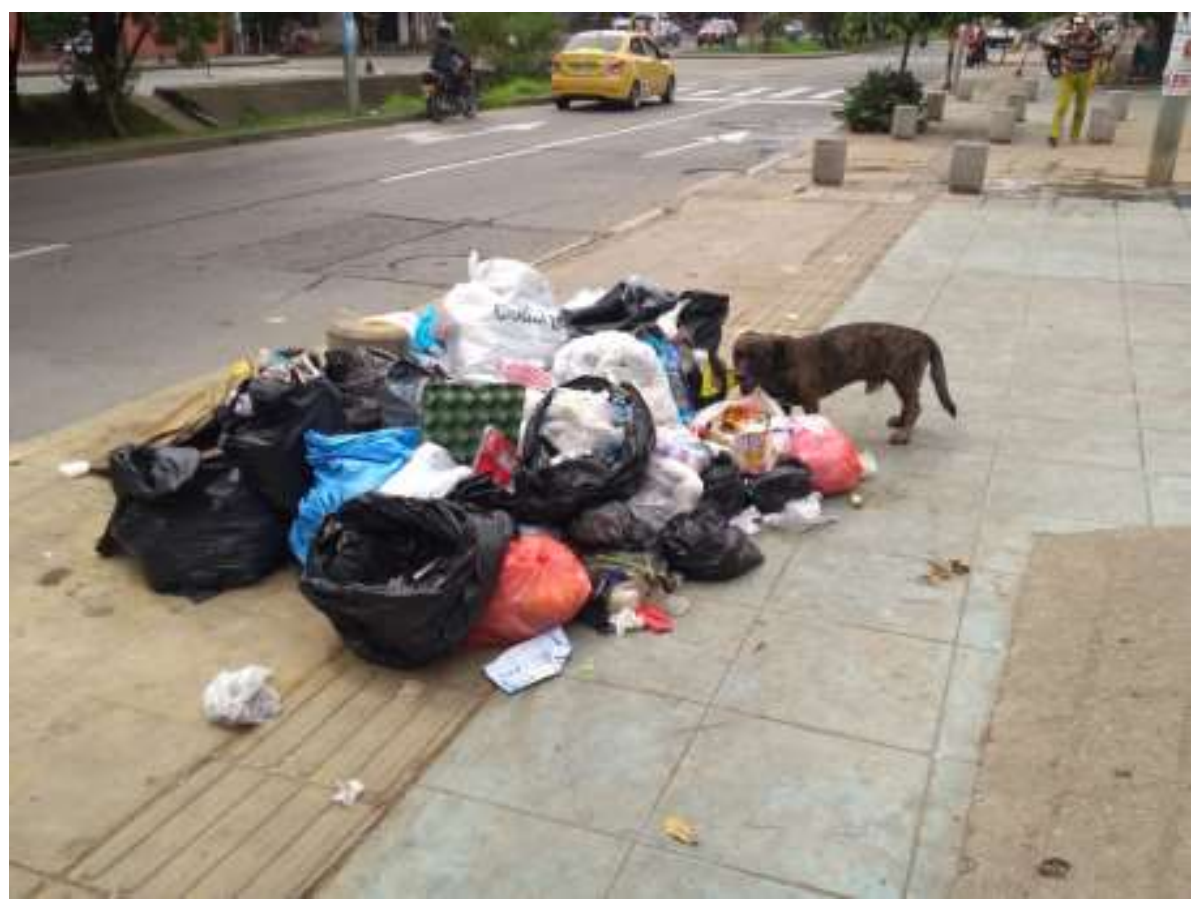

Figura 88 - Ponto de Coleta - Calle 1 - parte baixa - dia de coleta. Fonte: Maria Izabel de Carvalho, out. 2019.

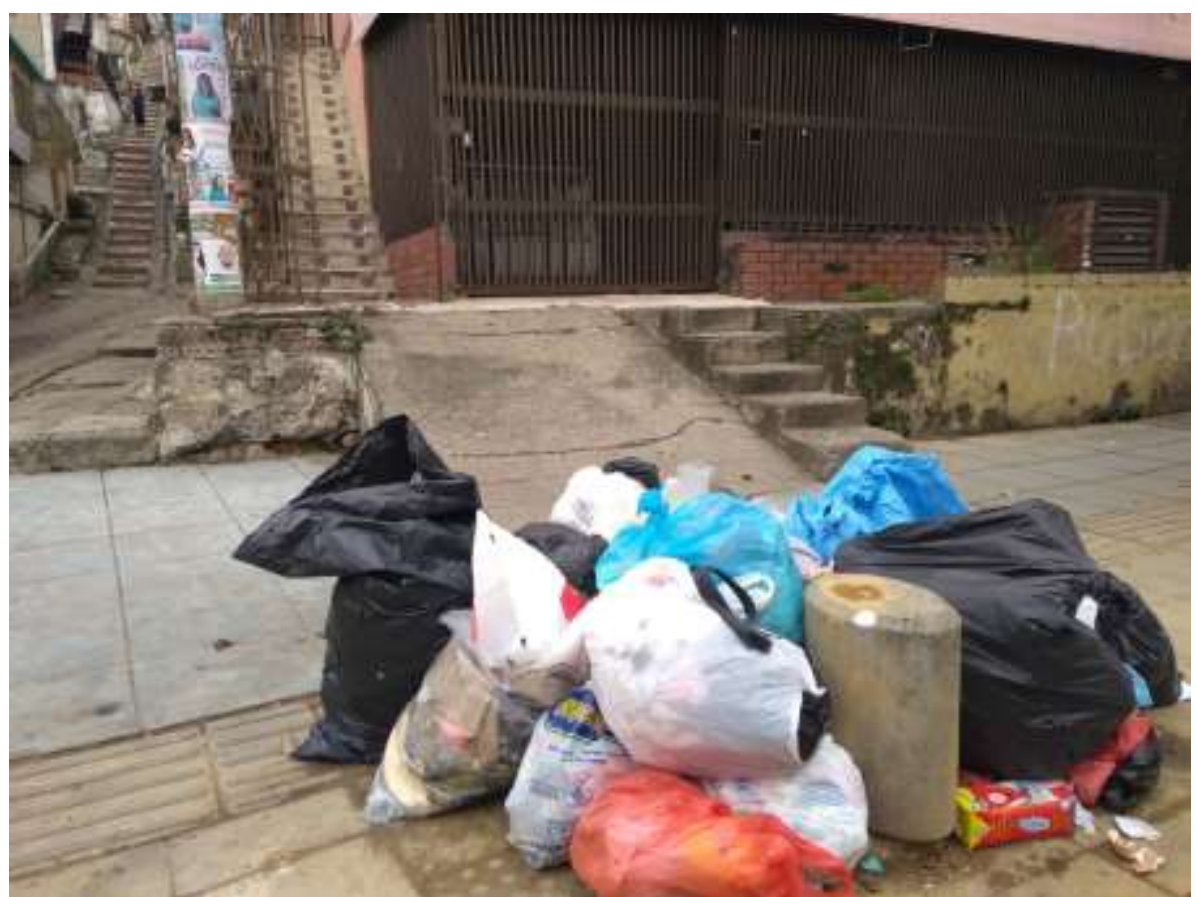

Figura 89 - Ponto de Coleta - Calle 1 - parte baixa -- próximo a uma escadaria dia de coleta.

Fonte: Maria Izabel de Carvalho, out. 2019. 


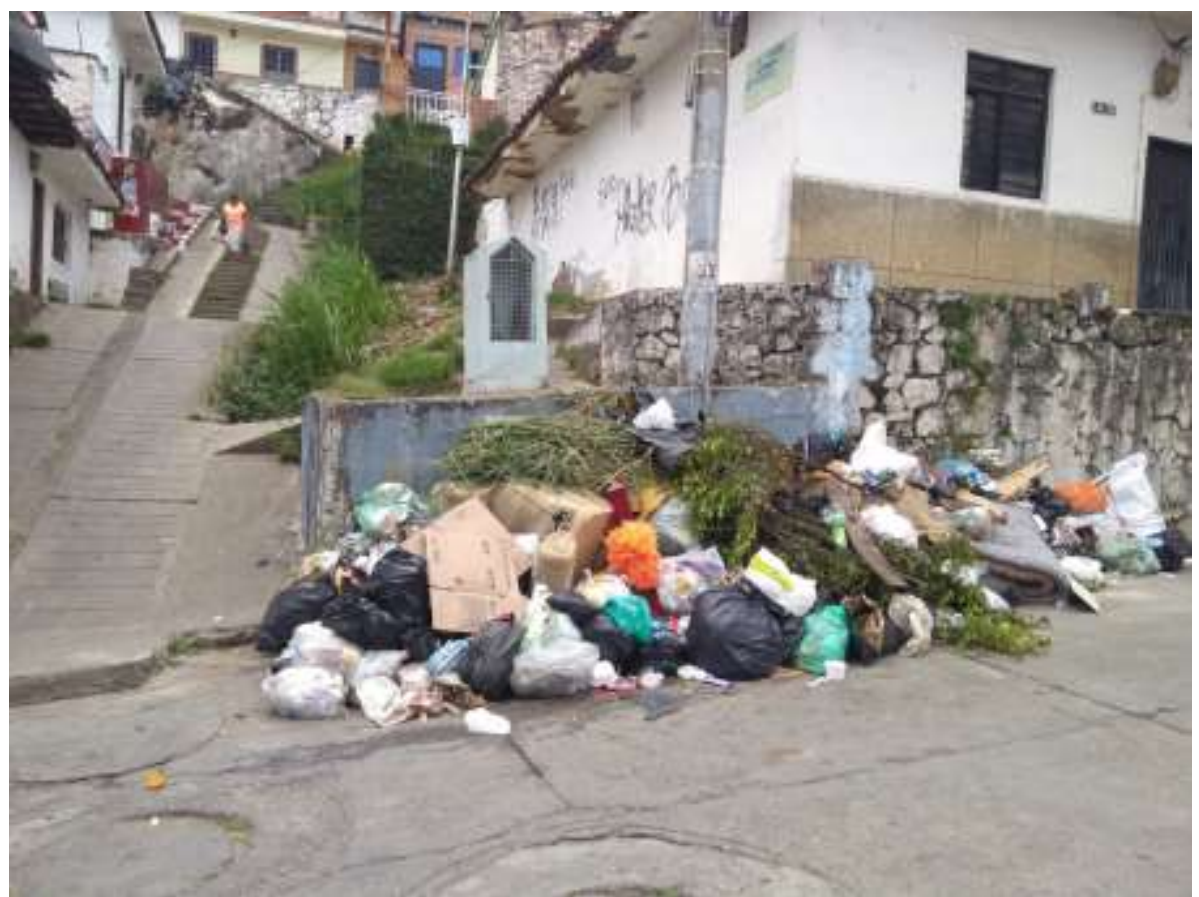

Figura 90 - Ponto de Coleta - Setor Los Pombos- parte baixa - dia de coleta. Fonte: Maria Izabel de Carvalho, out. 2019.

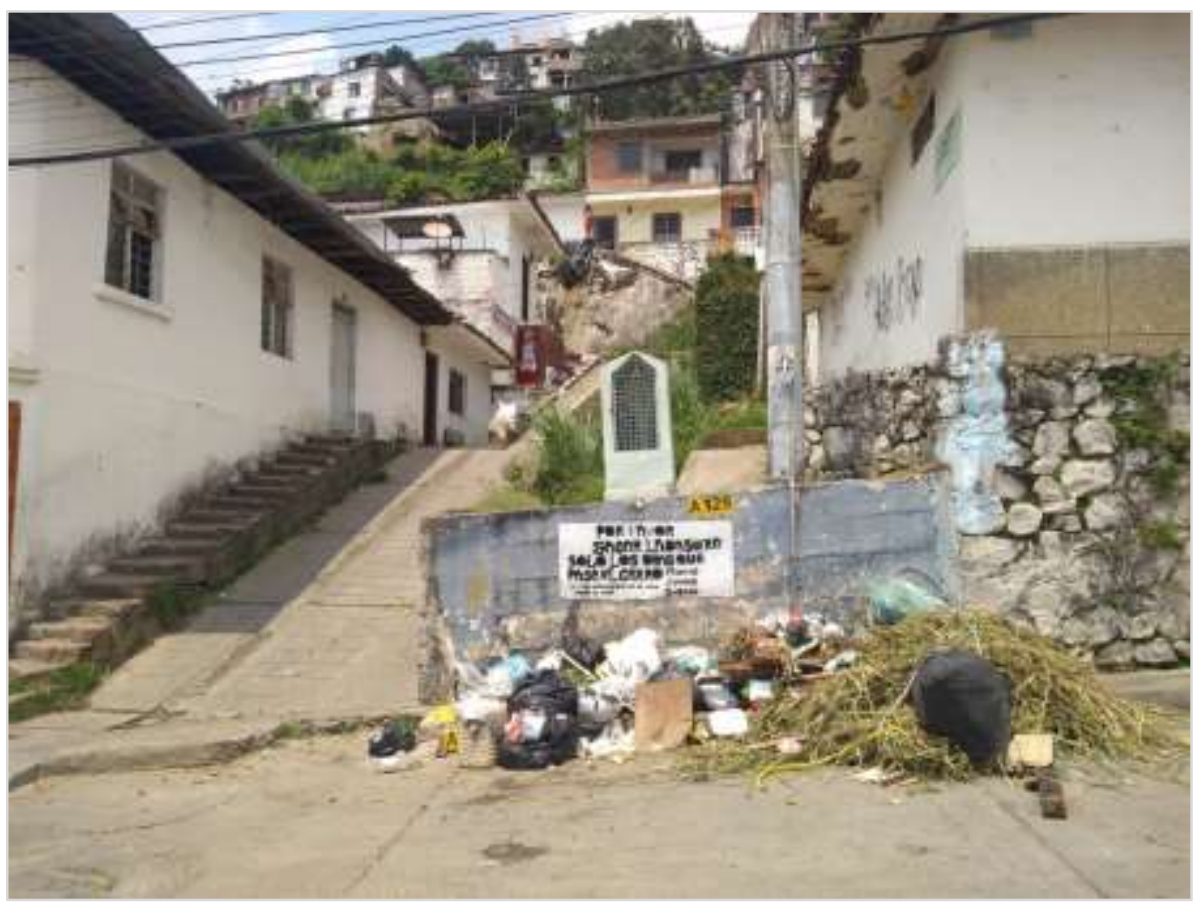

Figura 91 - Ponto de Coleta - Setor Los Pombos - não era dia de coleta. Fonte: Maria Izabel de Carvalho, out. 2019. 


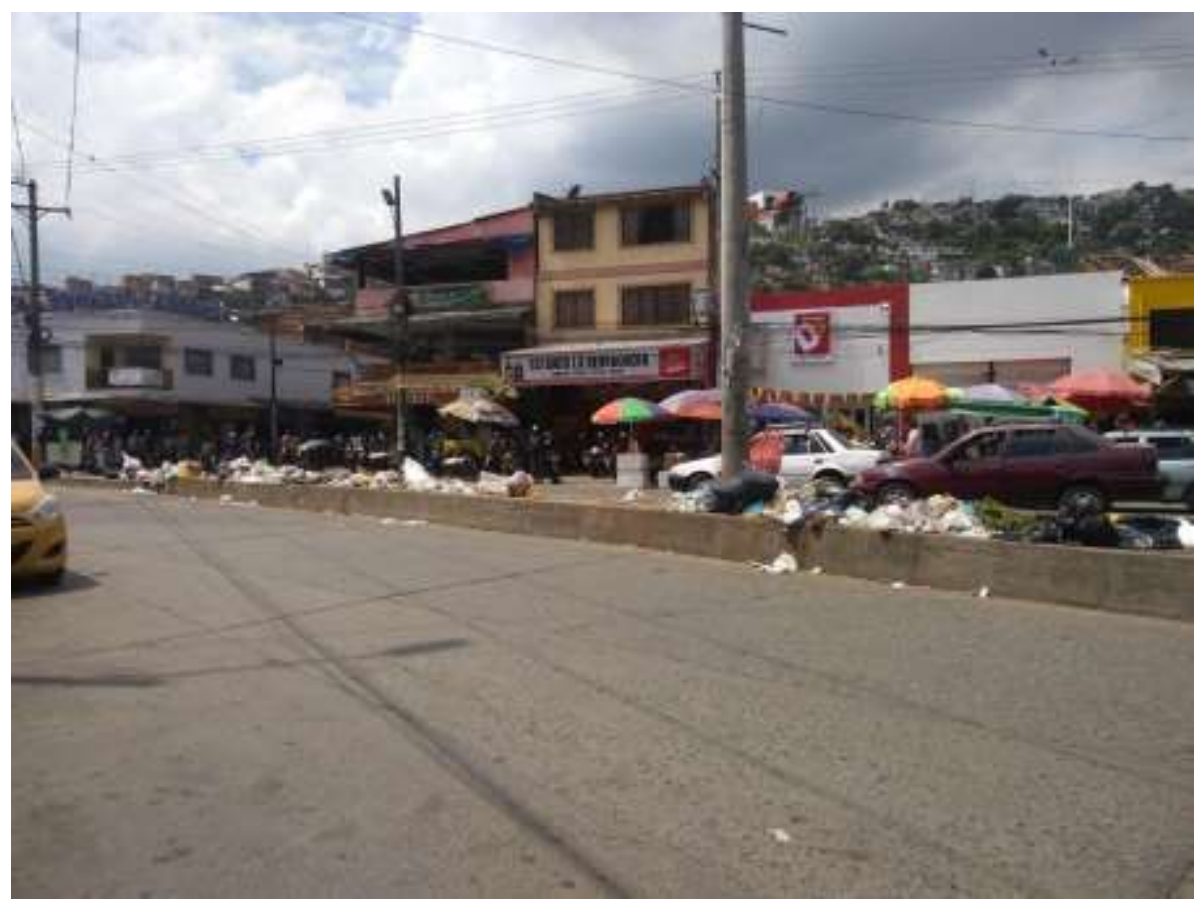

Figura 92 - Ponto de Coleta - El Separador - Diagonal 50 - área comercial de Siloé.

Fonte: Maria Izabel de Carvalho, out. 2019.

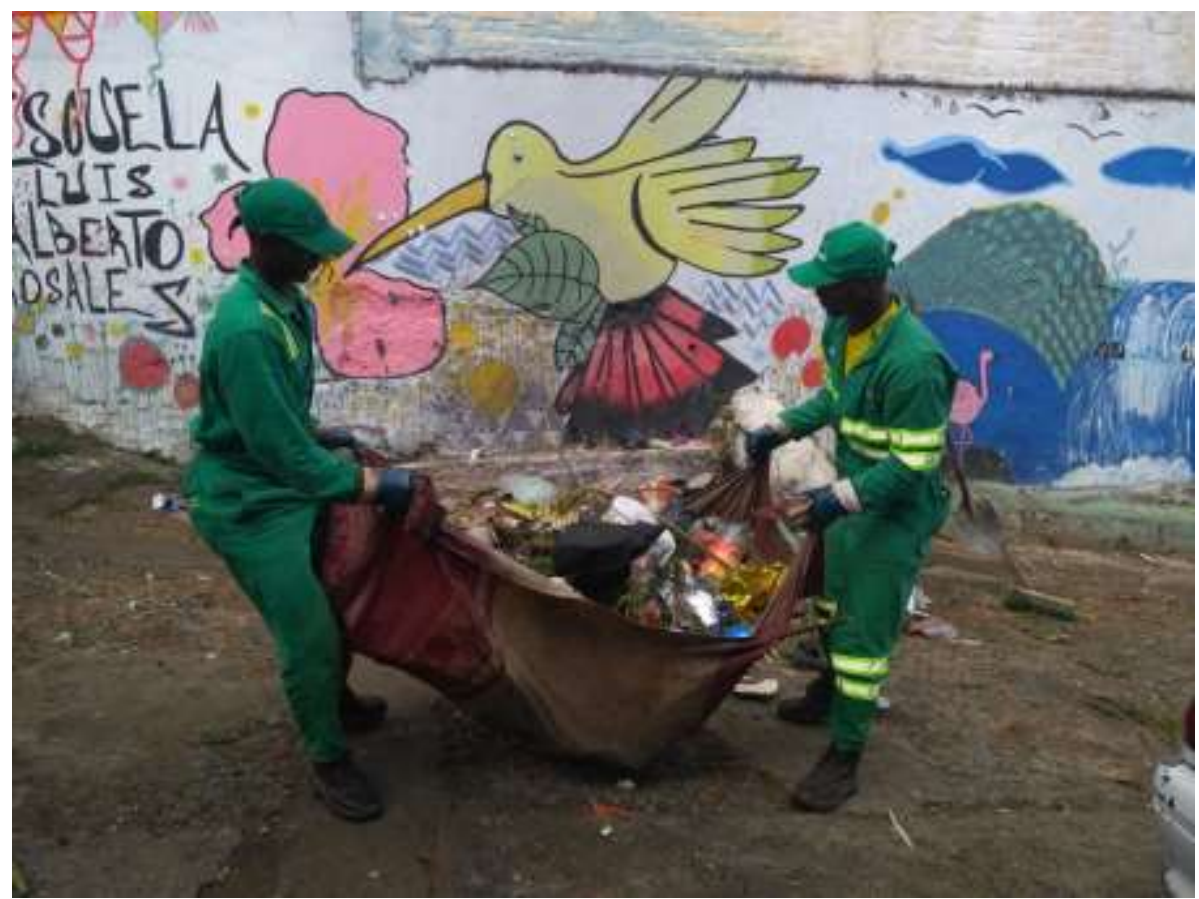

Figura 93 - Realização da coleta - Tierra Blanca - resíduo sendo retirado do chão em um pano para ser depositado no caminhão coletor.

Fonte: Maria Izabel de Carvalho, nov. 2019. 


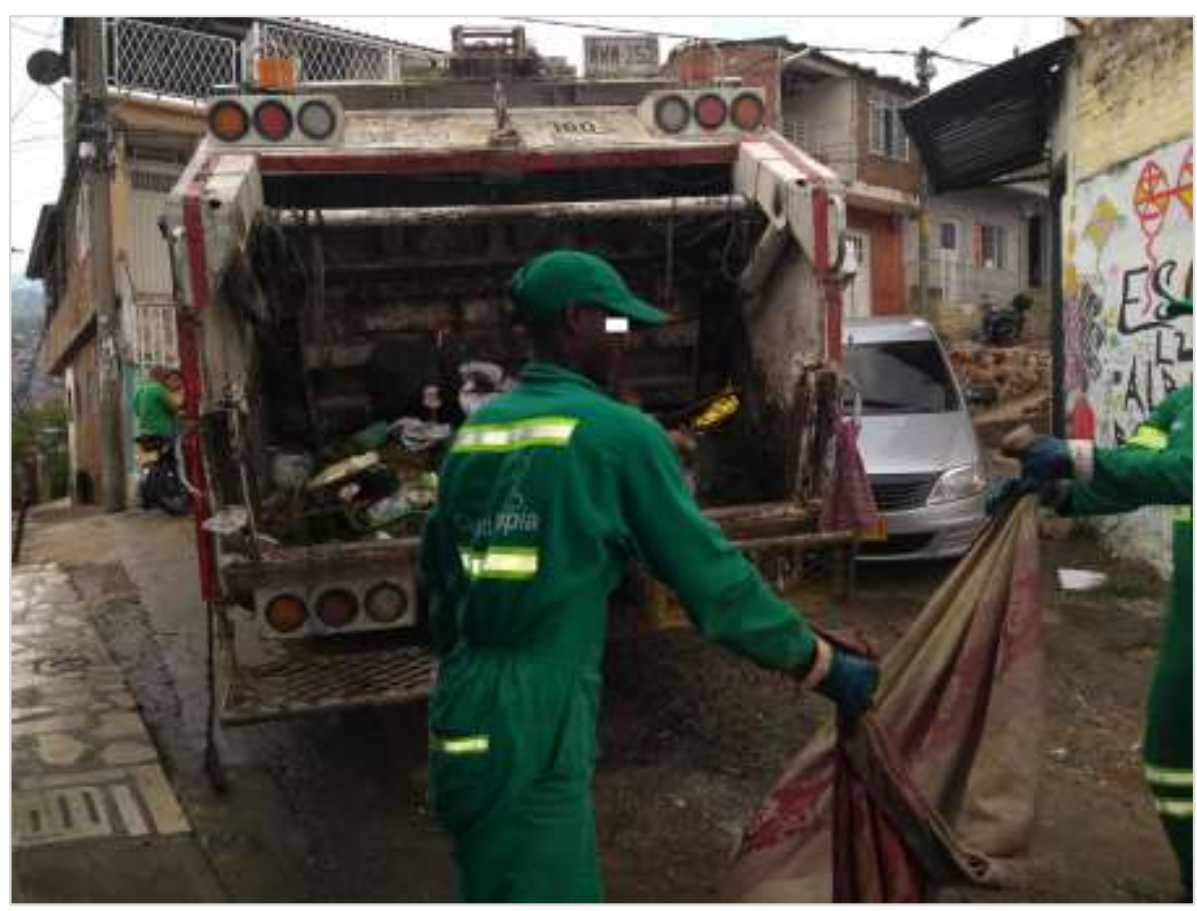

Figura 94 - Realização da coleta - Tierra Blanca - resíduo sendo depositado no caminhão coletor com o auxílio de um pano.

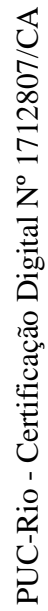

Fonte: Maria Izabel de Carvalho, nov. 2019.

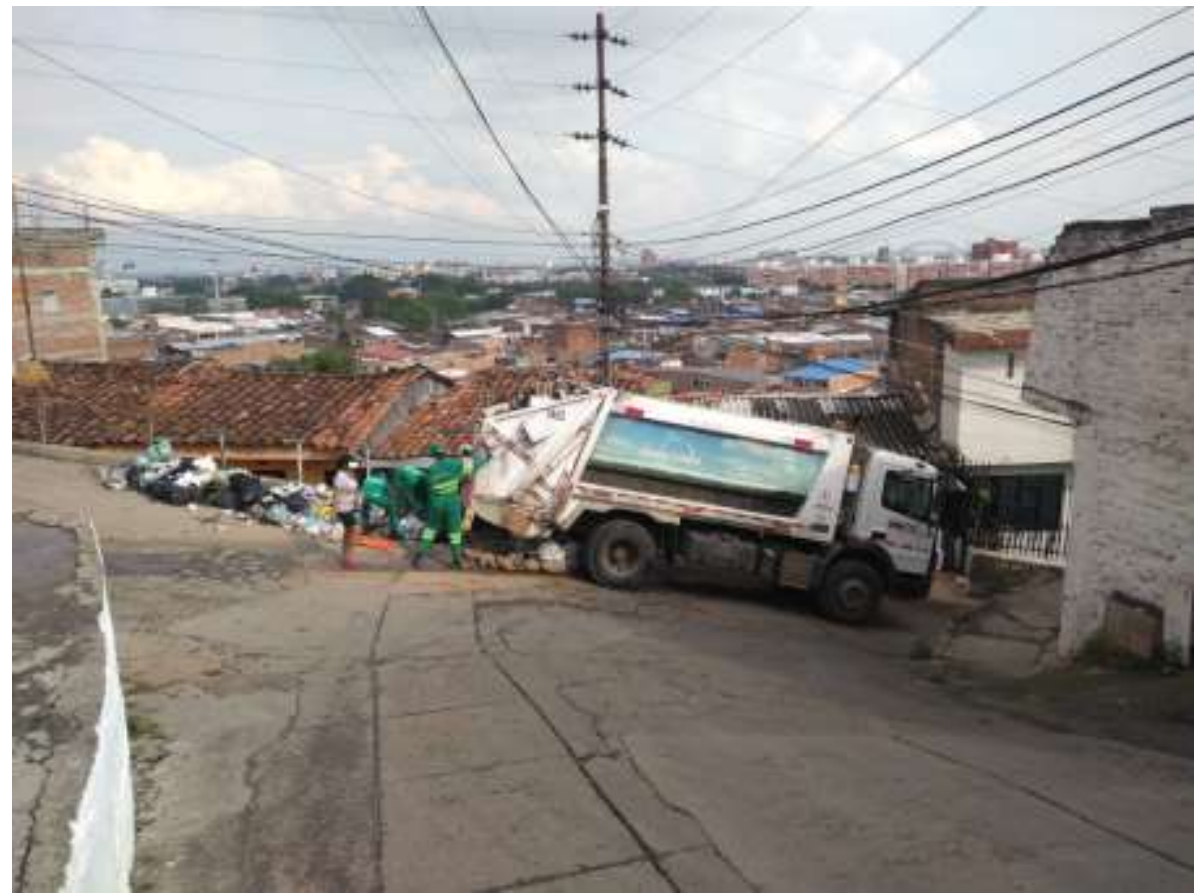

Figura 95 - Realização da coleta - Tierra Blanca.

Fonte: Maria Izabel de Carvalho, nov. 2019. 


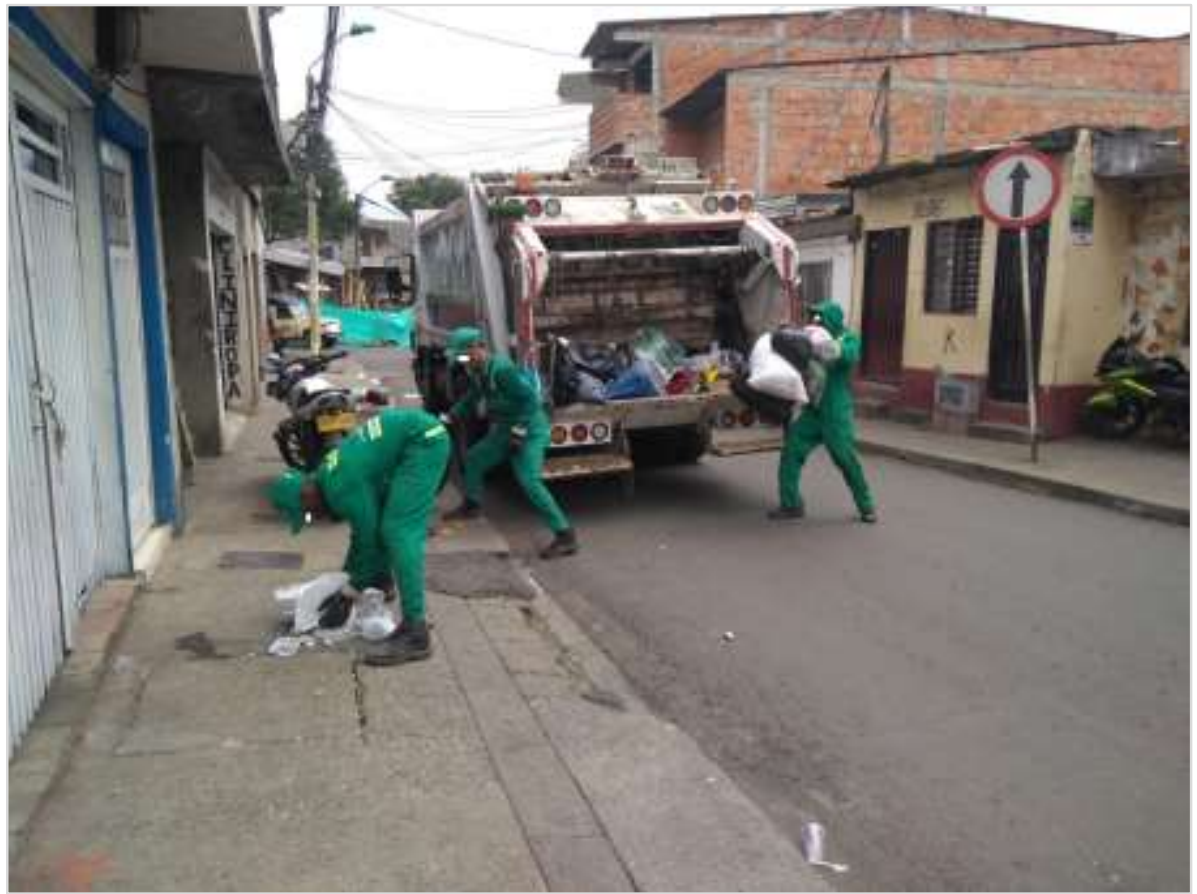

Figura 96 - Realização da coleta - El Cortijo.

Fonte: Maria Izabel de Carvalho, out. 2019.

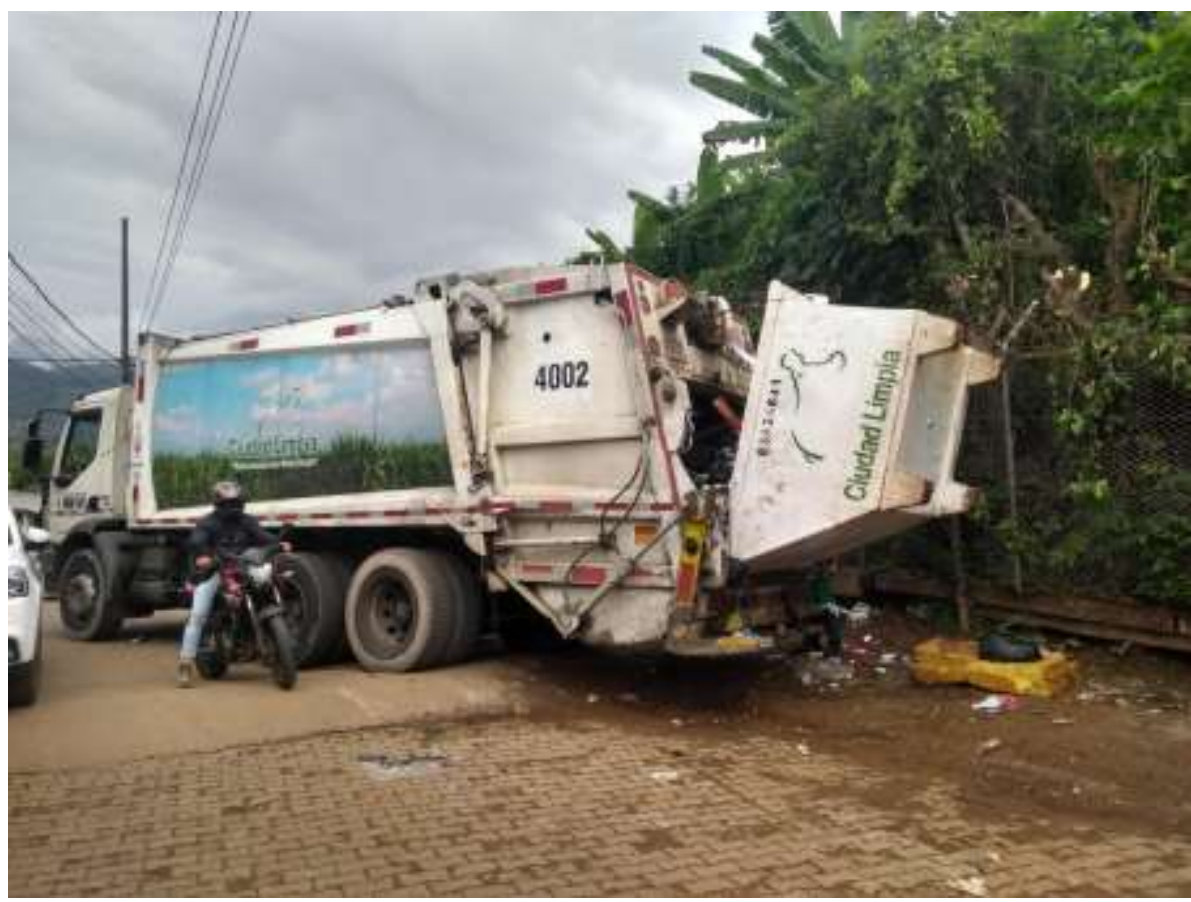

Figura 97 - Realização da coleta - Brisas de Mayo.

Fonte: Maria Izabel de Carvalho, maio. 2019. 


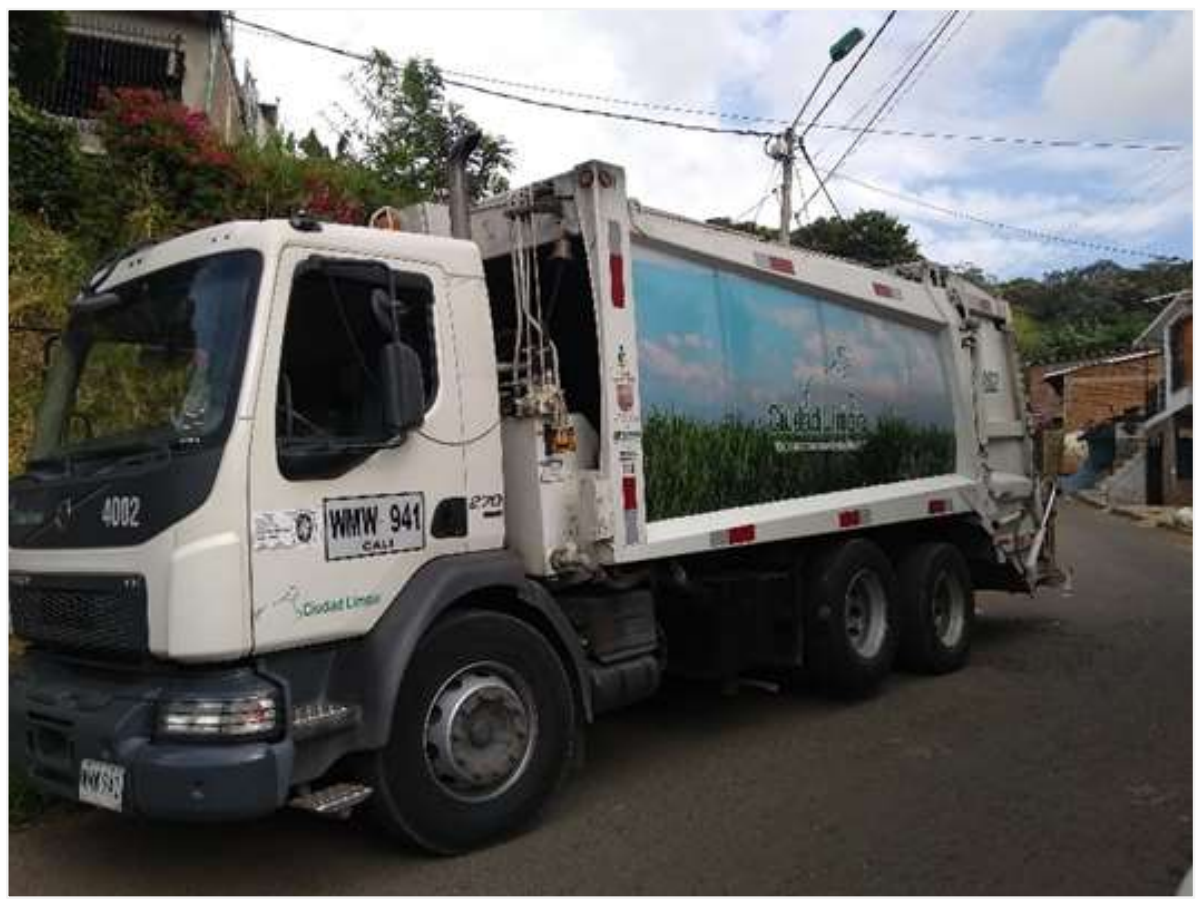

Figura 98 - Equipamento de coleta - caminhão compactador. Fonte: Maria Izabel de Carvalho, out. 2019.

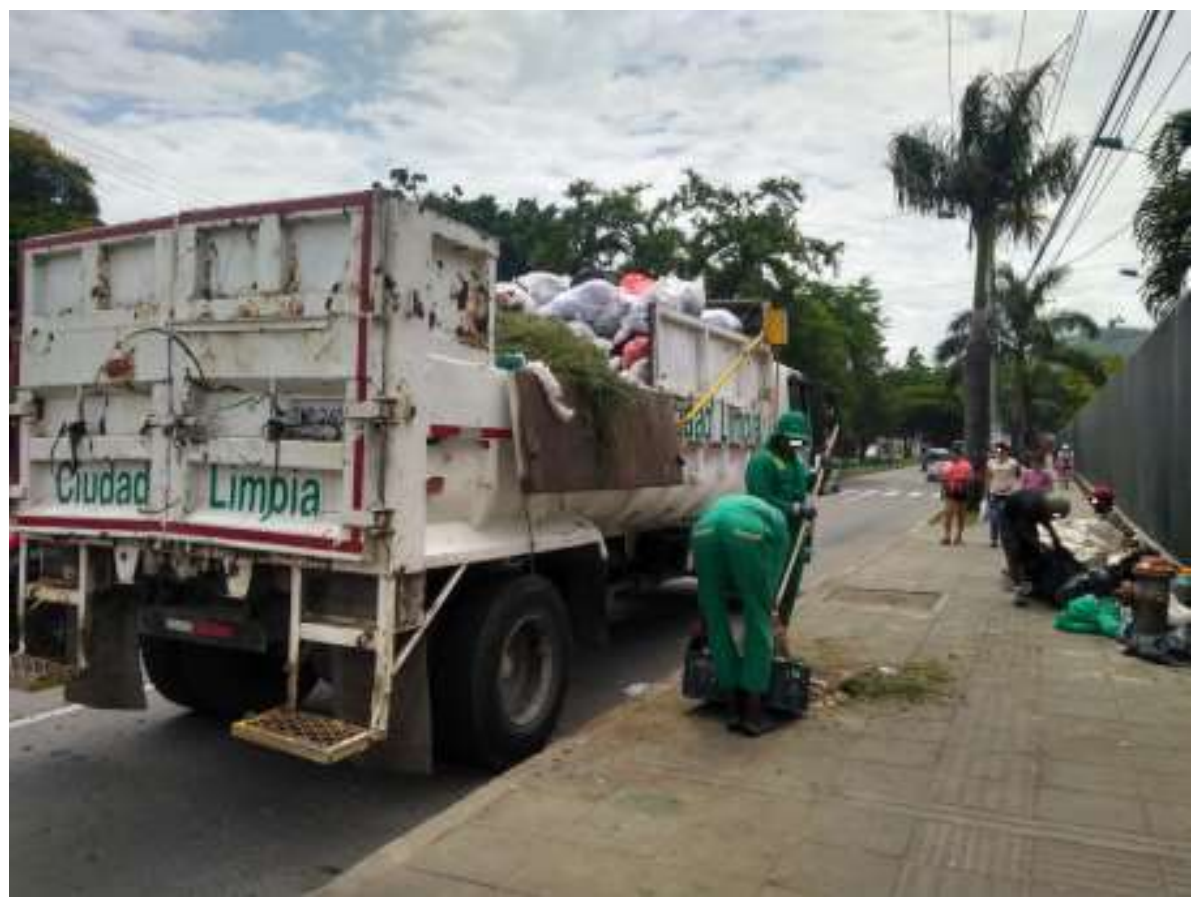

Figura 99 - Equipamento de coleta - caminhão de coleta dos resíduos da varrição. Fonte: Maria Izabel de Carvalho, out. 2019. 


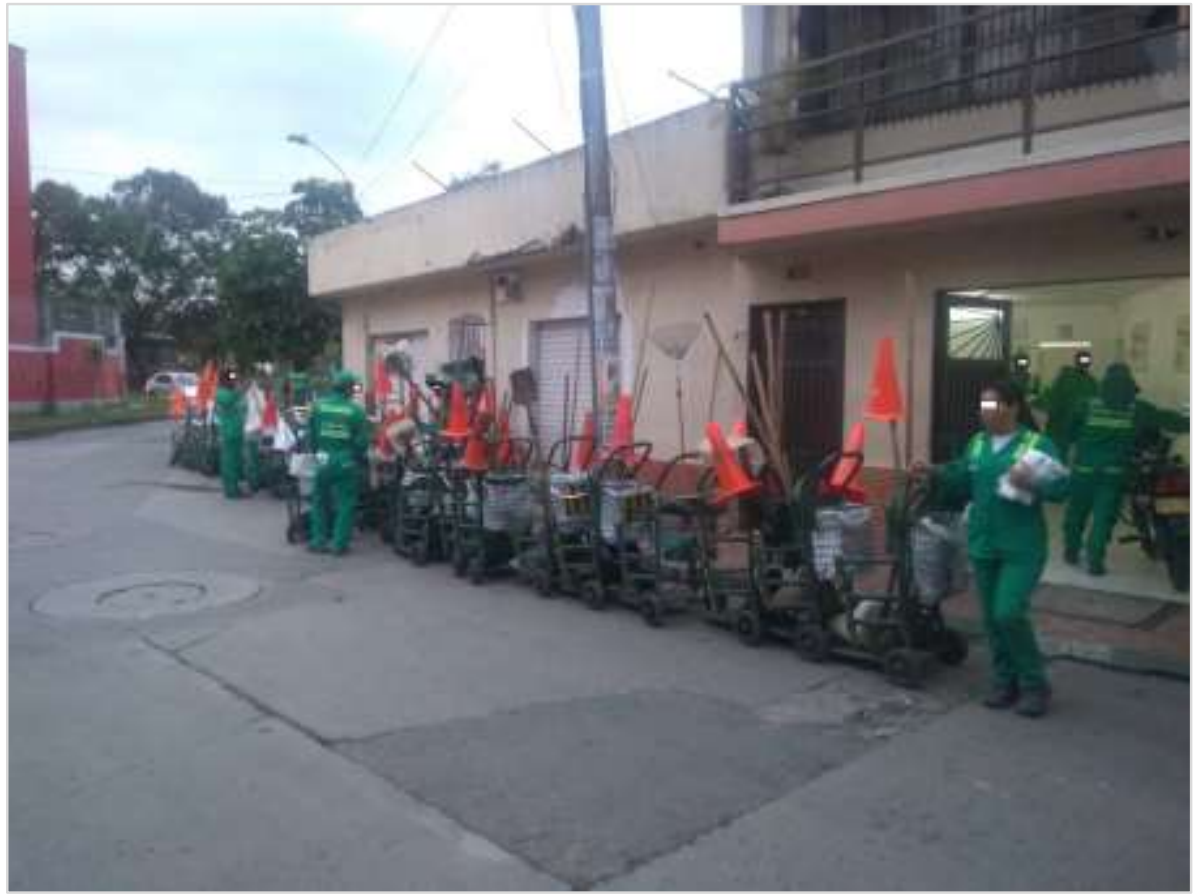

Figura 100 - Equipe de varrição se preparando para sair para mais um dia de trabalho.

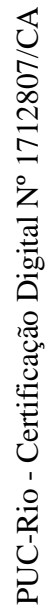

Fonte: Maria Izabel de Carvalho, fev. 2019.

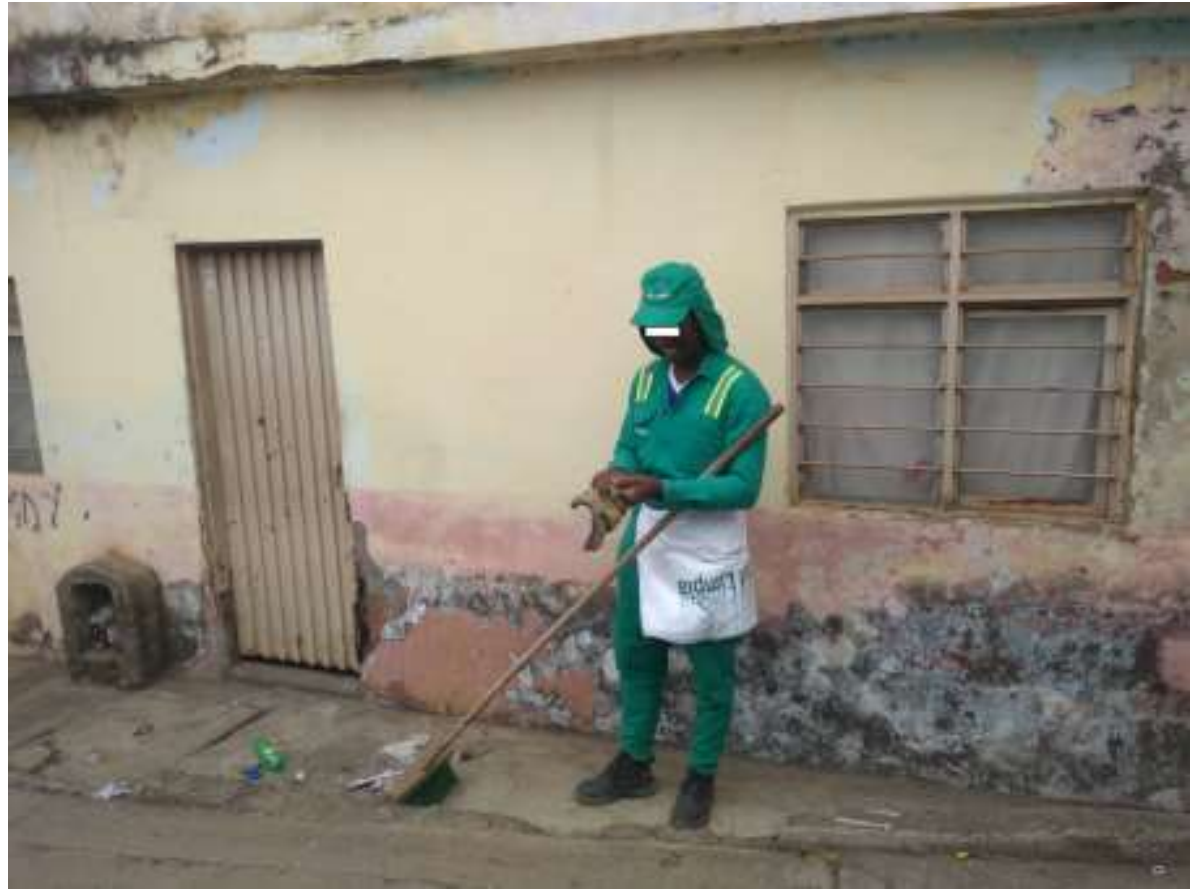

Figura 101 - Realização da varrição na parte alta - não utiliza o carrinho. Fonte: Maria Izabel de Carvalho, fev. 2019. 


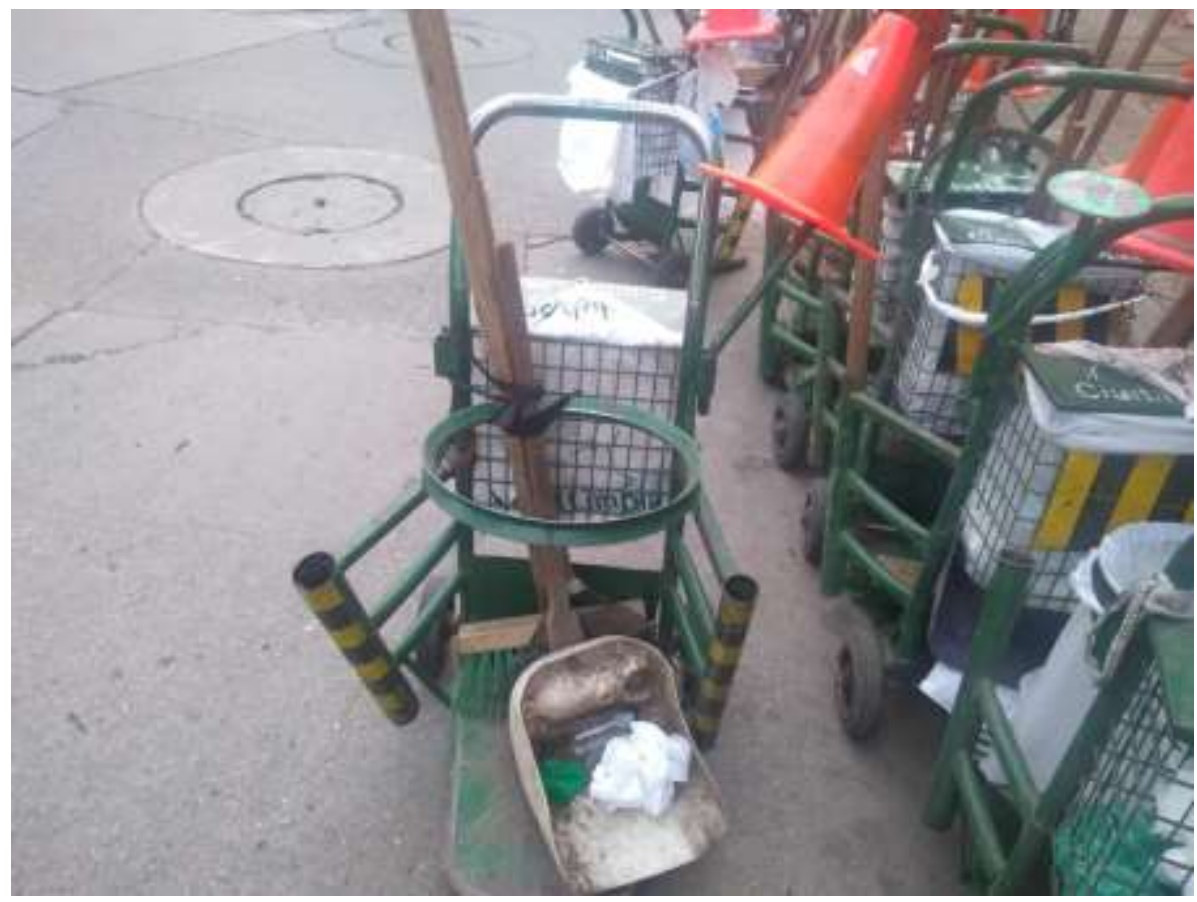

Figura 102 - Carrinho utilizado pelos funcionários que realizam a varrição na parte baixa.

U

Fonte: Maria Izabel de Carvalho, fev. 2019.

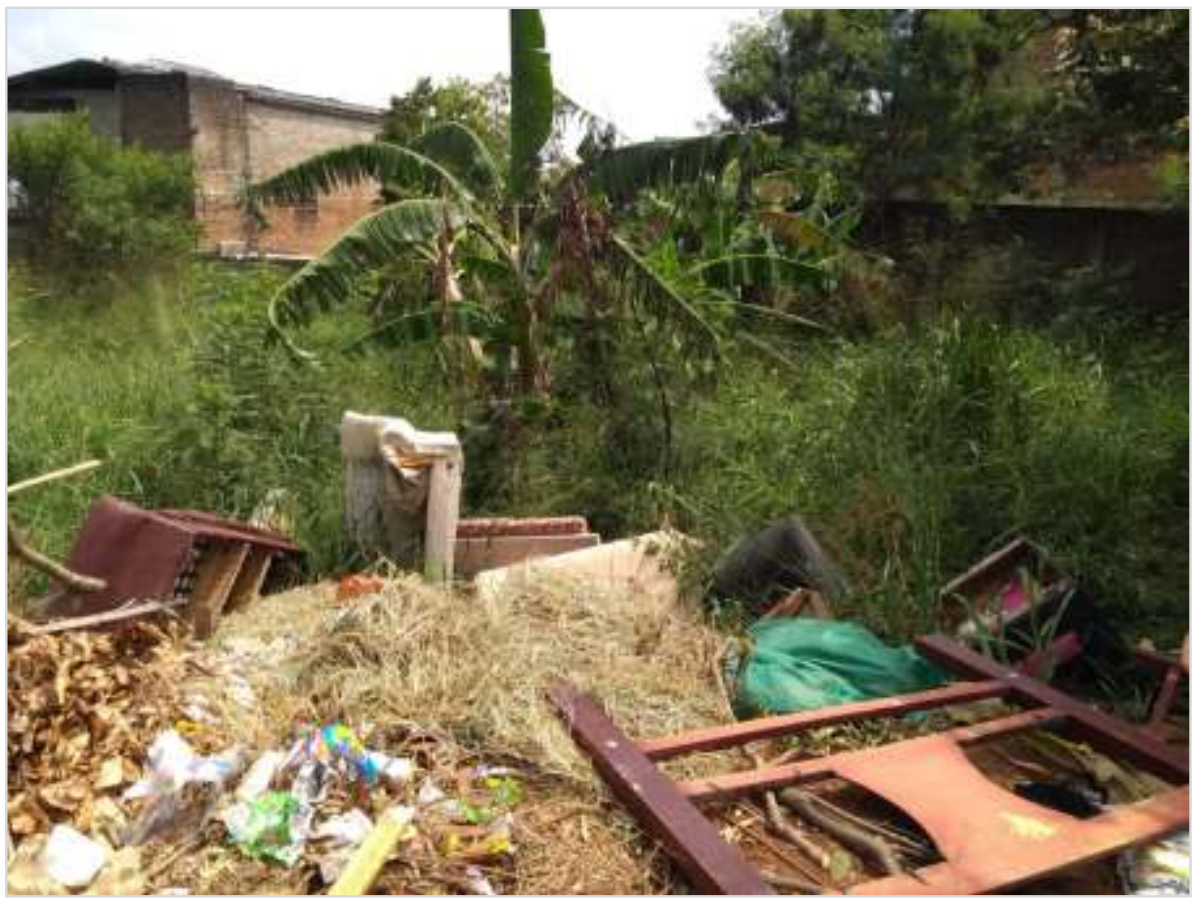

Figura 103 - Descarte inadequado de bens inservíveis em um terreno baldio - La Estrella.

Fonte: Maria Izabel de Carvalho, dez. 2019. 


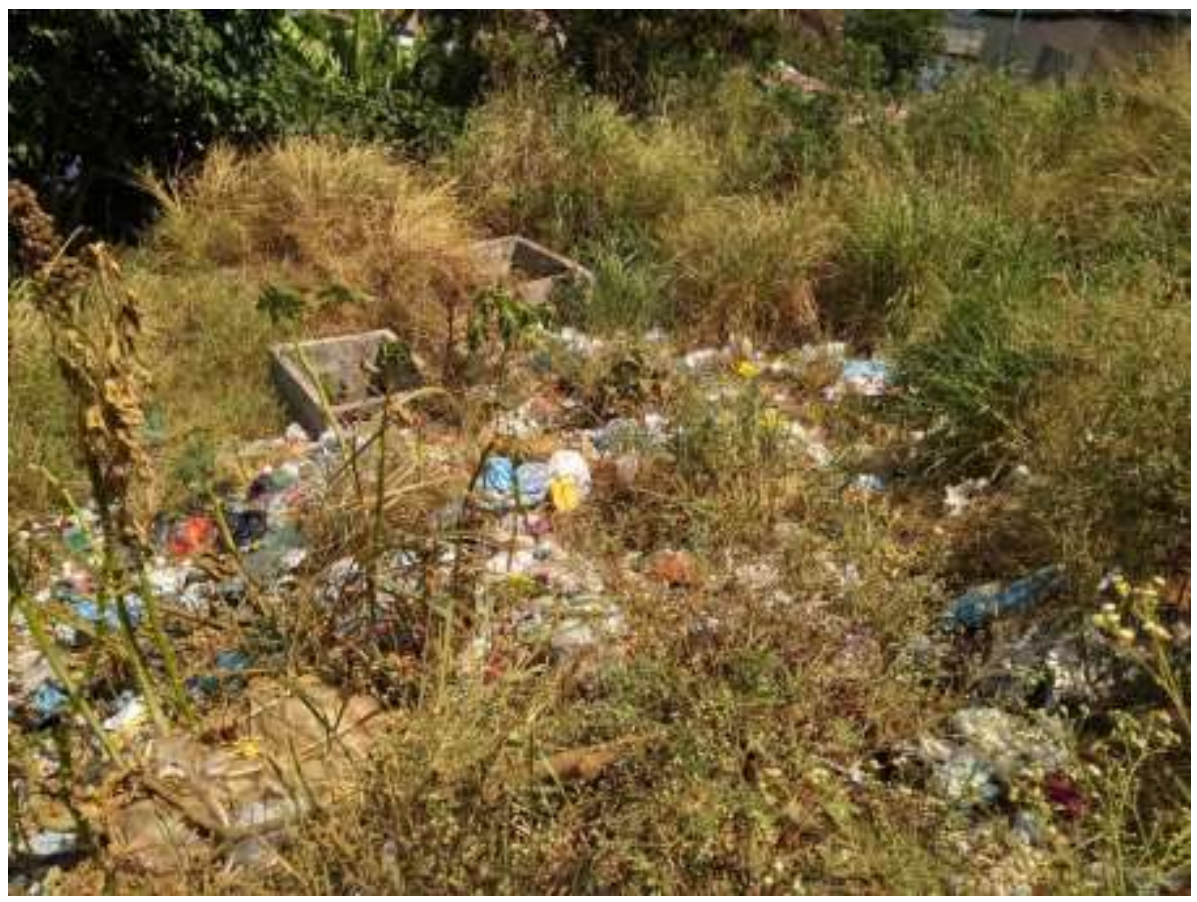

Figura 104 - Descarte inadequado de resíduos sólidos em terreno baldio - La Estrella.

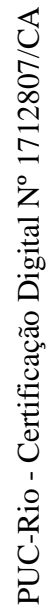

Fonte: Maria Izabel de Carvalho, set. 2019.

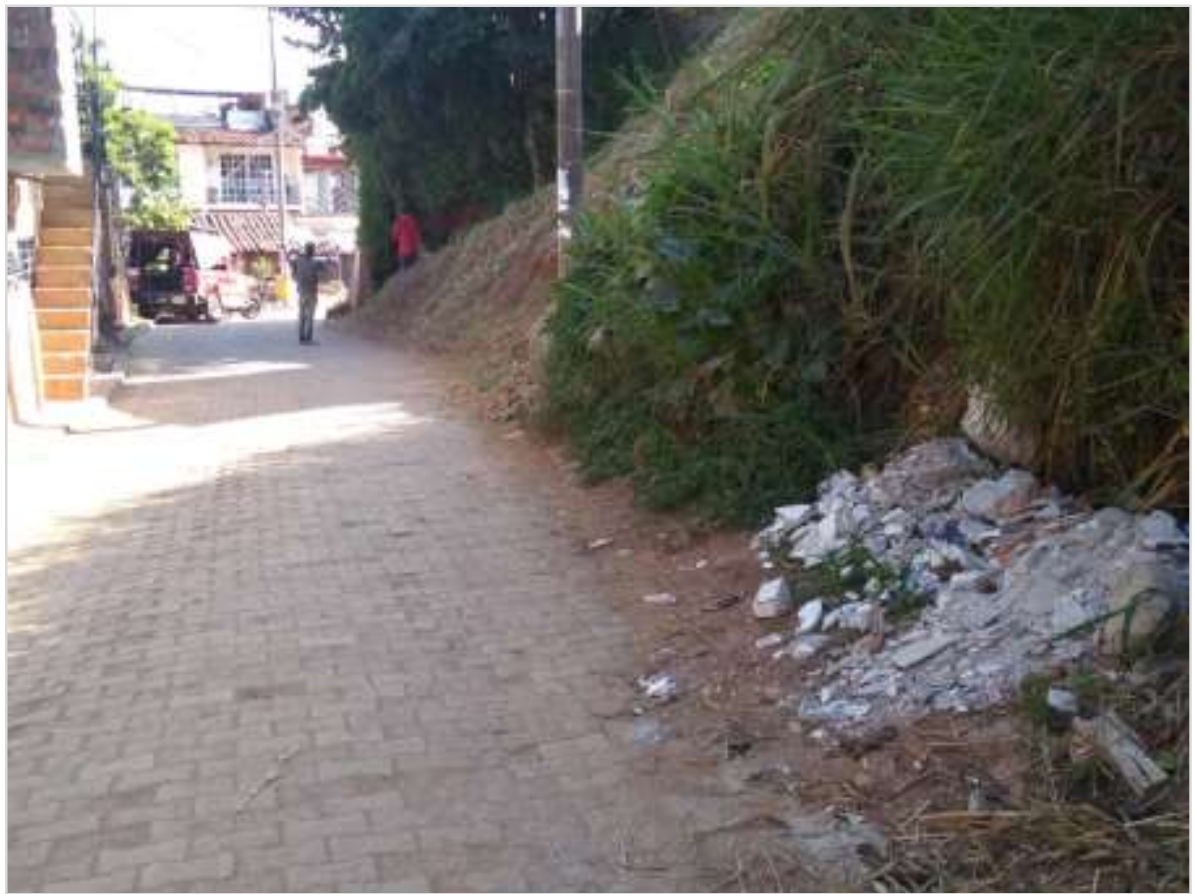

Figura 105 - Descarte inadequado de entulho - Sultana.

Fonte: Maria Izabel de Carvalho, dez. 2019. 


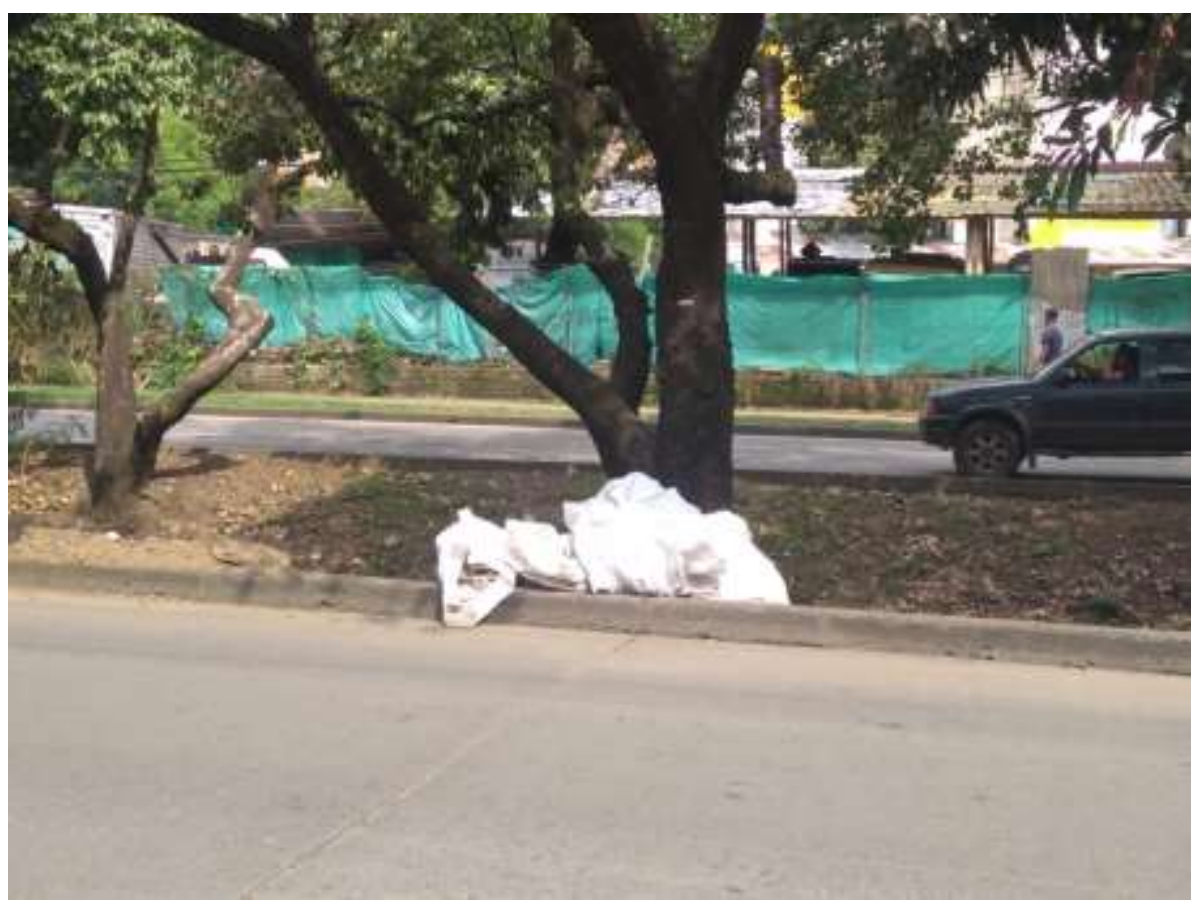

Figura 106 - Descarte inadequado de entulho - Belisário Caicedo. Fonte: Maria Izabel de Carvalho, out. 2019.

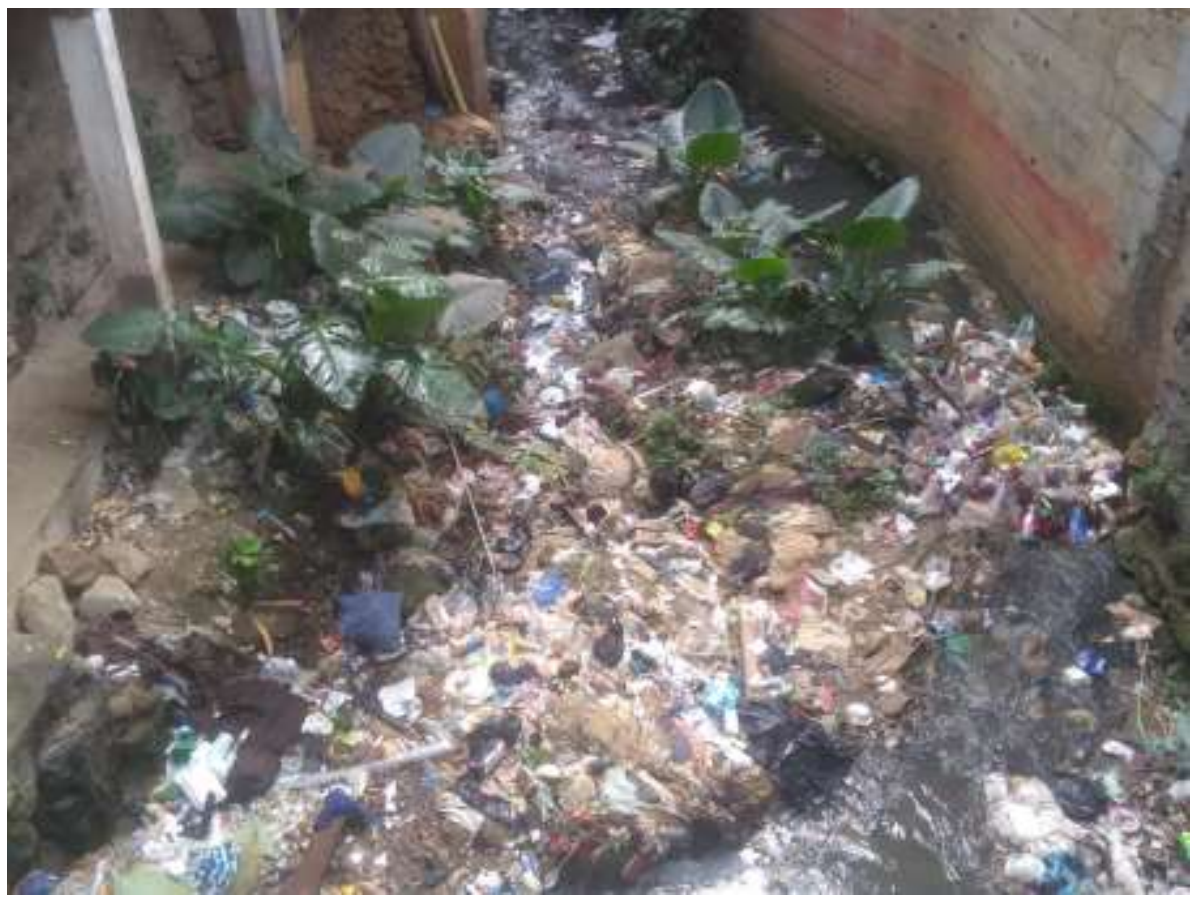

Figura 107 - Descarte inadequado em cursos d'água - El Cortijo. Fonte: Maria Izabel de Carvalho, dez. 2019. 


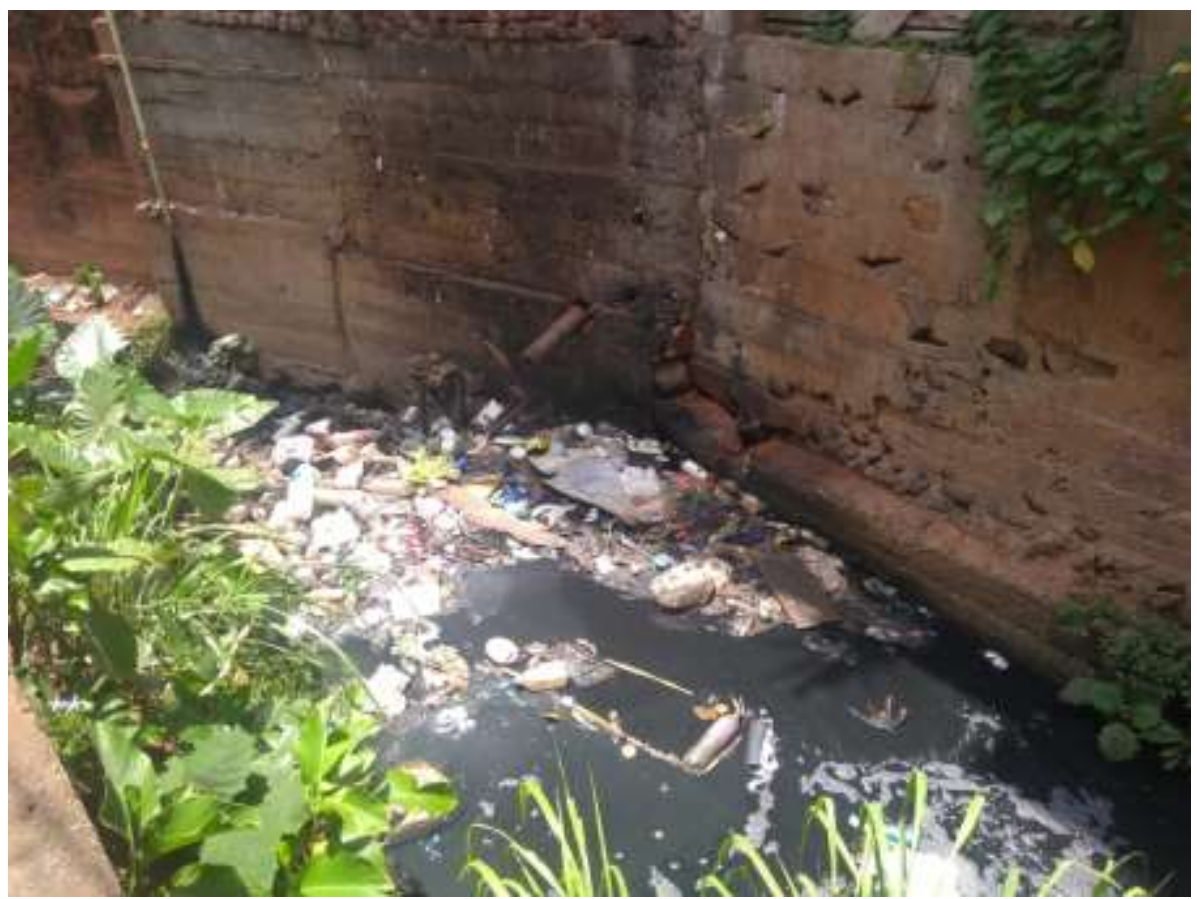

Figura 108 - Descarte inadequado em cursos d'água - Lleras Camargo. Fonte: Maria Izabel de Carvalho, set. 2019.

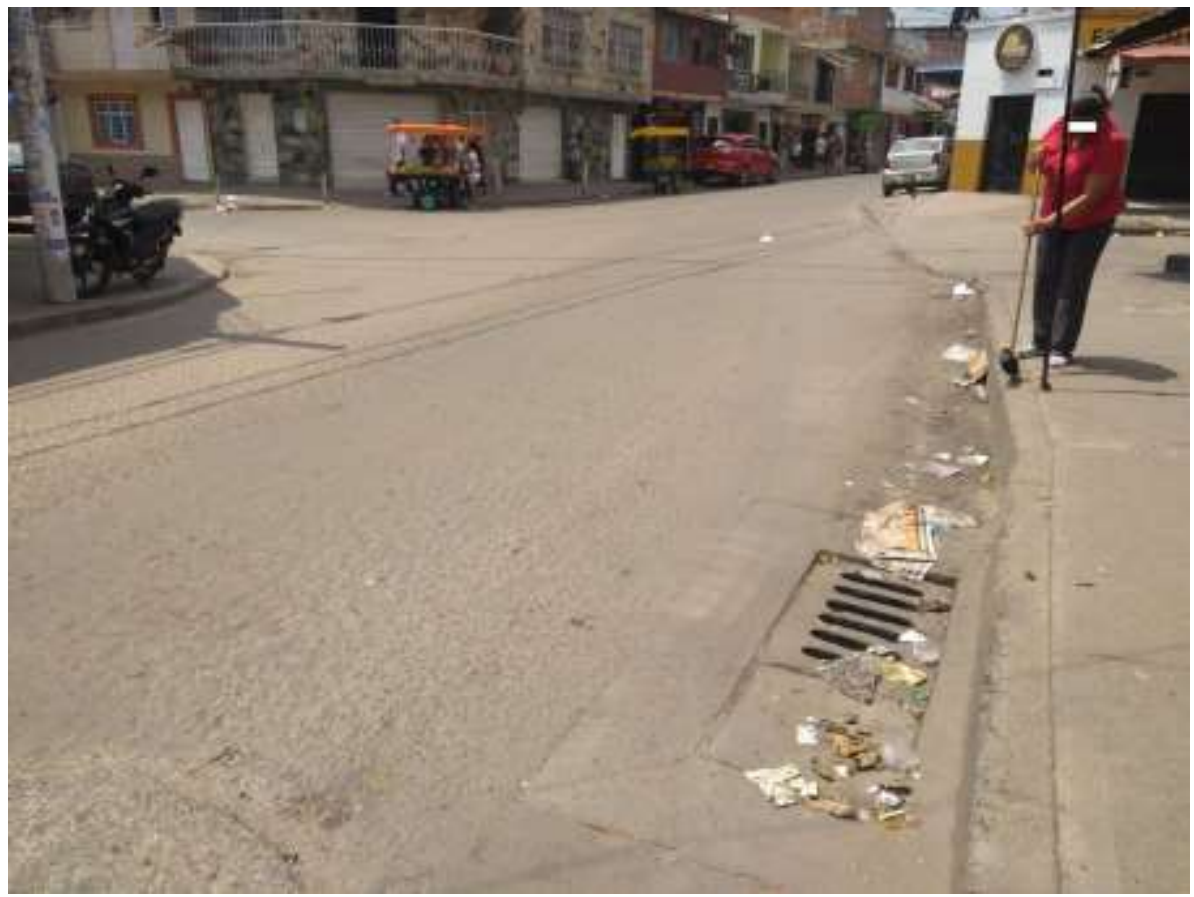

Figura 109 - Descarte inadequado na rua e moradora varrendo - El Cortijo - parte baixa.

Fonte: Maria Izabel de Carvalho, out. 2019. 


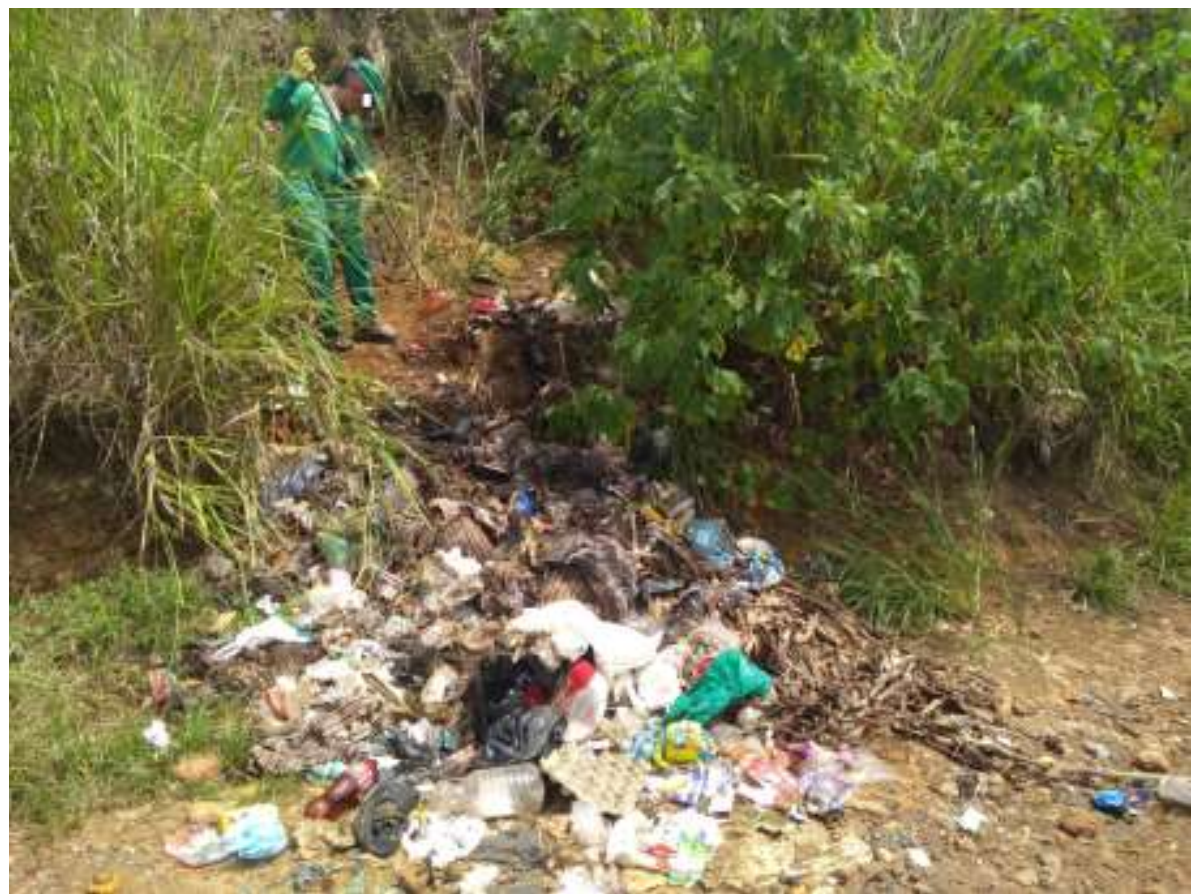

Figura 110 - Ação de limpeza de um terreno baldio realizado por Ciudad Limpia La Estrella.

Fonte: Maria Izabel de Carvalho, abr. 2019.

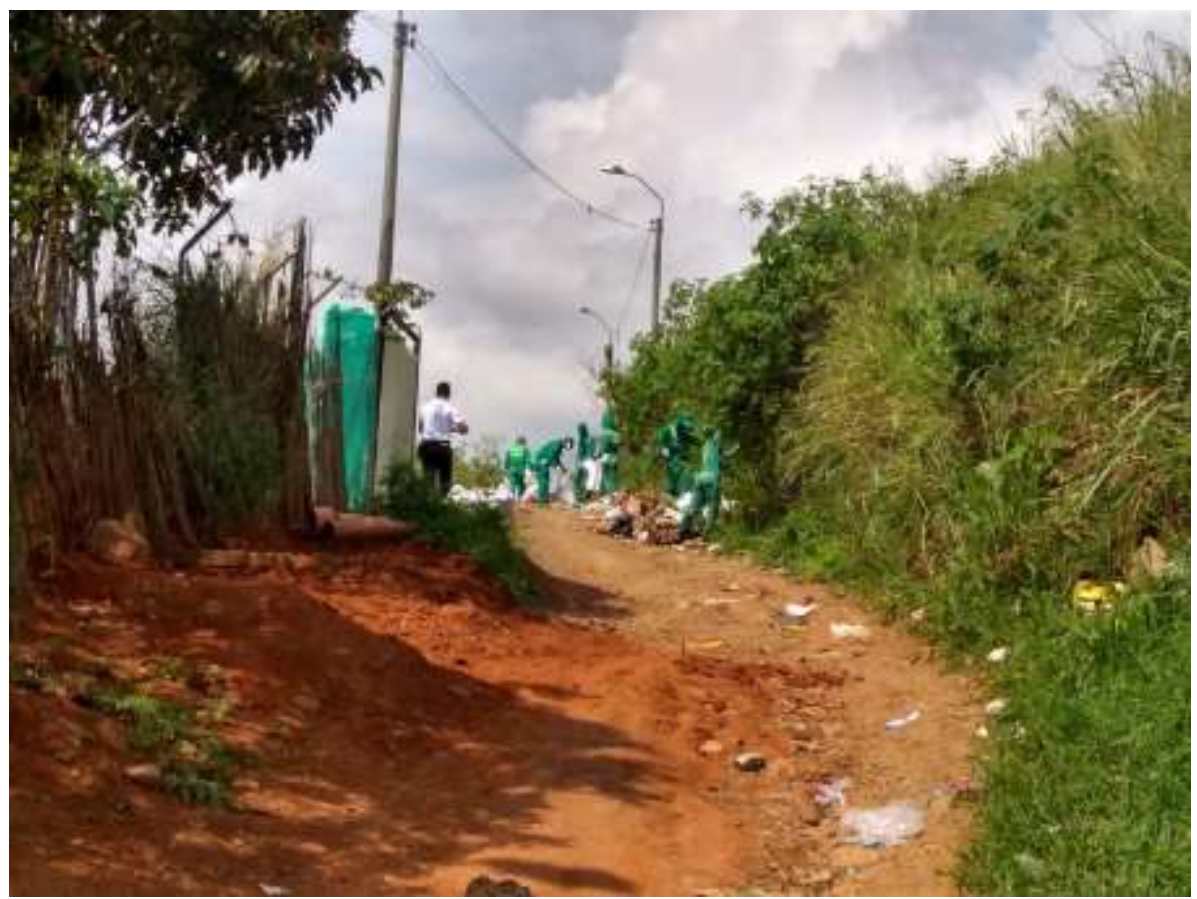

Figura 111 - Ação de limpeza de um terreno baldio realizado por Ciudad Limpia La Estrella.

Fonte: Maria Izabel de Carvalho, abr. 2019. 


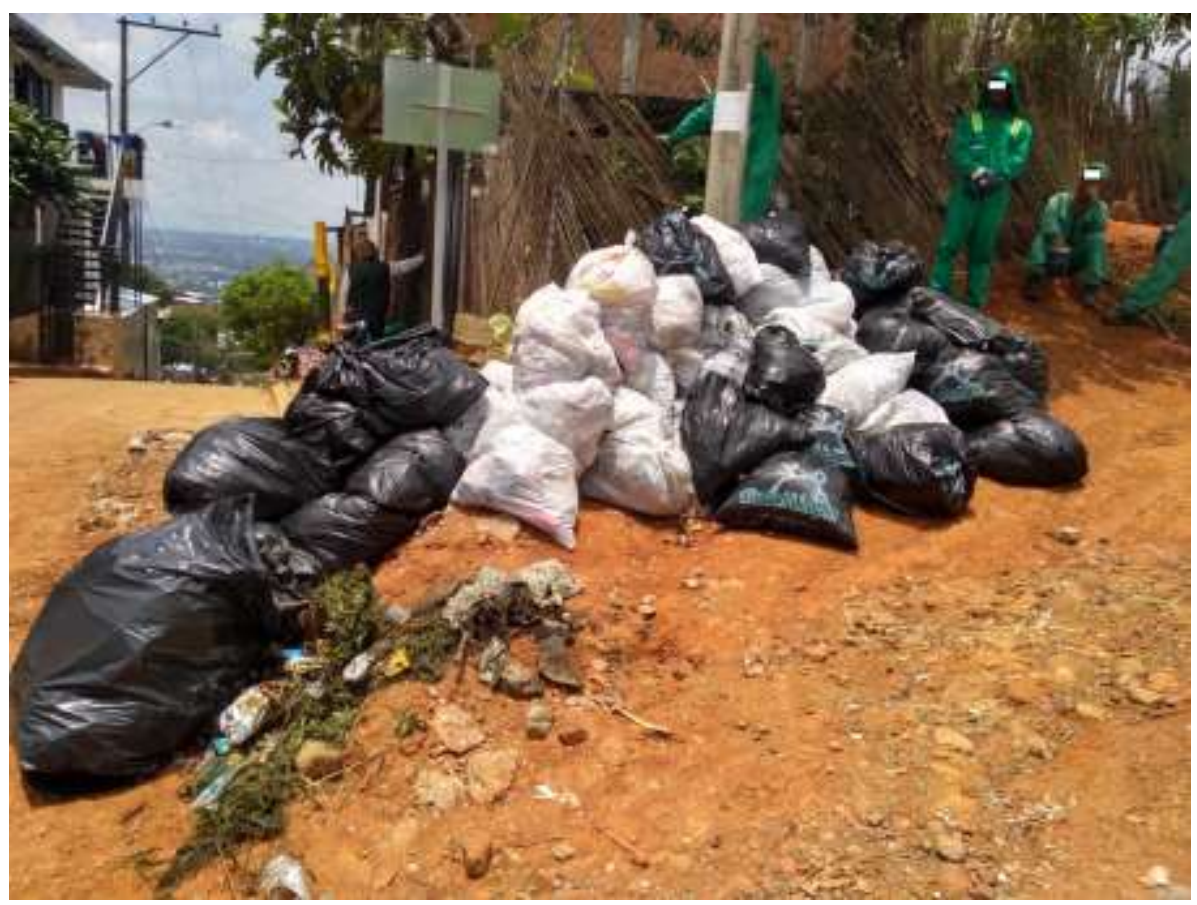

Figura 112 - Resíduo coletado durante a ação de limpeza de um terreno baldio realizado por Ciudad Limpia - La Estrella.

Fonte: Maria Izabel de Carvalho, abr. 2019.

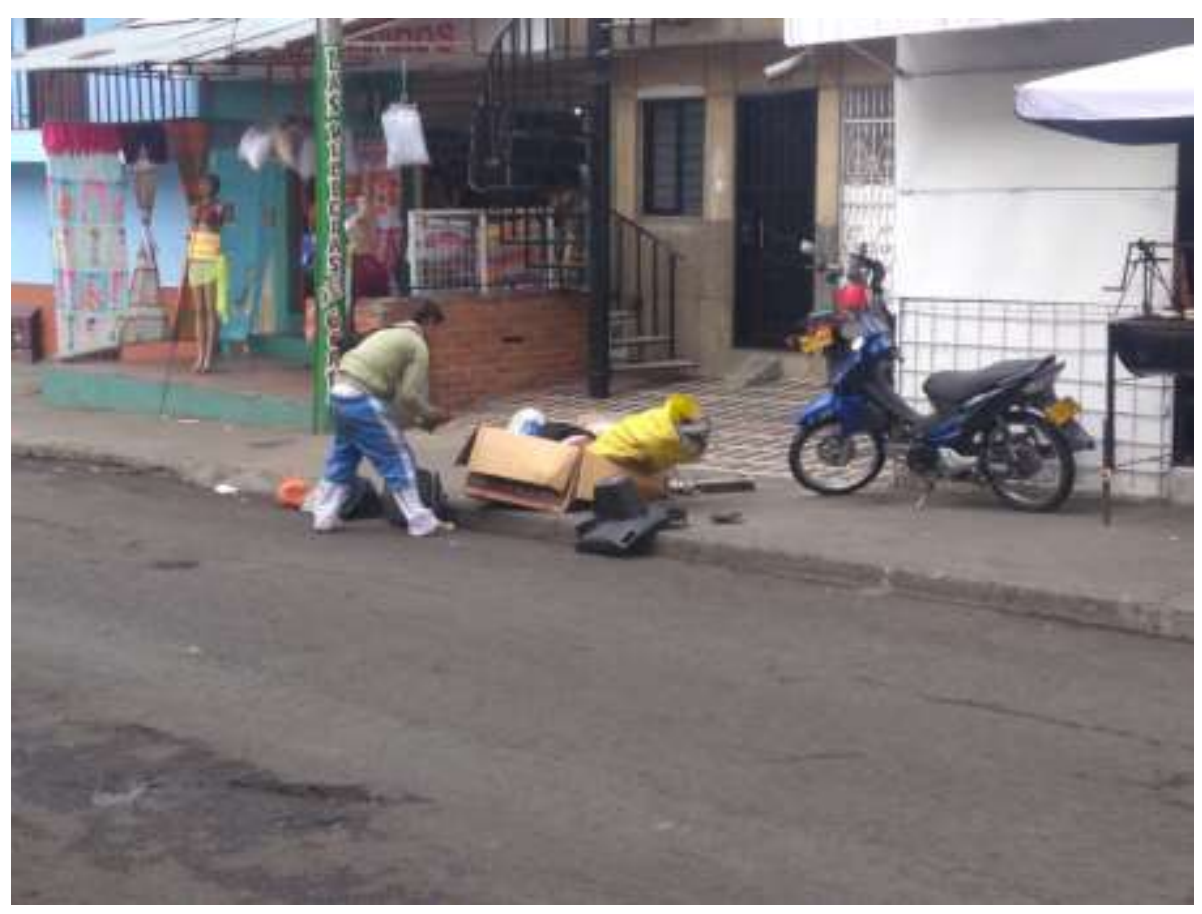

Figura 113 - Reciclador realizando a catação.

Fonte: Maria Izabel de Carvalho, set. 2019. 


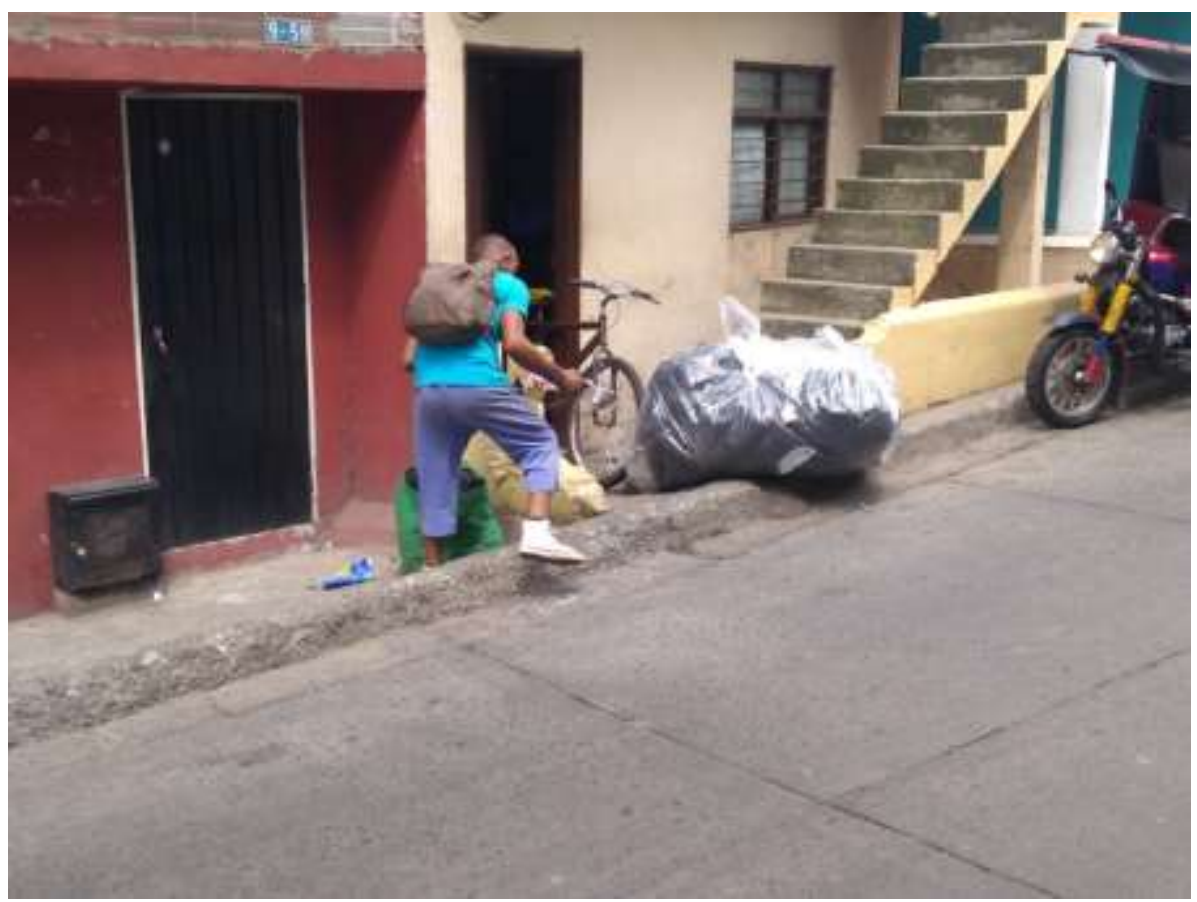

Figura 114 - Reciclador realizando a catação.

Fonte: Maria Izabel de Carvalho, ago. 2019.

U

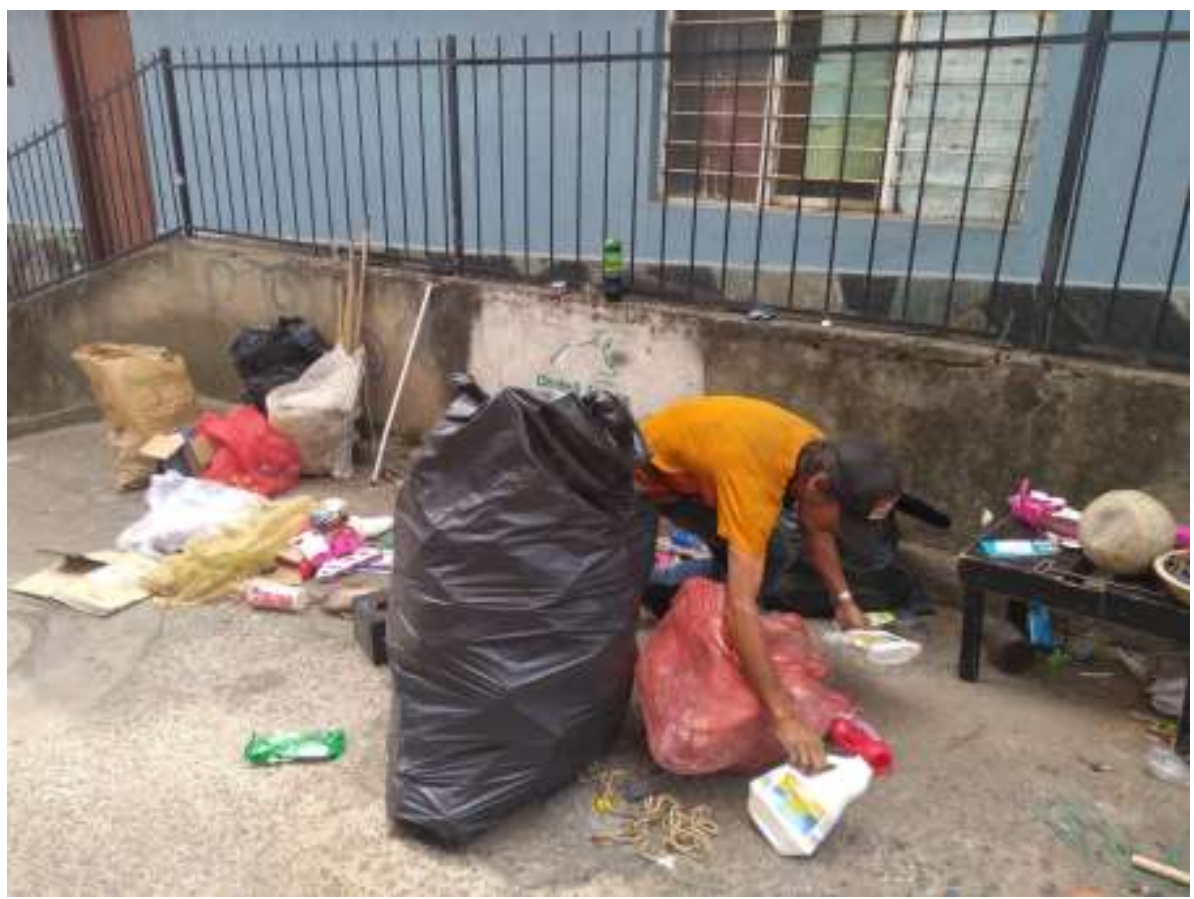

Figura 115 - Reciclador realizando a catação.

Fonte: Maria Izabel de Carvalho, ago. 2019. 


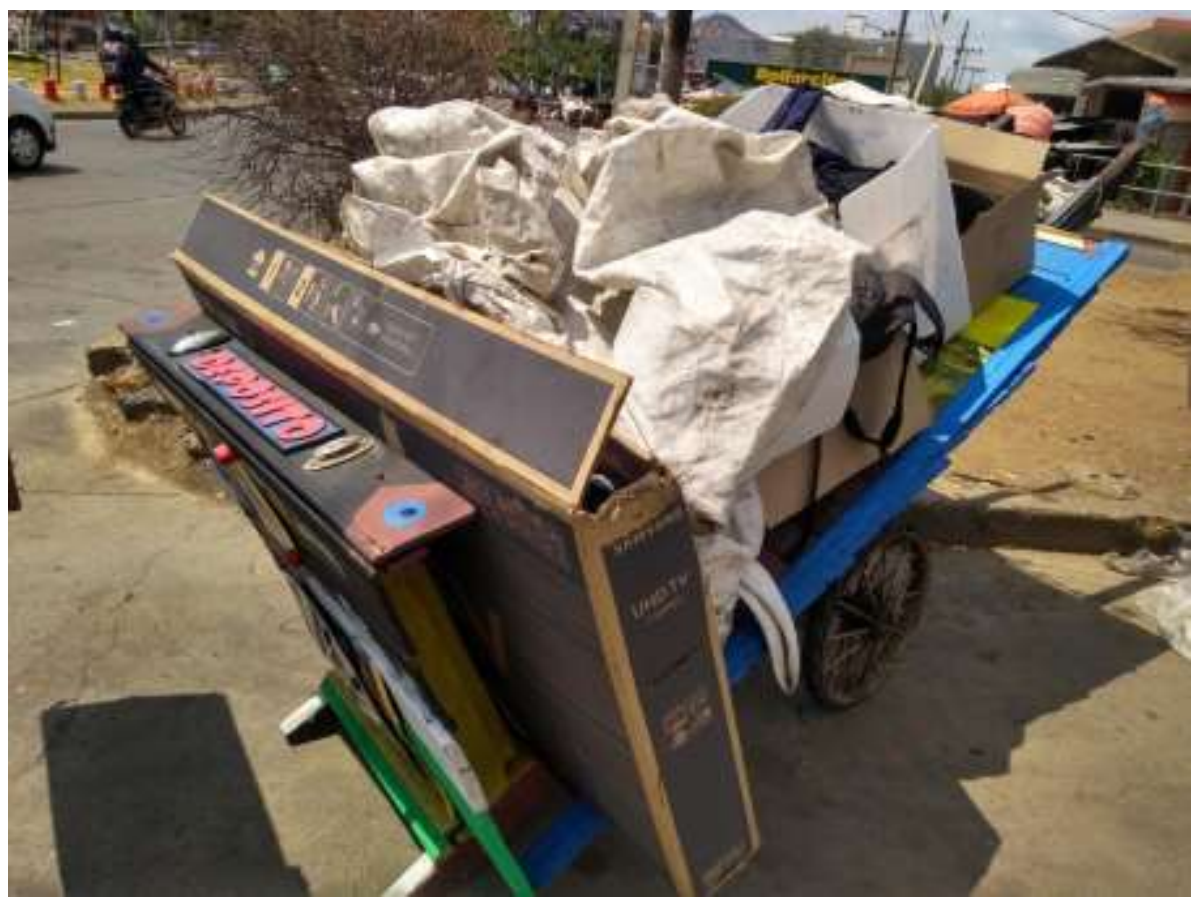

Figura 116 - Carinho para deslocamento do material reciclável - pertencente a um reciclador.

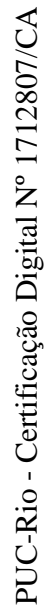

Fonte: Maria Izabel de Carvalho, set. 2019.

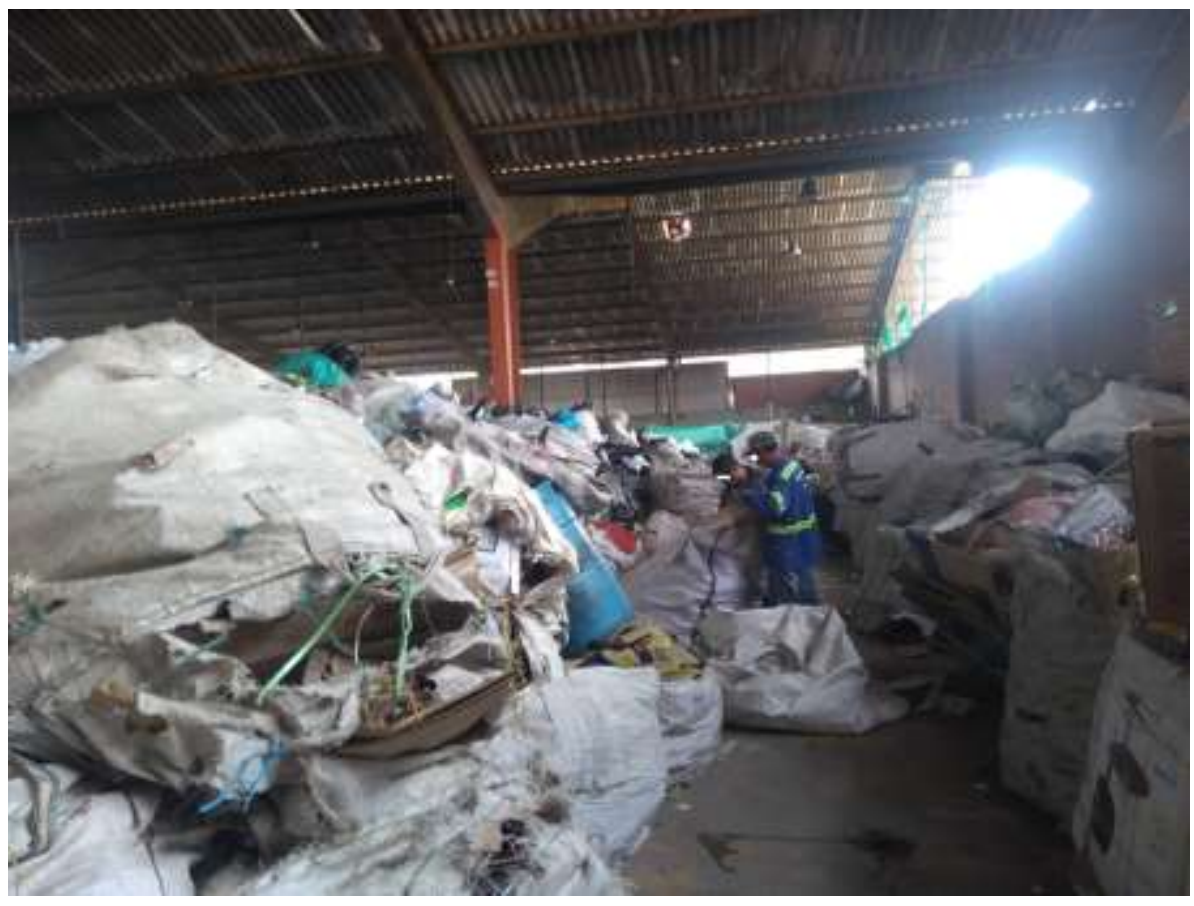

Figura 117 - Galpão de uma das Associações de Recicladores visitadas. Fonte: Maria Izabel de Carvalho, ago. 2019. 


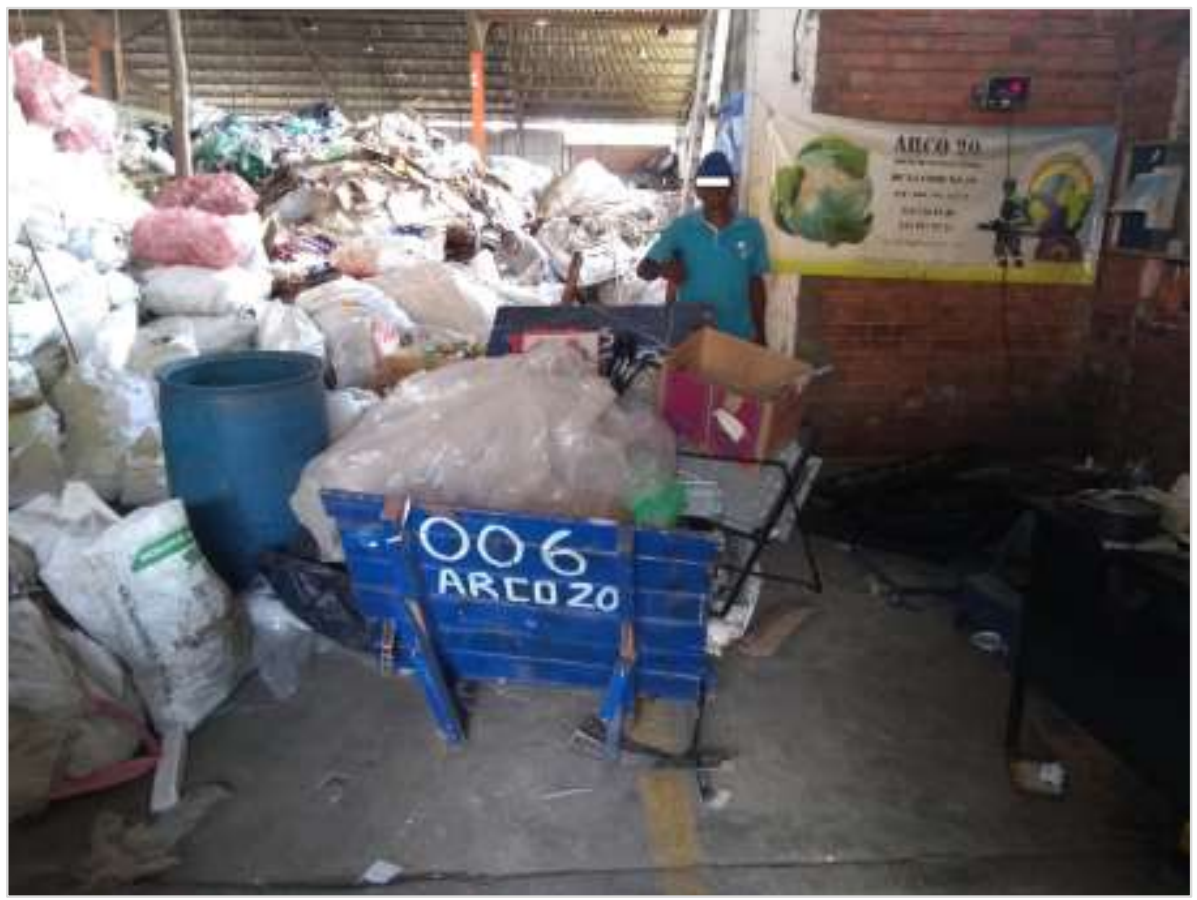

Figura 118 - Galpão de uma das Associações de Recicladores visitadas. Fonte: Maria Izabel de Carvalho, ago. 2019.

U

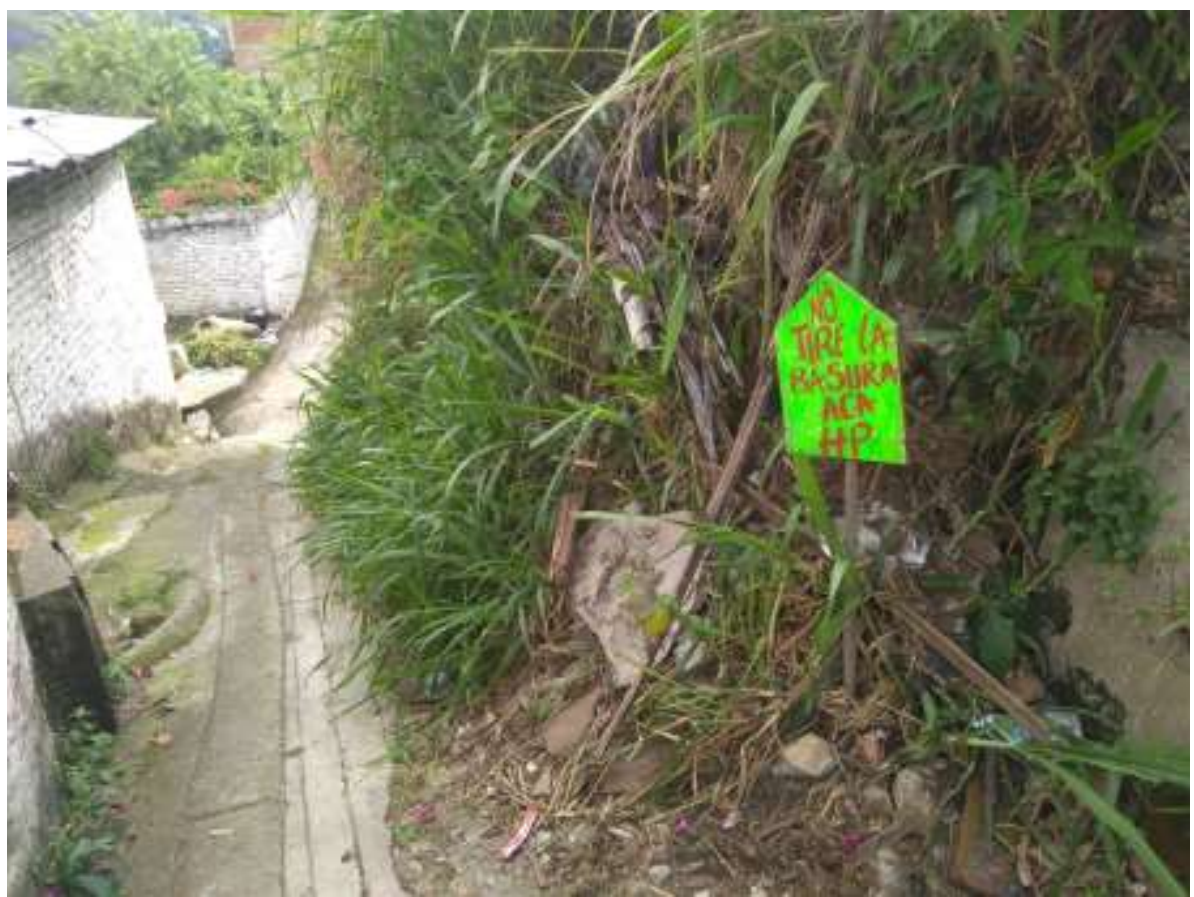

Figura 119 - Placa de "Não coloque seu lixo aqui". Fonte: Maria Izabel de Carvalho, nov. 2019. 


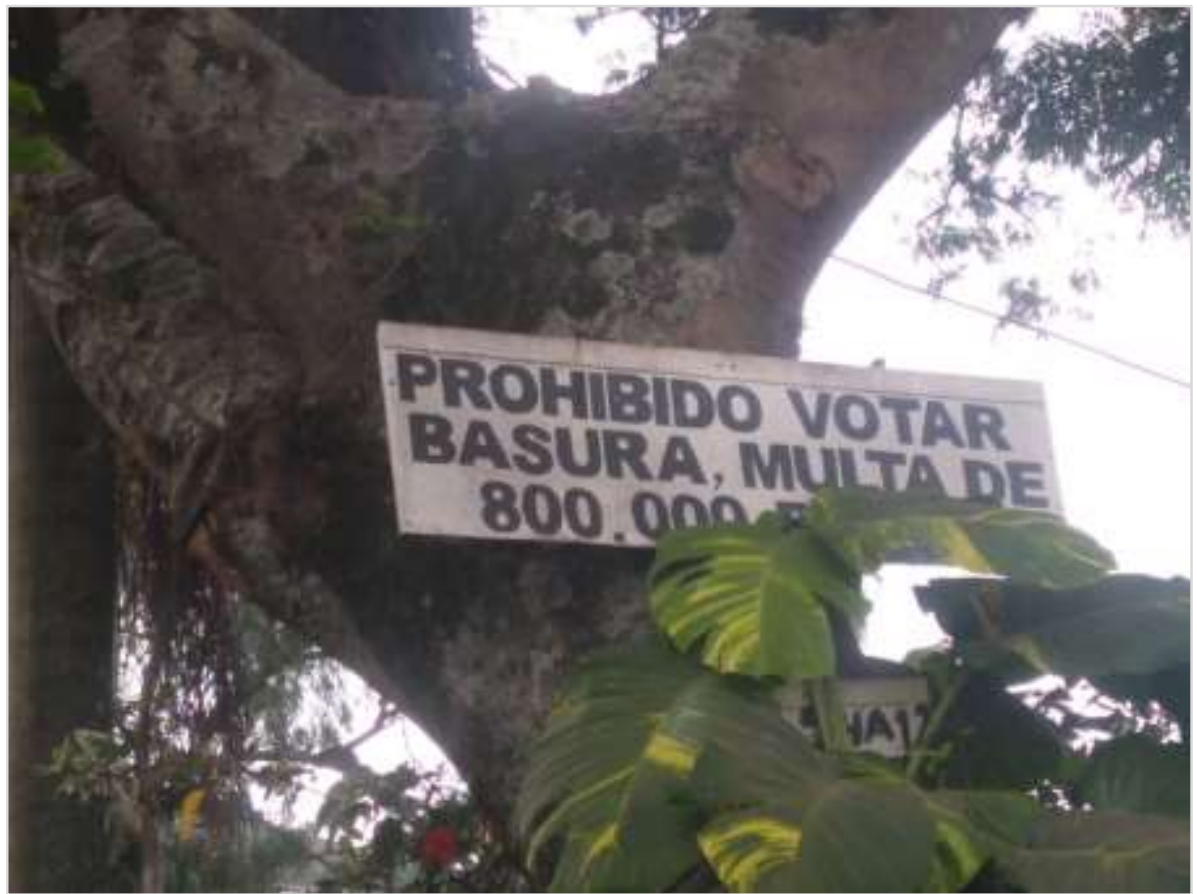

Figura 120 - Placa de "proibido botar lixo, multa de $\$ 800.000 " 41$. Fonte: Maria Izabel de Carvalho, set. 2019.

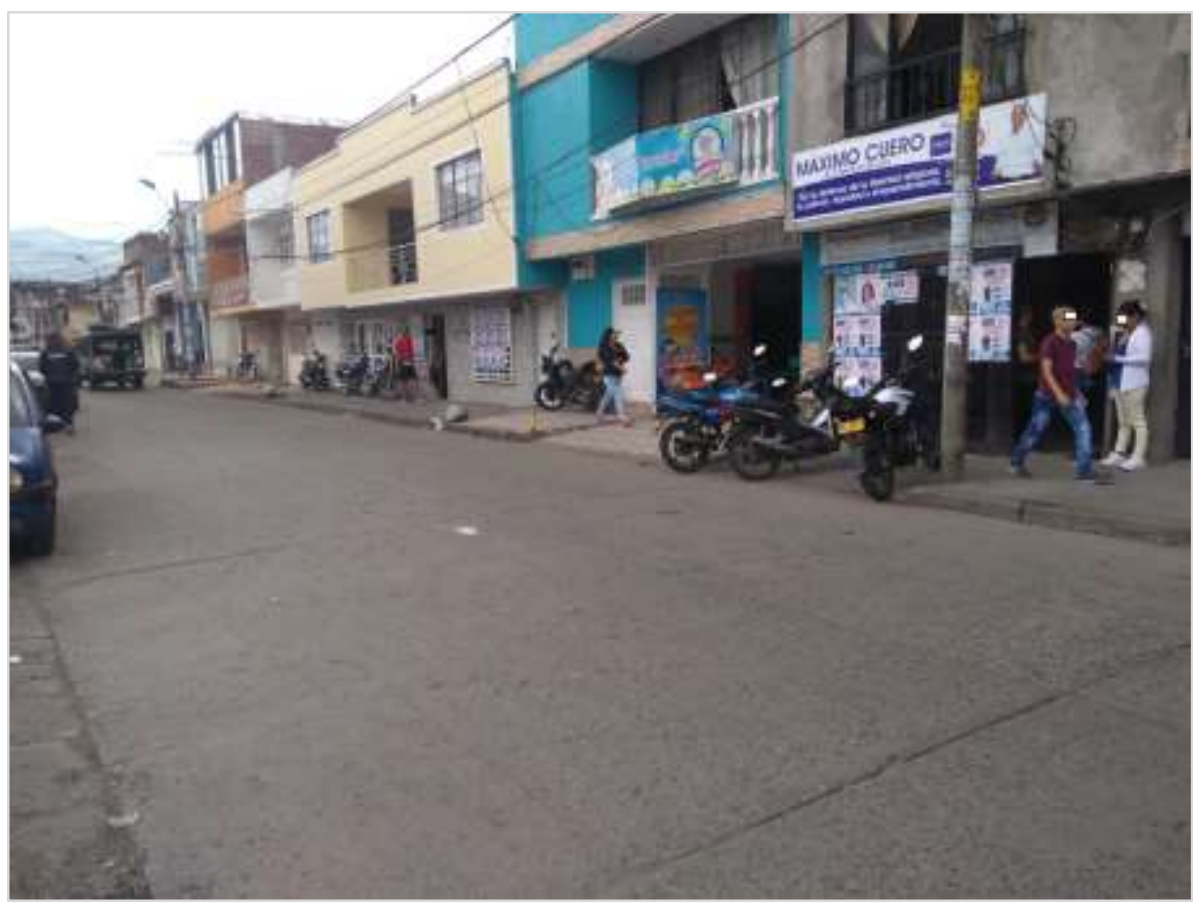

Figura 121 - Rua de Siloé em dia de votação - eleição 2019 - Diagonal 51 - El Cortijo.

Fonte: Maria Izabel de Carvalho, out. 2019.

${ }^{41}$ Segundo alguns moradores, a placa é posta com o objetivo de inibir o descarte inadequado, porém a multa não é cobrada de fato. 


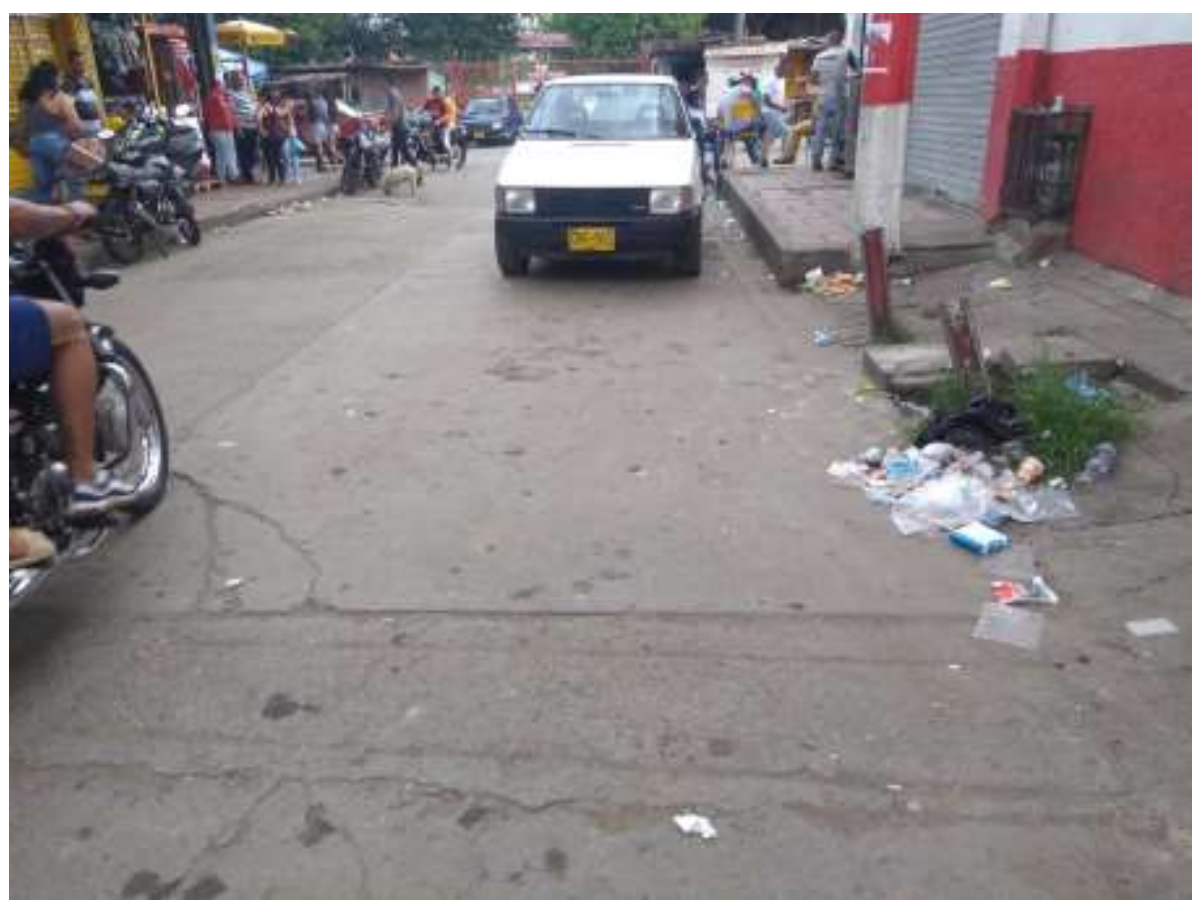

Figura 122 - Rua de Siloé em dia de votação - eleição 2019 - El Cortijo. Fonte: Maria Izabel de Carvalho, out. 2019. 